EVANDRO GONÇALVES PIZETA

\title{
ANÁLISE DA REGULAMENTAÇÃO DO SUPRIMENTO DE ENERGIA ELÉTRICA AOS PÓLOS INDUSTRIAIS COMO FATOR DE COMPETITIVIDADE
}


EVANDRO GONÇALVES PIZETA

\section{ANÁLISE DA REGULAMENTAÇÃO DO SUPRIMENTO DE ENERGIA ELÉTRICA AOS PÓLOS INDUSTRIAIS COMO FATOR DE COMPETITIVIDADE}

Dissertação apresentada à Escola

Politécnica da Universidade de São Paulo para obtenção do título de Mestre em

Engenharia Elétrica 
EVANDRO GONÇALVES PIZETA

\section{ANÁLISE DA REGULAMENTAÇÃO DO SUPRIMENTO DE ENERGIA ELÉTRICA AOS PÓLOS INDUSTRIAIS COMO FATOR DE COMPETITIVIDADE}

Dissertação apresentada à Escola

Politécnica da Universidade de São Paulo para obtenção do título de Mestre em Engenharia Elétrica

Área de Concentração:

Sistemas Elétricos de Potência

Orientador:

Prof. Dr. Luiz Natal Rossi 
Este exemplar foi revisado e alterado em relação à versão original, sob responsabilidade única do autor e com a anuência de seu orientador.

São Paulo, 21 de outubro de 2009

Assinatura do autor

Assinatura do orientador

FICHA CATALOGRÁFICA

Pizeta, Evandro Gonçalves

Análise da regulamentação do suprimento de energia elétrica aos pólos industriais como fator de competitividade / E.G.

Pizeta. -- São Paulo, 2009.

p.

Dissertação (Mestrado) - Escola Politécnica da Universidade de São Paulo. Departamento de Engenharia de Energia e Automação Elétricas.

1.Indústrias 2.Pólo industrial 3.Clusters 4.Energia elétrica 5.Planejamento energético 6.Política de desenvolvimento 7.Tarifas I.Universidade de São Paulo. Escola Politécnica. Departamento de Engenharia de Energia e Automação Elétricas II. t. 


\section{DEDICATÓRIA}

Aos meus pais João e Áurea

e a minha esposa Lindsay. 


\section{AGRADECIMENTOS}

Aos meus pais que sempre me incentivaram a estudar e a me desenvolver profissionalmente.

A minha esposa Lindsay por todo incentivo e compreensão pelos sábados e domingos dedicados à dissertação.

Ao meu orientador, Prof. Dr. Luiz Natal Rossi, por todo o seu suporte e contribuições ao longo da elaboração deste trabalho.

Ao Marcos Vinícius Gusmão do Nascimento, pelas contribuições e em especial pela a confiança depositada em mim para atuar como representante da Braskem S.A. e como coordenador do Grupo de Trabalho de pólos industriais instituído na Associação Brasileira dos Grandes Consumidores de Energia Elétrica e Consumidores Livres - ABRACE.

Ao pessoal da ABRACE, em especial ao presidente Ricardo Lima, pela permissão de utilização dos estudos de pólos industriais desenvolvidos nesta associação.

À Ana Carla Petti, pelas contribuições e sugestões no desenvolvimento dos trabalhos, principalmente na fase de conclusão da dissertação.

Ao Taurus, meu cachorro, que sempre me acompanhou e me deu alegria durante as madrugadas de trabalho. 


\section{RESUMO}

Os pólos industriais são uma realidade no Brasil, mas, do ponto de vista da legislação, carecem de um tratamento específico e claro, particularmente com relação ao compartilhamento da infra-estrutura e aquisição de insumos energéticos. A falta de clareza na regulamentação brasileira abre espaço para interpretações divergentes com relação ao suprimento energético, que muitas vezes acaba prejudicando a captura de sinergias e ganhos de escala nos pólos industriais, principalmente para as empresas menores. Este cenário gera incerteza com relação aos preços finais de energia e reduz, de forma artificial, os benefícios inerentes à formação de pólos industriais. A adequação na legislação do setor elétrico brasileiro é fundamental para se criar um ambiente regulatório que defina de forma clara e objetiva soluções para a questão energética nos pólos industriais. Neste trabalho apresentam-se proposições de inovações na legislação do setor elétrico brasileiro que poderiam criar um ambiente regulatório transparente e seguro às empresas, no que se refere ao suprimento elétrico, compartilhamento de infra-estrutura e aquisição de energia elétrica em pólos industriais. As inovações propostas preservam as condições de suprimento elétrico dos pólos existentes e também incentivam a criação de novos pólos.

Palavras-chave: Pólo industrial, cluster, indústria, competitividade, infra-estrutura, energia, suprimento elétrico, transmissão, distribuição, tarifa, encargos, tributos 


\begin{abstract}
Industrial cluster systems are a reality in Brazil but Brazilian electric regulation does not have a specific and clear treatment about industrial cluster electric supply, especially regarding infra-structure common usage and group energy purchase.

This lack of regulation generates a scenario of uncertainty about the energy costs for companies placed in Industrial cluster systems, and reduce, in an artificial way, the advantages that industrial clusters naturally has.

The modification in Brazilian electric regulation is fundamental to define energy policies aspects for industrial clusters, to provide a safe environmental for existents industrial clusters and to generate conditions to create new ones.

In this dissertation, innovations in Brazilian electric regulation are presented aiming to create a safe and clear environmental for industrial clusters.

The proposed innovations preserve the electric supply conditions for the existents industrial clusters and support the creation of new sites, where two or more industries can share electric infra-structure and purchase energy together.
\end{abstract}

Key-words: Industry, cluster, infra-structure, energy, electric supply, transmission, distribution, tariff, levies, taxes 


\section{LISTA DE ILUSTRAÇÕES}

Figura 1 - Formas de acesso ao SIN para geradores e consumidores 22

Figura 2 - Esquemático dos componentes da tarifa final de um consumidor livre conectado ao sistema de distribuição .29

Figura 3 - Componentes da tarifa global de energia de um consumidor cativo. 30

Figura 4 - Componentes da tarifa global de energia de um consumidor livre 31 Figura 5 - Componentes da tarifa global de energia de um consumidor na Rede Básica

Figura 6 - Exemplo da composição da tarifa de um consumidor industrial conectado na Eletropaulo em $138 \mathrm{kV}$

Figura 7 - Comparativo de TUST e TUSD de algumas distribuidoras de energia elétrica (Valores incluem Fio e Encargos Setoriais)

Figura 8 - Análise de sensibilidade da economia anual com migração à Rede Básica em virtude da variação de demanda e tarifa reduzida (Fator de Carga de 92\% Ponta e F. Ponta). 39

Figura 9 - Comparativo de TUSD de algumas distribuidoras de energia elétrica......44

Figura 10 - Comparativo de TUSD de algumas distribuidoras de energia elétrica ....45

Figura 11 - Comparativo de TUSD de algumas concessionárias de distribuição......45

Figura 12 - Comparativo de TUSD de algumas distribuidoras de energia elétrica ....46

Figura 13 - Comparativo de TUSD de algumas distribuidoras de energia elétrica ....46

Figura 14 - Evolução da criação de encargos setoriais 48

Figura 15 - Evolução da arrecadação dos encargos setoriais e do mercado de energia elétrica.

Figura 16 - Aumento acumulado da arrecadação dos encargos setoriais e do mercado de energia elétrica

Figura 17 - Evolução da arrecadação de ICMS total e sobre energia elétrica. 56

Figura 18 - Aumento acumulado da arrecadação de ICMS e do mercado de energia elétrica.

Figura 19 - Evolução das tarifas finais de energia em alguns países (Base: 2007) Valores finais incluindo impostos. Taxa de câmbio de 2007 em 2,11 R \$/US\$. 59

Figura 20 - Comparação da matriz de geração de energia elétrica do Brasil, EUA França 
Figura 21 - Comparação dos custos médios de geração por fonte 60

Figura 22 - Evolução da participação dos encargos e tributos como parte da tarifa de energia

Figura 23 - Comparação da carga tributária tarifa final de energia elétrica de alguns países industrializados (Base 2007).

Figura 24 - Crescimento das tarifas finais de energia elétrica de 2002 a 2007 em alguns países.

Figura 25 - Composição do mercado de energia elétrica do Brasil, Estados Unidos e Alemanha

Figura 26 - Ciclo de desenvolvimento dos pólos industriais ..............................72

Figura 27 - Mapa de pólos industriais nos EUA .............................................. 75

Figura 28 - Mapa de pólos industriais em Portugal ..........................................77

Figura 29 - Mapa de pólos industriais no Japão ..........................................78

Figura 30 - Mapa de pólos industriais na Coréia do Sul .....................................79

Figura 31 - Resumo de algumas políticas de incentivos à pólos industriais nos Estados Unidos, Canadá, Europa e Ásia ...................................................... 81

Figura 32 - Esquemático de reestruturações societárias de um caso específico .....83

Figura 33 - Vista aérea do Pólo Petroquímico de Triunfo - RS ............................8

Figura 34 - Esquemático do Pólo Petroquímico de Camaçari - BA .......................90

Figura 35: Esquemático simplificado do fluxo de energia elétrica no Pólo $E$...........95

Figura 36 - Fatores de atração de empresas................................................101

Figura 37: Exemplo genérico de um pólo industrial onde há compartilhamento de subestação transformadora

Figura 38: Esquemático do entendimento da ANEEL para acesso de consumidor diretamente à Rede Básica (Anterior ao Decreto $\left.N^{\circ} 5597 / 2005\right)$. 121

Figura 39: Esquemático do entendimento da ANEEL para acesso de consumidor à Rede Básica via distribuidora (Anterior ao Decreto N5597/2005). 122

Figura 40: Análise comparativa do DEC 129

Figura 41: Análise comparativa do FEC 129

Figura 42: Esquemático das Poligonais definidas no Acordo Operacional celebrado entre COPENE e COELBA no Pólo Petroquímico de Camaçari

Figura 43: Detalhamento do atendimento elétrico definido no Acordo Operacional celebrado entre COPENE e COELBA no Pólo Petroquímico de Camaçari 131 


\section{LISTA DE TABELAS}

Tabela 1 - Resumo da evolução do setor elétrico brasileiro.....................................21

Tabela 2 - Resumo dos critérios para um consumidor se tornar livre ......................24

Tabela 3 - Resumo dos componentes da tarifa final de energia elétrica ...................28

Tabela 4 - Critérios de classificação dos consumidores em função da tensão de conexão.

Tabela 5 - Modalidades de tarifas de fornecimento para consumidores cativo do Grupo A. 35

Tabela 6 - Comparação entre TUST e TUSD A2 de algumas distribuidoras de energia elétrica

Tabela 7 - Comparação entre TUST e TUSD A3 de algumas distribuidoras de energia elétrica.

Tabela 8 - Comparação entre TUST e TUSD A3a de algumas distribuidoras de energia elétrica.

Tabela 9 - Comparação entre TUST e TUSD A4 de algumas distribuidoras de energia elétrica. .43

Tabela 10 - Encargos setoriais incidentes nas tarifas de energia. 49

Tabela 11 - Tributos incidentes sobre energia elétrica 53

Tabela 12 - Análise da arrecadação de ICMS sobre energia elétrica e do mercado de energia

Tabela 13 - Comparação da evolução das tarifas médias de energia elétrica do setor industrial de alguns países

Tabela 14 - Comparação da evolução das tarifas médias industriais e residenciais de alguns países

Tabela 15 - Comparação dos aumentos das tarifas médias de energia elétrica do setor industrial de alguns países

Tabela 16 - Benefícios que os pólos industriais podem proporcionar a sociedade e às empresas.

Tabela 17 - Características de suprimento elétrico do Pólo Petroquímico de Triunfo

Tabela 18 - Características de suprimento elétrico do Pólo Petroquímico de Camaçari 89

Tabela 19 - Características de suprimento elétrico do Pólo A. 
Tabela 20 - Características de suprimento elétrico do Pólo B ..............................92

Tabela 21 - Características de suprimento elétrico do Pólo C .............................93

Tabela 22 - Características de suprimento elétrico do Pólo D ..............................94

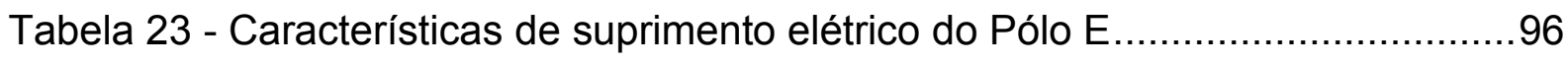

Tabela 24 - Resumo das principais características dos pólos industriais estudados 


\section{LISTA DE ABREVIATURAS E SIGLAS}

ABRACE Associação Brasileira dos Grandes Consumidores de Energia Elétrica e Consumidores Livres

ABRADEE Associação Brasileira de Distribuidores de Energia Elétrica

ACL Ambiente de Contratação Livre

ACR Ambiente de Contratação Regulada

ANEEL Agência Nacional de Energia Elétrica

AGU Advocacia Geral da União

APE Autoprodutor de energia

BACEN Banco Central do Brasil

CCEAR Contrato de Comercialização de Energia no Ambiente Regulado

CCEE Câmara de Comercialização de Energia Elétrica

CCC Conta Consumo de Combustíveis Fósseis

CCD Contrato de Conexão à Distribuição

CCT Contrato de Conexão à Transmissão

CDE Conta de Desenvolvimento Energético

CDI Conselho de Desenvolvimento Industrial

CEEE Companhia Estadual de Energia Elétrica

CHESF Companhia Hidro Elétrica do São Francisco

CMSE Comitê de Monitoramento do Sistema Elétrico

CNPE Conselho Nacional de Política Energética

COELBA Companhia de Eletricidade do Estado da Bahia

COFIC Comitê de Fomento Industrial de Camaçari

COFINS Contribuição para o Financiamento da Seguridade Social

COFURH Compensação Financeira pelo Uso dos Recursos Hídricos

COPEC Complexo Petroquímico de Camaçari

COPENE Petroquímica do Nordeste

CPFL Companhia Paulista de Força e Luz

CSPG Concessionário do Serviço Público de Geração

CTEEP Companhia de Transmissão de Energia Elétrica Paulista

CUSD Contrato de Uso dos Sistemas de Distribuição

CUST Contrato de Uso dos Sistemas de Transmissão

CVA Conta de Variação de Valores da Parcela A

CVM Comissão de Valores Imobiliários 
DIT Demais Instalações de Transmissão

DEC Duração equivalente de interrupção por conjunto de consumidores.

EIA Energy Information Administration

EPE Empresa de Pesquisa Energética

ESS Encargos de Serviços do Sistema

FEC Freqüência equivalente de interrupções por conjunto de consumidores

GCPS Grupo Coordenador do Planejamento dos Sistemas Elétricos

ICMS Imposto sobre a Circulação de Mercadorias e Serviços

IEA International Energy Agency

MDIC Ministério do Desenvolvimento da Indústria e Comércio

MAE Mercado Atacadista de Energia

MME Ministério de Minas e energia

MIN Ministério da Integração

ONS Operador Nacional do sistema Elétrico

O\&M Operação e Manutenção

$\mathrm{PCH} \quad$ Pequena Central Hidrelétrica

P\&D Pesquisa e Desenvolvimento

PIB Produto Interno Bruto

PIE Produtor Independente de Energia

PIS Programas de Integração Social

PRODIST Procedimentos de Distribuição de Energia Elétrica no Sistema Elétrico Nacional

PROINFA Programa de Incentivo a Fontes Alternativas de Energia

RGR Reserva Global de Reversão

SCT Superintendência de Regulação dos Serviços de Transmissão

SRD Superintendência de Regulação dos Serviços de Distribuição

SIN Sistema Interligado Nacional

SPG Serviço Público de Geração

STF Supremo Tribunal Federal

TFSEE Tarifa de Fiscalização dos Serviços de Energia Elétrica

TUSD Tarifa de Uso dos Sistemas de Distribuição

TUST Tarifa de Uso dos Sistemas de Transmissão 
1 - RESUMO DA ESTRUTURA DO SETOR ELÉTRICO BRASILEIRO.................19

1.1 - Histórico da Evolução do Setor Elétrico …………....................................19

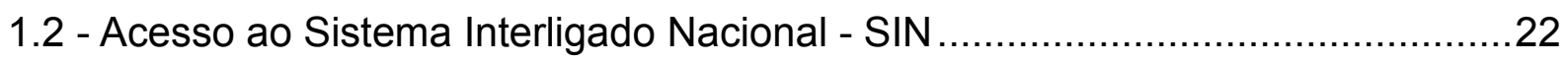

1.3 - Ambientes de Contratação de Energia Elétrica...............................................23

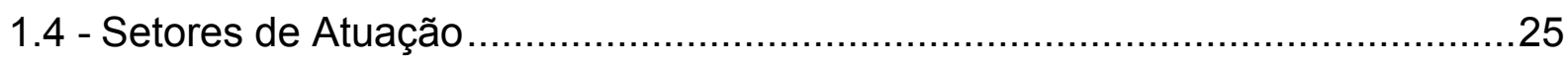

2 - ANÁLISE DAS TARIFAS DE ENERGIA ELÉTRICA …...............................27

2.1 - Visão Geral da Tarifa de Energia de Consumidores Industriais .......................27

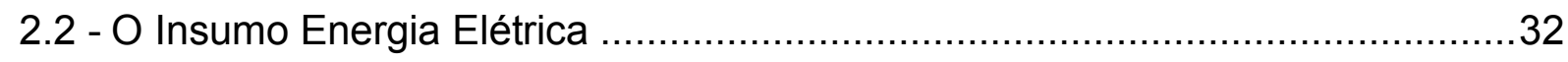

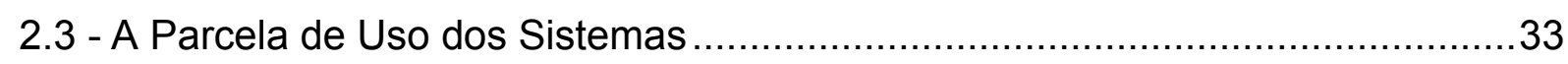

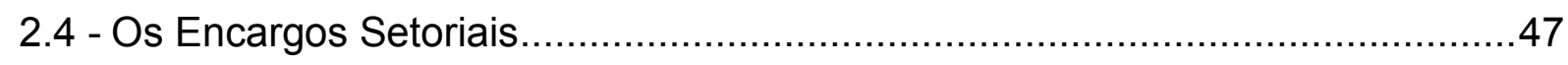

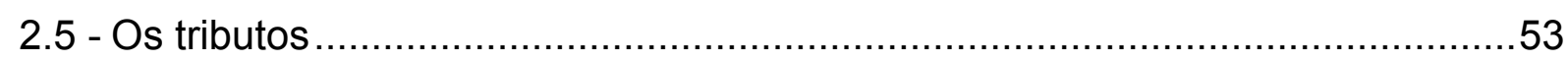

3 - ANÁLISE DAS TARIFAS INDUSTRIAIS DE ENERGIA ELÉTRICA EM

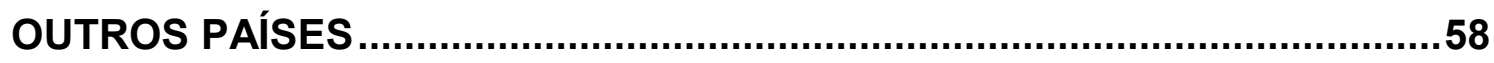

4 - PRINCIPAIS BENEFícIOS INERENTES À FORMAÇÃO DE PÓLOS

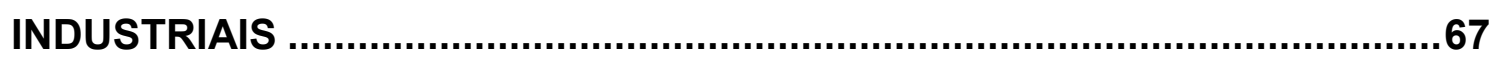

5 - POLÍtICAS INTERNACIONAIS DE SUPRIMENTO ENERGÉTICO A PÓLOS INDUSTRIAIS

6 - SUPRIMENTO DE ENERGIA ELÉTRICA AOS PÓLOS INDUSTRIAIS BRASILEIROS.

7 - PRINCIPAIS OBSTÁCULOS AO DESENVOLVIMENTO DE PÓLOS INDUSTRIAIS ENVOLVENDO A QUESTÃO ENERGÉTICA..........................99 
8 - PRINCIPAIS PONTOS DE DIVERGÊNCIAS ENTRE SETOR INDUSTRIAL E CONCESSIONÁRIAS DE DISTRIBUIÇÃO DE ENERGIA ELÉTRICA ..........109

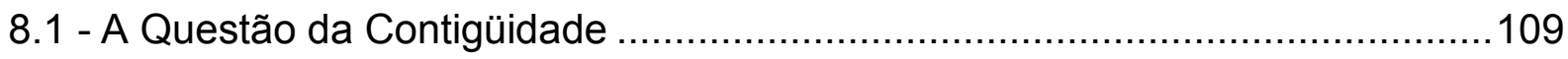

8.2 - A Questão do Monopólio dos Serviços de Distribuição de Energia Elétrica....114

8.3 - Propriedade de Redes Elétricas Particulares ............................................120

8.4 - A Aquisição Conjunta de Energia ..........................................................124

9 - EXEMPLO DE CASO DE CONFLITO ENTRE INDÚSTRIA E CONCESSIONÁRIA DE DISTRIBUIÇÃO....................................................127

10 - PROPOSIÇÃO DE REGULAMENTAÇÃO SOBRE PÓLOS INDUSTRIAIS ABORDANDO A QUESTÃO ENERGÉTICA.

11 - CONCLUSÃO

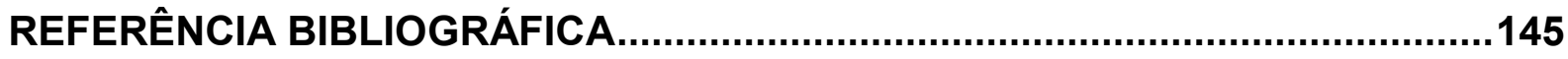

ANEXOS 


\section{INTRODUÇÃO}

O agrupamento de empresas em pólos industriais tem sido utilizado por diversos países, ao longo dos anos, como uma importante estratégia para fomentar o desenvolvimento econômico.

A criação de pólos industriais propicia a concentração de investimento em torno de uma cadeia produtiva que beneficia a sociedade em geral e, conseqüentemente, gera riquezas e crescimento econômico ao país, principalmente para regiões menos favorecidas.

Dentre os benefícios inerentes à criação de pólos industriais, podem-se citar: (i) desenvolvimento de infra-estrutura, como rodovias, portos, aeroportos e saneamento; (ii) geração de empregos diretos e indiretos, (iii) incentivos à realização de investimentos em educação para qualificação da mão de obra local; (iv) aumento da arrecadação de impostos aos municípios e estados, com posterior aplicação destes impostos na geração de benefícios à sociedade.

A fim de garantir os benefícios que um pólo industrial possa gerar, o mesmo deve prover às empresas nele instaladas condições favoráveis de operação, principalmente no que se refere ao compartilhamento de infra-estrutura, em especial de redes elétricas de transporte de energia. Para que estas condições possam ser asseguradas, é fundamental a existência no setor elétrico de uma legislação clara que ofereça a segurança de retorno dos investimentos realizados pelas empresas que se instalam nos pólos industriais.

No Brasil, os pólos industriais são uma realidade, mas carecem de um tratamento específico e claro, particularmente com relação ao compartilhamento da infraestrutura e aquisição de insumos energéticos. A falta de clareza na regulamentação abre espaço para interpretações divergentes com relação ao suprimento elétrico, que muitas vezes acaba prejudicando a captura de sinergias e ganhos de escala em pólos industriais, principalmente para as empresas menores.

Políticas de incentivo aos pólos industriais no Brasil devem ser analisadas criteriosamente, devido à complexidade e particularidade das questões regulatórias envolvendo o compartilhamento de infra-estrutura elétrica e a construção de redes elétricas privativas. 
O Brasil é um país que apresenta uma elevada carga de encargos setoriais e tributos nos preços finais de energia, sendo que a parcela relacionada ao uso dos sistemas, em especial dos sistemas de distribuição, configura-se como um item significativo nos preços finais de energia.

O simples compartilhamento de infra-estrutura elétrica por duas ou mais indústrias na forma de um pólo industrial não necessariamente proporciona a competitividade necessária para que as indústrias se instalem. A classificação da indústria em relação à aquisição de energia elétrica (se consumidor livre ou cativo) e a classe de faturamento (Rede Básica, A1, A2 etc.), em muitos casos, influenciam na competitividade das empresas e na decisão de se instalar ou não no Brasil.

A falta de regulamentação em relação ao suprimento elétrico gera um cenário de incerteza que, na maioria dos casos, traz insegurança e dúvida às indústrias em relação aos preços finais de energia. Isto faz com que os benefícios naturais inerentes à formação de pólos industriais sejam ameaçados pela falta de transparência na legislação do setor elétrico.

A estruturação de uma regulamentação na legislação do setor elétrico que estabeleça de forma clara e objetiva a questão energética nos pólos industriais é fundamental para manter a competitividade dos pólos existentes, bem como para criar condições para o estabelecimento de novos pólos industriais no Brasil. Enquadra-se dentro deste tema a defesa da competitividade da indústria nacional pelo compartilhamento de infra-estruturas.

Diante do cenário exposto, o presente trabalho tem como objetivo analisar a regulamentação do suprimento de energia elétrica aos pólos industriais no Brasil, identificando alguns dos obstáculos relacionados à questão energética que inibem o desenvolvimento dos pólos existentes e a criação de novos pólos. O trabalho foi desenvolvido também com intuito de apresentar inovações na legislação do setor elétrico que contribuam para aumentar a competitividade do setor industrial no Brasil.

A presente dissertação está estruturada da seguinte forma.

O Capítulo 1 apresenta uma breve descrição da estrutura do setor elétrico brasileiro, fundamental para o correto entendimento das discussões acerca das características dos pólos industriais envolvendo o suprimento de energia elétrica, bem como dos riscos regulatórios enfrentados pelos pólos existentes no Brasil. 
No Capítulo 2 é feita uma análise das tarifas de energia elétrica de consumidores industriais, apresentando a descrição de suas parcelas e estratégias de redução das mesmas.

Um estudo da evolução da tarifa final de energia elétrica no Brasil do setor industrial é apresentado no Capítulo 3, onde também é efetuada uma análise comparativa com as tarifas de alguns países industrializados.

O Capítulo 4 apresenta os principais benefícios inerentes aos pólos industriais e no Capítulo 5 são descritos alguns casos internacionais onde políticas de incentivos a pólos industriais foram aplicadas com resultados importantes.

Uma abordagem das características diversas dos pólos industriais em operação no Brasil enfocando questão de suprimento elétrico é apresentada no Capítulo 6. Esta abordagem é fundamental para o entendimento dos principais obstáculos enfrentados pelos pólos industriais existentes no Brasil, os quais são apresentados no Capítulo 7.

No Capítulo 8 são descritos os principais pontos de divergências entre indústrias e concessionárias de distribuição de energia elétrica, os quais afetam os pólos industriais em operação no Brasil.

Um exemplo prático de divergências entre indústria e concessionária de distribuição de energia elétrica é relatado no Capítulo 9, em que é abordado o caso do Pólo Petroquímico de Camaçari, para o qual existe um processo administrativo em andamento na ANEEL envolvendo a Braskem S.A., empresa líder do pólo, e a Companhia de Eletricidade do Estado da Bahia - COELBA, distribuidora local.

Por último, são descritas no Capítulo 10 algumas proposições de inovações regulatórias na legislação do setor elétrico que poderiam auxiliar na competitividade dos pólos industriais existentes e viabilizar a criação de novos pólos. 


\section{1 - RESUMO DA ESTRUTURA DO SETOR ELÉTRICO BRASILEIRO}

Este capítulo apresenta uma breve descrição da evolução do setor elétrico brasileiro, sendo relacionados os principais pontos da estrutura do novo modelo com intuito de facilitar o entendimento das questões regulatórias inerentes aos pólos industriais que serão abordadas posteriormente nos Capítulos 5 e 7.

\section{1 - Histórico da Evolução do Setor Elétrico}

Neste item é apresentada uma breve descrição da evolução do setor elétrico brasileiro, que passou de uma estrutura verticalizada sob o domínio do governo para uma estrutura desverticalizada com inserção de competição em alguns setores, como o de geração e comercialização. O histórico aqui apresentado foi baseado nas informações disponibilizadas no site da Câmara de Comercialização de Energia Elétrica - CCEE ${ }^{1}$.

O modelo atual do Setor Elétrico Brasileiro começou a ser estruturado no ano de 1993, com a publicação da Lei №8.631 de 04.03.1993, que, dentre outras disposições, extinguiu a equalização tarifária vigente até então e criou os contratos de suprimento entre geradores e distribuidores de energia elétrica.

Em seguida veio a Lei $n^{\circ} 8.987$, de 13.02.1995, que, dentre outras providências, dispôs sobre o regime de concessão e permissão da prestação de serviços públicos previstos no Artigo $\mathrm{N}^{\circ} 175$ da Constituição Federal.

No mesmo ano foi publica a Lei № 9.074, de 07.07.1995, a qual estabeleceu normas para outorga e prorrogações das concessões e permissões de serviços públicos, criando a figura do Produtor Independente de Energia - PIE e o conceito de Consumidor livre.

Em 1996, sob a coordenação do Ministério de Minas e Energia - MME, foi implantado o Projeto de Reestruturação do Setor Elétrico Brasileiro (Projeto RESEB). Neste projeto a empresa Coopers \& Lybrand foi contratada para analisar e propor as mudanças no setor elétrico, com participação também de diversos técnicos brasileiros com experiência no assunto.

\footnotetext{
${ }^{1}$ www.ccee.org.br (Acesso em abril de 2009)
} 
O projeto RE-SEB foi concluído em agosto de 1998 e teve como conclusões principais a necessidade de implementar a desverticalização das empresas de energia elétrica do Brasil, dividindo-as nos segmentos de geração, transmissão e distribuição, incentivar a competição nos segmentos de geração e comercialização e manter sob regulação os setores de distribuição e transmissão de energia elétrica, considerados como monopólios naturais. Identificou-se também a necessidade de se criar um órgão regulador, um operador para o sistema elétrico nacional e um ambiente para realização das transações de compra e venda de energia elétrica A partir de então várias alterações na legislação foram instituídas por meio de leis, decretos, resoluções etc. com a finalidade de avançar com as mudanças no modelo do setor elétrico brasileiro. Foram criados a Agência Nacional de Energia Elétrica ANEEL, o Operador Nacional do Sistema Elétrico - ONS e o Mercado Atacadista de Energia - MAE, o qual foi posteriormente substituído pela CCEE.

A consolidação do novo modelo do setor elétrico brasileiro ocorreu no ano de 2004 , com a publicação das Leis № 10.847 e 10.848, ambas de 15.03.2004, e posterior publicação do Decreto No 5163, de 30.07.2004.

A Lei No 10.847/2004 instituiu a Empresa de Pesquisa Energética - EPE, que tem como função realizar pesquisas e estudos voltados ao planejamento do setor energético.

A Lei N $N^{0} 10.848 / 2004$ dispôs sobre a comercialização de energia elétrica e alterou uma série de regulamentações anteriores, visando adequá-las aos critérios do novo modelo do setor elétrico. O Decreto $N^{\circ} 5.163 / 2004$ regulamentou a comercialização de energia elétrica, o processo de outorga de concessões e de autorizações de geração de energia elétrica e deu outras providências.

Após a criação de uma agência reguladora (ANEEL) e um operador do sistema elétrico (ONS), o governo prosseguiu com a criação de uma instituição responsável pela realização de pesquisas e estudos voltados ao planejamento energético (a Empresa de Pesquisa Energética - EPE) e uma instituição com a função de avaliar a segurança do suprimento elétrico (o Comitê de Monitoramento do Sistema Elétrico CMSE).

Foi criada também a CCEE, a qual deu continuidade às atividades do MAE, relacionadas à comercialização de energia elétrica. $A$ tabela seguinte apresenta um resumo da evolução do setor elétrico. 
Tabela 1 - Resumo da evolução do setor elétrico brasileiro

\begin{tabular}{|c|c|c|}
\hline $\begin{array}{l}\text { Modelo Antigo } \\
\text { (até 1995) }\end{array}$ & $\begin{array}{l}\text { Modelo de Livre Mercado } \\
\text { (1995 a 2003) }\end{array}$ & $\begin{array}{l}\text { Novo Modelo } \\
\text { (a partir de 2004) }\end{array}$ \\
\hline $\begin{array}{l}\text { Financiamento através de recursos } \\
\text { públicos }\end{array}$ & $\begin{array}{l}\text { Financiamento através de recursos } \\
\text { públicos e privados }\end{array}$ & $\begin{array}{l}\text { Financiamento através de recursos } \\
\text { públicos e privados }\end{array}$ \\
\hline Empresas verticalizadas & $\begin{array}{l}\text { Empresas divididas por atividade: } \\
\text { geração, transmissão, distribuição e } \\
\text { comercialização }\end{array}$ & $\begin{array}{l}\text { Empresas divididas por atividade: } \\
\text { geração, transmissão, distribuição, } \\
\text { comercialização, importação e } \\
\text { exportação. }\end{array}$ \\
\hline $\begin{array}{c}\text { Empresas predominantemente } \\
\text { Estatais }\end{array}$ & $\begin{array}{l}\text { Abertura e ênfase na privatização } \\
\text { das Empresas }\end{array}$ & $\begin{array}{c}\text { Convivência entre Empresas } \\
\text { Estatais e Privadas }\end{array}$ \\
\hline $\begin{array}{l}\text { Monopólios - Competição } \\
\text { inexistente }\end{array}$ & $\begin{array}{l}\text { Competição na geração e } \\
\text { comercialização }\end{array}$ & $\begin{array}{l}\text { Competição na geração e } \\
\text { comercialização }\end{array}$ \\
\hline Consumidores Cativos & Consumidores Livres e Cativos & Consumidores Livres e Cativos \\
\hline $\begin{array}{c}\text { Tarifas reguladas em todos os } \\
\text { segmentos }\end{array}$ & $\begin{array}{l}\text { Preços livremente negociados na } \\
\text { geração e comercialização }\end{array}$ & $\begin{array}{l}\text { No ambiente livre: Preços } \\
\text { livremente negociados na geração e } \\
\text { comercialização. No ambiente } \\
\text { regulado: leilão e licitação pela } \\
\text { menor tarifa }\end{array}$ \\
\hline Mercado Regulado & Mercado Livre & $\begin{array}{c}\text { Convivência entre Mercados Livre e } \\
\text { Regulado }\end{array}$ \\
\hline $\begin{array}{l}\text { Planejamento Determinativo - } \\
\text { Grupo Coordenador do } \\
\text { Planejamento dos Sistemas } \\
\text { Elétricos (GCPS) }\end{array}$ & $\begin{array}{c}\text { Planejamento Indicativo pelo } \\
\text { Conselho Nacional de Política } \\
\text { Energética (CNPE) }\end{array}$ & $\begin{array}{l}\text { Planejamento pela Empresa de } \\
\text { Pesquisa Energética (EPE) }\end{array}$ \\
\hline Contratação: $100 \%$ do Mercado & $\begin{array}{c}\text { Contratação : } 85 \% \text { do mercado (até } \\
\text { agosto/2003) e 95\% mercado (até } \\
\text { dez./2004) }\end{array}$ & $\begin{array}{c}\text { Contratação: } 100 \% \text { do mercado + } \\
\text { reserva }\end{array}$ \\
\hline $\begin{array}{l}\text { Sobras/déficits do balanço } \\
\text { energético rateados entre } \\
\text { compradores }\end{array}$ & $\begin{array}{l}\text { Sobras/déficits do balanço } \\
\text { energético liquidados no MAE }\end{array}$ & $\begin{array}{l}\text { Sobras/déficits do balanço } \\
\text { energético liquidados na CCEE. } \\
\text { Mecanismo de Compensação de } \\
\text { Sobras e Déficits (MCSD) para as } \\
\text { Distribuidoras. }\end{array}$ \\
\hline
\end{tabular}

Fonte: Site CCEE (www.ccee.org.br) - Acesso em Abril de 2009 


\section{2 - Acesso ao Sistema Interligado Nacional - SIN}

Um dos pilares fundamentais em todas as reformas no setor elétrico mundial foi a introdução do acesso aberto às redes de transmissão e de distribuição, com o objetivo de permitir o desenvolvimento de diversas opções de suprimento para compradores e vendedores de energia em mercado competitivo. Na maior parte dos países, a transmissão e a distribuição estão submetidas a uma forte regulação técnica e econômica, o que significa estabelecer tarifas de acesso para os usuários dos sistemas.

No Brasil, a Lei № 9.648/1998 estabeleceu que a compra e venda de energia elétrica deve ser contratada separadamente do acesso e do uso dos sistemas de transmissão e distribuição. Este conceito se aplica a todos os usuários do sistema, sejam eles consumidores livres, consumidores cativos, produtores independentes, autoprodutores ou concessionárias de distribuição. Isto significa na prática que, no caso de um autoprodutor, a contratação dos serviços de transporte deve ser feita pelo lado da geração e pelo lado da carga que utilizará esta energia.

As diferenças no tipo de contratação de acesso à Rede Elétrica estão diretamente ligadas ao fato do acessante, seja ele carga ou gerador, estar conectado ao sistema de transmissão (a chamada Rede Básica) ou ao sistema de distribuição. A Figura 1 ilustra, de forma simplificada, as formas de acesso ao SIN de consumidores e geradores.

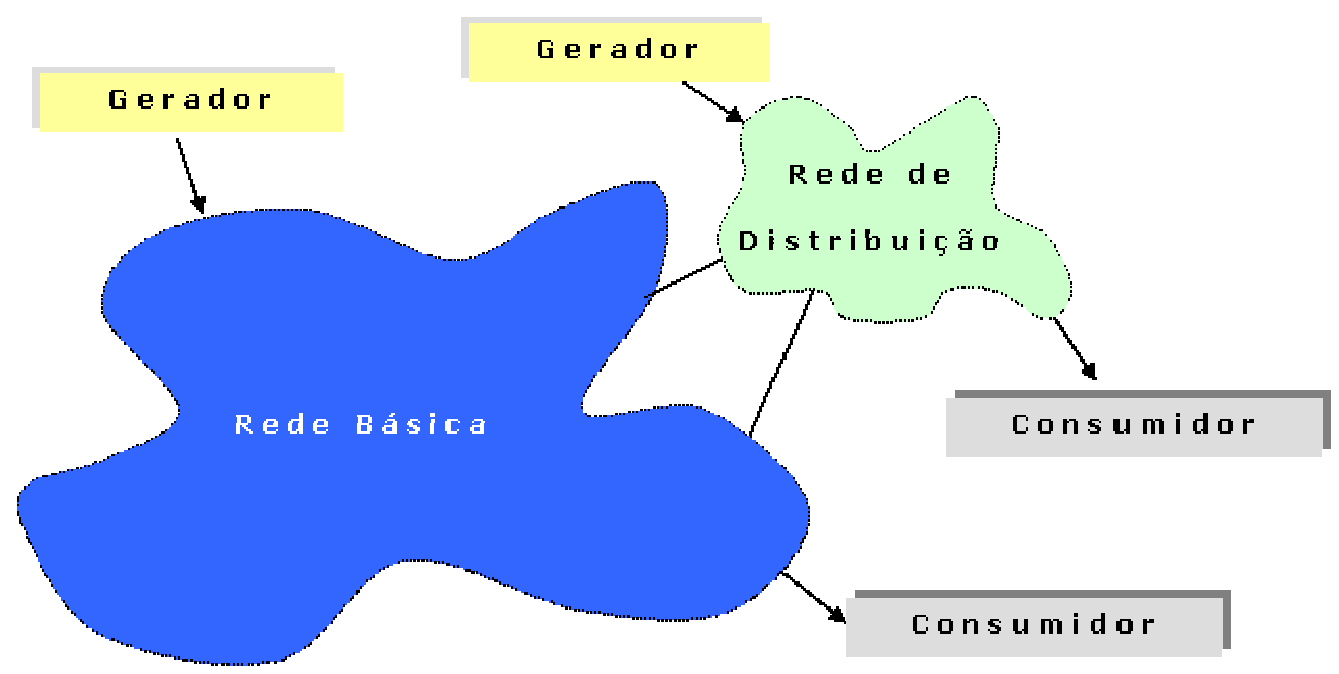

Figura 1 - Formas de acesso ao SIN para geradores e consumidores 
No caso de o acessante estar conectado à Rede Básica, o mesmo deve celebrar o Contrato de Uso do Sistema de Transmissão (CUST) com o ONS, que em nome das empresas de transmissão administra a Rede Básica, e o Contrato de Conexão à Transmissão (CCT) com a sua transmissora local.

De forma análoga, se o acessante estiver conectado ao sistema de distribuição devem ser celebrados os Contratos de Uso do Sistema de Distribuição (CUSD) e de Contrato Conexão à Distribuição (CCD), ambos com o seu distribuidor local.

Tanto na Rede Básica quanto no sistema de distribuição, o acessante deve também celebrar o Acordo Operativo com a transmissora ou distribuidora local.

\section{3 - Ambientes de Contratação de Energia Elétrica}

Dois ambientes de contratação de energia foram instituídos para celebração dos contratos de compra e venda de energia elétrica, são eles: (i) o Ambiente de Contratação Regulada - ACR; (ii) e o Ambiente de Contratação Livre - ACL.

O ACR consiste no segmento do mercado no qual se realizam as operações de compra e venda de energia elétrica entre agentes vendedores e agentes de distribuição, precedidas de licitação, sendo ressalvados os casos previstos em lei, conforme regras e procedimentos de comercialização específicos. A contratação de energia no ACR é formalizada por meio de contratos denominados Contrato de Comercialização de Energia no Ambiente Regulado - CCEAR, celebrados entre cada concessionária ou autorizada de geração e todas as concessionárias, permissionárias e autorizadas do serviço público de distribuição.

O ACL é o segmento do mercado no qual se realizam as operações de compra e venda de energia elétrica objeto de contratos bilaterais livremente negociados, conforme regras e procedimentos de comercialização específicos. No ACL participam os agentes de geração, importadores e exportadores de energia, comercializadores e consumidores livres.

Para que um consumidor possa se tornar livre e escolher seu fornecedor de energia por meio de negociação bilateral, alguns critérios devem ser obedecidos, os quais são estabelecidos pelos Artigos 15 e 16 da Lei Nº 9.074/1995.

Os consumidores que se conectaram ao SIN antes da data de publicação da Lei No 9.074/1995, ou seja, 08.07.1995, podem se tornar livres desde que possuam 
carga igual ou superior à $3 \mathrm{MW}$ e sejam atendidos em tensão igual ou superior à $69 \mathrm{kV}$. Consumidores que se conectaram ao SIN depois de 08.07.1995 podem se tornar consumidores livres desde que possuam carga igual ou superior à $3 \mathrm{MW}$, independente da tensão de suprimento elétrico.

Assim, para consumidores ligados antes 08.07.1995 dois critérios devem ser obedecidos, o de tensão e o de carga, enquanto que para os consumidores novos apenas o critério de carga deve ser obedecido. A tabela seguinte resume os critérios para um consumidor se tornar livre.

Tabela 2 - Resumo dos critérios para um consumidor se tornar livre

\begin{tabular}{ccc}
\hline Data de ligação ao SIN & Tensão & Demanda \\
\hline Antes de 08.07.1995 & $\geq 69 \mathrm{kV}$ & $3 \mathrm{MW}$ \\
\hline Depois de 08.07.1995 & Qualquer tensão & $3 \mathrm{MW}$ \\
\hline
\end{tabular}

Fonte: Artigos 15 e 16 da Lei № 9.074/1995

Posteriormente, o critério para migração de consumidores ao mercado livre foi ampliado pela publicação da Lei No 9.427/1995, que definiu em seu Artigo 26, parágrafo 5 , que um consumidor ou conjunto de consumidores reunidos por comunhão de interesses de fato ou de direito, cuja carga seja maior ou igual a $500 \mathrm{~kW}$, podem se tornar livres desde que adquiram energia proveniente de Pequenas Centrais Hidrelétricas - PCHs ou de fontes alternativas de energia, tais como, biomassa, solar e eólica.

Um consumidor livre conectado ao SIN tem o direito de adquirir energia de quem desejar, porém remunerando a distribuidora ou transmissora local, pelo uso do sistema, o também chamado "Fio". Caso esteja conectado ao sistema de distribuição, o consumidor paga à distribuidora a parcela correspondente ao Fio, por meio da Tarifa de Uso do Sistema de Distribuição - TUSD, e pode comprar energia de qualquer gerador ou comercializador.

O mesmo princípio se aplica a um consumidor conectado diretamente à Rede Básica, porém, neste caso, o consumidor paga apenas a parcela relacionada à 
Tarifa de Uso do Sistema de Transmissão - TUST. Na Rede Básica não há pagamento de TUSD, pois o consumidor não utiliza as redes de distribuição.

\section{4 - Setores de Atuação}

No novo modelo do setor elétrico ocorreu a desverticalização das empresas do setor elétrico, tendo sido desagregadas as atividades de geração, transmissão e distribuição de energia elétrica.

O setor de geração manteve a característica de competição, sendo permitido ao agente de geração vender energia tanto no ACR quanto no ACL. A venda no ACR ocorre por meio de leilões de energia promovidos pela EPE e realizados pela CCEE, por delegação da ANEEL, seguindo as diretrizes determinadas pelo Ministério de Minas e Energia - MME. Nestes leilões são celebrados contratos de compra e venda de energia diretamente entre os geradores e os distribuidores de energia elétrica, sendo vencedores os geradores que ofertarem as menores tarifas.

A venda de energia no ACL ocorre por meio de contratos bilaterais, negociados livremente entre o gerador e o comprador, que pode ser um consumidor ou um comercializador.

Os agentes de geração podem ser classificados em:

- Concessionários do Serviço Público de Geração - CSPG: agente titular de serviço público federal delegado pelo Poder Concedente mediante licitação, na modalidade de concorrência, à pessoa jurídica ou consórcio de empresas para exploração e prestação de serviços públicos de energia elétrica, nos termos da Lei No 8.987 de 13.02.1995;

- Produtor Independente de Energia Elétrica: pessoa jurídica ou empresas reunidas em consórcio que recebam concessão ou autorização para produzir energia elétrica destinada ao comércio de toda ou de parte da energia produzida, por sua conta e risco;

- Autoprodutor de Energia Elétrica: pessoa física ou jurídica ou empresas reunidas em consórcio que recebam concessão ou autorização para produzir energia elétrica destinada ao seu uso exclusivo. 
Ao setor de transmissão coube a administração das instalações de integrantes da Rede Básica e das Demais Instalações de Transmissão, as chamadas DITs. A Rede Básica pode ser definida como sendo uma rede de transmissão sob controle do ONS, com regras operativas definidas nos Procedimentos de Rede, cuja expansão é planejada setorialmente pela EPE e implementada pela ANEEL, mediante licitação de concessão ou autorização. Atualmente os critérios para composição da Rede Básica do SIN são definidos pela Resolução ANEEL № 67, de 08.06.2004. De acordo com o Artigo $3^{\circ}$ desta resolução, integram à Rede Básica:

- Linhas de transmissão, barramentos, transformadores de potência e equipamentos de subestação em tensão igual ou superior a $230 \mathrm{kV}$;

- Transformadores de potência com tensão primária igual ou superior a $230 \mathrm{kV}$ e tensões secundária e terciária inferiores a $230 \mathrm{kV}$, bem como as respectivas conexões e demais equipamentos ligados ao terciário

As instalações da Rede Básica do SIN têm receita autorizada pela ANEEL. Essa receita, juntamente com uma parcela do orçamento do ONS, tributos e eventuais diferenças financeiras de exercício anterior, devem ser cobertos pelos encargos de uso do sistema de transmissão cobrados de todos os usuários. As receitas são revistas anualmente, autorizadas pela ANEEL e representam um impacto direto nas tarifas de uso da transmissão (TUSTs).

As TUSTs nada mais são do que tarifas calculadas por um processo de alocação de custo entre todos os usuários do sistema, necessárias para cobrir toda a receita permitida definida pela ANEEL em resoluções específicas, publicadas usualmente ao final do primeiro semestre de cada ano. A metodologia em vigor, a Resolução ANEEL N ${ }^{\circ} 671 / 2008$, estabelece os valores das TUST e fixa a tarifa de transporte da energia elétrica proveniente de Itaipu Binacional.

Assim como o setor de transmissão, o setor de distribuição também manteve o caráter regulado. À cada distribuidora foi atribuída uma área de concessão, onde a mesma tem o direito de prestar o serviço de distribuição de energia elétrica aos agentes de geração, bem como aos consumidores livre e cativos. 


\section{2 - ANÁLISE DAS TARIFAS DE ENERGIA ELÉTRICA}

O capítulo anterior apresentou de forma simplificada a evolução do setor elétrico brasileiro, que passou de uma estrutura verticalizada sob domínio estatal para uma estrutura desverticalizada com inserção de competição em alguns setores. Foram apresentados os tipos de acesso ao SIN, via sistema de distribuição ou diretamente à Rede Básica, e as formas de remuneração dos sistemas.

A mudança organizacional também promoveu alterações na estrutura tarifária dos consumidores de energia elétrica. Este capítulo apresenta uma análise da tarifa de energia elétrica de consumidores, em especial do setor industrial, sendo descritas as parcelas que compõem tarifa final de energia, bem como indicadas as estratégias possíveis de redução das mesmas.

São apresentadas propostas que poderiam levar a reduções nas tarifas finais de energia, caso as inovações regulatórias aqui apresentadas para a questão energética de pólos industriais fossem postas em prática.

\section{1 - Visão Geral da Tarifa de Energia de Consumidores Industriais}

De forma simplificada, as tarifas de energia são compostas por quatro componentes, a saber: (i) transporte; (ii) energia; (iii) encargos setoriais; e (iv) tributos. A Tabela 3 a seguir apresenta de forma resumida a descrição de cada um dos componentes que integram a tarifa final de energia elétrica de um consumidor. 
Tabela 3 - Resumo dos componentes da tarifa final de energia elétrica

Componente
Descrição

Corresponde ao insumo energia elétrica, podendo ser adquirido no mercado

Energia livre (por meio de contratos bilaterais com geradores ou comercializadores) ou cativo (via distribuidora de energia), bem como ser provido por meio de auto-produção de energia.

Fio

Parcela referente ao uso das redes de transmissão e distribuição para que a energia vendida por um gerador ou adquirida por um consumidor possa circular no sistema. De forma simplificada, a Tarifa Fio pode ser considerado como um aluguel, que é pago pelo usuário para que as redes elétricas estejam disponíveis para seu uso, pagamento este que é proporcional à demanda contratada. Trata-se da contratação da demanda nos horário de ponta e fora ponta.

Encargos Setoriais

Os encargos setoriais são subsídios arrecadados para aplicações específicas relacionadas ao mercado de energia, como por exemplo, incentivar a geração de fontes alternativas, promover a universalização do serviço de energia elétrica, dentre outras.

Tributos

Impostos federais e estaduais aplicados ao transporte e à aquisição de energia elétrica. Os principais tributos sobre energia elétrica são: Imposto sobre a Circulação de Mercadorias e Serviços - ICMS, Programas de Integração Social - PIS e Contribuição para o Financiamento da Seguridade Social - COFINS.

A Figura 2 ilustra a cadeia de incidência dos diversos componentes da tarifa final de energia elétrica à qual um consumidor livre conectado ao sistema de distribuição estaria sujeito. Verifica-se que o consumidor final é responsável pelo pagamento de toda a cadeia de encargos setoriais e tributos incidentes na geração, transmissão e distribuição. 


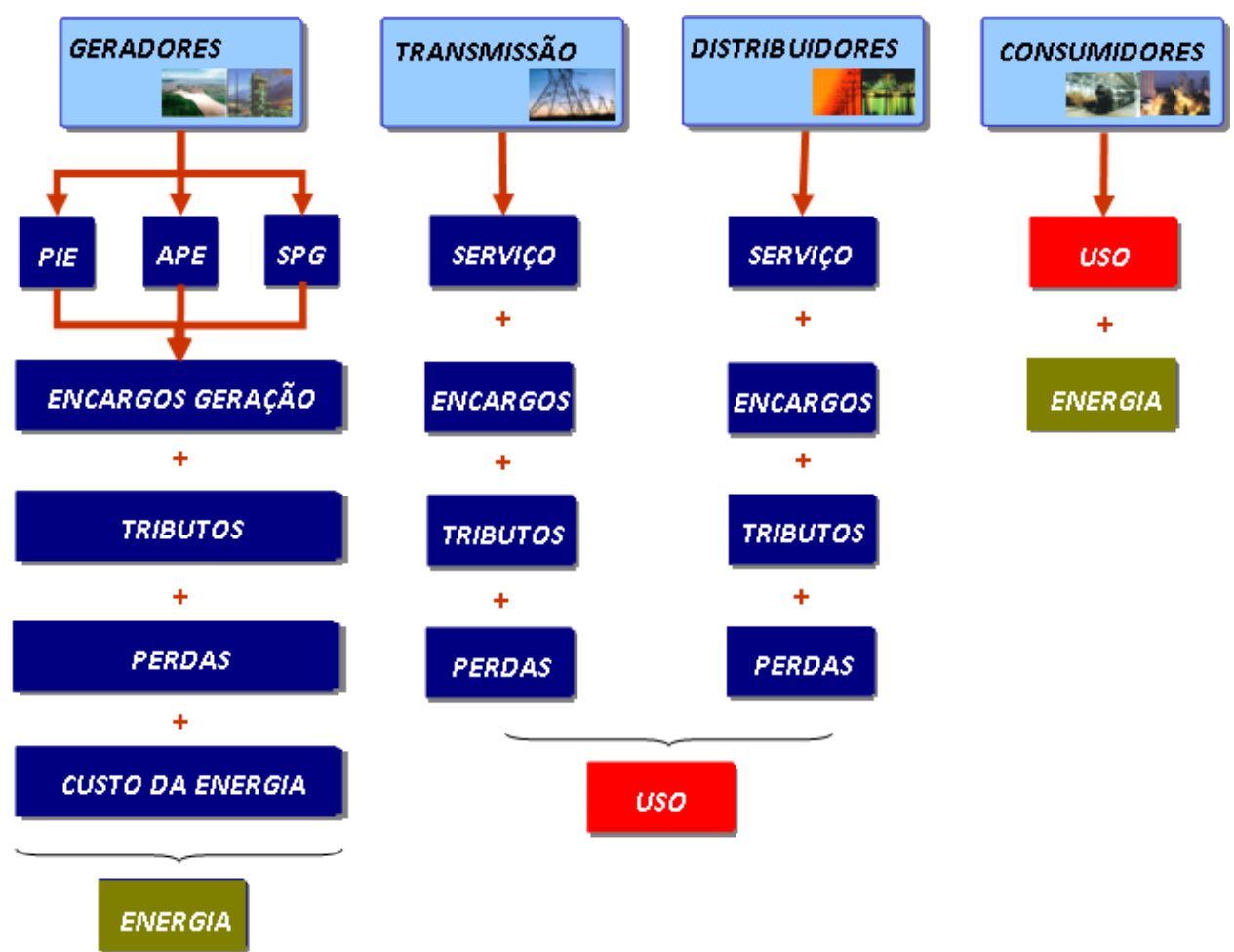

Figura 2 - Esquemático dos componentes da tarifa final de um consumidor livre conectado ao sistema de distribuição

Os itens que compõem a tarifa de uso e energia de consumidores cativos e livres conectados no sistema de distribuição, estabelecidos pelas resoluções da ANEEL, são resumidos na Figura 3 e Figura 4 apresentadas a seguir. Verifica-se que os itens que compõem a Tarifa "Fio" de um consumidor cativo são os mesmos da tarifa de um consumidor livre, havendo diferenciação apenas na parcela relacionada a energia.

De forma análoga, na Figura 5 são apresentados os itens que compõem a tarifa de uso e energia de um consumidor livre atendido via Rede Básica do SIN. Nota-se que um consumidor na Rede Básica não está sujeito ao pagamento de perdas comerciais. O encargo P\&D é cobrado apenas na TUST, não sendo recolhido na parcela correspondente aos encargos, que no caso da Rede Básica, englobam Conta de Consumo de Combustíveis Fósseis - CCC, Conta de Desenvolvimento Energético - CDE e Programa de Incentivo a Fontes Alternativas de Energia PROINFA. 
Nas figuras citadas, a sigla CVA corresponde à conta de Variação de Valores da Parcela $A^{2}$, a qual foi criada em 2001, para registrar as variações ocorridas entre os reajustes tarifários anuais das distribuidoras de energia elétrica, dos valores dos orçados e realizados dos itens da Parcela A das tarifas.

\section{TARIFA DE FORNECIMENTO - CONSUMIIDOR CATIVO}
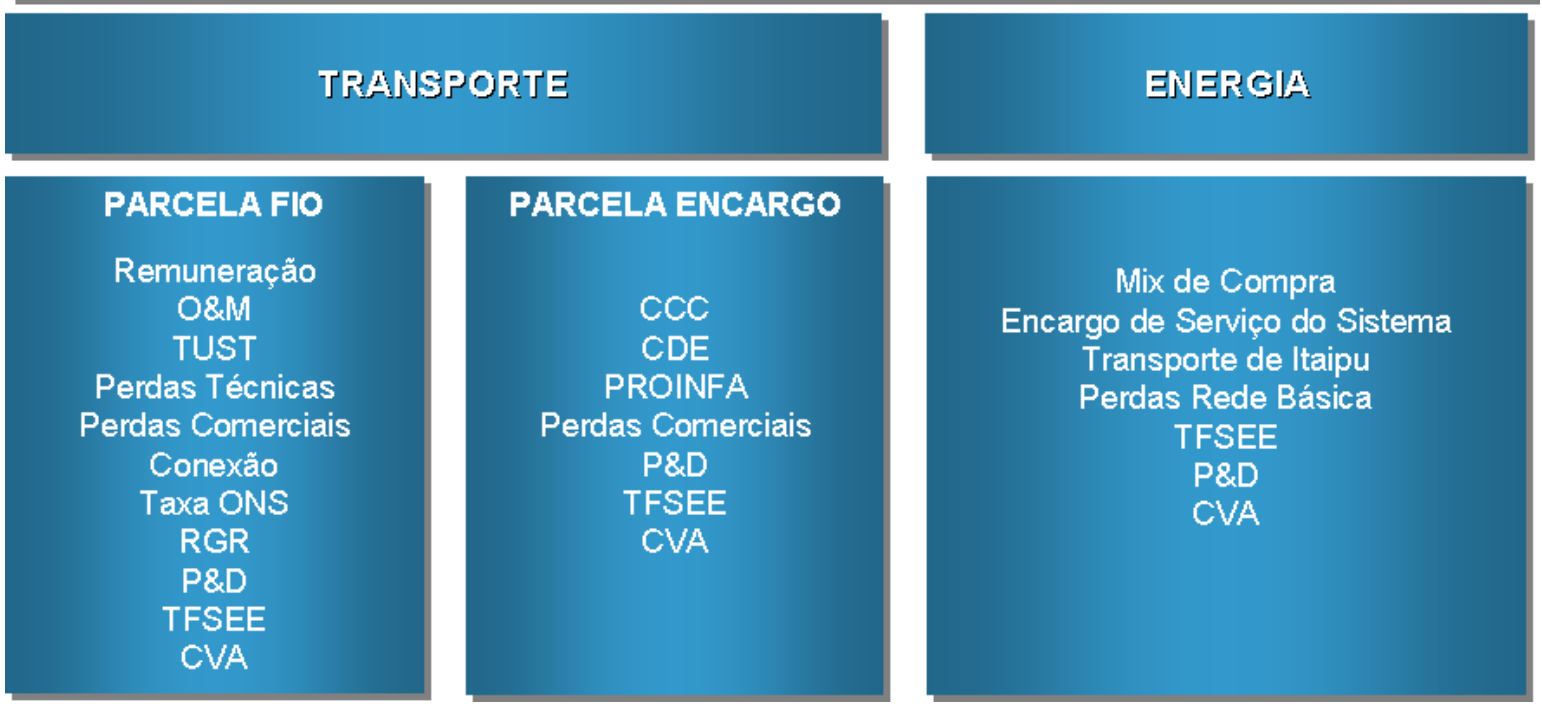

Figura 3 - Componentes da tarifa global de energia de um consumidor cativo (Tarifa final ex-impostos)

\footnotetext{
2 Parcela A da TUSD corresponde ao custo não gerenciável das distribuidoras, compostos pelos encargos setoriais (RGR, P\&D, TFSEE, Taxa ONS, CCC, CDE, PROINFA), perdas elétricas, TUST $T_{R B}, T$ TUST $_{F R}$, uso da rede de outras concessionárias, custo de conexão à transmissão.
} 
TARNFA FINAL - CONSUMIDOR LJVRE
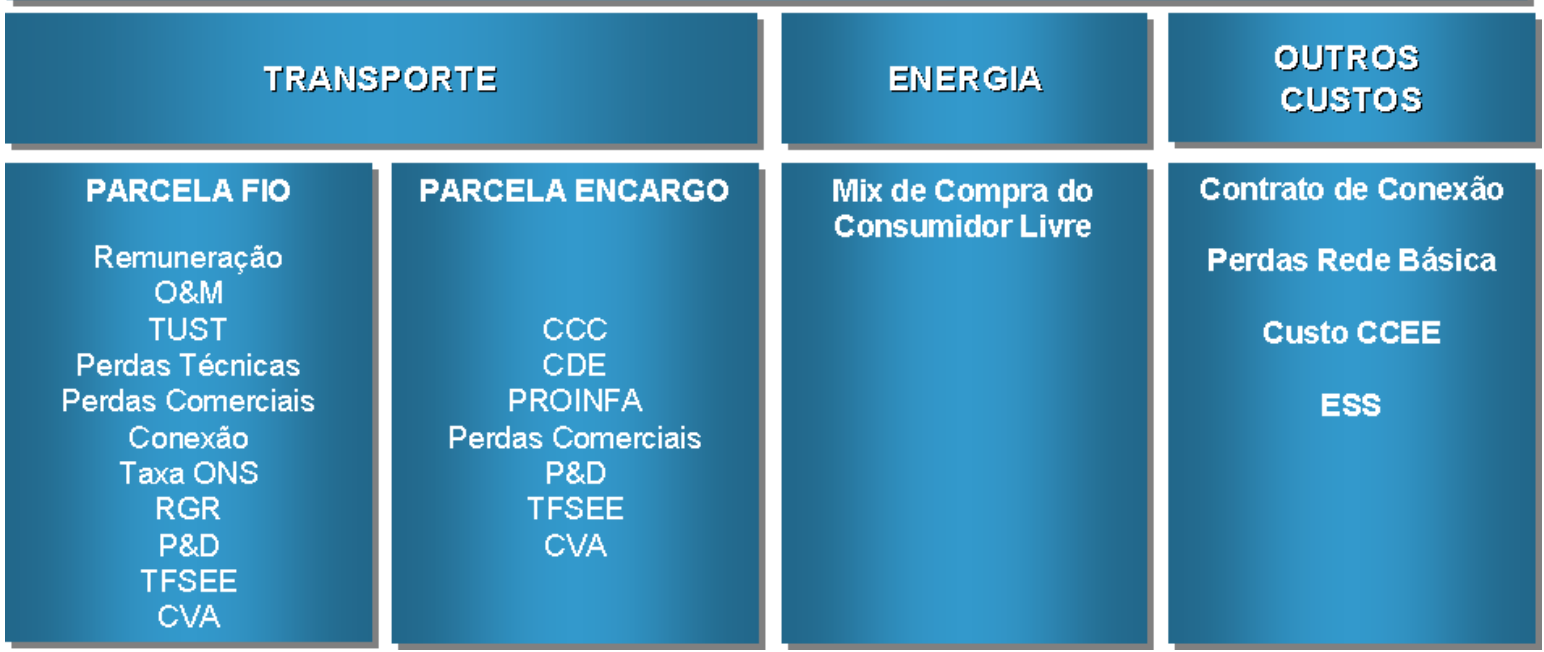

Figura 4 - Componentes da tarifa global de energia de um consumidor livre (Ex-impostos)

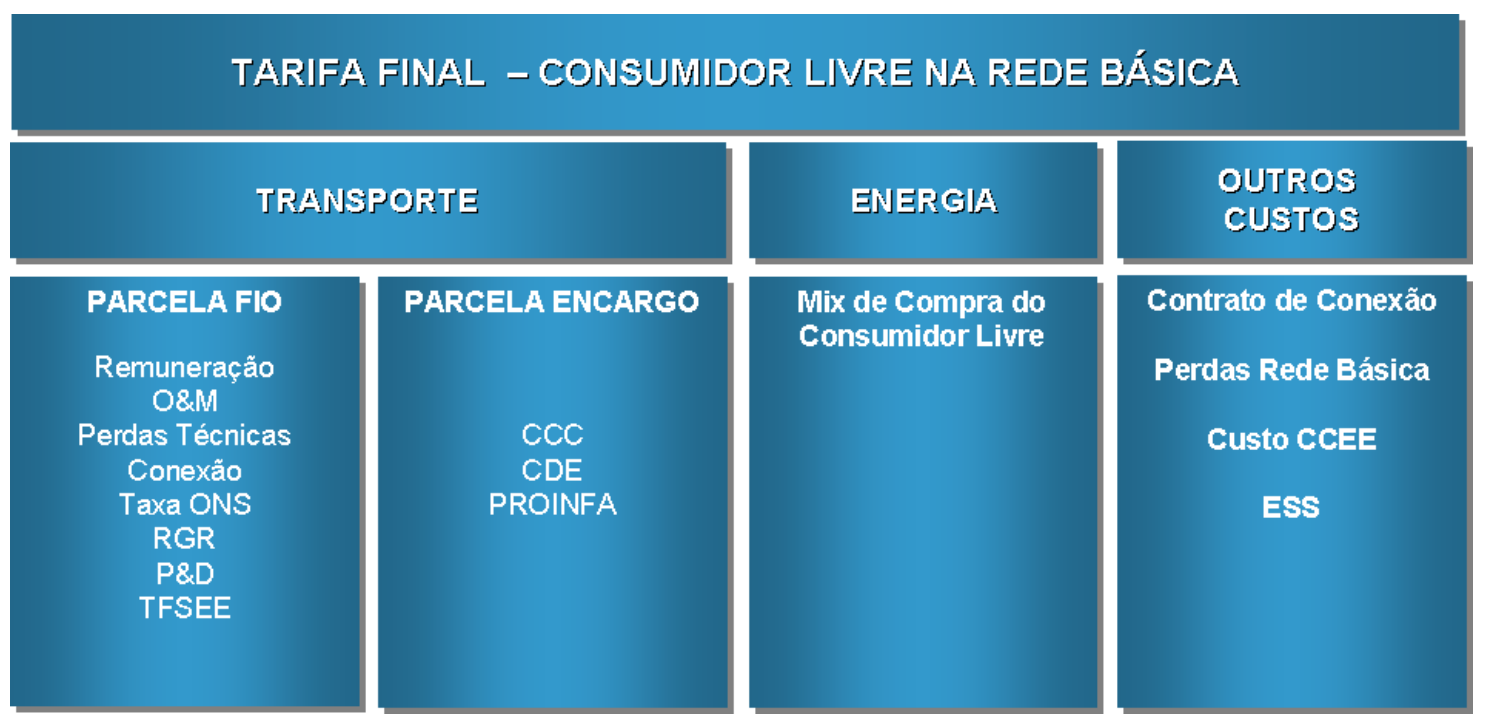

Figura 5 - Componentes da tarifa global de energia de um consumidor na Rede Básica (Ex-impostos)

A Figura 6 apresenta, a título de exemplo, a composição da tarifa final de um consumidor industrial com demanda de 90 MW (Ponta = Fora Ponta) ${ }^{3}$ e Fator de Carga de $95 \%$ (Ponta = Fora Ponta) conectado na distribuidora Eletropaulo em $138 \mathrm{kV}(\mathrm{A} 2)$. Verifica-se que apenas $52 \%$ da tarifa correspondem ao insumo energia e que encargos e tributos somados representam $35 \%$ do total da tarifa. As parcelas

\footnotetext{
3 Horário de Ponta corresponde ao intervalo de 3 horas consecutivas, ajustado de comum acordo entre a concessionária e o cliente, no período compreendido entre as $19 \mathrm{~h}$ e $22 \mathrm{~h}$.
} 
relacionadas de fato aos serviços de transmissão e distribuição representam apenas $13 \%$ do total da tarifa.

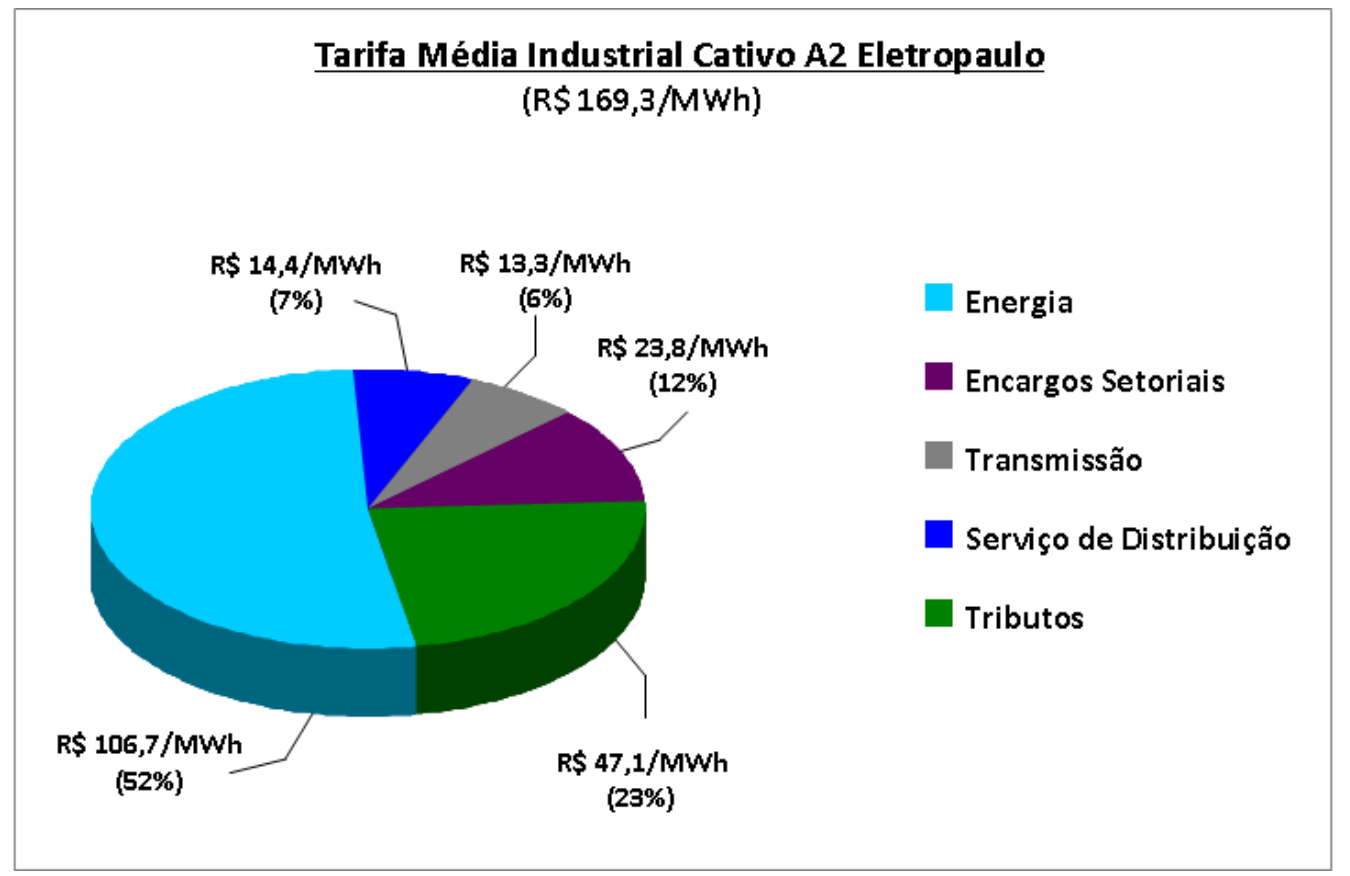

Figura 6 - Exemplo da composição da tarifa de um consumidor industrial conectado na Eletropaulo em $138 \mathrm{kV}$

Fonte: Resolução ANEEL N 675/2008 (Cálculo com base numa demanda de 90 MW e fator de carga de $95 \%$, tanto no horário de ponta quanto fora de ponta)

\section{2 - O Insumo Energia Elétrica}

Com a abertura do mercado de energia elétrica e criação do ACL, os consumidores de energia passaram a ter oportunidade de buscar no mercado condições mais competitivas de contratação de energia elétrica.

A redução dos custos com aquisição do insumo energia elétrica pode ser feita de duas formas: (i) por meio da auto-produção de energia elétrica, com construção de usinas próprias e/ou participação em consórcios; (ii) aquisição de energia no mercado livre via contratos bilaterais negociados com agente gerador ou comercializador.

$\mathrm{Na}$ auto-produção o consumidor passa a ter uma energia que possui um custo composto pelo Operação e Manutenção - O\&M da usina, remuneração dos investimentos, parcela Fio do gerador para entrega da energia gerada até o Centro de Gravidade do Sistema Elétrico, encargos setoriais e tributos. Atualmente, o autoprodutor de energia elétrica é isento do pagamento dos encargos setoriais CCC, CDE e PROINFA sobre a parcela de energia gerada para consumo próprio. Há 
isenção também do pagamento da parcela referente à segurança energética do ESS.

O Centro de Gravidade corresponde ao ponto virtual do sistema elétrico onde as perdas elétricas da carga e da geração são iguais e é justamente neste ponto que são consideradas todas as compras e vendas de energia na CCEE. Trata-se de um ponto virtual onde $50 \%$ das perdas são alocadas à geração e $50 \%$ aos consumidores.

A migração ao mercado livre, como já abordado, é possível somente para consumidores com demanda superior a $3 \mathrm{MW}$ ou para consumidores com demanda entre $500 \mathrm{~kW}$ e $3 \mathrm{MW}$, desde que compre energia de fontes incentivadas.

Esta limitação, em muitos casos, acaba restringindo os consumidores com demandas menores de energia elétrica de buscar condições mais competitivas de aquisição de energia. Na faixa de consumo de 500 kW a $3 \mathrm{MW}$ é permitida a migração ao mercado livre com compra de energia de fontes incentivadas, entretanto, estas fontes, em geral, apresentam custos de geração superiores às fontes convencionais. Assim, os requisitos para migração ao mercado livre ainda impedem muitas indústrias de adquirem energia a preços mais competitivos. A instituição de uma regulamentação que possibilite indústrias integrantes de pólos industriais a adquirem energia de forma centralizada, constituindo uma única unidade consumidora, proporcionaria condições importantes de competitividade. $\mathrm{Na}$ proposição citada, os critérios para viabilizar a migração ao mercado livre passariam a seguir a carga conjunta das indústrias e não as cargas individuais. Mesmo nos casos em que indústrias individualmente podem se tornar consumidores livres, a aquisição de energia em conjunto proporcionaria ganho de escala significativo, gerando condições mais atraentes de negociação de preços juntos aos vendedores.

\section{3 - A Parcela de Uso dos Sistemas}

No Brasil, a remuneração pelo uso dos sistemas de transmissão e distribuição, o chamado Fio, segue a metodologia de que quanto maior a utilização das redes do sistema elétrico, maior é a tarifa de transporte a ser paga pelo consumidor. Assim, quanto menor o nível de tensão que um consumidor é atendido, maior será a parcela referente ao transporte da energia. 
A remuneração pelo uso dos sistemas de transmissão é feita com base no rateio igualitário de custos entre consumidores e geradores, ou seja, metade da remuneração do sistema de transmissão é paga pelos consumidores, enquanto que a outra metade é paga pelos geradores.

Nos sistemas de distribuição a tarifa é calculada pelo custo marginal, que consiste numa metodologia que objetiva simular um mercado de concorrência perfeita, onde há naturalmente um incentivo a eficiência produtiva e a alocação de custos entres os segmentos e usuários das redes.

Nos sistemas de distribuição, a TUSD a ser paga por um agente consumidor depende apenas da área de concessão em que o mesmo se encontre e do subgrupo tarifário a que pertença. A Resolução ANEEL $N^{\circ} 456 / 2000$, que estabelece as condições gerais de fornecimento de energia elétrica, definiu seis subgrupos tarifários para consumidores de alta tensão conectados às redes de distribuição, os quais são relacionados na Tabela 4 a seguir.

Tabela 4 - Critérios de classificação dos consumidores em função da tensão de conexão ${ }^{4}$
Tensão de
Atendimento
Classificação

Subgrupo A1 Tensão de fornecimento igual ou superior a $230 \mathrm{kV}$.

Subgrupo A2 Tensão de fornecimento de $88 \mathrm{kV}$ a $138 \mathrm{kV}$.

Subgrupo A3 Tensão de fornecimento de $69 \mathrm{kV}$.

Subgrupo A3a Tensão de fornecimento de $30 \mathrm{kV}$ a $44 \mathrm{kV}$.

Subgrupo A4 Tensão de fornecimento de $2,3 \mathrm{kV}$ a $25 \mathrm{kV}$.

Subgrupo AS Tensão de fornecimento inferior a 2,3 kV, atendidas a partir de sistema subterrâneo de distribuição e faturadas neste Grupo em caráter opcional.

Fonte: Resolução ANEEL N 456/2000

Consumidores atendidos em baixa tensão fazem parte do Grupo B, que engloba as unidades consumidoras com fornecimento em tensão inferior a 2,3 kV, ou, ainda, atendidas em tensão superior a $2,3 \mathrm{kV}$ e faturadas neste Grupo nos termos definidos nos Arts. 79 a 81 da Resolução No 456/2000. Consumidores de Grupo B possuem estruturação tarifária monômia e são divididos nos seguintes subgrupos: (a) Subgrupo B1 - residencial; (b) Subgrupo B1 - residencial baixa renda; (c) Subgrupo B2 - rural; (d) Subgrupo B2 cooperativa de eletrificação rural; (e) Subgrupo B2 - serviço público de irrigação; (f) Subgrupo B3 - demais classes; (g) Subgrupo B4 - iluminação pública. 
As tarifas do Grupo A para consumidores cativos possuem três modalidades de fornecimento, as quais são descritas na Tabela 5 a seguir.

Tabela 5 - Modalidades de tarifas de fornecimento para consumidores cativo do Grupo A

\begin{tabular}{|c|c|}
\hline $\begin{array}{c}\text { Tensão de } \\
\text { Atendimento }\end{array}$ & Classificação \\
\hline Convencional & $\begin{array}{l}\text { Caracterizada pela aplicação de tarifas de consumo de energia e/ou } \\
\text { demanda de potência independentemente das horas de utilização do dia } \\
\text { e dos períodos do ano. }\end{array}$ \\
\hline Horo-Sazonal Azul & $\begin{array}{l}\text { Modalidade de fornecimento estruturada para a aplicação de tarifas } \\
\text { diferenciadas de consumo de energia elétrica, de acordo com as horas de } \\
\text { utilização do dia e dos períodos do ano, bem como de tarifas } \\
\text { diferenciadas de demanda de potência de acordo com as horas de } \\
\text { utilização do dia. }\end{array}$ \\
\hline Horo-sazonal Verde & $\begin{array}{l}\text { Modalidade de fornecimento estruturada para a aplicação de tarifas } \\
\text { diferenciadas de consumo de energia elétrica, de acordo com as horas de } \\
\text { utilização do dia e dos períodos do ano, bem como de uma única tarifa de } \\
\text { demanda de potência. }\end{array}$ \\
\hline
\end{tabular}

Fonte: Resolução ANEEL № 456/2000

A tarifa horo-sazonal se aplica obrigatoriamente às unidades consumidoras atendidas pelo sistema elétrico interligado com tensão de fornecimento inferior a $69 \mathrm{kV}$ e demanda contratada igual ou superior a $300 \mathrm{~kW}$, com opção do consumidor pela modalidade azul ou verde. As unidades consumidoras atendidas pelo sistema elétrico interligado com tensão de fornecimento inferior a $69 \mathrm{kV}$ e demanda contratada inferior a $300 \mathrm{~kW}$ podem optar pela tarifa horo-sazonal, seja na modalidade azul ou verde.

Os consumidores livres possuem apenas diferenciação de contratação de demanda no horário de ponta e fora de ponta, sendo a energia negociada diretamente com o vendedor.

Numa determinada classe de tensão os valores da TUSD são iguais para todos consumidores, independentemente da localização do mesmo em relação ao sistema elétrico. Portanto, um consumidor que esteja muito próximo ao sistema de Rede Básica, mas que seja atendido em $138 \mathrm{kV}$, por exemplo, pagará a mesma TUSD A2 que um consumidor que esteja no final de um sistema radial de $138 \mathrm{kV}$. Apesar de 
usar menos o sistema elétrico de distribuição, o consumidor próximo à Rede Básica deve pagar TUSD igual a um consumidor que está usando o sistema de forma mais intensa.

Nos sistemas de distribuição o pagamento do componente Fio e Encargos é feito à distribuidora na qual o acessante esteja conectado e a parcela correspondente à TUST já está integrada na TUSD da distribuidora.

Caso o consumidor esteja conectado à Rede Básica, não há necessidade de pagamento do uso dos sistemas de distribuição, uma vez que não os utilizam. Os encargos de uso dependem apenas da sua localização elétrica no ponto de conexão. As TUSTs são calculadas pela metodologia nodal, que define tarifas em $\mathrm{R} \$ / \mathrm{kW}$ para cada barra de Rede Básica do SIN, proporcionalmente à utilização do sistema. Atualmente, o faturamento de consumidores conectados às instalações de Rede Básicas, no que se refere à demanda contratada, é efetuado somente no horário de ponta, ou seja, o período em que se registram os maiores níveis nacionais de consumo, sendo nula a tarifa de demanda no horário fora de ponta.

Encargos como CCC, CDE e PROINFA são cobrados na parcela de uso do sistema, entretanto, são recolhidos por meio da aplicação de uma tarifa em $\mathrm{R} \$ / \mathrm{MWh}$ sobre o consumo mensal do consumidor. Para um consumidor que esteja conectado à Rede Básica, as parcelas correspondentes aos encargos setoriais (CCC, CDE, PROINFA) e aos encargos de uso do sistema são recolhidas pela transmissora no qual o acessante esteja conectado. O pagamento da TUST é feito diretamente às concessionárias de transmissão do SIN, assim, um consumidor na Rede Básica recebe uma fatura de cada transmissora do SIN.

Com base nos pontos apresentados, pode-se concluir que a elevação na tensão de atendimento elétrico consiste numa forma de redução da parcela Fio da tarifa de energia.

A aquisição de energia proveniente de fontes incentivadas também consiste numa forma de redução da tarifa fio, pois, conforme estabelecido na Resolução ANEEL $N^{\circ} 77 / 2004$, há redução de $50 \%$ na parcela Fio para os casos de compra de energia de PCHs, eólicas, solar ou biomassa, e de 100\% na compra de energia proveniente de geração via gases de aterros sanitários.

A aquisição de energia de fontes incentivadas, apesar de proporcionar redução na parcela Fio, torna-se atrativa nos casos em que a TUSD é mais elevada uma vez que os preços de energia de fontes incentivadas, em geral, são maiores que os de 
fontes convencionais. A aquisição de energia de fontes incentivadas é mais atraente para consumidores em 13,8 kV do que consumidores em $138 \mathrm{kV}$, dado que a TUSD é maior.

A elevação da tensão de suprimento elétrico requer investimentos em instalações como linhas de transmissão e subestações, os quais aumentam de forma proporcional à tensão de conexão. Verifica-se então, que a conexão em tensões mais elevadas torna-se viável apenas para consumidores com significativo consumo de energia elétrica, casos onde a diferença na Tarifa Fio atinge cifras elevadas o suficiente para remunerar os investimentos nas instalações de conexão.

Consumidores com menores demandas elétricas acabam optando por serem atendidos em tensões mais baixas e, conseqüentemente, pagam maiores tarifas pelo transporte da energia.

Os consumidores conectados aos sistemas de distribuição acabam tendo que pagar na tarifa a parcela de uso dos sistemas de transmissão (a chamada TUST) e a parcela referente ao uso dos sistemas de distribuição. A tarifa Fio global para um consumidor conectado ao sistema de distribuição é denominada TUSD, que contém já em seu montante a parcela correspondente à TUST. A diferença ente a TUSD e TUST na maioria dos pontos do sistema elétrico atinge valores muito elevados, que prejudicam a competitividade das indústrias, principalmente as eletro-intensivas. A título de exemplo, em indústrias produtoras de cloro-soda e alumínio, onde o uso de energia é intenso em virtude de presença de eletrólise, os custos com energia elétrica podem chegar a $60 \%$ dos custos totais de produção. Nestes casos, qualquer redução na tarifa de energia representa ganhos de competitividade.

A Figura 7 ilustra o quanto pode ser importante a diferença de tarifas, ao uma comparar os valores de TUSDs praticados por algumas distribuidoras brasileiras de energia elétrica, para quatro classes de tensão distintas, com os valores da TUST de algumas barras de Rede Básica na área de concessão das respectivas distribuidoras. Pode-se observar nesta figura como evoluem as tarifas de uso do sistemas em função da diminuição da tensão de conexão, sendo evidente que a TUSD é sempre muito mais elevada que a TUST. Pode-se observar ainda que na área de concessão da Companhia de Eletricidade do Estado da Bahia - COELBA, por exemplo, o crescimento da TUSD em função da redução da tensão de conexão é bastante expressivo, havendo, por exemplo, uma diferença de cerca de R\$ 57/MWh entre a tensão de 138 kV (A2) e 13,8 kV (A4). Já na Companhia Paulista 
de Força e Luz - CPFL Paulista a variação da TUSD não é tão expressiva entre as classes de tensão desta distribuidora.

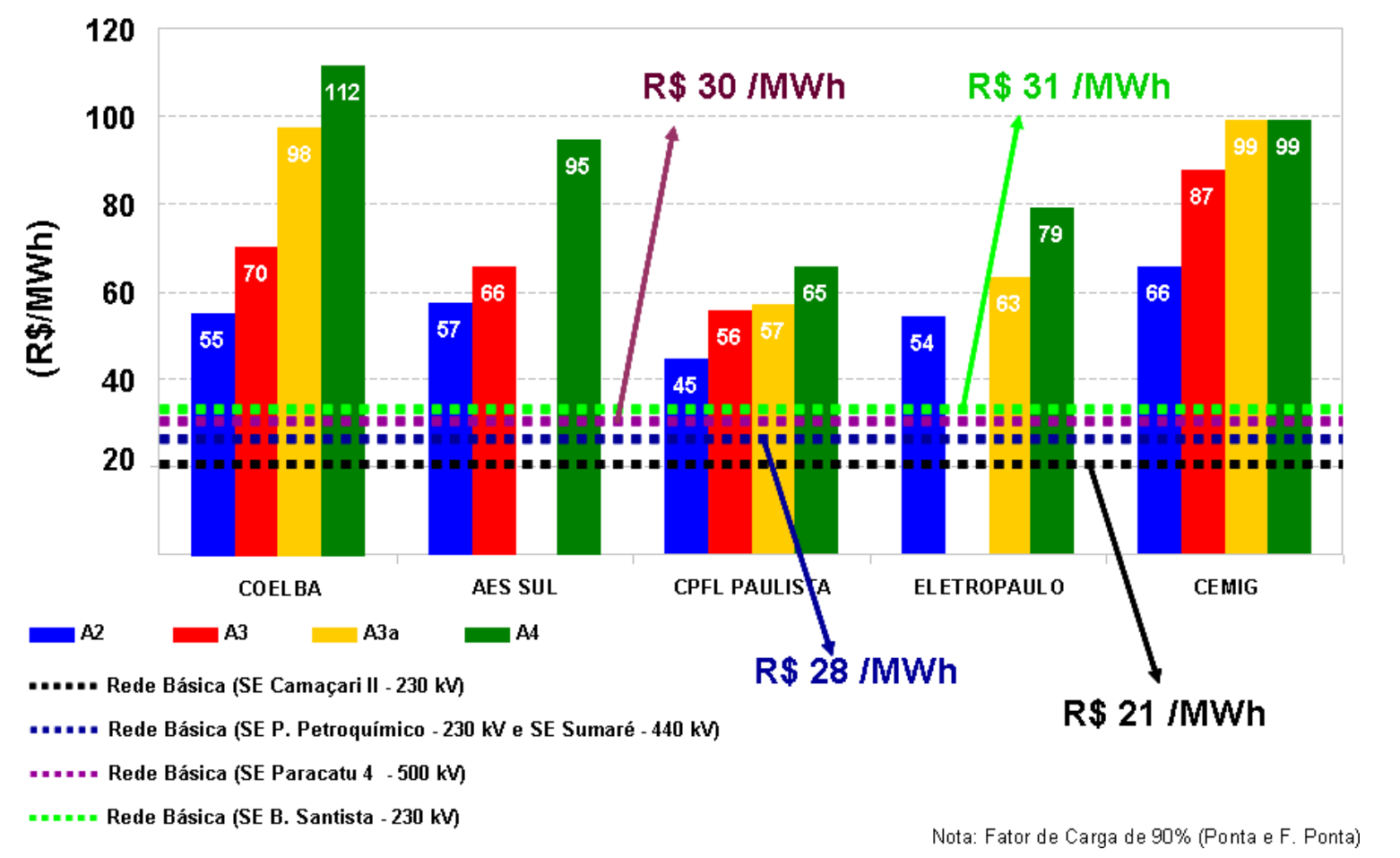

Figura 7 - Comparativo de TUST e TUSD de algumas distribuidoras de energia elétrica (Valores incluem Fio e Encargos Setoriais) ${ }^{5}$

Fonte: Resoluções ANEEL Nº 638/2008, 635/2008, 627/2008, 675/2008, 626/2008, 671/2008, $567 / 2007$

A possibilidade de se atender o consumidor de energia elétrica em alta tensão, conectando-o diretamente à Rede Básica constitui, sem dúvida alguma, um importante fator de competitividade industrial.

A título de exemplo, uma redução de $\mathrm{R} \$ 30 / \mathrm{MWh}$ na Tarifa Fio de um consumidor de $50 \mathrm{MW}$ de demanda constante, ou flat, no horário de ponta e fora de ponta, com fator de carga de $92 \%$, proporciona economia média anual de $\mathrm{R} \$ 15$ milhões. Esta economia seria suficiente para pagar em dois ou três anos os investimentos de ordem de $\mathrm{R} \$ 30$ a 40 milhões para construção de linhas de transmissão e subestações em tensão de $230 \mathrm{kV}$.

A Figura 8 apresenta uma análise de sensibilidade da economia anual que seria proporcionada com a migração à Rede Básica, considerando variação na demanda para quatro valores de diferença entre TUST e TUSD. Por exemplo, no caso em que

\footnotetext{
${ }^{5}$ A distribuidora AES Sul não possui tarifa na classe de tensão A3a e Eletropaulo não possui tarifa na classe de tensão A3.
} 
a diferença entre TUST e TUSD for de $30 \mathrm{R} \$ / \mathrm{MWh}$, um consumidor de $80 \mathrm{MW}$ de demanda flat com fator de carga de $92 \%$ teria uma economia anual estimada em $\mathrm{R} \$$ 20 milhões.

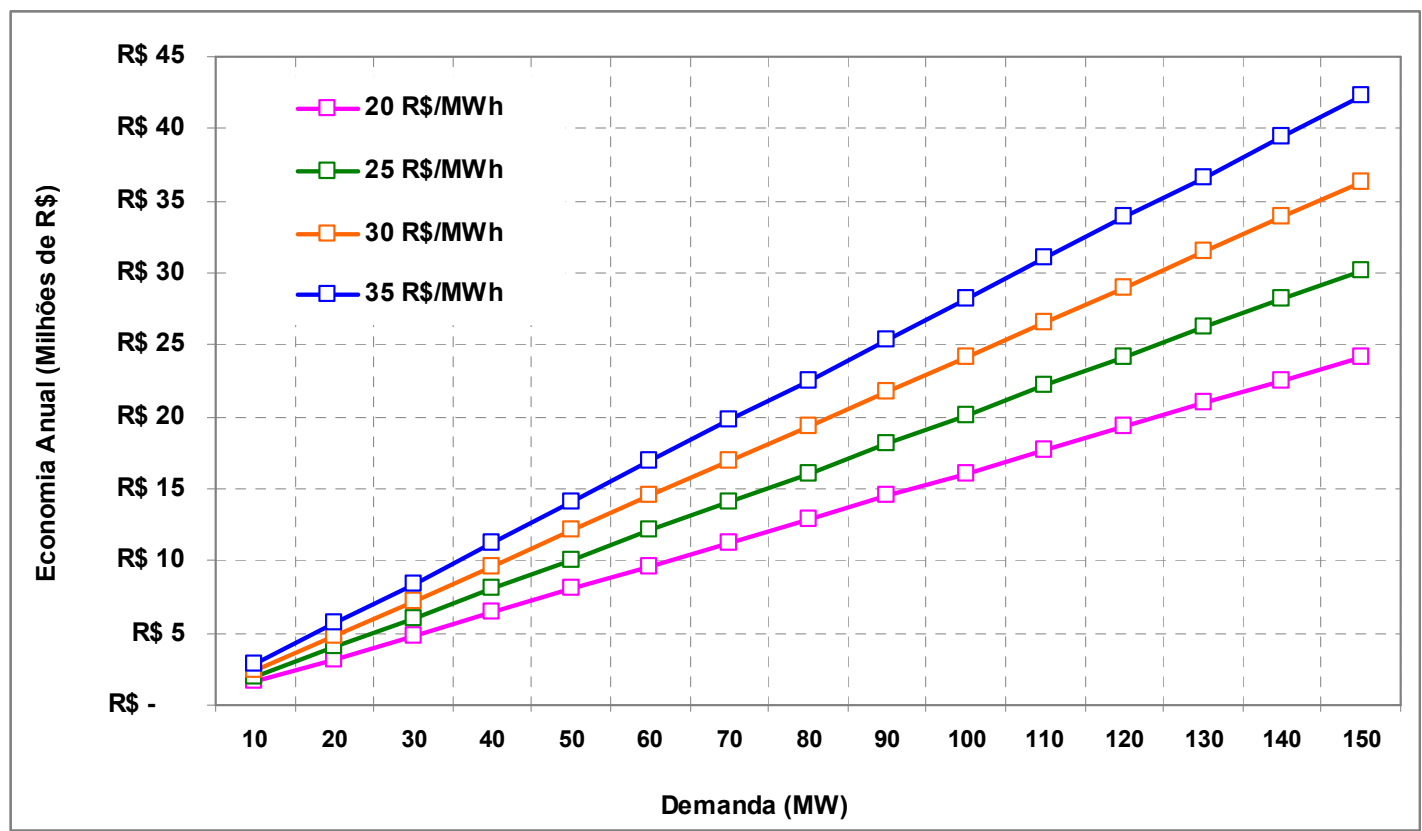

Figura 8 - Análise de sensibilidade da economia anual com migração à Rede Básica em virtude da variação de demanda e tarifa reduzida (Fator de Carga de 92\% Ponta e F. Ponta)

É importante destacar que a conexão de indústrias em tensões mais elevadas não possibilita apenas ganhos econômicos com a redução da Tarifa Fio, mas também ganhos técnicos substanciais, uma vez que em tensões mais elevadas o suprimento elétrico é mais confiável e menos susceptível a interrupções e oscilações sistêmicas, principalmente em tensão igual ou superior à $230 \mathrm{kV}$.

As tabelas 6, 7, 8 e 9 apresentadas a seguir fazem uma análise comparativa dos valores de TUSTs de algumas barras de Rede Básica do Sistema Elétrico Interligado - SIN com as respectivas TUSDs que o consumidor pagaria estando conectado ao sistema da concessionária de distribuição. Na comparação foram selecionadas as distribuidoras COELBA e AES Sul, as quais possuem em sua área de concessão importantes pólos industriais, como o Pólo Petroquímico de Camaçari, na Bahia, e o Pólo Petroquímico de Triunfo, no Rio Grande do Sul, e também as distribuidoras CPFL Paulista, Eletropaulo e Cemig, que atuam em regiões com grande potencial para formação de novos pólos industriais e que possuem em sua área de concessão importantes grupos industriais com elevados consumos de eletricidade. Os cálculos das TUSTs e TUSDs em R\$/MWh foram efetuados considerando-se uma demanda 
de referência de $65 \mathrm{MW}$, no horário de ponta e fora de ponta, com fator de carga de $90 \%$.

Tabela 6 - Comparação entre TUST e TUSD A2 de algumas distribuidoras de energia elétrica

\begin{tabular}{|c|c|c|c|c|c|c|}
\hline \multicolumn{7}{|c|}{ | PERFIL DE CARGA } \\
\hline Demanda (Ponta = Fora Ponta) & MW & 65 & 65 & 65 & 65 & 65 \\
\hline Fator de Carga (Ponta = Fora Ponta) & $\%$ & $90 \%$ & $90 \%$ & $90 \%$ & $90 \%$ & $90 \%$ \\
\hline \multicolumn{7}{|c|}{ ANÁLISE DAS TARIFAS DE USO DOS SISTEMAS DE DISTRIBUIÇÃO (TUSD A2) } \\
\hline Concessionária de distribuição & - & COELBA & AES SUL & CPFL PAULISTA & ELETROPAULO & CEMIG \\
\hline Resolução homologatória ANEEL & - & Res $N^{\circ} 638 / 2008$ & Res $N^{\circ} 635 / 2008$ & Res $N^{\circ} 627 / 2008$ & Res $N^{\circ} 675 / 2008$ & $\operatorname{Res} \mathrm{N}^{\circ} 635 / 2008$ \\
\hline \multicolumn{7}{|c|}{ Tarifas nos sistemas de distribuição na classe A3 (138 kV): } \\
\hline Demanda Ponta: & $\mathrm{R} \$ / \mathrm{kW}$ & 23,64 & 21,44 & 13,89 & 19,03 & 25,62 \\
\hline Demanda Fora Ponta: & $\mathrm{R} \$ / \mathrm{kW}$ & 3,83 & 2,83 & 1,77 & 2,79 & 4,36 \\
\hline Encargos: & $\mathrm{R} \$ / \mathrm{MWh}$ & 13,32 & 20,29 & 20,72 & 21,04 & 20,01 \\
\hline \multicolumn{7}{|l|}{ Estimativa de Gastos Anuais $(\mathrm{R} \$)$} \\
\hline TUSD & $\mathrm{R} \$$ & $28.252 .567,20$ & $29.328 .864,61$ & $22.833 .673,75$ & $27.803 .041,56$ & $33.641 .312,19$ \\
\hline Fio & $\mathrm{R} \$$ & $21.426 .600,00$ & $18.930 .891,24$ & $12.215 .175,84$ & $17.020 .385,52$ & $23.386 .198,80$ \\
\hline Encargos & $\mathrm{R} \$$ & $6.825 .967,20$ & 10.397.973,37 & $10.618 .497,91$ & $10.782 .656,04$ & $10.255 .113,39$ \\
\hline \multicolumn{7}{|l|}{ Estimativa da TUSD em R\$/MWh } \\
\hline TUSD & $\mathrm{R} \$ / \mathrm{MWh}$ & 55,13 & 57,23 & 44,56 & 54,25 & 65,64 \\
\hline Fio & $\mathrm{R} \$ / \mathrm{MWh}$ & 41,81 & 36,94 & 23,84 & 33,21 & 45,63 \\
\hline Encargos & $\mathrm{R} \$ / \mathrm{MWh}$ & 13,32 & 20,29 & 20,72 & 21,04 & 20,01 \\
\hline \multicolumn{7}{|c|}{ ANÁLISE DAS TARIFAS DE USO DO SISTEMA NA REDE BÁSICA (TUST) } \\
\hline Concessionária & - & Chesf & CEEE & CTEEP & CTEEP & SMTE \\
\hline Subestação de conexão & - & SE Camaçari II & SE Pólo Petroquímico & SE Sumaré & SE Baixada Santista & SE Paracatu 4 \\
\hline Tensão & - & $230 \mathrm{kV}$ & $230 \mathrm{kV}$ & $440 \mathrm{kV}$ & $230 \mathrm{kV}$ & $500 \mathrm{kV}$ \\
\hline $\mathrm{N}^{\circ}$ da Barra & - & Barra 5751 & Barra 1204 & Barra 571 & Barra 473 & Barra 4066 \\
\hline Resolução Homologatória ANEEL & & Res $N^{\circ} 671 / 2008$ & Res $N^{\circ} 671 / 2008$ & Res No 671/2008 & Res $N^{\circ} 671 / 2008$ & Res $N^{\circ} 671 / 2008$ \\
\hline \multicolumn{7}{|c|}{ Tarifas nos sistemas de transmissão (Rede Básica): } \\
\hline Demanda Ponta: & $\mathrm{R} \$ / \mathrm{kW}$ & 4,174 & 5,489 & 5,203 & 5,559 & 3,645 \\
\hline Demanda Fora Ponta: & $\mathrm{R} \$ / \mathrm{kW}$ & 0,00 & 0,00 & 0,00 & 0,00 & 0,00 \\
\hline Encargos: & $\mathrm{R} \$ / \mathrm{MWh}$ & 14,27 & 22,07 & 22,07 & 22,07 & 22,07 \\
\hline $\mathrm{CCC}$ & $\mathrm{R} \$ / \mathrm{MWh}$ & 9,22 & 9,22 & 9,22 & 9,22 & 9,22 \\
\hline $\mathrm{CDE}$ & $\mathrm{R} \$ / \mathrm{MWh}$ & 2,20 & 10,00 & 10,00 & 10,00 & 10,00 \\
\hline PROIINFA & $\mathrm{R} \$ / \mathrm{MWh}$ & 2,85 & 2,85 & 2,85 & 2,85 & 2,85 \\
\hline \multicolumn{7}{|l|}{ Estimativa de Gastos Anuais ( $R \$$ ) } \\
\hline TUST & $\mathrm{R} \$$ & $10.568 .524,20$ & $15.591 .652,07$ & $15.368 .805,07$ & $15.646 .734,32$ & $14.154 .180,90$ \\
\hline $\mathrm{FIO}$ & $\mathrm{R} \$$ & $3.255 .720,00$ & $4.281 .485,87$ & $4.058 .464,87$ & $4.336 .220,12$ & $2.843 .318,70$ \\
\hline Encargos & $\mathrm{R} \$$ & $7.312 .804,20$ & $11.310 .166,20$ & $11.310 .340,20$ & $11.310 .514,20$ & $11.310 .862,20$ \\
\hline \multicolumn{7}{|l|}{ Estimativa da TUST em R $\$ / M W h$} \\
\hline TUST & $\mathrm{R} \$ / M W h$ & 20,62 & 30,42 & 29,99 & 30,53 & 27,62 \\
\hline $\mathrm{FIO}$ & $\mathrm{R} \$ / \mathrm{MWh}$ & 6,35 & 8,35 & 7,92 & 8,46 & 5,55 \\
\hline Encargos & $\mathrm{R} \$ / \mathrm{MWh}$ & 14,27 & 22,07 & 22,07 & 22,07 & 22,07 \\
\hline \multicolumn{7}{|c|}{ DIFERENÇA ENTRE TUST E TUSD } \\
\hline TUSD - TUST em R\$/MWh & $\mathrm{R} \$ / \mathrm{MWh}$ & 34,51 & 26,81 & 14,57 & 23,72 & 38,02 \\
\hline
\end{tabular}

Fonte: Resoluções ANEEL Nº638/2008, 635/2008, 627/2008, 675/2008, 626/2008, 671/2008 e $567 / 2007$ 
Tabela 7 - Comparação entre TUST e TUSD A3 de algumas distribuidoras de energia elétrica

\begin{tabular}{|c|c|c|c|c|c|c|}
\hline \multicolumn{7}{|c|}{ PERFIL DE CARGA } \\
\hline Demanda (Ponta $=$ Fora Ponta) & MW & 65 & 65 & 65 & 65 & 65 \\
\hline Fator de Carga (Ponta = Fora Ponta) & $\%$ & $90 \%$ & $90 \%$ & $90 \%$ & $90 \%$ & $90 \%$ \\
\hline \multicolumn{7}{|c|}{ ANÁLISE DAS TARIFAS DE USO DOS SISTEMAS DE DISTRIBUIÇÃO (TUSD A3) } \\
\hline Concessionária de distribuição & - & COELBA & AES SUL & CPFL PAULISTA & ELETROPAULO ${ }^{2}$ & CEMIG \\
\hline Resolução homologatória ANEEL & - & Res $N^{\circ} 638 / 2008$ & Res $N^{\circ} 635 / 2008$ & Res $N^{\circ} 627 / 2008$ & Res $N^{\circ} 675 / 2008$ & Res $N^{\circ} 635 / 2008$ \\
\hline \multicolumn{7}{|c|}{ Tarifas nos sistemas de distribuição na classe A3 (138 kV): } \\
\hline Demanda Ponta: & $\mathrm{R} \$ / \mathrm{kW}$ & 30,95 & 25,48 & 19,45 & - & 36,25 \\
\hline Demanda Fora Ponta: & $\mathrm{R} \$ / \mathrm{kW}$ & 6,48 & 4,33 & 3,61 & - & 8,07 \\
\hline Encargos: & $\mathrm{R} \$ / \mathrm{MWh}$ & 13,32 & 20,29 & 20,72 & - & 20,01 \\
\hline \multicolumn{7}{|l|}{ Estimativa de Gastos Anuais ( $R \$)$} \\
\hline TUSD & $\mathrm{R} \$$ & $36.021 .367,20$ & $33.650 .131,09$ & $28.605 .851,35$ & - & $44.827 .372,59$ \\
\hline Fio & $\mathrm{R} \$$ & $29.195 .400,00$ & 23.252.157,72 & $17.987 .353,44$ & - & $34.572 .259,20$ \\
\hline Encargos & $\mathrm{R} \$$ & $6.825 .967,20$ & $10.397 .973,37$ & 10.618.497,91 & - & $10.255 .113,39$ \\
\hline \multicolumn{7}{|l|}{ Estimativa da TUSD em R $\$ / M W h$} \\
\hline TUSD & $\mathrm{R} \$ / M W h$ & 70,29 & 65,66 & 55,82 & - & 87,47 \\
\hline Fio & $\mathrm{R} \$ / \mathrm{MWh}$ & 56,97 & 45,37 & 35,10 & - & 67,46 \\
\hline Encargos & $\mathrm{R} \$ / \mathrm{MWh}$ & 13,32 & 20,29 & 20,72 & - & 20,01 \\
\hline \multicolumn{7}{|c|}{ ANÁLISE DAS TARIFAS DE USO DO SISTEMA NA REDE BÁSICA (TUST) } \\
\hline Concessionária & - & Chesf & CEEE & CTEEP & - & SMTE \\
\hline Subestação de conexão & - & SE Camaçari II & SE Pólo Petroquímico & SE Sumaré & - & SE Paracatu 4 \\
\hline Tensão & - & $230 \mathrm{kV}$ & $230 \mathrm{kV}$ & $440 \mathrm{kV}$ & - & $500 \mathrm{kV}$ \\
\hline $\mathrm{N}^{\circ}$ da Barra & - & Barra 5751 & Barra 1204 & Barra 571 & - & Barra 4066 \\
\hline Resolução Homologatória ANEEL & & Res $N^{\circ} 671 / 2008$ & Res $N^{\circ} 671 / 2008$ & Res $N^{\circ} 671 / 2008$ & - & Res $N^{\circ} 671 / 2008$ \\
\hline \multicolumn{7}{|c|}{ Tarifas nos sistemas de transmissão (Rede Básica): } \\
\hline Demanda Ponta: & $\mathrm{R} \$ / \mathrm{kW}$ & 4,174 & 5,489 & 5,203 & - & 3,645 \\
\hline Demanda Fora Ponta: & $\mathrm{R} \$ / \mathrm{kW}$ & 0,00 & 0,00 & 0,00 & - & 0,00 \\
\hline Encargos: & $\mathrm{R} \$ / \mathrm{MWh}$ & 14,27 & 22,07 & 22,07 & - & 22,07 \\
\hline $\mathrm{CcC}$ & $\mathrm{R} \$ / \mathrm{MWh}$ & 9,22 & 9,22 & 9,22 & - & 9,22 \\
\hline CDE & $\mathrm{R} \$ / \mathrm{MWh}$ & 2,20 & 10,00 & 10,00 & - & 10,00 \\
\hline PROIINFA & $\mathrm{R} \$ / \mathrm{MWh}$ & 2,85 & 2,85 & 2,85 & - & 2,85 \\
\hline \multicolumn{7}{|l|}{ Estimativa de Gastos Anuais ( $R \$)$} \\
\hline TUST & $\mathrm{R} \$$ & $10.568 .524,20$ & $15.591 .652,07$ & $15.368 .805,07$ & - & $14.154 .180,90$ \\
\hline $\mathrm{FIO}$ & $\mathrm{R} \$$ & $3.255 .720,00$ & $4.281 .485,87$ & $4.058 .464,87$ & - & $2.843 .318,70$ \\
\hline Encargos & $\mathrm{R} \$$ & $7.312 .804,20$ & $11.310 .166,20$ & $11.310 .340,20$ & - & $11.310 .862,20$ \\
\hline \multicolumn{7}{|l|}{ Estimativa da TUST em R\$/MWh } \\
\hline TUST & $\mathrm{R} \$ / M W h$ & 20,62 & 30,42 & 29,99 & - & 27,62 \\
\hline $\mathrm{FIO}$ & $\mathrm{R} \$ / \mathrm{MWh}$ & 6,35 & 8,35 & 7,92 & - & 5,55 \\
\hline Encargos & $\mathrm{R} \$ / \mathrm{MWh}$ & 14,27 & 22,07 & 22,07 & - & 22,07 \\
\hline \multicolumn{7}{|c|}{ DIFERENÇA ENTRE TUST E TUSD } \\
\hline TUSD - TUST em R\$/MWh & $\mathrm{R} \$ / \mathrm{MWh}$ & 49,67 & 35,24 & 25,83 & - & 59,85 \\
\hline
\end{tabular}

Fonte: Resoluções ANEEL N 638/2008, 635/2008, 627/2008, 675/2008, 626/2008, 671/2008 e $567 / 2007$ 
Tabela 8 - Comparação entre TUST e TUSD A3a de algumas distribuidoras de energia elétrica

\begin{tabular}{|c|c|c|c|c|c|c|}
\hline \multicolumn{7}{|c|}{ PERFIL DE CARGA } \\
\hline Demanda (Ponta $=$ Fora Ponta) & MW & 65 & 65 & 65 & 65 & 65 \\
\hline Fator de Carga (Ponta = Fora Ponta) & $\%$ & $90 \%$ & $90 \%$ & $90 \%$ & $90 \%$ & $90 \%$ \\
\hline \multicolumn{7}{|c|}{ ANÁLISE DAS TARIFAS DE USO DOS SISTEMAS DE DISTRIBUIÇÃO (TUSD A3a) } \\
\hline Concessionária de distribuição & - & COELBA & AES SUL ${ }^{2}$ & CPFL PAULISTA & ELETROPAULO & CEMIG \\
\hline Resolução homologatória ANEEL & - & Res $N^{\circ} 638 / 2008$ & Res $N^{\circ} 635 / 2008$ & Res $N^{\circ} 627 / 2008$ & Res $N^{\circ} 675 / 2008$ & Res $N^{\circ} 635 / 2008$ \\
\hline \multicolumn{7}{|c|}{ Tarifas nos sistemas de distribuição na classe A3 (138 kV): } \\
\hline Demanda Ponta: & $\mathrm{R} \$ / \mathrm{kW}$ & 43,51 & - & 19,47 & 22,66 & 40,66 \\
\hline Demanda Fora Ponta: & $\mathrm{R} \$ / \mathrm{kW}$ & 12,00 & - & 4,38 & 4,91 & 11,27 \\
\hline Encargos: & $\mathrm{R} \$ / \mathrm{MWh}$ & 13,32 & - & 20,72 & 21,04 & 20,01 \\
\hline \multicolumn{7}{|l|}{ Estimativa de Gastos Anuais (R\$) } \\
\hline TUSD & $\mathrm{R} \$$ & $50.123 .767,20$ & - & $29.222 .070,31$ & $32.288 .248,56$ & $50.763 .629,19$ \\
\hline Fio & $\mathrm{R} \$$ & $43.297 .800,00$ & - & $18.603 .572,40$ & $21.505 .592,52$ & $40.508 .515,80$ \\
\hline Encargos & $\mathrm{R} \$$ & $6.825 .967,20$ & - & $10.618 .497,91$ & $10.782 .656,04$ & $10.255 .113,39$ \\
\hline \multicolumn{7}{|l|}{ Estimativa da TUSD em R\$/MWh } \\
\hline TUSD & $\mathrm{R} \$ / M W h$ & 97,81 & - & 57,02 & 63,00 & 99,05 \\
\hline Fio & $\mathrm{R} \$ / \mathrm{MWh}$ & 84,49 & - & 36,30 & 41,96 & 79,04 \\
\hline Encargos & $\mathrm{R} \$ / \mathrm{MWh}$ & 13,32 & - & 20,72 & 21,04 & 20,01 \\
\hline \multicolumn{7}{|c|}{ ANÁLISE DAS TARIFAS DE USO DO SISTEMA NA REDE BÁSICA (TUST) } \\
\hline Concessionária & - & Chesf & - & CTEEP & CTEEP & SMTE \\
\hline Subestação de conexão & - & SE Camaçari II & - & SE Sumaré & SE Baixada Santista & SE Paracatu 4 \\
\hline Tensão & - & $230 \mathrm{kV}$ & - & $440 \mathrm{kV}$ & $230 \mathrm{kV}$ & $500 \mathrm{kV}$ \\
\hline $\mathrm{N}^{\circ}$ da Barra & - & Barra 5751 & - & Barra 571 & Barra 473 & Barra 4066 \\
\hline Resolução Homologatória ANEEL & & Res No 671/2008 & - & Res $N^{\circ} 671 / 2008$ & Res $N^{\circ} 671 / 2008$ & Res No $671 / 2008$ \\
\hline \multicolumn{7}{|c|}{ Tarifas nos sistemas de transmissão (Rede Básica): } \\
\hline Demanda Ponta: & $\mathrm{R} \$ / \mathrm{kW}$ & 4,174 & - & 5,203 & 5,559 & 3,645 \\
\hline Demanda Fora Ponta: & $\mathrm{R} \$ / \mathrm{kW}$ & 0,00 & - & 0,00 & 0,00 & 0,00 \\
\hline Encargos: & $\mathrm{R} \$ / \mathrm{MWh}$ & 14,27 & - & 22,07 & 22,07 & 22,07 \\
\hline $\operatorname{CCC}$ & $\mathrm{R} \$ / \mathrm{MWh}$ & 9,22 & - & 9,22 & 9,22 & 9,22 \\
\hline CDE & $\mathrm{R} \$ / \mathrm{MWh}$ & 2,20 & - & 10,00 & 10,00 & 10,00 \\
\hline PROIINFA & $\mathrm{R} \$ / \mathrm{MWh}$ & 2,85 & - & 2,85 & 2,85 & 2,85 \\
\hline \multicolumn{7}{|l|}{ Estimativa de Gastos Anuais (R\$) } \\
\hline TUST & $\mathrm{R} \$$ & $10.568 .524,20$ & - & $15.368 .805,07$ & $15.646 .734,32$ & $14.154 .180,90$ \\
\hline FIO & $\mathrm{R} \$$ & $3.255 .720,00$ & - & $4.058 .464,87$ & $4.336 .220,12$ & $2.843 .318,70$ \\
\hline Encargos & $\mathrm{R} \$$ & $7.312 .804,20$ & - & $11.310 .340,20$ & $11.310 .514,20$ & $11.310 .862,20$ \\
\hline \multicolumn{7}{|l|}{ Estimativa da TUST em R\$/MWh } \\
\hline TUST & $\mathrm{R} \$ / M W h$ & 20,62 & - & 29,99 & 30,53 & 27,62 \\
\hline $\mathrm{FIO}$ & $\mathrm{R} \$ / \mathrm{MWh}$ & 6,35 & - & 7,92 & 8,46 & 5,55 \\
\hline Encargos & $\mathrm{R} \$ / \mathrm{MWh}$ & 14,27 & - & 22,07 & 22,07 & 22,07 \\
\hline \multicolumn{7}{|c|}{ DIFERENÇA ENTRE TUST E TUSD } \\
\hline TUSD - TUST em R\$/MWh & $\mathrm{R} \$ / M W h$ & 77,19 & - & 27,03 & 32,47 & 71,43 \\
\hline
\end{tabular}

Fonte: Resoluções ANEEL N 638/2008, 635/2008, 627/2008, 675/2008, 626/2008, 671/2008 e $567 / 2007$ 
Tabela 9 - Comparação entre TUST e TUSD A4 de algumas distribuidoras de energia elétrica

\begin{tabular}{|c|c|c|c|c|c|c|}
\hline \multicolumn{7}{|c|}{ PERFIL DE CARGA } \\
\hline Demanda (Ponta $=$ Fora Ponta) & MW & 65 & 65 & 65 & 65 & 65 \\
\hline Fator de Carga (Ponta = Fora Ponta) & $\%$ & $90 \%$ & $90 \%$ & $90 \%$ & $90 \%$ & $90 \%$ \\
\hline \multicolumn{7}{|c|}{ ANÁLISE DAS TARIFAS DE USO DOS SISTEMAS DE DISTRIBUIÇÃO (TUSD A4) } \\
\hline Concessionária de distribuição & - & COELBA & AES SUL & CPFL PAULISTA & ELETROPAULO & CEMIG \\
\hline Resolução homologatória ANEEL & - & Res $N^{\circ} 638 / 2008$ & Res $N^{\circ} 635 / 2008$ & Res $N^{\circ} 627 / 2008$ & Res $N^{\circ} 675 / 2008$ & Res $N^{\circ} 635 / 2008$ \\
\hline \multicolumn{7}{|c|}{ Tarifas nos sistemas de distribuição na classe A3 (138 kV): } \\
\hline Demanda Ponta: & $\mathrm{R} \$ / \mathrm{kW}$ & 50,53 & 39,17 & 23,65 & 30,62 & 40,80 \\
\hline Demanda Fora Ponta: & $\mathrm{R} \$ / \mathrm{kW}$ & 14,31 & 9,65 & 5,76 & 7,55 & 11,28 \\
\hline Encargos: & $\mathrm{R} \$ / \mathrm{MWh}$ & 13,32 & 20,29 & 20,72 & 21,04 & 20,01 \\
\hline \multicolumn{7}{|l|}{ Estimativa de Gastos Anuais ( $R \$)$} \\
\hline TUSD & $\mathrm{R} \$$ & $57.401 .167,20$ & $48.478 .159,21$ & $33.559 .003,75$ & $40.556 .630,16$ & $50.880 .638,19$ \\
\hline Fio & $\mathrm{R} \$$ & $50.575 .200,00$ & $38.080 .185,84$ & $22.940 .505,84$ & $29.773 .974,12$ & $40.625 .524,80$ \\
\hline Encargos & $\mathrm{R} \$$ & $6.825 .967,20$ & $10.397 .973,37$ & 10.618.497,91 & $10.782 .656,04$ & $10.255 .113,39$ \\
\hline \multicolumn{7}{|l|}{ Estimativa da TUSD em R $\$ / M W h$} \\
\hline TUSD & $\mathrm{R} \$ / M W h$ & 112,01 & 94,60 & 65,48 & 79,14 & 99,28 \\
\hline Fio & $\mathrm{R} \$ / \mathrm{MWh}$ & 98,69 & 74,31 & 44,76 & 58,10 & 79,27 \\
\hline Encargos & $\mathrm{R} \$ / \mathrm{MWh}$ & 13,32 & 20,29 & 20,72 & 21,04 & 20,01 \\
\hline \multicolumn{7}{|c|}{ ANÁLISE DAS TARIFAS DE USO DO SISTEMA NA REDE BÁSICA (TUST) } \\
\hline Concessionária & - & Chesf & CEEE & CTEEP & CTEEP & SMTE \\
\hline Subestação de conexão & - & SE Camaçari II & SE Pólo Petroquímico & SE Sumaré & SE Baixada Santista & SE Paracatu 4 \\
\hline Tensão & - & $230 \mathrm{kV}$ & $230 \mathrm{kV}$ & $440 \mathrm{kV}$ & $230 \mathrm{kV}$ & $500 \mathrm{kV}$ \\
\hline $\mathrm{N}^{\circ}$ da Barra & - & Barra 5751 & Barra 1204 & Barra 571 & Barra 473 & Barra 4066 \\
\hline Resolução Homologatória ANEEL & & Res $N^{\circ} 671 / 2008$ & Res $N^{\circ} 671 / 2008$ & Res $N^{\circ} 671 / 2008$ & Res $N^{\circ} 671 / 2008$ & Res $N^{\circ} 671 / 2008$ \\
\hline \multicolumn{7}{|c|}{ Tarifas nos sistemas de transmissão (Rede Básica): } \\
\hline Demanda Ponta: & $\mathrm{R} \$ / \mathrm{kW}$ & 4,174 & 5,489 & 5,203 & 5,559 & 3,645 \\
\hline Demanda Fora Ponta: & $\mathrm{R} \$ / \mathrm{kW}$ & 0,00 & 0,00 & 0,00 & 0,00 & 0,00 \\
\hline Encargos: & $\mathrm{R} \$ / \mathrm{MWh}$ & 14,27 & 22,07 & 22,07 & 22,07 & 22,07 \\
\hline $\mathrm{CcC}$ & $\mathrm{R} \$ / \mathrm{MWh}$ & 9,22 & 9,22 & 9,22 & 9,22 & 9,22 \\
\hline CDE & $\mathrm{R} \$ / \mathrm{MWh}$ & 2,20 & 10,00 & 10,00 & 10,00 & 10,00 \\
\hline PROIINFA & $\mathrm{R} \$ / \mathrm{MWh}$ & 2,85 & 2,85 & 2,85 & 2,85 & 2,85 \\
\hline \multicolumn{7}{|l|}{ Estimativa de Gastos Anuais ( $R \$)$} \\
\hline TUST & $\mathrm{R} \$$ & $10.568 .524,20$ & $15.591 .412,20$ & $15.368 .332,20$ & $15.646 .012,20$ & $14.153 .092,20$ \\
\hline $\mathrm{FIO}$ & $\mathrm{R} \$$ & $3.255 .720,00$ & $4.281 .420,00$ & $4.058 .340,00$ & $4.336 .020,00$ & $2.843 .100,00$ \\
\hline Encargos & $\mathrm{R} \$$ & $7.312 .804,20$ & $11.309 .992,20$ & $11.309 .992,20$ & $11.309 .992,20$ & $11.309 .992,20$ \\
\hline \multicolumn{7}{|l|}{ Estimativa da TUST em R\$/MWh } \\
\hline TUST & $\mathrm{R} \$ / M W h$ & 20,62 & 30,42 & 29,99 & 30,53 & 27,62 \\
\hline $\mathrm{FIO}$ & $\mathrm{R} \$ / \mathrm{MWh}$ & 6,35 & 8,35 & 7,92 & 8,46 & 5,55 \\
\hline Encargos & $\mathrm{R} \$ / \mathrm{MWh}$ & 14,27 & 22,07 & 22,07 & 22,07 & 22,07 \\
\hline \multicolumn{7}{|c|}{ DIFERENÇA ENTRE TUST E TUSD } \\
\hline TUSD - TUST em R\$/MWh & $\mathrm{R} \$ / \mathrm{MWh}$ & 91,39 & 64,17 & 35,49 & 48,61 & 71,66 \\
\hline
\end{tabular}

Fonte: Resoluções ANEEL N 638/2008, 635/2008, 627/2008, 675/2008, 626/2008, 671/2008 e $567 / 2007$ 
Na Figura 9 é efetuada uma análise comparativa das TUSDs da Companhia de Eletricidade do Estado da Bahia - COELBA, com a TUST de Rede Básica na barra de $230 \mathrm{kV}$ da SE Camaçari II, que consiste na barra onde está conectada uma grande indústria petroquímica, a Braskem S.A., situada no pólo de Camaçari. Analisando a figura nota-se a elevada diferença entre TUST $_{R B}$ e as TUSDs da COELBA.

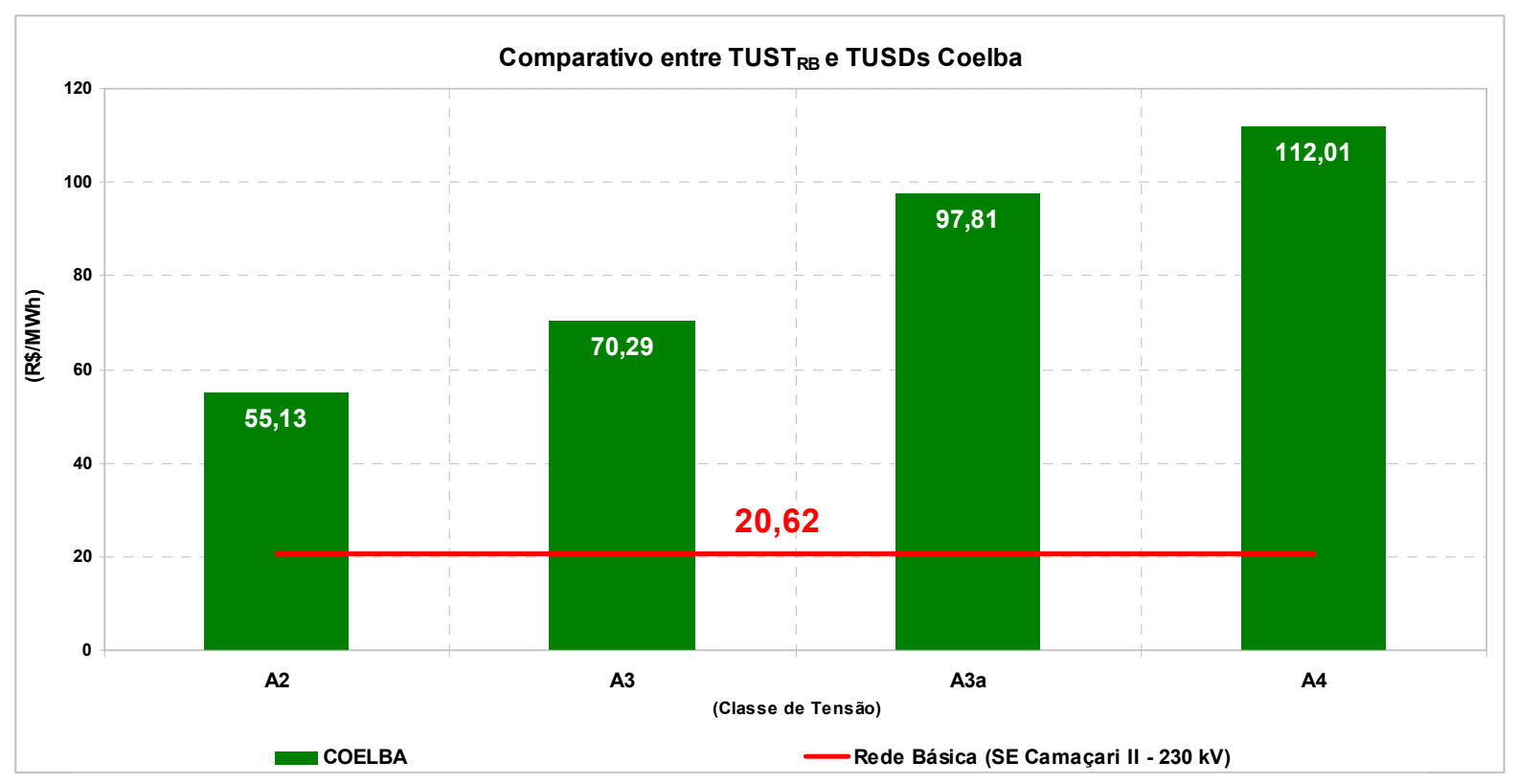

Figura 9 - Comparativo de TUSDs da distribuidora Coelba

Fonte: Resoluções ANEEL N 638/2008, 671/2008 e 567/2007

Na Figura 10 a seguir é efetuada uma análise comparativa das TUSDs da AES Sul, com a TUST de Rede Básica na barra de 230 kV da SE do Pólo Petroquímico, que consiste na barra da subestação compartilhada pelas empresas do Pólo Petroquímico de Triunfo, no Rio Grande do Sul. Analisando a figura nota-se a elevada diferença entre a TUST RB $_{\text {e }}$ as TUSDs da AES Sul. 


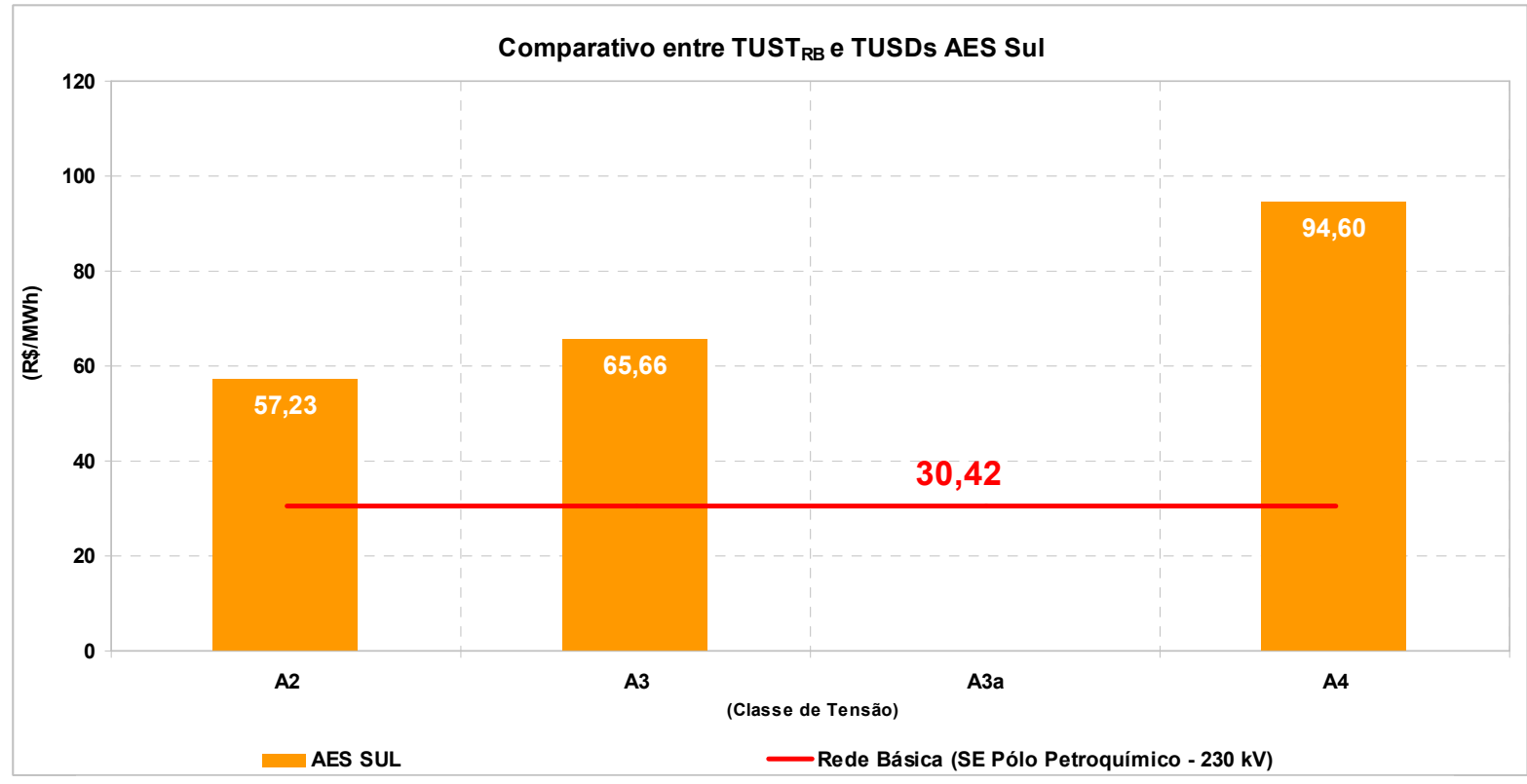

Figura 10 - Comparativo de TUSDs da distribuidora AES Sul

Fonte: Resoluções ANEEL N 635/2008, 671/2008 e 567/2007

De forma similar como feita para as distribuidoras COELBA e AES Sul, as figuras apresentadas a seguir ilustram a diferença entre a TUST e TUSDs das distribuidoras CPFL Paulista, Eletropaulo e Cemig. Destas três citadas distribuidoras, a CPFL Paulista é a que apresenta a menor diferença entre as TUSDs e a TUST RB $_{\text {adotada. }}$

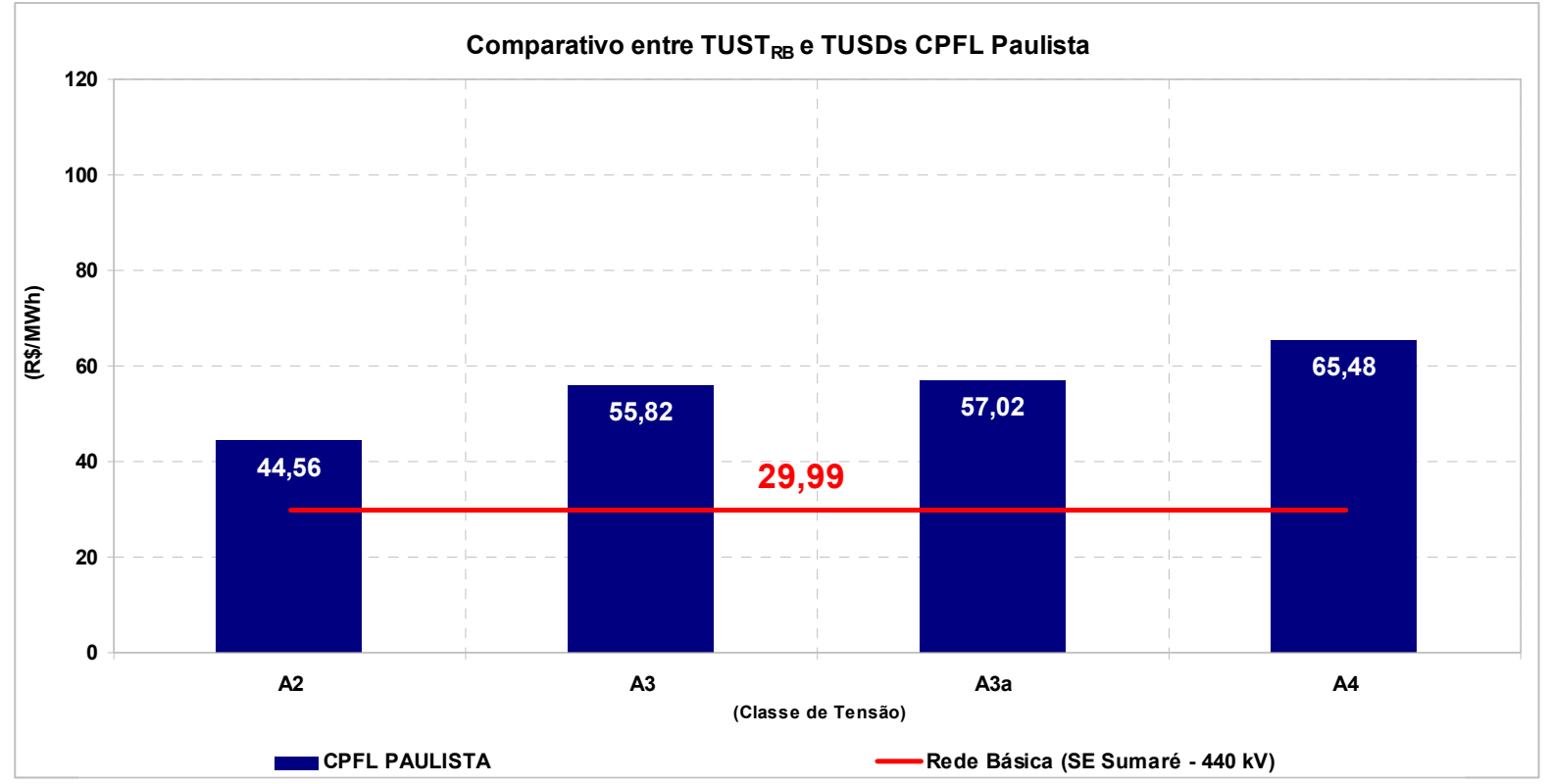

Figura 11 - Comparativo de TUSDs da distribuidora CPFL Paulista

Fonte: Resoluções ANEEL Nº 627/2008, 671/2008 e 567/2007 


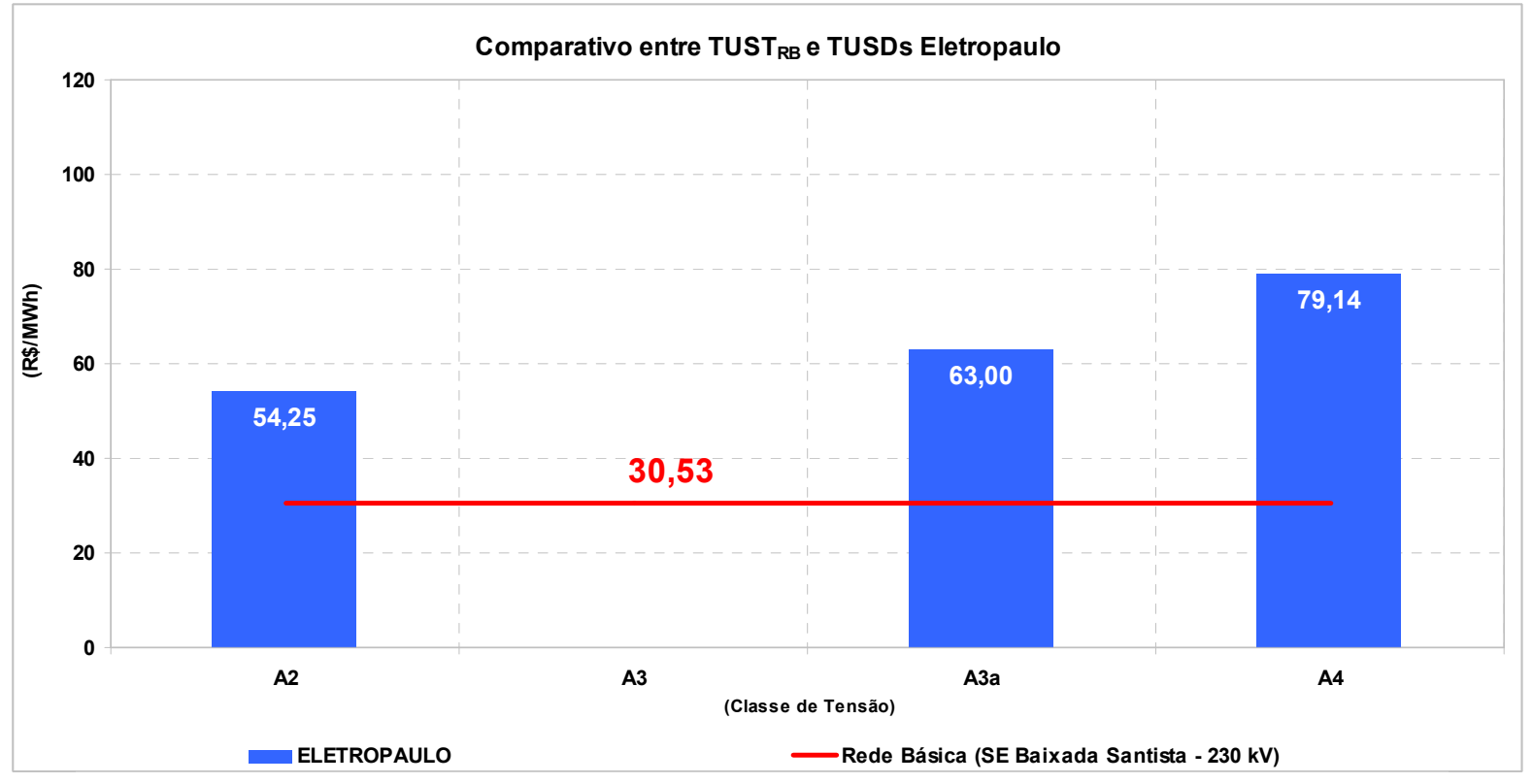

Figura 12 - Comparativo de TUSDs da distribuidora Eletropaulo

Fonte: Resoluções ANEEL № 675/2008, 626/2008, 671/2008 e 567/2007

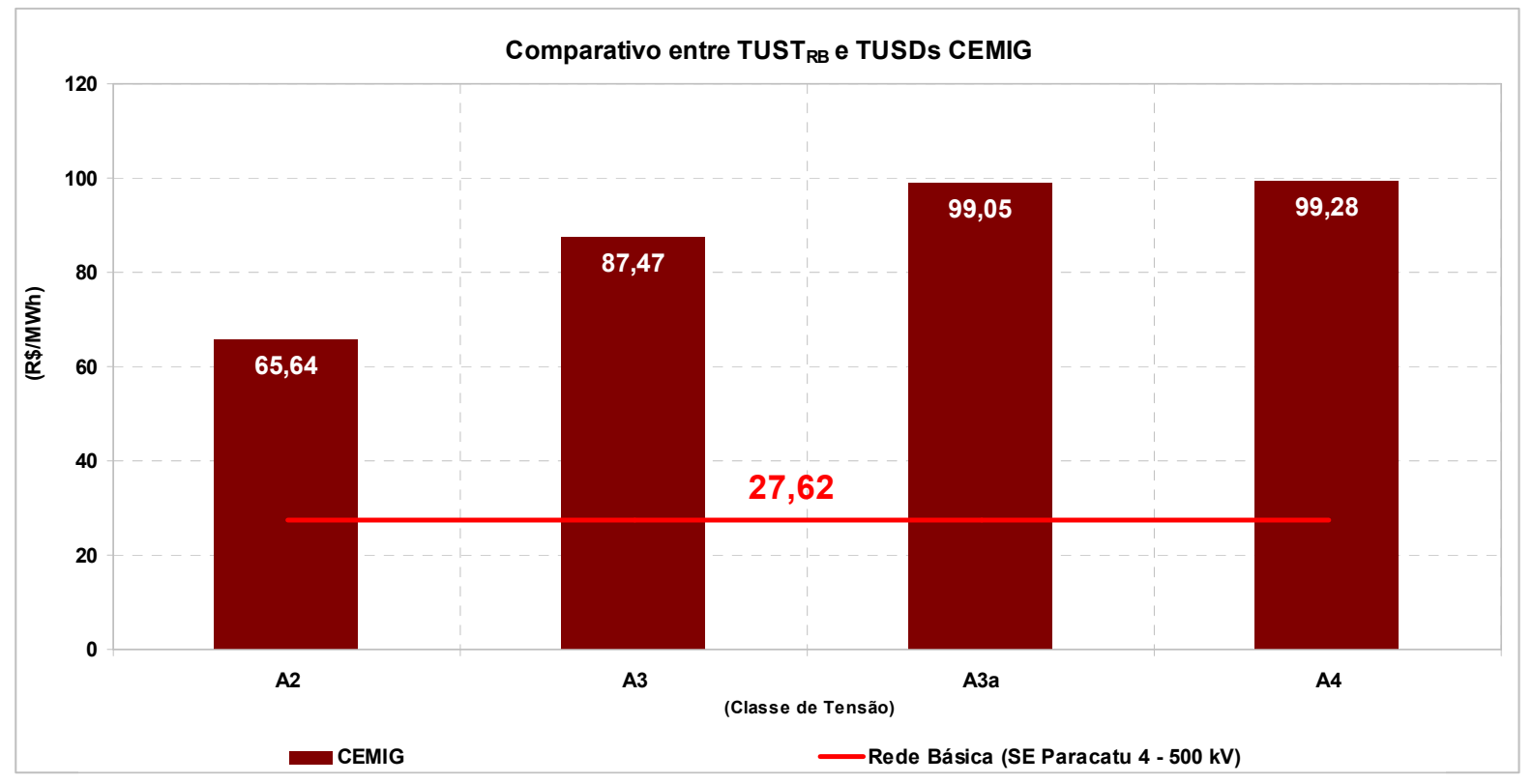

Figura 13 - Comparativo de TUSDs da distribuidora CEMIG

Fonte: Resoluções ANEEL N 626/2008, 671/2008 e 567/2007

A análise da Tarifa Fio comprova que o agrupamento de indústrias na forma de pólos industriais para compartilhar infra-estrutura elétrica e assim acessar tensões mais elevadas configura-se como uma importante estratégia para reduzir gastos com 
energia e, conseqüentemente, aumentar a competitividade ao setor industrial. Entretanto, a falta de regulamentação sobre o tema impede que esta estratégia seja aplicada de forma eficaz, em virtude dos riscos regulatórios atualmente existentes.

No Brasil já existem pólos em que este tipo de acesso conjunto é efetuado, como por exemplo, o Pólo Petroquímico de Triunfo, no Rio Grande do Sul, onde as indústrias se conectam à Rede Básica por meio de uma subestação transformadora 23034,5 kV compartilhada. Neste pólo todas as empresas são faturadas na tensão de $230 \mathrm{kV}$, sendo alguns consumidores cativos, que possuem demandas inferiores a $3 \mathrm{MW}$, e outros livres. Esta forma de faturamento gera uma vantagem competitiva substancial às empresas do pólo. Dado que este tipo de compartilhamento não é tratado de forma clara na legislação do setor elétrico, há incertezas se esta forma de faturamento permanecerá no futuro, o que pode inibir importantes expansões de unidade industriais existentes e instalação de novas indústrias no pólo.

\section{4 - Os Encargos Setoriais}

De forma simplificada, os encargos setoriais podem ser definidos como subsídios que são arrecadados dos geradores e consumidores, via concessionárias de transmissão e distribuição, para uma destinação específica relacionada ao mercado de energia, como por exemplo, incentivar a geração de fontes alternativas, sustentar as atividade de instituições, como ANEEL, ONS e CCEE, promover a universalização do serviço de energia elétrica, dentre outras.

Os aumentos dos encargos, em conjunto com outros fatores que pressionam para cima as tarifas de energia, elevam os custos de produção de importantes setores industriais, atingido, principalmente, os grandes consumidores de energia.

A falta de previsibilidade dos aumentos e a sua baixa aderência aos indicadores econômicos constituem um fator de risco permanente para os consumidores. A criação de novos encargos e a prorrogação daqueles previsto para serem extintos são fatores importantes e preocupantes na sistemática de aumento das tarifas do setor elétrico.

A Figura 14 apresenta a evolução de criação dos encargos setoriais ao longo do tempo. A descrição das siglas listadas nesta figura é apresentada na Tabela 10. 
Pode-se notar que, a partir de 1996, diversos encargos setoriais foram criados, o que contribuiu para aumentar as tarifas de energia.

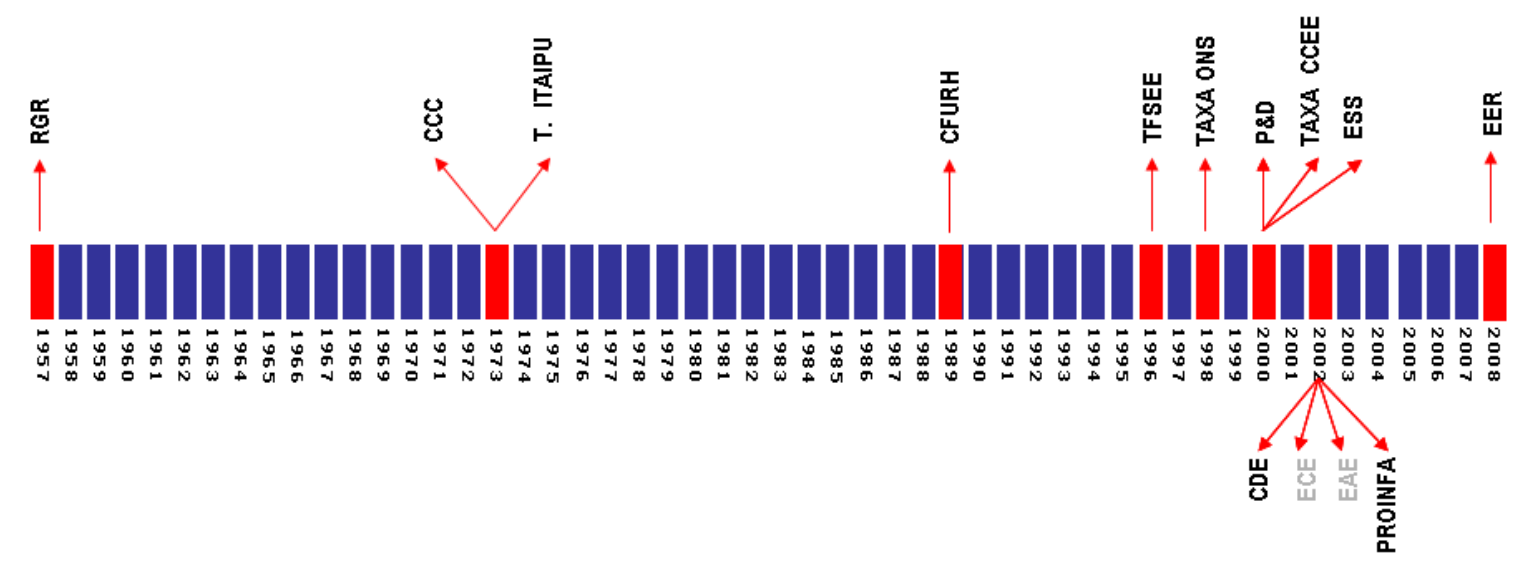

Linha do Tempo

Figura 14 - Evolução da criação de encargos setoriais

Fonte: Elaboração própria com base na legislação relacionada aos encargos setoriais

As siglas EAE e ECE indicados na Figura 14, correspondem ao Encargo de Capacidade Emergencial e ao Encargo de Aquisição de Energia Emergencial, que foram extintos em $2006 .^{6}$

A Tabela 10 apresenta em resumo a relação dos encargos setoriais que integram a tarifa de energia dos consumidores, descrevendo de forma resumida a finalidade de cada encargo.

6 O ECE e o EAE foram criados na época da crise de abastecimento de energia elétrica de 2001. O ECE era usado para remunerar os geradores termelétricos dos custos para que as usinas estivessem prontas para operar. O EAE era cobrado somente quando as usinas eram despachadas e tinham a finalidade de remunerar os custos com combustíveis usados durante o período em que as usinas estivessem gerando. 
Tabela 10 - Encargos setoriais incidentes nas tarifas de energia

\begin{tabular}{|c|c|c|}
\hline Encargo & Sigla & Finalidade \\
\hline Reserva Global de Reversão & RGR & $\begin{array}{l}\text { Indenizar ativos vinculados à concessão e fomentar a } \\
\text { expansão do setor elétrico }\end{array}$ \\
\hline Encargo de Serviço do Sistema & ESS & $\begin{array}{l}\text { Subsidiar a manutenção da confiabilidade e estabilidade } \\
\text { do Sistema Interligado Nacional e o despacho fora da } \\
\text { ordem de mérito por segurança energética. }\end{array}$ \\
\hline Pesquisa e Desenvolvimento & P\&D & $\begin{array}{l}\text { Promover pesquisa científica e tecnológicas relacionadas } \\
\text { à eletricidade e ao uso sustentável dos recursos naturais }\end{array}$ \\
\hline $\begin{array}{l}\text { Conta de Consumo de } \\
\text { Combustíveis }\end{array}$ & $\mathrm{CCC}$ & Subsidiar a geração térmica dos sistemas isolados. \\
\hline Royalties de Itaipu & - & $\begin{array}{l}\text { Pagar a energia gerada de acordo com o Tratado Brasil \& } \\
\text { Paraguai }\end{array}$ \\
\hline $\begin{array}{l}\text { Compensação Financeira pelo } \\
\text { Uso de Recursos Hídricos }\end{array}$ & CFURF & $\begin{array}{l}\text { Compensar financeiramente o uso da água e terras } \\
\text { produtivas para finas de geração de energia elétrica. }\end{array}$ \\
\hline $\begin{array}{l}\text { Taxa de Fiscalização dos } \\
\text { Serviços de Energia Elétrica }\end{array}$ & TFSEE & Prover recursos para o funcionamento da ANEEL. \\
\hline Taxa de Administração do ONS & Taxa ONS & Prover recursos para o funcionamento do ONS. \\
\hline $\begin{array}{l}\text { Taxa de Administração da } \\
\text { CCEE }\end{array}$ & Taxa CCEE & Prover recursos para o funcionamento da CCEE. \\
\hline $\begin{array}{c}\text { Conta de Desenvolvimento } \\
\text { Energético }\end{array}$ & CDE & $\begin{array}{l}\text { Propiciar o desenvolvimento a partir de fontes } \\
\text { alternativas, promover a universalização do serviço de } \\
\text { energia e subsidiar as tarifas residenciais dos } \\
\text { consumidores de Baixa Renda e a geração a carvão } \\
\text { vegetal no S/SE/CO. }\end{array}$ \\
\hline $\begin{array}{l}\text { Programa de Incentivo às } \\
\text { Fontes Alternativas de Energia }\end{array}$ & PROINFA & Subsidiar as fontes alternativas de energia. \\
\hline Encargo de Energia de Reserva & ERR & Subsidiar a geração de energia de reserva. \\
\hline
\end{tabular}

Fonte: Site ANEEL e legislação relacionada aos encargos setoriais

Apesar de não se configurarem como um encargo setorial, as perdas técnicas e comerciais de energia elétrica também são consideradas na formação de preços das tarifas de uso dos sistemas. As perdas técnicas correspondem às perdas inerentes 
ao processo de transmissão e distribuição, e são causadas pela dissipação de potência nos elementos que compõem os sistemas elétricos de potência, como os transformadores e linhas de transmissão e distribuição. As perdas comerciais são definidas como a diferença entre as perdas totais e as perdas técnicas, relacionando-se à energia efetivamente entregue ao consumidor, mas que não é faturada. Dentre suas causas destacam-se as ligações clandestinas, autoreligações, cadastro de iluminação pública desatualizado etc. As perdas comerciais estão diretamente associadas à gestão comercial da concessionária distribuidora.

No Brasil, a prática de criação de encargos setoriais tornou-se uma política muito comum para subsidiar programas, como por exemplo, incentivar o uso de fontes alternativas de energia, universalização do serviço de energia, a geração a biomassa, dentre outros.

Por outro lado, verifica-se historicamente que a extinção dos encargos é algo raro, como aconteceu com o ECE e EAE. Após criados, os encargos setoriais dificilmente são extintos, e passam a ser prorrogados, a exemplo do que ocorreu com a CCC dos sistemas isolados, que teve a sua extinção prorrogada para 2023.

Em 2007 a arrecadação de encargos sofreu uma redução de 17\% em relação ao ano de 2006, porém, em 2008 a arrecadação dos encargos setoriais voltou a aumentar e atingiu o mesmo patamar que a arrecadação de 2006.

Recentemente, outro encargo que até pouco tempo apresentava parcela pequena ganhou força com o despacho de termelétricas fora da ordem de mérito econômico ${ }^{7}$ pelo CNPE. Este encargo é o Encargos de Serviço do Sistema, que chegou a atingir a cifra de $\mathrm{R} \$ 8 / \mathrm{MWh}$ em 2008.

Como o ESS passou a desempenhar mais uma finalidade, a de segurança energética, a elevação deste encargo acabou compensando a extinção do ECE e EAE.

Em 2008 estima-se que o total arrecadado com encargos setoriais atingiu a cifra de R\$ 14 bilhões, sendo que apenas três encargos foram responsáveis por, aproximadamente, $60 \%$ do total recolhido. Estes encargos são CCC, CDE e

\footnotetext{
O despacho de termelétricas fora da ordem de mérito econômico foi autorizado pela Resolução Conselho Nacional de Política Energética - CNPE No 08, de 20.12.2007. Este despacho foi realizado a partir do início de 2008 para assegurar os níveis dos reservatórios das hidrelétricas do Brasil, que diminuíram significativamente em função do atraso no regime de chuvas do segundo semestre de 2007. A referida resolução do CNPE determinou que o Custo Variável Unitário - CVU das usinas despachadas fora da ordem de mérito econômico não seria utilizado para cálculo do Preço de Liquidação das Diferenças - PLD, ou preço no mercado spot de energia. Assim, o custo adicional do despacho passou a ser cobrado dos consumidores via Encargo de Serviços do Sistema - ESS.
} 
PROINFA. A Figura 15 apresenta a evolução da arrecadação de encargos setoriais de 2002 a 2008, comparando com a evolução do mercado de energia no mesmo período.

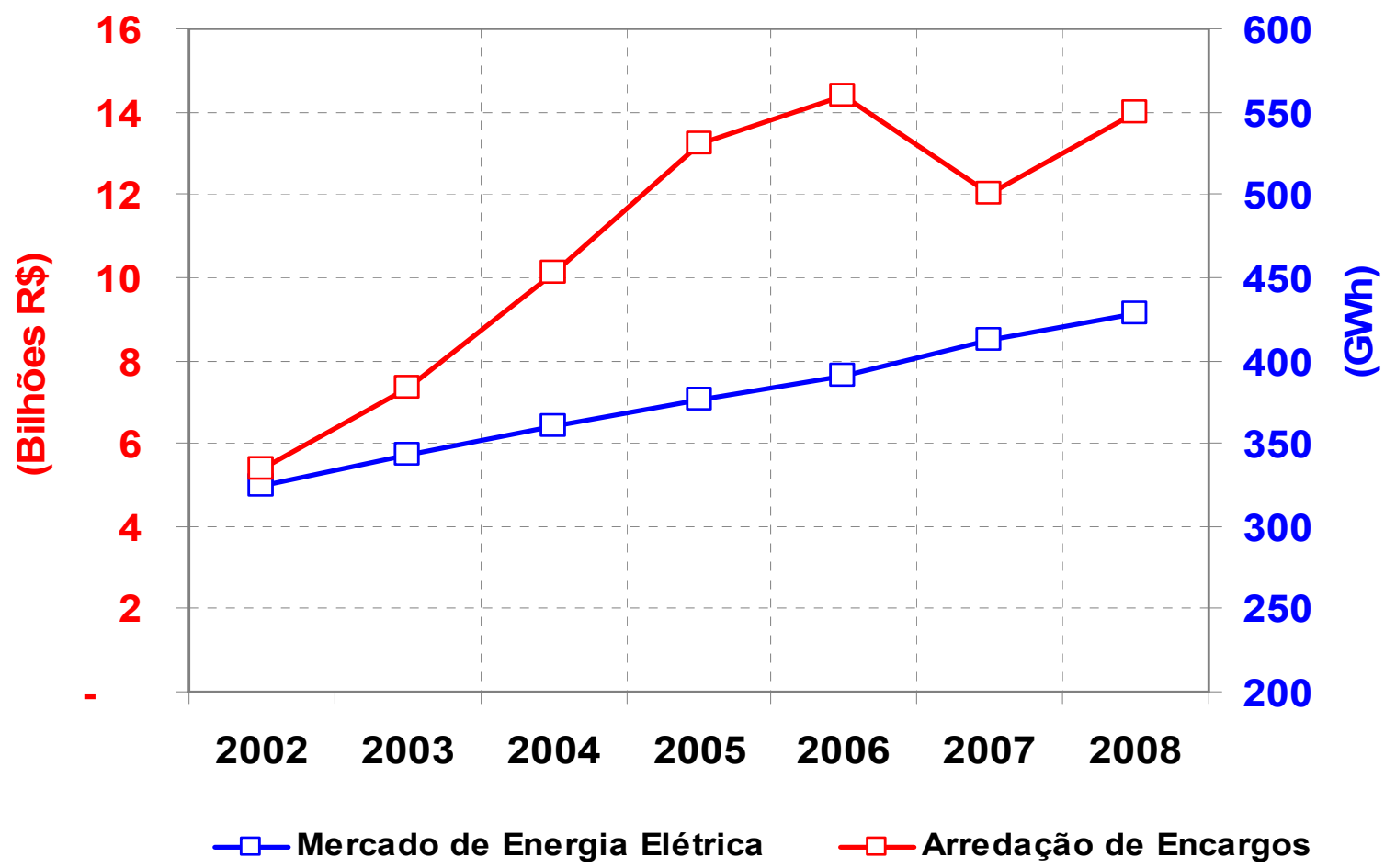

Figura 15 - Evolução da arrecadação dos encargos setoriais e do mercado de energia elétrica

Fonte: Associação Brasileira dos Grandes Consumidores de Energia e Consumidores Livre ABRACE / MME (Balanço Energético Nacional 2009 / Ano Base 2008).

$\mathrm{Na}$ Figura 16 são apresentados aumentos acumulados da arrecadação dos encargos setoriais e do mercado de energia elétrica. Nesta figura pode-se observar que a arrecadação dos encargos sofreu um aumento de $160 \%$ de 2002 a 2008, enquanto que no mesmo período, o mercado de energia elétrica aumentou $32 \%$. Isto mostra que a elevação da arrecadação dos encargos setoriais ocorreu mais em função do aumento do valor dos encargos setoriais do que devido ao crescimento do mercado de energia. 


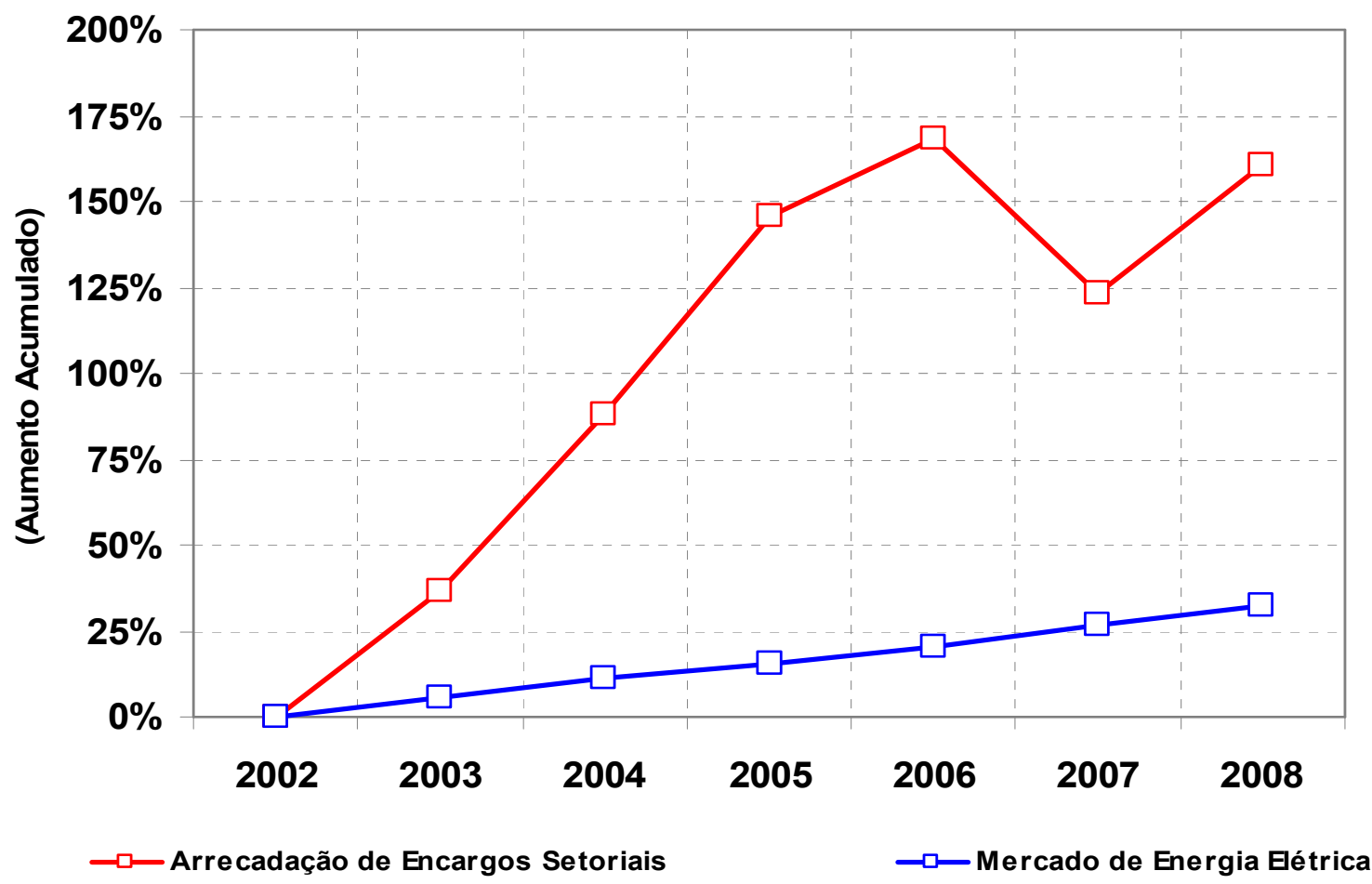

Figura 16 - Aumento acumulado da arrecadação dos encargos setoriais e do mercado de energia elétrica

Fonte: Associação Brasileira dos Grandes Consumidores de Energia e Consumidores Livre ABRACE / MME (Balanço Energético Nacional 2009 / Ano Base 2008)

Os encargos setoriais e os tributos são pagos por qualquer consumidor independente da tensão de conexão ao sistema elétrico e se o mesmo é cativo ou livre. Atualmente, a única forma de um consumidor reduzir o pagamento de encargos setoriais é por meio da auto-produção de energia elétrica, onde há isenção, sobre a parcela de energia gerada pelo próprio consumidor, dos encargos CCC, CDE, PROINFA e da parcela do ESS relacionada à segurança energética.

A instituição da uma legislação que isente o pagamento de encargos setoriais sobre a energia gerada e consumida internamente por indústrias integrantes de pólos industriais consiste numa medida muito interessante que pode incentivar a geração elétrica e, ao mesmo tempo, proporcionar energia mais competitiva às indústrias.

Atualmente, os encargos setoriais CCC, CDE e PROINFA juntos totalizam $\mathrm{R} \$ 23,65 / \mathrm{MWh}$ nos sub-mercados do Sudeste/Centro-Oeste e Sul, e R \$ 15,85/MWh nos sub-mercados Norte e Nordeste.

A isenção de encargos setoriais sobre a energia gerada e consumida internamente em pólos industriais poderia incentivar a implantação de novas plantas de cogeração 
de energia no país e contribuir para o uso racional de combustíveis e para o abastecimento elétrico do Brasil.

\section{5 - Os tributos}

O Brasil é um dos países com maior carga tributária incidente sobre a energia elétrica e o setor industrial vem cada vez mais perdendo competitividade devido à elevação das tarifas de energia elétrica, ocasionadas, em parte, pelo progressivo aumento da carga tributária.

A Tabela 11 a seguir apresenta os principais tributos incidentes sobre as tarifas de energia.

Tabela 11 - Tributos incidentes sobre energia elétrica

\begin{tabular}{ccc}
\hline Tributo & Sigla & Classificação \\
Programas de Integração Social & PIS & Federal \\
\hline Contribuição para o Financiamento da & COFINS & Federal \\
Seguridade Social & ICMS & Estadual \\
\hline Contribuição para Custeio do Serviço de lluminação \\
Pública
\end{tabular}

Fonte: Cartilha ANEEL - "Por Dentro da Conta de Luz" (2008)

A seguir é feita uma breve explicação sobre os tributos PIS/COFINS e ICMS, as quais foram obtidas da Cartilha ANEEL - "Por Dentro da Conta de Luz" (2008), disponibilizada no site desta agência. 


\section{PIS/COFINS}

Os tributos PIS/COFINS são cobrados pela União para manter programas voltados ao trabalhador e para atender a programas sociais do Governo Federal. A aplicação desses tributos foi recentemente alterada, com elevação no valor da conta de energia. Com a edição das Leis $n^{\circ} 10.637 / 2002$, $10.833 / 2003$ e $10.865 / 2004$, o PIS e a COFINS tiveram suas alíquotas alteradas para $1,65 \%$ e 7,6\%, respectivamente, passando a ser apurados de forma não cumulativa. Dessa forma, a alíquota média desses tributos passou a variar com 0 volume de créditos apurados mensalmente pelas concessionárias e com o PIS e a COFINS pagos sobre custos e despesas no mesmo período, tais como a energia adquirida para revenda ao consumidor.

\section{ICMS}

A cobrança do ICMS está prevista no Art. 155 da Constituição Federal de 1988. Este imposto incide sobre as operações relativas à circulação de mercadorias e serviços e é de competência dos governos estaduais e do Distrito Federal. O ICMS é regulamentado pelo código tributário de cada estado, ou seja, estabelecido em lei pelas casas legislativas. Por isso são variáveis. A distribuidora tem a obrigação de realizar a cobrança do ICMS direto na fatura e repassá-lo integralmente ao Governo Estadual.

A incidência do ICMS não é cumulativa, ou seja, há a possibilidade de se abater o ICMS pago (ou parte dele) com a parcela de ICMS recolhida com a venda final do produto industrializado. Por exemplo, o ICMS pago por uma indústria na aquisição de energia elétrica pode ser abatido do ICMS recolhido na venda de seus produtos finais. Em virtude desta possibilidade de obtenção de crédito do ICMS devido, o imposto acaba não sendo contestado com intensidade pelos contribuintes. Cabe ressaltar que sobre a parcela de produtos exportados, o crédito de ICMS acaba não sendo aproveitado.

A cobrança, não só do ICMS, mas de outros tributos sobre a energia elétrica ocasiona distorções substanciais, pois, ao incidir ao longo da cadeia de transformação de matéria e energia, os impostos acabam incidindo também sobre as perdas de todo o processo de transformação. Uma alternativa seria reduzir (ou até isentar) as alíquotas de tributos sobre a energia elétrica e aplicar os impostos sobre os produtos finais. 
Os tributos ICMS, PIS e COFINS são apurados na metodologia de cálculo por dentro, onde os próprios tributos integram a base de cálculo sobre a qual incidem suas respectivas alíquotas. Assim, o percentual real cobrado nas faturas de energia é maior que a alíquota fixada. Abaixo é apresentado o procedimento de cálculo da alíquota efetiva dos tributos sobre energia elétrica.

$$
\text { Alíquota Efetiva }=\frac{\text { Alíquota }}{(1-\text { Alíquota })}
$$

Uma alíquota de ICMS igual a 25\%, por exemplo, na metodologia de cálculo por dentro faz com que o peso real do tributo ao consumidor seja de $33 \%$, conforme procedimento de cálculo ilustrado a seguir.

$$
\text { Alíquota Efetiva }=\frac{25 \%}{(1-25 \%)}=33,33 \%
$$

$\mathrm{Na}$ conta de energia elétrica estão presentes tributos federais, estaduais e municipais e as distribuidoras são responsáveis apenas pelo recolhimento e repasse dos tributos às autoridades competentes pela sua cobrança. As resoluções publicadas pela ANEEL anualmente com as tarifas de cada distribuidora de energia elétrica não apresentam os tributos em seus valores.

A seguir é apresentado o procedimento de cálculo para se obter o valor final da tarifa de energia elétrica publicada pela ANEEL acrescendo os tributos PIS/COFINS e ICMS.

$$
\text { Tarifa Com Tributos }=\frac{\text { Tarifa publicada pela ANEEL }}{1-(P I S+C O F I N S+I C M S)}
$$


Ao longo dos anos a energia elétrica tornou-se um meio de arrecadação muito atraente, sendo o ICMS o imposto com maior peso nos custos de energia. Dada a facilidade na arrecadação de tributos sobre a energia elétrica, diversos estados brasileiros vem utilizando o ICMS como estratégia de arrecadação. A Figura 17 apresenta a evolução da arrecadação global do ICMS, bem como da parcela específica de arrecadação sobre energia elétrica. Verifica-se que a energia elétrica contribui com cerca de $12 \%$ sobre a arrecadação total do ICMS pelos estados.

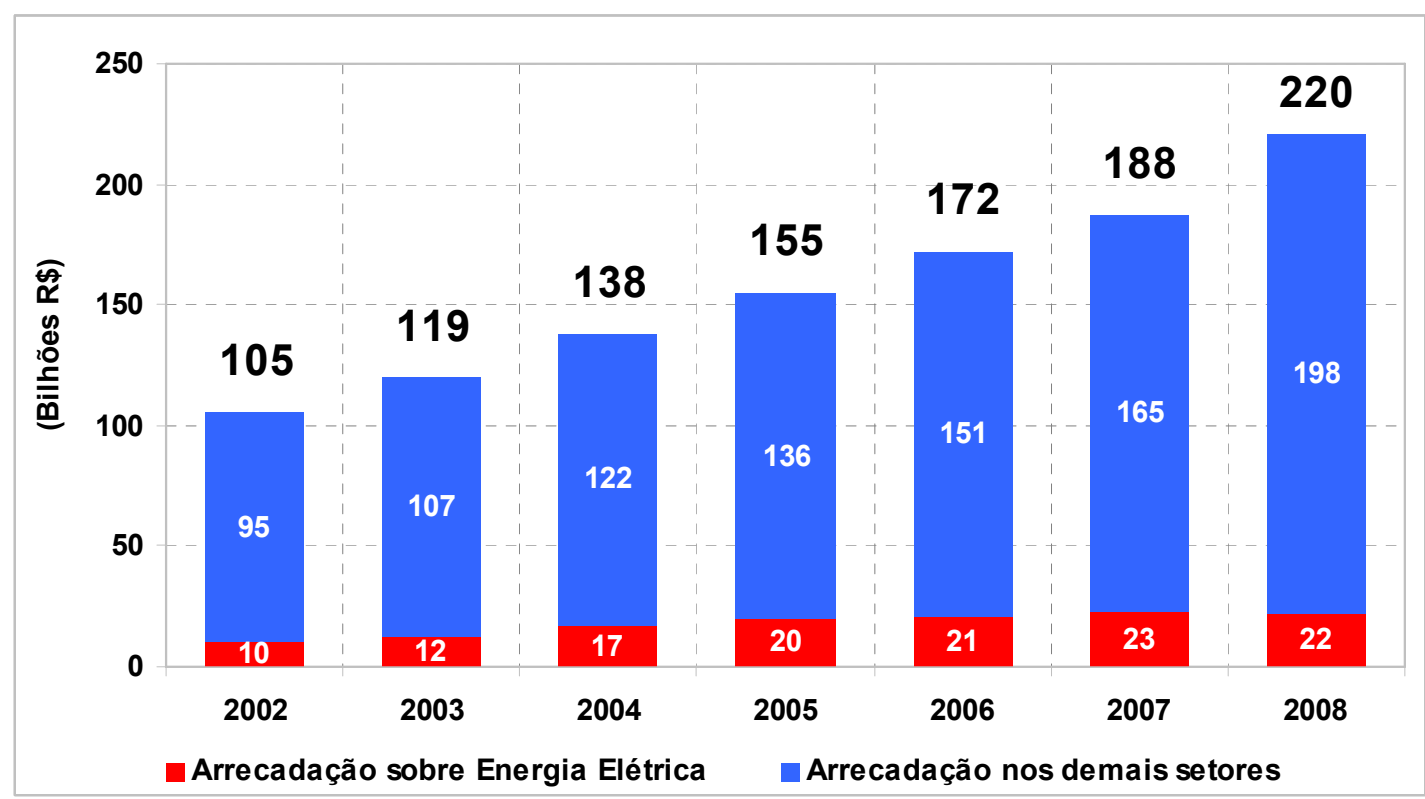

Figura 17 - Evolução da arrecadação de ICMS total e sobre energia elétrica

Fonte: Site do Conselho Nacional de Política Fazendária - Confaz, Comissão Técnica Permanente do ICMS - COTEPE (www.fazenda.gov/confaz/boletim/) - Acesso em 15.05.2009

Na Tabela 12 são apresentados dados do histórico de arrecadação do ICMS total e sobre a energia elétrica, comparando com a evolução do mercado de energia elétrica. Verifica-se que de 2002 a 2008 o mercado de energia elétrica teve um crescimento de $32 \%$, enquanto que a arrecadação de ICMS sobre a energia elétrica teve um aumento de $120 \%$ no mesmo período. Isto mostra que o aumento na arrecadação do ICMS sobre energia elétrica pode ter ocorrido devido a aumentos nas alíquotas fixadas pelos estados para este tributo. 
Tabela 12 - Análise da arrecadação de ICMS sobre energia elétrica e do mercado de energia

\begin{tabular}{lcccccccc}
\cline { 2 - 7 } & & $\mathbf{2 0 0 2}$ & $\mathbf{2 0 0 3}$ & $\mathbf{2 0 0 4}$ & $\mathbf{2 0 0 5}$ & $\mathbf{2 0 0 6}$ & $\mathbf{2 0 0 7}$ & $\mathbf{2 0 0 8}$ \\
\hline Mercado de Energia Elétrica & $(\mathrm{TWh})$ & 325 & 343 & 360 & 376 & 390 & 413 & 429 \\
\hline $\begin{array}{l}\text { Crescimento Acumulado do } \\
\text { Mercado de Energia Elétrica }\end{array}$ & $(\%)$ & - & $6 \%$ & $11 \%$ & $16 \%$ & $20 \%$ & $27 \%$ & $32 \%$ \\
\hline $\begin{array}{l}\text { Arrecadação do ICMS sobre } \\
\text { Energia Elétrica }\end{array}$ & $($ Bilhões R\$) & 10 & 12 & 17 & 20 & 21 & 23 & 22 \\
\hline $\begin{array}{l}\text { Crescimento Acumulado da } \\
\text { Arrecadação do ICMS sobre } \\
\text { Energia Elétrica }\end{array}$ & $(\%)$ & - & $21 \%$ & $66 \%$ & $95 \%$ & $107 \%$ & $124 \%$ & $120 \%$ \\
\hline
\end{tabular}

Fonte: Site do Conselho Nacional de Política Fazendária - Confaz, Comissão Técnica Permanente do ICMS - COTEPE (www.fazenda.gov/confaz/boletim/) - Acesso em 15.05.2009 e MME (Balanço Energético Nacional 2009 / Ano Base 2008)

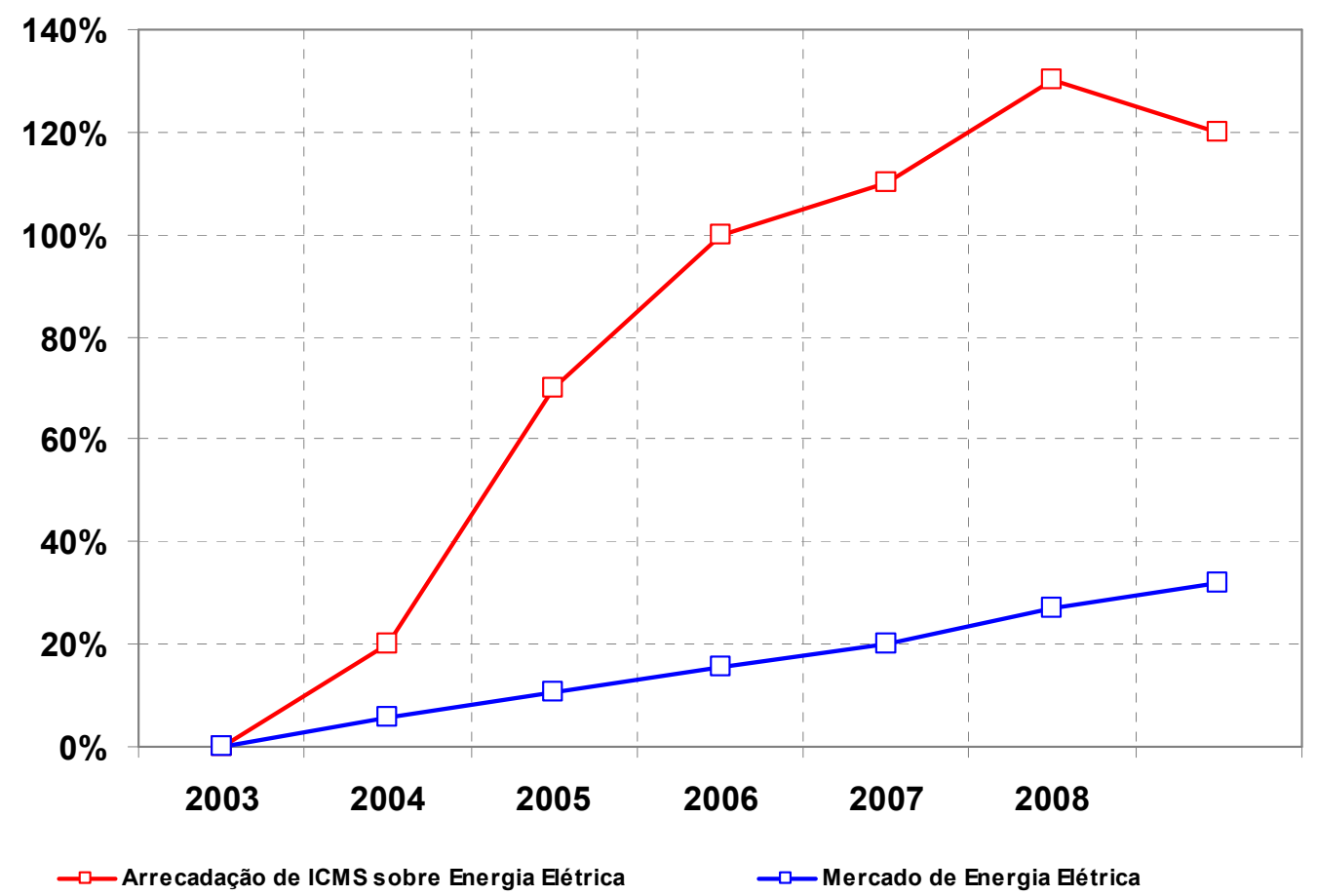

Figura 18 - Aumento acumulado da arrecadação de ICMS e do mercado de energia elétrica

Fonte: Site do Conselho Nacional de Política Fazendária - Confaz, Comissão Técnica Permanente do ICMS - COTEPE (www.fazenda.gov/confaz/boletim/) e MME (Balanço Energético Nacional 2009 / Ano Base 2008) 


\section{3 - ANÁLISE DAS TARIFAS INDUSTRIAIS DE ENERGIA ELÉTRICA EM OUTROS PAÍSES}

No capítulo anterior foi apresentada uma abordagem dos componentes da tarifa final de energia elétrica dos consumidores, indicando, em alguns casos, as medidas que podem ser adotadas para redução de cada componente.

Neste capítulo será feita uma análise comparativa das tarifas finais de energia elétrica do setor industrial no Brasil com as tarifas de alguns países industrializados, onde será evidenciado que nos últimos anos a tarifa industrial no Brasil sofreu aumentos expressivos, prejudicando a competitividade do setor.

Apesar de possuir uma matriz de geração de energia elétrica predominantemente hídrica, o Brasil possui uma das maiores tarifas de energia elétrica, quando considerados todos os componentes como uso do sistema elétrico, energia, encargos setoriais e impostos.

A Figura 19 apresenta a evolução, em valores médios e incluindo impostos, das tarifas finais de energia de alguns países. Verifica-se que a partir de 2004 as tarifas de energia elétrica no Brasil sofreram aumentos expressivos, chegando em 2008 a atingir o maior valor em relação aos países analisados. 


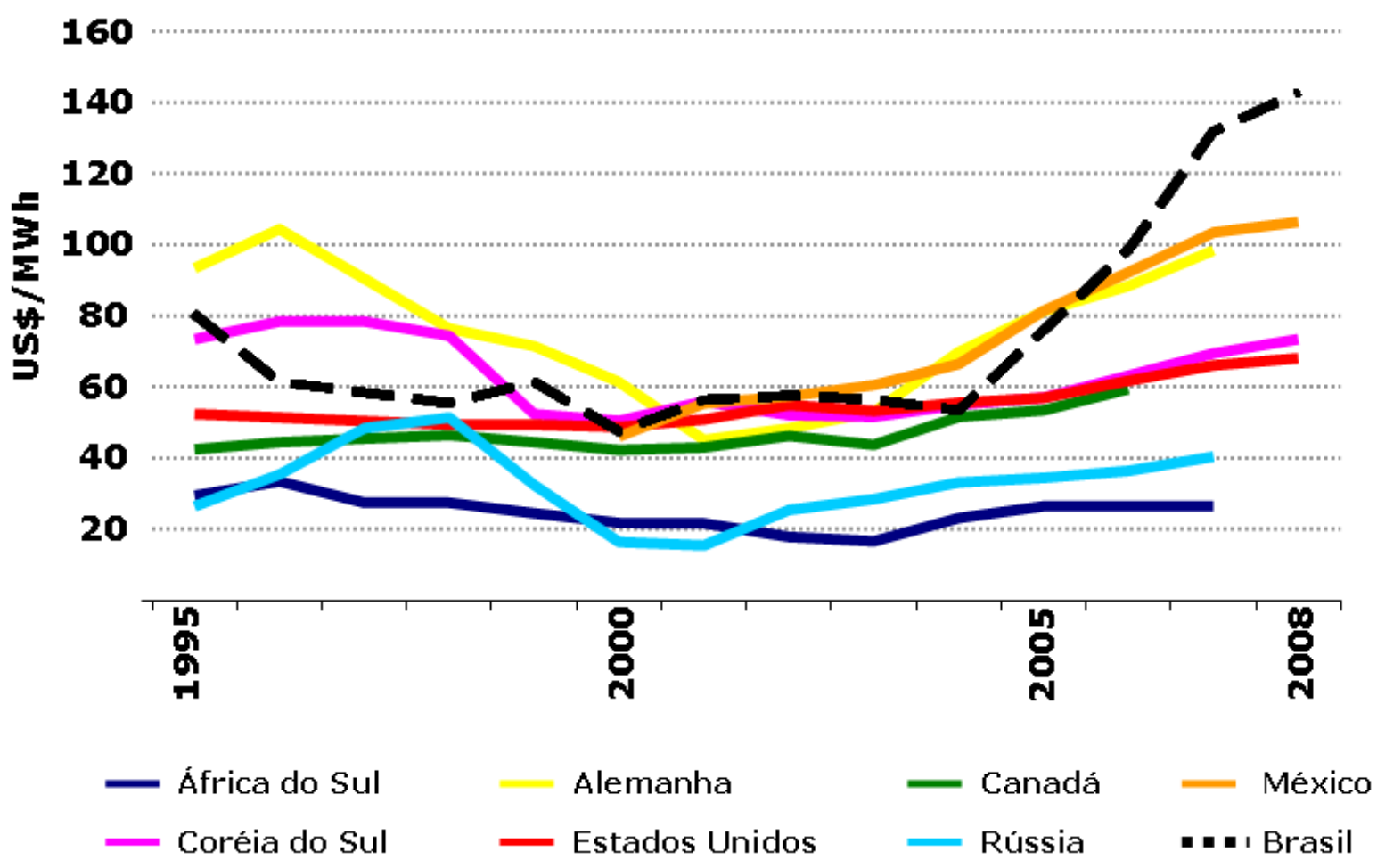

Figura 19 - Evolução das tarifas finais de energia em alguns países (Base: 2007) - Valores finais incluindo impostos. Taxa de câmbio de 2007 em 2,11 R\$/US\$

Fonte: Gráfico apresentado pela ABRACE no Evento "Agenda Regulatória 2009", promovido pelo Canal Energia em 11.05.2009.

Na Figura 20 é apresentada uma comparação entre as matrizes de geração de energia elétrica do Brasil, dos Estados Unidos da América - EUA e da França, sendo possível verificar claramente a predominância de geração hídrica no Brasil, térmica nos EUA e nuclear na França. 


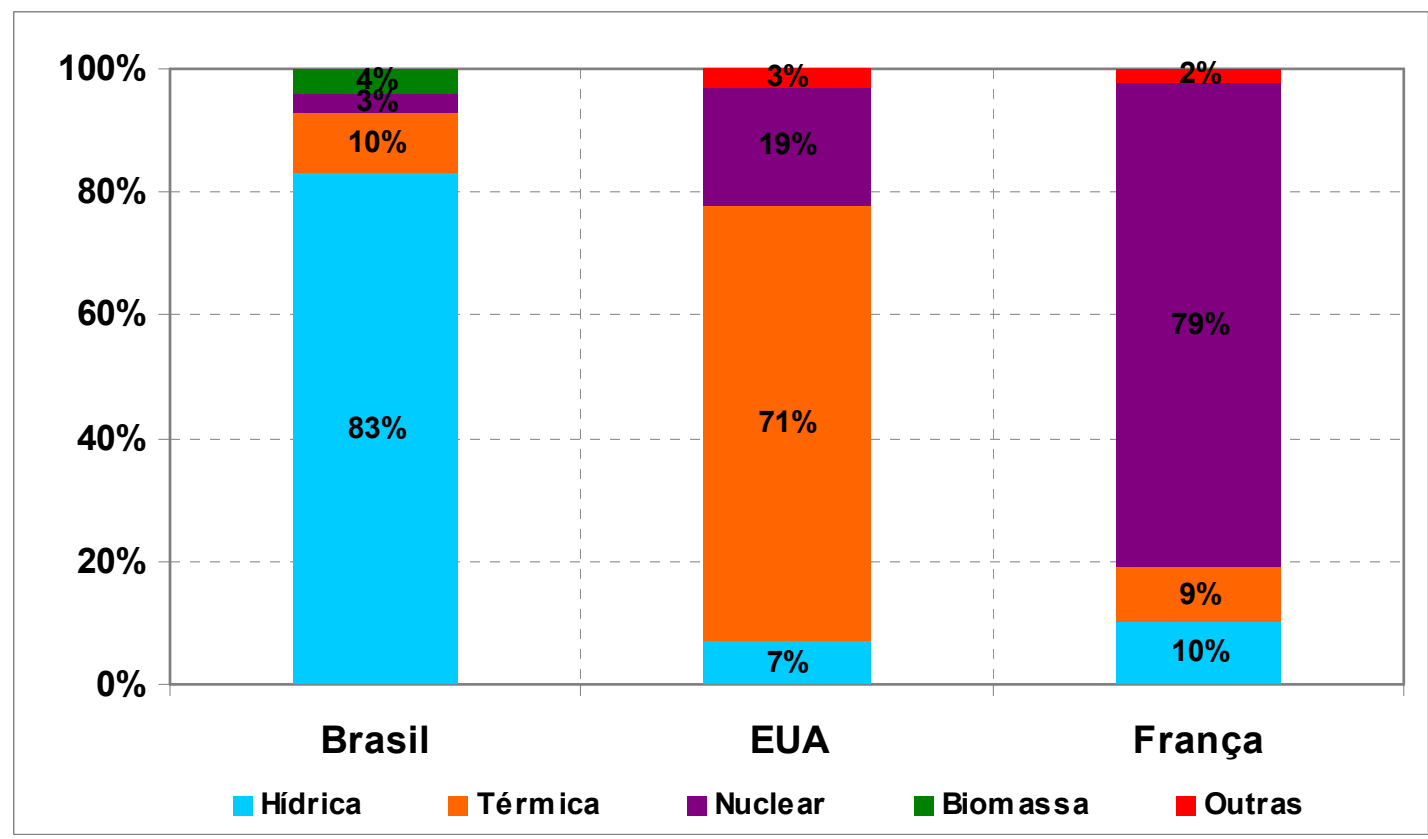

Figura 20 - Comparação da matriz de geração de energia elétrica do Brasil, EUA França Fonte: Energy Information Administration - EIA

Na Figura 21 são apresentados os custos médios de geração de energia elétrica por fonte. Os valores correspondem ao valor mínimo da tarifa que remunera o capital nos percentuais previamente definidos para o projeto, zerando o Valor Presente Líquido - VPL. Nota-se que a geração hidrelétrica possui os menores custos de geração.

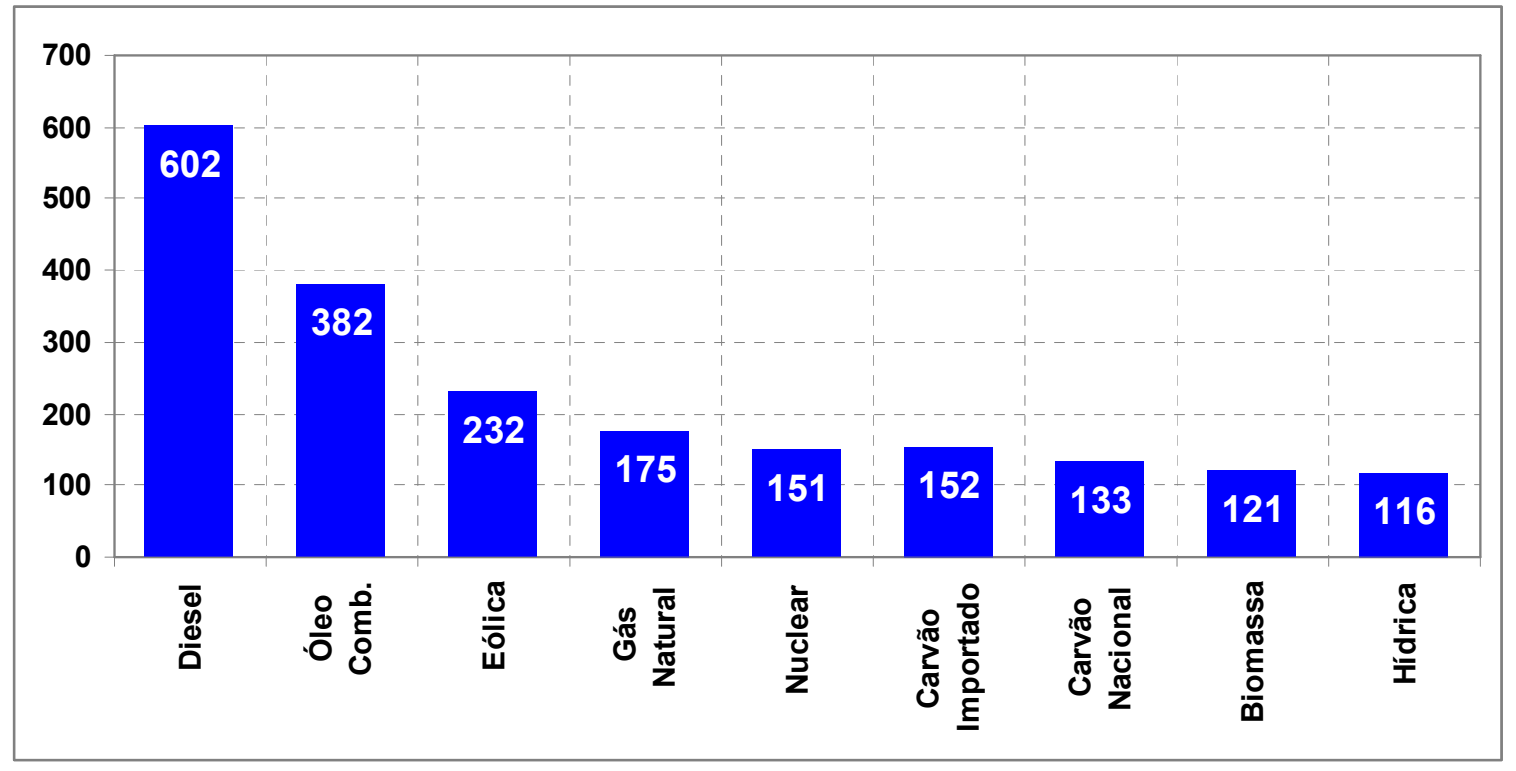

Figura 21 - Comparação dos custos médios de geração por fonte

Fonte: Energy Tax Fórum Brasil 2009 - Apresentação de Marcos Vinícius Gusmão no dia 19.05.2009 
Mesmo apresentando uma participação de $83 \%$ de fonte hídrica na matriz de geração de energia elétrica, o Brasil possui, em média, tarifas finais de energia elétrica superiores a dos Estados Unidos e França, que possuem matrizes energéticas baseada em geração térmica e nuclear, respectivamente. Este fato está relacionado, em parte, ao aumento dos impostos e encargos setoriais nas tarifas de energia elétrica, conforme abordado anteriormente nos Capítulo 2.5 e 2.4 .

A Figura 22 apresenta como evoluiu a participação dos encargos setoriais e tributos nas tarifas de energia no período de 2002 a 2007. Em 2007, a participação dos encargos setoriais e impostos nas tarifas de energia foi de $12 \%$ e $39 \%$, respectivamente, totalizando $51 \%$ da parcela da tarifa. Portanto, a maior parte da tarifa não está diretamente relacionada ao serviço de energia elétrica.

Ao mudar a base de cálculo colocando como referência a parcela relacionada de fato com o serviço energia elétrica, ou seja, $49 \%$, tem-se um pagamento adicional de 104\% sobre o que seria a remuneração pela prestação do serviço de energia elétrica e aquisição de energia. Em outras palavras, os encargos setoriais e tributos somam valor superior ao próprio valor da prestação do serviço de energia elétrica.

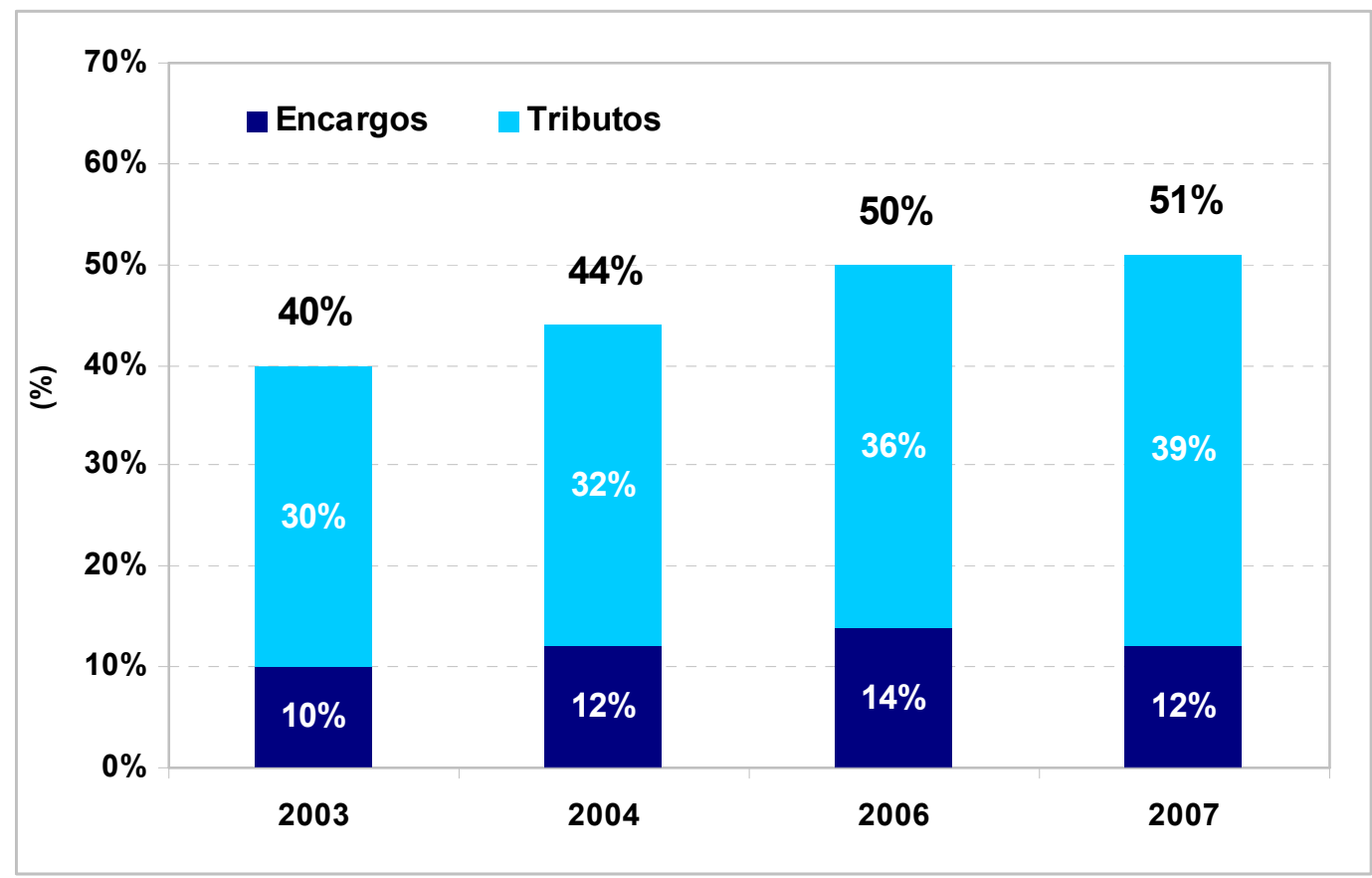

Figura 22 - Evolução da participação dos encargos e tributos como parte da tarifa de energia

Fonte: Estudo ABRACE com base em informações de Relatórios da Comissão de Valores Imobiliários - CVM, Eurostat; International Energy Agency - IEA. Gráfico apresentado pela ABRACE no Evento “Agenda Regulatória 2009”, promovido pelo Canal Energia em 11.05.2009. 
A carga tributária sobre a eletricidade no Brasil é bastante superior à de outros países, conforme pode ser observado na Tabela13. Este fato, em muitos casos, pode ocasionar a transferência de indústrias do Brasil para países onde os custos finais de energia são mais competitivos.

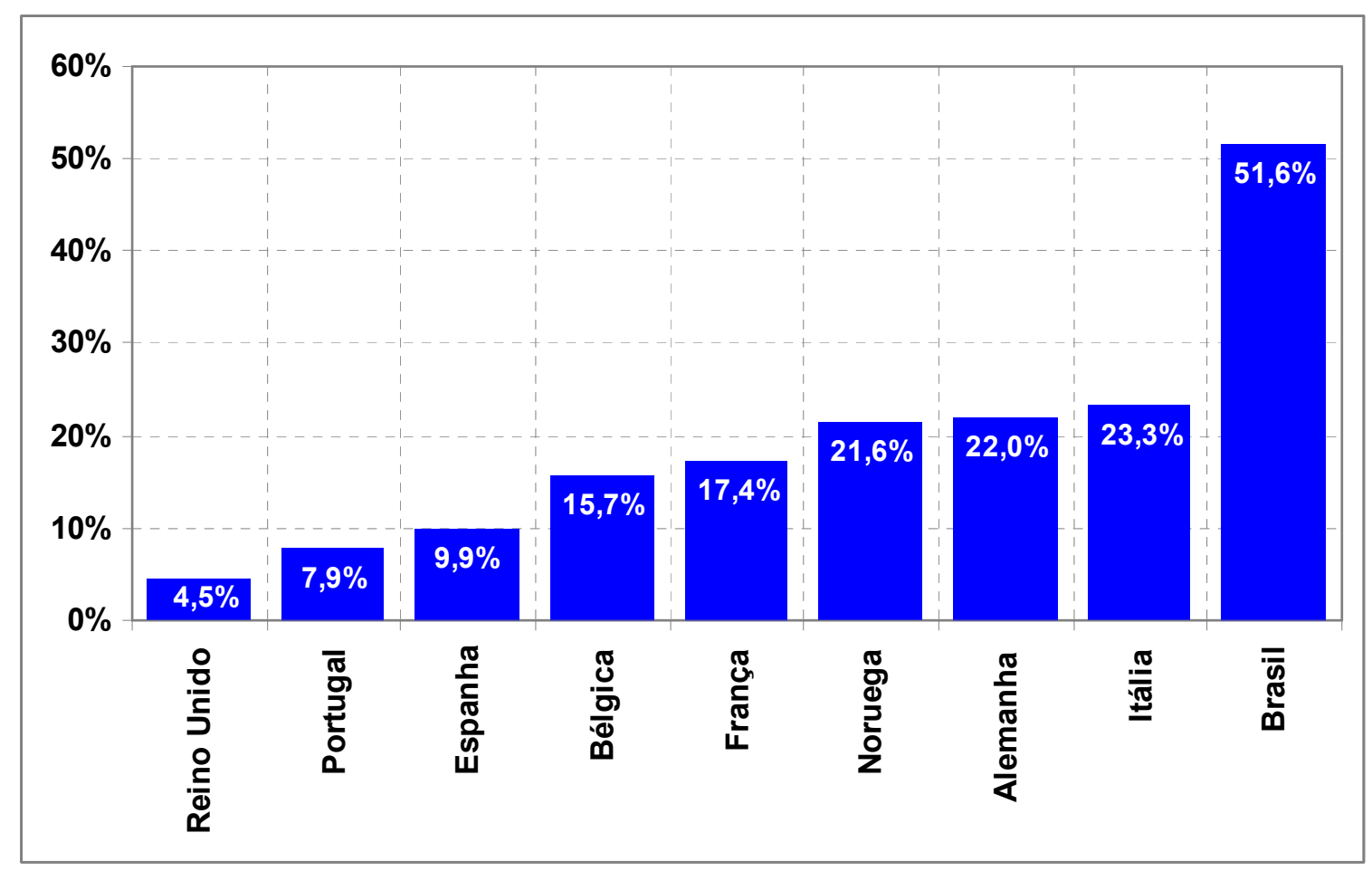

Tabela13 - Comparação da carga tributária tarifa final de energia elétrica de alguns países industrializados (Base 2007)

Fonte: Energy Tax Fórum Brasil 2009 - Apresentação de Marcos Vinícius Gusmão no dia 19.05.2009

Conforme pode ser observado na Figura 23 apresentada a seguir, a tarifa média final de energia elétrica do setor industrial do Brasil sofreu no período de 2002 a 2007 um aumento de 166\%, o que corresponde à uma taxa de crescimento anual composta de $21,6 \%$, percentual muito superior aos países analisados, como mostrado na Tabela 14. 


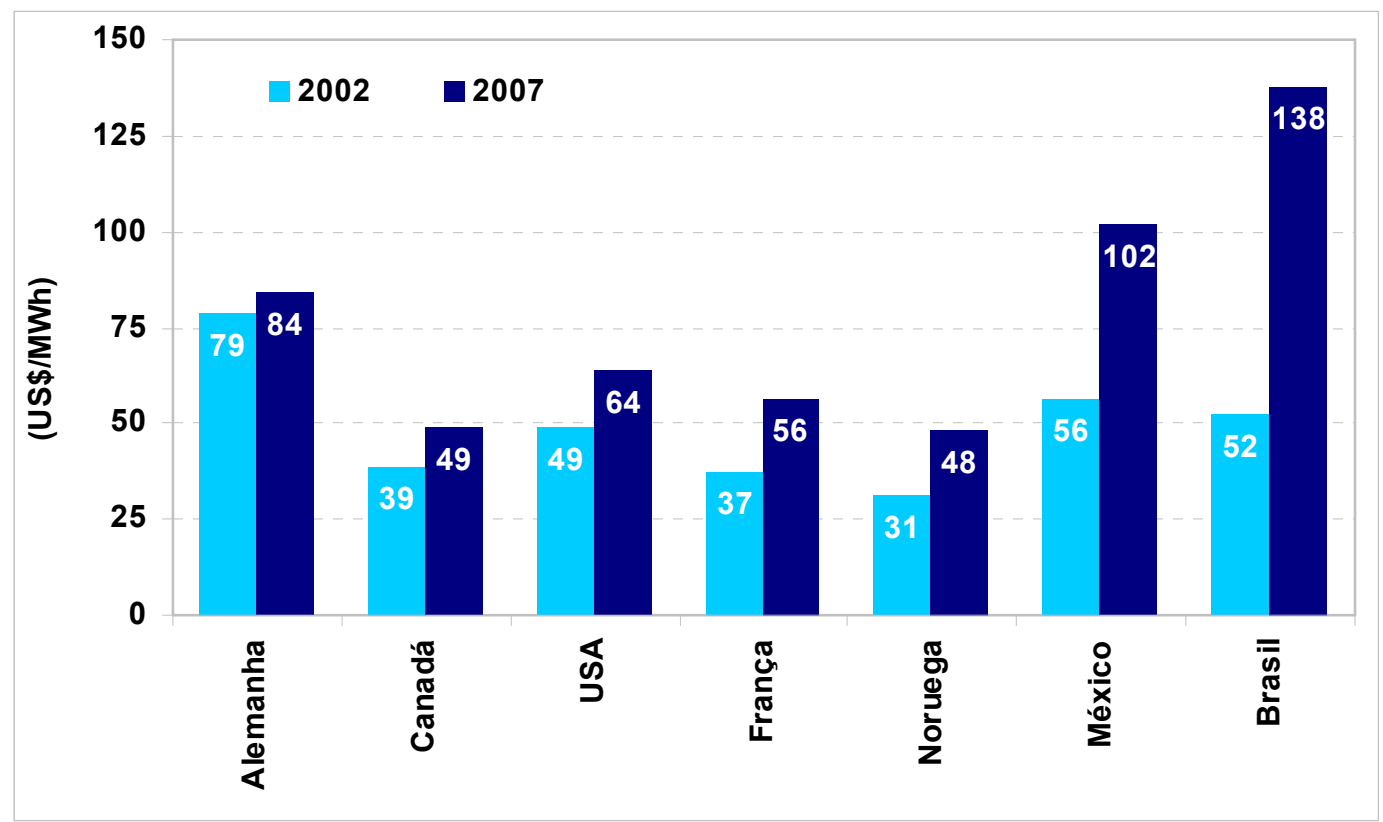

Figura 23 - Crescimento das tarifas finais de energia elétrica de 2002 a 2007 em alguns países Fonte: Estudo ABRACE com base em informações da EIA, IEA, ANEEL. Gráfico apresentado pela ABRACE no Evento “Agenda Regulatória 2009", promovido pelo Canal Energia em 11.05.2009.

Tabela 14 - Comparação da evolução das tarifas médias de energia elétrica do setor industrial de alguns países

\begin{tabular}{cccc}
\hline \multirow{2}{*}{ País } & \multicolumn{2}{c}{ Tarifa Média Industrial (US\$/MWh) } & Taxa de crescimento anual \\
\cline { 2 - 3 } composta
\end{tabular}

Fonte: Energy Tax Fórum Brasil 2009 - Informações apresentadas por Marcos Vinícius Gusmão no dia 19.05.2009 
O Brasil apresenta uma particularidade interessante que difere de alguns países desenvolvidos. De 2002 a 2007, a diferença relativa entre as tarifa médias do setor industrial e residencial vem diminuindo substancialmente.

$\mathrm{Na}$ Tabela 15 a seguir, são apresentados os valores das tarifas médias do setor industrial e residencial do Brasil e de alguns países industrializados em 2002 e 2007. Nota-se que de 2002 a 2007 a relação percentual entre a diferença de tarifa de energia elétrica industrial e residencial no Brasil passou de $27 \%$ para apenas $8 \%$, enquanto que em alguns países industrializadas a relação até aumentou. Entre os países industrializados estudados, o Canadá foi o que apresentou a maior redução na relação percentual das tarifas, passando de 35\% em 2002 para 27\% em 2007.

Tabela 15 - Comparação da evolução das tarifas médias industriais e residenciais de alguns países

\begin{tabular}{|c|c|c|c|c|c|c|}
\hline \multirow{2}{*}{ País } & \multicolumn{3}{|c|}{2002} & \multicolumn{3}{|c|}{2007} \\
\hline & Indust. & Resid. & $\begin{array}{c}\text { Relação } \\
\text { (Res-Ind)/Ind }\end{array}$ & Indust. & Resid. & $\begin{array}{c}\text { Relação } \\
\text { (Res-Ind)/Ind }\end{array}$ \\
\hline Alemanha & 79 & 167 & $52 \%$ & 84 & 212 & $60 \%$ \\
\hline Canadá & 39 & 60 & $35 \%$ & 49 & 68 & $27 \%$ \\
\hline USA & 49 & 84 & $42 \%$ & 64 & 106 & $40 \%$ \\
\hline França & 37 & 105 & $65 \%$ & 56 & 158 & $64 \%$ \\
\hline Noruega & 31 & 81 & $62 \%$ & 48 & 132 & $64 \%$ \\
\hline Brasil & 52 & 71 & $27 \%$ & 138 & 150 & $8 \%$ \\
\hline
\end{tabular}

Fonte: Energy Tax Fórum Brasil 2009 - Informações apresentadas por Marcos Vinícius Gusmão no dia 19.05.2009

Os números apresentados na Tabela 15 mostram que o Brasil está seguindo numa linha contrária a postura dos países desenvolvidos, nos quais as tarifas de energia elétrica do setor industrial são bem inferiores que as tarifas residenciais.

O fato de o Brasil ter em sua classe de consumidores residenciais com poder aquisitivo menor do que dos países desenvolvidos pode ser um dos fatores que explicam a redução gradativa na diferença entre as tarifas. 
Nos países desenvolvidos, os consumidores residenciais possuem um maior poder de compra e possuem condições de arcar com custos maiores de energia, inclusive para subsidiar a geração por meio de fontes alternativas, por exemplo. No Brasil, a tarifa de energia elétrica do setor industrial vem aumentando cada vez mais e se aproximando das tarifas residenciais.

A Figura 24 apresenta a composição do mercado de energia no Brasil, Estados Unidos e Alemanha. Nota-se que os Estados Unidos possui um mercado de consumidores residenciais de $35 \%$, enquanto que no Brasil este mercado representa $22 \%$. A Alemanha apresenta mercado industrial e residencial parecidos com os Brasil, porém, o poder aquisitivo da população alemã é muito superior ao Brasil.

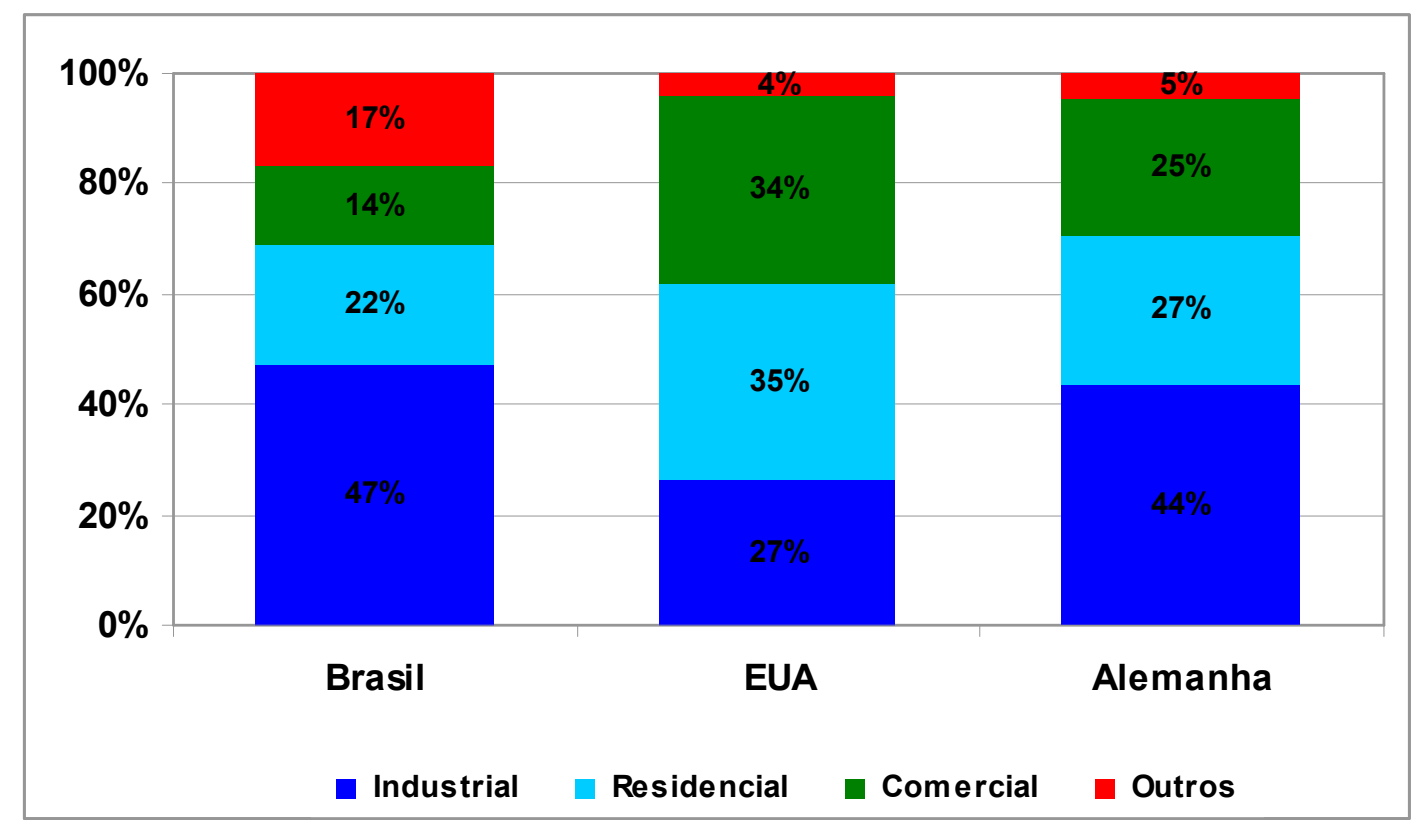

Figura 24 - Composição do mercado de energia elétrica do Brasil, Estados Unidos e Alemanha Fonte: EIA e EPE

A Tabela 16 seguinte apresenta uma análise do consumo de energia elétrica per capita do setor residencial e do PIB per capta do Brasil, Estados Unidos e Alemanha. Verifica-se que os Estados Unidos possui PIB per capta cerca de 5 vezes maior que o Brasil e consumo per capta de energia elétrico do setor residencial é 9,1 vezes maior.

A Alemanha, que possui participação parecida do setor industrial e residencial no mercado global de energia elétrica, o PIB per capta é 3,5 vezes maior que o Brasil e o consumo per capta de energia elétrica 3,4 vezes maior. Estas análises mostram 
que os consumidores residenciais dos países em desenvolvimento têm uma capacidade maior de absorver tarifas mais elevadas de energia elétrica.

Tabela 16 - Comparação dos aumentos das tarifas médias de energia elétrica do setor industrial de alguns países

\begin{tabular}{lcccc}
\cline { 3 - 5 } & & Brasil & EUA & Alemanha \\
\hline Mercado total & TWh & 390 & 3.814 & 526 \\
\hline População & $10^{6}$ hab. & 186 & 297 & 82 \\
\hline E.E. Residencial Per capta Mensal & kWh / hab/mês & 42 & 383 & 142 \\
\hline PIB Per capta (PPC / US\$ 2000) & US\$/hab/mês & 623 & 3.089 & 2.192 \\
\hline
\end{tabular}

Fonte: EIA / Key World Statstic (Ano Base 2006) / EPE (BEN 2008 / Ano Base 2007)

No Brasil a remuneração dos sistemas de distribuição é proporcional ao uso das redes elétricas e, portanto, a tarifa fio dos consumidores residenciais são maiores que de outros setores, uma vez que o serviço de distribuição residencial é feito em média e baixa tensão. Como a população do Brasil, em geral, possui baixo poder de compra, o setor industrial pode estar sendo onerado a fim de que as tarifas do setor residencial não atinjam valores muito elevados.

Transferir ao setor industrial parte dos custos da tarifa do setor residencial é uma forma prover à população energia elétrica mais barata, no entanto, esta política de subsídio deve ser analisada com bastante atenção, pois o encarecimento da tarifa da indústria pode prejudicar a competitividade deste setor e desestimular a atração de empresas ao país. Em alguns casos, acredita-se até ser possível o fechamento de plantas, principalmente as eletro-intensivas, em que os custos de energia elétrica contribuem com parcela significativa dos custos de produção, podendo atingir percentual da ordem de $60 \%$.

É importante pensar no fato de que a atração de indústrias ao país ocasiona aumento na geração de empregos, o que, conseqüentemente, gera um aumento no poder aquisitivo da população que passa então a ter condições de arcar com preços de energia elétrica maiores. 


\section{4 - PRINCIPAIS BENEFÍCIOS INERENTES À FORMAÇÃO DE PÓLOS INDUSTRIAIS}

Um dos primeiros autores a estudar os fatores que levam à concentração de empresas numa determinada região foi Marshall (1982), ao estudar os distritos industriais na Grã-Bretanha. Marshall observou que a concentração de empresas de negócios similares em localidades específicas fazem com que as mesmas se tornem mais eficientes e obtenham vantagens competitivas que individualmente não teriam. Os estudos de Marshall mostraram que a formação e a ampliação de redes de empresas industriais assumem uma dimensão estratégica no aumento da produtividade dos sistemas de produção locais e no fortalecimento da competitividade de cidades e regiões.

Após Marshall, outro importante autor sobre pólos foi Michael E. Porter (1990), que, aliás, é considerado um dos mais importantes estudiosos sobre o tema. Segundo Porter, a competição e cooperação entre empresas de um pólo são fatores essenciais ao desenvolvimento dos mesmos. Na visão de Porter, no mundo moderno a competição depende diretamente da produtividade, uma vez que o acesso à informação tornou-se muito facilitado a todos. Produtividade está relacionada na maneira que as empresas competem entre si e não nos campos em que elas competem.

Olímpio J. de Arroxelas Galvão (2000) ao estudar alguns casos de clusters em países industrializados conclui que "a idéia básica de Porter é que a vitalidade econômica de um setor é o resultado direto da competitividade de indústrias locais e que, num mundo globalizado, os indivíduos, as empresas, as regiões e o governo devem pensar globalmente, mas agir localmente". Segundo Galvão (2000) "essas idéias básicas trazem, como principal implicação, a de que o objetivo primordial a ser perseguido é o de criar, em cada local ou região, uma atmosfera favorável ao desenvolvimento de atividades econômicas, de modo a transformar essas regiões e locais em pólos dinâmicos de atração de novos investimentos e de inovação".

Porter estudou as características de pólos industriais de diversos países, dentre eles, Alemanha, Itália, Japão, Coréia, Cingapura, Suécia, Suíça, Reino Unido e Estados Unidos. Os estudos por Porter nos pólos da Dinamarca serviram de base empírica para formulação de sua teoria apresentada no livro "The Competitive Advantages of Nations", publicado em 1990. A Dinamarca é um país que possui uma 
política extremamente liberal em relação aos pólos industriais focando a questão energética, onde indústrias integrantes de pólos possuem liberdade para definir suas políticas sem interferências externas.

$\mathrm{Na}$ visão de Porter, os pólos promovem, ao mesmo tempo, a competição e cooperação entre seus integrantes, que são fatores fundamentais para que os pólos prosperem. Ao se desenvolverem, os pólos promovem não somente a competitividade entre suas empresas integrantes, mas também entre regiões e países, pois o pólo passa a ter vantagem competitiva em nível global.

As interações entre as empresas integrantes de um cluster, segundo Porter, podem ocorrer verticalmente, baseadas na relação comprador/fornecedor, como em cadeias produtivas completas, ou horizontalmente, entre concorrentes, clientes etc.

Goldstein e Toledo (2004) no trabalho "Vantagens Competitivas em Clusters Industriais", relatam as pesquisa de Piore e Sabel (1984, apud Bennet, 1994) que constataram o surgimento de aglomerações de empresas menores na Europa na década de 1970, especialmente na Itália, as quais foram denominadas distritos industriais. Esses distritos industriais concentrados em determinada cadeia produtiva despertaram a atenção de pesquisadores pela alta eficiência obtida por meio de especialização e pela forte relação entre seus integrantes.

A Europa tem diversas experiências bem sucedidas de políticas de incentivos a pólos utilizando-se várias iniciativas, tendo-se obtidos resultados animadores. A Europa hoje possui importante participação na economia mundial, indicando que o dinamismo da economia européia se deva, em grande parte, à existência de pólos industriais.

Goldstein e Toledo (2004) apresentam também conclusões de estudos de Schmitz e -Nadvi (1999, p.1508) sobre pólos industriais, que constataram que ao longo da história as empresas que aumentaram a cooperação apresentaram melhorias no seu desempenho.

A aglomeração de indústrias pode atrair serviços correlacionados à atividade principal do cluster. Goldstein e Toledo (2004) apresentam em seu trabalho "Competição e Cooperação em Clusters: Estágios e Políticas", a constatação de Dyer (1996, apud Hoffman e Molina, 2004) "de que o fato de os fornecedores estarem muito próximos às empresas, por se situarem geograficamente dentro ou perto do cluster, há um favorecimento do contato freqüente deles com as empresas. A partir do momento em que as empresas são agrupadas, naturalmente haverá uma 
mudança na relação comprador/fornecedor". Os fornecedores percebem que é vantajoso oferecer facilidades ao pólo e são estimulados a criarem filiais ou até mudarem suas instalações para a proximidade do pólo.

As empresas de um pólo têm maior facilidade de formar parcerias para terceirizar atividades e se concentrar no negócio principal, proporcionando uma administração mais enxuta. Essa prática leva a uma redução nos custos operacionais e uma vantagem competitiva nos custos finais dos produtos.

A cooperação entre as empresas de um pólo promovem a disseminação de informações, que consiste numa vantagem competitiva importante e que auxilia, por exemplo, na redução de custos e na descoberta de inovações tecnológicas. A cooperação entre empresas internas a um pólo com o propósito de aprendizagem e inovação é o que alguns autores chamaram de "eficiência coletiva ativa" (Goldstein e Toledo (2004).

Verifica-se claramente que cooperação e competição são fatores intrínsecos aos pólos industriais e que proporcionam vantagens substanciais às empresas.

A cooperação nos pólos pode ser verticalizada, onde há relação entre os processos produtivos das indústrias, ou seja, produtos de uma determinada indústria são usados como matérias primas ou insumos de outros processos industriais, como também horizontal, onde as empresas obtêm reduções de custos operacionais, devido ao uso compartilhamento de infra-estrutura e troca de conhecimentos.

A competição pode andar em conjunto com cooperação porque elas ocorrem em dimensões diferentes e entre diferentes agentes econômicos.

Os pólos podem afetar a competição por meio de três maneiras diferentes: (i) aumentando a produtividade das empresas; (ii) como vetor de inovação tecnológica; (iii) estimulando a formação de novos negócios, que fazem com que os pólos se fortaleçam ou novos pólos sejam criados.

O surgimento de um pólo ocasiona aumento na demanda por mão-de-obra qualificada e especializada, o que acaba gerando maior interesse dos governos em melhorar a educação da população local e também incentivar as empresas a investirem em cursos e treinamentos.

Além do crescimento econômico do país e maior geração de riquezas, os impactos da criação ou ampliação de pólos industriais geram efeitos regionais sobre a população. Estes efeitos compreendem a geração de empregos diretos e indiretos de alta qualidade, o incentivo a investimentos em educação e o aumento da 
arrecadação de impostos na região, que são posteriormente revertidos em benefícios à sociedade.

Os pólos industriais proporcionam também vantagens ambientais, uma vez que resíduos de um determinado processo industrial pode ser usado em processo de indústrias vizinhas. Há também maior interesse na reciclagem de materiais, dado que o volume produzido em conjunto pelas indústrias passa a ser significativo o suficiente para atrair empresas interessadas em instalar plantas de reciclagem de papel, plástico e outros.

A participação do governo é fator fundamental no desenvolvimento de pólos industriais. Goldstein e Toledo (2004) inclusive citam Bennet (1994, p.14/15) como um dos que defendia a participação do governo no incentivo aos pólos. Como exemplo Bennet usa os casos do Japão, América do Norte e Europa, onde os "governos regionais e locais deram ativo suporte aos seus distritos industriais, com uma variedade de serviços de infra-estrutura e de negócios".

Verifica-se que importantes estudiosos sobre o tema de pólos industriais, ou clusters, identificaram vantagens significativas inerentes a formação dos mesmos, não só para as empresas, como também para a sociedade.

Estas vantagens são ratificadas pela ABRACE eu seu documento "Pólos Industriais: uma ferramenta para o desenvolvimento" (2008), onde esta associação apresenta seus argumentos em defesa de incentivos para formação de pólos industriais no Brasil.

A Tabela 17 resume algumas das vantagens, reconhecidas pela ABRACE, que os pólos podem proporcionar tanto para a sociedade quanto para as empresas. 
Tabela 17 - Benefícios que os pólos industriais podem proporcionar à sociedade e às empresas

\section{Benefícios que os pólos industriais podem proporcionar à sociedade}

\begin{tabular}{|c|c|}
\hline Geração de empregos & $\begin{array}{l}\text { - Os pólos propiciam a geração de empregos diretos e de alta qualidade, } \\
\text { devido aos níveis de remuneração pagos e à qualificação dos funcionários. } \\
\text { - Aumento do número de empregos indiretos devido à atração de população } \\
\text { para a região e ao desenvolvimento da infra-estrutura necessária ao } \\
\text { funcionamento do pólo industrial. }\end{array}$ \\
\hline $\begin{array}{l}\text { Educação e qualificação } \\
\text { da mão-de-obra }\end{array}$ & $\begin{array}{l}\text { - Investimentos diretos em educação para qualificação da mão-de-obra } \\
\text { necessária às empresas dos pólos industriais. } \\
\text { - Parcerias com associações de classe para formação de pessoal } \\
\text { qualificado, com investimentos e benefícios duradouros. } \\
\text { - Projetos sociais ligados à educação básica das populações localizadas na } \\
\text { região, como é observado em pólos industriais já existentes. }\end{array}$ \\
\hline Arrecadação de impostos & $\begin{array}{l}\text { - Aumento da arrecadação em conseqüência direta do aumento da atividade } \\
\text { econômica. } \\
\text { - Posterior conversão dos impostos arrecadados em benefícios à sociedade. }\end{array}$ \\
\hline
\end{tabular}

Benefícios que os pólos industriais podem proporcionar às empresas

\section{Compartilhamento da infra-estrutura}

- Os pólos atraem empresas por meio da oferta de bens e serviços essenciais ao seu funcionamento, como terrenos, energia elétrica, água, tratamento de efluentes, acesso a transporte;

- Esta infra-estrutura em geral é fornecida pelas grandes empresas do pólo ou por parcerias com o setor público.

\section{Ganhos de escala por meio do compartilhamento de insumos e serviços}

- Geração interna ou aquisição conjunta de energia, vapor, gases e água;

- Custos de manutenção divididos;

- Atração e treinamento de mão-de-obra.

\section{Sinergias operacionais, geralmente \\ obtidas por meio da integração}

- Logística: redução de custos devido à proximidade entre produtores e consumidores;

- Co-geração: subprodutos de alguns processos são insumo para outros;

- Desenvolvimento tecnológico e compartilhamento de informações e conhecimento.
Incentivos fiscais
- Muitos estados e municípios oferecem incentivos fiscais para a instalação de pólos industriais, visando a atrair os benefícios decorrentes deles.

- Normalmente, os incentivos são temporários e perduram até que os ganhos de escala se efetivem e o pólo se torne vantajoso para novas empresas.

Fonte: ABRACE - Pólos Industriais: uma ferramenta para o desenvolvimento (2008) 
Estes benefícios descritos na tabela anterior podem ser verificados na prática quando analisado o desenvolvimento regional de locais como Triunfo e Gravataí, no Rio Grande do Sul, onde se encontra instalado um pólo petroquímico e automotivo (liderado pela General Motors - GM), respectivamente, e em Camaçari, na Bahia, onde também há a presença de um pólo petroquímico e automotivo (liderado pela Ford). Estes locais foram substancialmente beneficiados com a atração de indústrias, as quase contribuíram para aumentar a geração de empregos e arrecadação de impostos, dentre outros benefícios. Em todos estes pólos há compartilhamento de infra-estrutura elétrica pelos integrantes do pólo.

O pólo industrial desde sua criação gera um processo de desenvolvimento contínuo sustentável, o qual é ilustrado na Figura 25.

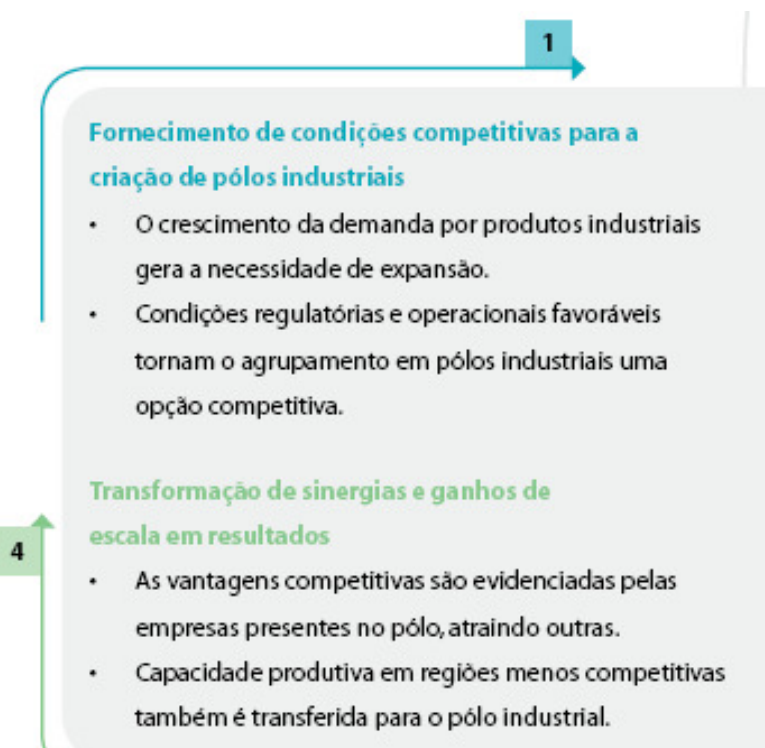

Criaçaào do pólo industrial com construçăo

de novas plantas

- Empresas săo atraídas para o pólo industrial pelo potencial de captura de vantagens competitivas.

- Parcerias entre o governo,empresas e outras entidades geram as condiçòes necessárias à criação do pólo.

Geraçāo de beneficios à sociedade

- A construçăo das indústrias e posteriormente a necessidade de måo-de-obra geram empregose desenvolvem a economia da regiào.

- Os impostos pagos pelas empresas do pólo sảo revertidos em beneficios à populaçào local.

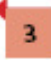

Figura 25 - Ciclo de desenvolvimento dos pólos industriais

Fonte: ABRACE - Pólos Industriais: uma ferramenta para o desenvolvimento (2008)

Para que os pólos industriais proporcionem vantagens competitivas é preciso que as políticas de desenvolvimento local sejam formuladas sob um enfoque sistêmico, levando em conta as características e demandas da região, procurando conhecer as potencialidades regionais, os problemas, interesses e necessidades das empresas locais e ao mesmo tempo, buscando conhecer outras experiências neste sentido para poder criar mecanismos de ajustes às características políticas, econômicas e sociais da região. 
Os pólos emergem em regiões que promovem vantagens específicas às empresas como forma de atraí-las e políticas de governo têm influência significativa no desenvolvimento dos mesmos.

Facilitar o processo de formação de pólos industriais, por meio de incentivos a sua formação, caracteriza-se como atribuição fundamental para os governos. Governos podem, e devem, direcionar o desenvolvimento de pólos industriais, particularmente promovendo ambiente apropriado, tais como, educação, financiamentos, competição e regulação.

Em geral, as políticas públicas de incentivos a formação de pólos industriais se baseiam em investimentos diretos e linhas de financiamento especiais às empresas. A participação do governo na expansão de infra-estruturas, como construção de rodovias e linhas de transmissão, para alcançar o raio de atuação dos pólos industriais é fundamental para auxiliar na competitividade das empresas.

Esta prática é muito comum em alguns países, sendo observados exemplos em que a infra-estrutura básica do pólo industrial é construída pelo governo e disponibilizada a empresas interessadas com valores inferiores aos investimentos realizados, visando fomentar a criação de novas empresas. Estas práticas são observadas principalmente em países mais desenvolvidos, nos quais o governo possui recursos disponíveis para estes tipos de investimentos.

No Brasil, onde a capacidade de investimento dos governos é menor que dos países desenvolvidos, soluções criativas de incentivos aos pólos industriais devem ser investigadas. A prática mais comum no Brasil foca a redução ou até isenção de tributos.

Uma forma inovadora seria a implantação de mecanismos de tratamento diferenciados visando ganhos de produtividade mediante reduções nos custos operacionais, o que pode ser efetuado por meio tratamento especial a determinados grupos de consumidores ou por meio da criação de tarifas e encargos diferenciados. Esta última alternativa, inclusive, é verificada em países como Dinamarca, EUA e Canadá, onde as indústrias possuem condições especiais para acesso à infraestrutura, conforme descrito no Capítulo 5. 


\section{5 - POLÍTICAS INTERNACIONAIS DE SUPRIMENTO ENERGÉTICO A PÓLOS INDUSTRIAIS}

No capítulo anterior, foram apresentadas as diversas vantagens inerentes à formação de pólos industriais, identificadas em função de estudos de importantes autores que pesquisaram casos de sucessos em diversos países.

No presente capítulo, são apresentados casos internacionais nos quais políticas de incentivos a pólos industriais envolvendo a questão energética foram adotadas, tendo-se obtido resultados importantes.

As informações aqui apresentadas tomaram como base os estudos desenvolvidos pela ABRACE, que teve como um de seus objetivos analisar os aspectos energéticos de pólos industriais. A utilização, nesta dissertação, dos estudos desenvolvidos pela ABRACE foi autorizada pelo seu Presidente Executivo, Dr. Ricardo Lima.

Vários países vêm utilizando políticas de incentivo à criação de pólos industriais não só como forma de incentivo à indústria, mas também com forma de fomentar o desenvolvimento em determinadas regiões. Diversas políticas de incentivo vêm sendo aplicadas há mais de vinte e cinco anos em muitos países e novas iniciativas de fomento estão sendo implementadas continuamente.

Nos EUA a regulamentação do sistema elétrico é determinada em grande parte pelos Estados. Em Novo México e Wisconsin, por exemplo, aos pólos industriais são oferecidas tarifas diferenciadas como forma de atrair empresas. No Texas, importantes incentivos são dados às empresas para viabilizar iniciativas conjuntas de co-geração e autoprodução. Dentre estes incentivos, destaca-se a isenção de encargos setoriais sobre a energia gerada e consumida internamente nos pólos.

A Figura 26 a seguir apresenta o mapa da distribuição de pólos industriais nos EUA. 


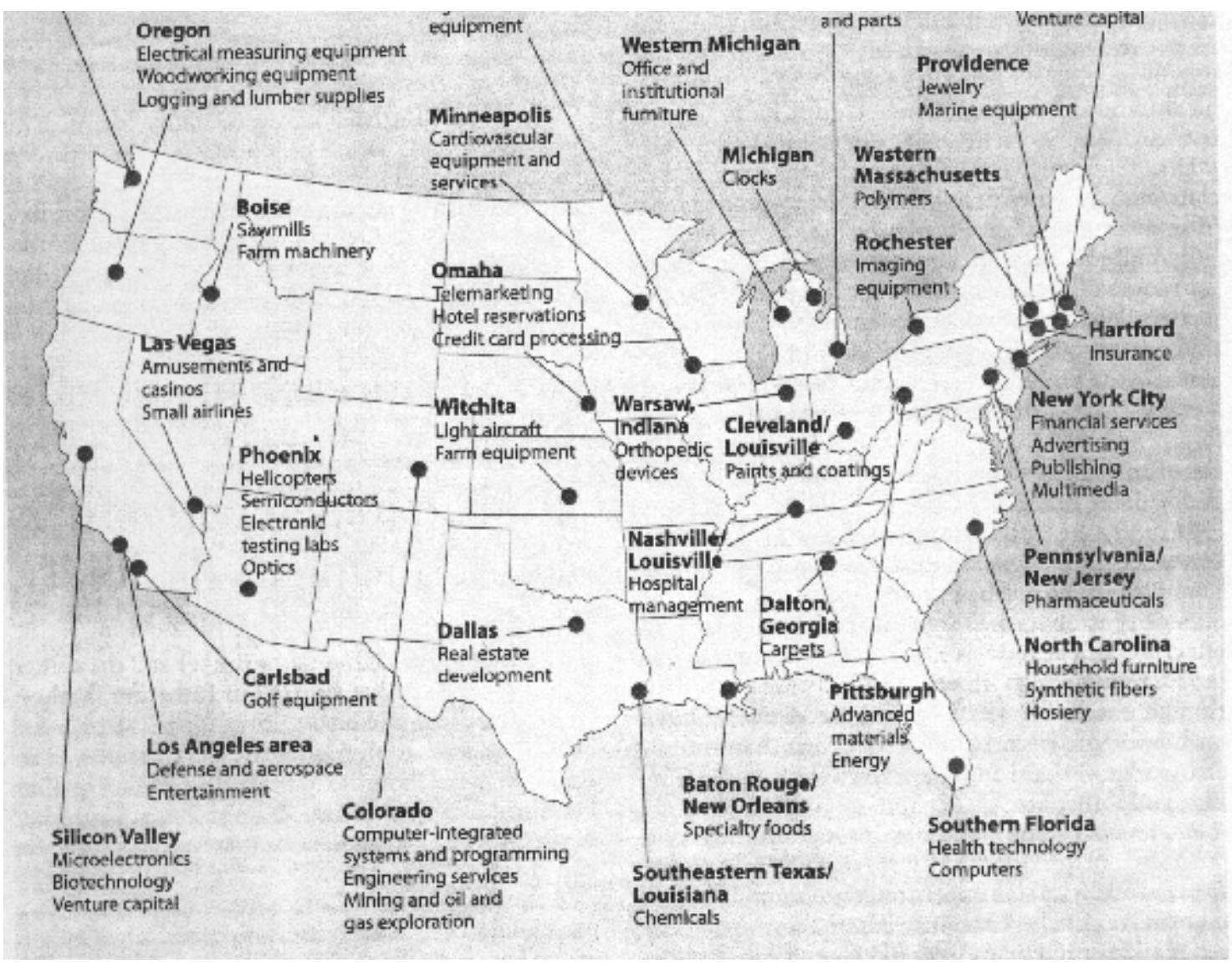

Figura 26 - Mapa de pólos industriais nos EUA

Fonte: Porter, Michael E.; "Clusters and the new economics of competition"; Harvard Business Review; Boston, 1998

Outro exemplo importante pode ser observado no Canadá, onde a regulamentação é flexível e permite a criação de "ecossistemas industriais", que são pólos industriais que compartilham uma serie de recursos e infra-estrutura, inclusive energia. Nestes sistemas, é permitida a aquisição conjunta de insumos e repasses internos entre duas ou mais empresas, havendo ou não co-geração envolvida.

Conforme já apresentado no capítulo anterior, na Europa o agrupamento de indústria sob a forma de pólos ocorre freqüentemente. Neste continente, os governos locais têm implantado uma série de políticas de fomento à criação de pólos industriais em países como Dinamarca, Reino Unido, Portugal, Alemanha e Noruega, muitas delas por meio de incentivos ao compartilhamento de infra-estrutura e a iniciativas de cogeração de energia.

$\mathrm{Na}$ Dinamarca, as indústrias desenvolveram redes de interação baseadas principalmente no compartilhamento de insumos e infra-estruturas, conhecidas no país como "simbiose industrial". A título de exemplo, no pólo industrial de 
Kalundundborg ocorre o agrupamento de uma refinaria, uma geradora de energia, uma fábrica de gesso e uma indústria farmacêutica (de diferentes proprietários), os quais compartilham poços artesianos, fornecimento externo de água, tratamento de rejeitos, vapor combustíveis, e principalmente subprodutos de seus processos internos. A energia elétrica gerada internamente pela planta de geração é utilizada pelas indústrias do pólo, não havendo interações com o sistema externo. Cabe destacar que a legislação da Dinamarca permite o compartilhamento e repasse interno de energia e outros insumos entre as empresas do pólo, bem como compartilhamento de custos de manutenção e ampliações. Estas transações são realizadas sem a interferência de agentes externos, sendo de total responsabilidade dos pólos industriais.

No Reino Unido, os incentivos a formação de pólos industriais iniciados em 1999 foram alinhados a iniciativas para aumento da capacidade de geração no país e do uso eficiente de energia. O governo tem incentivado o compartilhamento de energia através de duas modalidades principais:

- Fontes de geração distribuídas, onde grupos de empresas localizadas em pólos industriais têm incentivos ao compartilhamento de fontes de geração locais, sem necessidade de comercialização junto ao sistema centralizado. Quando estas redes locais utilizam apenas infra-estrutura privada, sem exportar energia para o sistema, as isenções de licenças e encargos são praticamente totais;

- Medidas de suporte a projetos de cogeração com benefícios como isenção de encargos, concessão de credito subsidiado para aquisição de subestações e outros equipamentos e redução de impostos.

Em Portugal, um programa de governo promove incentivo a pólos industriais para investimentos em cogeração de energia e a regulamentação fornece aos pólos industriais condições flexíveis para compartilhamento de energia, tais como tarifas diferenciadas e isenção ou redução de impostos e encargos sobre energia adquirida pelo pólo, bem como garantia de tarifas mínimas para a venda, ao sistema elétrico, de energia excedente gerada.

A Figura 27 a seguir apresenta o mapa da distribuição de pólos industriais em Portugal. 


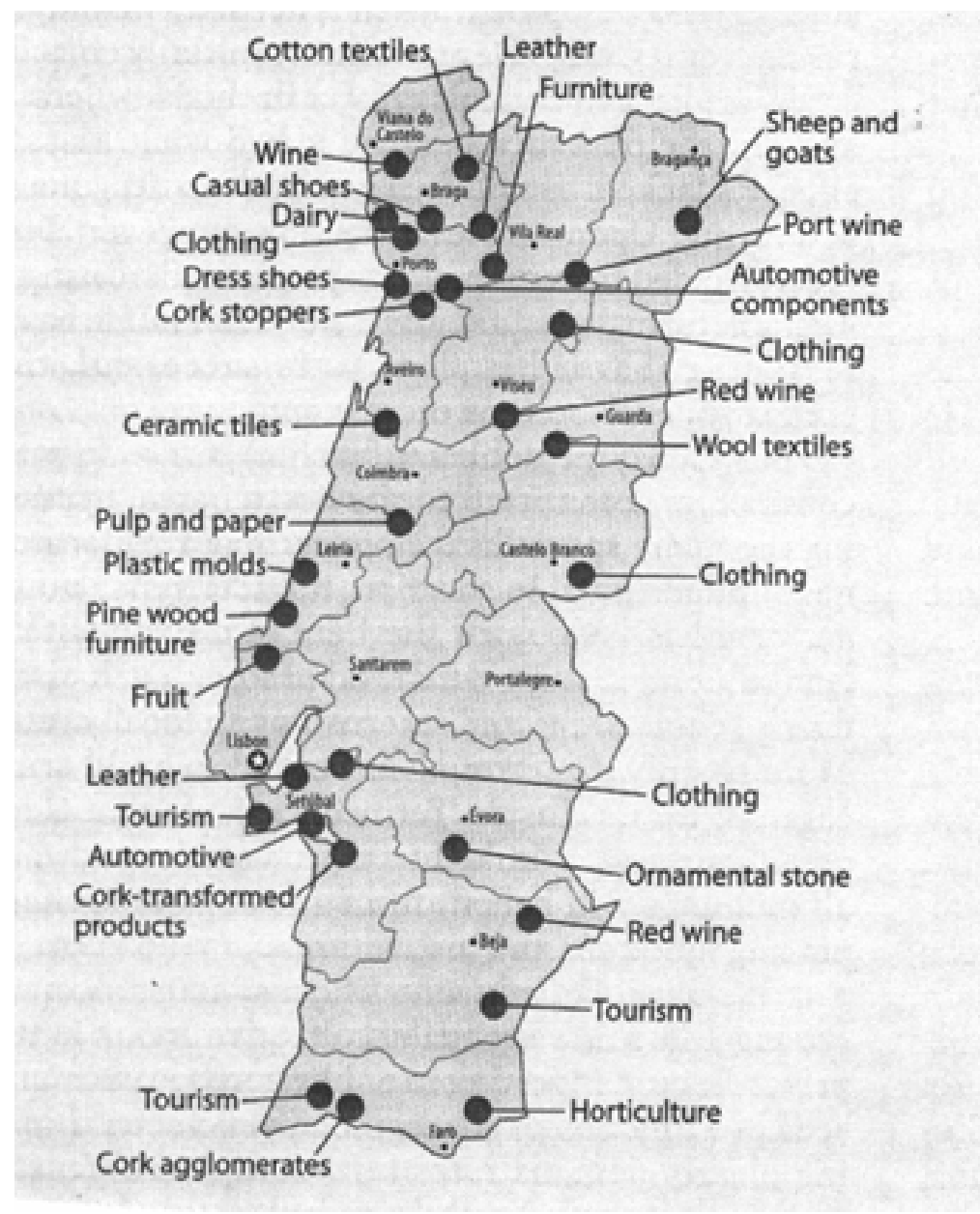

Figura 27- Mapa de pólos industriais em Portugal

Fonte: Porter, Michael E.; "Clusters and the new economics of competition"; Harvard Business Review; Boston, 1998

Na Ásia, os estudos da ABRACE observaram a adoção de modelo de "pólos ecoindustriais", que visam ao desenvolvimento industrial de forma sustentável, principalmente em países como Índia, Tailândia, Vietnam e Japão, onde este modelo tem se tornado uma tendência cada vez mais discutida, sendo que algumas definições incluem o compartilhamento eficiente de energia, matérias-primas e água como características essenciais à criação de novos pólos. 


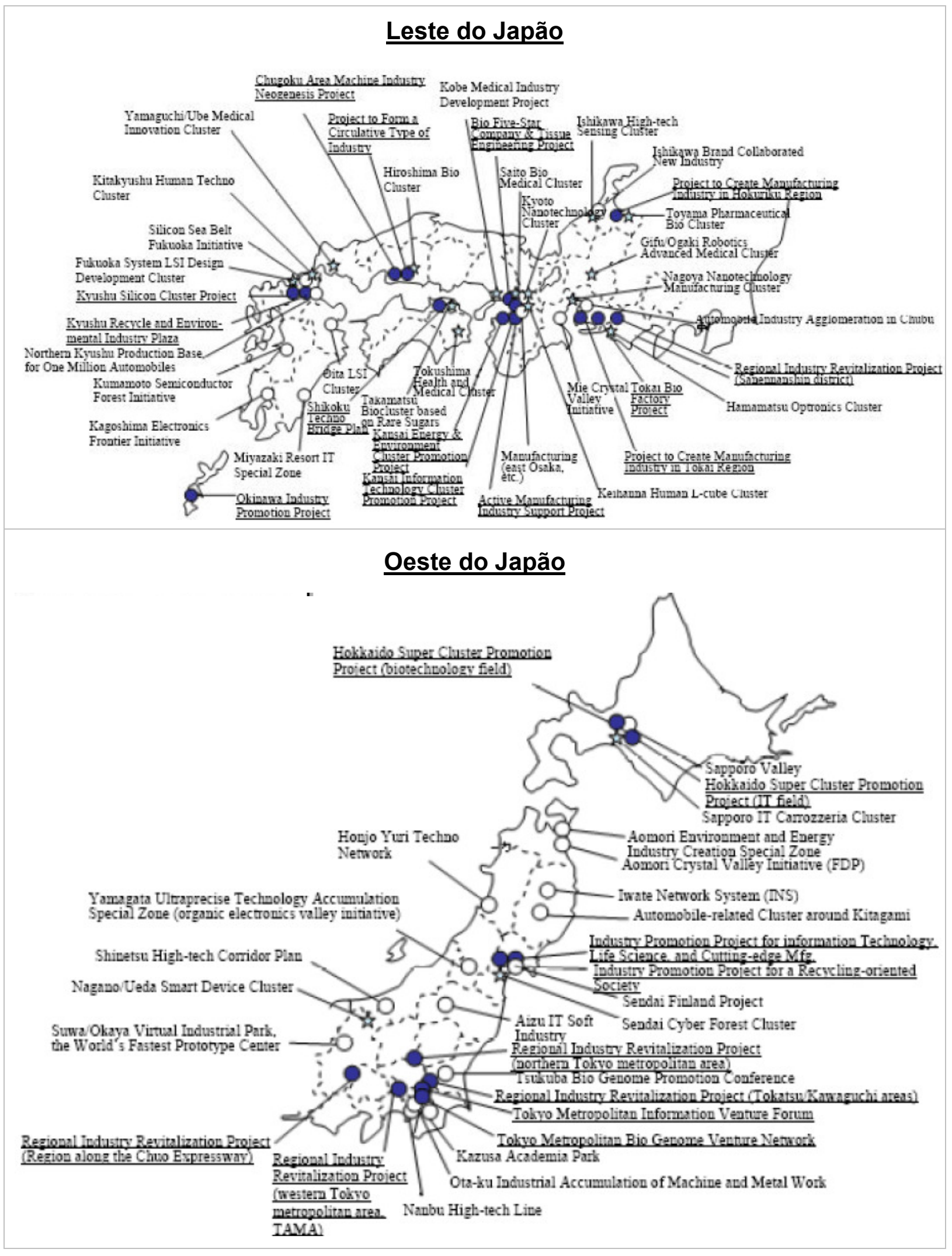

Figura 28 - Mapa de pólos industriais no Japão

Fonte: ABRACE, 2008 


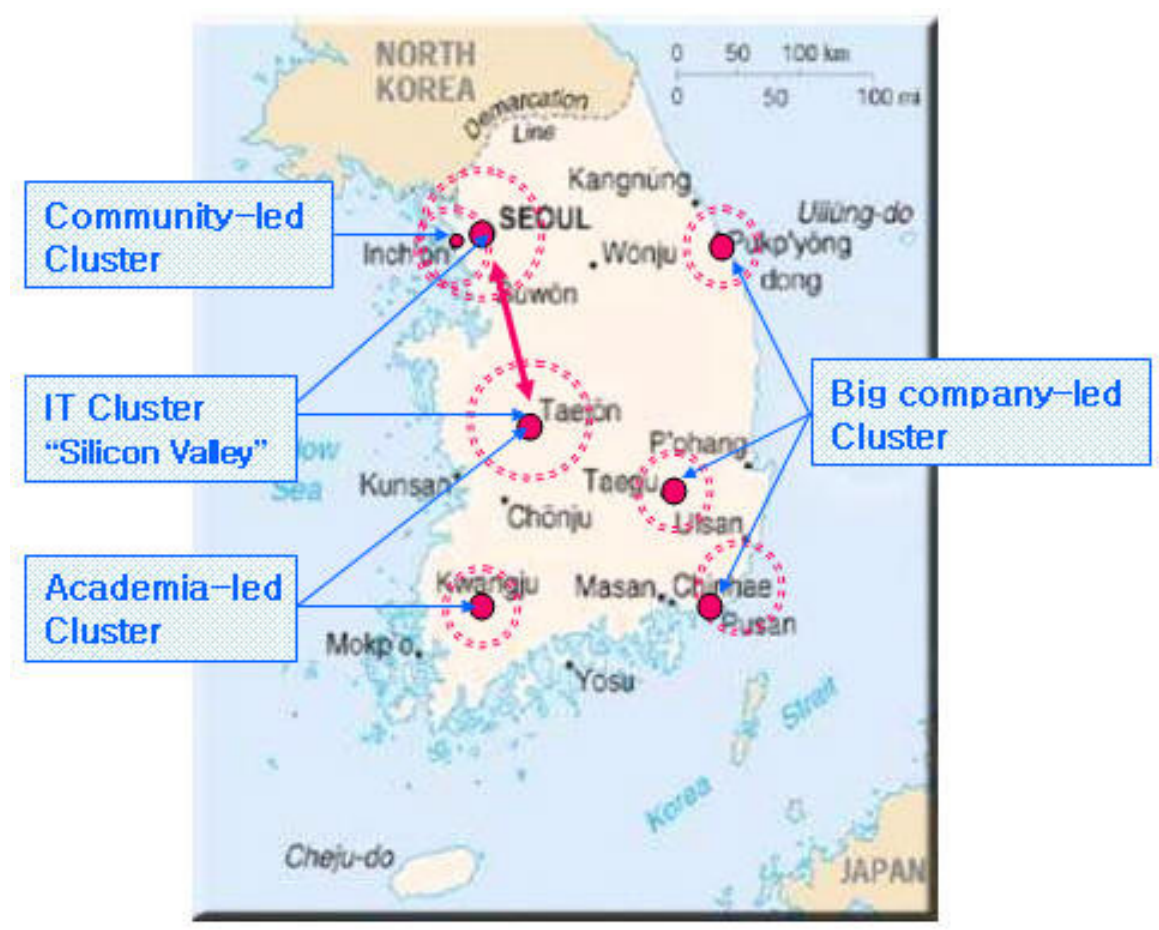

Figura 29 - Mapa de pólos industriais na Coréia do Sul

Fonte: Internet (http://www1.american.edu/initeb/hp2566a/IT\%20Geographic/new_page_3.htm)

$\mathrm{Na}$ China, por exemplo, diversas iniciativas de fomento à criação de pólos industriais com incentivos do governo central e de governos locais são verificadas. No pólo industrial de Guangzhou a construção da infra-estrutura básica foi realizada através de parcerias entre o governo e grandes montadoras de automóveis japonesas. Este pólo foi desenvolvido através da atração destas empresas-líderes, que receberam subsídios e isenções fiscais para se estabelecerem na região, atraindo outras indústrias menores. No caso citado, a infra-estrutura básica (incluindo estradas, estações de fornecimento de água e tratamento de efluentes, redes de energia, subestações e transformadores) é compartilhada pelas empresas do pólo e gerenciada pelo pólo industrial. O pólo também contém infra-estrutura compartilhada de hotéis e restaurantes, considerados integrantes do pólo e usufruindo dos mesmos benefícios e acesso à infra-estrutura básica. Adicionalmente, iniciativas de fomento à co-geração, similares às encontradas em alguns países europeus, também tem sido utilizadas pelo governo chinês como forma de incentivo ao aumento da geração de energia, promovendo a construção de infra-estrutura de geração e o compartilhamento da mesma entra as empresas de pólos industriais. 
Nas Filipinas, regras específicas para redistribuição de energia elétrica foram criadas, permitindo casos particulares de compartilhamento de infra-estrutura. Segundo esta regulamentação, um usuário final tem permissão para redistribuir serviços de energia elétrica e repassar aos demais consumidores do pólo os custos relacionados ao consumo de energia elétrica, tais como perdas elétricas internas, O\&M das redes e transformadores, dentre outros.

A análise de casos de pólos em outros países mostra que países que já atingiram patamares mais avançados de desenvolvimento continuam ativos em suas políticas de fomento à criação e ao crescimento de pólos industriais. Verifica-se também que a estratégia de obter desenvolvimento econômico por meio de agrupamentos industriais não é utilizada apenas por países desenvolvidos e exemplos com impactos significativos podem ser encontrados também em países em desenvolvimento. Independentemente do país, o foco recorrente na atração de empresas de setores considerados estratégicos para formação de pólos industriais foi, e ainda é, utilizado como parte fundamental de uma política de desenvolvimento, trazendo resultados positivos.

A Figura 30 apresenta um quadro resumo das principais políticas de incentivos envolvendo a questão energética aplicadas nos Estados Unidos, Canadá, Europa e Ásia. 


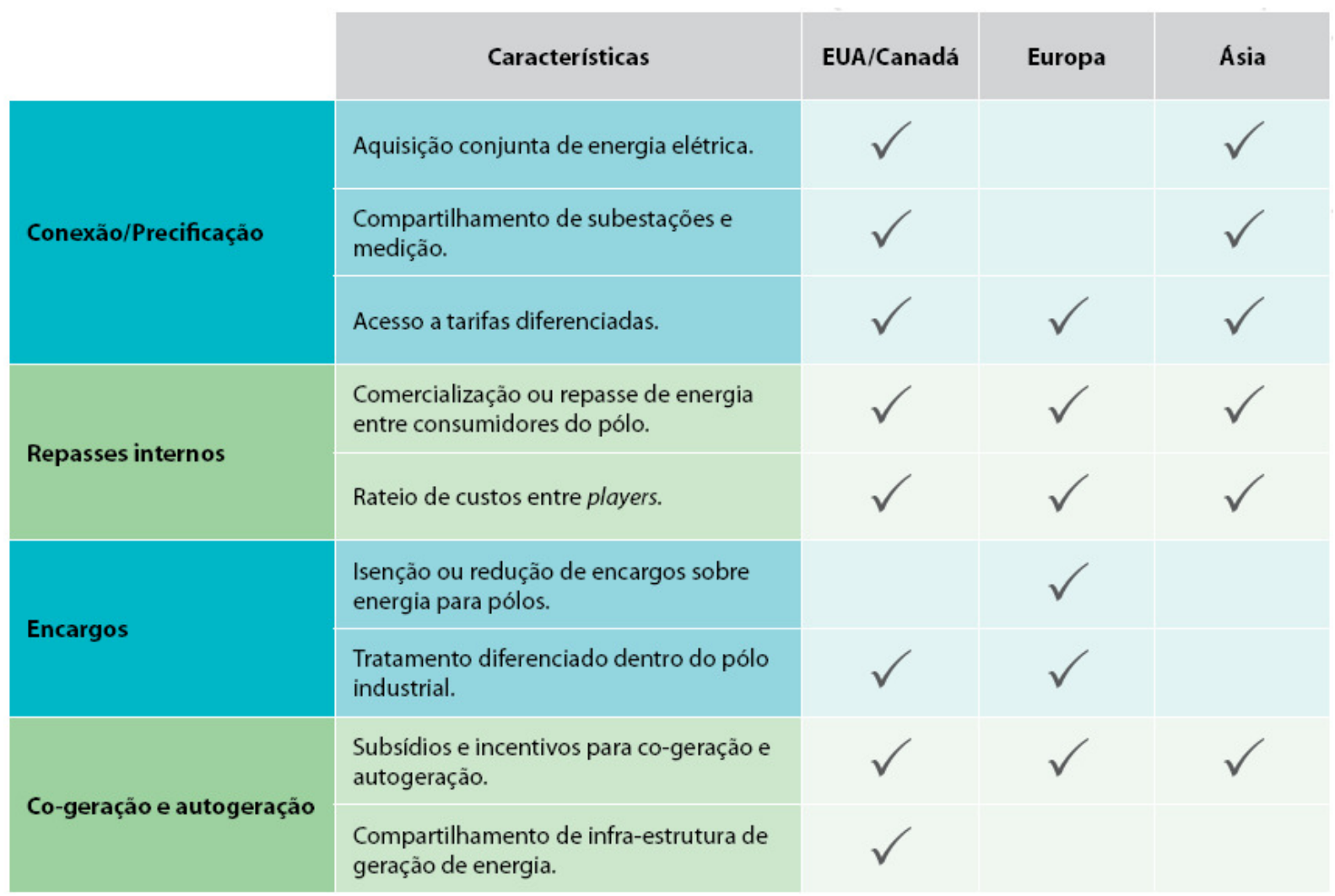

Figura 30 - Resumo de algumas políticas de incentivos à pólos industriais nos Estados Unidos, Canadá, Europa e Ásia

Fonte: ABRACE - Pólos Industriais: uma ferramenta para o desenvolvimento (2008)

As experiências internacionais de incentivos a pólos industriais envolvendo a questão energética mostram que existem diversas oportunidades que poderiam ser aproveitadas Brasil para fomentar o desenvolvimento dos pólos industriais atualmente em operação, bem como para promover a criação de novos pólos. 


\section{6 - SUPRIMENTO DE ENERGIA ELÉTRICA AOS PÓLOS INDUSTRIAIS BRASILEIROS}

No capítulo anterior foram apresentados casos de sucesso internacionais de aplicação de incentivos à formação de pólos industriais envolvendo a questão energética. Verificou-se que as políticas de incentivos variam conforme as necessidades de cada país, entretanto, nota-se que a função principal das políticas visa sempre ao encontro do desenvolvimento do país.

Para que uma regulamentação que aborde a questão energética de pólos industriais seja criada no Brasil, é extremamente importante conhecer as características dos pólos industriais em operação no Brasil, para que a competitividade dos mesmos seja preservada.

Atualmente, existem no país diversos sites em que duas ou mais indústrias compartilham infra-estrutura elétrica, entretanto, a legislação do setor elétrico não possui instrumentos que regulem estes casos, o que acaba gerando os aqui denominados "vácuos regulatórios".

Cabe ressaltar que o termo pólo industrial não é utilizado aqui exatamente da forma tradicional como estudados por importantes autores, como Porter (1990), que define um pólo industrial ou "cluster" como sendo a concentração de empresas relacionadas entre si, numa zona geográfica definida. O termo pólo industrial é abordado nesta dissertação referindo-se ao agrupamento de indústrias que de alguma forma compartilham infra-estrutura energética e, em especial, de energia elétrica. Assim, segundo esta definição, um site onde duas indústrias compartilhem uma subestação transformadora poderia ser considerado como um pólo industrial.

Outras denominações poderiam ser abordadas, como complexos industriais ou condomínios industriais. A denominação complexo industrial traz consigo uma idéia de inter-relação entre processos produtivos, enquanto condomínios industriais remete à um conceito de co-propriedade de terrenos, Assim, nesta dissertação optou-se pela denominação pólos industriais, que pode ser usada de forma mais abrangente, permitindo que duas ou mais indústrias compartilhem infra-estrutura elétrica mesmo não havendo qualquer relação entre seus processos produtivos. $O$ nome Pólos industriais também foi a terminologia adotada pela ABRACE em sua proposta de regulamentação sobre o assunto em pauta. 
Esta dissertação apresenta um enfoque sobre o suprimento de energia elétrica, não sendo abordados outros insumos energéticos como gás natural ou vapor. Isto porque o setor elétrico é o que apresenta uma legislação mais avançada, com maior complexidade e com diversas instituições já estabelecidas, como ANEEL, ONS, EPE, CCEE. Esta estrutura mais avançada e complexa do setor elétrico acaba gerando interpretações divergentes sobre um mesmo tema (neste caso sobre pólos industriais), o que não ocorre com outros insumos energéticos.

A maior parte dos pólos industriais existentes que compartilham infra-estrutura elétrica foi formada antes da estruturação do novo modelo do setor elétrico, que se iniciou em meados da década de 90.

Muitos pólos industriais hoje em operação no Brasil se formaram após reestruturações societárias, onde, por exemplo, partes de processo produtivo de uma indústria é vendida a outras empresas. Como exemplo deste tipo de formação de pólos industriais, a Figura 31 a seguir ilustra um esquemático de um site em operação no Brasil que no passado chegou a se configurar como um pólo industrial. O símbolo " $X$ " representa o término das operações da empresa, enquanto as setas indicam os processos de fusões/aquisições ou desmembramento de empresas. Atualmente, todas as unidades industriais em operação pertencem a uma única empresa e não há mais um pólo industrial como definido nesta dissertação. Entretanto, como pode ser observado na figura, este site no passado chegou a ter cinco diferentes indústrias, as quais compartilhavam infra-estrutura elétrica, enquanto que para o sistema elétrico apenas uma empresa era vista.

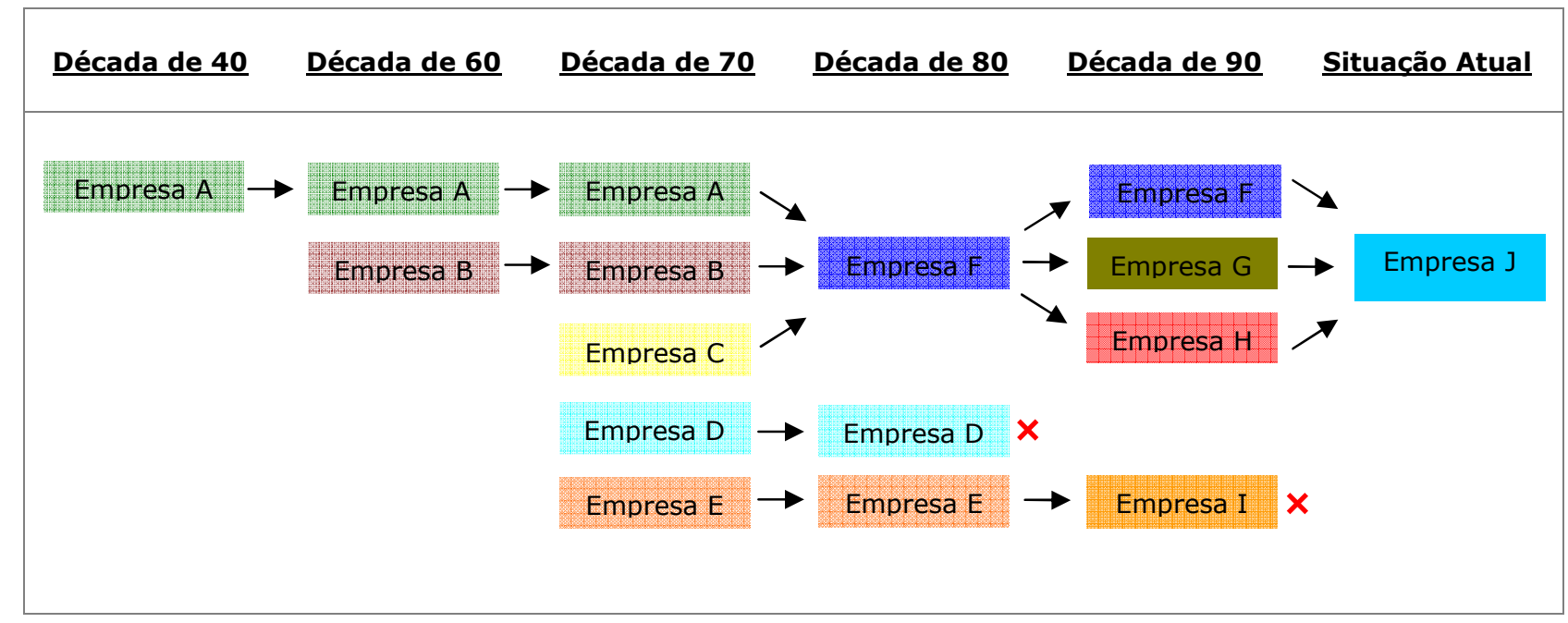

Figura 31 - Esquemático de reestruturações societárias de um caso específico 
Reestruturações societárias no Brasil são comuns e podem acontecer com uma rapidez impressionante. Mudar a estrutura física de um site para adequar a legislação a cada vez que ocorra uma incorporação ou desmembramento de empresa não é uma medida coerente. Mais plausível é a criação de uma regulamentação que aborde a questão de suprimento elétrico em pólos industriais, abrangendo a diversidade de casos existentes, bem como prevendo possíveis arranjos para os novos pólos industriais, garantindo assim segurança regulatória às empresas.

Dada a diversidade dos casos de pólos industriais e a falta de regulamentação no setor elétrico sobre o tema, os agentes do setor elétrico, nestes incluídos ANEEL, Distribuidoras e Agências Estaduais, adotam posturas diferenciadas para fiscalizar os pólos em operação.

É sabido que a ANEEL tem conhecimento que existem diferenças relevantes na questão elétrica de pólos industriais em operação no Brasil e já manifestou interesse em iniciar estudos para regulamentação em regular o tema. Em passado recente, a ANEEL enviou a diversas empresas um questionário solicitando informações relacionadas aos principais fatores de diferenciação dos pólos, o qual se encontra no ANEXO E. O questionário criado pela ANEEL foi adotado como base para um trabalho desenvolvido pela ABRACE que buscou identificar os pólos industriais que, devido suas particularidades em relação à questão de suprimento elétrico, enfrentam ou possam vir a enfrentar riscos regulatórios.

A ABRACE é uma sociedade sem fins lucrativos, formada por 64 grupos empresariais, que congrega grandes grupos industriais, de energointensivos a consumidores livres, que em 2008 respondeu por $20 \%$ de toda energia consumida no Brasil, sendo $45 \%$ do consumo de energia elétrica e $40 \%$ da energia térmica da indústria brasileira. No ANEXO F é apresentada a relação de empresas associadas da ABRACE, obtida no site desta associação em junho de 2009.

Dada a relevância da referida associação para o Brasil, a qual agrega as maiores e mais importantes indústrias do país, pode-se afirmar que as respostas representam parcela significativa dos casos de pólos industriais no Brasil onde há compartilhamento de infra-estrutura elétrica. Dentre os associadas da ABRACE, cerca de 14 afirmaram possuir unidades industriais instaladas pólos industriais conforme definido nesta dissertação. 
A ação da ABRACE no sentido de conhecer as características dos pólos industriais em operação no Brasil resultou na criação de um grupo especialmente criado para estruturar uma regulamentação sobre o tema. Este grupo teve a liderança da empresa petroquímica Braskem S.A., sob a coordenação do autor da presente dissertação. A Braskem S.A. é a empresa líder de dois importantes pólos petroquímicos no Brasil, um situado em Camaçari, no estado da Bahia, e outro em Triunfo, no estado do Rio Grande do Sul. Os trabalhos desenvolvidos por este grupo de trabalho tiveram como produto final uma minuta de decreto, apresentada no ANEXO A, que foi submetida ao Ministério de Minas e Energia - MME, Ministério do Desenvolvimento da Indústria e Comércio - MDIC e Ministério da Integração Nacional - MIN para apreciação.

Os pólos foram analisados e comparados com os seguintes critérios:

- Existências de vias públicas, tais como rios, rodovias, ferrovias etc., que atravessem redes elétricas internas ao pólo;

- Existências de consumidores não industriais que utilizem a infra-estrutura elétrica do pólo;

- Propriedade dos terrenos onde as indústrias estão instaladas;

- Como foram custeados os investimentos na construção da infra-estrutura elétrica do pólo;

- Classificação dos consumidores no interior do pólo, verificando se os mesmos são cativos ou livres;

- Formas de aquisição de energia (individual por cada empresa ou de forma coletiva);

- Como é feita a medição de faturamento (individual ou de forma coletiva);

- Formas de contratação do uso do sistema de transmissão e de distribuição (individual empresa ou de forma coletiva);

- Verificação da existência de geração de energia internamente ao pólo por uma ou mais empresas;

- Exportação de energia ao SIN;

- Comercialização entre os integrantes do pólo da energia gerada, por meio de infra-estrutura própria. 
Os pólos industriais foram nomeados de forma genérica para manter sigilo em relação às empresas que os integram. Todos os casos relacionados são reais e consistem em importantes pólos industriais em operação no Brasil.

Apenas os pólos petroquímicos de Camaçari e Triunfo, ambos liderados pela empresa Braskem S.A., tiveram seus nomes divulgados, pois tal divulgação foi autorizada pelo Diretor de Energia desta empresa.

A Tabela 18, a seguir, apresenta as principais características do pólo petroquímico de Triunfo, considerando os fatores de diferenciação de pólos industriais listados anteriormente. 
Tabela 18 - Características de suprimento elétrico do Pólo Petroquímico de Triunfo

\section{PÓLO PETROQUÍMICO DE TRIUNFO}

Pólo petroquímico composto por diversas empresas independentes que compartilham subestação transformadora de Rede Básica com tensão primária de $230 \mathrm{kV}$.

A Braskem S.A. é a empresa líder do pólo e possui uma unidade de insumos básicos, a qual é responsável pelo fornecimento de produtos petroquímicos e utilidades (vapor, água desmineralizada, ar de processo etc.) às demais indústrias do pólo.

A empresa líder possui também outras unidades industriais, produtoras de polipropileno e polietileno, que recebem utilidades de sua unidade de insumos básicos.

\begin{tabular}{ll}
\hline & O pólo não possui vias públicas em seu interior, mas é delimitado por uma rodovia \\
& estadual. \\
Vias públicas & No entorno do pólo, há rodovias, ferrovia e rios. Assim, caso uma nova unidade \\
& industrial se instale fora da área hoje delimitada, o pólo passará a ter redes \\
& elétricas atravessando vias públicas.
\end{tabular}

Presença de consumidores não industriais

Não há consumidores não industriais no interior do pólo.

Propriedade dos terrenos

Cada indústria é proprietária do terreno onde se encontra instalada.

Investimentos em infra-estrutura

Todos os investimentos em infra-estrutura interna ao pólo foram custeados pelas indústrias que lá se instalaram. Parte dos equipamentos de entrada do pátio de $230 \mathrm{kV}$ de Rede Básica compartilhada foi custeada pela transmissora, a qual continua como proprietária destes equipamentos.

Classificação dos consumidores

A maioria dos consumidores instalados no pólo é livre, entretanto, há alguns consumidores cativos atendidos pela distribuidora local.

Aquisição de energia

Medição de faturamento
A aquisição de energia é feita individualmente pelas empresas, seja no mercado livre ou cativo.

Cada indústria possui seu sistema de medição de faturamento individual. Há também medição na entrada da subestação em $230 \mathrm{kV}$, para contabilização e rateio das perdas elétricas internas. Todos consumidores são faturados em $230 \mathrm{~V}$. Os consumidores livres são consumidores de Rede Básica, enquanto que os cativos são consumidores $\mathrm{A} 1$ da distribuidora local.

Contratos de uso e conexão

Geração de energia
Os consumidores livres possuem contrato de conexão e uso com a transmissora, enquanto que os consumidores cativos possuem contratos de fornecimento com a distribuidora local.

A empresa líder possui em sua unidade de insumos básicos uma planta de cogeração de energia que é usada para consumo próprio. As demais empresas não possuem geração de energia elétrica.

Exportação de energia ao SIN

A energia gerada pela empresa líder é utilizada integralmente para consumo próprio. Apesar de ser possível, não há exportação de energia ao SIN. 
A Figura 32 a seguir apresenta uma imagem de satélite do pólo petroquímico de Triunfo, sendo indicada a área onde está localizada a unidade de insumos básicos da Braskem S.A., empresa líder do pólo, bem como da subestação compartilhada. É possível verificar também a delimitação do pólo pelas ruas e rodovias.

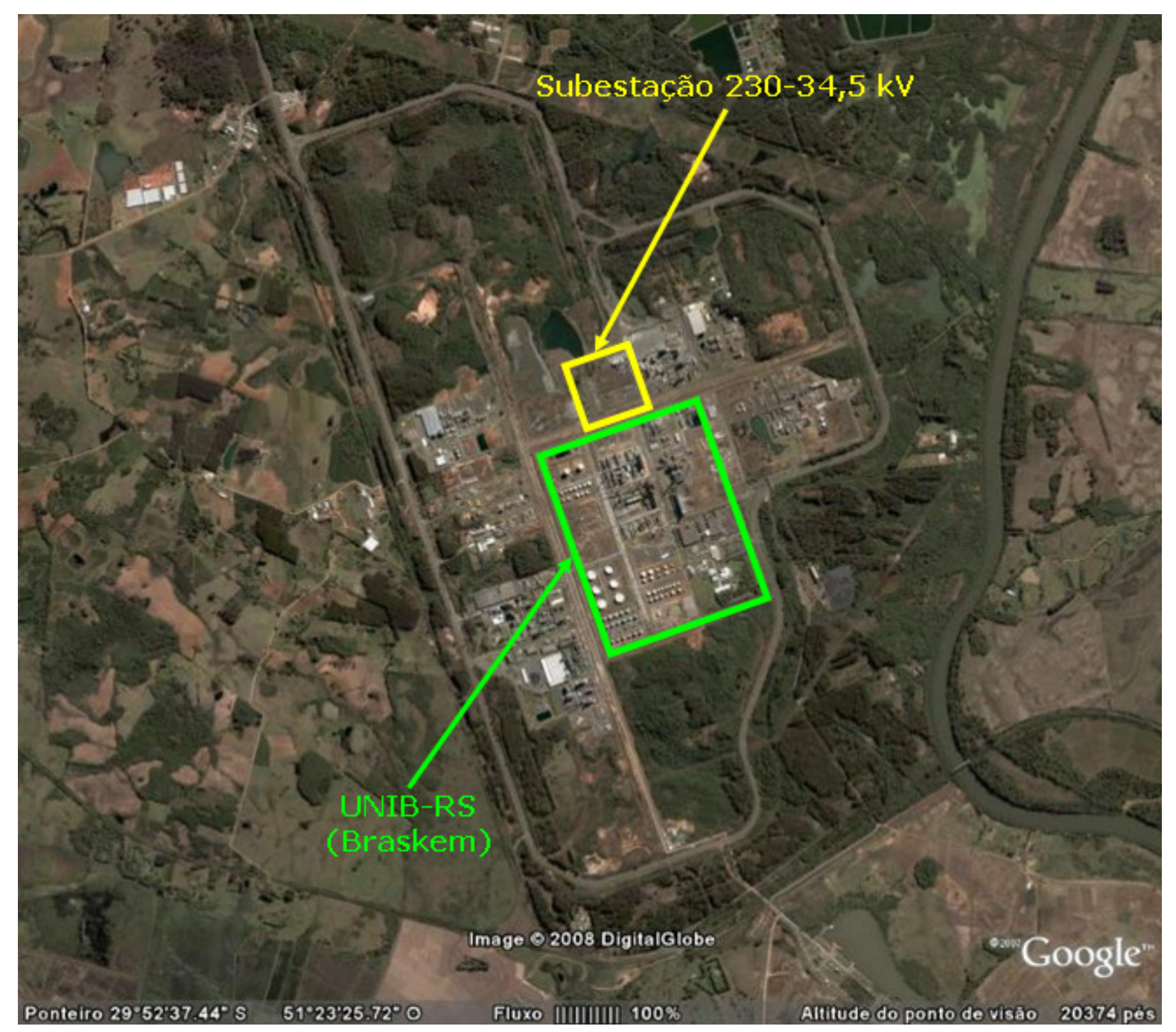

Figura 32 - Vista aérea do Pólo Petroquímico de Triunfo - RS

Fonte: Google Earth

As tabelas que se seguem, de 19 a 24, resumem a análise dos demais pólos, conforme os mesmos critérios utilizados para análise do pólo petroquímico de Triunfo. 
Tabela 19 - Características de suprimento elétrico do Pólo Petroquímico de Camaçari

\section{PÓLO PETROQUÍMICO DE CAMAÇARI}

\begin{tabular}{|c|c|}
\hline Descrição geral & $\begin{array}{l}\text { Pólo petroquímico composto por diversas empresas independentes. } \\
\text { A Braskem S.A. é a empresa líder do pólo e possui uma unidade de insumos } \\
\text { básicos, a qual é responsável pelo fornecimento de produtos petroquímicos, } \\
\text { energia elétrica e utilidades (vapor, água desmineralizada, ar de processo etc.) às } \\
\text { demais indústrias do pólo. } \\
\text { Há importação de energia do SIN mas a mesma é utilizada apenas para consumo } \\
\text { da empresa líder. As demais indústrias do pólo são atendida pela cogeração da } \\
\text { Braskem por meio de redes elétricas privativas e expressas que interligam a } \\
\text { cogeração ao consumidor. } \\
\text { A empresa líder possui também outras unidades industriais, produtoras de } \\
\text { polietileno, que recebem utilidades da unidade de insumos básicos. }\end{array}$ \\
\hline Vias públicas & $\begin{array}{l}\text { O pólo possui diversas redes elétricas, pertencentes à empresa líder, que } \\
\text { atravessam vias públicas. }\end{array}$ \\
\hline $\begin{array}{l}\text { Presença de consumidores não } \\
\text { industriais }\end{array}$ & O pólo possui consumidores não industriais, tais como prestadores de serviços. \\
\hline Propriedade dos terrenos & Cada indústria é proprietária do terreno onde a mesma encontra-se instalada. \\
\hline Investimentos em infra-estrutura & Informação não disponível. \\
\hline Classificação dos consumidores & $\begin{array}{l}\text { Para o sistema elétrico apenas a empresa líder caracteriza-se como unidade } \\
\text { consumidora, a qual está conectada à Rede Básica. } \\
\text { As demais indústrias, como são atendidas pela cogeração da empresa líder por } \\
\text { meio de redes privativas, não "aparecem" para o sistema elétrico. }\end{array}$ \\
\hline Aquisição de energia & $\begin{array}{l}\text { A energia adquirida do SIN é usada apenas para consumo das unidades } \\
\text { industriais da empresa líder, não havendo transferência de energia. }\end{array}$ \\
\hline Medição de faturamento & $\begin{array}{l}\text { A medição de energia adquirida do SIN é feita na fronteira com a Rede Básica. } \\
\text { Cada indústria possui sistema de medição de faturamento, entretanto estes } \\
\text { sistemas são usados apenas para faturamento da energia gerada e vendida pela } \\
\text { empresa líder. }\end{array}$ \\
\hline Contratos de uso e conexão & $\begin{array}{l}\text { Apenas a empresa líder possui contrato de conexão e uso com a transmissora. As } \\
\text { demais indústrias não "aparecem" para o sistema elétrico. }\end{array}$ \\
\hline Geração de energia & $\begin{array}{l}\text { A empresa líder possui em sua unidade de insumos básicos uma planta de } \\
\text { cogeração de energia, a qual é responsável pelo suprimento, por meio de redes } \\
\text { privativas, de energia elétrica às demais indústrias do pólo, }\end{array}$ \\
\hline Exportação de energia ao SIN & Não há exportação de energia ao SIN. \\
\hline Comercialização da energia gerada & $\begin{array}{l}\text { A energia elétrica gerada pela empresa líder é vendida às demais indústrias do } \\
\text { pólo por meio de redes privativas. }\end{array}$ \\
\hline
\end{tabular}


A Figura 33, a seguir, apresenta uma ilustração do pólo petroquímico de Camaçari, onde se pode observar as estradas e ferrovias atravessando o pólo industrial.

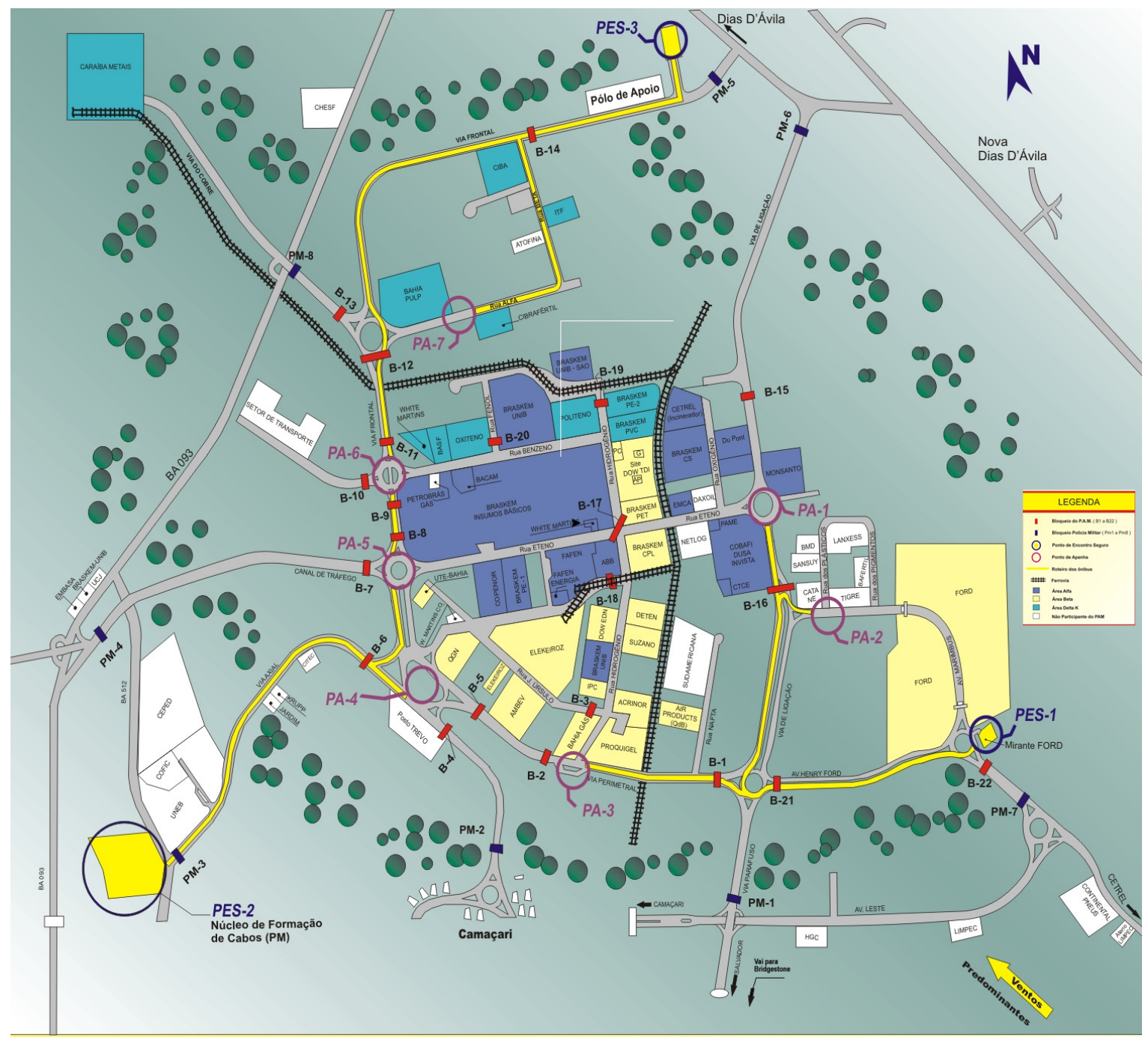

Figura 33 - Esquemático do Pólo Petroquímico de Camaçari - BA

Fonte: Site COFIC (www.cofic.org.br) 
Tabela 20 - Características de suprimento elétrico do Pólo A

\section{PÓLO A}

\begin{tabular}{|c|c|}
\hline Descrição geral & $\begin{array}{l}\text { Presença de duas empresas sendo que uma delas (Indústria } X) \text { é fornecedora de } \\
\text { utilidades, tais como, energia elétrica, vapor, água quente, etc., à outra empresa } \\
\text { (Indústria Y). }\end{array}$ \\
\hline Vias públicas & Neste pólo não existem vias publicas em seu interior. \\
\hline $\begin{array}{l}\text { Presença de consumidores não } \\
\text { industriais }\end{array}$ & Não há consumidores não industriais no interior do pólo. \\
\hline Propriedade dos terrenos & $\begin{array}{l}\text { Terreno onde as indústrias estão instaladas pertence à Indústria } Y \text {, que é a } \\
\text { compradora de utilidades produzidas na Indústria } X \text {. }\end{array}$ \\
\hline Investimentos em infra-estrutura & Todos os investimentos foram feitos pelas indústrias do pólo. \\
\hline Classificação dos consumidores & $\begin{array}{l}\text { Apenas a Indústria } \mathrm{X} \text { é vista pelo sistema elétrico e caracteriza-se como } \\
\text { consumidor livre. }\end{array}$ \\
\hline
\end{tabular}

Aquisição de energia

A energia é adquirida do SIN apenas em casos de parada na planta de cogeração da Indústria X. Quando adquirida do SIN, a energia é negociada no mercado livre.

\begin{tabular}{cl}
\hline Medição de faturamento & $\begin{array}{l}\text { A medição para faturamento da energia proveniente do SIN é feita de forma } \\
\text { centralizada na subestação principal compartilhada. }\end{array}$ \\
\hline Contratos de uso e conexão & $\begin{array}{l}\text { Há apenas contrato de Reserva de Capacidade para utilização em casos de } \\
\text { parada na planta de cogeração, o qual foi firmado entre Indústria } X \text { e a } \\
\text { distribuidora local. Para o sistema elétrico a Indústria } Y \text { não se configura como } \\
\text { uma unidade consumidora. }\end{array}$ \\
\hline Geração de energia & $\begin{array}{l}\text { A Indústria X possui uma planta de cogeração de energia para consumo próprio e } \\
\text { suprimento à Empresa Y. }\end{array}$ \\
\hline Exportação de energia ao SIN & Não há exportação de energia ao SIN, embora exista esta possibilidade. \\
\hline Comercialização da energia gerada & $\begin{array}{l}\text { A energia elétrica gerada pela Indústria X é vendida à Indústria Y em conjunto com } \\
\text { outras utilidades, como vapor e água quente etc. }\end{array}$ \\
\hline
\end{tabular}


Tabela 21 - Características de suprimento elétrico do Pólo B

\section{PÓLO B}

\begin{tabular}{|c|c|}
\hline Descrição geral & $\begin{array}{l}\text { Pólo composto por diversas empresas independentes que compartilham } \\
\text { subestação transformadora com tensão primária de } 138 \mathrm{kV} \text {. Pólo possui uma } \\
\text { empresa líder que é responsável pela interface com o SIN. }\end{array}$ \\
\hline Vias públicas & Este pólo possui rios atravessando suas instalações. \\
\hline $\begin{array}{l}\text { Presença de consumidores não } \\
\text { industriais }\end{array}$ & O pólo possui em seu interior alguns prestadores de serviços. \\
\hline Propriedade dos terrenos & Cada indústria é proprietária do terreno onde a mesma encontra-se instalada. \\
\hline Investimentos em infra-estrutura & Todas as obras de infra-estrutura foram custeadas pelas empresas do pólo. \\
\hline Classificação dos consumidores & O pólo possui consumidores livres e cativos em seu interior. \\
\hline
\end{tabular}

Aquisição de energia

A aquisição de energia é feita de forma centralizada pela empresa líder, com rateio dos custos entre seus integrantes proporcionais aos seus consumos.

\begin{tabular}{ll}
\hline Medição de faturamento & o faturamento dos consumidores livre é feito com base nas medições individuais \\
existentes em suas unidades industriais. & Já o faturamento dos consumidores cativos é feito considerando a diferença entre \\
o medidor geral da subestação principal e o somatório das medições dos \\
consumidores livres.
\end{tabular}

Contratos de uso e conexão

A contratação do uso e conexão com a distribuidora é feita de forma centralizada pela indústria líder. Demais indústrias não constituem unidades consumidoras para o sistema elétrico.

Geração de energia

A indústria líder possui planta de cogeração de energia, que é utilizada apenas para consumo próprio.

Exportação de energia ao SIN

Não há exportação de energia ao SIN.

Comercialização da energia gerada

A energia elétrica gerada é usada para consumo próprio da indústria líder do pólo, não havendo venda ou transferências internas de energia. 
Tabela 22 - Características de suprimento elétrico do Pólo C

\section{PÓLO C}

\begin{tabular}{cl}
\hline Descrição geral & $\begin{array}{l}\text { Pólo composto por diversas empresas independentes que compartilham } \\
\text { subestação transformadora com tensão primária de 138 kV. Pólo possui uma } \\
\text { indústria líder que é responsável pela interface com o SIN. }\end{array}$ \\
\hline Vias públicas & $\begin{array}{l}\text { O pólo é atravessado por avenidas, linhas de distribuição de energia elétrica e } \\
\text { terrenos de terceiros. }\end{array}$ \\
\hline $\begin{array}{c}\text { Presença de consumidores não } \\
\text { industriais }\end{array}$ & $\begin{array}{l}\text { Há prestadores de serviços que são atendidos eletricamente pela redes elétricas } \\
\text { do pólo. }\end{array}$ \\
\hline $\begin{array}{l}\text { Propriedade dos terrenos } \\
\text { Investimentos em infra-estrutura }\end{array}$ & Área do pólo pertence apenas à indústria líder. \\
\hline Tlassificação dos consumidores obras de infra-estrutura foram custeadas pelas indústrias do pólo. \\
\hline
\end{tabular}

Aquisição de energia

A aquisição de energia é feita de forma centralizada pela indústria líder, com rateio dos custos entre seus integrantes proporcionais aos seus consumos.

\begin{tabular}{cc}
\hline Medição de faturamento & $\begin{array}{l}\text { Medição de faturamento é feita de forma centralizada na subestação principal do } \\
\text { pólo. }\end{array}$ \\
\hline Contratos de uso e conexão & $\begin{array}{l}\text { A contratação do uso e conexão com a distribuidora é feita de forma centralizada } \\
\text { pela indústria líder. Demais indústrias não constituem unidades consumidoras para } \\
\text { o sistema elétrico. }\end{array}$ \\
\hline Geração de energia & $\begin{array}{l}\text { A indústria líder possui planta de cogeração de energia, que é utilizada apenas } \\
\text { para consumo próprio. }\end{array}$ \\
\hline Exportação de energia ao SIN & Não há exportação de energia ao SIN. \\
\hline Comercialização da energia gerada & $\begin{array}{l}\text { A energia elétrica gerada é usada para consumo próprio da indústria líder do pólo, } \\
\text { não havendo venda ou transferências internas de energia. }\end{array}$ \\
\hline
\end{tabular}


Tabela 23 - Características de suprimento elétrico do Pólo D

\section{PóLO D}

\begin{tabular}{|c|c|}
\hline Descrição geral & $\begin{array}{l}\text { Pólo constituído apenas por duas indústrias independentes, conectados à Rede } \\
\text { Básica em } 230 \mathrm{kV} \text {. }\end{array}$ \\
\hline Vias públicas & Este pólo não possui vias públicas em seu interior. \\
\hline $\begin{array}{l}\text { Presença de consumidores não } \\
\text { industriais }\end{array}$ & Não há consumidores não industriais no interior do pólo. \\
\hline Propriedade dos terrenos & $\begin{array}{l}\text { Área do pólo pertence apenas a uma indústria, que cede em comodato parte de } \\
\text { seu terreno para utilização da outra empresa. }\end{array}$ \\
\hline Investimentos em infra-estrutura & $\begin{array}{l}\text { Todos os investimentos em infra-estrutura interna do pólo foram feitos pelas } \\
\text { indústrias do pólo. }\end{array}$ \\
\hline Classificação dos consumidores & Ambas as indústrias são consumidores livres de energia. \\
\hline Aquisição de energia & $\begin{array}{l}\text { A aquisição de energia é feita individualmente pelas empresas, seja no mercado } \\
\text { livre ou cativo. }\end{array}$ \\
\hline Medição de faturamento & Cada indústria possui seu sistema de medição de faturamento individualizado. \\
\hline Contratos de uso e conexão & $\begin{array}{l}\text { Cada indústria possui contrato de uso e conexão individualizado com a } \\
\text { transmissora. }\end{array}$ \\
\hline Geração de energia & $\begin{array}{l}\text { A indústria proprietária do terreno possui uma planta de cogeração de energia } \\
\text { para consumo próprio com venda de excedente à segunda indústria, que também } \\
\text { adquire uma parcela de energia do SIN para atender sua demanda global. }\end{array}$ \\
\hline Exportação de energia ao SIN & $\begin{array}{l}\text { Não há exportação de energia ao SIN. A transferência de energia de uma indústria } \\
\text { à outra é feita utilizando apenas o pátio de alta tensão da subestação } \\
\text { compartilhada, não havendo circulação no SIN da energia gerada. }\end{array}$ \\
\hline
\end{tabular}


A Figura 34 - apresenta o esquemático do fluxo de energia elétrica no pólo denominado "D", em condições usuais de operação. Nesta figura, observa-se que a energia gerada por uma indústria e transferida à outra não circula no SIN, mas apenas em instalações particulares. Todavia, há cobrança de encargos setoriais sobre a energia gerada e vendida internamente no pólo.

O Pólo "D" configura-se como um caso típico em que uma política de isenção de encargos sobre a energia gerada e consumida internamente no pólo poderia aumentar a competitividade das indústrias nele instaladas. Conforme abordado no Capítulo 5, este tipo de política já foi aplicada no estado do Texas, nos EUA, e em alguns países da Europa, como Dinamarca e Reino Unidos, tendo sido obtidos resultados importantes.

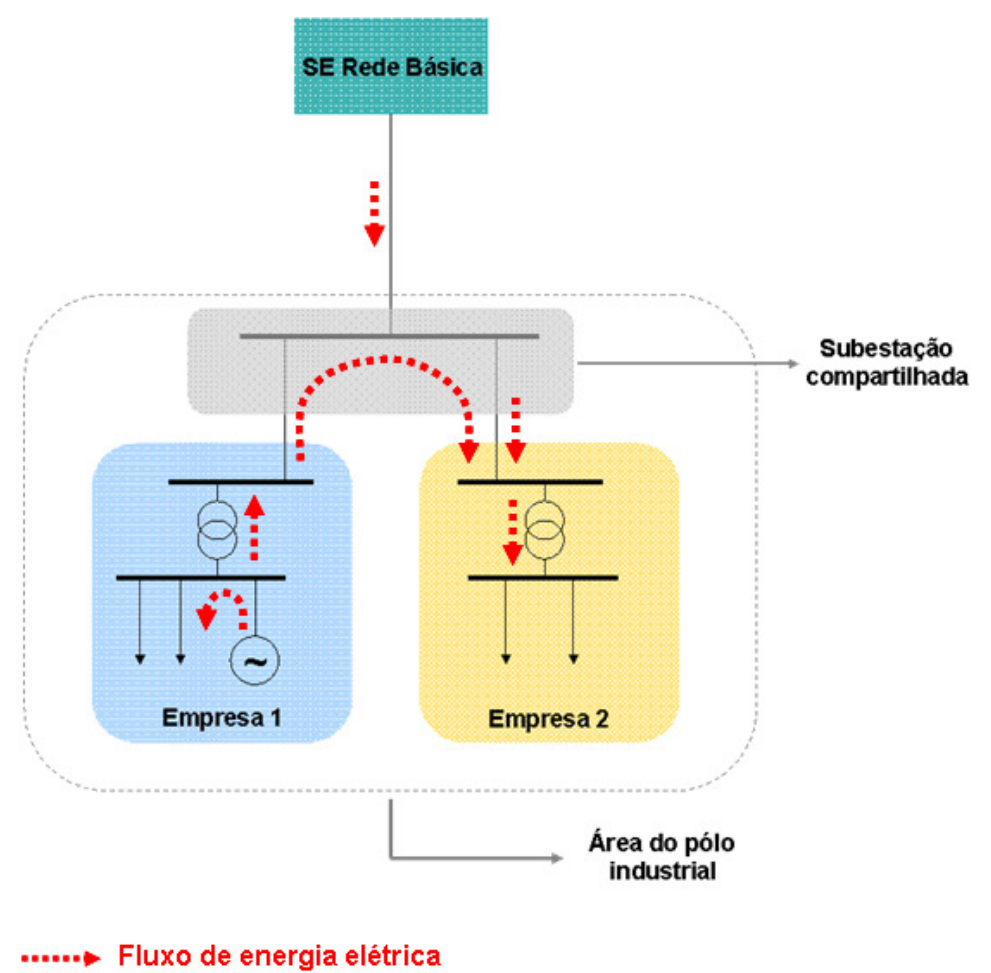

Figura 34 - Esquemático simplificado do fluxo de energia elétrica no Pólo D

Fonte: ABRACE 
Tabela 24 - Características de suprimento elétrico do Pólo E

\section{PÓLO E}

Pólo constituído por diversas indústrias, que se formou devido ao desmembramento de grupos empresariais. Pólo possui uma indústria líder que é responsável pelo fornecimento de utilidades às demais indústrias instaladas.

Vias públicas

Este pólo não possui vias públicas em seu interior.

Presença de consumidores não industriais

Não há consumidores não industriais no interior do pólo.

Propriedade dos terrenos Área do pólo pertence apenas à indústria líder.

Investimentos em infra-estrutura Todas as obras de infra-estrutura foram custeadas pelas indústrias do pólo.

Classificação dos consumidores

Consumidores do pólo são tratados como uma unidade consumidora, que atualmente é livre.

Aquisição de energia

A aquisição de energia é feita de forma centralizada pela indústria líder, com rateio dos custos entre seus integrantes proporcionais aos seus consumos.

Medição de faturamento

Medição de faturamento é feita de forma centralizada na subestação principal do pólo.

A contratação do uso e conexão com a distribuidora é feita de forma centralizada

Contratos de uso e conexão pela indústria líder. Demais indústrias não constituem unidades consumidoras para o sistema elétrico.

Geração de energia

Este pólo não possui geração de energia, sendo constituído apenas de unidades consumidoras.

Exportação de energia ao SIN

Não há geração de energia elétrica no pólo.

\section{A tabela a seguir apresenta uma comparação das principais características dos pólos industriais estudados.}


Tabela 25 - Resumo das principais características dos pólos industriais estudados

\begin{tabular}{|c|c|c|c|c|c|c|c|}
\hline Característica & Triunfo & Camaçari & A & B & C & D & $\mathbf{E}$ \\
\hline Há vias públicas no interior do pólo & Não & Sim & Não & $\operatorname{Sim}$ & $\operatorname{Sim}$ & Não & Não \\
\hline Há consumidores não industriais dentro do pólo & Não & Sim & Não & $\operatorname{Sim}$ & Sim & Não & Não \\
\hline Terreno pertence apenas à uma indústria & Não & Não & Não & Não & Sim & Sim & Sim \\
\hline Indústrias custearam a infra-estrutura elétrica & Sim & - & $\operatorname{Sim}$ & Sim & $\operatorname{Sim}$ & Sim & $\operatorname{Sim}$ \\
\hline Há convivência de consumidores livres e cativos & Sim & Não & Não & $\operatorname{Sim}$ & Não & Não & Não \\
\hline Aquisição de energia é feita de forma centralizada & Não & Não & $\operatorname{Sim}$ & $\operatorname{Sim}$ & $\operatorname{Sim}$ & Não & $\operatorname{Sim}$ \\
\hline Medição de faturamento é feita de forma centralizada & Não & Não & $\operatorname{Sim}$ & Sim & $\operatorname{Sim}$ & Não & $\operatorname{Sim}$ \\
\hline Contrato de uso/conexão é centralizado & Não & Não & $\operatorname{Sim}$ & $\operatorname{Sim}$ & Sim & Não & Sim \\
\hline Há geração de energia & Sim & Sim & $\operatorname{Sim}$ & $\operatorname{Sim}$ & $\operatorname{Sim}$ & Sim & Não \\
\hline Há exportação de energia ao SIN & Não & Não & Não & Não & Não & Não & Não \\
\hline Energia gerada é comercializada entre os integrantes do pólo & Não & Sim & $\operatorname{Sim}$ & Não & Não & Sim & Não \\
\hline
\end{tabular}


As características dos pólos descritas acima mostram que a grande maioria possui via públicas em seu interior, tais como ruas, rodovias, ferrovias e rios. Em alguns casos, as ruas e rodovias foram construídas e custeadas pelas próprias indústrias dos pólos com posterior doação aos órgãos municipais ou estaduais.

Na maioria dos pólos estudados, os investimentos na infra-estrutura, em especial de energia elétrica, foram custeados pelas próprias indústrias, não havendo participação financeira das concessionárias de distribuição. Apenas em um caso, no pólo petroquímico de Triunfo, é que parte dos equipamentos do setor de alta tensão (230 kV) da subestação principal foi custeada pela transmissora local, porém, estes equipamentos integram a Rede Básica e pertencem à transmissora.

Com relação aos contratos de uso do sistema (CUST/CUSD/Acordo Operativo) verifica-se grande variedade de situações. Em alguns casos verifica-se a celebração de um único contrato de uso/conexão por uma indústria líder, enquanto em outros casos a contratação é feita individualmente.

Em alguns pólos há convivência de consumidores livres e cativos, porém sendo faturados na tensão da entrega da subestação compartilhada. Com relação à aquisição de energia verificam-se casos em que a compra é feita de forma centralizada por uma empresa líder, com rateio entre seus integrantes sem obtenção de lucro, e casos onde cada indústria adquire sua energia. No primeiro caso, se houver uma posição da ANEEL contrária em relação à forma de aquisição de energia no mercado livre, algumas indústrias não poderiam ser consumidores livres, pois não se enquadrariam nos requisitos necessários de carga maior ou igual $3 \mathrm{MW}$. Em muitos pólos é comum a existência de consumidores não industriais, como restaurantes, bancos e demais prestadores de serviços. Assim, uma proposição de regulamentação sobre pólos industriais deve considerar a possibilidade dos prestadores de serviços instalados em pólos industriais serem atendidos pelas instalações elétricas do pólo.

Nem todos os pólos possuem geração de energia, mas verifica-se que nos pólos em que a geração está presente as características de destinação da energia são bem diferentes. Em alguns pólos as indústrias geram energia apenas para consumo próprio, enquanto que em outros ocorre a venda de energia às demais indústrias integrantes do pólo. 


\section{7 - PRINCIPAIS OBSTÁCULOS AO DESENVOLVIMENTO DE PÓLOS INDUSTRIAIS ENVOLVENDO A QUESTÃO ENERGÉTICA}

No Capítulo 6 foram apresentados os principais fatores de diferenciação de alguns pólos industriais em operação no Brasil, onde se verificou casos muito diversos em relação aos parâmetros de suprimento elétrico.

Ao longo deste capítulo serão apresentados os principais obstáculos ligados ao suprimento de energia elétrica que impedem o desenvolvimento dos pólos industriais no Brasil. Cabe ressaltar novamente que ao longo desta dissertação o termo pólo industrial não é utilizado da forma tradicional como estudados por importantes autores, como Michael Porter, que define um pólo industrial ou "cluster" como sendo a concentração de empresas relacionadas entre si, numa zona geográfica relativamente definida. O termo pólo industrial é utilizado referindo-se ao agrupamento de indústrias que de alguma forma compartilham infra-estrutura energética e, em especial, de energia elétrica.

Conforme citado anteriormente, o acesso conjunto de duas ou mais indústrias ao SIN por meio de compartilhamento de infra-estrutura elétrica consiste numa excelente alternativa, em especial para as que possuam menores demandas elétricas, para viabilizar conexão em níveis de tensão mais elevados e, conseqüentemente, reduzir custos com energia elétrica por meio da diminuição da tarifa de uso do sistema. Entretanto, a legislação vigente do setor elétrico brasileiro não aborda de forma clara e objetiva a questão do compartilhamento de infraestrutura elétrica.

Conforme apresentado no Capítulo 6, os pólos industriais em operação no Brasil apresentam características diferenciadas no que se refere ao suprimento elétrico e ao compartilhamento de infra-estrutura, bem como com relação à aquisição de energia elétrica, seja no mercado cativo ou livre.

Em alguns casos, o compartilhamento de subestações transformadoras e redes elétricas em média tensão, como por exemplo $34,5 \mathrm{kV}$, ocorre devido a estruturações societárias, oriundas de fusões e aquisições empresariais, que fizeram com que duas ou mais indústrias fossem atendidas por uma infra-estrutura elétrica comum. Em outros casos, como nos pólos petroquímicos e automobilísticos, o 
agrupamento de indústrias ocorre de forma natural, devido à forte inter-relação entre os processos produtivos das indústrias integrantes do pólo.

Dado que a legislação do setor elétrico brasileiro não aborda de forma clara a questão de compartilhamento de infra-estrutura elétrica e aquisição conjunta de energia nos pólos industriais, as indústrias enfrentam riscos regulatórios que geram um cenário de incerteza com relação aos custos futuros de energia.

Basicamente, os riscos regulatórios dos pólos industriais consistem em:

- Risco de reclassificação na tarifa de uso dos sistemas elétricos;

- Risco de incorporação (com ressarcimento aos proprietários) pela concessionária de distribuição local, dos ativos de redes elétricas internas ao pólo industrial;

- Risco da aplicação de penalidades devido à aquisição conjunta de energia pelas empresas dos pólos, com rateio entre seus integrantes.

Os riscos enfrentados em cada pólo industrial estão relacionados às suas características individuais, como as apresentadas na Tabela 25.

A principal referência na legislação do setor elétrico brasileiro com relação ao compartilhamento de infra-estrutura elétrica é feita no Art. 12 da Resolução ANEEL $N^{\circ} 456 / 2000$, o qual estabelece que o compartilhamento de subestações é permitido somente em instalações contíguas. Todavia, é justamente na terminologia contígua que reside a maior parte dos complicadores regulatórios.

A regulamentação do setor elétrico abre espaço para uma interpretação divergente, onde a existência de vias públicas, como uma rodovia, por exemplo, entre duas unidades industriais possa ser utilizado como argumento para descaracterizar a contigüidade entre as instalações, embora, em alguns casos, esteja claro que as unidades fabris são vizinhas e cheguem mesmo a otimizar processos industriais compartilhando operações.

Sob a lógica da interpretação citada, as indústrias de um pólo industrial teriam então que ser atendidas pela distribuidora local e faturadas na tensão de suprimento de suas plantas industriais, ou seja, na tensão secundária dos transformadores da subestação compartilhada pelas indústrias do pólo (que em geral são 13,8 kV, 23 kV e $34,5 \mathrm{kV})$, com tarifas nas classes de tensão A3a (30 kV a 44 kV) e A4 (2,3 kV a $25 \mathrm{kV})$. 
A mudança no faturamento da classe de tensão, como 138 kV (classe A2) ou 230 kV (classe A1 ou Rede Básica), para as classes A3a e A4 ocasionaria aumento significativo nos custos finais de energia elétrica das indústrias dos pólos, prejudicando de forma expressiva a competitividade das mesmas. Em muitos casos, os aumentos nos custos finais de energia elétrica poderiam até ocasionar o encerramento das atividades da indústria no Brasil e transferência a outros países, em busca de menores custos de energia e maior segurança regulatória.

A Figura 35 apresenta o resultado de uma pesquisa feita pela consultoria AT Kerney sobre os fatores que motivam empresas a se instalarem em países. Esta figura foi apresentada pela Prof. Virgínia Parente, do Instituto de Energia elétrica - IEE da Universidade de São Paulo - USP, no evento Energy Tax Fórum Brasil 2009, promovido pelo International Quality \& Productivity Center - IQPC em maio de 2009. Verifica-se que 0 ambiente regulatório foi considerado 0 terceiro fator mais importante para atração empresas num determinado país.

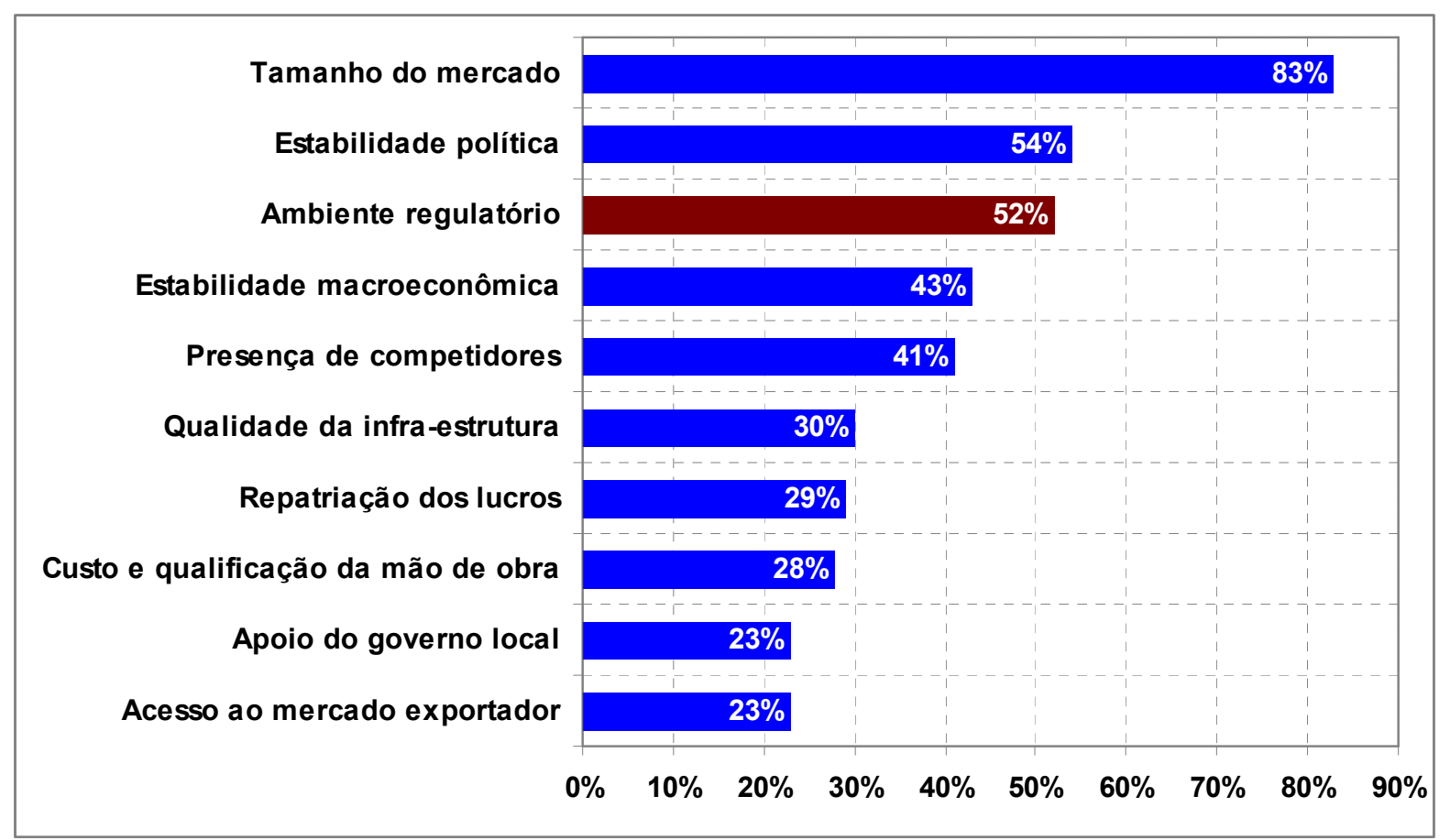

Figura 35 - Fatores de atração de empresas

Fonte: Energy Tax Fórum Brasil 2009 - Apresentação da Prof. Virgínia Parente no dia 19.05.2009

Em decorrência da falta de definição regulatória, pode se estabelecer um conflito de interesses que colocam em lados opostos consumidores e distribuidoras, abrindo espaço para que as distribuidoras busquem, por meio de instâncias administrativas, 
como a ANEEL, a reclassificação tarifária das indústrias instaladas em pólos industriais.

Mesmo nos pólos que já estão conectados diretamente à Rede Básica, onde as empresas possuem CUST e CCT celebrados diretamente com as concessionárias de transmissão, há o risco de que estas mesmas empresas passem a ser atendidas via distribuidoras, sendo faturadas na tensão secundária da subestação compartilhada. Apesar das distribuidoras não possuírem ativo algum que justificasse o faturamento dos consumidores na tensão secundária de transformação, o risco de reclassificação existe devido à existência de redes elétricas compartilhadas atravessando vias públicas ou terrenos de terceiros.

Este conjunto de indefinições, que se pode denominar "vácuo regulatório", cria uma situação de incerteza com relação aos custos finais de energia às empresas instaladas em pólos industriais, o que pode inibir importantes investimentos no país, seja no desenvolvimento dos pólos existentes ou por meio da criação de novo pólos industriais.

Em matéria publicada no site Canal Energia em 02 de abril de 2009, intitulada "Pólos industriais: segurança regulatória e energia competitiva" e assinada pelo Deputado Federal Arnaldo Jardim, integrante da Comissão Especial da Lei do Gás e da Comissão de Minas e Energia da Câmara dos Deputados, é ressaltado que a eliminação da insegurança jurídica aos pólos proporcionaria um aumento de $11 \%$ nos investimentos previstos em expansão industrial nos próximos cinco anos e de $47 \%$ nos próximos 10 anos. Em termos absolutos, estes percentuais representariam $\mathrm{R} \$ 40,3$ milhões e $\mathrm{R} \$ 75$ bilhões, respectivamente.

Conforme mostrado no Capítulo 6, há pólos industriais em operação no Brasil que possuem redes elétricas compartilhadas atravessando vias públicas e terrenos de terceiros. Portanto, caso a ANEEL adote uma postura em favor das distribuidoras de energia elétrica e exija na prática a mudança no faturamento das indústrias que compartilhem redes elétricas em pólos, o impacto que seria causado ao setor industrial seria significativo. Este impacto, pode-se imaginar, seria refletido na economia nacional e poderia prejudicar o desempenho do setor industrial brasileiro. Por outro lado, haveria um fortalecimento de algumas distribuidoras de energia, devido ao aumento de suas receitas. Todavia, é importante refletir com cuidado sobre este tema. A mudança na classe de faturamento das indústrias poderia prejudicar a competitividade das mesmas e desestimular investimentos em 
expansões ou instalação de novas unidades fabris. Dependendo do impacto causado pela reclassificação na tarifa fio, algumas indústrias poderiam até encerrar suas atividade no Brasil e transferi-las a outros países.

Políticas de incentivos ao desenvolvimento de pólos industriais podem também proporcionar aumento na receita das concessionárias de distribuição, uma vez que o crescimento do setor industrial traz consigo aumento na geração de empregos, o que, conseqüentemente, pode ocasionar uma elevação no consumo de eletricidade no setor residencial. Trata-se de uma estratégia que deve ser analisada com atenção, levando-se em consideração os interesses da indústria, das concessionárias de distribuição e da população.

Nos pólos industriais em que há geração interna de energia elétrica, em plantas de cogeração com venda interna às indústrias do pólo por meio de redes elétricas privativas, o risco regulatório é ainda maior. O Art. 12 da Lei $N^{\circ}$ 9074/1995 e o Art. 23 do Decreto $N^{\circ}$ 2003/1999 estabelecem que a venda de energia elétrica por produtor independente pode ser feita para consumidores de energia elétrica integrantes de complexo industrial ou comercial, aos quais o produtor independente também forneça vapor oriundo de processo de co-geração. Todavia, pelo fato de não haver citação clara a respeito da cobrança da parcela "Fio", algumas distribuidoras de energia se sentem encorajadas a buscar o faturamento desta parcela. Há casos no qual as distribuidoras desejam até mesmo a incorporação dos ativos de rede elétricas dos pólos industriais, mediante indenização ao proprietário, como por exemplo ocorreu no Pólo Petroquímico de Camaçari, na Bahia, que será abordado com maiores detalhes no Capítulo 8.

O Art. 12 da Lei N 9074/1995 e Art. 23 do Decreto $N^{\circ}$ 2003/1999 explicitam permissão de que energia gerada por um produtor independente seja vendida ao consumidor final em conjunto com a venda de vapor. Assim, caso não haja venda de vapor, a venda de energia do gerador diretamente ao consumidor por meio de redes particulares não seria permitida, devendo o transporte ser pago ao concessionário local.

O Art. 12 da Lei N 9074/1995 e o Art. 23 do Decreto $N^{\circ}$ 2003/1999 são muito parecidos, diferindo-se apenas em alguns pontos. A seguir são transcritos os referidos artigos. 


\section{Artigo 12 da Lei $N^{\circ}$ 9074/1995}

Art. 12. A venda de energia elétrica por produtor independente poderá ser feita para:

I - concessionário de serviço público de energia elétrica;

II - consumidor de energia elétrica, nas condições estabelecidas nos arts. 15 e 16 ;

III - consumidores de energia elétrica integrantes de complexo industrial ou comercial, aos quais o produtor independente também forneça vapor oriundo de processo de co-geração;

IV - conjunto de consumidores de energia elétrica, independentemente de tensão e carga, nas condições previamente ajustadas com o concessionário local de distribuição;

$\mathrm{V}$ - qualquer consumidor que demonstre ao poder concedente não ter o concessionário local the assegurado o fornecimento no prazo de até cento e oitenta dias contado da respectiva solicitação.

Parágrafo único. A comercialização na forma prevista nos incisos I, IV e $V$ do caput deste artigo deverá ser exercida de acordo com critérios gerais fixados pelo Poder Concedente. (Redação dada pela Lei n 10.848 , de 2004)

\section{Artigo 23 do Decreto 2003/1999}

Art. 23. O produtor independente poderá comercializar a potência e/ou energia com:

I - concessionário ou permissionário de serviço público de energia elétrica;

II - consumidores de energia elétrica nas condições estabelecidas nos artigos 15 e 16 da Lei n 9.074, de 1995;

III - consumidores de energia elétrica integrantes de complexo industrial ou comercial, aos quais forneça vapor ou outro insumo oriundo de processo de cogeração;

IV - conjunto de consumidores de energia elétrica, independentemente de tensão e carga, nas condições previamente ajustadas com o concessionário local de distribuição;

$\mathrm{V}$ - qualquer consumidor que demonstre ao poder concedente não ter o concessionário local the assegurado o fornecimento no prazo de até 180 dias, contado da respectiva solicitação.

Parágrafo único. A comercialização de energia elétrica nas hipóteses dos incisos I, IV e $\mathrm{V}$ deste artigo deverá ser feita a preços sujeitos aos critérios gerais fixados pelo poder concedente 
Conforme se pode verificar, no caput do Art. 23 do Decreto № 2003/1999 é citado que o produtor independente pode comercializar potência e/ou energia, enquanto que no Art. 12 da Lei N 9074/1995 há referência apenas sobre a venda de energia. Apesar de comumente conhecido no setor elétrico que potência (em kW ou MW) está relacionada à demanda ou carga e energia se refere ao insumo, a divergência nos textos da legislação abre espaço para diferentes interpretações sobre a comercialização de energia entre PIE e consumidores de complexos industriais.

No Art. 12 da Lei $N^{\circ}$ 9074/1995 não está claro se a venda de energia está relacionada apenas ao insumo ou se engloba também a parcela Fio, enquanto que no Art. 23 do Decreto $N^{\circ}$ 2003/1999 há a citação de possibilidade de venda de potência, o que dá um entendimento de que o PIE pode comercializar energia elétrica por meio de redes particulares.

Trata-se de um tema muito importante uma vez que em alguns pólos industriais, como o Pólo Petroquímico de Camaçari, na Bahia, há venda de energia elétrica, em conjunto com vapor de processo, por cogeradores por meio de redes privativas.

Em complexos petroquímicos, por exemplo, é comum a existência de plantas de cogeração de energia que utilizam combustível residual do processamento da nafta para geração de energia elétrica e vapor. A produção de energia elétrica e vapor estão fortemente relacionados e eventuais desequilíbrios entre o consumo de vapor e de eletricidade podem gerar condições desfavoráveis de operação, ocasionando elevados custos de geração. Um aumento elevado no consumo de eletricidade, sem contrapartida no consumo de vapor, colocaria a central de utilidades ${ }^{8}$ numa condição de operação inviável do ponto de vista econômico, tornando necessária a aquisição de energia externa para suprir as necessidades do pólo, uma vez que a venda interna estaria limitada pelo nível de consumo de vapor. Como a aquisição de energia externa para repasse a terceiros não apresenta tratamento regulatório adequado, a carga elétrica adicional teria, em princípio que ser suprida por uma das alternativas:

(i) Atendida via concessionária de distribuição de energia elétrica, a qual teria que construir suas redes próprias para suprir o consumidor;

\footnotetext{
8 Em pólos industriais é comum a existência de uma Central de Utilidades que, em geral, é responsável pelo fornecimento, aos demais integrantes do pólo, de vapor, energia elétrica, água, água desmineralizada, água clarificada, ar de processo, ar comprimido, dentre outros.
} 
(ii) Atendida por meio de compra direta de energia para cada consumidor no mercado livre, utilizando a infra-estrutura elétrica interna do pólo. Neste último caso, a indústria que comprasse energia elétrica no mercado livre teria então que utilizar uma rede privativa pertencente à outra indústria do pólo, que por usa vez teria que cobrar um aluguel pelo uso de sua rede para remunerar seus custos de O\&M. Entretanto, este tipo de aquisição de energia externa com cobrança de uso de redes particulares por um gerador ou consumidor não é abordado na legislação do setor elétrico, o que pode impedir a sua prática.

A segurança operacional em alguns complexos industriais petroquímicos consiste num fator de extrema importância, uma vez que as indústrias manuseiam, em muitos casos, produtos voláteis com elevado riscos de explosão. Alguns processos industriais exigem índices de confiabilidade de suprimento elétrico elevadíssimos, que dificilmente seriam possíveis de serem obtidos via sistema elétrico das concessionárias de distribuição, até mesmo em função da regulação sobre qualidade de atendimento estabelecer parâmetros menos rigorosos que os necessários às indústrias. Nestes casos, cabe às indústrias a responsabilidade pelos investimentos em melhorias no sistema elétrico para que a qualidade requerida de suprimento seja atingida.

Incentivos à comercialização interna da energia gerada nos pólos industriais poderiam ser criados como forma de proporcionar o desenvolvimento dos pólos industriais e também para contribuir com a ampliação do parque gerador elétrico brasileiro. A instituição de uma regulamentação que elimine interpretações divergentes e que permita, livremente entre as empresas de pólos industriais, as operações de compra, venda e fornecimento de energia elétrica gerada, sem restringi-la a uma venda conjunta de vapor, configura-se como uma importante estratégia para contribuir com o desenvolvimento do setor industrial e também com a expansão da capacidade de geração de energia elétrica no Brasil.

As diversas formas de aquisição de energia elétrica pelas indústrias de pólos é outro ponto que merece atenção especial e também acarreta riscos regulatórios substanciais. Em muitos pólos, nos quais indústrias compartilham infra-estrutura elétrica, é comum a aquisição conjunta de energia, que é feita por uma empresa líder, com rateio entre seus integrantes, sem obtenção de lucro. Do ponto de vista do 
sistema elétrico, o pólo consiste de apenas uma empresa, que celebra contratos de uso (CUSD ou CUST) e conexão (CCT ou CCD) com o concessionário local e adquire energia no mercado para todas as empresas integrantes do pólo.

Nos pólos industriais em que isto ocorre, diversas empresas são prestadores de serviço da empresa líder, como produtores de ar comprimido e de oxigênio, que possuem unidades industriais menores com pequenas demandas elétricas. Caso estas empresas menores passem a ser faturadas em média tensão pela distribuidora local, seus custos produtivos seriam aumentados e a competitividade das empresas do pólo seria prejudicada de forma geral.

A criação de uma regulamentação que permita a aquisição conjunta de energia para empresas instaladas em pólos industriais, por meio de uma empresa líder, por exemplo, consiste numa inovação regulatória que contribuiria de forma substancial para preservar a operação dos pólos existentes e para criar condições de competitividade para formação de novos pólos.

No Artigo 14 da Resolução ANEEL N 456/2000 é citada a possibilidade de aquisição de energia de forma conjunta, porém, especificamente para prédios com predominância de estabelecimentos comerciais de serviços, varejistas e/ou atacadistas. A seguir é transcrito o referido artigo.

Art. 14. Prédio com predominância de estabelecimentos comerciais de serviços, varejistas e/ou atacadistas, poderá ser considerado uma só unidade consumidora, se atendidas, cumulativamente, as seguintes condições:

I - que a propriedade de todos os compartimentos do imóvel, prédio ou o conjunto de edificações, seja de uma só pessoa física ou jurídica e que o mesmo esteja sob a responsabilidade administrativa de organização incumbida da prestação de serviços comuns a seus integrantes;

II - que a organização referida no inciso anterior assuma as obrigações de que trata o inciso III, art. $2^{\circ}$, na condição de consumidor;

III - que a demanda contratada, para prédio ou conjunto de estabelecimentos comerciais varejistas e/ou atacadistas, seja igual ou superior a $500 \mathrm{~kW}$, e, para conjunto de estabelecimentos comerciais de serviços, seja igual ou superior a $5000 \mathrm{~kW}$;

IV - que o valor da fatura relativa ao fornecimento seja rateado entre seus integrantes, sem qualquer acréscimo; e

V - que as instalações internas de utilização de energia elétrica permitam a colocação, a qualquer tempo, de equipamentos de medição individualizados para cada compartimento do prédio ou do conjunto de edificações. 
$\S 1^{\circ}$ À organização mencionada no inciso I deste artigo caberá manifestar, por escrito, a opção pelo fornecimento nas condições previstas neste artigo. $\S 2^{\circ} \mathrm{A}$ organização de que trata $\mathrm{o}$ inciso I deste artigo não poderá interromper, suspender ou interferir na utilização de energia elétrica por parte dos integrantes do prédio ou do conjunto de edificações.

$\S 3^{\circ}$ Qualquer compartimento do prédio, com carga instalada superior ao limite mínimo estabelecido para atendimento em tensão primária de distribuição, poderá ser atendido diretamente pela concessionária, desde que haja pedido neste sentido e que sejam satisfeitas as condições regulamentares e técnicas pertinentes.

Pode-se concluir que os conceitos estabelecidos no Artigo 14 da Resolução ANEEL $N^{\circ} 456 / 2000$ foram criados para shoppings, aeroportos e instalações similares, uma vez que a referida resolução permite aquisição conjunta de energia apenas para estabelecimentos comerciais de serviços, varejistas e/ou atacadistas. Não há para os pólos industriais uma regulamentação parecida. 


\section{8 - PRINCIPAIS PONTOS DE DIVERGÊNCIAS ENTRE SETOR INDUSTRIAL E CONCESSIONÁRIAS DE DISTRIBUIÇÃO DE ENERGIA ELÉTRICA}

No Capítulo 7 foram apresentados os principais riscos regulatórios enfrentados pelos pólos industriais em operação no Brasil, resultantes do fato da legislação do setor elétrico brasileiro não ser clara o suficiente em relação ao tema em pauta, permitindo a existência de pontos de divergências.

No presente capítulo são descritos alguns pontos de divergências criadas na legislação do setor elétrico, que colocam em campos opostos os interesses das indústrias e das concessionárias de distribuição de serviços de eletricidade.

A distribuição de energia consiste num serviço público de concessão, que é prestado por empresas privadas ou estatais, as quais devem obedecer rigorosamente os conceitos estabelecidos na legislação do setor elétrico.

Como citado anteriormente, em alguns casos, as concessionárias de distribuição de energia elétrica buscam a cobrança do "Fio" em indústrias integrantes de pólos industriais que compartilham infra-estrutura elétrica, seja por meio de incorporação das redes privativas, ou simplesmente pela reclassificação da "Tarifa Fio", instituindo-se assim a cobrança de uma taxa.

A seguir serão apresentados os principais pontos da regulamentação do setor elétrico que permitem interpretações divergentes sobre um mesmo tema.

\section{1 - A Questão da Contigüidade}

A principal referência na legislação do setor elétrico com relação ao compartilhamento de infra-estrutura elétrica é feita no Art. 12 da Resolução ANEEL $N^{\circ} 456 / 2000$, a qual estabelece as condições gerais de fornecimento de energia elétrica. No referido artigo, que foi alterado pela Resolução ANEEL N 226/2002, são estabelecidos os critérios a serem respeitados para que dois ou mais consumidores compartilhem uma subestação.

A seguir é feita a transcrição do Artigo 12 da Resolução ANEEL N 456/2000 já com as alterações inseridas pela Resolução ANEEL N²26/2002: 
Art. 12. A cada consumidor corresponderá uma ou mais unidades consumidoras, no mesmo local ou em locais diversos.

$\S 1^{\circ} \mathrm{O}$ atendimento a mais de uma unidade consumidora, de um mesmo consumidor, no mesmo local, condicionar-se-á à observância de requisitos técnicos e de segurança previstos nas normas e/ou padrões da concessionária.

$\S 2^{\circ}$ Poderá ser efetuado fornecimento a mais de uma unidade consumidora do Grupo "A", por meio de subestação transformadora compartilhada, desde que pactuados e atendidos os requisitos técnicos da concessionária e dos consumidores, e observadas as seguintes condições: (Redação dada pela Resolução ANEEL nº 226, de 24.04.2002)

a) Somente poderão compartilhar subestação transformadora, nos termos do parágrafo anterior, unidades consumidoras do Grupo A, localizadas em uma mesma propriedade e/ou cujas propriedades sejam contíguas, sendo vedada utilização de propriedade de terceiros, não envolvidos no referido compartilhamento, para ligação de unidade consumidora que participe do mesmo. (Alínea acrescentada pela Resolução ANEEL nº 226, de 24.04.2002)

b) Não será permitida a adesão de outras unidades consumidoras, além daquelas inicialmente pactuadas, salvo mediante acordo entre os consumidores participantes do compartilhamento e a concessionária. (Alínea acrescentada pela Resolução ANEEL $n^{\circ} 226$, de 24.04.2002)

$3^{\circ} \mathrm{O}$ compartilhamento a que se refere o parágrafo anterior, poderá ser realizado entre concessionária e consumidores, mediante acordo entre as partes. (Redação dada pela Resolução ANEEL n 226, de 24.04.2002)

$4^{\circ}$ As medições individualizadas deverão ser integralizadas para fins de faturamento quando, por necessidade técnica da concessionária, existirem vários pontos de entrega no mesmo local e desde que o fornecimento esteja sendo efetuado na mesma tensão. (Parágrafo acrescentado pela Resolução ANEEL n²26, de 24.04.2002)

A Alínea a, $\S 2^{\circ}$ do Artigo 12 da Resolução ANEEL $N^{\circ} 456 / 2000$ deixa claro que o compartilhamento de subestação transformadora somente é possível caso as unidades consumidoras estejam localizadas numa mesma propriedade ou em propriedades contíguas. Acontece que em nenhum documento da legislação do setor elétrico é apresentada a definição de propriedades contíguas. Uma definição que aparentemente seria muito simples de ser entendida acaba gerando interpretações divergentes sobre seu entendimento. 
A existência de vias públicas, tais como rios, rodovias e ferrovias, gera uma situação em que a contigüidade de terrenos possa ser contestada. Interpretando-se o Art. 12 da Resolução ANEEL $N^{\circ}$ 456/2000, pode-se entender que não havendo contigüidade o compartilhamento de subestações por duas ou mais indústrias não é permitido.

Dado que no Brasil existem muitos pólos industriais com vias públicas em seu interior e com redes elétricas privativas atravessando-as, as indústrias destes pólos ficam vulneráveis ao risco de reclassificação tarifária na parcela correspondente ao uso do sistema elétrico.

Recentemente, a ANEEL, no processo de Audiência Pública $N^{\circ}$ 008/2009, que teve como objetivo obter subsídios e informações adicionais para aprimoramento das condições gerais de fornecimento de energia elétrica, propôs, como alteração do Art. 12 da Resolução ANEEL N 456/2000, a eliminação da possibilidade de compartilhamento de subestação em caso de existência de vias públicas entre terrenos.

No texto apresentado a seguir, o qual foi extraído da minuta de resolução proposta pela ANEEL na AP 008/2009, pode-se verificar o posicionamento da ANEEL com relação ao tema citado:

Art. 9o. Poderá ser efetuado o fornecimento de energia elétrica a mais de uma unidade consumidora do Grupo A, por meio de subestação compartilhada, desde que atendidos os requisitos técnicos da distribuidora e observadas as seguintes condições:

I - as unidades consumidoras estejam localizadas em uma mesma propriedade e/ou em propriedades contíguas, sendo vedada a utilização de vias públicas e propriedades de terceiros não envolvidos no referido compartilhamento; e

II - é vedada a adesão de outras unidades consumidoras além daquelas inicialmente pactuadas, salvo mediante acordo entre os consumidores participantes do compartilhamento.

Parágrafo único. O compartilhamento de subestação pertencente a consumidor do Grupo A, mediante acordo entre as partes, poderá ser realizado com a distribuidora para atendimento a unidades consumidoras de sua responsabilidade, desde que haja conveniência técnica e econômica para seu sistema elétrico. 
Da forma como proposto pela ANEEL na minuta de resolução, a grande maioria dos pólos industriais existentes no Brasil seria prejudicada.

No Módulo 3 dos Procedimentos de Distribuição de Energia Elétrica no Sistema Elétrico Nacional - PRODIST ${ }^{9}$, que aborda o acesso ao sistema de distribuição, não há um tratamento sobre o tema de compartilhamento de subestação.

No Item 2.3.1 do Módulo 3 do PRODIST é citado que a conexão de mais de uma unidade consumidora por meio de subestação transformadora compartilhada deve seguir o disposto em regulamentação específica. Acontece que a regulamentação específica vigente sobre compartilhamento de subestações, que é a Resolução ANEEL N 456/2000, não é clara e ocasiona complicadores de ordem regulatória.

Nesta resolução, se define o ponto de entrega como sendo o ponto de conexão do sistema elétrico da concessionária com as instalações elétricas da unidade consumidora, caracterizando-se como o limite de responsabilidade do fornecimento. Ou seja, até o ponto de entrega a concessionária é responsável pelas instalações elétricas. Após o ponto de entrega, cabe ao consumidor a responsabilidade pelas instalações elétricas.

A Figura 36 - apresenta um exemplo genérico de um pólo industrial composto por oito empresas que compartilham uma subestação transformadora 138-13,8 kV, onde vias públicas atravessam as redes elétricas internas do pólo. Neste exemplo, caso o compartilhamento de subestação transformadora não seja possível devido à existência de vias públicas entre as unidades industriais, estas passariam então a ser faturadas na tensão secundária do transformador compartilhado e não mais na tensão primária da subestação, pois haveria alteração no ponto de entrega.

9 Os PRODIST são normas que disciplinam o relacionamento entre as distribuidoras de energia elétrica e demais agentes (unidades consumidoras e centrais geradores) conectados aos sistemas de distribuição, que incluem redes e linhas em tensão inferior a $230 \mathrm{kV}$. Tratam, também, do relacionamento entre as distribuidoras e a Agência, no que diz respeito ao intercâmbio de informações. Os PRODIST foi aprovado pela Resolução Normativa n 345, de 16 de dezembro de 2008, publicada no Diário Oficial da União - DOU em 31 de dezembro de 2008. 


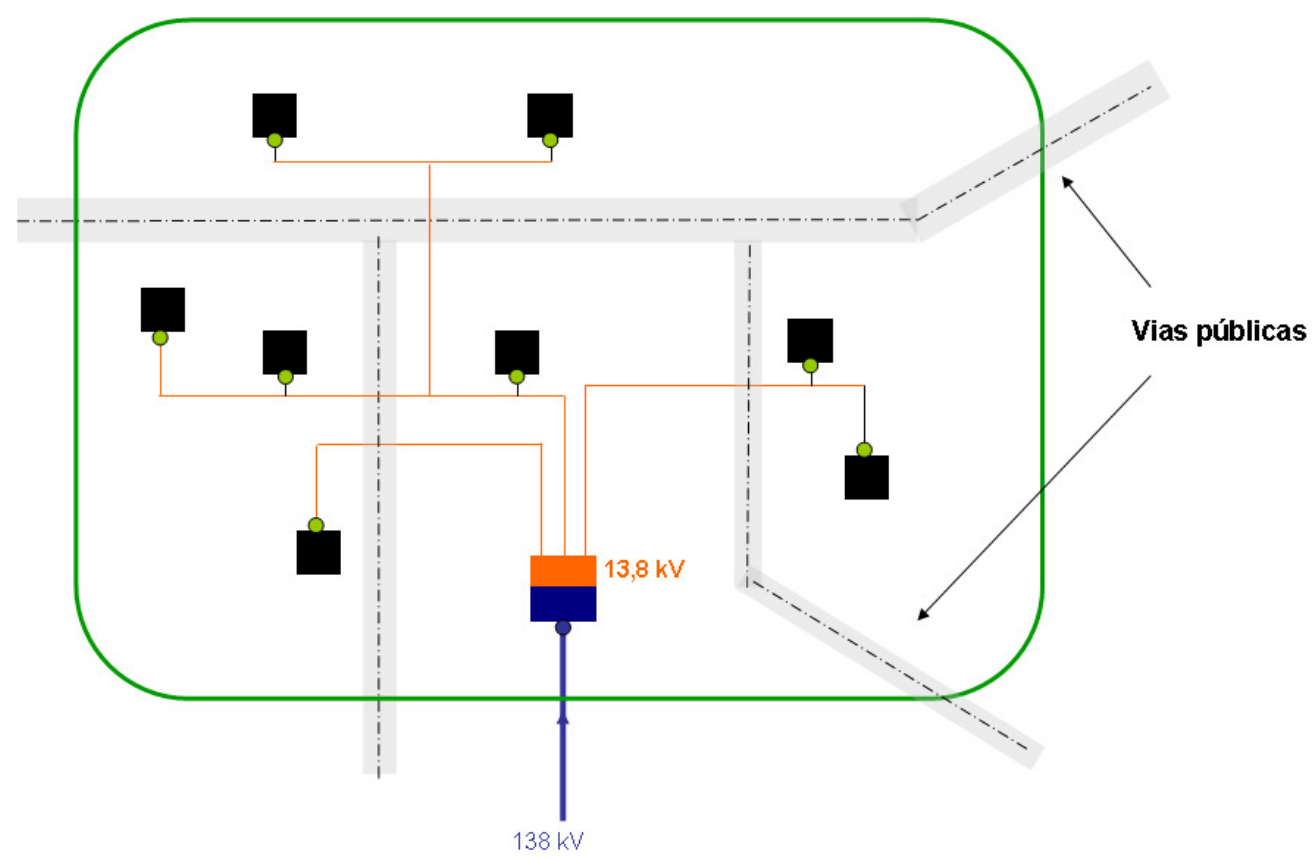

Figura 36 - Exemplo genérico de um pólo industrial onde há compartilhamento de subestação transformadora

Caso as indústrias permaneçam como proprietários das redes elétricas, a distribuidora não teria o direito faturar o consumidor na tensão secundária, pois estaria cobrando um serviço que não estaria sendo realizado. Este tipo de cobrança vai contra a lógica da concessão de serviço público, onde a concessionária deve ser remunerada pelos serviços prestados e por ativos existentes a partir de investimentos por ela realizados.

Assim, para efetuar a alteração no faturamento das indústrias do pólo, a concessionária de distribuição local teria que incorporar as redes elétricas internas aos pólos, para ficar como responsável pelas instalações até o ponto de entrega de cada indústria e ser então remunerada por um serviço prestado.

Para extinguir o risco regulatório da reclassificação e garantir o faturamento na tensão de entrada da subestação compartilhada, cada indústria do pólo teria que implantar sistemas de transformação de tensão independentes, a fim de eliminar o compartilhamento existente. Esta hipótese levaria as indústrias a efetuar elevados investimentos em equipamentos elétricos, como transformadores, disjuntores, seccionadores, pára-raios dentre outros, para evitar a reclassificação.

Caso as oito indústrias do pólo do exemplo acima tomassem a decisão de implantar suas próprias transformações para atendimento de suas cargas para evitar a 
reclassificação tarifária, a subestação do pólo seria gigantesca e com capacidade de transformação ociosa.

A proposta da ANEEL para alteração do Art. 12 da Resolução ANEEL N 456/2000 pode vir a prejudicar o setor industrial e favorecer os interesses das concessionárias de distribuição de energia elétrica. A exigência de contigüidade para compartilhamento de subestações sem uma definição clara gera um "vácuo regulatório" no setor elétrico que permite interpretações divergentes e afeta muitos pólos industriais existentes.

\section{2 - A Questão do Monopólio dos Serviços de Distribuição de Energia Elétrica}

A questão do monopólio dos serviços de distribuição configura-se como um tema extremamente polêmico, que foi fortemente usado pela Associação Brasileira de Distribuidores de Energia Elétrica - ABRADEE como argumento para impedir que consumidores livres acessassem diretamente Rede Básica do SIN, prescindindo do sistema de distribuição.

Como abordado anteriormente, a diferença entre TUST e TUSD em muitos casos é muito elevada e acaba por motivar a saída de consumidores dos sistemas das distribuidoras para conectar-se diretamente à Rede Básica. Este acesso à Rede Básica por consumidores é atualmente regulamentado pelo Decreto $N^{\circ} 5.597 / 2005$. De acordo com o referido decreto, para que um consumidor possa ser conectar diretamente à Rede Básica, pelo menos um dos requisitos citados a seguir devem ser obedecidos:

- Ligação de nova unidade consumidora não conectada anteriormente, desde que seja tecnicamente compatível com o nível de tensão igual ou superior a $230 \mathrm{kV}$, nos termos do que dispuser a portaria do Ministério de Minas e Energia prevista no inciso I do art. $2^{\circ}$; ou

- Alteração da forma de conexão de unidade consumidora já atendida em tensão inferior a $230 \mathrm{kV}$, em decorrência de:

- Aumento de carga; ou

- Necessidade de melhoria de qualidade, devidamente demonstrada pelo consumidor interessado e reconhecida pela ANEEL. 
O Decreto $N^{\circ} 5.597$, que se encontram transcrito no ANEXO B, exige que a conexão à Rede Básica obedeça ao critério do mínimo custo global para o sistema elétrico. Neste estudo analisam-se as alternativas de suprimento elétrico considerando os investimentos nas instalações de conexão e perdas elétricas, sempre sob a óptica do sistema elétrico.

Antes da publicação do Decreto N 5597/2005, havia um entendimento por parte da ABRADEE e da ANEEL, de que o acesso de consumidores à Rede Básica somente seria possível se as instalações do consumidor fossem contíguas às instalações de Rede Básica. Com a publicação do Decreto $N^{\circ} 5597 / 2005$ a questão de contigüidade para acesso à Rede Básica foi eliminada, permitindo ao consumidor construir suas linhas de transmissão particulares, desde que com tensão igual ou superior a 230 kV, e acessar diretamente o sistema de transmissão.

Entretanto, após a publicação do Decreto $N^{\circ}$ 5597/2005 pelo governo federal, a ABRADEE entrou com Ação de Descumprimento de Preceito Fundamental ADPF $^{10} \mathrm{~N}^{\circ} 93$ no Supremo Tribunal Federal - STF solicitando anulação do citado decreto, alegando diversos motivos, dentre eles, que o acesso à Rede Básica de consumidores violaria o monopólio de sua área de concessão.

O pleito da ABRADEE foi de anulação do Decreto $N^{\circ} 5.597 / 2005$, sob a alegação de o mesmo "viola preceitos fundamentais da Constituição de 1998". No ANEXO C, são apresentados os principais pontos de contestação pela ABRADEE na ADPF $N^{\circ} 93$.

Dentre diversos argumentos, a ABRADEE manifesta na ADPF $N^{\circ} 93$ que o Decreto $N^{\circ} 5597 / 2005$ :

- Desvaloriza o serviço público de distribuição de energia elétrica;

- Provoca incremento tarifário aos consumidores cativos;

- Contraria a lógica econômica de funcionamento das atividades de rede;

- Afronta o objeto claro e definido dos contratos de concessão de distribuição;

- Gera incerteza jurídica, dados seus efeitos colaterais.

Ao longo da ADPF N93 a ABRADEE argumenta diversas vezes que ao consumidor de energia elétrica não é permitido ser detentor de redes elétricas fora de sua

10 Argüição de Descumprimento de Preceito Fundamental (ADPF) é a denominação dada no Direito brasileiro à ferramenta utilizada para evitar ou reparar lesão a preceito fundamental resultante de ato do Poder Público. 
propriedade e que o acesso à Rede Básica fere a exclusividade de atendimento do serviço de distribuição de energia elétrica.

A ABRADEE afirma ainda que a conexão à Rede Básica dos consumidores industriais é uma "distribuição de riqueza às avessas levada a efeito por meio da desconstrução do conceito constitucional de serviço público".

É constante a posição da ABRADEE de que a migração de consumidores à Rede Básica prejudica o serviço de concessão e principalmente os consumidores cativos, e alega que estes consumidores acabam sendo onerados devido ao aumento em sua tarifa.

Na visão da ABRADEE, a área de concessão do serviço de distribuição de energia elétrica caracteriza-se como um condomínio, que deve ter a participação de todos os consumidores integrantes de sua área de concessão.

Há que se destacar que esta visão de condomínio chegou a ser também defendida pela ANEEL, conforme pode ser verificado no texto transcrito abaixo, extraído da Nota Técnica 034/2005, que integrou o processo da Audiência Pública 010/2205. Esta AP tinha como objetivo obter subsídios e informações adicionais para 0 aprimoramento das Resoluções Ns 281/1999, 715/2001, 513/2002, 67/2004 e $68 / 2004$.

"Portanto, o negócio de uma concessionária ou permissionária de distribuição de
energia elétrica é administrar um condomínio que deve ter participação de
todos os consumidores inseridos em sua área de concessão ou permissão,
sob pena que as exclusões deste universo onerem os remanescentes deste
condomínio. Não é, portanto, o negócio de uma concessão ou permissão de
distribuição a venda de energia elétrica."

“Não pode haver diferenciação de tratamento entre consumidores iguais apenas pela sua posição geográfica, nem pela sua opção pela compra de energia, quando se trata da divisão dos encargos de um condomínio, que neste caso está ligado a uma área de concessão."

"Dar tratamento diferenciado a estes consumidores com livre opção de compra de energia é transferir aos demais remanescentes o ônus da divisão, com um denominador cada vez menor, dos encargos de uma área de concessão, contrariando portanto tanto ao principio da isonomia de tratamento quanto ao principio legal de que esta opção não pode onerar o resto da concessão."

Nos argumentos apresentados pela ABRADEE na ADPF $\mathrm{N}^{\circ}$ 093, bem como nos pontos abordados na Nota Técnica ANEEL 034/2005, a conexão direta de um 
consumidor à Rede Básica estaria ferindo a concessão dos serviços de distribuição de energia elétrica.

Em sua ADPF, a ABRADEE chega até a fazer uma comparação da migração de consumidores livres à Rede Básica com os condôminos do andar térreo de um edifício, que entendem não ser justo pagar os custos do elevador e da faxina das escadas, posto que não os utilizam.

Em resposta às alegações apresentadas pela ABRADEE na ADPF $N^{\circ} 93$ contra o Decreto 5597/2005, a Advocacia Geral da União - AGU contestou a analogia usada pela associação das distribuidoras citando outra analogia, esta relacionada ao transporte coletivo. A AGU cita os casos em que grandes empresas e grandes indústrias efetuam o transporte de seus empregados de casa para o trabalho e viceversa. Segundo a AGU, se a visão da ABRADEE fosse aplicada neste caso, tal transporte de passageiros pelas empresas violaria o serviço público de passageiros, cuja obrigação da concessionária é atender a todos indistintamente. A AGU ressalta ainda que na interpretação da ABRADEE, seria uma afronta à solidariedade social dar carona ao colega de trabalho que mora no mesmo prédio, pois haveria uma diminuição da receita da concessionária com o não pagamento da tarifa (preço de transporte).

Contra a alegação da ABRADEE, de que um consumidor não poderia ser atendido diretamente por uma concessionária de transmissão, a AGU faz referência ao Art. $4^{\circ}$ do Decreto $N^{\circ} 41.019 / 1957$ para embasar sua defesa, o qual estabelece que:

\footnotetext{
Art. $4^{\circ} \mathrm{O}$ serviço de transmissão de energia elétrica consiste no transporte desta energia do sistema produtor às subestações distribuidoras, ou na interligação de dois ou mais sistemas geradores.

$\S 1^{\circ} \mathrm{A}$ transmissão de energia compreende também o transporte pelas linhas de subtransmissão ou de transmissão secundária que existiram entre subestações de distribuição.

$\S 2^{\circ} \mathrm{O}$ serviço de transmissão pode ainda compreender o fornecimento de energia a consumidores em alta tensão, mediante suprimentos diretos das linhas de transmissão e subtranmissão.
}

O Art. $4^{\circ}$ do Decreto $N^{\circ} 41.019 / 1957$ prevê expressamente a possibilidade do agente de transmissão conectar o consumidor final na chamada "alta tensão". 
Com relação ao direito de exclusividade defendido pela ABRADEE, ou seja, o monopólio dos serviços de distribuição, a AGU utiliza-se do Art. 16 da Lei N 8.987/1995, conhecida como Lei Geral das Concessões, para fazer sua defesa. Abaixo é transcrito o citado artigo.

Art. 16. A outorga de concessões ou permissão não terá caráter de exclusividade, salvo no caso de inviabilidade técnica ou econômica justificada no ato a que se refere $o$ art. $5^{\circ}$ desta Lei.

No artigo transcrito acima fica evidente que o serviço de concessão não tem caráter de exclusividade como defendido pelas distribuidoras de energia elétrica.

Outro ponto defendido pela ABRADEE, formulado com base nos Arts. 15 e 16 da Lei $N^{\circ}$ 9074/1995, é de que a liberdade do consumidor está apenas na compra de energia e não no Fio.

A seguir são descritos os artigos supracitados da Lei N 9074/1995.

\footnotetext{
"Art. 15. Respeitados os contratos de fornecimento vigentes, a prorrogação das atuais e as novas concessões serão feitas sem exclusividade de fornecimento de energia elétrica a consumidores com carga igual ou maior que $10.000 \mathrm{~kW}$, atendidos em tensão igual ou superior a $69 \mathrm{kV}$, que podem optar por contratar seu fornecimento, no todo ou em parte, com produtor independente de energia elétrica.

(...)"

"Art. 16. É de livre escolha dos novos consumidores, cuja carga seja igual ou maior que $3.000 \mathrm{~kW}$, atendidos em qualquer tensão, o fornecedor com quem contratará sua compra de energia elétrica."
}

Este mesmo entendimento chegou a ser defendido pela ANEEL no passado, conforme texto apresentado na NT 034/2005, onde é citado que não existe liberdade do consumidor em acessar as redes de transmissão, mas apenas a opção pela compra de energia. A seguir é transcrito o texto extraído da citada nota técnica.

\footnotetext{
"Também, a tarifa de uso do sistema de distribuição, quando o acesso do consumidor de uma determinada área de concessão ou permissão de distribuição se dá diretamente no sistema da transmissora, ou através de ativos em tensão de transmissão, mas de propriedade da distribuidora, obedece ao sinal locacional, sendo calculada pelo método nodal exatamente da mesma forma da tarifa de uso do sistema de transmissão, acrescida dos encargos que são pagos pelos demais consumidores, independente de sua opção de compra de energia ou de sua posição geográfica dentro da área de concessão ou
} 
permissão. Não existe liberdade para escolha do provedor de serviço de rede (transporte da energia), existe sim, o livre comercio para a energia elétrica para aqueles consumidores que se enquadram no disposto no art. 15, da Lei $n^{\circ} 9.074$, de 1995, com redação dada pela Lei $n^{\circ} 9.648$, de 1998."

Na visão da AGU, a ABRADEE utilizou-se de interpretação de pontos isolados da legislação do setor elétrico para embasar sua tese de que a migração à Rede Básica fere a concessão do serviço público de distribuição e prejudica os consumidores cativos.

Os argumentos apresentados no parecer da AGU apresentam um posicionamento de que não existe o tal monopólio dos serviços de distribuição de energia elétrica como defendido pelas distribuidoras e que um consumidor tem o direito de buscar condições mais viáveis de suprimento elétrico. Os argumentos apresentados pela AGU, o que existe na verdade é uma obrigação por parte das distribuidoras de energia elétrica de atender ao consumidor, todavia, não há obrigação por parte do consumidor em ser atendido pela distribuidora.

O entendimento da AGU foi validado pelo relator do processo, o Ministro Ricardo Lewandowski, do STF, que acolheu o parecer do Ministério Público Federal e não reconheceu a argüição de descumprimento de preceito fundamental da ABRADEE. No ANEXO D, é apresentada o despacho do Ministro Ricardo Lewandowski.

Em julgamento realizado em 20 de maio de 2009, o Plenário do STF por maioria de votos decidiu manter a decisão do ministro Ricardo Lewandowski e, em conseqüência, arquivou ADPF $N^{\circ} 93$ movida pela ABRADEE contra o Decreto $\mathrm{N}^{0} 5.597 / 05$.

O resultado da ADPF $N^{\circ} 93$ permite concluir que o papel de uma concessão pública de distribuição de energia elétrica não se configura como um monopólio exclusivo e que a atividade de distribuição de energia elétrica significa um "dever de atender" e não "um direito irrestrito de prestar o serviço".

Um exemplo interessante citado pela AGU em seu parecer é do setor de telecomunicações, em que é citado que os agentes autorizados de telefonia fixa podem oferecer seus serviços em determinadas localidades, sem exclusividade nem obrigação de atendimento a todas as localidades. Já as concessionárias de serviço público de telefonia fixa têm a obrigação de atendimento a todos os consumidores, independentemente da área geográfica em que se localizem. 
O mesmo raciocínio utilizado pela ABRADEE em sua ADPF contra o Decreto $N^{\circ} 5.597 / 2005$ é utilizado pela distribuidora COELBA contra a petroquímica Braskem S.A, que fornece energia elétrica em conjunto com vapor às industriais do pólo petroquímico de Camaçari. No Capítulo 9, este caso será abordado com a maior profundidade, suficiente para evidenciar um caso real de risco regulatório enfrentado por um pólo industrial.

Fazendo uma analogia aos pólos industriais com os argumentos da AGU contra a ADPF da ABRADEE, pode-se concluir que o compartilhado de indústrias na forma de pólos industriais e a venda de energia por meio de redes particulares não fere o direito de concessão das distribuidoras de energia elétrica, dado que não há exclusividade no atendimento elétrico. Todavia, pelo fato de não haver citação clara a respeito destes tópicos, a insegurança regulatória nos pólos industriais ainda existe e pode dar ensejo ao surgimento de ações administrativas e judiciais.

\section{3 - Propriedade de Redes Elétricas Particulares}

Outro argumento polêmico que gera risco aos pólos industriais é a possibilidade de um consumidor ser detentor de redes elétricas fora de suas propriedades ou que atravesse vias públicas, tais como rios, ferrovias e rodovias.

Antes da publicação do Decreto $N^{\circ}$ 5597/2005, a Superintendência de Regulação dos Serviços de Transmissão - SCT da ANEEL tinha o entendimento de que um consumidor não poderia ser proprietário de redes elétricas fora de sua propriedade. Esta posição da ANEEL é claramente percebida na Nota Técnica 012/2005, no processo de Audiência Pública 010/2205.

Na referida nota técnica, é citado como uma das conclusões da ANEEL, com relação aos princípios de concessão de distribuição, que:

\footnotetext{
"O consumidor, como particular que é, não é considerado agente setorial regulado, pois não é titular de autorização, permissão ou concessão para explorar serviços e instalações de energia elétrica. $\underline{A}$ ele é vedado, portanto, deter a propriedade de instalações de energia elétrica em áreas públicas, pois não existe a possibilidade legal de instituição de servidão administrativa ou desapropriacão de terras em seu favor. Se isso ocorresse, o interesse particular estaria sendo beneficiado em detrimento do interesse público."
} 
Na mesma Nota Técnica, com relação ao acesso de consumidores diretamente à Rede Básica por meio de instalações elétricas próprias, a ANEEL volta a mencionar:

“...pois é vedado ao consumidor instituir linha de transmissão (redes particulares) em áreas que não sejam de sua propriedade."

"O segundo, e bem menos óbvio, decorre da impossibilidade legal do consumidor deter instalações de energia elétrica fora de sua propriedade (áreas públicas), conjugado com a responsabilidade da distribuidora pelo atendimento aos consumidores em sua área de atuação. Para estes casos, mesmo os acessos à Rede Básica deverão ser feitos por intermédio da distribuidora."

Este entendimento da ANEEL prejudicou o acesso de muitos consumidores à Rede Básica, que passou a ser permitido apenas nos casos em que a instalação do consumidor fosse vizinha à uma instalação de Rede Básica. Caso contrário, o acesso do consumidor deveria ser feito via distribuidora local.

Os pontos abordados na Nota Técnica 012/2005, permitem concluir que, no passado, criou-se internamente na ANEEL um conceito de contigüidade para acesso à Rede Básica que não é abordado em regulamentação alguma do setor elétrico.

A questão de contigüidade, como já descrita no Capítulo 7 , é abordada apenas no Art. 12 da Resolução ANEEL N 456/2000 e com foco no compartilhamento de subestações transformadoras.

Na Figura 37 e Figura 38 são apresentados esquemáticos, extraídos da Nota Técnica 012/2005, que ilustram o entendimento da SCT da ANEEL em relação ao acesso à Rede Básica, antes da publicação do Decreto № 5597/2005.

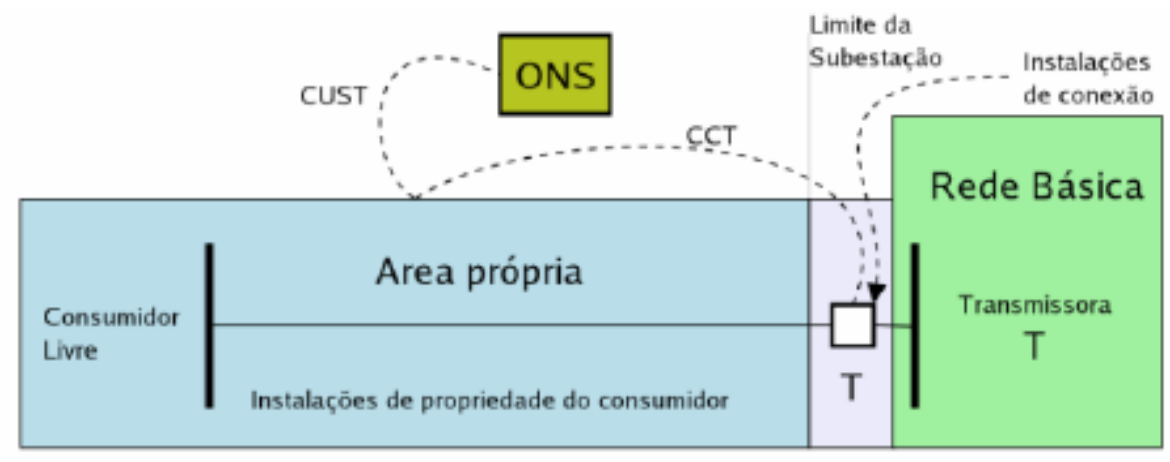

Figura 37 - Esquemático do entendimento da ANEEL para acesso de consumidor diretamente à Rede Básica (Anterior ao Decreto $N^{\circ} 5597 / 2005$ )

Fonte: Nota Técnica ANEEL Nº12/2005 


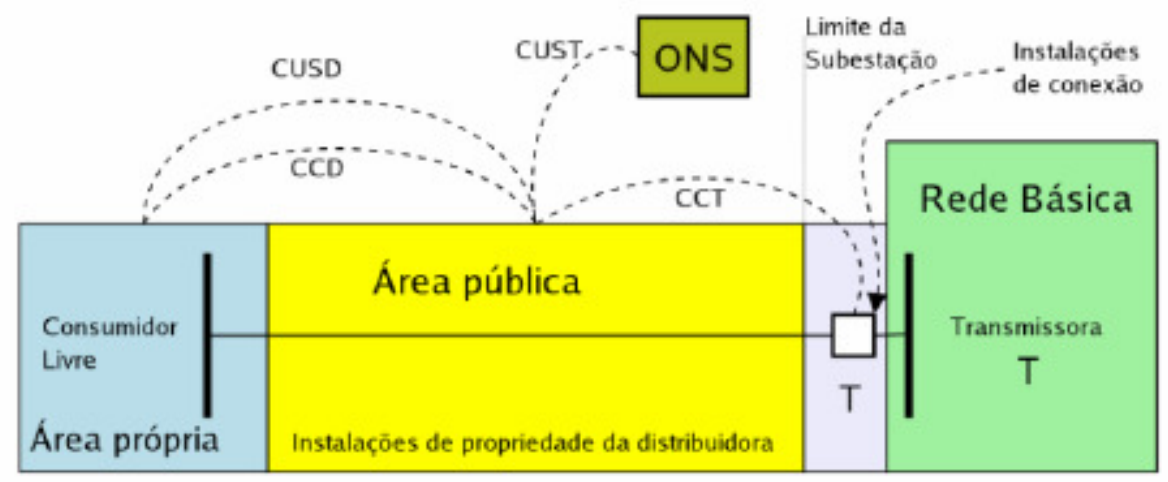

Figura 38 - Esquemático do entendimento da ANEEL para acesso de consumidor à Rede Básica via distribuidora (Anterior ao Decreto $N^{\circ} 5597 / 2005$ )

Fonte: Nota Técnica ANEEL N 012/2005

As figuras acima ilustradas evidenciam claramente o posicionamento da ANEEL contra a possibilidade de um consumidor ser detentor de redes privativas para acesso à Rede Básica. Nota-se que na visão da ANEEL, caso haja terrenos de terceiros ou vias públicas entre a propriedade do consumidor e a Rede Básica acessada, o consumidor teria então que ser atendido via concessionária de distribuição.

Na NT 034/2005, que também integrou o processo da Audiência Pública 010/2205 e foi divulgada pela Superintendência de Regulação dos Serviços de Distribuição SRD a posição da ANEEL é ainda mais contundente, conforme pode ser observado no texto transcrito a seguir.

A relação contratual de uso de sistemas elétricos, seja de distribuição ou de transmissão, pelos consumidores, livres ou não, é sempre com a concessionária ou permissionária de distribuição responsável pela área onde estes consumidores estão inseridos, independentemente de sua situação particular de contigüidade com ativos da rede básica, de demais instalações de transmissão ou de instalações de outras concessionárias ou permissionárias de distribuição que por ventura se encontrem na área de atendimento.

O conceito de contigüidade defendido pela ANEEL para acesso à Rede Básica foi derrubado pelo Decreto $N^{\circ} 5.597 / 2005$, que estabeleceu os critérios de conexão de consumidores livres à Rede Básica, permitindo o acesso è Rede Básica por meio de redes privativas desde que em tensão igual ou superior a $230 \mathrm{kV}$. 
O argumento de que um consumidor não possui o direito de ser detentor de redes elétrica fora de sua propriedade, ou que atravessa vias públicas, também foi usado pela ABRADEE na ADPF $N^{\circ}$ 93. Em sua defesa a ABRADEE citou o Art. 17 da Lei $N^{\circ} 9074 / 1995$, que relaciona algumas das instalações que o poder concedente deve definir como integrantes dos sistemas de transmissão. Pelo fato do referido artigo não fazer citação a respeito de redes elétricas de consumidores, o entendimento da ABRADEE foi que consumidores somente poderia ser detentor de redes elétricas que estejam integralmente em sua propriedade.

Por outro lado, a AGU, em seu parecer apresentado contra a ADPF da ABRADEE, manifesta o entendimento em favor dos consumidores afirmando que nada impede consumidor de ser detentor de redes elétricas fora de sua propriedade, desde que as mesmas sejam devidamente autorizadas pela ANEEL.

Para os pólos industriais ainda não há uma regulamentação clara como o Decreto $N^{\circ} 5597 / 2005$ que aborde a questão de compartilhamento de infra-estrutura elétrica por duas ou mais indústrias. Assim, o risco de uma eventual reclassificação tarifária das indústrias integrantes de pólos industriais ainda existe, principalmente quando analisados os posicionamentos da ANEEL em relação a temas similares.

Nos pólos industriais há o compartilhamento de subestações e transformadores, sendo as indústrias proprietárias de redes particulares que, em muitos casos, atravessam via públicas e/ou terrenos de terceiros. Estas redes elétricas interligam as indústrias ao barramento de baixa tensão dos transformadores compartilhados, mas as mesmas são faturadas na tensão de entrada da subestação.

Caso a ANEEL adote uma posição que proíba ao consumidor ser detentor de redes particulares fora de sua propriedade, o mesmo teria então que ser faturado na tensão secundária dos transformadores compartilhados. Por exemplo, num pólo em que a subestação compartilhada faça o abaixamento de 230 para $34,5 \mathrm{kV}$, os consumidores deixariam de ser faturados em $230 \mathrm{kV}$, como consumidores de Rede Básica, e passariam a ser faturados como consumidor A3a. Esta reclassificação acarretaria prejuízos expressivos às indústrias dos pólos, podendo, em alguns casos, ocasionar o encerramento das operações da indústria.

A Lei $N^{\circ} 10848 / 2004$ estabeleceu em seu Art. 15 que as concessionárias de distribuição devem incorporar a seus patrimônios as redes particulares que não possuam autorização do Poder Concedente, ou aqueles que possuam, mas que haja interesse das partes para transferência das redes. 
O Art. 15 da Lei $N^{\circ} 10848 / 2004$ foi regulamentado pela Resolução ANEEL $N^{\circ} 229$, de 08.03.2006, a qual estabeleceu as condições gerais para a incorporação de redes particulares, conectadas aos sistemas elétricos de distribuição. No Art. $4^{\circ}$ desta resolução é estabelecido que as "redes particulares, em qualquer tensão, localizadas integralmente em imóveis de seus proprietários não serão objeto de incorporação, ficando dispensadas, inclusive, da obtenção de ato autorizativo do Poder Concedente".

Apesar de estar subentendido na Resolução ANEEL N²29/2006 que a finalidade desta é de regularizar a situação de redes elétricas particulares que não possuem autorização, esta resolução poderia ser usada como argumento para incorporação de redes privativas internas aos pólos industriais, pelo fato das mesmas não estarem integralmente em terrenos de seus proprietários.

\section{4 - A Aquisição Conjunta de Energia}

Conforme verificado no Capítulo 6, em alguns pólos industriais do Brasil é comum ocorrer aquisição conjunta de energia por uma empresa líder com rateio entre os demais integrantes do pólo.

No entanto, pelo fato de não haver tratamento legal desta forma de aquisição de energia, as indústrias, em especial a indústria líder do pólo, enfrentam riscos constantes de sofrer uma penalidade e ter o suprimento elétrico interrompido.

Em geral, as indústrias que são supridas eletricamente por meio das indústrias líderes são menores e consistem em prestadores de serviços, como por exemplo, fornecedores de ar comprimido, água desmineralizada, vapor e oxigênio. Dados que estas indústrias fornecedoras de serviços possuem baixas demandas elétricas, inferiores a $3 \mathrm{MW}$, por exemplo, caso fossem atendidas pela concessionária local de distribuição de energia elétrica as mesmas teriam que ser atendidas em tensões reduzidas, como $13,8 \mathrm{kV}$. Isto elevaria os custos globais de energia dos fornecedores de utilidades e insumos, que seriam então repassados às indústrias consumidoras, prejudicando a competitividade do pólo industrial de forma geral.

A Resolução ANEEL $N^{\circ}$ 247, 21.12.2006, criou para aquisição de energia no mercado livre a figura do "Consumidor Especial", que se configura como "responsável por unidade consumidora ou conjunto de unidades consumidoras do 
Grupo A reunidas por comunhão de interesses de fato ou de direito, cuja carga seja maior ou igual a 500 kW".

Assim, é possível que empresas com carga elétricas individuais inferiores a $500 \mathrm{~kW}$ se agrupem e adquiram energia no mercado livre por meio de fontes incentivadas, desde que a carga do conjunto de consumidores seja superior a $500 \mathrm{~kW}$.

Como condição para esta aquisição conjunta, as empresas devem possuir reunião por comunhão de interesses de fato ou de direito e estarem localizadas em áreas contíguas. Caso as unidades não sejam contíguas, as mesmas devem possuir o mesmo CNPJ.

No caso de unidades não contíguas, fica evidente que a compra de energia em conjunto se aplica apenas para uma mesma empresa, que pode adquirir energia para suas filiais. Não sendo o mesmo CNPJ, além da necessidade de reunião por comunhão de interesse ou de fato, há a restrição de que as empresas devem ser contíguas, o que remete novamente a questão abordada no Capítulo 8.1.

Novamente, há a referência na legislação para a questão de contigüidade, que, como já citado, não possui uma abordagem clara e objetiva.

No Art. 90 da Resolução ANEEL N456/2000 são estabelecidas as situações em que a concessionária pode suspender, de imediato, o fornecimento de energia elétrica. A seguir é transcrito o referido artigo.

Art. 90. A concessionária poderá suspender o fornecimento, de imediato, quando verificar a ocorrência de qualquer das seguintes situações: I - utilização de procedimentos irregulares referidos no art. 72;

II - revenda ou fornecimento de energia elétrica a terceiros sem a devida autorização federal;

III - ligação clandestina ou religação à revelia; e

IV - deficiência técnica e/ou de segurança das instalações da unidade consumidora, que ofereça risco iminente de danos a pessoas ou bens, inclusive ao funcionamento do sistema elétrico da concessionária.

É claro no texto do Art. 90 da Resolução ANEEL N 456/2000 que em caso de revenda ou fornecimento de energia elétrica a terceiros a concessionária pode suspender de imediato fornecimento de energia elétrica ao consumidor. Como não há um tratamento regulatório sobre a aquisição conjunta de energia com rateio interno entre as indústrias integrantes dos pólos, gera-se um risco regulatório nos pólos onde este tipo de aquisição de energia é praticado. 
Há de se destacar também que em muitas indústrias é comum a existência, por exemplo, de bancos, lanchonetes, restaurantes, bancas de jornais, dentre outros, que são administrados por terceiros e consumem água e energia elétrica da indústria onde estão instalados. Estes estabelecimentos pagam à indústria em que estão instaladas, na forma de contrato de utilidades, uma determinada quantia para remunerar o consumo de água e energia elétrica.

Se o Art. 90 da Resolução ANEEL N 456/2000 for aplicado nestes casos, a concessionária poderia suspender de imediato o fornecimento de energia elétrica à indústria. Os estabelecimentos de serviço teriam então que ser supridos via distribuidora, que teria que construir suas redes elétricas para atendê-los, uma vez que a incorporação de redes privativa nestes casos seria completamente inviável.

A aquisição conjunta de energia elétrica é um dos principais temas que gera forte insegurança regulatória aos pólos industriais, por não ser suficientemente esclarecido na legislação.

Trata-se de um tema de grande importância para os pólos automotivos, onde uma indústria líder atrai para sua proximidade fornecedores de peças e serviços necessários à fabricação de automóveis, como por exemplo, fabricantes de pneus, vidros, rodas, carpetes, dentre outros. Nestes pólos, o compartilhamento de infraestrutura e aquisição conjunta de energia elétrica caracteriza-se como fator de extrema importância na manutenção da competitividade. 


\section{9 - EXEMPLO DE CASO DE CONFLITO ENTRE INDÚSTRIA E CONCESSIONÁRIA DE DISTRIBUIÇÃO}

Este capítulo apresenta os riscos enfrentados pelas indústrias integrantes do pólo petroquímico de Camaçari, em especial a Braskem S.A., empresa líder do pólo e que efetua venda, por meio de redes elétricas particulares, de energia elétrica gerada em sua planta de cogeração. As informações aqui apresentadas foram baseadas em documentos públicos de diversos processos em andamento na ANEEL, os quais estão relacionados nas referências bibliográficas.

A partir da definição do governo federal, que escolheu a região de Camaçari como a adequada para implantação de um pólo de indústrias petroquímicas no nordeste brasileiro, o Conselho de Desenvolvimento Industrial - CDI, do Ministério da Indústria e Comércio, por meio da Resolução $N^{\circ} 002$, de 20.07.1970, delegou à Secretaria Geral a responsabilidade pelas ações necessárias para implantação do Pólo Petroquímico do Nordeste. A liderança do empreendimento foi atribuída à Petrobrás por intermédio de sua subsidiária Petroquisa - Petrobrás Química S.A., a qual constituiu a COPENE - Petroquímica do Nordeste S.A., com a finalidade de coordenar a implantação desse complexo básico.

Ao estado da Bahia coube a responsabilidade pela execução das obras de infraestrutura e apoio. Uma área de $233 \mathrm{~km}^{2}$ foi declarada de utilidade pública para desapropriação e implantação do pólo petroquímico, a qual foi transferida à entidade responsável pela implantação do empreendimento, a COPEC - complexo Petroquímico de Camaçari. Em 1974 o estado da Bahia transferiu à COPENE a área desapropriada.

O Complexo Petroquímico de Camaçari teve como principal objetivo conciliar a necessidade de ampliação da indústria petroquímica nacional com características regionais específicas. O complexo foi estruturado de forma a proporcionar uma sinergia de logística entre as empresas e para isto, foi instalada uma Unidade de Insumos Petroquímicos Básicos com uma Central de Utilidades associada, compondo a antiga COPENE, que atualmente constitui a Unidade de Insumos Básicos da Braskem na Bahia, a UNIB-BA.

A maioria das empresas do Pólo está interligada por dutovias à unidade de insumos básicos da Braskem S.A., a qual recebe derivados de petróleo, principalmente a nafta, em sua UNIB-BA e os transforma em petroquímicos básicos (eteno, propeno, 
benzeno, tolueno, butadieno, xilenos, solventes e outros). Estes produtos e também utilidades, como energia elétrica, vapor, água e ar de instrumento, são fornecidos às outras unidades produtivas da própria Braskem S.A. e às indústrias vizinhas, de segunda geração da cadeia petroquímica, que, por sua vez, fabricam os petroquímicos intermediários, como polietileno e polipropileno, e alguns produtos finais.

A Braskem S.A. possui uma central de cogeração na UNIB-BA com capacidade instalada de aproximadamente $230 \mathrm{MW}$, como PIE. Para tal atendimento, a Braskem utiliza suas instalações de uso restrito, compreendendo a unidade de geração e o sistema elétrico associado destinado ao transporte da energia elétrica produzida, nos termos da Portaria MME N³21/1996.

O fornecimento da energia e vapor gerados pela planta de cogeração até as cargas das unidades industriais localizadas no pólo petroquímico ocorre por meio de interligações expressas e diretas de exclusiva propriedade da Braskem S.A. Todos os usuários são servidos por dois alimentadores expressos, redundantes e exclusivos, o que garante, adicionalmente, altos índices de confiabilidade e flexibilidade para manutenções.

A título de comparação, as figuras seguintes apresentam uma análise, de 2000 a 2006, dos valores de Duração Equivalente de Interrupção por Conjunto de Consumidores - DEC e Freqüência Equivalente de Interrupções por Conjunto de Consumidores - FEC do sistema COELBA com os valores de DEC e FEC adotados pela ANEEL como benchmarking, para o grupo de distribuidoras do qual a COELBA faz parte. Os dados de DEC e FEC são apresentados para sistema COELBA como um todo e também para o grupo de consumidores da região de Camaçari.

O DEC possui relação com o tempo que as unidades consumidoras ficaram sem energia elétrica, enquanto que o FEC relaciona-se ao número de interrupções ocorridas. Assim quanto maiores são o DEC e o FEC, piores são as condições de suprimento elétrico.

Verifica-se que a COELBA apresenta índices superiores aos valores adotados pela ANEEL como benchmarking. 


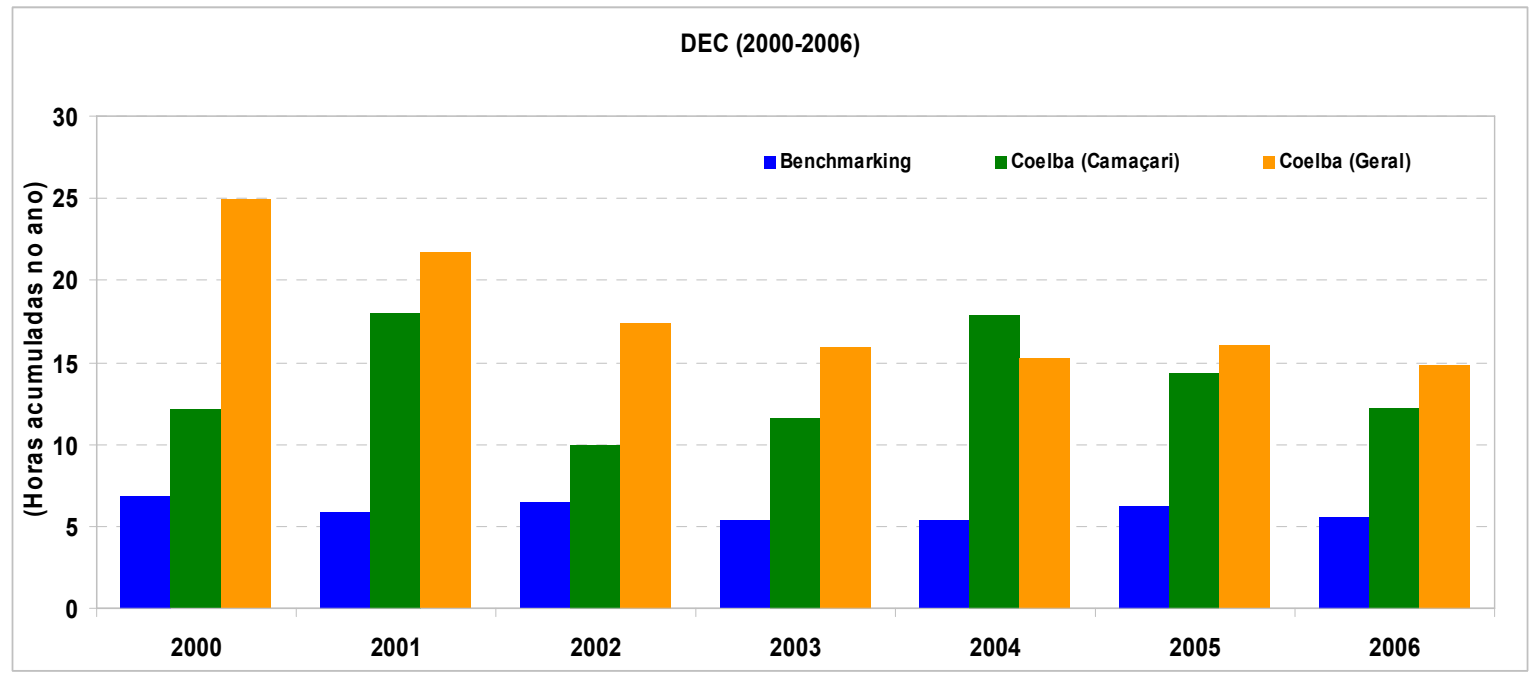

Figura 39 - Análise comparativa do DEC

Fonte: Site ABRADEE (www.abradee.org.br) / Site ANEEL (www.aneel.gov.br)

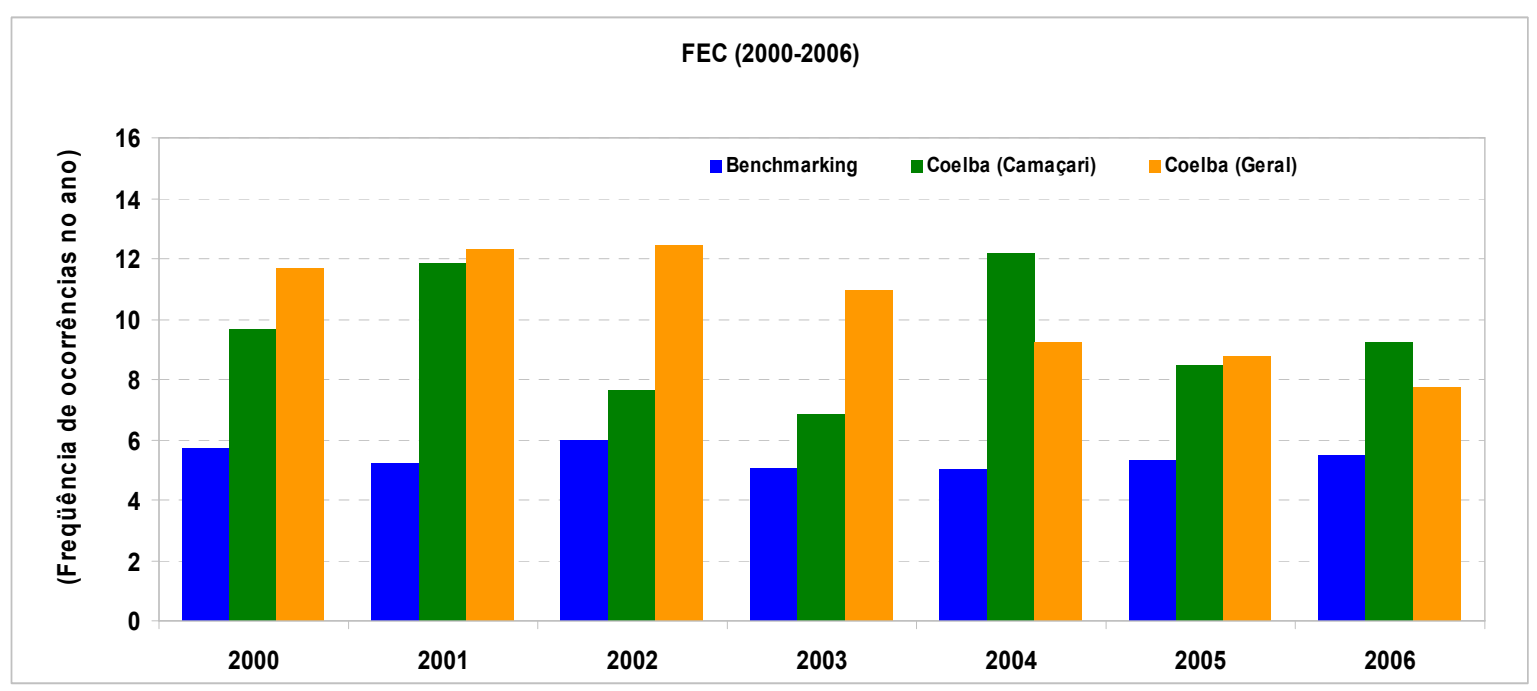

Figura 40 - Análise comparativa do FEC

Fonte: Site ABRADEE (www.abradee.org.br) / Site ANEEL (www.aneel.gov.br)

Índices de DEC e FEC estão muito relacionados às particularidades do sistema elétrico de cada distribuidora e diferem conforme o nível de tensão. Sabe-se que a COELBA cumpre os limites de DEC e FEC estabelecidos pela ANEEL. O fato é que em muitos casos os limites estabelecidos pela ANEEL não são satisfatórios para o setor industrial, que necessita de extrema confiabilidade de suprimento elétrico. Interrupções de fornecimento elétrico com baixa duração podem acarretar horas para retomada de alguns processos industriais, ocasionando perdas significativas. 
Ressalta-se também que desligamentos de produção não ocorrem somente devido a interrupções de fornecimento elétrico, sendo comum ocorrer parada em processos produtivos devido a oscilações de tensão. Para processos produtivos sensíveis, como o petroquímico, por exemplo, a qualidade e confiabilidade de atendimento elétrico são fatores fundamentais e qualquer oscilação no suprimento pode ocasionar perdas substanciais.

A estrutura de suprimento elétrico no pólo Petroquímico de Camaçari foi concebida no início da década de 80 , ou seja, antes da estruturação do novo modelo do setor elétrico brasileiro, que ocorreu em meados da década de 90. Em 1983 a antiga COPENE e a COELBA firmaram um acordo em que foram estabelecidas poligonais delimitando as áreas em que o atendimento elétrico das indústrias do pólo deveria ser feito pela COPENE ou pela distribuidora local. Neste acordo, duas poligonais foram estabelecidas para definição das áreas de fornecimento de energia elétrica.. $O$ Acordo Operacional previa que a COPENE efetuasse $O$ atendimento de energia elétrica as indústrias que estivessem dentro da Poligonal $\mathrm{A}$. Na outra área, entre a Poligonal A e B, o suprimento elétrico pela COPENE é facultativo. A tabela e figura apresentadas a seguir resumem a questão de suprimento nas poligonais.

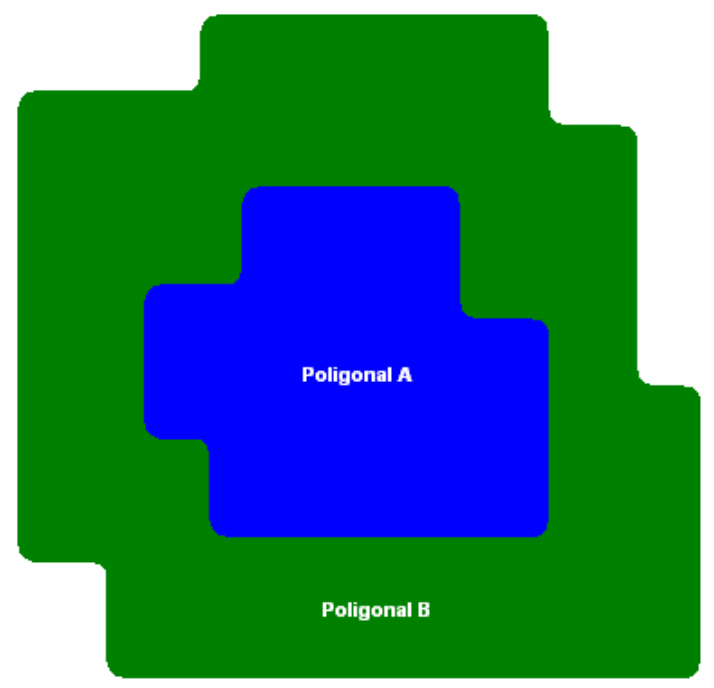

Figura 41 - Esquemático das Poligonais definidas no Acordo Operacional celebrado entre COPENE e COELBA no Pólo Petroquímico de Camaçari

Fonte: Processo ANEEL 48100.000383/1996-58 
Tabela 26 - Detalhamento do atendimento elétrico definido no Acordo Operacional celebrado entre COPENE e COELBA no Pólo Petroquímico de Camaçari

Área

Descrição do suprimento elétrico

A Braskem S.A. (COPENE) efetua o atendimento elétrico a todas as

Poligonal A empresas instaladas, e que venham a se instalar, no interior da poligonal A.

As empresas instaladas entre as poligonais $A$ e $B$, tem o direito de

Poligonal B
razões técnicas e econômicas, a maioria das empresas atualmente
situadas entre as poligonais A e B são atendidas pela Braskem S.A.

$\begin{array}{ll}\text { Poligonal B } & \begin{array}{l}\text { optar pelo atendimento via Braskem S.A. (COPENE) ou COELBA. Por } \\ \text { razões técnicas e econômicas, a maioria das empresas atualmente } \\ \text { situadas entre as poligonais A e B são atendidas pela Braskem S.A. }\end{array}\end{array}$

Poligonal B $\begin{aligned} & \text { optar pelo atendimento via Braskem S.A. (COPENE) ou COELBA. Por } \\ & \text { razões técnicas e econômicas, a maioria das empresas atualmente } \\ & \text { situadas entre as poligonais A e B são atendidas pela Braskem S.A. }\end{aligned}$

Área Externa

$\mathrm{Na}$ área externa à poligonal $\mathrm{B}$ as empresas devem ser atendidas pela distribuidora local.

Fonte: Processo ANEEL N 48100.000383/1996-58

Analisando a definição de atendimento elétrico das indústrias do pólo petroquímico de Camaçari conforme poligonais $\mathrm{A}$ e $\mathrm{B}$, pode-se concluir que os limites foram definidos em função da viabilidade econômica do transporte de vapor e utilidades.

No interior da Poligonal A, onde o transporte de vapor é técnica e economicamente viável, a COPENE passou a ter preferência pelo atendimento elétrico. Entre as Poligonais $\mathrm{A}$ e $\mathrm{B}$, onde a viabilidade técnica e econômica do transporte de vapor e utilidades é reduzida, a COELBA passou a ter preferência pelo atendimento elétrico. Entretanto, a indústria que se instalasse entre as Poligonais A e B, poderia optar por ser atendida pela COPENE em função de outros fatores.

$\mathrm{Na}$ área externa à Poligonal $\mathrm{B}$, onde a viabilidade de transporte de vapor e utilidades é mais reduzida e viável apenas em casos específicos, o atendimento elétrico foi atribuído à COELBA.

Após a estruturação do novo modelo do setor elétrico, em que se criaram as figuras do produtor independente de energia, auto-produtor, comercializador etc., a então COPENE solicitou sua regularização perante a ANEEL.

Em 15.10.1996 o MME por meio da Portaria MME N 321 autorizou a COPENE a se estabelecer como produtor independente de energia. Esta portaria foi embasada pelo Parecer CONJUR /MME N²08/1996, que ao longo do texto chega a citar que 
"o modelo de suprimento elétrico adotado pela COPENE é piloto e serve como modelo ao país, pois proporcionou ao país um modelo exemplar de geração e utilização de energia elétrica associada ao fornecimento de outro insumo, como o vapor".

Após a incorporação da COPENE pela Braskem S.A., esta solicitou alteração da razão social da primeira, o que ocorreu em por meio do Despacho ANEEL $N^{\circ} 2706 / 2006$.

Com a publicação da Resolução ANEEL N²29/2006, que estabeleceu as condições gerais para a incorporação de redes particulares, conectadas aos sistemas elétricos de distribuição, a Braskem S.A. efetuou consulta à ANEEL sobre a regularidade de suas redes elétricas particulares. O Parecer 220/2005 PGE/ANEEL afirmou que as instalações operadas pela Braskem S.A. estavam devidamente regularizadas e não deveriam ser incorporadas pela distribuidora local.

Em 2000, a Monsanto, indústria do setor de alimentos, decidiu implantar uma nova unidade industrial no pólo de Camaçari, na Bahia, e solicitou o atendimento de vapor e energia elétrica à Braskem S.A., na época ainda COPENE. A área prevista para instalação da unidade industrial da Monsanto estava fora da Poligonal B, ou seja, onde o atendimento elétrico deveria ser feito pela COELBA, conforme acordo operativo já citado. Mesmo assim, a Monsanto manifestou interesse em ser atendida pela então COPENE.

Com base nos limites de atendimento definidos no acordo operativo e também devido ao fato da Monsanto ser o primeiro consumidor a se instalar no pólo de Camaçari depois da estruturação do novo modelo de setor elétrico, a então COPENE comunicou à ANEEL que desenvolveria projeto para atendimento da Monsanto. A COPENE também solicitou as autorizações de passagem ao Departamento de Infra-Estrutura e Transportes do Estado da Bahia - DERBA e à Ferrovia Centro Atlântico, dado que a rede elétrica para atendimento da Monsanto cruzava rodovia e ferrovia.

O atendimento da Monsanto pela COPENE foi aprovado pela Superintendência de Regulação dos Serviços de Transmissão - SRT e pela Procuradoria Geral - PGE da ANEEL e em 10.05.2001 esta agência publicou a Resolução $N^{\circ} 175$ autorizando a COPENE a implantar a linha de transmissão de $69 \mathrm{kV}$, em circuito duplo, com extensão de 3,8 km, para atendimento da nova planta da Monsanto. 
Em 2005, a Columbian Chemicals, produtora de negro de fumo (que é utilizado na fabricação de pneus, artefatos de borracha, plásticos e tintas) encaminhou à Braskem termo de intenção solicitando o fornecimento de energia elétrica, vapor e matérias primas. A planta industrial da Columbian Chemicals foi construída em área localizada entre as Poligonais A e B, ou seja, onde o atendimento elétrico poderia ser feito tanto pela COELBA quanto pela Braskem. A instalação da planta da Columbian Chemicals em Camaçari mobilizou investimentos ordem de $\mathrm{R} \$ 165$ milhões e foi concluída em 2006.

Segundo informações dos processos em andamento na ANEEL ${ }^{11}$, a Columbian Chemicals após discussões com a COELBA, concluiu que devido aos rigorosos padrões de confiabilidade e segurança, sua nova unidade industrial somente seria factível em razão da possibilidade da Braskem S.A. fornecer a matéria prima essencial e todas as utilidades necessárias ao seu processo produtivo (energia elétrica, água clarificada, água potável e vapor), com destaque para o alto índice de confiabilidade de suprimento elétrico. O contrato entre Braskem S.A. e Columbian Chemicals foi firmado em agosto de 2005.

Os diversos processo em andamento na ANEEL mostram que o atendimento elétrico da Monsanto e Columbian Chemicals pela Braskem S.A. passou a ser fortemente contestado pela COELBA. Em 2006, esta distribuidora protocolou na ANEEL pedidos de embargo e interdição das obras para atendimento da Columbian Chemicals e de invalidação contra a Resolução ANEEL № 175/2000.

Nos processos, a COELBA argumenta que a Braskem S.A. "não é titular de outorga do Poder Concedente que a legitime a prestar serviço público de distribuição de energia elétrica e que ela não obteve, e nem poderia obter, as necessárias autorizações da ANEEL para construção de rede de distribuição de energia elétrica para conectar sua UTE à Columbian".

Em documentos apresentados pela COELBA à ANEEL nos processos relacionados ao suprimento elétrico no pólo de Camaçari, a distribuidora afirma que o fornecimento de energia pela Braskem à Columbian Chemicals "representa quebra do contrato de concessão e gera um perigoso precedente que poderia se estender a outras áreas do país".

11 Processos 48100.000383/1996-58, 48500.001256/2006-80.

48500.002882/2000-15,

48500.001550/2005-56 
No processo a COELBA pede a cassação por parte da Braskem do fornecimento de energia elétrica à Columbian Chemicals, bem como todo e qualquer outro comprador de energia do PIE sem o uso da suas redes de distribuição.

A distribuidora afirma que autorização dada pela Portaria MME N 321/1996 à então COPENE para operar como PIE refere-se somente à energia e não ao transporte e que, desta forma, ela teria o direito de efetuar o serviço de transporte de energia pelo fato de ser uma concessionária de serviço público. Segundo a COELBA, caso um PIE queira vender energia elétrica que produz, ele terá obrigação de acessar e utilizar os sistemas de transmissão e distribuição de energia elétrica para viabilizar o seu transporte até seu comprador.

A COELBA cita que tanto ela quanto os consumidores cativos são prejudicados, pois a receita proveniente do uso do sistema de distribuição integra a rubrica Receita Requerida das concessionárias para fins de cálculo do reposicionamento tarifário por ocasiões das revisões periódicas. Afirma ainda que quanto menor for o mercado da concessionária, maior será o índice de reposicionamento tarifário a ser aplicado aos seus consumidores.

Com relação ao atendimento da Monsanto a COELBA em seu pleito solicita que este consumidor celebre CUSD e CDD com ela. No entanto, não se verifica no processo solicitação da distribuidora para a incorporação das redes elétricas.

Em sua defesa, a Braskem S.A. argumenta que o fornecimento de energia elétrica de sua planta de cogeração às indústrias do pólo petroquímico de Camaçari ocorre por meio de redes elétricas expressas, ponto a ponto, em sua maioria por dutos subterrâneos, não havendo redes de atendimento múltiplo e muito menos de distribuição. Desta forma, afirma a Braskem S.A., o fornecimento de energia elétrica efetuado por ela no pólo de Camaçari não se caracteriza como uma atividade de distribuição de energia elétrica, que envolve malhas de redes e outras instalações conectadas ao sistema de transmissão, regidas por normas de fornecimento e tarifas fixadas pelo poder concedente.

A Braskem defende que a comercialização de energia em complexos industriais, nos casos de cogeração, decorre de uma situação técnica específica, cujas peculiaridades impõem relacionamento direto com o cogerador, que produz vapor e energia elétrica e fornece às demais indústrias do pólo. Esta empresa ressalta que as especificidades técnicas do processo de cogeração existentes no pólo 
petroquímico de Camaçari comprovam que a atividade de produção e fornecimento de insumos (vapor, energia elétrica, água e outros) são indissociáveis e inerentes ao processo produtivo das indústrias dele integrantes e afirma ainda que estas especificidades foram considerada no Inciso II, do Art. 12 da Lei № 9074/1995, que permite ao PIE cogerador comercializar energia em conjunto com vapor de processo.

A Braskem S.A. afirma que suas atividades no pólo de Camaçari sempre foram autorizadas por órgãos competentes do setor de energia, como MME, DNAEE e ANEEL, por meio de resoluções, portarias e demais documentos, e que a Lei $N^{\circ}$ 9074/1995 prove respaldo legal as atividades que são contestadas pela COELBA.

A Columbian Chemicals também apresentou seus argumentos ao longo do processo, os quais foram sempre em defesa do atendimento de sua planta industrial pela Braskem S.A. por meio de redes elétricas particulares.

Sobre os casos Monsanto e Columbian Chemicals a ANEEL elaborou uma nota técnica em conjunto com três superintendências, a SFG, a SCT e a SCG, a qual teve posicionamento contrário aos pleitos da COELBA. Nesta NT, é citado "que o fornecimento de energia elétrica pela Braskem às empresas do pólo é parte indissociável do processo dessas indústrias, sem o qual não se sustenta o processo produtivo."

O processo foi analisado também pela Procuradoria Federal - PF da ANEEL, que elaborou uma nota técnica sobre o caso, porém, com posicionamento contrário ao adotado pelas superintendências acima citadas. A Procuradoria Federal chega a argumentar que "o serviço de distribuição de energia elétrica é prerrogativa da concessionária de distribuição e que PIEs tem função exclusiva de gerar energia elétrica, jamais de praticar atividades típicas de distribuição". Na mesma NT, a Procuradoria Federal cita ainda o exemplo do suprimento elétrico das empresas Aracruz e Nexen, em que há cogeração de energia pela Aracruz com venda de energia elétrica e vapor à Nexen, sem pagamento de parcela fio à distribuidora. A Procuradoria Federal afirma que neste caso o fornecimento de energia elétrica ocorre dentro de "muros" de propriedade da Aracruz, sendo que o fluxo de energia se dá exclusivamente dentro de uma área privada à unidade do mesmo processo industrial. 
A PF afirma que no caso do pólo de Camaçari a situação é diferente, pois dentro das poligonais há fornecimento de energia elétrica pela COELBA a algumas empresas e ressalta ainda que existem vias públicas atravessando o complexo petroquímico.

Em 05.06.2007, a ANEEL por meio do Despacho ANEEL N 1767/2007 determinou algumas medidas em relação ao atendimento elétrico da Braskem S.A. à Monsanto e à Columbian Chemicals, seguindo, basicamente, os pontos estabelecidos na Nota Técnica elaborada pela Procuradoria Federal.

Com relação ao suprimento da Monsanto, o Despacho ANEEL N 1767/2007 estabeleceu que a Resolução ANEEL N 175/2000 não fosse invalidada. Assim, o suprimento elétrico da Braskem à Monsanto foi ratificado pela ANEEL. Esta decisão foi tomada mais em função de aspectos jurídicos do que técnicos, pois o prazo decorrido para contestação da COELBA havia ultrapassado cinco anos, período que uma vez ultrapassado, impede que atos administrativos sejam anulados, conforme estabelecidos pelo Art. 54 da Lei 9784/1999.

Com relação ao suprimento elétrico da Columbian Chemicals pela Braskem as determinações do Despacho ANEEL N 1767/2007 foram diferentes. Este despacho determinou que "os bens e instalações de distribuição implantadas pela Braskem para o fornecimento de energia elétrica à empresa Columbian Chemicals fossem incorporados ao imobilizado em serviço da COELBA, mediante o correspondente ressarcimento à Braskem".

No mesmo despacho é determinado que a Braskem poderia fazer uso das instalações a serem transferidas para comercialização da energia gerada em sua planta de cogeração, porém, mediante ressarcimento do custo pelo transporte à COELBA.

Ainda de acordo com o Despacho ANEEL N 1767/2007, a ANEEL estabeleceu que a implantação de novas redes elétricas pela Braskem a indústrias localizadas no Complexo Petroquímico de Camaçari fosse condicionada à autorização específica prévia da ANEEL, devendo ser comprovado, dentre outras coisas, mas como condição imprescindível, a integração na cadeia produtiva do Complexo da nova indústria a ser atendida pela Braskem.

Após liminar judicial impetrada por uma das partes envolvidas no processo, a ANEEL por meio do Despacho $N^{\circ}$ 417/2008 voltou a atrás em sua decisão e anulou o Despacho ANEEL N¹767/2007, o que eliminou, temporariamente, a necessidade 
de transferência à COELBA dos ativos implantados pela Braskem para atendimento da Columbian Chemicals, entretanto, o caso ainda encontra-se em andamento na ANEEL aguardando um posicionamento final desta agência.

Os dois casos apresentados ao longo deste capítulo evidenciam os conflitos atualmente existentes entre indústria e concessionárias de distribuição de energia elétrica em pólos industriais.

Uma política de incentivo à formação de pólos industriais deverá ser respaldada, necessariamente, por uma regulação adequada que evite estes tipos de divergências e proporcione um ambiente regulatório claro que favoreça a atração de empresas ao país. 


\title{
10 - PROPOSIÇÃO DE REGULAMENTAÇÃO SOBRE PÓLOS INDUSTRIAIS ABORDANDO A QUESTÃO ENERGÉTICA
}

Em diversos países, observa-se que algumas definições criadas para pólos industriais são mais genéricas, permitindo maior flexibilidade quanto aos tipos de empresas que podem se agrupar e usufruir dos benefícios gerados. Existem definições que permitem de forma explícita a inclusão de prestadores de serviço ou de outras empresas não industriais relacionadas ao dia-a-dia do pólo. Outra ocorrência comum é a exigência de uma área delimitada, aceitando vias públicas ou acidentes geográficos internos a esta área.

As definições de pólos industriais variam dependendo do contexto e das necessidades, mantendo-se constantes somente alguns parâmetros básicos da definição, como, por exemplo, a limitação do contexto a empresas industriais ou relacionadas a elas e algum tipo de restrição geográfica, obrigando que estas empresas se agrupem fisicamente para obter ganhos de escala e sinergias.

A seguir são apresentados alguns exemplos de definições para pólos industriais.

\footnotetext{
"Conjunto de indústrias que capturem benefícios através de ganhos de escala ou escopo, associadas por meio de relações de fornecedor-cliente, ou por tecnologias, clientes ou canais de distribuição em comum, ou pelo compartilhamento do mesmo pólo de mão-de-obra."
}

Michael E. Porter, 1990 - EUA

\begin{abstract}
"Toda área próxima a uma planta de produção industrial cuja atividade esteja relacionada à operação, incluindo mas não se limitando a estacionamentos, áreas fabris, edifícios, áreas verdes, tubulações, terminais ferroviários ou portuários e toda a área relacionada à produção industrial, sendo limitada, quando possível, por fronteiras legais ou naturais."
\end{abstract}

South California Legislature - EUA

"Concentrações de firmas envolvidas em processos interdependentes de produção freqüentemente na mesma indústria ou setores de mercado, cujas empresas estão relacionadas à mesma comunidade local e delimitadas pela distância diária de deslocamento dos funcionários."

Piore e Sabel, 1984; Goodman e Bamford, 1990 et al, Brusco, 1992 - Itália 
"Grupo de plantas industriais cujos membros se encontram em proximidade geográfica, ou seja, aglomerados de empresas do mesmo setor ou de setores similares."

Michael J. Enright, 1992, 1993 - Hong Kong

"qualquer conjunto de edifícios utilizado para a produção de bens, incluindo construções que ofereçam moradia ou serviços aos empregados, localizadas nas redondezas e separadas fisicamente das propriedades externas ao pólo. A área deve ser propriedade de uma única entidade."

Regras para Redistribuição de energia Elétrica (Energy Regulatory

Commision) - Filipinas

"Agrupamentos industriais com um mínio de 50 unidades, fabricando produtos relacionados e localizados dentro de um raio de $10 \mathrm{~km}$ de um local determinado. O número de unidades e distância podem ser flexibilizados pelo Estado para casos específicos."

Departamento de Minas e Indústria - Índia

Utilizando como referência as experiências internacionais, pode-se concluir que existe uma serie de oportunidades para fomentar o desenvolvimento por meio de incentivos à criação de novos pólos industriais ou ao crescimento de pólos já existentes no Brasil.

A regulamentação a ser estabelecida deve garantir o funcionamento do mercado sob regras claras, com tratamento padronizado, e manter o equilíbrio econômico entre os agentes do setor, permitindo o acesso aos benefícios a um número limitado de empresas com potencial para trazer desenvolvimento industrial a determinadas regiões do Brasil.

Dentre as condições relevantes que devem constar na regulamentação, destaca-se a definição do pólo industrial, as condições de gestão, inclusive para compartilhamento de infra-estrutura e a aquisição de insumos, o tratamento que deve ser dado à compra de energia elétrica e à contratação do uso e da conexão aos sistemas elétricos e a caracterização do ponto de entrega para fins destas contratações, incidência de encargos e aferição da medição.

Considerando a variedade de situações identificadas, a criação de uma regulamentação que aborde a questão energética de pólos industriais deve conter, 
mas sem se limitar a eles, os seguintes pontos para garantir da competitividade das indústrias:

- Possibilidade de existência de vias públicas internas ao pólo;

- Presença de consumidores não industriais, como prestadores de serviços, bancos, restaurantes etc;

- Possibilidade de convivência de consumidores livres e cativos;

- Possibilidade de aquisição de energia de forma centralizada por uma empresa líder ou de forma independente;

- Possibilidade de celebração de contratos de conexão (CUST/CUSD e CCT/CCD) de forma centralizada ou independente;

- Compartilhamento de infra-estrutura energética, como subestações, redes elétricas etc.;

- Faturamento dos consumidores com base na tensão de entrada da subestação compartilhada;

- Existência de contratos de reserva de capacidade (conexão de backup) ${ }^{12}$

- Possibilidade de comercialização de energia para fora do pólo.

O pólo industrial passaria a ter liberdade para definir a melhor forma de contratação de uso dos sistemas, medição de faturamento e aquisição de energia, cabendo aos integrantes do pólo definir se estes fatores são adquiridos em conjunto ou individualmente.

O faturamento dos consumidores seria efetuado com base na tensão de entrada da subestação do pólo, podendo as indústrias ser consumidores cativos ou livres.

Os encargos setoriais incidiriam somente sobre a energia proveniente do SIN, sendo isenta de encargos a energia gerada e vendida internamente no pólo. Esta medida poderia proporcionar incentivos à ampliação de plantas de cogeração existentes e à instalação novas cogerações.

A regulamentação deve garantir um ambiente propício para atração de novas empresas, visando o desenvolvimento dos pólos existentes e a criação de novos

12 A Reserva de Capacidade é regulamentada pela Resolução ANEEL No 371, de 29.12.1999 com alterações feita pela Resolução No 304, de 04.03.2008. A Reserva de Capacidade se refere ao "montante, em MW, requerido dos sistemas de transmissão e distribuição quando da ocorrência de interrupções ou reduções temporárias na geração de energia elétrica das usinas de autoprodutor ou produtor independente. A contratação deve ser efetuada entre o autoprodutor (ou produtor independente) e a concessionária de transmissão ou distribuição de energia elétrica que atue na área onde se localizada a unidade consumidora. 
pólos. Deve evitar ambigüidade de interpretação, eliminando assim os vácuos regulatórios hoje existentes.

Tomando como base os casos de sucesso em outros países em que políticas de incentivos a pólos industriais envolvendo a questão energética foram adotadas, e também as diversas características dos pólos industriais do Brasil, a ABRACE, em conjunto com empresas de consultoria técnica e jurídica, estabeleceu a seguinte definição para pólo industrial:

\footnotetext{
Pólo industrial é a reunião de empresas industriais, em área geográfica delimitada por um raio de até $10 \mathrm{~km}$, que tenham interesse comum no compartilhamento de infra-estrutura e na aquisição de insumos, compreendendo energia, água, vapor, gás, transporte, dentre outros".
}

A definição proposta pela ABRACE para pólos industriais é bastante abrangente e acredita-se que englobe todos os pólos existentes no Brasil e poderá comportar muitos outros futuros pólos.

O trabalho desenvolvido pela ABRACE teve como resultado a estruturação de uma minuta de decreto ministerial que aborda todos os pontos polêmicos envolvendo à questão energética de pólo industriais. No ANEXO A é apresentada a minuta de decreto proposto pela ABRACE.

A regulamentação do tema de pólos industriais envolvendo a questão de suprimento elétrico é polêmica e com certeza enfrentará obstáculos para sua concretização.

A proposta de decreto da ABRACE visa aos interesses dos pólos industriais existentes no Brasil e proporciona condições favoráveis para a criação de novos pólos, contribuindo para a manutenção da competitividade do setor industrial. Essa posição está coerente com a missão de uma associação de consumidores.

Entretanto, os pontos defendidos na minuta de decreto elaborado pela ABRACE divergem dos interesses das concessionárias de distribuição de energia elétrica e eventuais impactos que possam ser causados às mesmas devem ser analisados com atenção.

A solução do conflito deve ser uma decisão política. Os incentivos ao desenvolvimento de pólos industriais são ações no sentido de promove a geração de empregos mediante o crescimento do setor industrial, mas é necessário também financiar o setor elétrico e garantir a modicidade tarifária. 
O desenvolvimento do setor industrial pode levar também ao crescimento do setor elétrico, uma vez que o crescimento da indústria leva a uma maior geração de empregos. Isto proporciona um fortalecimento da economia com conseqüente aumento do poder aquisitivo da população, gerando crescimento do mercado residencial de energia elétrica. 


\section{1 - CONCLUSÃO}

Ao longo desta dissertação foram apresentados alguns dos obstáculos enfrentados por indústrias instaladas em pólos industriais no que se refere ao suprimento de energia elétrica.

As análises apresentadas no Capítulo 3 mostraram que as tarifas de energia elétrica do setor industrial no Brasil sofreram aumentos expressivos o que prejudicou a competitividade do setor. Verificou-se que apesar de o Brasil possuir uma matriz de geração de energia elétrica com base em hidrelétricas, o país apresenta uma das tarifas finais de energia mais elevadas, sendo superior às tarifas de países como Estados Unidos e França, que possuem base em geração térmica e nuclear, respectivamente.

O Capítulo 4 apresentou algumas das vantagens inerentes à formação de pólos industriais, tanto para as empresas quanto para a região onde os pólos se instalam. Para a região destaca-se a geração de empregos, qualificação de mão de obra, arrecadação de impostos etc. Para as empresas, tem-se, por exemplo, ganhos de escala na aquisição de produtos ou insumos, sinergias operacionais e redução de custos de O\&M.

O Capítulo 5 mostrou que diversos países, tais como Estados Unidos, Canadá, Dinamarca, dentre outros, tem adotado políticas de incentivos a pólo industriais envolvendo a questão energética e que estas políticas proporcionaram resultados substanciais, contribuindo assim para o desenvolvimento industrial do país.

Acontece que, com relação ao suprimento elétrico de pólos industriais, a legislação brasileira não é clara e apresenta vácuos regulatórios que acabam permitindo que interpretações divergentes sejam feitas sobre um determinado tema.

As análises das características diversas dos pólos industriais brasileiros apresentadas no Capítulo 6 em conjunto com os riscos regulatórios abordados no Capítulo 7 mostraram que a criação de uma regulamentação sobre pólo industriais envolvendo a questão energética é fundamental para garantir o funcionamento dos pólos existentes e permitir a criação de novos pólos. A regulamentação proposta pela ABRACE consiste numa iniciativa interessante que pode vir ao encontro destes interesses.

O suprimento elétrico aos pólos industriais consiste num tema polêmico que, acredita-se, enfrentará obstáculos para que seja regulamentado. Entretanto, é 
preciso refletir sobre o papel de uma concessão pública de distribuição de energia elétrica, que não é de um monopólio exclusivo, conforme pode-se observar ao longo da dissertação. Deve-se refletir sobre as diferentes missões: "dever de atender" ou "um direito irrestrito de prestar o serviço".

Políticas de incentivos a pólos industriais são fundamentais para fortalecer o setor industrial de um país e, conforme apresentado, muitos países já adotaram esta estratégia para alavancar o crescimento dos mesmos.

Os casos de sucesso internacionais indicam que no Brasil há ainda diversas ações de incentivos a pólos industriais envolvendo a questão energética que poderiam ser aplicadas, de forma a incentivar o desenvolvimento do setor industrial e, conseqüentemente do país. 


\section{REFERÊNCIAS BIBLIOGRÁFICAS}

A. Lagendijk, A., Charles, D.; "Clustering as a New Growth Strategy for Regional Economies? A discussion of New Forms of Regional Industrial Policy in United Kingdom"; OECD Proceedings: Boosting Innovation - The Cluster Approach (1999);

Carrão, A. M. R.; "Cooperação entre empresas de pequeno porte em pólos industriais: um estudo comparativo"; Universidade Metodista de Piracicaba UNIMEP (2003);

Ceglie, G., Clara, M., Dini, M.; "Cluster and Network Development Projects in Developing Countries: Lessons Learned through the UNIDO Experience"; Private Sector Development Branch, UNIDO, Vienna; OECD Proceedings: Boosting Innovation - The Cluster Approach - (1999);

"The European Cluster Memorandum: Promoting European Innovation through Clusters"; Centre for Strategy and Competitiveness, CSC; Europe Cluster Observatory - (2007);

Cerejeira, J. C.; "Distritos Industriais em Portugal: Identificação e Avaliação das Externalidades Dinâmicas Associadas"; Universidade do Minho - Escola de Economia e Gestão - (1999);

Cezarino, L. O., Campomar, M. C.; "Vantagem competitiva para micro, pequenas e médias empresas: clusters e APLs" - (2006);

Coutinho, L; Ferraz, J.C. "Estudo da Competitividade da Indústria Brasileira". Campinas: Papirus e Ed.Unicamp - (1994);

Dias, Ana Valéria C.; "Consórcio modular e condomínio industrial: elementos para análise de novas configurações produtivas na indústria automobilística"; Dissertação de Mestrado - Departamento de Engenharia de Produção, Escola Politécnica, Universidade de São Paulo - (1998);

Dias, A. V. C., Salerno, M. S.; "Condomínios Industriais: Novas Fábricas, Novos Arranjos Produtivos e Novas Discussões na Indústria Automobilística Brasileira"; Departamento de Engenharia de Produção - Escola Politécnica - Universidade de São Paulo; 
Drejer, I., Kristensen, F. S., Laursen, K.; "Studies of Clusters as a Basis for Industrial and Technology Policy in the Danish Economy" - Danish Reserch Unit for Industrial Dynamics - (1997)

Decreto $N^{\circ} 41.019$, de 26 de fevereiro de 1957;

Decreto $N^{\circ} 2.003$, de 10 de setembro de 1999;

Decreto $N^{\circ} 5.597$, de 28 de novembro de 2005;

Decreto $N^{\circ} 5.163$, de 30 de julho de 2007;

Despacho ANEEL № 2.706, de 17 de novembro de 2006;

Despacho ANEEL No 1.767, de 5 de junho de 2007;

Despacho ANEEL N².329, de 25 de julho de 2007;

Despacho ANEEL № 417, de 12 de fevereiro de 2008 ;

E.M. Bergman (Vienna University of Economics and Business), E.J. Feser (University of North Carolina); "Industry Clusters: A Methodology and Framework for Regional Development Policy in the United States"; OECD Proceedings: Boosting Innovation The Cluster Approach - (1999);

Galvão, O. J. de A.; "Clusters e Distritos Industriais: Estudos de Casos em Países Selecionados e Implicações de Política"; Departamento de Economia da Universidade Federal de Pernambuco - UFPE - (2000);

Hoffmann, V.M.; Molina, F.X. "Cooperação e Transferência de Conhecimento entre Empresas Integradas a Redes de Base Territorial", Anais do congresso SLADE Sociedade Latino-Americana de Estratégia - (2004);

Ketels, C.; "European Clusters"; Harvard Business School, Boston MA, USA; Hagbarth Publications - (2004)

Lei $N^{\circ}$ 9.074, de 7 de julho de 1995;

Lei $N^{\circ}$ 8.631, de 4 de março de 1993;

Lei $N^{\circ} 8.987$, de 13 de fevereiro de 1995;

Lei $N^{\circ} 10.847$, de 15 de março de 2004;

Lei $N^{\circ} 10.848$, de 15 de março de 2004; 
Lei $N^{\circ}$ 9.648, de 27 de maio de 1998;

Lei $\mathrm{N}^{\circ}$ 9.427, de 26 de dezembro de 1996;

MARSHALL, A. "Princípios de Economia”, São Paulo: Abril Cultural - (1982.);

Medeiros, A. M. M., Pinhão, C. M. A.; "Pólos Automotivos Brasileiros"; BNDES Setorial, Rio de Janeiro - (1999);

Nota Técnica Nº12/2005-SRT/ANEEL

Nota Técnica Nº 034/2005-SRT/ANEEL

Nota Técnica Nº 046/2006-SFG-SCT-SCG/ANEEL;

Nota Técnica N²21/2007-PF/ANEEL;

Parecer CONJUR /MME N²08/1996;

Portaria DNAEE N 1.347, de 03 de novembro de 1975;

Portaria DNAEE N 881 , de 04 de julho de 1977;

Portaria MME N 1.555, de 03 de novembro de 1981;

Portaria DNAEE N 85 , de 16 de abril de 1984;

Portaria MME N 666, de 16 de maio de 1984;

Portaria DNAEE N 11, de 05 de março de 1990;

Portaria MME Nº 321 de 15/10/1996;

Procedimentos de Distribuição de Energia Elétrica no Sistema Elétrico Nacional PRODIST, Módulo 3 - Acesso ao Sistema de Distribuição, 2008

Processo da Audiência Pública ANEEL № 010 de 2005

Processo da Audiência Pública ANEEL № 008 de 2009

Processo ANEEL Nº 48100.000383/1996-58;

Processo ANEEL Nº 48500.004959/1999-03;

Processo ANEEL N ${ }^{\circ}$ 48500.004078/2001-25;

Processo ANEEL № 48500.002882/2000-15;

Processo ANEEL № 48500.001550/2005-56; 
Processo ANEEL N 48500.001256/2006-80;

Porter, Michael E.; How Competitive Forces Shape Strategy, Harvard Business Review; Boston - (1979);

Porter, Michael E.; "The Competitive Advantage of Nations"; Harvard Business Review Boston - (1990);

Porter, Michael E.; "Creating and Sustaining Superior Performance"; Harvard Business Review Boston;

Porter, Michael E.; "Clusters and the new economics of competition"; Harvard Business Review; Boston (1998);

Prochnik, V.; "Cadeias Produtivas e Complexos Industriais"; Seção do capítulo FIRMA, INDÚSTRIA E MERCADOS, do livro HASENCLEVER, L. \& KUPFER, D. ORGANIZAÇÃO INDUSTRIAL, Ed. Campus, 2002)

Queiroz, L. S., Mendonça, F. A. S.; "Regulação da Concorrência e Monopólios Naturais"; Anais do $3^{\circ}$ Congresso Brasileiro de P\&D em Petróleo e Gás promovido pelo Instituto Brasileiro de Petróleo e Gás - IBP - (2004);

Resolução ANEEL N² 281, de 01 de outubro de 1999;

Resolução ANEEL № 360, de 22 de dezembro de 1999;

Resolução ANEEL N 456, de 29 de novembro de 2000;

Resolução ANEEL N 175, de 10 de maio de 2001;

Resolução ANEEL N 715, de 28 de dezembro de 2001;

Resolução ANEEL N² 226, de 24 de abril de 2002;

Resolução ANEEL N 513, de 17 de setembro de 2001;

Resolução ANEEL N 67, de 08 de junho de 2004;

Resolução ANEEL N 68, de 08 de junho de 2004;

Resolução ANEEL Nº 77 de 18 de agosto de 2004

Resolução ANEEL N 166, de 10 de outubro de 2005; 
Resolução ANEEL N 229, de 8 de agosto de 2006;

Resolução ANEEL $N^{\circ}$ 247, de 21 de dezembro de 2006;

Resolução ANEEL $N^{\circ}$ 567, de 27 de novembro de 2007;

Resolução ANEEL № 626, de 07 de abril de 2008;

Resolução ANEEL № 627, de 07 de abril de 2008;

Resolução ANEEL № 635, de 17 de abril de 2008;

Resolução ANEEL № 636, de 17 de abril de 2008;

Resolução ANEEL № 638, de 17 de abril de 2008;

Resolução ANEELN 671, de 24 de junho de 2008;

Resolução ANEEL № 675, de 01 de julho de 2008;

Resolução ANEEL $N^{\circ}$ 345, de 16 de dezembro de 2008;

Site Associação Brasileira de Grandes Consumidores de Energia e Consumidores Livre - ABRACE (www.abrace.org.br);

Site Canal Energia (www.canalenergia.com.br);

Site Comitê de Fomento Industrial de Camaçari (www.cofic.org.br);

Site da Câmara de Comercialização de Energia Elétrica (www.ccee.org.br);

Site da Agência Nacional de Energia Elétrica - ANEEL (www.aneel.gov.br);

Site da Energy Information Administration - ElA (www.eia.doe.gov);

Sonzogno, V. E.; "Clusters Industriais: Um Estudo Sobre o Cluster de Calçados de Franca e seu Real Grau de Internacionalização"; FEA-USP - (2003);

Szafir-Goldstein, C.; Toledo, G.L. Comparação entre Clusters Industriais - breve caracterização do setor cerâmico de revestimento no Brasil e no mundo; VII SEMEAD - (2007);

Szafir-Goldstein, C.; Toledo, G.L.; Competição e Cooperação em Clusters Industriais: Estágios e Políticas; VII SEMEAD - (2007); 
Szafir-Goldstein, C.; Toledo, G.L. "Estratégia Competitiva, Cooperação e Relacionamento em Clusters Industriais", XVII Congresso Latino-Americano de Estratégia, Slade, Santa Catarina, Brasil - (2004);

Udo Staber, U., Morrison, C.; "The Empirical Foundations of Industrial District Theory"; Faculty of Administration University of New Brunswick - (200?);

Yamawaki, H.; "The Evolution and Structure of Industrial Clusters in Japan"; The International Bank for Reconstruction and Development/The World Bank; Washington, D.C. (2001) 


\section{ANEXOS}

ANEXO A Minuta de decreto proposta pela ABRACE para regulamentação da questão energética de pólos industriais

ANEXO B Decreto 5.597/2005

ANEXO C Pontos questionados pela ABRADEE em sua Ação de Descumprimento de Preceito Fundamental $\mathrm{N}^{\circ} 93$

ANEXO D Despacho do Ministro Ricardo Lewandowski, relator do procedo da ADPF 93

ANEXO E Questionário encaminhado aos associados ABRACE para coletar informações sobre os pólos industriais

ANEXO F Relação de empresas associadas à ABRACE 


\section{ANEXO A \\ Minuta de decreto proposta pela ABRACE para regulamentação da questão energética de pólos industriais}

Decreto $\mathrm{n}^{\circ}$ de de de 2008

Dispõe sobre normas gerais aplicáveis a empresas integrantes de pólos industriais, e dá outras providências.

O PRESIDENTE DA REPÚBLICA, no uso da atribuição que the confere o art. 84, inciso IV, da Constituição, e tendo em vista o disposto no Decreto n ${ }^{\circ}$ 41.019, de 26 de fevereiro de 1957, nas Leis nos.9.074, de 7 de julho de 1995 e 9.427, de 26 de dezembro de 1996,

DECRETA:

Art. $1^{\circ}$. Este Decreto estabelece normas e diretrizes regulamentadoras para o funcionamento dos pólos industriais, compreendendo a gestão e o compartilhamento de infra-estrutura e a aquisição de insumos pelas empresas integrantes dos pólos industriais.

Art. $2^{\circ}$. Para fins da aplicação do presente Decreto, entende-se como pólos industriais a reunião de empresas industriais, em área geográfica delimitada por um raio de até $10 \mathrm{~km}$, que tenham interesse comum no compartilhamento de infra-estrutura e na aquisição de insumos, compreendendo energia, água, vapor, gás, transporte, dentre outros.

$\S 1^{\circ}$. O conceito referido no caput abrange as empresas prestadoras de serviços, instaladas nos pólos industriais, que atendem as indústrias neles localizadas.

$\S 2^{\circ}$. A existência de vias de terceiros, sejam públicas ou privadas, e/ou acidentes geográficos na área do pólo industrial, não descaracteriza o conceito definido no caput, devendo ser obtidas as autorizações de passagem correspondentes.

Art. $3^{\circ}$. As empresas integrantes do pólo industrial estabelecerão livremente, mediante instrumento particular, as condições que regerão suas relações e deverão nomear uma empresa, que, dentre outras atribuições, será responsável pela gestão do compartilhamento de infra-estrutura, aquisição de insumos e rateio dos custos correspondentes.

Parágrafo único. A empresa gestora do pólo industrial poderá ser uma entidade criada para este fim ou uma empresa industrial integrante do pólo nomeada pelas demais, proprietária ou não da área geográfica ou das instalações do pólo. 
Art. $4^{\circ}$. As empresas integrantes do pólo industrial poderão adquirir energia elétrica individualmente ou através da empresa gestora nomeada na forma prevista no artigo anterior.

$\S 1^{\circ} \mathrm{A}$ empresa que optar por adquirir energia elétrica individualmente, como consumidor regulado ou livre na forma da legislação aplicável, deverá ter as medições e contratações de acesso e de energia aferidos e celebrados separadamente.

$\S 2^{\circ}$ A compra de energia elétrica, quando realizada através da empresa gestora do pólo industrial, ressalvado o disposto no artigo $6^{\circ}$ deste Decreto, observará as seguintes condições:

A carga total do pólo deverá ser igual ou superior a $3.000 \mathrm{~kW}$ e a tensão de atendimento do pólo deverá ser igual ou superior a 69kV;

A contratação será formalizada mediante a assinatura de contrato de compra e venda de energia elétrica, entre a empresa gestora e o vendedor;

Os custos com a aquisição de energia elétrica serão rateados entre as empresas integrantes do pólo proporcionalmente ao consumo individualizado de cada uma.

Art. $5^{\circ}$. Na hipótese prevista no $\S 2^{\circ}$ do artigo $4^{\circ}$, a contratação do uso e da conexão aos sistemas de transmissão ou de distribuição será formalizada pela empresa gestora com o concessionário ou permissionário local e os custos correspondentes serão rateados entre as empresas integrantes do pólo industrial, proporcionalmente à demanda de cada uma.

Art. $6^{\circ}$. Para fins do disposto nos artigos $4^{\circ}$ e $5^{\circ}$ acima, inclusive para medição, perdas, encargos, acesso aos sistemas elétricos e/ou aquisição de energia elétrica, deverá ser considerado como ponto de entrega a instalação elétrica que conectará o pólo industrial aos sistemas elétricos de distribuição ou de transmissão.

Art. $7^{\circ}$. A partir do ponto de entrega, definido conforme artigo $6^{\circ}$, as condições operacionais e contratuais pertinentes à infra-estrutura interna do pólo industrial, inclusive o rateio das perdas e dos custos de operação e manutenção desta, serão estabelecidas no instrumento particular a que se refere o artigo $3^{\circ}$.

Parágrafo único. As instalações referidas no caput são de uso exclusivo das empresas integrantes do pólo industrial e não constituem instalações destinas ao serviço público de distribuição e/ou transmissão.

Art. $8^{\circ}$. A energia elétrica e/ou outros insumos oriundos de processo de cogeração de empresa integrante do pólo industrial, autorizada sob regime de autoprodução ou produção independente, vendidos às demais empresas integrantes do pólo industrial, serão entregues diretamente através de instalações pertencentes à empresa produtora ou através das instalações de infra-estrutura do pólo industrial.

Art. 9 ${ }^{\circ}$. As disposições deste Decreto aplicam-se aos pólos industriais novos e existentes, que deverão observar o disposto neste Decreto a partir de sua publicação.

Art. 10. Este Decreto entra em vigor na data de sua publicação. 
Brasília, ...... de ..... de $2008 ; 187^{\circ}$ da Independência e $120^{\circ}$ da República.

LUIZ INÁCIO LULA DA SILVA

Edson Lobão 


\section{ANEXO B \\ Decreto 5.597/2005}

\section{DECRETO N 5.597, DE 28 DE NOVEMBRO DE 2005.}

Regulamenta o acesso de consumidores livres às redes de transmissão de energia elétrica e dá outras providências.

O PRESIDENTE DA REPÚBLICA, no uso da atribuição que the confere o art. 84, inciso IV, da Constituição, e tendo em vista o disposto nos arts. 59 do Decreto-Lei no 227, de 28 de fevereiro de 1967, 15 e 16 da Lei no 9.074, de 7 de julho de 1995, 2 o e 3o-A da Lei no 9.427, de 26 de dezembro de 1996 , e 15 da Lei no 10.848 , de 15 de março de 2004,

\section{DECRETA:}

Art. $10 \mathrm{O}$ acesso de consumidores atendidos em tensão igual ou superior a $230 \mathrm{kV}$ à rede básica de transmissão de energia elétrica deverá ser efetuado pelas formas a seguir descritas:

I - atendimento por intermédio do concessionário local de distribuição de energia elétrica;

II - atendimento por intermédio do concessionário de transmissão de energia elétrica, nos termos do $\S 20$ do art. 40 do Decreto no 41.019, de 26 de fevereiro de 1957; ou

III - mediante construção das instalações necessárias para o acesso diretamente pelo próprio consumidor.

$\S 10 \mathrm{O}$ acesso de consumidores nas formas referidas nos incisos II e III deste artigo será objeto de autorização a ser expedida pela Agência Nacional de Energia Elétrica - ANEEL.

$\S 20$ As autorizações de que trata o $\S 10$ serão concedidas apenas nos casos de atendimento exclusivo ao respectivo consumidor.

Art. $20 \mathrm{O}$ acesso a que se refere o art. 10, para atendimento exclusivo de um único consumidor, deverá ser precedido de:

I - portaria do Ministério de Minas e Energia fundamentada em parecer técnico, o qual deverá considerar o critério de mínimo custo global de interligação e reforço nas redes, além de estar compatibilizado com o planejamento da expansão do setor elétrico para um horizonte mínimo de cinco anos; e

II - parecer de acesso emitido pelo Operador Nacional do Sistema Elétrico - ONS.

Parágrafo único. Quando da elaboração do parecer de acesso, pelo ONS, deverão ser observados os Procedimentos de Rede aprovados pela ANEEL e os padrões técnicos da instalação de transmissão acessada.

Art. 3o O acesso de que tratam os incisos II e III do art. 10 será autorizado apenas nos seguintes casos:

I- ligação de nova unidade consumidora não conectada anteriormente, desde que seja tecnicamente compatível com o nível de tensão igual ou superior a $230 \mathrm{kV}$, nos termos do que dispuser a portaria do Ministério de Minas e Energia prevista no inciso I do art. 20; ou 
II - alteração da forma de conexão de unidade consumidora já atendida em tensão inferior a 230 $\mathrm{kV}$, em decorrência de:

a) aumento de carga; ou

b) necessidade de melhoria de qualidade, devidamente demonstrada pelo consumidor interessado e reconhecida pela ANEEL.

Parágrafo único. O consumidor autorizado na forma deste artigo somente poderá efetivar o acesso após a celebração de contratos de conexão e de uso dos sistemas de transmissão.

Art. 40 A autorização de que trata o art. 3o poderá incluir as seguintes instalações, sujeitas à fiscalização da ANEEL:

I - a construção de entradas de linhas de transmissão igual ou superior a $230 \mathrm{kV}$ na subestação da rede básica;

II - o seccionamento de linhas do sistema de transmissão;

III - o barramento de alta tensão da subestação da unidade consumidora; e

IV - as linhas de transmissão em tensão igual ou superior a $230 \mathrm{kV}$, para conexão da unidade de consumo com o sistema de transmissão.

$\S 10$ No caso de o acesso, previsto na forma do inciso II deste artigo, ser promovido pelo próprio consumidor, os bens e instalações necessários ao seccionamento e acesso serão cedidos sem qualquer ônus ao concessionário de transmissão acessado, na forma de doação, e incorporados à rede básica.

§ 20 Caso o acesso do consumidor, previsto no referido inciso II, seja feito por meio do concessionário de transmissão, os bens e instalações e adequações necessários ao seccionamento e acesso deverão ser remunerados pelo respectivo consumidor, nos termos previstos no contrato de conexão de transmissão celebrado entre o consumidor e a concessionária de transmissão acessada.

§3o Os bens e instalações necessários exclusivamente ao seccionamento nas hipóteses previstas nos $\S \S 10$ e 20 deste artigo deverão ser incorporados à rede básica.

Art. 5o As instalações de transmissão para uso exclusivo de um consumidor ou de um agente poderão ser acessadas por outro agente ou consumidor interessado que atenda às condições legais e à regulação expedida pela ANEEL.

$\S 10$ A regulação do acesso de que trata o caput deverá dispor sobre:

I - as condições gerais de acesso, de acordo com estudos técnicos aprovados pelo ONS;

II - o ressarcimento a quem promoveu, às suas custas, a construção da obra de uso exclusivo;

III - a incorporação à rede básica da rede de transmissão de uso comum; e

IV - a remuneração do agente de transmissão que incorporar a rede de transmissão de uso comum.

§ 20 No acesso de que trata este artigo, o acessante interessado deverá atender às mesmas exigências técnicas e legais previstas para o acesso de consumidor ou agente ao sistema de transmissão.

§ 30 A parte de uso comum das instalações de transmissão acessada, na tensão de $230 \mathrm{kV}$ ou superior, será doada à concessionária de transmissão que celebrou o contrato de conexão com o consumidor ou agente e será incorporada à rede básica. 
Art. 6o A autorização de que trata o art. 3o deste Decreto, no caso de consumidores já conectados à rede de distribuição e que pretendam se conectar à rede básica, somente será outorgada após a homologação pela ANEEL do instrumento contratual cabível, a ser celebrado entre o consumidor e seu respectivo agente de distribuição.

$\S 10$ Como condição para pleitear a autorização, os consumidores interessados deverão observar os seguintes aspectos relacionados ao pagamento de encargos:

I - ressarcimento ao agente de distribuição dos investimentos específicos feitos na rede de distribuição para atendimento ao consumidor, descontada a depreciação contábil;

II - quitação, pelo consumidor, do valor referente aos Encargos de Serviços de Sistema - ESS e do saldo da Conta de Compensação de Variação de Valores de Itens da Parcela A - CVA, das parcelas relativas ao respectivo consumidor no período em que utilizou a rede de distribuição; e

III - quando cabível, pagamento, ao agente de distribuição, dos encargos relativos à Recomposição Tarifária Extraordinária - RTE, de que trata o art. 4o da Lei no 10.438, de 26 de abril de 2002, conforme regulação da ANEEL.

$\S 20$ Caberá à ANEEL estabelecer os critérios, montantes e prazos para as obrigações previstas neste artigo.

Art. 7o A ANEEL estabelecerá os procedimentos para que o consumidor possa ser atendido pela concessionária de distribuição, mediante participação financeira, no todo ou em parte.

Art. 8o Aplicam-se as disposições deste Decreto no livre acesso de autoprodutor de energia elétrica, para conexão de suas unidades de produção e de consumo aos sistemas de transmissão e distribuição, mesmo que estas se localizem em áreas geográficas distintas, de forma a permitir a utilização e comercialização da energia produzida, nos termos do Decreto no 2.003 , de 10 de novembro de 1996.

Art. 90 o § 80 do art. 71 do Decreto no 5.163 , de 30 de julho de 2004, passa a vigorar com a seguinte redação:

"§ 80 As redes particulares instaladas exclusivamente em imóveis de seus proprietários não serão objeto de ato autorizativo ou de incorporação, salvo, neste último caso, se houver expresso acordo entre as partes." (NR)

Art. 10. Este Decreto entra em vigor na data de sua publicação.

Brasília, 28 de novembro de 2005; 184o da Independência e 117o da República.

LUIZ INÁCIO LULA DA SILVA

Silas Rondeau Cavalcante Silva

Este texto não substitui o publicado no DOU de 29.11.2005 


\section{ANEXO C \\ Pontos questionados pela ABRADEE em sua Ação de Descumprimento de Preceito Fundamental $N^{\circ} 93$}

Em sua ação de ADPF a ABRADEE argumenta que o Decreto $N^{\circ} 5.597 / 2005$ fere os seguintes princípios:

a) o princípio da solidariedade social que inspira o conceito de serviço público e que faz indissoluvelmente ligado à satisfação de necessidades individuais básicas, vinculadas à conservação e/ou promoção da dignidade da pessoa humana (arts. $1^{\circ}, \mathrm{III}, 3^{\circ}$, I e 175 da Constituição de 1988);

b) princípio da isonomia, tanto no sentido da igualdade do art. $5^{\circ}$, caput, quanto no sentido de impessoalidade no art. 37, caput, da Constituição de 1988, por instituir discriminação fundada em critério material constitucionalmente não permitindo, uma vez que favorece os fortes às custas dos hipossuficientes no universo dos usuários do serviço público de energia elétrica;

c) O princípio da proteção do consumidor, inscrito nos arts. $5^{\circ} \mathrm{XXXII}$ e art. 170, V. da Constituição de 1988, não só por instituir discrimen não permitido (alínea "b", supra) como, especialmente, porque tal discrimen tem por efeito prático prejudicar economicamente a grande massa dos consumidores do serviço de energia elétrica;

d) O princípio da legalidade da ação administrativa, tanto em sua vertente "reserva" quanto "supremacia" da Lei (arts. $5^{\circ}$ II e 37, caput, da Constituição de 1988) porque o Decreto não só regula matéria afeita à lei como também viola, positivamente, inúmeros dispositivos de lei; 
e) $O$ princípio da separação dos Poderes do art. $2^{\circ}$, com desdobramentos pelo art. 48, e art. 84, IV, da constituição de 1988, em decorrência da violação citada na alínea anterior;

f) O princípio da moralidade, do art. 37, caput, e o princípio da confiança, enquanto princípio componente do Estado de Direito , do art. $1^{\circ}$, caput, da Constituição de 1988, porque o Decreto repropõe, parcialmente, matéria que já foi objeto de impugnação judicial da ABRADEE - e disso resultou a retirada do ato normativo anterior que tratava da mesma matéria agora regulada no indigitado Decreto (uma Resolução da ANEEL). 


\title{
ANEXO D \\ Despacho do Ministro Ricardo Lewandowski, relator do procedo da ADPF 93
}

\author{
ADPF 93 / DF - DISTRITO FEDERAL \\ ARGÜIÇÃO DE DESCUMPRIMENTO DE PRECEITO FUNDAMENTAL \\ Relator(a): Min. RICARDO LEWANDOWSKI \\ Julgamento: 24/08/2006
}

Publicação

DJ $31 / 08 / 2006$ PP-00026

Partes

ARGTE.(S): ASSOCIAÇÃO BRASILEIRA DE DISTRIBUIDORES DE ENERGIA

ELÉTRICA - ABRADEE

ADV. (A/S): JOÃO GERALDO PIQUET CARNEIRO E OUTRO (A/S)

ARGDO. (A/S): PRESIDENTE DA REPÚBLICA

ADV. (A/S) : ADVOGADO-GERAL DA UNIÃO

\section{Despacho}

Trata-se de argüição de descumprimento de preceito fundamental, com pedido de medida liminar, promovida pela Associação Brasileira de Distribuidores de Energia Elétrica - ABRADEE com o objetivo de ver desconstituído o Decreto no 5.597, de 28 de novembro de 2005, editado pelo Senhor Presidente da República. O ato normativo impugnado "dispõe sobre condições de livre acesso de consumidores atendidos em tensão igual ou superior a 230 kilovolts (i.e. os grandes consumidores industriais), à Rede Básica de energia elétrica" (fl. 03). A ABRADEE, que se qualifica como "pessoa jurídica sem fins lucrativos que representa em âmbito nacional os interesses das empresas concessionárias do serviço público de distribuição de energia elétrica" (fl. 02), após sustentar a sua legitimidade ativa ad causam, alega ofensa a preceitos fundamentais, nos seguintes termos: "(...) Ao perseguir seu objetivo, o Decreto no 5.597/05 viola as seguintes normas constitucionais, cuja natureza de 'preceito fundamental' será oportunamente considerada: a) o princípio da solidariedade social que inspira o conceito de serviço público e que o faz indissoluvelmente ligado à satisfação de necessidades individuais básicas, vinculadas à conservação e/ou promoção da dignidade da pessoa humana (arts. 10, III; 30, I e 175 da Constituição de 1988); b) o princípio da isonomia, tanto no sentido da igualdade do art. 50, caput, quanto no sentido de impessoalidade no art. 37, caput, da Constituição de 1988, por instituir discriminação fundada em critério material constitucionalmente não permitido, uma vez que favorece os fortes às custas dos hipossuficientes no universo dos usuários do serviço público de energia elétrica; c) o princípio da proteção do consumidor, inscrito nos arts. 50, XXXII e art. 170, V, da Constituição de 1988, não só por instituir discrímen não permitido (alínea 'b', supra) como, especialmente, porque tal discrímen tem por efeito prático prejudicar economicamente a grande massa dos consumidores do serviço de energia elétrica; d) o princípio da legalidade da ação administrativa, tanto em sua vertente 'reserva' quanto 'supremacia' da Lei (arts. 50, II e 37, caput, da Constituição de 1988) porque o Decreto não só regula matéria afeita à lei como também viola, positivamente, inúmeros dispositivos de lei; e) o princípio da separação dos Poderes do art $2^{\circ}$, com desdobramentos pelo art. 48, e art. 84, IV, da Constituição de 1988, em decorrência da violação citada na alínea anterior; f) o princípio da moralidade, do art. 37, caput, e o principio da confiança, enquanto princípio componente do Estado de Direito, do art. 10, caput, da Constituição de 1988, porque o Decreto repropõe, parcialmente, matéria que já foi objeto de impugnação judicial da ABRADEE - e disso resultou a retirada do ato normativo anterior que tratava da mesma matéria agora regulada no indigitado Decreto. (...)." (Fls. 04-05) Requisitadas prévias informações (fl. 403), foram estas prestadas às fls. 408-627. Determinei, ainda, a audiência da douta Procuradoria Geral da República que ofereceu parecer no sentido do não-cabimento da presente ADPF, por se tratar de impugnação a ato regulamentar apto a produzir mera ofensa reflexa à Constituição da República (fls. 629-632), o que não viabiliza o controle concentrado de constitucionalidade. Passo a decidir. Tendo em conta que o objeto desta ação é, precisamente, a invalidação jurídico-constitucional de dispositivos do Decreto no 5.597/2005, ato normativo secundário editado pelo Senhor Presidente da República que "regulamenta o acesso de consumidores livres às redes de transmissão de energia elétrica" (fl. 134), tenho que se revela absolutamente preciso o entendimento esposado pela douta Procuradoria Geral da República. Por essa razão de ordem formal não vejo, pois, como franquear o acesso à via do controle normativo abstrato em sede de argüição de descumprimento de preceito fundamental, nos termos de remansosa jurisprudência desta Corte. No entanto, ainda que se pudesse ultrapassar esse óbice de natureza formal, entendo que também não se viabilizaria o conhecimento da presente ação por outras razões. Em primeiro lugar, devo afirmar, desde logo, que, diante da jurisprudência da Corte, não há como reconhecer-se legitimidade ativa ad causam à associação argüente. Com efeito, o Estatuto Social da ABRADEE prevê a possibilidade da participação, em seus quadros, de pessoas físicas ou jurídicas (art. $4^{\circ}$ ), sendo que as primeiras, além de possuírem direitos explicitamente elencados (art. $6^{\circ}$ ), também devem pagar contribuições (art. $8^{\circ}$, b). Configurada está, em conseqüência, a composição híbrida da ABRADEE, tendo em vista a existência, entre os associados, de pessoas físicas e jurídicas, ainda que aquelas na qualidade de associados 
assinantes, eventualmente sem poder decisório. Insista-se, nesse caso, no fato de que os assinantes pagam contribuição e detêm direitos definidos no próprio estatuto social. Forçoso é concluir, portanto, que essa heterogeneidade na participação social macula a legitimidade da argüente para agir em sede de controle abstrato de constitucionalidade. No mesmo sentido: ADI 23/SP, Rel. p/ acórdão o Min. Moreira Alves; ADI 967/SP, Rel. Min. Celso de Mello; ADI 1.631-AgR/União Federal, Rel. Min. Maurício Corrêa; ADI 2.041-MC/RJ, Rel. Min. Sepúlveda Pertence; ADI 2.360/MS, Rel. Min. Moreira Alves. Entendo, ainda, que a Associação Brasileira de Distribuidores de Energia Elétrica constitui apenas uma fração do setor elétrico, composto, também, por outras associações, representantes de outros segmentos, quais sejam os de geração e de transmissão de energia elétrica. É certo, ainda, que o Supremo Tribunal Federal, em situação análoga à destes autos, entendeu que "não é parte legítima para a proposição de ação direta a entidade que congrega mero segmento do ramo das entidades das empresas prestadoras de serviços de telecomunicações ou dedicadas à indústria e ao comércio nessa área" (ADI 2.183-AgR/AM, Rel. Min. Octavio Gallotti). No mesmo sentido, menciono as ADI 353-QO/DF, Rel. Min. Celso de Mello; 976/RJ, Rel. Min. Carlos Velloso; 1.771/DF, Rel. Min. Moreira Alves; 1.409/ES, Rel. Min. Moreira Alves; 1.427/PE, Rel. Min. Néri da Silveira; 1.574-QO/RS, Rel. Min. Octavio Gallotti; 1.580-QO/União Federal, Rel. Min. Maurício Corrêa; 1.806-QO/DF, Rel. Min. Maurício Corrêa. Por outro lado, mesmo que se pudesse, em tese, superar o óbice da ilegitimidade ativa ad causam da argüente, também não caberia reconhecer-se, no caso, a existência de controvérsia constitucional relevante (como pretende a ABRADEE), cuja mera potencialidade, segundo sustenta, seria bastante para permitir a via do controle concentrado. É que a jurisprudência do STF assentou a necessidade de vislumbrar-se claramente a possibilidade de séria ameaça ao princípio da segurança jurídica (ADPF 33-MC/PA, Rel. Min. Gilmar Mendes), o que não verifico ocorrente neste caso. De todo modo, quanto a esse aspecto, entendo, apenas para o fim de mero registro, que a Associação argüente não conseguiu demonstrar inequívoca potencialidade lesiva a decorrer de graves e amplas repercussões jurídicas capazes de afetar, seriamente, a segurança jurídica como um todo. Ao contrário, o raciocínio no tema constrói-se por uma superposição de pressuposições, seja quanto ao eventual prejuízo das operações das empresas distribuidoras de energia elétrica, em seu todo, em razão das prescrições inscritas no decreto presidencial ora impugnado; seja quanto ao incerto repasse de custos, sempre dependente de uma fórmula econômico-financeira complexa em face da realidade de mercado; seja, por essas mesmas razões, pela alegação de que essa cadeia de eventos levaria, supostamente, a uma situação de gravíssima ameaça ao princípio da segurança jurídica. Assim, bem examinadas as alegações da parte argüente quanto à possível existência de potencial controvérsia constitucional relevante ainda que delas, como se vê, não derive nenhum efeito processual, pois há, quanto a esta ação de controle objetivo, óbice intransponível relativo a questões preliminares em torno do cabimento desta ação, não tenho como conclusivo que se configurasse possível antever qualquer situação de extrema ameaça ao princípio da segurança jurídica. Não fossem bastantes as considerações que venho de tecer apenas para simples registro, ressalto, ainda, a conclusiva passagem do parecer de lavra do eminente Procurador-Geral da República, Dr. Antonio Fernando Barros e Silva de Souza, no que se refere à aplicabilidade dos precedentes invocados pela Associação argüente: "(...) Note-se que na ADPF 33, Rel. Min. Gilmar Mendes, e na ADPF 47, Rel. Min. Nelson Jobim, cujos julgados (na última só em sede de liminar) foram invocados pela argüente com o fim de embasar a sua tese de que é cabível ADPF contra ato regulamentar, as normas eram anteriores à atual Constituição Nacional, o que autoriza o cabimento da referida ação, ante o comando do art. 10, parágrafo único, inciso I, da Lei 9.882/1999. (...)." (Fl. 631) Isso posto, tendo em consideração a remansosa jurisprudência desta Suprema Corte, que não reconhece a possibilidade de controle concentrado de atos que consubstanciam mera ofensa reflexa à Constituição, tais como o ato regulamentar consubstanciado no Decreto presidencial ora impugnado, e em razão, ainda, da ilegitimidade ativa ad causam da ABRADEE e da inocorrência de controvérsia constitucional relevante, acolho o parecer do Ministério Público Federal para não conhecer desta argüição de descumprimento de preceito fundamental, ficando prejudicado, em conseqüência, o exame do pedido de medida liminar. Arquivem-se estes autos. Publique-se. Brasília, 24 de agosto de 2006. Ministro RICARDO LEWANDOWSKI - Relator -

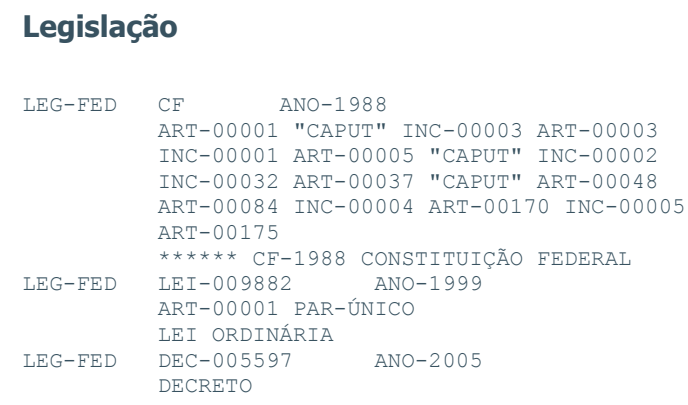

\section{Observação}

Legislação feita por: (WAS) .

\section{fim do documento}




\section{ANEXO E \\ Questionário encaminhado aos associados ABRACE para coletar informações sobre os pólos industriais}

a) Qual o nome e a data de criação do pólo industrial ao qual essa empresa pertence?

b) Há quaisquer atos legais, normativos ou contratuais disciplinando ou tratando do pólo industrial (informar se o funcionamento do pólo ocorre como condomínio)? Quais são e o que dizem?

c) Informar as relações societárias entre os integrantes do pólo, indicando as subsidiárias, coligadas, as empresas totalmente independentes, as eventuais SPE's na produção/gestão de energia e utilidades, etc.

d) O pólo tem área própria ou região delimitada geograficamente?

e) O pólo possui vias públicas (redes de distribuição e transmissão de serviço público, ruas, rodovias, ferrovias, etc.) e/ou rios cruzando a área que o delimita?

f) Há outros consumidores que não pertencem ao pólo e que poderiam ser agregados pela sua condição de proximidade e atendimento energético?

g) Existem consumidores não industriais dentro pólo com atendimento diferenciado do da distribuição?

h) Como se dá o fornecimento (compra) de energia elétrica no interior do pólo? De quem é a responsabilidade (distribuidor, gerador ou outro consumidor)?

i) Informar o arranjo físico simplificado do sistema elétrico que atende ao pólo.

j) Caso a responsabilidade citada não seja da concessionária local de distribuição, quem é o responsável? Há algum tipo de outorga para esse serviço (autorização ou permissão)?

k) Caso o fornecimento não seja feito pela concessionária de distribuição, como é custeada esta distribuição interna?

I) Existe geração de energia elétrica dentro do pólo? Qual o regime (produção independente ou autoprodução)? Há exportação de excedente de energia para o sistema elétrico?

m) Como é contratado o uso dos sistemas de transmissão e/ou de distribuição, individualmente ou de forma coletiva através de um consumidor com rateio interno?

n) Por quem foram custeadas as obras de infra-estrutura energética para suprimento do pólo (subestações e linhas de transmissão/distribuição bem como a rede de distribuição interna)? Distribuidora? Transmissora? Consumidor(es)? Governos?

o) Há pagamento de encargos setoriais na transferência de energia entre as unidades do pólo? Os encargos incidem apenas sobre o aporte líquido de energia do Sistema Elétrico Interligado?

p) Como se dá a medição para faturamento da energia consumida? Apenas na fronteira da rede básica ou da rede de distribuição e/ou em cada unidade consumidora ou geradora? 
q) Todos os consumidores do pólo são livres ou também há consumidores cativos e potencialmente livres? No caso de haver consumidores cativos, como é a atuação da distribuidora na garantia da qualidade, no rateio dos custos e na leitura do consumo?

r) Existe comercialização de energia entre consumidores/geradores dentro do pólo? Em caso afirmativo, essa comercialização é realizada por meio de contratos bilaterais de compra e venda de energia, registrados na Câmara de Comercialização de Energia Elétrica - CCEE?

s) O sistema de medição de faturamento - SMF já está adequado em relação aos padrões da CCEE?

t) Existe comercialização ou troca de insumos energéticos e/ou não energéticos entre empresas do pólo industrial? Como se dá essa troca? A energia elétrica participa da troca?

u) No caso de existir um gerador de energia que atenda parte ou todo o pólo, como se dá a relação contratual com os consumidores? Cada consumidor detém cota deste gerador, ou a energia é comercializada?

v) Houve por parte da distribuidora local ou da ANEEL manifestação sobre a situação do pólo? Caso afirmativo, indicar. 


\section{ANEXO F}

Relação de empresas associadas à ABRACE

(Fonte: Site ABRACE: julho de 2009)

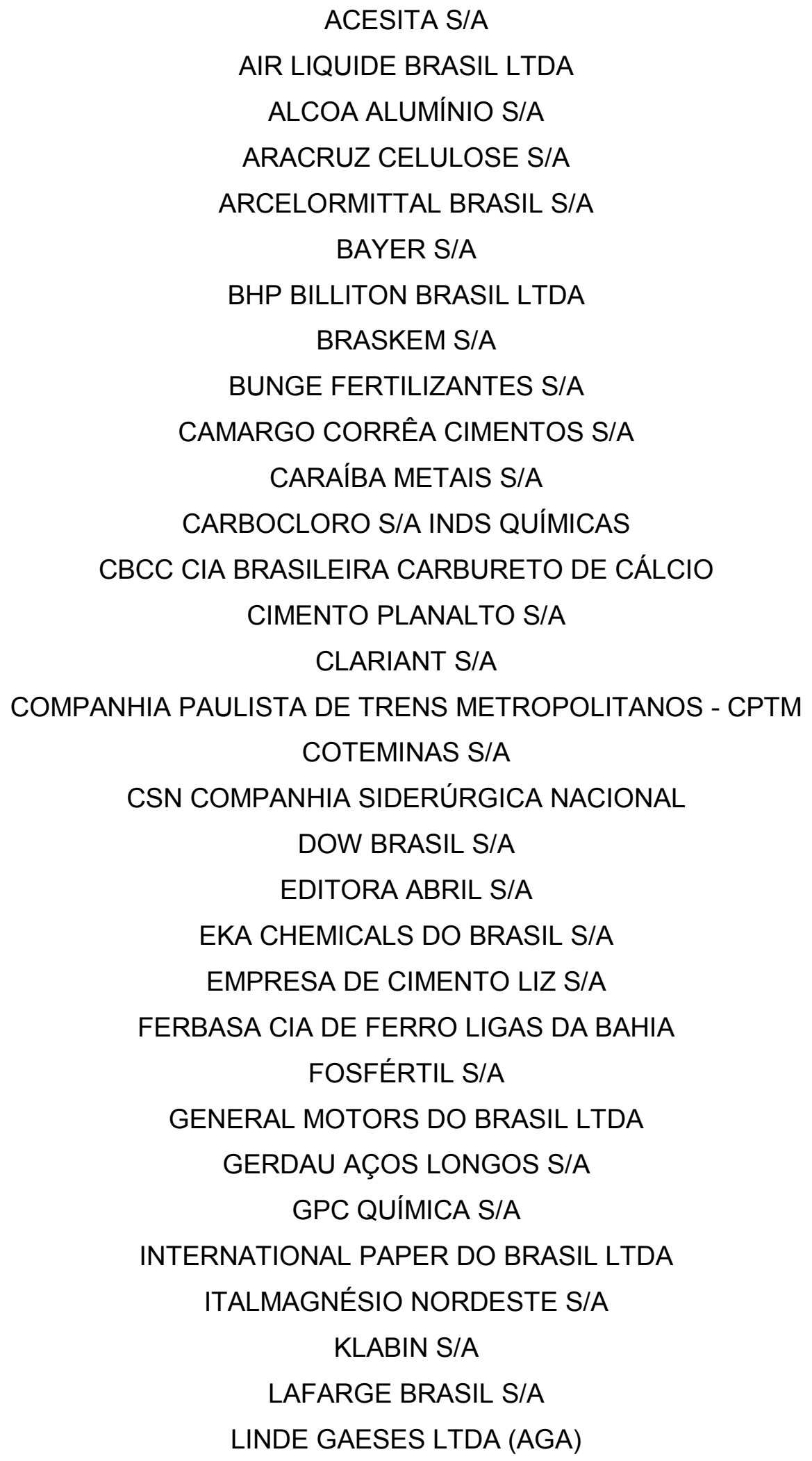


NADIR FIGUEIREDO IND E COM S/A

NESTLÉ BRASIL LTDA

NOVELIS DO BRASIL LTDA

RHODIA BRASIL LTDA

RIGESA, CELULOSE, PAPEL E EMBALAGENS LTDA

RIO TINTO ALCAN BRASIL LTDA.

SAINT-GOBAIN DO BRASIL PRODUTOS INDUSTRIAIS E PARA CONSTRUCAO LTDA

SAMARCO MINERAÇÃO S/A

SANTANA TEXTIL S/A

SOLVAY DO BRASIL

STORA ENSO ARAPOTI INDUSTRIA DE PAPEL S.A.

SUZANO PAPEL E CELULOSE S/A

TBM TÊXTIL BEZERRA DE MENEZES S/A

USIMINAS - USINAS SIDERÚRGICAS DE MINAS GERAIS S/A

VALE

VALLOUREC \& MANNESMANN TUBES

VOTORANTIM CELULOSE E PAPEL S/A

VOTORANTIM CIMENTOS LTDA

WHEATON BRASIL VIDROS LTDA

WHITE MARTINS GASES INDS S/A

YAMANA DESENVOLVIMENTO MINERAL S/A 
EVANDRO GONÇALVES PIZETA

\section{ANÁLISE DA REGULAMENTAÇÃO DO SUPRIMENTO DE ENERGIA ELÉTRICA AOS PÓLOS INDUSTRIAIS COMO FATOR DE COMPETITIVIDADE}


EVANDRO GONÇALVES PIZETA

\section{ANÁLISE DA REGULAMENTAÇÃO DO SUPRIMENTO DE ENERGIA ELÉTRICA AOS PÓLOS INDUSTRIAIS COMO FATOR DE COMPETITIVIDADE}

Dissertação apresentada à Escola

Politécnica da Universidade de São Paulo para obtenção do título de Mestre em

Engenharia Elétrica 
EVANDRO GONÇALVES PIZETA

\section{ANÁLISE DA REGULAMENTAÇÃO DO SUPRIMENTO DE ENERGIA ELÉTRICA AOS PÓLOS INDUSTRIAIS COMO FATOR DE COMPETITIVIDADE}

Dissertação apresentada à Escola

Politécnica da Universidade de São Paulo para obtenção do título de Mestre em Engenharia Elétrica

Área de Concentração:

Sistemas Elétricos de Potência

Orientador:

Prof. Dr. Luiz Natal Rossi 
Este exemplar foi revisado e alterado em relação à versão original, sob responsabilidade única do autor e com a anuência de seu orientador.

São Paulo, 21 de outubro de 2009

Assinatura do autor

Assinatura do orientador

FICHA CATALOGRÁFICA

Pizeta, Evandro Gonçalves

Análise da regulamentação do suprimento de energia elétrica aos pólos industriais como fator de competitividade / E.G.

Pizeta. -- São Paulo, 2009.

p.

Dissertação (Mestrado) - Escola Politécnica da Universidade de São Paulo. Departamento de Engenharia de Energia e Automação Elétricas.

1.Indústrias 2.Pólo industrial 3.Clusters 4.Energia elétrica 5.Planejamento energético 6.Política de desenvolvimento 7.Tarifas I.Universidade de São Paulo. Escola Politécnica. Departamento de Engenharia de Energia e Automação Elétricas II. t. 


\section{DEDICATÓRIA}

Aos meus pais João e Áurea

e a minha esposa Lindsay. 


\section{AGRADECIMENTOS}

Aos meus pais que sempre me incentivaram a estudar e a me desenvolver profissionalmente.

A minha esposa Lindsay por todo incentivo e compreensão pelos sábados e domingos dedicados à dissertação.

Ao meu orientador, Prof. Dr. Luiz Natal Rossi, por todo o seu suporte e contribuições ao longo da elaboração deste trabalho.

Ao Marcos Vinícius Gusmão do Nascimento, pelas contribuições e em especial pela a confiança depositada em mim para atuar como representante da Braskem S.A. e como coordenador do Grupo de Trabalho de pólos industriais instituído na Associação Brasileira dos Grandes Consumidores de Energia Elétrica e Consumidores Livres - ABRACE.

Ao pessoal da ABRACE, em especial ao presidente Ricardo Lima, pela permissão de utilização dos estudos de pólos industriais desenvolvidos nesta associação.

À Ana Carla Petti, pelas contribuições e sugestões no desenvolvimento dos trabalhos, principalmente na fase de conclusão da dissertação.

Ao Taurus, meu cachorro, que sempre me acompanhou e me deu alegria durante as madrugadas de trabalho. 


\section{RESUMO}

Os pólos industriais são uma realidade no Brasil, mas, do ponto de vista da legislação, carecem de um tratamento específico e claro, particularmente com relação ao compartilhamento da infra-estrutura e aquisição de insumos energéticos. A falta de clareza na regulamentação brasileira abre espaço para interpretações divergentes com relação ao suprimento energético, que muitas vezes acaba prejudicando a captura de sinergias e ganhos de escala nos pólos industriais, principalmente para as empresas menores. Este cenário gera incerteza com relação aos preços finais de energia e reduz, de forma artificial, os benefícios inerentes à formação de pólos industriais. A adequação na legislação do setor elétrico brasileiro é fundamental para se criar um ambiente regulatório que defina de forma clara e objetiva soluções para a questão energética nos pólos industriais. Neste trabalho apresentam-se proposições de inovações na legislação do setor elétrico brasileiro que poderiam criar um ambiente regulatório transparente e seguro às empresas, no que se refere ao suprimento elétrico, compartilhamento de infra-estrutura e aquisição de energia elétrica em pólos industriais. As inovações propostas preservam as condições de suprimento elétrico dos pólos existentes e também incentivam a criação de novos pólos.

Palavras-chave: Pólo industrial, cluster, indústria, competitividade, infra-estrutura, energia, suprimento elétrico, transmissão, distribuição, tarifa, encargos, tributos 


\begin{abstract}
Industrial cluster systems are a reality in Brazil but Brazilian electric regulation does not have a specific and clear treatment about industrial cluster electric supply, especially regarding infra-structure common usage and group energy purchase.

This lack of regulation generates a scenario of uncertainty about the energy costs for companies placed in Industrial cluster systems, and reduce, in an artificial way, the advantages that industrial clusters naturally has.

The modification in Brazilian electric regulation is fundamental to define energy policies aspects for industrial clusters, to provide a safe environmental for existents industrial clusters and to generate conditions to create new ones.

In this dissertation, innovations in Brazilian electric regulation are presented aiming to create a safe and clear environmental for industrial clusters.

The proposed innovations preserve the electric supply conditions for the existents industrial clusters and support the creation of new sites, where two or more industries can share electric infra-structure and purchase energy together.
\end{abstract}

Key-words: Industry, cluster, infra-structure, energy, electric supply, transmission, distribution, tariff, levies, taxes 


\section{LISTA DE ILUSTRAÇÕES}

Figura 1 - Formas de acesso ao SIN para geradores e consumidores 22

Figura 2 - Esquemático dos componentes da tarifa final de um consumidor livre conectado ao sistema de distribuição .29

Figura 3 - Componentes da tarifa global de energia de um consumidor cativo. 30

Figura 4 - Componentes da tarifa global de energia de um consumidor livre 31 Figura 5 - Componentes da tarifa global de energia de um consumidor na Rede Básica

Figura 6 - Exemplo da composição da tarifa de um consumidor industrial conectado na Eletropaulo em $138 \mathrm{kV}$

Figura 7 - Comparativo de TUST e TUSD de algumas distribuidoras de energia elétrica (Valores incluem Fio e Encargos Setoriais)

Figura 8 - Análise de sensibilidade da economia anual com migração à Rede Básica em virtude da variação de demanda e tarifa reduzida (Fator de Carga de 92\% Ponta e F. Ponta). 39

Figura 9 - Comparativo de TUSD de algumas distribuidoras de energia elétrica......44

Figura 10 - Comparativo de TUSD de algumas distribuidoras de energia elétrica ....45

Figura 11 - Comparativo de TUSD de algumas concessionárias de distribuição......45

Figura 12 - Comparativo de TUSD de algumas distribuidoras de energia elétrica ....46

Figura 13 - Comparativo de TUSD de algumas distribuidoras de energia elétrica ....46

Figura 14 - Evolução da criação de encargos setoriais 48

Figura 15 - Evolução da arrecadação dos encargos setoriais e do mercado de energia elétrica.

Figura 16 - Aumento acumulado da arrecadação dos encargos setoriais e do mercado de energia elétrica

Figura 17 - Evolução da arrecadação de ICMS total e sobre energia elétrica. 56

Figura 18 - Aumento acumulado da arrecadação de ICMS e do mercado de energia elétrica.

Figura 19 - Evolução das tarifas finais de energia em alguns países (Base: 2007) Valores finais incluindo impostos. Taxa de câmbio de 2007 em 2,11 R \$/US\$. 59

Figura 20 - Comparação da matriz de geração de energia elétrica do Brasil, EUA França 
Figura 21 - Comparação dos custos médios de geração por fonte 60

Figura 22 - Evolução da participação dos encargos e tributos como parte da tarifa de energia

Figura 23 - Comparação da carga tributária tarifa final de energia elétrica de alguns países industrializados (Base 2007).

Figura 24 - Crescimento das tarifas finais de energia elétrica de 2002 a 2007 em alguns países.

Figura 25 - Composição do mercado de energia elétrica do Brasil, Estados Unidos e Alemanha

Figura 26 - Ciclo de desenvolvimento dos pólos industriais ..............................72

Figura 27 - Mapa de pólos industriais nos EUA .............................................. 75

Figura 28 - Mapa de pólos industriais em Portugal ..........................................77

Figura 29 - Mapa de pólos industriais no Japão ..........................................78

Figura 30 - Mapa de pólos industriais na Coréia do Sul .....................................79

Figura 31 - Resumo de algumas políticas de incentivos à pólos industriais nos Estados Unidos, Canadá, Europa e Ásia ...................................................... 81

Figura 32 - Esquemático de reestruturações societárias de um caso específico .....83

Figura 33 - Vista aérea do Pólo Petroquímico de Triunfo - RS ............................8

Figura 34 - Esquemático do Pólo Petroquímico de Camaçari - BA .......................90

Figura 35: Esquemático simplificado do fluxo de energia elétrica no Pólo $E$...........95

Figura 36 - Fatores de atração de empresas................................................101

Figura 37: Exemplo genérico de um pólo industrial onde há compartilhamento de subestação transformadora

Figura 38: Esquemático do entendimento da ANEEL para acesso de consumidor diretamente à Rede Básica (Anterior ao Decreto $\left.N^{\circ} 5597 / 2005\right)$. 121

Figura 39: Esquemático do entendimento da ANEEL para acesso de consumidor à Rede Básica via distribuidora (Anterior ao Decreto N5597/2005). 122

Figura 40: Análise comparativa do DEC 129

Figura 41: Análise comparativa do FEC 129

Figura 42: Esquemático das Poligonais definidas no Acordo Operacional celebrado entre COPENE e COELBA no Pólo Petroquímico de Camaçari

Figura 43: Detalhamento do atendimento elétrico definido no Acordo Operacional celebrado entre COPENE e COELBA no Pólo Petroquímico de Camaçari 131 


\section{LISTA DE TABELAS}

Tabela 1 - Resumo da evolução do setor elétrico brasileiro.....................................21

Tabela 2 - Resumo dos critérios para um consumidor se tornar livre ......................24

Tabela 3 - Resumo dos componentes da tarifa final de energia elétrica ...................28

Tabela 4 - Critérios de classificação dos consumidores em função da tensão de conexão.

Tabela 5 - Modalidades de tarifas de fornecimento para consumidores cativo do Grupo A. 35

Tabela 6 - Comparação entre TUST e TUSD A2 de algumas distribuidoras de energia elétrica

Tabela 7 - Comparação entre TUST e TUSD A3 de algumas distribuidoras de energia elétrica.

Tabela 8 - Comparação entre TUST e TUSD A3a de algumas distribuidoras de energia elétrica.

Tabela 9 - Comparação entre TUST e TUSD A4 de algumas distribuidoras de energia elétrica. .43

Tabela 10 - Encargos setoriais incidentes nas tarifas de energia. 49

Tabela 11 - Tributos incidentes sobre energia elétrica 53

Tabela 12 - Análise da arrecadação de ICMS sobre energia elétrica e do mercado de energia

Tabela 13 - Comparação da evolução das tarifas médias de energia elétrica do setor industrial de alguns países

Tabela 14 - Comparação da evolução das tarifas médias industriais e residenciais de alguns países

Tabela 15 - Comparação dos aumentos das tarifas médias de energia elétrica do setor industrial de alguns países

Tabela 16 - Benefícios que os pólos industriais podem proporcionar a sociedade e às empresas.

Tabela 17 - Características de suprimento elétrico do Pólo Petroquímico de Triunfo

Tabela 18 - Características de suprimento elétrico do Pólo Petroquímico de Camaçari 89

Tabela 19 - Características de suprimento elétrico do Pólo A. 
Tabela 20 - Características de suprimento elétrico do Pólo B ..............................92

Tabela 21 - Características de suprimento elétrico do Pólo C .............................93

Tabela 22 - Características de suprimento elétrico do Pólo D ..............................94

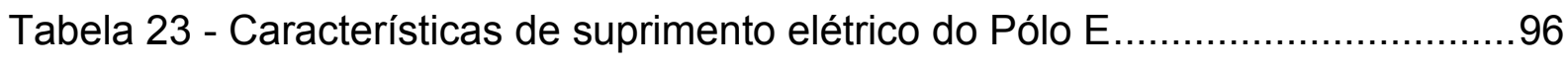

Tabela 24 - Resumo das principais características dos pólos industriais estudados 


\section{LISTA DE ABREVIATURAS E SIGLAS}

ABRACE Associação Brasileira dos Grandes Consumidores de Energia Elétrica e Consumidores Livres

ABRADEE Associação Brasileira de Distribuidores de Energia Elétrica

ACL Ambiente de Contratação Livre

ACR Ambiente de Contratação Regulada

ANEEL Agência Nacional de Energia Elétrica

AGU Advocacia Geral da União

APE Autoprodutor de energia

BACEN Banco Central do Brasil

CCEAR Contrato de Comercialização de Energia no Ambiente Regulado

CCEE Câmara de Comercialização de Energia Elétrica

CCC Conta Consumo de Combustíveis Fósseis

CCD Contrato de Conexão à Distribuição

CCT Contrato de Conexão à Transmissão

CDE Conta de Desenvolvimento Energético

CDI Conselho de Desenvolvimento Industrial

CEEE Companhia Estadual de Energia Elétrica

CHESF Companhia Hidro Elétrica do São Francisco

CMSE Comitê de Monitoramento do Sistema Elétrico

CNPE Conselho Nacional de Política Energética

COELBA Companhia de Eletricidade do Estado da Bahia

COFIC Comitê de Fomento Industrial de Camaçari

COFINS Contribuição para o Financiamento da Seguridade Social

COFURH Compensação Financeira pelo Uso dos Recursos Hídricos

COPEC Complexo Petroquímico de Camaçari

COPENE Petroquímica do Nordeste

CPFL Companhia Paulista de Força e Luz

CSPG Concessionário do Serviço Público de Geração

CTEEP Companhia de Transmissão de Energia Elétrica Paulista

CUSD Contrato de Uso dos Sistemas de Distribuição

CUST Contrato de Uso dos Sistemas de Transmissão

CVA Conta de Variação de Valores da Parcela A

CVM Comissão de Valores Imobiliários 
DIT Demais Instalações de Transmissão

DEC Duração equivalente de interrupção por conjunto de consumidores.

EIA Energy Information Administration

EPE Empresa de Pesquisa Energética

ESS Encargos de Serviços do Sistema

FEC Freqüência equivalente de interrupções por conjunto de consumidores

GCPS Grupo Coordenador do Planejamento dos Sistemas Elétricos

ICMS Imposto sobre a Circulação de Mercadorias e Serviços

IEA International Energy Agency

MDIC Ministério do Desenvolvimento da Indústria e Comércio

MAE Mercado Atacadista de Energia

MME Ministério de Minas e energia

MIN Ministério da Integração

ONS Operador Nacional do sistema Elétrico

O\&M Operação e Manutenção

$\mathrm{PCH} \quad$ Pequena Central Hidrelétrica

P\&D Pesquisa e Desenvolvimento

PIB Produto Interno Bruto

PIE Produtor Independente de Energia

PIS Programas de Integração Social

PRODIST Procedimentos de Distribuição de Energia Elétrica no Sistema Elétrico Nacional

PROINFA Programa de Incentivo a Fontes Alternativas de Energia

RGR Reserva Global de Reversão

SCT Superintendência de Regulação dos Serviços de Transmissão

SRD Superintendência de Regulação dos Serviços de Distribuição

SIN Sistema Interligado Nacional

SPG Serviço Público de Geração

STF Supremo Tribunal Federal

TFSEE Tarifa de Fiscalização dos Serviços de Energia Elétrica

TUSD Tarifa de Uso dos Sistemas de Distribuição

TUST Tarifa de Uso dos Sistemas de Transmissão 
1 - RESUMO DA ESTRUTURA DO SETOR ELÉTRICO BRASILEIRO.................19

1.1 - Histórico da Evolução do Setor Elétrico …………....................................19

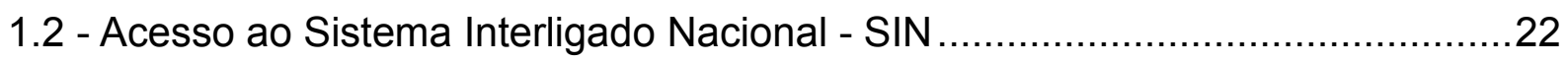

1.3 - Ambientes de Contratação de Energia Elétrica...............................................23

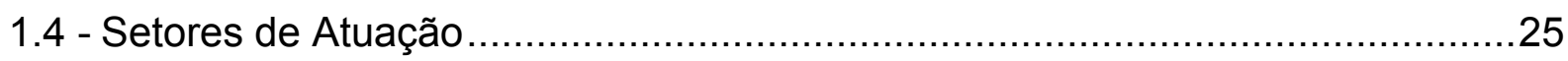

2 - ANÁLISE DAS TARIFAS DE ENERGIA ELÉTRICA …...............................27

2.1 - Visão Geral da Tarifa de Energia de Consumidores Industriais .......................27

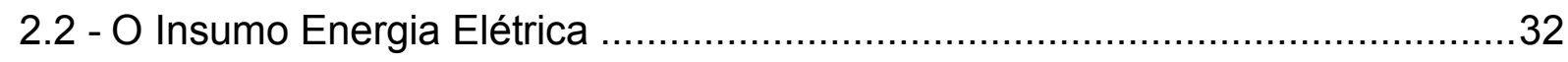

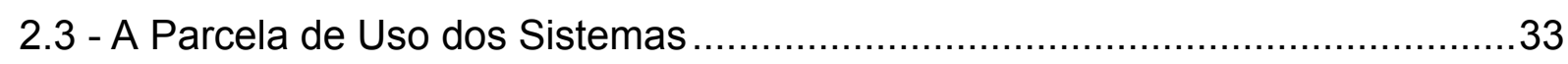

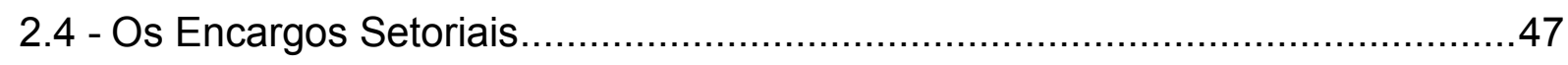

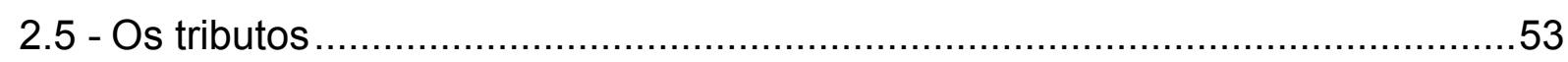

3 - ANÁLISE DAS TARIFAS INDUSTRIAIS DE ENERGIA ELÉTRICA EM

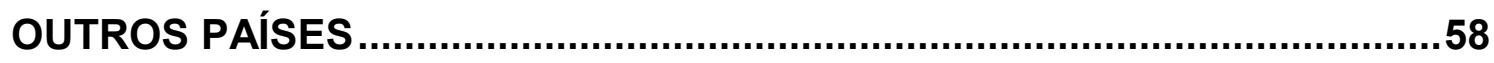

4 - PRINCIPAIS BENEFícIOS INERENTES À FORMAÇÃO DE PÓLOS

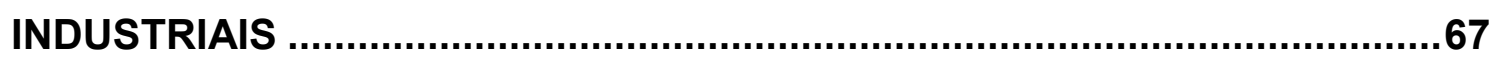

5 - POLÍtICAS INTERNACIONAIS DE SUPRIMENTO ENERGÉTICO A PÓLOS INDUSTRIAIS

6 - SUPRIMENTO DE ENERGIA ELÉTRICA AOS PÓLOS INDUSTRIAIS BRASILEIROS.

7 - PRINCIPAIS OBSTÁCULOS AO DESENVOLVIMENTO DE PÓLOS INDUSTRIAIS ENVOLVENDO A QUESTÃO ENERGÉTICA..........................99 
8 - PRINCIPAIS PONTOS DE DIVERGÊNCIAS ENTRE SETOR INDUSTRIAL E CONCESSIONÁRIAS DE DISTRIBUIÇÃO DE ENERGIA ELÉTRICA ..........109

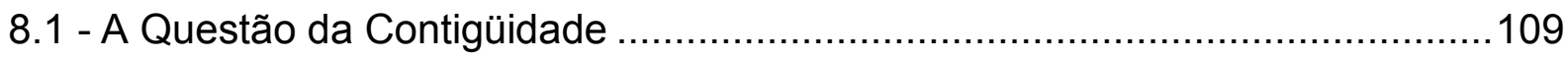

8.2 - A Questão do Monopólio dos Serviços de Distribuição de Energia Elétrica....114

8.3 - Propriedade de Redes Elétricas Particulares ............................................120

8.4 - A Aquisição Conjunta de Energia ..........................................................124

9 - EXEMPLO DE CASO DE CONFLITO ENTRE INDÚSTRIA E CONCESSIONÁRIA DE DISTRIBUIÇÃO....................................................127

10 - PROPOSIÇÃO DE REGULAMENTAÇÃO SOBRE PÓLOS INDUSTRIAIS ABORDANDO A QUESTÃO ENERGÉTICA.

11 - CONCLUSÃO

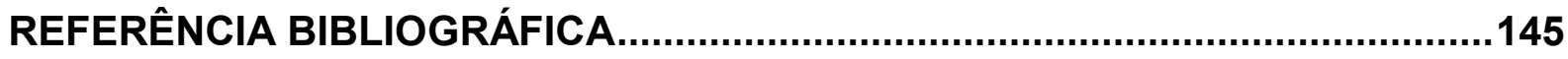

ANEXOS 


\section{INTRODUÇÃO}

O agrupamento de empresas em pólos industriais tem sido utilizado por diversos países, ao longo dos anos, como uma importante estratégia para fomentar o desenvolvimento econômico.

A criação de pólos industriais propicia a concentração de investimento em torno de uma cadeia produtiva que beneficia a sociedade em geral e, conseqüentemente, gera riquezas e crescimento econômico ao país, principalmente para regiões menos favorecidas.

Dentre os benefícios inerentes à criação de pólos industriais, podem-se citar: (i) desenvolvimento de infra-estrutura, como rodovias, portos, aeroportos e saneamento; (ii) geração de empregos diretos e indiretos, (iii) incentivos à realização de investimentos em educação para qualificação da mão de obra local; (iv) aumento da arrecadação de impostos aos municípios e estados, com posterior aplicação destes impostos na geração de benefícios à sociedade.

A fim de garantir os benefícios que um pólo industrial possa gerar, o mesmo deve prover às empresas nele instaladas condições favoráveis de operação, principalmente no que se refere ao compartilhamento de infra-estrutura, em especial de redes elétricas de transporte de energia. Para que estas condições possam ser asseguradas, é fundamental a existência no setor elétrico de uma legislação clara que ofereça a segurança de retorno dos investimentos realizados pelas empresas que se instalam nos pólos industriais.

No Brasil, os pólos industriais são uma realidade, mas carecem de um tratamento específico e claro, particularmente com relação ao compartilhamento da infraestrutura e aquisição de insumos energéticos. A falta de clareza na regulamentação abre espaço para interpretações divergentes com relação ao suprimento elétrico, que muitas vezes acaba prejudicando a captura de sinergias e ganhos de escala em pólos industriais, principalmente para as empresas menores.

Políticas de incentivo aos pólos industriais no Brasil devem ser analisadas criteriosamente, devido à complexidade e particularidade das questões regulatórias envolvendo o compartilhamento de infra-estrutura elétrica e a construção de redes elétricas privativas. 
O Brasil é um país que apresenta uma elevada carga de encargos setoriais e tributos nos preços finais de energia, sendo que a parcela relacionada ao uso dos sistemas, em especial dos sistemas de distribuição, configura-se como um item significativo nos preços finais de energia.

O simples compartilhamento de infra-estrutura elétrica por duas ou mais indústrias na forma de um pólo industrial não necessariamente proporciona a competitividade necessária para que as indústrias se instalem. A classificação da indústria em relação à aquisição de energia elétrica (se consumidor livre ou cativo) e a classe de faturamento (Rede Básica, A1, A2 etc.), em muitos casos, influenciam na competitividade das empresas e na decisão de se instalar ou não no Brasil.

A falta de regulamentação em relação ao suprimento elétrico gera um cenário de incerteza que, na maioria dos casos, traz insegurança e dúvida às indústrias em relação aos preços finais de energia. Isto faz com que os benefícios naturais inerentes à formação de pólos industriais sejam ameaçados pela falta de transparência na legislação do setor elétrico.

A estruturação de uma regulamentação na legislação do setor elétrico que estabeleça de forma clara e objetiva a questão energética nos pólos industriais é fundamental para manter a competitividade dos pólos existentes, bem como para criar condições para o estabelecimento de novos pólos industriais no Brasil. Enquadra-se dentro deste tema a defesa da competitividade da indústria nacional pelo compartilhamento de infra-estruturas.

Diante do cenário exposto, o presente trabalho tem como objetivo analisar a regulamentação do suprimento de energia elétrica aos pólos industriais no Brasil, identificando alguns dos obstáculos relacionados à questão energética que inibem o desenvolvimento dos pólos existentes e a criação de novos pólos. O trabalho foi desenvolvido também com intuito de apresentar inovações na legislação do setor elétrico que contribuam para aumentar a competitividade do setor industrial no Brasil.

A presente dissertação está estruturada da seguinte forma.

O Capítulo 1 apresenta uma breve descrição da estrutura do setor elétrico brasileiro, fundamental para o correto entendimento das discussões acerca das características dos pólos industriais envolvendo o suprimento de energia elétrica, bem como dos riscos regulatórios enfrentados pelos pólos existentes no Brasil. 
No Capítulo 2 é feita uma análise das tarifas de energia elétrica de consumidores industriais, apresentando a descrição de suas parcelas e estratégias de redução das mesmas.

Um estudo da evolução da tarifa final de energia elétrica no Brasil do setor industrial é apresentado no Capítulo 3, onde também é efetuada uma análise comparativa com as tarifas de alguns países industrializados.

O Capítulo 4 apresenta os principais benefícios inerentes aos pólos industriais e no Capítulo 5 são descritos alguns casos internacionais onde políticas de incentivos a pólos industriais foram aplicadas com resultados importantes.

Uma abordagem das características diversas dos pólos industriais em operação no Brasil enfocando questão de suprimento elétrico é apresentada no Capítulo 6. Esta abordagem é fundamental para o entendimento dos principais obstáculos enfrentados pelos pólos industriais existentes no Brasil, os quais são apresentados no Capítulo 7.

No Capítulo 8 são descritos os principais pontos de divergências entre indústrias e concessionárias de distribuição de energia elétrica, os quais afetam os pólos industriais em operação no Brasil.

Um exemplo prático de divergências entre indústria e concessionária de distribuição de energia elétrica é relatado no Capítulo 9, em que é abordado o caso do Pólo Petroquímico de Camaçari, para o qual existe um processo administrativo em andamento na ANEEL envolvendo a Braskem S.A., empresa líder do pólo, e a Companhia de Eletricidade do Estado da Bahia - COELBA, distribuidora local.

Por último, são descritas no Capítulo 10 algumas proposições de inovações regulatórias na legislação do setor elétrico que poderiam auxiliar na competitividade dos pólos industriais existentes e viabilizar a criação de novos pólos. 


\section{1 - RESUMO DA ESTRUTURA DO SETOR ELÉTRICO BRASILEIRO}

Este capítulo apresenta uma breve descrição da evolução do setor elétrico brasileiro, sendo relacionados os principais pontos da estrutura do novo modelo com intuito de facilitar o entendimento das questões regulatórias inerentes aos pólos industriais que serão abordadas posteriormente nos Capítulos 5 e 7.

\section{1 - Histórico da Evolução do Setor Elétrico}

Neste item é apresentada uma breve descrição da evolução do setor elétrico brasileiro, que passou de uma estrutura verticalizada sob o domínio do governo para uma estrutura desverticalizada com inserção de competição em alguns setores, como o de geração e comercialização. O histórico aqui apresentado foi baseado nas informações disponibilizadas no site da Câmara de Comercialização de Energia Elétrica - CCEE ${ }^{1}$.

O modelo atual do Setor Elétrico Brasileiro começou a ser estruturado no ano de 1993, com a publicação da Lei №8.631 de 04.03.1993, que, dentre outras disposições, extinguiu a equalização tarifária vigente até então e criou os contratos de suprimento entre geradores e distribuidores de energia elétrica.

Em seguida veio a Lei $n^{\circ} 8.987$, de 13.02.1995, que, dentre outras providências, dispôs sobre o regime de concessão e permissão da prestação de serviços públicos previstos no Artigo $\mathrm{N}^{\circ} 175$ da Constituição Federal.

No mesmo ano foi publica a Lei № 9.074, de 07.07.1995, a qual estabeleceu normas para outorga e prorrogações das concessões e permissões de serviços públicos, criando a figura do Produtor Independente de Energia - PIE e o conceito de Consumidor livre.

Em 1996, sob a coordenação do Ministério de Minas e Energia - MME, foi implantado o Projeto de Reestruturação do Setor Elétrico Brasileiro (Projeto RESEB). Neste projeto a empresa Coopers \& Lybrand foi contratada para analisar e propor as mudanças no setor elétrico, com participação também de diversos técnicos brasileiros com experiência no assunto.

\footnotetext{
${ }^{1}$ www.ccee.org.br (Acesso em abril de 2009)
} 
O projeto RE-SEB foi concluído em agosto de 1998 e teve como conclusões principais a necessidade de implementar a desverticalização das empresas de energia elétrica do Brasil, dividindo-as nos segmentos de geração, transmissão e distribuição, incentivar a competição nos segmentos de geração e comercialização e manter sob regulação os setores de distribuição e transmissão de energia elétrica, considerados como monopólios naturais. Identificou-se também a necessidade de se criar um órgão regulador, um operador para o sistema elétrico nacional e um ambiente para realização das transações de compra e venda de energia elétrica A partir de então várias alterações na legislação foram instituídas por meio de leis, decretos, resoluções etc. com a finalidade de avançar com as mudanças no modelo do setor elétrico brasileiro. Foram criados a Agência Nacional de Energia Elétrica ANEEL, o Operador Nacional do Sistema Elétrico - ONS e o Mercado Atacadista de Energia - MAE, o qual foi posteriormente substituído pela CCEE.

A consolidação do novo modelo do setor elétrico brasileiro ocorreu no ano de 2004 , com a publicação das Leis № 10.847 e 10.848, ambas de 15.03.2004, e posterior publicação do Decreto No 5163, de 30.07.2004.

A Lei No 10.847/2004 instituiu a Empresa de Pesquisa Energética - EPE, que tem como função realizar pesquisas e estudos voltados ao planejamento do setor energético.

A Lei N $N^{0} 10.848 / 2004$ dispôs sobre a comercialização de energia elétrica e alterou uma série de regulamentações anteriores, visando adequá-las aos critérios do novo modelo do setor elétrico. O Decreto $N^{\circ} 5.163 / 2004$ regulamentou a comercialização de energia elétrica, o processo de outorga de concessões e de autorizações de geração de energia elétrica e deu outras providências.

Após a criação de uma agência reguladora (ANEEL) e um operador do sistema elétrico (ONS), o governo prosseguiu com a criação de uma instituição responsável pela realização de pesquisas e estudos voltados ao planejamento energético (a Empresa de Pesquisa Energética - EPE) e uma instituição com a função de avaliar a segurança do suprimento elétrico (o Comitê de Monitoramento do Sistema Elétrico CMSE).

Foi criada também a CCEE, a qual deu continuidade às atividades do MAE, relacionadas à comercialização de energia elétrica. $A$ tabela seguinte apresenta um resumo da evolução do setor elétrico. 
Tabela 1 - Resumo da evolução do setor elétrico brasileiro

\begin{tabular}{|c|c|c|}
\hline $\begin{array}{l}\text { Modelo Antigo } \\
\text { (até 1995) }\end{array}$ & $\begin{array}{l}\text { Modelo de Livre Mercado } \\
\text { (1995 a 2003) }\end{array}$ & $\begin{array}{l}\text { Novo Modelo } \\
\text { (a partir de 2004) }\end{array}$ \\
\hline $\begin{array}{l}\text { Financiamento através de recursos } \\
\text { públicos }\end{array}$ & $\begin{array}{l}\text { Financiamento através de recursos } \\
\text { públicos e privados }\end{array}$ & $\begin{array}{l}\text { Financiamento através de recursos } \\
\text { públicos e privados }\end{array}$ \\
\hline Empresas verticalizadas & $\begin{array}{l}\text { Empresas divididas por atividade: } \\
\text { geração, transmissão, distribuição e } \\
\text { comercialização }\end{array}$ & $\begin{array}{l}\text { Empresas divididas por atividade: } \\
\text { geração, transmissão, distribuição, } \\
\text { comercialização, importação e } \\
\text { exportação. }\end{array}$ \\
\hline $\begin{array}{c}\text { Empresas predominantemente } \\
\text { Estatais }\end{array}$ & $\begin{array}{l}\text { Abertura e ênfase na privatização } \\
\text { das Empresas }\end{array}$ & $\begin{array}{c}\text { Convivência entre Empresas } \\
\text { Estatais e Privadas }\end{array}$ \\
\hline $\begin{array}{l}\text { Monopólios - Competição } \\
\text { inexistente }\end{array}$ & $\begin{array}{l}\text { Competição na geração e } \\
\text { comercialização }\end{array}$ & $\begin{array}{l}\text { Competição na geração e } \\
\text { comercialização }\end{array}$ \\
\hline Consumidores Cativos & Consumidores Livres e Cativos & Consumidores Livres e Cativos \\
\hline $\begin{array}{c}\text { Tarifas reguladas em todos os } \\
\text { segmentos }\end{array}$ & $\begin{array}{l}\text { Preços livremente negociados na } \\
\text { geração e comercialização }\end{array}$ & $\begin{array}{l}\text { No ambiente livre: Preços } \\
\text { livremente negociados na geração e } \\
\text { comercialização. No ambiente } \\
\text { regulado: leilão e licitação pela } \\
\text { menor tarifa }\end{array}$ \\
\hline Mercado Regulado & Mercado Livre & $\begin{array}{c}\text { Convivência entre Mercados Livre e } \\
\text { Regulado }\end{array}$ \\
\hline $\begin{array}{l}\text { Planejamento Determinativo - } \\
\text { Grupo Coordenador do } \\
\text { Planejamento dos Sistemas } \\
\text { Elétricos (GCPS) }\end{array}$ & $\begin{array}{c}\text { Planejamento Indicativo pelo } \\
\text { Conselho Nacional de Política } \\
\text { Energética (CNPE) }\end{array}$ & $\begin{array}{l}\text { Planejamento pela Empresa de } \\
\text { Pesquisa Energética (EPE) }\end{array}$ \\
\hline Contratação: $100 \%$ do Mercado & $\begin{array}{c}\text { Contratação : } 85 \% \text { do mercado (até } \\
\text { agosto/2003) e 95\% mercado (até } \\
\text { dez./2004) }\end{array}$ & $\begin{array}{c}\text { Contratação: } 100 \% \text { do mercado + } \\
\text { reserva }\end{array}$ \\
\hline $\begin{array}{l}\text { Sobras/déficits do balanço } \\
\text { energético rateados entre } \\
\text { compradores }\end{array}$ & $\begin{array}{l}\text { Sobras/déficits do balanço } \\
\text { energético liquidados no MAE }\end{array}$ & $\begin{array}{l}\text { Sobras/déficits do balanço } \\
\text { energético liquidados na CCEE. } \\
\text { Mecanismo de Compensação de } \\
\text { Sobras e Déficits (MCSD) para as } \\
\text { Distribuidoras. }\end{array}$ \\
\hline
\end{tabular}

Fonte: Site CCEE (www.ccee.org.br) - Acesso em Abril de 2009 


\section{2 - Acesso ao Sistema Interligado Nacional - SIN}

Um dos pilares fundamentais em todas as reformas no setor elétrico mundial foi a introdução do acesso aberto às redes de transmissão e de distribuição, com o objetivo de permitir o desenvolvimento de diversas opções de suprimento para compradores e vendedores de energia em mercado competitivo. Na maior parte dos países, a transmissão e a distribuição estão submetidas a uma forte regulação técnica e econômica, o que significa estabelecer tarifas de acesso para os usuários dos sistemas.

No Brasil, a Lei № 9.648/1998 estabeleceu que a compra e venda de energia elétrica deve ser contratada separadamente do acesso e do uso dos sistemas de transmissão e distribuição. Este conceito se aplica a todos os usuários do sistema, sejam eles consumidores livres, consumidores cativos, produtores independentes, autoprodutores ou concessionárias de distribuição. Isto significa na prática que, no caso de um autoprodutor, a contratação dos serviços de transporte deve ser feita pelo lado da geração e pelo lado da carga que utilizará esta energia.

As diferenças no tipo de contratação de acesso à Rede Elétrica estão diretamente ligadas ao fato do acessante, seja ele carga ou gerador, estar conectado ao sistema de transmissão (a chamada Rede Básica) ou ao sistema de distribuição. A Figura 1 ilustra, de forma simplificada, as formas de acesso ao SIN de consumidores e geradores.

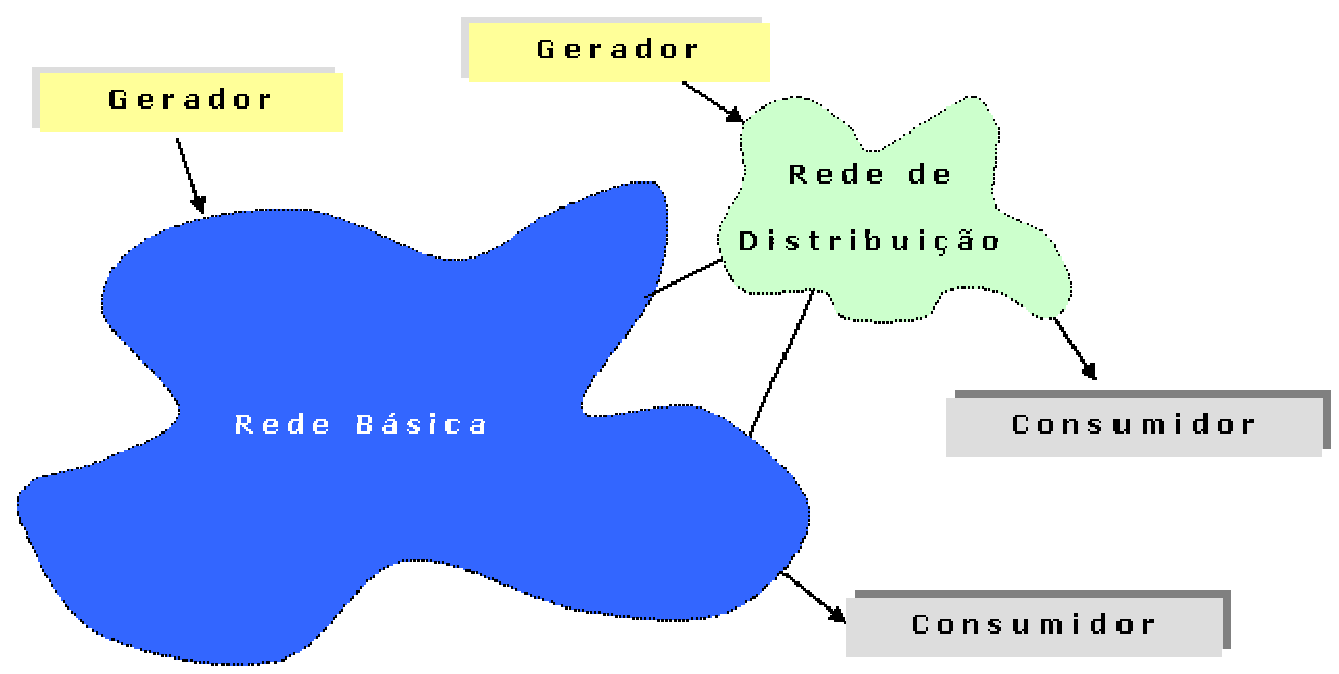

Figura 1 - Formas de acesso ao SIN para geradores e consumidores 
No caso de o acessante estar conectado à Rede Básica, o mesmo deve celebrar o Contrato de Uso do Sistema de Transmissão (CUST) com o ONS, que em nome das empresas de transmissão administra a Rede Básica, e o Contrato de Conexão à Transmissão (CCT) com a sua transmissora local.

De forma análoga, se o acessante estiver conectado ao sistema de distribuição devem ser celebrados os Contratos de Uso do Sistema de Distribuição (CUSD) e de Contrato Conexão à Distribuição (CCD), ambos com o seu distribuidor local.

Tanto na Rede Básica quanto no sistema de distribuição, o acessante deve também celebrar o Acordo Operativo com a transmissora ou distribuidora local.

\section{3 - Ambientes de Contratação de Energia Elétrica}

Dois ambientes de contratação de energia foram instituídos para celebração dos contratos de compra e venda de energia elétrica, são eles: (i) o Ambiente de Contratação Regulada - ACR; (ii) e o Ambiente de Contratação Livre - ACL.

O ACR consiste no segmento do mercado no qual se realizam as operações de compra e venda de energia elétrica entre agentes vendedores e agentes de distribuição, precedidas de licitação, sendo ressalvados os casos previstos em lei, conforme regras e procedimentos de comercialização específicos. A contratação de energia no ACR é formalizada por meio de contratos denominados Contrato de Comercialização de Energia no Ambiente Regulado - CCEAR, celebrados entre cada concessionária ou autorizada de geração e todas as concessionárias, permissionárias e autorizadas do serviço público de distribuição.

O ACL é o segmento do mercado no qual se realizam as operações de compra e venda de energia elétrica objeto de contratos bilaterais livremente negociados, conforme regras e procedimentos de comercialização específicos. No ACL participam os agentes de geração, importadores e exportadores de energia, comercializadores e consumidores livres.

Para que um consumidor possa se tornar livre e escolher seu fornecedor de energia por meio de negociação bilateral, alguns critérios devem ser obedecidos, os quais são estabelecidos pelos Artigos 15 e 16 da Lei Nº 9.074/1995.

Os consumidores que se conectaram ao SIN antes da data de publicação da Lei No 9.074/1995, ou seja, 08.07.1995, podem se tornar livres desde que possuam 
carga igual ou superior à $3 \mathrm{MW}$ e sejam atendidos em tensão igual ou superior à $69 \mathrm{kV}$. Consumidores que se conectaram ao SIN depois de 08.07.1995 podem se tornar consumidores livres desde que possuam carga igual ou superior à $3 \mathrm{MW}$, independente da tensão de suprimento elétrico.

Assim, para consumidores ligados antes 08.07.1995 dois critérios devem ser obedecidos, o de tensão e o de carga, enquanto que para os consumidores novos apenas o critério de carga deve ser obedecido. A tabela seguinte resume os critérios para um consumidor se tornar livre.

Tabela 2 - Resumo dos critérios para um consumidor se tornar livre

\begin{tabular}{ccc}
\hline Data de ligação ao SIN & Tensão & Demanda \\
\hline Antes de 08.07.1995 & $\geq 69 \mathrm{kV}$ & $3 \mathrm{MW}$ \\
\hline Depois de 08.07.1995 & Qualquer tensão & $3 \mathrm{MW}$ \\
\hline
\end{tabular}

Fonte: Artigos 15 e 16 da Lei № 9.074/1995

Posteriormente, o critério para migração de consumidores ao mercado livre foi ampliado pela publicação da Lei No 9.427/1995, que definiu em seu Artigo 26, parágrafo 5 , que um consumidor ou conjunto de consumidores reunidos por comunhão de interesses de fato ou de direito, cuja carga seja maior ou igual a $500 \mathrm{~kW}$, podem se tornar livres desde que adquiram energia proveniente de Pequenas Centrais Hidrelétricas - PCHs ou de fontes alternativas de energia, tais como, biomassa, solar e eólica.

Um consumidor livre conectado ao SIN tem o direito de adquirir energia de quem desejar, porém remunerando a distribuidora ou transmissora local, pelo uso do sistema, o também chamado "Fio". Caso esteja conectado ao sistema de distribuição, o consumidor paga à distribuidora a parcela correspondente ao Fio, por meio da Tarifa de Uso do Sistema de Distribuição - TUSD, e pode comprar energia de qualquer gerador ou comercializador.

O mesmo princípio se aplica a um consumidor conectado diretamente à Rede Básica, porém, neste caso, o consumidor paga apenas a parcela relacionada à 
Tarifa de Uso do Sistema de Transmissão - TUST. Na Rede Básica não há pagamento de TUSD, pois o consumidor não utiliza as redes de distribuição.

\section{4 - Setores de Atuação}

No novo modelo do setor elétrico ocorreu a desverticalização das empresas do setor elétrico, tendo sido desagregadas as atividades de geração, transmissão e distribuição de energia elétrica.

O setor de geração manteve a característica de competição, sendo permitido ao agente de geração vender energia tanto no ACR quanto no ACL. A venda no ACR ocorre por meio de leilões de energia promovidos pela EPE e realizados pela CCEE, por delegação da ANEEL, seguindo as diretrizes determinadas pelo Ministério de Minas e Energia - MME. Nestes leilões são celebrados contratos de compra e venda de energia diretamente entre os geradores e os distribuidores de energia elétrica, sendo vencedores os geradores que ofertarem as menores tarifas.

A venda de energia no ACL ocorre por meio de contratos bilaterais, negociados livremente entre o gerador e o comprador, que pode ser um consumidor ou um comercializador.

Os agentes de geração podem ser classificados em:

- Concessionários do Serviço Público de Geração - CSPG: agente titular de serviço público federal delegado pelo Poder Concedente mediante licitação, na modalidade de concorrência, à pessoa jurídica ou consórcio de empresas para exploração e prestação de serviços públicos de energia elétrica, nos termos da Lei No 8.987 de 13.02.1995;

- Produtor Independente de Energia Elétrica: pessoa jurídica ou empresas reunidas em consórcio que recebam concessão ou autorização para produzir energia elétrica destinada ao comércio de toda ou de parte da energia produzida, por sua conta e risco;

- Autoprodutor de Energia Elétrica: pessoa física ou jurídica ou empresas reunidas em consórcio que recebam concessão ou autorização para produzir energia elétrica destinada ao seu uso exclusivo. 
Ao setor de transmissão coube a administração das instalações de integrantes da Rede Básica e das Demais Instalações de Transmissão, as chamadas DITs. A Rede Básica pode ser definida como sendo uma rede de transmissão sob controle do ONS, com regras operativas definidas nos Procedimentos de Rede, cuja expansão é planejada setorialmente pela EPE e implementada pela ANEEL, mediante licitação de concessão ou autorização. Atualmente os critérios para composição da Rede Básica do SIN são definidos pela Resolução ANEEL № 67, de 08.06.2004. De acordo com o Artigo $3^{\circ}$ desta resolução, integram à Rede Básica:

- Linhas de transmissão, barramentos, transformadores de potência e equipamentos de subestação em tensão igual ou superior a $230 \mathrm{kV}$;

- Transformadores de potência com tensão primária igual ou superior a $230 \mathrm{kV}$ e tensões secundária e terciária inferiores a $230 \mathrm{kV}$, bem como as respectivas conexões e demais equipamentos ligados ao terciário

As instalações da Rede Básica do SIN têm receita autorizada pela ANEEL. Essa receita, juntamente com uma parcela do orçamento do ONS, tributos e eventuais diferenças financeiras de exercício anterior, devem ser cobertos pelos encargos de uso do sistema de transmissão cobrados de todos os usuários. As receitas são revistas anualmente, autorizadas pela ANEEL e representam um impacto direto nas tarifas de uso da transmissão (TUSTs).

As TUSTs nada mais são do que tarifas calculadas por um processo de alocação de custo entre todos os usuários do sistema, necessárias para cobrir toda a receita permitida definida pela ANEEL em resoluções específicas, publicadas usualmente ao final do primeiro semestre de cada ano. A metodologia em vigor, a Resolução ANEEL N ${ }^{\circ} 671 / 2008$, estabelece os valores das TUST e fixa a tarifa de transporte da energia elétrica proveniente de Itaipu Binacional.

Assim como o setor de transmissão, o setor de distribuição também manteve o caráter regulado. À cada distribuidora foi atribuída uma área de concessão, onde a mesma tem o direito de prestar o serviço de distribuição de energia elétrica aos agentes de geração, bem como aos consumidores livre e cativos. 


\section{2 - ANÁLISE DAS TARIFAS DE ENERGIA ELÉTRICA}

O capítulo anterior apresentou de forma simplificada a evolução do setor elétrico brasileiro, que passou de uma estrutura verticalizada sob domínio estatal para uma estrutura desverticalizada com inserção de competição em alguns setores. Foram apresentados os tipos de acesso ao SIN, via sistema de distribuição ou diretamente à Rede Básica, e as formas de remuneração dos sistemas.

A mudança organizacional também promoveu alterações na estrutura tarifária dos consumidores de energia elétrica. Este capítulo apresenta uma análise da tarifa de energia elétrica de consumidores, em especial do setor industrial, sendo descritas as parcelas que compõem tarifa final de energia, bem como indicadas as estratégias possíveis de redução das mesmas.

São apresentadas propostas que poderiam levar a reduções nas tarifas finais de energia, caso as inovações regulatórias aqui apresentadas para a questão energética de pólos industriais fossem postas em prática.

\section{1 - Visão Geral da Tarifa de Energia de Consumidores Industriais}

De forma simplificada, as tarifas de energia são compostas por quatro componentes, a saber: (i) transporte; (ii) energia; (iii) encargos setoriais; e (iv) tributos. A Tabela 3 a seguir apresenta de forma resumida a descrição de cada um dos componentes que integram a tarifa final de energia elétrica de um consumidor. 
Tabela 3 - Resumo dos componentes da tarifa final de energia elétrica

Componente
Descrição

Corresponde ao insumo energia elétrica, podendo ser adquirido no mercado

Energia livre (por meio de contratos bilaterais com geradores ou comercializadores) ou cativo (via distribuidora de energia), bem como ser provido por meio de auto-produção de energia.

Fio

Parcela referente ao uso das redes de transmissão e distribuição para que a energia vendida por um gerador ou adquirida por um consumidor possa circular no sistema. De forma simplificada, a Tarifa Fio pode ser considerado como um aluguel, que é pago pelo usuário para que as redes elétricas estejam disponíveis para seu uso, pagamento este que é proporcional à demanda contratada. Trata-se da contratação da demanda nos horário de ponta e fora ponta.

Encargos Setoriais

Os encargos setoriais são subsídios arrecadados para aplicações específicas relacionadas ao mercado de energia, como por exemplo, incentivar a geração de fontes alternativas, promover a universalização do serviço de energia elétrica, dentre outras.

Tributos

Impostos federais e estaduais aplicados ao transporte e à aquisição de energia elétrica. Os principais tributos sobre energia elétrica são: Imposto sobre a Circulação de Mercadorias e Serviços - ICMS, Programas de Integração Social - PIS e Contribuição para o Financiamento da Seguridade Social - COFINS.

A Figura 2 ilustra a cadeia de incidência dos diversos componentes da tarifa final de energia elétrica à qual um consumidor livre conectado ao sistema de distribuição estaria sujeito. Verifica-se que o consumidor final é responsável pelo pagamento de toda a cadeia de encargos setoriais e tributos incidentes na geração, transmissão e distribuição. 


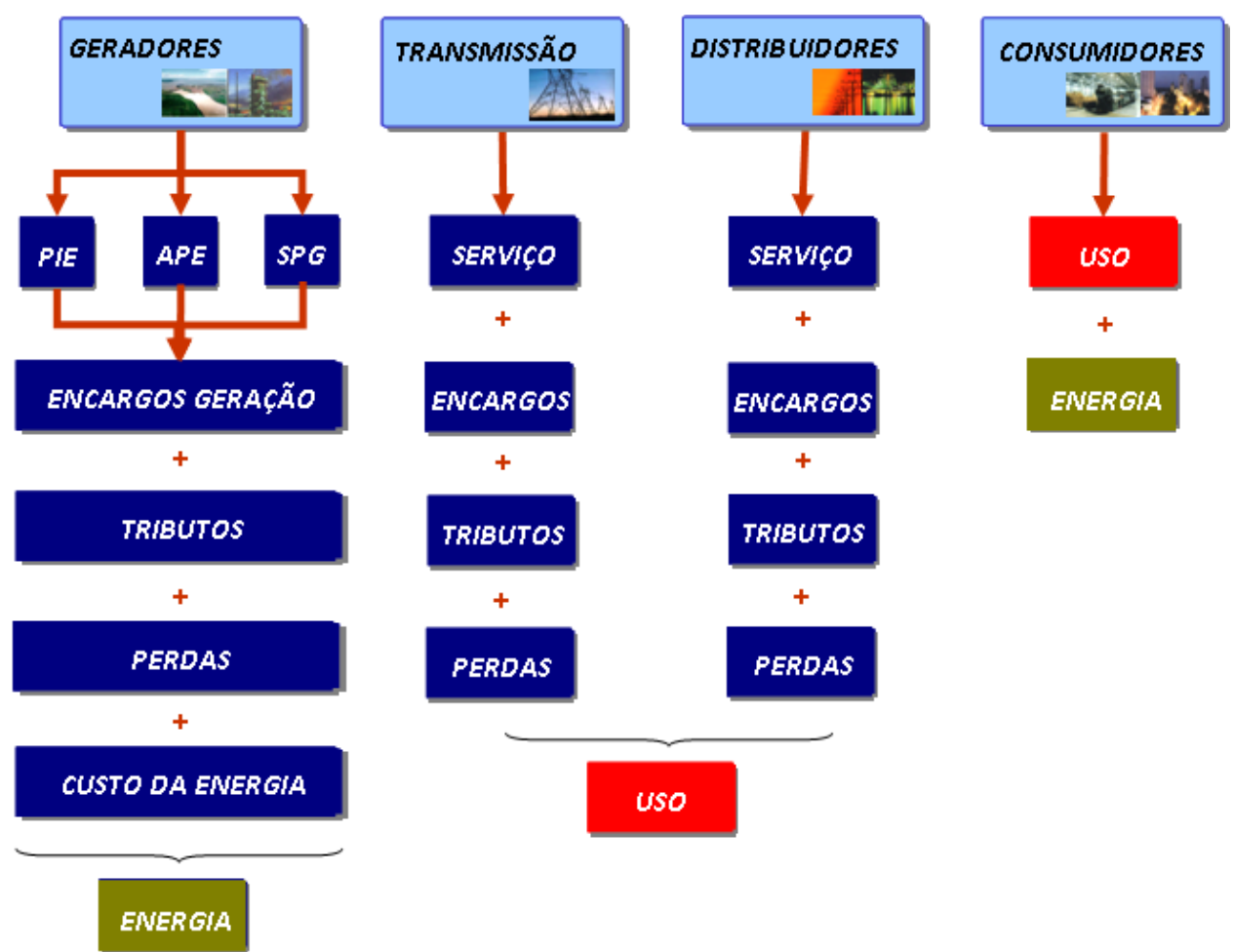

Figura 2 - Esquemático dos componentes da tarifa final de um consumidor livre conectado ao sistema de distribuição

Os itens que compõem a tarifa de uso e energia de consumidores cativos e livres conectados no sistema de distribuição, estabelecidos pelas resoluções da ANEEL, são resumidos na Figura 3 e Figura 4 apresentadas a seguir. Verifica-se que os itens que compõem a Tarifa "Fio" de um consumidor cativo são os mesmos da tarifa de um consumidor livre, havendo diferenciação apenas na parcela relacionada a energia.

De forma análoga, na Figura 5 são apresentados os itens que compõem a tarifa de uso e energia de um consumidor livre atendido via Rede Básica do SIN. Nota-se que um consumidor na Rede Básica não está sujeito ao pagamento de perdas comerciais. O encargo P\&D é cobrado apenas na TUST, não sendo recolhido na parcela correspondente aos encargos, que no caso da Rede Básica, englobam Conta de Consumo de Combustíveis Fósseis - CCC, Conta de Desenvolvimento Energético - CDE e Programa de Incentivo a Fontes Alternativas de Energia PROINFA. 
Nas figuras citadas, a sigla CVA corresponde à conta de Variação de Valores da Parcela $A^{2}$, a qual foi criada em 2001, para registrar as variações ocorridas entre os reajustes tarifários anuais das distribuidoras de energia elétrica, dos valores dos orçados e realizados dos itens da Parcela A das tarifas.

\section{TARIFA DE FORNECIMENTO - CONSUMIIDOR CATIVO}
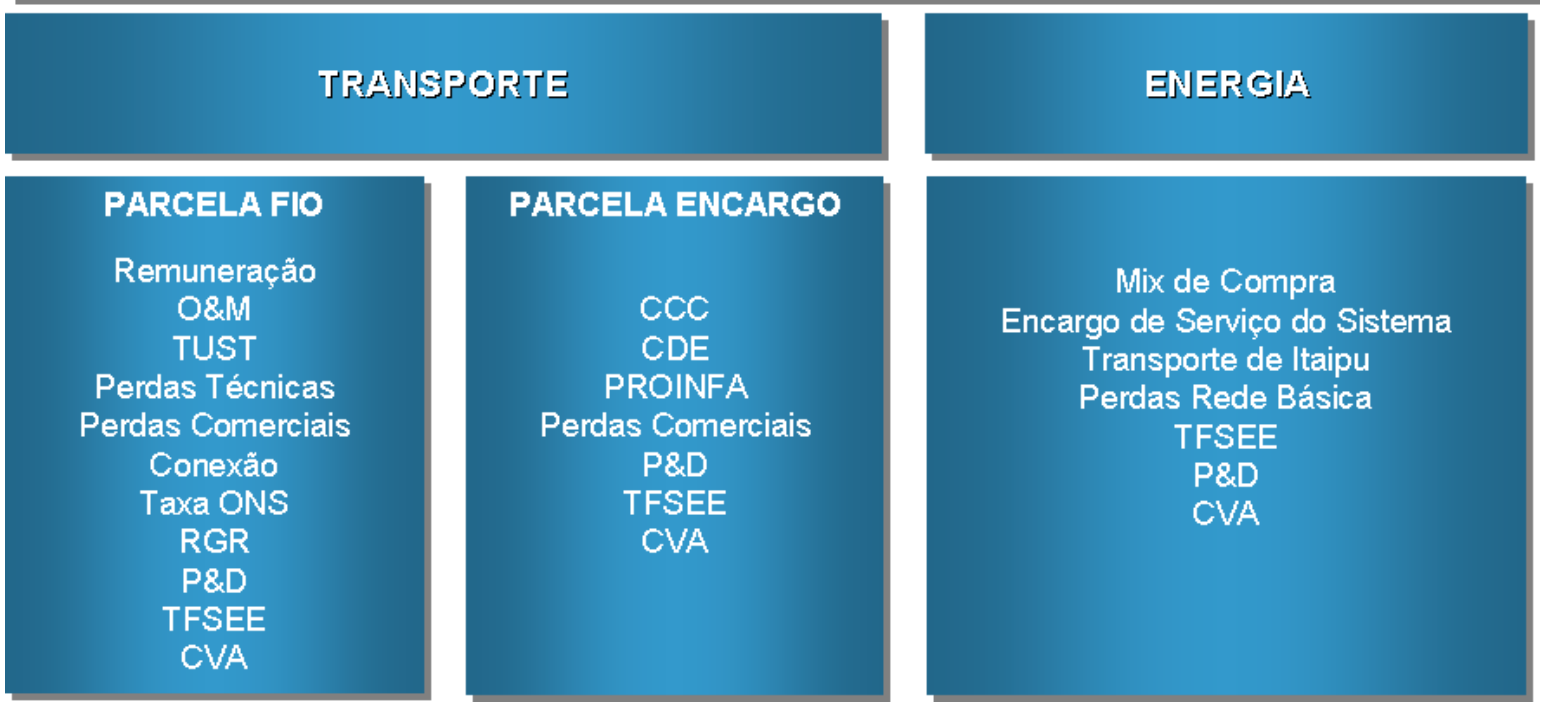

Figura 3 - Componentes da tarifa global de energia de um consumidor cativo (Tarifa final ex-impostos)

\footnotetext{
2 Parcela A da TUSD corresponde ao custo não gerenciável das distribuidoras, compostos pelos encargos setoriais (RGR, P\&D, TFSEE, Taxa ONS, CCC, CDE, PROINFA), perdas elétricas, TUST $T_{R B}, T$ TUST $_{F R}$, uso da rede de outras concessionárias, custo de conexão à transmissão.
} 
TARNFA FINAL - CONSUMIDOR LJVRE
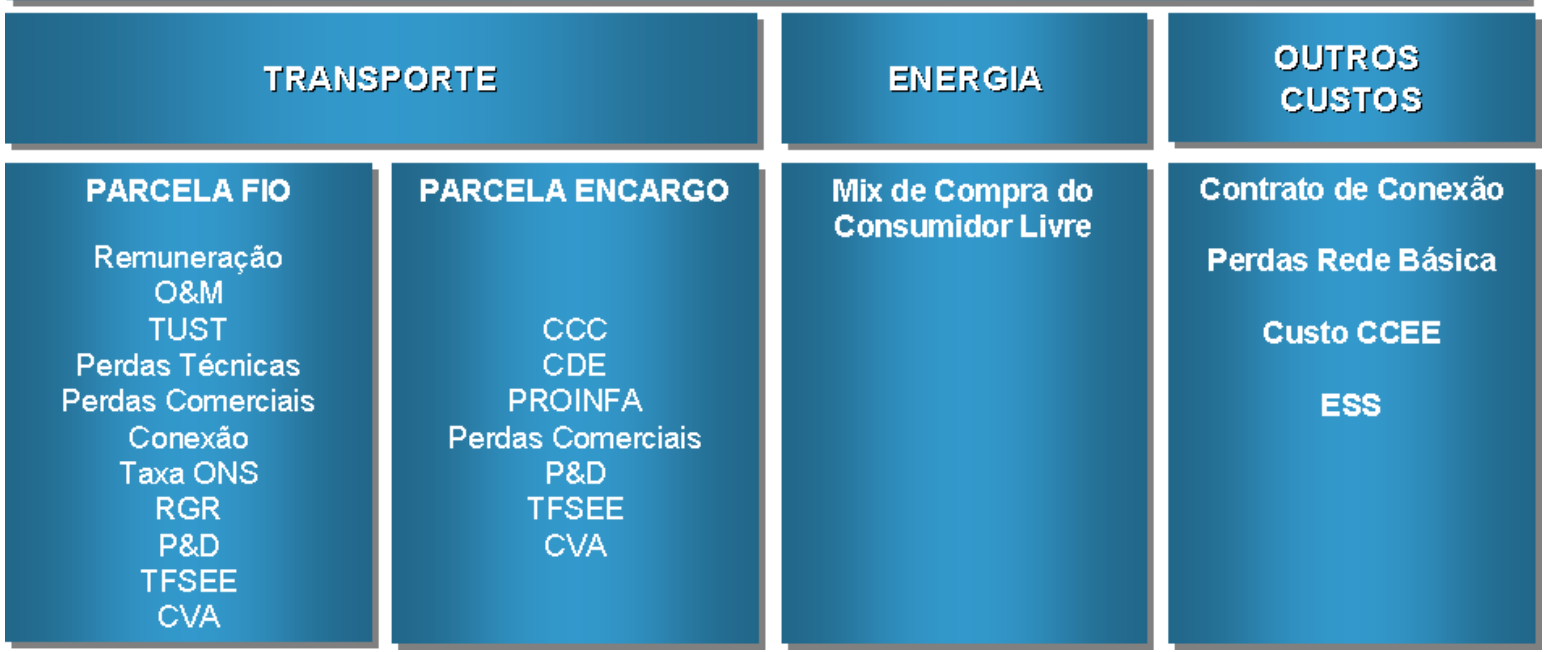

Figura 4 - Componentes da tarifa global de energia de um consumidor livre (Ex-impostos)

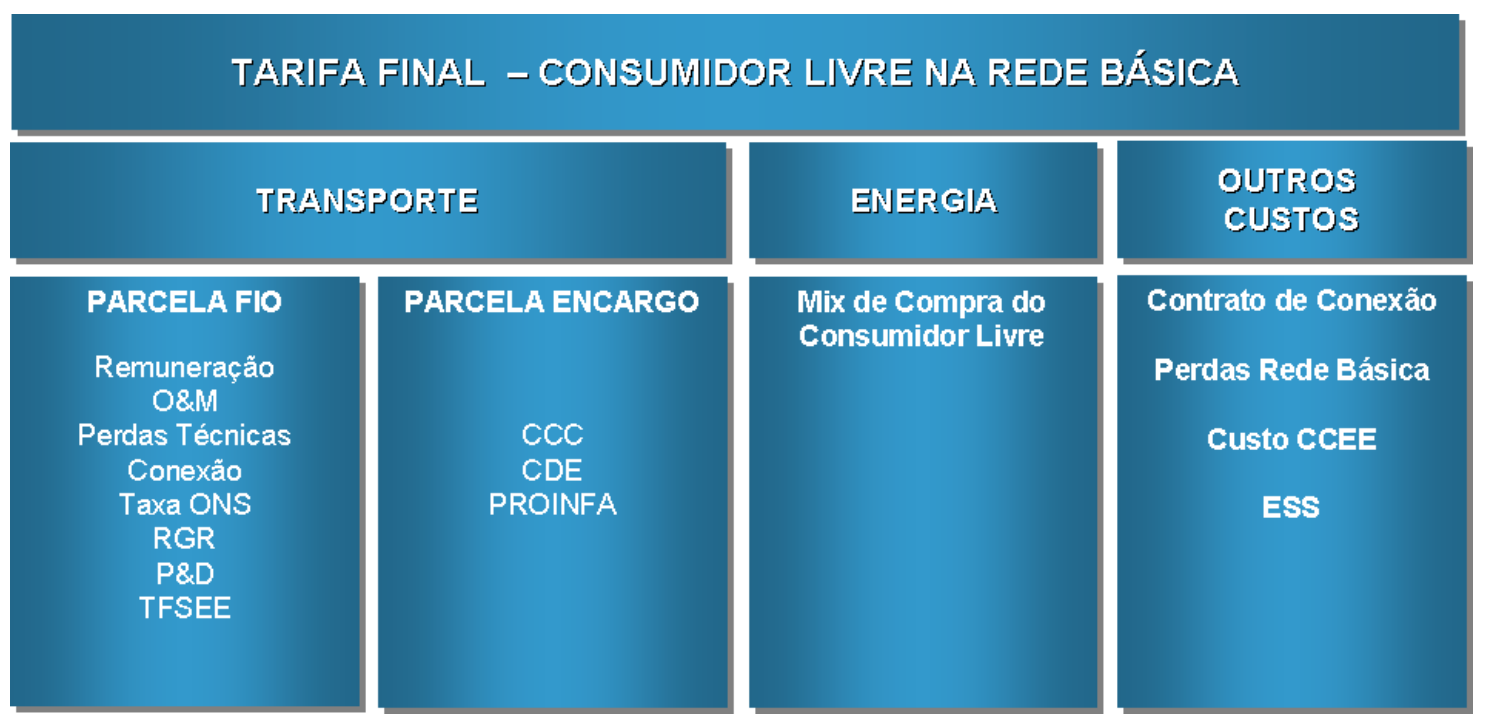

Figura 5 - Componentes da tarifa global de energia de um consumidor na Rede Básica (Ex-impostos)

A Figura 6 apresenta, a título de exemplo, a composição da tarifa final de um consumidor industrial com demanda de 90 MW (Ponta = Fora Ponta) ${ }^{3}$ e Fator de Carga de $95 \%$ (Ponta = Fora Ponta) conectado na distribuidora Eletropaulo em $138 \mathrm{kV}(\mathrm{A} 2)$. Verifica-se que apenas $52 \%$ da tarifa correspondem ao insumo energia e que encargos e tributos somados representam $35 \%$ do total da tarifa. As parcelas

\footnotetext{
3 Horário de Ponta corresponde ao intervalo de 3 horas consecutivas, ajustado de comum acordo entre a concessionária e o cliente, no período compreendido entre as $19 \mathrm{~h}$ e $22 \mathrm{~h}$.
} 
relacionadas de fato aos serviços de transmissão e distribuição representam apenas $13 \%$ do total da tarifa.

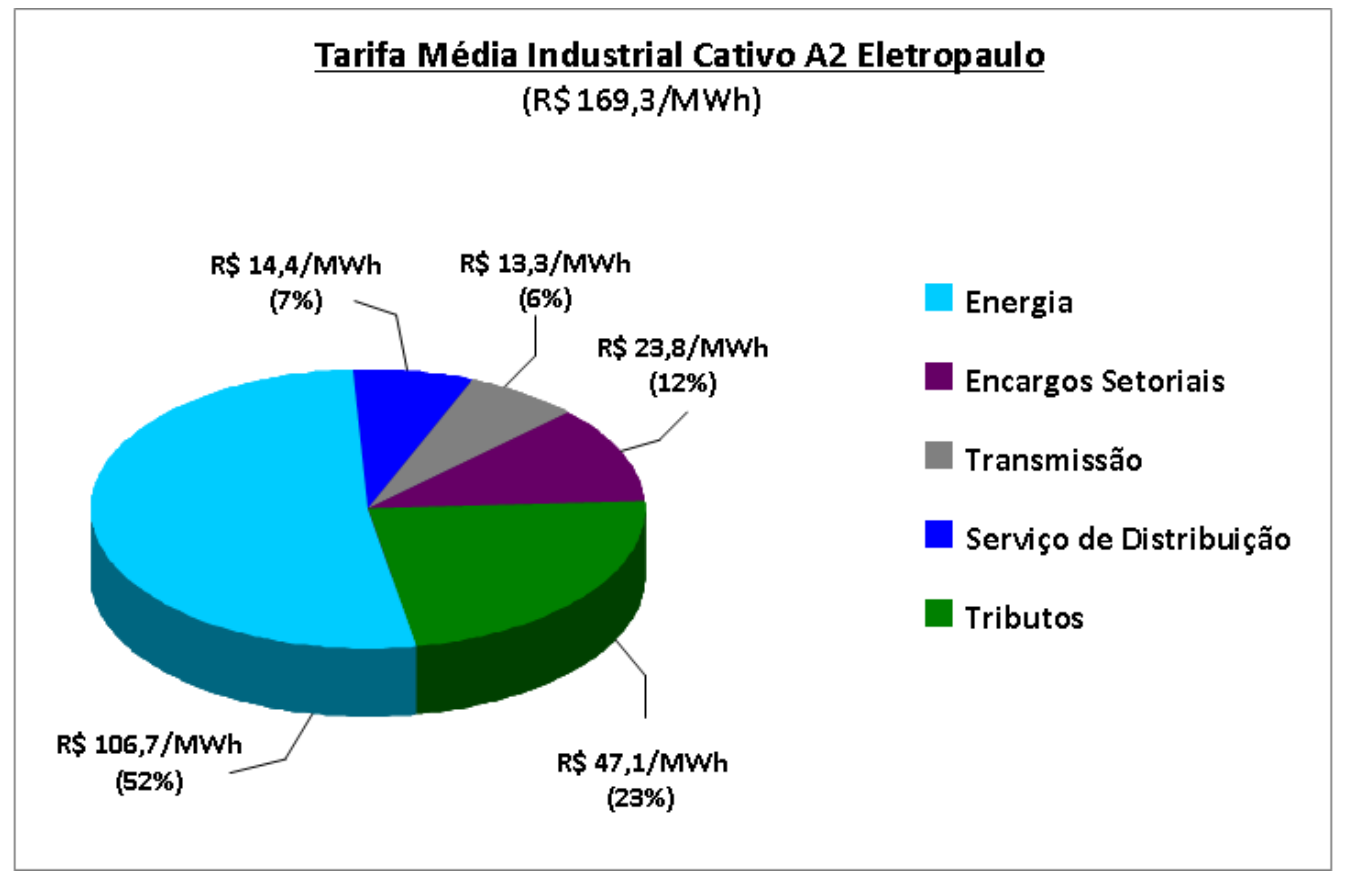

Figura 6 - Exemplo da composição da tarifa de um consumidor industrial conectado na Eletropaulo em $138 \mathrm{kV}$

Fonte: Resolução ANEEL N 675/2008 (Cálculo com base numa demanda de 90 MW e fator de carga de $95 \%$, tanto no horário de ponta quanto fora de ponta)

\section{2 - O Insumo Energia Elétrica}

Com a abertura do mercado de energia elétrica e criação do ACL, os consumidores de energia passaram a ter oportunidade de buscar no mercado condições mais competitivas de contratação de energia elétrica.

A redução dos custos com aquisição do insumo energia elétrica pode ser feita de duas formas: (i) por meio da auto-produção de energia elétrica, com construção de usinas próprias e/ou participação em consórcios; (ii) aquisição de energia no mercado livre via contratos bilaterais negociados com agente gerador ou comercializador.

$\mathrm{Na}$ auto-produção o consumidor passa a ter uma energia que possui um custo composto pelo Operação e Manutenção - O\&M da usina, remuneração dos investimentos, parcela Fio do gerador para entrega da energia gerada até o Centro de Gravidade do Sistema Elétrico, encargos setoriais e tributos. Atualmente, o autoprodutor de energia elétrica é isento do pagamento dos encargos setoriais CCC, CDE e PROINFA sobre a parcela de energia gerada para consumo próprio. Há 
isenção também do pagamento da parcela referente à segurança energética do ESS.

O Centro de Gravidade corresponde ao ponto virtual do sistema elétrico onde as perdas elétricas da carga e da geração são iguais e é justamente neste ponto que são consideradas todas as compras e vendas de energia na CCEE. Trata-se de um ponto virtual onde $50 \%$ das perdas são alocadas à geração e $50 \%$ aos consumidores.

A migração ao mercado livre, como já abordado, é possível somente para consumidores com demanda superior a $3 \mathrm{MW}$ ou para consumidores com demanda entre $500 \mathrm{~kW}$ e $3 \mathrm{MW}$, desde que compre energia de fontes incentivadas.

Esta limitação, em muitos casos, acaba restringindo os consumidores com demandas menores de energia elétrica de buscar condições mais competitivas de aquisição de energia. Na faixa de consumo de 500 kW a $3 \mathrm{MW}$ é permitida a migração ao mercado livre com compra de energia de fontes incentivadas, entretanto, estas fontes, em geral, apresentam custos de geração superiores às fontes convencionais. Assim, os requisitos para migração ao mercado livre ainda impedem muitas indústrias de adquirem energia a preços mais competitivos. A instituição de uma regulamentação que possibilite indústrias integrantes de pólos industriais a adquirem energia de forma centralizada, constituindo uma única unidade consumidora, proporcionaria condições importantes de competitividade. $\mathrm{Na}$ proposição citada, os critérios para viabilizar a migração ao mercado livre passariam a seguir a carga conjunta das indústrias e não as cargas individuais. Mesmo nos casos em que indústrias individualmente podem se tornar consumidores livres, a aquisição de energia em conjunto proporcionaria ganho de escala significativo, gerando condições mais atraentes de negociação de preços juntos aos vendedores.

\section{3 - A Parcela de Uso dos Sistemas}

No Brasil, a remuneração pelo uso dos sistemas de transmissão e distribuição, o chamado Fio, segue a metodologia de que quanto maior a utilização das redes do sistema elétrico, maior é a tarifa de transporte a ser paga pelo consumidor. Assim, quanto menor o nível de tensão que um consumidor é atendido, maior será a parcela referente ao transporte da energia. 
A remuneração pelo uso dos sistemas de transmissão é feita com base no rateio igualitário de custos entre consumidores e geradores, ou seja, metade da remuneração do sistema de transmissão é paga pelos consumidores, enquanto que a outra metade é paga pelos geradores.

Nos sistemas de distribuição a tarifa é calculada pelo custo marginal, que consiste numa metodologia que objetiva simular um mercado de concorrência perfeita, onde há naturalmente um incentivo a eficiência produtiva e a alocação de custos entres os segmentos e usuários das redes.

Nos sistemas de distribuição, a TUSD a ser paga por um agente consumidor depende apenas da área de concessão em que o mesmo se encontre e do subgrupo tarifário a que pertença. A Resolução ANEEL $N^{\circ} 456 / 2000$, que estabelece as condições gerais de fornecimento de energia elétrica, definiu seis subgrupos tarifários para consumidores de alta tensão conectados às redes de distribuição, os quais são relacionados na Tabela 4 a seguir.

Tabela 4 - Critérios de classificação dos consumidores em função da tensão de conexão ${ }^{4}$
Tensão de
Atendimento
Classificação

Subgrupo A1 Tensão de fornecimento igual ou superior a $230 \mathrm{kV}$.

Subgrupo A2 Tensão de fornecimento de $88 \mathrm{kV}$ a $138 \mathrm{kV}$.

Subgrupo A3 Tensão de fornecimento de $69 \mathrm{kV}$.

Subgrupo A3a Tensão de fornecimento de $30 \mathrm{kV}$ a $44 \mathrm{kV}$.

Subgrupo A4 Tensão de fornecimento de $2,3 \mathrm{kV}$ a $25 \mathrm{kV}$.

Subgrupo AS Tensão de fornecimento inferior a 2,3 kV, atendidas a partir de sistema subterrâneo de distribuição e faturadas neste Grupo em caráter opcional.

Fonte: Resolução ANEEL N 456/2000

Consumidores atendidos em baixa tensão fazem parte do Grupo B, que engloba as unidades consumidoras com fornecimento em tensão inferior a 2,3 kV, ou, ainda, atendidas em tensão superior a $2,3 \mathrm{kV}$ e faturadas neste Grupo nos termos definidos nos Arts. 79 a 81 da Resolução No 456/2000. Consumidores de Grupo B possuem estruturação tarifária monômia e são divididos nos seguintes subgrupos: (a) Subgrupo B1 - residencial; (b) Subgrupo B1 - residencial baixa renda; (c) Subgrupo B2 - rural; (d) Subgrupo B2 cooperativa de eletrificação rural; (e) Subgrupo B2 - serviço público de irrigação; (f) Subgrupo B3 - demais classes; (g) Subgrupo B4 - iluminação pública. 
As tarifas do Grupo A para consumidores cativos possuem três modalidades de fornecimento, as quais são descritas na Tabela 5 a seguir.

Tabela 5 - Modalidades de tarifas de fornecimento para consumidores cativo do Grupo A

\begin{tabular}{|c|c|}
\hline $\begin{array}{c}\text { Tensão de } \\
\text { Atendimento }\end{array}$ & Classificação \\
\hline Convencional & $\begin{array}{l}\text { Caracterizada pela aplicação de tarifas de consumo de energia e/ou } \\
\text { demanda de potência independentemente das horas de utilização do dia } \\
\text { e dos períodos do ano. }\end{array}$ \\
\hline Horo-Sazonal Azul & $\begin{array}{l}\text { Modalidade de fornecimento estruturada para a aplicação de tarifas } \\
\text { diferenciadas de consumo de energia elétrica, de acordo com as horas de } \\
\text { utilização do dia e dos períodos do ano, bem como de tarifas } \\
\text { diferenciadas de demanda de potência de acordo com as horas de } \\
\text { utilização do dia. }\end{array}$ \\
\hline Horo-sazonal Verde & $\begin{array}{l}\text { Modalidade de fornecimento estruturada para a aplicação de tarifas } \\
\text { diferenciadas de consumo de energia elétrica, de acordo com as horas de } \\
\text { utilização do dia e dos períodos do ano, bem como de uma única tarifa de } \\
\text { demanda de potência. }\end{array}$ \\
\hline
\end{tabular}

Fonte: Resolução ANEEL № 456/2000

A tarifa horo-sazonal se aplica obrigatoriamente às unidades consumidoras atendidas pelo sistema elétrico interligado com tensão de fornecimento inferior a $69 \mathrm{kV}$ e demanda contratada igual ou superior a $300 \mathrm{~kW}$, com opção do consumidor pela modalidade azul ou verde. As unidades consumidoras atendidas pelo sistema elétrico interligado com tensão de fornecimento inferior a $69 \mathrm{kV}$ e demanda contratada inferior a $300 \mathrm{~kW}$ podem optar pela tarifa horo-sazonal, seja na modalidade azul ou verde.

Os consumidores livres possuem apenas diferenciação de contratação de demanda no horário de ponta e fora de ponta, sendo a energia negociada diretamente com o vendedor.

Numa determinada classe de tensão os valores da TUSD são iguais para todos consumidores, independentemente da localização do mesmo em relação ao sistema elétrico. Portanto, um consumidor que esteja muito próximo ao sistema de Rede Básica, mas que seja atendido em $138 \mathrm{kV}$, por exemplo, pagará a mesma TUSD A2 que um consumidor que esteja no final de um sistema radial de $138 \mathrm{kV}$. Apesar de 
usar menos o sistema elétrico de distribuição, o consumidor próximo à Rede Básica deve pagar TUSD igual a um consumidor que está usando o sistema de forma mais intensa.

Nos sistemas de distribuição o pagamento do componente Fio e Encargos é feito à distribuidora na qual o acessante esteja conectado e a parcela correspondente à TUST já está integrada na TUSD da distribuidora.

Caso o consumidor esteja conectado à Rede Básica, não há necessidade de pagamento do uso dos sistemas de distribuição, uma vez que não os utilizam. Os encargos de uso dependem apenas da sua localização elétrica no ponto de conexão. As TUSTs são calculadas pela metodologia nodal, que define tarifas em $\mathrm{R} \$ / \mathrm{kW}$ para cada barra de Rede Básica do SIN, proporcionalmente à utilização do sistema. Atualmente, o faturamento de consumidores conectados às instalações de Rede Básicas, no que se refere à demanda contratada, é efetuado somente no horário de ponta, ou seja, o período em que se registram os maiores níveis nacionais de consumo, sendo nula a tarifa de demanda no horário fora de ponta.

Encargos como CCC, CDE e PROINFA são cobrados na parcela de uso do sistema, entretanto, são recolhidos por meio da aplicação de uma tarifa em $\mathrm{R} \$ / \mathrm{MWh}$ sobre o consumo mensal do consumidor. Para um consumidor que esteja conectado à Rede Básica, as parcelas correspondentes aos encargos setoriais (CCC, CDE, PROINFA) e aos encargos de uso do sistema são recolhidas pela transmissora no qual o acessante esteja conectado. O pagamento da TUST é feito diretamente às concessionárias de transmissão do SIN, assim, um consumidor na Rede Básica recebe uma fatura de cada transmissora do SIN.

Com base nos pontos apresentados, pode-se concluir que a elevação na tensão de atendimento elétrico consiste numa forma de redução da parcela Fio da tarifa de energia.

A aquisição de energia proveniente de fontes incentivadas também consiste numa forma de redução da tarifa fio, pois, conforme estabelecido na Resolução ANEEL $N^{\circ} 77 / 2004$, há redução de $50 \%$ na parcela Fio para os casos de compra de energia de PCHs, eólicas, solar ou biomassa, e de 100\% na compra de energia proveniente de geração via gases de aterros sanitários.

A aquisição de energia de fontes incentivadas, apesar de proporcionar redução na parcela Fio, torna-se atrativa nos casos em que a TUSD é mais elevada uma vez que os preços de energia de fontes incentivadas, em geral, são maiores que os de 
fontes convencionais. A aquisição de energia de fontes incentivadas é mais atraente para consumidores em 13,8 kV do que consumidores em $138 \mathrm{kV}$, dado que a TUSD é maior.

A elevação da tensão de suprimento elétrico requer investimentos em instalações como linhas de transmissão e subestações, os quais aumentam de forma proporcional à tensão de conexão. Verifica-se então, que a conexão em tensões mais elevadas torna-se viável apenas para consumidores com significativo consumo de energia elétrica, casos onde a diferença na Tarifa Fio atinge cifras elevadas o suficiente para remunerar os investimentos nas instalações de conexão.

Consumidores com menores demandas elétricas acabam optando por serem atendidos em tensões mais baixas e, conseqüentemente, pagam maiores tarifas pelo transporte da energia.

Os consumidores conectados aos sistemas de distribuição acabam tendo que pagar na tarifa a parcela de uso dos sistemas de transmissão (a chamada TUST) e a parcela referente ao uso dos sistemas de distribuição. A tarifa Fio global para um consumidor conectado ao sistema de distribuição é denominada TUSD, que contém já em seu montante a parcela correspondente à TUST. A diferença ente a TUSD e TUST na maioria dos pontos do sistema elétrico atinge valores muito elevados, que prejudicam a competitividade das indústrias, principalmente as eletro-intensivas. A título de exemplo, em indústrias produtoras de cloro-soda e alumínio, onde o uso de energia é intenso em virtude de presença de eletrólise, os custos com energia elétrica podem chegar a $60 \%$ dos custos totais de produção. Nestes casos, qualquer redução na tarifa de energia representa ganhos de competitividade.

A Figura 7 ilustra o quanto pode ser importante a diferença de tarifas, ao uma comparar os valores de TUSDs praticados por algumas distribuidoras brasileiras de energia elétrica, para quatro classes de tensão distintas, com os valores da TUST de algumas barras de Rede Básica na área de concessão das respectivas distribuidoras. Pode-se observar nesta figura como evoluem as tarifas de uso do sistemas em função da diminuição da tensão de conexão, sendo evidente que a TUSD é sempre muito mais elevada que a TUST. Pode-se observar ainda que na área de concessão da Companhia de Eletricidade do Estado da Bahia - COELBA, por exemplo, o crescimento da TUSD em função da redução da tensão de conexão é bastante expressivo, havendo, por exemplo, uma diferença de cerca de R\$ 57/MWh entre a tensão de 138 kV (A2) e 13,8 kV (A4). Já na Companhia Paulista 
de Força e Luz - CPFL Paulista a variação da TUSD não é tão expressiva entre as classes de tensão desta distribuidora.

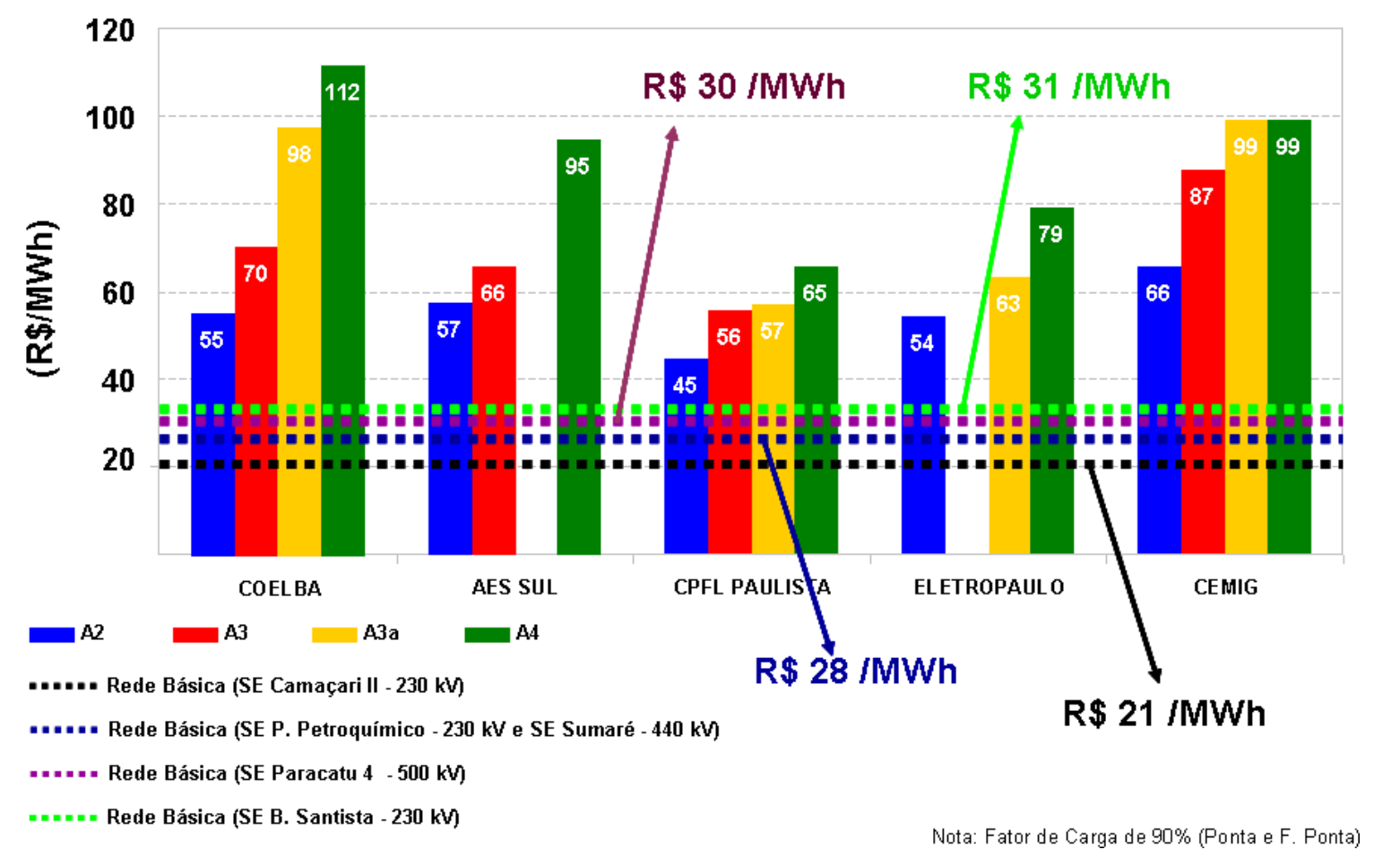

Figura 7 - Comparativo de TUST e TUSD de algumas distribuidoras de energia elétrica (Valores incluem Fio e Encargos Setoriais) ${ }^{5}$

Fonte: Resoluções ANEEL Nº 638/2008, 635/2008, 627/2008, 675/2008, 626/2008, 671/2008, $567 / 2007$

A possibilidade de se atender o consumidor de energia elétrica em alta tensão, conectando-o diretamente à Rede Básica constitui, sem dúvida alguma, um importante fator de competitividade industrial.

A título de exemplo, uma redução de $\mathrm{R} \$ 30 / \mathrm{MWh}$ na Tarifa Fio de um consumidor de $50 \mathrm{MW}$ de demanda constante, ou flat, no horário de ponta e fora de ponta, com fator de carga de $92 \%$, proporciona economia média anual de $\mathrm{R} \$ 15$ milhões. Esta economia seria suficiente para pagar em dois ou três anos os investimentos de ordem de $\mathrm{R} \$ 30$ a 40 milhões para construção de linhas de transmissão e subestações em tensão de $230 \mathrm{kV}$.

A Figura 8 apresenta uma análise de sensibilidade da economia anual que seria proporcionada com a migração à Rede Básica, considerando variação na demanda para quatro valores de diferença entre TUST e TUSD. Por exemplo, no caso em que

\footnotetext{
${ }^{5}$ A distribuidora AES Sul não possui tarifa na classe de tensão A3a e Eletropaulo não possui tarifa na classe de tensão A3.
} 
a diferença entre TUST e TUSD for de $30 \mathrm{R} \$ / \mathrm{MWh}$, um consumidor de $80 \mathrm{MW}$ de demanda flat com fator de carga de $92 \%$ teria uma economia anual estimada em $\mathrm{R} \$$ 20 milhões.

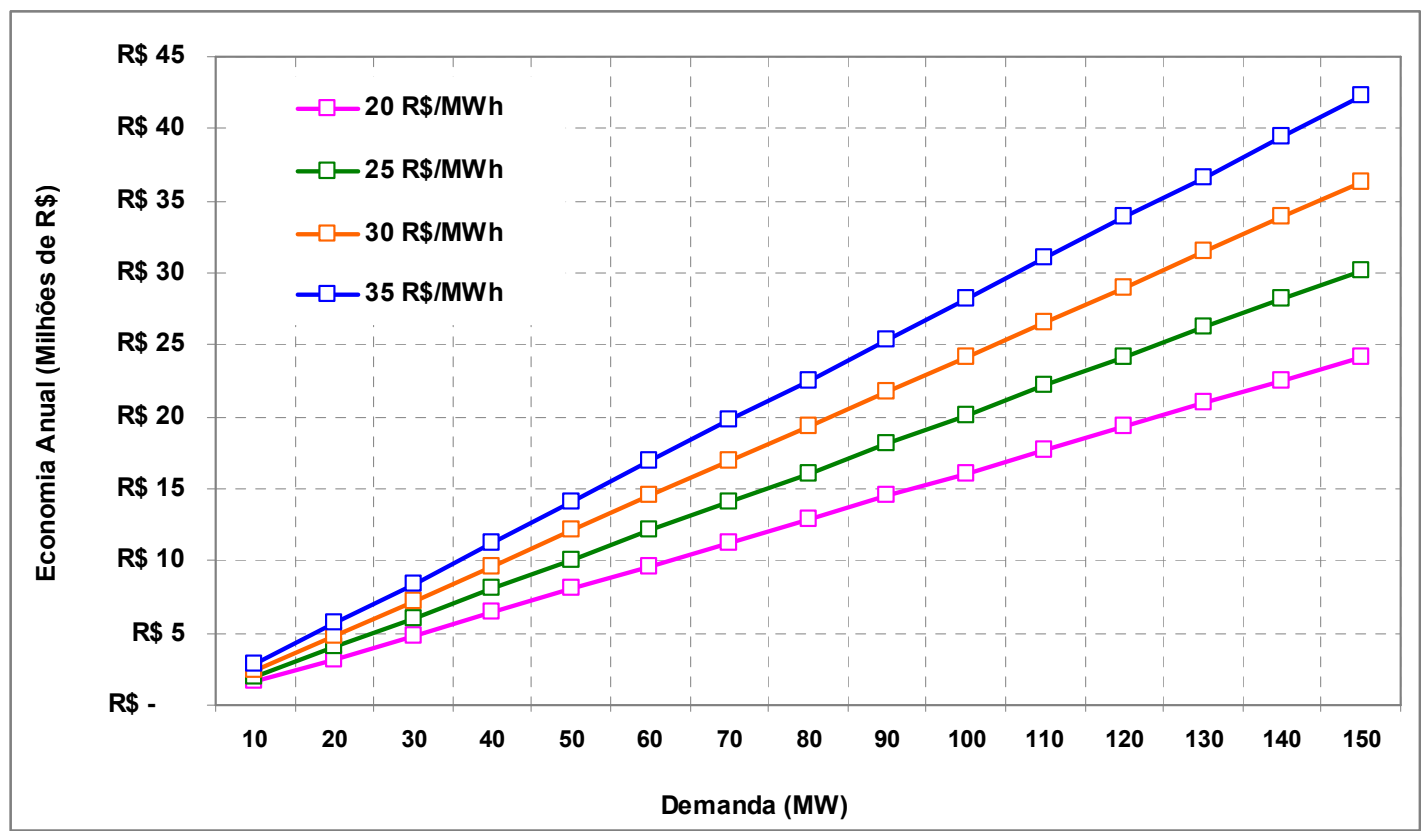

Figura 8 - Análise de sensibilidade da economia anual com migração à Rede Básica em virtude da variação de demanda e tarifa reduzida (Fator de Carga de 92\% Ponta e F. Ponta)

É importante destacar que a conexão de indústrias em tensões mais elevadas não possibilita apenas ganhos econômicos com a redução da Tarifa Fio, mas também ganhos técnicos substanciais, uma vez que em tensões mais elevadas o suprimento elétrico é mais confiável e menos susceptível a interrupções e oscilações sistêmicas, principalmente em tensão igual ou superior à $230 \mathrm{kV}$.

As tabelas 6, 7, 8 e 9 apresentadas a seguir fazem uma análise comparativa dos valores de TUSTs de algumas barras de Rede Básica do Sistema Elétrico Interligado - SIN com as respectivas TUSDs que o consumidor pagaria estando conectado ao sistema da concessionária de distribuição. Na comparação foram selecionadas as distribuidoras COELBA e AES Sul, as quais possuem em sua área de concessão importantes pólos industriais, como o Pólo Petroquímico de Camaçari, na Bahia, e o Pólo Petroquímico de Triunfo, no Rio Grande do Sul, e também as distribuidoras CPFL Paulista, Eletropaulo e Cemig, que atuam em regiões com grande potencial para formação de novos pólos industriais e que possuem em sua área de concessão importantes grupos industriais com elevados consumos de eletricidade. Os cálculos das TUSTs e TUSDs em R\$/MWh foram efetuados considerando-se uma demanda 
de referência de $65 \mathrm{MW}$, no horário de ponta e fora de ponta, com fator de carga de $90 \%$.

Tabela 6 - Comparação entre TUST e TUSD A2 de algumas distribuidoras de energia elétrica

\begin{tabular}{|c|c|c|c|c|c|c|}
\hline \multicolumn{7}{|c|}{ | PERFIL DE CARGA } \\
\hline Demanda (Ponta = Fora Ponta) & MW & 65 & 65 & 65 & 65 & 65 \\
\hline Fator de Carga (Ponta = Fora Ponta) & $\%$ & $90 \%$ & $90 \%$ & $90 \%$ & $90 \%$ & $90 \%$ \\
\hline \multicolumn{7}{|c|}{ ANÁLISE DAS TARIFAS DE USO DOS SISTEMAS DE DISTRIBUIÇÃO (TUSD A2) } \\
\hline Concessionária de distribuição & - & COELBA & AES SUL & CPFL PAULISTA & ELETROPAULO & CEMIG \\
\hline Resolução homologatória ANEEL & - & Res $N^{\circ} 638 / 2008$ & Res $N^{\circ} 635 / 2008$ & Res $N^{\circ} 627 / 2008$ & Res $N^{\circ} 675 / 2008$ & $\operatorname{Res} \mathrm{N}^{\circ} 635 / 2008$ \\
\hline \multicolumn{7}{|c|}{ Tarifas nos sistemas de distribuição na classe A3 (138 kV): } \\
\hline Demanda Ponta: & $\mathrm{R} \$ / \mathrm{kW}$ & 23,64 & 21,44 & 13,89 & 19,03 & 25,62 \\
\hline Demanda Fora Ponta: & $\mathrm{R} \$ / \mathrm{kW}$ & 3,83 & 2,83 & 1,77 & 2,79 & 4,36 \\
\hline Encargos: & $\mathrm{R} \$ / \mathrm{MWh}$ & 13,32 & 20,29 & 20,72 & 21,04 & 20,01 \\
\hline \multicolumn{7}{|l|}{ Estimativa de Gastos Anuais $(\mathrm{R} \$)$} \\
\hline TUSD & $\mathrm{R} \$$ & $28.252 .567,20$ & $29.328 .864,61$ & $22.833 .673,75$ & $27.803 .041,56$ & $33.641 .312,19$ \\
\hline Fio & $\mathrm{R} \$$ & $21.426 .600,00$ & $18.930 .891,24$ & $12.215 .175,84$ & $17.020 .385,52$ & $23.386 .198,80$ \\
\hline Encargos & $\mathrm{R} \$$ & $6.825 .967,20$ & 10.397.973,37 & $10.618 .497,91$ & $10.782 .656,04$ & $10.255 .113,39$ \\
\hline \multicolumn{7}{|l|}{ Estimativa da TUSD em R\$/MWh } \\
\hline TUSD & $\mathrm{R} \$ / \mathrm{MWh}$ & 55,13 & 57,23 & 44,56 & 54,25 & 65,64 \\
\hline Fio & $\mathrm{R} \$ / \mathrm{MWh}$ & 41,81 & 36,94 & 23,84 & 33,21 & 45,63 \\
\hline Encargos & $\mathrm{R} \$ / \mathrm{MWh}$ & 13,32 & 20,29 & 20,72 & 21,04 & 20,01 \\
\hline \multicolumn{7}{|c|}{ ANÁLISE DAS TARIFAS DE USO DO SISTEMA NA REDE BÁSICA (TUST) } \\
\hline Concessionária & - & Chesf & CEEE & CTEEP & CTEEP & SMTE \\
\hline Subestação de conexão & - & SE Camaçari II & SE Pólo Petroquímico & SE Sumaré & SE Baixada Santista & SE Paracatu 4 \\
\hline Tensão & - & $230 \mathrm{kV}$ & $230 \mathrm{kV}$ & $440 \mathrm{kV}$ & $230 \mathrm{kV}$ & $500 \mathrm{kV}$ \\
\hline $\mathrm{N}^{\circ}$ da Barra & - & Barra 5751 & Barra 1204 & Barra 571 & Barra 473 & Barra 4066 \\
\hline Resolução Homologatória ANEEL & & Res $N^{\circ} 671 / 2008$ & Res $N^{\circ} 671 / 2008$ & Res No 671/2008 & Res $N^{\circ} 671 / 2008$ & Res $N^{\circ} 671 / 2008$ \\
\hline \multicolumn{7}{|c|}{ Tarifas nos sistemas de transmissão (Rede Básica): } \\
\hline Demanda Ponta: & $\mathrm{R} \$ / \mathrm{kW}$ & 4,174 & 5,489 & 5,203 & 5,559 & 3,645 \\
\hline Demanda Fora Ponta: & $\mathrm{R} \$ / \mathrm{kW}$ & 0,00 & 0,00 & 0,00 & 0,00 & 0,00 \\
\hline Encargos: & $\mathrm{R} \$ / \mathrm{MWh}$ & 14,27 & 22,07 & 22,07 & 22,07 & 22,07 \\
\hline $\mathrm{CCC}$ & $\mathrm{R} \$ / \mathrm{MWh}$ & 9,22 & 9,22 & 9,22 & 9,22 & 9,22 \\
\hline $\mathrm{CDE}$ & $\mathrm{R} \$ / \mathrm{MWh}$ & 2,20 & 10,00 & 10,00 & 10,00 & 10,00 \\
\hline PROIINFA & $\mathrm{R} \$ / \mathrm{MWh}$ & 2,85 & 2,85 & 2,85 & 2,85 & 2,85 \\
\hline \multicolumn{7}{|l|}{ Estimativa de Gastos Anuais ( $R \$$ ) } \\
\hline TUST & $\mathrm{R} \$$ & $10.568 .524,20$ & $15.591 .652,07$ & $15.368 .805,07$ & $15.646 .734,32$ & $14.154 .180,90$ \\
\hline $\mathrm{FIO}$ & $\mathrm{R} \$$ & $3.255 .720,00$ & $4.281 .485,87$ & $4.058 .464,87$ & $4.336 .220,12$ & $2.843 .318,70$ \\
\hline Encargos & $\mathrm{R} \$$ & $7.312 .804,20$ & $11.310 .166,20$ & $11.310 .340,20$ & $11.310 .514,20$ & $11.310 .862,20$ \\
\hline \multicolumn{7}{|l|}{ Estimativa da TUST em R $\$ / M W h$} \\
\hline TUST & $\mathrm{R} \$ / M W h$ & 20,62 & 30,42 & 29,99 & 30,53 & 27,62 \\
\hline $\mathrm{FIO}$ & $\mathrm{R} \$ / \mathrm{MWh}$ & 6,35 & 8,35 & 7,92 & 8,46 & 5,55 \\
\hline Encargos & $\mathrm{R} \$ / \mathrm{MWh}$ & 14,27 & 22,07 & 22,07 & 22,07 & 22,07 \\
\hline \multicolumn{7}{|c|}{ DIFERENÇA ENTRE TUST E TUSD } \\
\hline TUSD - TUST em R\$/MWh & $\mathrm{R} \$ / \mathrm{MWh}$ & 34,51 & 26,81 & 14,57 & 23,72 & 38,02 \\
\hline
\end{tabular}

Fonte: Resoluções ANEEL Nº638/2008, 635/2008, 627/2008, 675/2008, 626/2008, 671/2008 e $567 / 2007$ 
Tabela 7 - Comparação entre TUST e TUSD A3 de algumas distribuidoras de energia elétrica

\begin{tabular}{|c|c|c|c|c|c|c|}
\hline \multicolumn{7}{|c|}{ PERFIL DE CARGA } \\
\hline Demanda (Ponta $=$ Fora Ponta) & MW & 65 & 65 & 65 & 65 & 65 \\
\hline Fator de Carga (Ponta = Fora Ponta) & $\%$ & $90 \%$ & $90 \%$ & $90 \%$ & $90 \%$ & $90 \%$ \\
\hline \multicolumn{7}{|c|}{ ANÁLISE DAS TARIFAS DE USO DOS SISTEMAS DE DISTRIBUIÇÃO (TUSD A3) } \\
\hline Concessionária de distribuição & - & COELBA & AES SUL & CPFL PAULISTA & ELETROPAULO ${ }^{2}$ & CEMIG \\
\hline Resolução homologatória ANEEL & - & Res $N^{\circ} 638 / 2008$ & Res $N^{\circ} 635 / 2008$ & Res $N^{\circ} 627 / 2008$ & Res $N^{\circ} 675 / 2008$ & Res $N^{\circ} 635 / 2008$ \\
\hline \multicolumn{7}{|c|}{ Tarifas nos sistemas de distribuição na classe A3 (138 kV): } \\
\hline Demanda Ponta: & $\mathrm{R} \$ / \mathrm{kW}$ & 30,95 & 25,48 & 19,45 & - & 36,25 \\
\hline Demanda Fora Ponta: & $\mathrm{R} \$ / \mathrm{kW}$ & 6,48 & 4,33 & 3,61 & - & 8,07 \\
\hline Encargos: & $\mathrm{R} \$ / \mathrm{MWh}$ & 13,32 & 20,29 & 20,72 & - & 20,01 \\
\hline \multicolumn{7}{|l|}{ Estimativa de Gastos Anuais ( $R \$)$} \\
\hline TUSD & $\mathrm{R} \$$ & $36.021 .367,20$ & $33.650 .131,09$ & $28.605 .851,35$ & - & $44.827 .372,59$ \\
\hline Fio & $\mathrm{R} \$$ & $29.195 .400,00$ & 23.252.157,72 & $17.987 .353,44$ & - & $34.572 .259,20$ \\
\hline Encargos & $\mathrm{R} \$$ & $6.825 .967,20$ & $10.397 .973,37$ & 10.618.497,91 & - & $10.255 .113,39$ \\
\hline \multicolumn{7}{|l|}{ Estimativa da TUSD em R $\$ / M W h$} \\
\hline TUSD & $\mathrm{R} \$ / M W h$ & 70,29 & 65,66 & 55,82 & - & 87,47 \\
\hline Fio & $\mathrm{R} \$ / \mathrm{MWh}$ & 56,97 & 45,37 & 35,10 & - & 67,46 \\
\hline Encargos & $\mathrm{R} \$ / \mathrm{MWh}$ & 13,32 & 20,29 & 20,72 & - & 20,01 \\
\hline \multicolumn{7}{|c|}{ ANÁLISE DAS TARIFAS DE USO DO SISTEMA NA REDE BÁSICA (TUST) } \\
\hline Concessionária & - & Chesf & CEEE & CTEEP & - & SMTE \\
\hline Subestação de conexão & - & SE Camaçari II & SE Pólo Petroquímico & SE Sumaré & - & SE Paracatu 4 \\
\hline Tensão & - & $230 \mathrm{kV}$ & $230 \mathrm{kV}$ & $440 \mathrm{kV}$ & - & $500 \mathrm{kV}$ \\
\hline $\mathrm{N}^{\circ}$ da Barra & - & Barra 5751 & Barra 1204 & Barra 571 & - & Barra 4066 \\
\hline Resolução Homologatória ANEEL & & Res $N^{\circ} 671 / 2008$ & Res $N^{\circ} 671 / 2008$ & Res $N^{\circ} 671 / 2008$ & - & Res $N^{\circ} 671 / 2008$ \\
\hline \multicolumn{7}{|c|}{ Tarifas nos sistemas de transmissão (Rede Básica): } \\
\hline Demanda Ponta: & $\mathrm{R} \$ / \mathrm{kW}$ & 4,174 & 5,489 & 5,203 & - & 3,645 \\
\hline Demanda Fora Ponta: & $\mathrm{R} \$ / \mathrm{kW}$ & 0,00 & 0,00 & 0,00 & - & 0,00 \\
\hline Encargos: & $\mathrm{R} \$ / \mathrm{MWh}$ & 14,27 & 22,07 & 22,07 & - & 22,07 \\
\hline $\mathrm{CcC}$ & $\mathrm{R} \$ / \mathrm{MWh}$ & 9,22 & 9,22 & 9,22 & - & 9,22 \\
\hline CDE & $\mathrm{R} \$ / \mathrm{MWh}$ & 2,20 & 10,00 & 10,00 & - & 10,00 \\
\hline PROIINFA & $\mathrm{R} \$ / \mathrm{MWh}$ & 2,85 & 2,85 & 2,85 & - & 2,85 \\
\hline \multicolumn{7}{|l|}{ Estimativa de Gastos Anuais ( $R \$)$} \\
\hline TUST & $\mathrm{R} \$$ & $10.568 .524,20$ & $15.591 .652,07$ & $15.368 .805,07$ & - & $14.154 .180,90$ \\
\hline $\mathrm{FIO}$ & $\mathrm{R} \$$ & $3.255 .720,00$ & $4.281 .485,87$ & $4.058 .464,87$ & - & $2.843 .318,70$ \\
\hline Encargos & $\mathrm{R} \$$ & $7.312 .804,20$ & $11.310 .166,20$ & $11.310 .340,20$ & - & $11.310 .862,20$ \\
\hline \multicolumn{7}{|l|}{ Estimativa da TUST em R\$/MWh } \\
\hline TUST & $\mathrm{R} \$ / M W h$ & 20,62 & 30,42 & 29,99 & - & 27,62 \\
\hline $\mathrm{FIO}$ & $\mathrm{R} \$ / \mathrm{MWh}$ & 6,35 & 8,35 & 7,92 & - & 5,55 \\
\hline Encargos & $\mathrm{R} \$ / \mathrm{MWh}$ & 14,27 & 22,07 & 22,07 & - & 22,07 \\
\hline \multicolumn{7}{|c|}{ DIFERENÇA ENTRE TUST E TUSD } \\
\hline TUSD - TUST em R\$/MWh & $\mathrm{R} \$ / \mathrm{MWh}$ & 49,67 & 35,24 & 25,83 & - & 59,85 \\
\hline
\end{tabular}

Fonte: Resoluções ANEEL N 638/2008, 635/2008, 627/2008, 675/2008, 626/2008, 671/2008 e $567 / 2007$ 
Tabela 8 - Comparação entre TUST e TUSD A3a de algumas distribuidoras de energia elétrica

\begin{tabular}{|c|c|c|c|c|c|c|}
\hline \multicolumn{7}{|c|}{ PERFIL DE CARGA } \\
\hline Demanda (Ponta $=$ Fora Ponta) & MW & 65 & 65 & 65 & 65 & 65 \\
\hline Fator de Carga (Ponta = Fora Ponta) & $\%$ & $90 \%$ & $90 \%$ & $90 \%$ & $90 \%$ & $90 \%$ \\
\hline \multicolumn{7}{|c|}{ ANÁLISE DAS TARIFAS DE USO DOS SISTEMAS DE DISTRIBUIÇÃO (TUSD A3a) } \\
\hline Concessionária de distribuição & - & COELBA & AES SUL ${ }^{2}$ & CPFL PAULISTA & ELETROPAULO & CEMIG \\
\hline Resolução homologatória ANEEL & - & Res $N^{\circ} 638 / 2008$ & Res $N^{\circ} 635 / 2008$ & Res $N^{\circ} 627 / 2008$ & Res $N^{\circ} 675 / 2008$ & Res $N^{\circ} 635 / 2008$ \\
\hline \multicolumn{7}{|c|}{ Tarifas nos sistemas de distribuição na classe A3 (138 kV): } \\
\hline Demanda Ponta: & $\mathrm{R} \$ / \mathrm{kW}$ & 43,51 & - & 19,47 & 22,66 & 40,66 \\
\hline Demanda Fora Ponta: & $\mathrm{R} \$ / \mathrm{kW}$ & 12,00 & - & 4,38 & 4,91 & 11,27 \\
\hline Encargos: & $\mathrm{R} \$ / \mathrm{MWh}$ & 13,32 & - & 20,72 & 21,04 & 20,01 \\
\hline \multicolumn{7}{|l|}{ Estimativa de Gastos Anuais (R\$) } \\
\hline TUSD & $\mathrm{R} \$$ & $50.123 .767,20$ & - & $29.222 .070,31$ & $32.288 .248,56$ & $50.763 .629,19$ \\
\hline Fio & $\mathrm{R} \$$ & $43.297 .800,00$ & - & $18.603 .572,40$ & $21.505 .592,52$ & $40.508 .515,80$ \\
\hline Encargos & $\mathrm{R} \$$ & $6.825 .967,20$ & - & $10.618 .497,91$ & $10.782 .656,04$ & $10.255 .113,39$ \\
\hline \multicolumn{7}{|l|}{ Estimativa da TUSD em R\$/MWh } \\
\hline TUSD & $\mathrm{R} \$ / M W h$ & 97,81 & - & 57,02 & 63,00 & 99,05 \\
\hline Fio & $\mathrm{R} \$ / \mathrm{MWh}$ & 84,49 & - & 36,30 & 41,96 & 79,04 \\
\hline Encargos & $\mathrm{R} \$ / \mathrm{MWh}$ & 13,32 & - & 20,72 & 21,04 & 20,01 \\
\hline \multicolumn{7}{|c|}{ ANÁLISE DAS TARIFAS DE USO DO SISTEMA NA REDE BÁSICA (TUST) } \\
\hline Concessionária & - & Chesf & - & CTEEP & CTEEP & SMTE \\
\hline Subestação de conexão & - & SE Camaçari II & - & SE Sumaré & SE Baixada Santista & SE Paracatu 4 \\
\hline Tensão & - & $230 \mathrm{kV}$ & - & $440 \mathrm{kV}$ & $230 \mathrm{kV}$ & $500 \mathrm{kV}$ \\
\hline $\mathrm{N}^{\circ}$ da Barra & - & Barra 5751 & - & Barra 571 & Barra 473 & Barra 4066 \\
\hline Resolução Homologatória ANEEL & & Res No 671/2008 & - & Res $N^{\circ} 671 / 2008$ & Res $N^{\circ} 671 / 2008$ & Res No $671 / 2008$ \\
\hline \multicolumn{7}{|c|}{ Tarifas nos sistemas de transmissão (Rede Básica): } \\
\hline Demanda Ponta: & $\mathrm{R} \$ / \mathrm{kW}$ & 4,174 & - & 5,203 & 5,559 & 3,645 \\
\hline Demanda Fora Ponta: & $\mathrm{R} \$ / \mathrm{kW}$ & 0,00 & - & 0,00 & 0,00 & 0,00 \\
\hline Encargos: & $\mathrm{R} \$ / \mathrm{MWh}$ & 14,27 & - & 22,07 & 22,07 & 22,07 \\
\hline $\operatorname{CCC}$ & $\mathrm{R} \$ / \mathrm{MWh}$ & 9,22 & - & 9,22 & 9,22 & 9,22 \\
\hline CDE & $\mathrm{R} \$ / \mathrm{MWh}$ & 2,20 & - & 10,00 & 10,00 & 10,00 \\
\hline PROIINFA & $\mathrm{R} \$ / \mathrm{MWh}$ & 2,85 & - & 2,85 & 2,85 & 2,85 \\
\hline \multicolumn{7}{|l|}{ Estimativa de Gastos Anuais (R\$) } \\
\hline TUST & $\mathrm{R} \$$ & $10.568 .524,20$ & - & $15.368 .805,07$ & $15.646 .734,32$ & $14.154 .180,90$ \\
\hline FIO & $\mathrm{R} \$$ & $3.255 .720,00$ & - & $4.058 .464,87$ & $4.336 .220,12$ & $2.843 .318,70$ \\
\hline Encargos & $\mathrm{R} \$$ & $7.312 .804,20$ & - & $11.310 .340,20$ & $11.310 .514,20$ & $11.310 .862,20$ \\
\hline \multicolumn{7}{|l|}{ Estimativa da TUST em R\$/MWh } \\
\hline TUST & $\mathrm{R} \$ / M W h$ & 20,62 & - & 29,99 & 30,53 & 27,62 \\
\hline $\mathrm{FIO}$ & $\mathrm{R} \$ / \mathrm{MWh}$ & 6,35 & - & 7,92 & 8,46 & 5,55 \\
\hline Encargos & $\mathrm{R} \$ / \mathrm{MWh}$ & 14,27 & - & 22,07 & 22,07 & 22,07 \\
\hline \multicolumn{7}{|c|}{ DIFERENÇA ENTRE TUST E TUSD } \\
\hline TUSD - TUST em R\$/MWh & $\mathrm{R} \$ / M W h$ & 77,19 & - & 27,03 & 32,47 & 71,43 \\
\hline
\end{tabular}

Fonte: Resoluções ANEEL N 638/2008, 635/2008, 627/2008, 675/2008, 626/2008, 671/2008 e $567 / 2007$ 
Tabela 9 - Comparação entre TUST e TUSD A4 de algumas distribuidoras de energia elétrica

\begin{tabular}{|c|c|c|c|c|c|c|}
\hline \multicolumn{7}{|c|}{ PERFIL DE CARGA } \\
\hline Demanda (Ponta $=$ Fora Ponta) & MW & 65 & 65 & 65 & 65 & 65 \\
\hline Fator de Carga (Ponta = Fora Ponta) & $\%$ & $90 \%$ & $90 \%$ & $90 \%$ & $90 \%$ & $90 \%$ \\
\hline \multicolumn{7}{|c|}{ ANÁLISE DAS TARIFAS DE USO DOS SISTEMAS DE DISTRIBUIÇÃO (TUSD A4) } \\
\hline Concessionária de distribuição & - & COELBA & AES SUL & CPFL PAULISTA & ELETROPAULO & CEMIG \\
\hline Resolução homologatória ANEEL & - & Res $N^{\circ} 638 / 2008$ & Res $N^{\circ} 635 / 2008$ & Res $N^{\circ} 627 / 2008$ & Res $N^{\circ} 675 / 2008$ & Res $N^{\circ} 635 / 2008$ \\
\hline \multicolumn{7}{|c|}{ Tarifas nos sistemas de distribuição na classe A3 (138 kV): } \\
\hline Demanda Ponta: & $\mathrm{R} \$ / \mathrm{kW}$ & 50,53 & 39,17 & 23,65 & 30,62 & 40,80 \\
\hline Demanda Fora Ponta: & $\mathrm{R} \$ / \mathrm{kW}$ & 14,31 & 9,65 & 5,76 & 7,55 & 11,28 \\
\hline Encargos: & $\mathrm{R} \$ / \mathrm{MWh}$ & 13,32 & 20,29 & 20,72 & 21,04 & 20,01 \\
\hline \multicolumn{7}{|l|}{ Estimativa de Gastos Anuais ( $R \$)$} \\
\hline TUSD & $\mathrm{R} \$$ & $57.401 .167,20$ & $48.478 .159,21$ & $33.559 .003,75$ & $40.556 .630,16$ & $50.880 .638,19$ \\
\hline Fio & $\mathrm{R} \$$ & $50.575 .200,00$ & $38.080 .185,84$ & $22.940 .505,84$ & $29.773 .974,12$ & $40.625 .524,80$ \\
\hline Encargos & $\mathrm{R} \$$ & $6.825 .967,20$ & $10.397 .973,37$ & 10.618.497,91 & $10.782 .656,04$ & $10.255 .113,39$ \\
\hline \multicolumn{7}{|l|}{ Estimativa da TUSD em R $\$ / M W h$} \\
\hline TUSD & $\mathrm{R} \$ / M W h$ & 112,01 & 94,60 & 65,48 & 79,14 & 99,28 \\
\hline Fio & $\mathrm{R} \$ / \mathrm{MWh}$ & 98,69 & 74,31 & 44,76 & 58,10 & 79,27 \\
\hline Encargos & $\mathrm{R} \$ / \mathrm{MWh}$ & 13,32 & 20,29 & 20,72 & 21,04 & 20,01 \\
\hline \multicolumn{7}{|c|}{ ANÁLISE DAS TARIFAS DE USO DO SISTEMA NA REDE BÁSICA (TUST) } \\
\hline Concessionária & - & Chesf & CEEE & CTEEP & CTEEP & SMTE \\
\hline Subestação de conexão & - & SE Camaçari II & SE Pólo Petroquímico & SE Sumaré & SE Baixada Santista & SE Paracatu 4 \\
\hline Tensão & - & $230 \mathrm{kV}$ & $230 \mathrm{kV}$ & $440 \mathrm{kV}$ & $230 \mathrm{kV}$ & $500 \mathrm{kV}$ \\
\hline $\mathrm{N}^{\circ}$ da Barra & - & Barra 5751 & Barra 1204 & Barra 571 & Barra 473 & Barra 4066 \\
\hline Resolução Homologatória ANEEL & & Res $N^{\circ} 671 / 2008$ & Res $N^{\circ} 671 / 2008$ & Res $N^{\circ} 671 / 2008$ & Res $N^{\circ} 671 / 2008$ & Res $N^{\circ} 671 / 2008$ \\
\hline \multicolumn{7}{|c|}{ Tarifas nos sistemas de transmissão (Rede Básica): } \\
\hline Demanda Ponta: & $\mathrm{R} \$ / \mathrm{kW}$ & 4,174 & 5,489 & 5,203 & 5,559 & 3,645 \\
\hline Demanda Fora Ponta: & $\mathrm{R} \$ / \mathrm{kW}$ & 0,00 & 0,00 & 0,00 & 0,00 & 0,00 \\
\hline Encargos: & $\mathrm{R} \$ / \mathrm{MWh}$ & 14,27 & 22,07 & 22,07 & 22,07 & 22,07 \\
\hline $\mathrm{CcC}$ & $\mathrm{R} \$ / \mathrm{MWh}$ & 9,22 & 9,22 & 9,22 & 9,22 & 9,22 \\
\hline CDE & $\mathrm{R} \$ / \mathrm{MWh}$ & 2,20 & 10,00 & 10,00 & 10,00 & 10,00 \\
\hline PROIINFA & $\mathrm{R} \$ / \mathrm{MWh}$ & 2,85 & 2,85 & 2,85 & 2,85 & 2,85 \\
\hline \multicolumn{7}{|l|}{ Estimativa de Gastos Anuais ( $R \$)$} \\
\hline TUST & $\mathrm{R} \$$ & $10.568 .524,20$ & $15.591 .412,20$ & $15.368 .332,20$ & $15.646 .012,20$ & $14.153 .092,20$ \\
\hline $\mathrm{FIO}$ & $\mathrm{R} \$$ & $3.255 .720,00$ & $4.281 .420,00$ & $4.058 .340,00$ & $4.336 .020,00$ & $2.843 .100,00$ \\
\hline Encargos & $\mathrm{R} \$$ & $7.312 .804,20$ & $11.309 .992,20$ & $11.309 .992,20$ & $11.309 .992,20$ & $11.309 .992,20$ \\
\hline \multicolumn{7}{|l|}{ Estimativa da TUST em R\$/MWh } \\
\hline TUST & $\mathrm{R} \$ / M W h$ & 20,62 & 30,42 & 29,99 & 30,53 & 27,62 \\
\hline $\mathrm{FIO}$ & $\mathrm{R} \$ / \mathrm{MWh}$ & 6,35 & 8,35 & 7,92 & 8,46 & 5,55 \\
\hline Encargos & $\mathrm{R} \$ / \mathrm{MWh}$ & 14,27 & 22,07 & 22,07 & 22,07 & 22,07 \\
\hline \multicolumn{7}{|c|}{ DIFERENÇA ENTRE TUST E TUSD } \\
\hline TUSD - TUST em R\$/MWh & $\mathrm{R} \$ / \mathrm{MWh}$ & 91,39 & 64,17 & 35,49 & 48,61 & 71,66 \\
\hline
\end{tabular}

Fonte: Resoluções ANEEL N 638/2008, 635/2008, 627/2008, 675/2008, 626/2008, 671/2008 e $567 / 2007$ 
Na Figura 9 é efetuada uma análise comparativa das TUSDs da Companhia de Eletricidade do Estado da Bahia - COELBA, com a TUST de Rede Básica na barra de $230 \mathrm{kV}$ da SE Camaçari II, que consiste na barra onde está conectada uma grande indústria petroquímica, a Braskem S.A., situada no pólo de Camaçari. Analisando a figura nota-se a elevada diferença entre TUST $_{R B}$ e as TUSDs da COELBA.

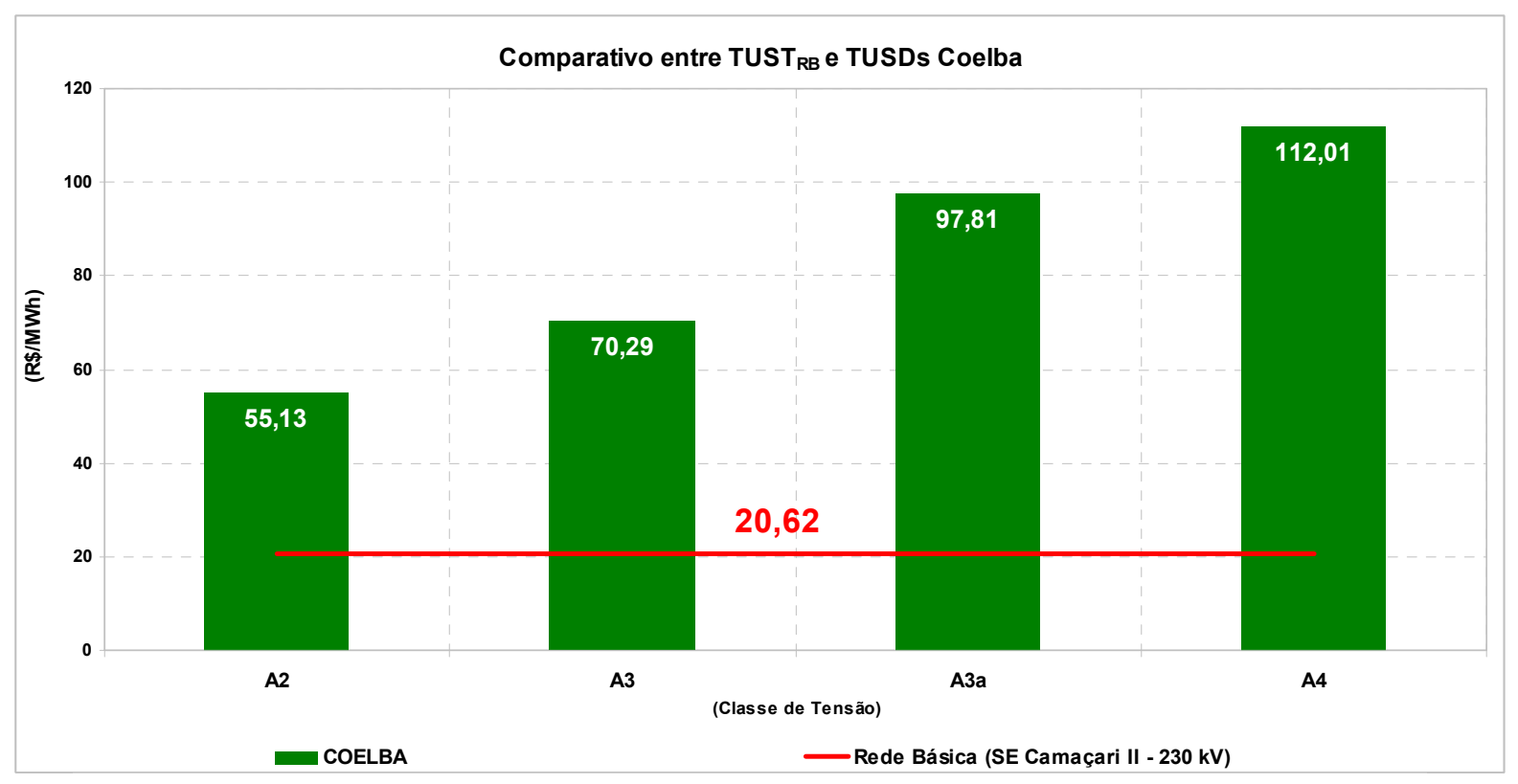

Figura 9 - Comparativo de TUSDs da distribuidora Coelba

Fonte: Resoluções ANEEL N 638/2008, 671/2008 e 567/2007

Na Figura 10 a seguir é efetuada uma análise comparativa das TUSDs da AES Sul, com a TUST de Rede Básica na barra de 230 kV da SE do Pólo Petroquímico, que consiste na barra da subestação compartilhada pelas empresas do Pólo Petroquímico de Triunfo, no Rio Grande do Sul. Analisando a figura nota-se a elevada diferença entre a TUST RB $_{\text {e }}$ as TUSDs da AES Sul. 


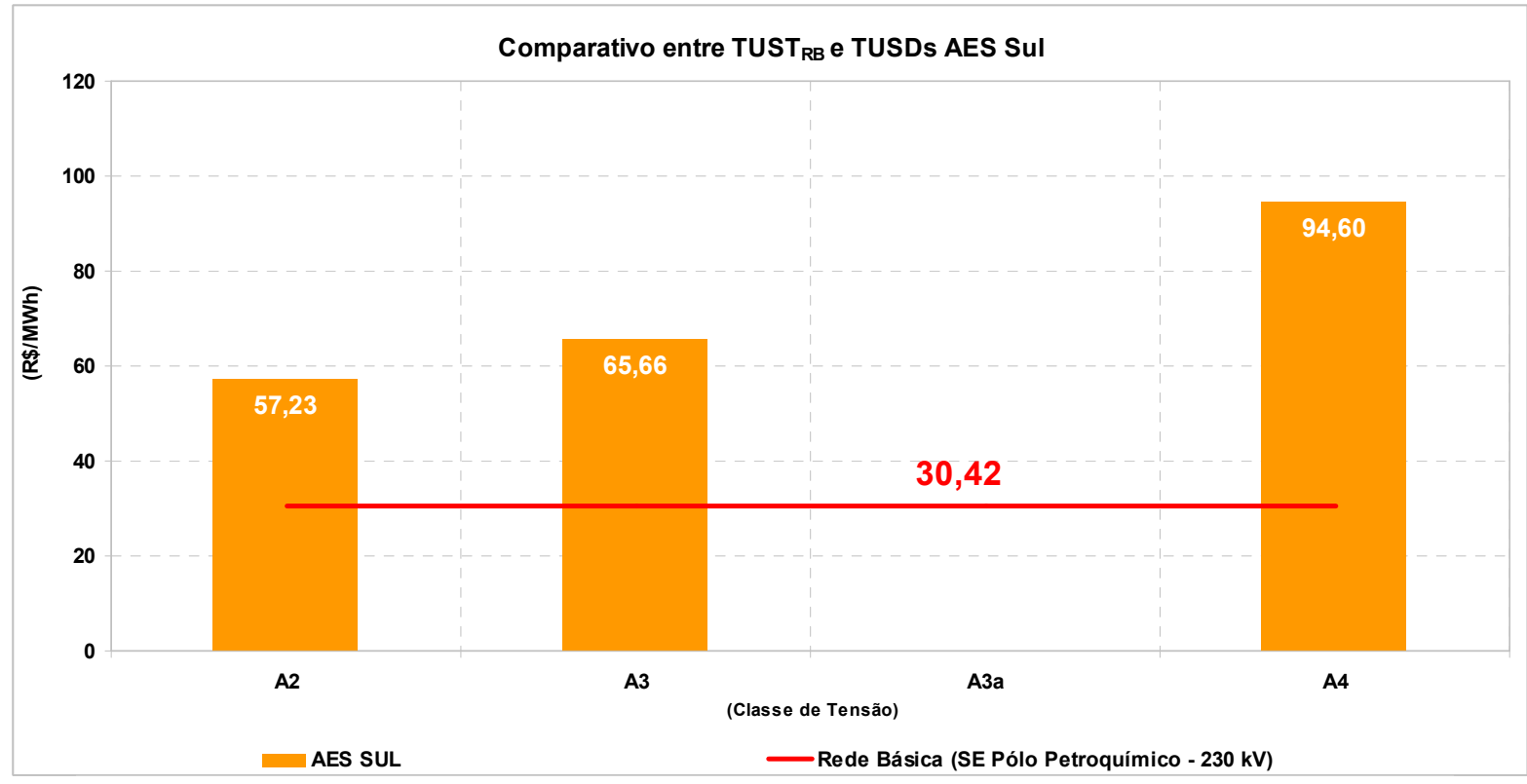

Figura 10 - Comparativo de TUSDs da distribuidora AES Sul

Fonte: Resoluções ANEEL N 635/2008, 671/2008 e 567/2007

De forma similar como feita para as distribuidoras COELBA e AES Sul, as figuras apresentadas a seguir ilustram a diferença entre a TUST e TUSDs das distribuidoras CPFL Paulista, Eletropaulo e Cemig. Destas três citadas distribuidoras, a CPFL Paulista é a que apresenta a menor diferença entre as TUSDs e a TUST RB $_{\text {adotada. }}$

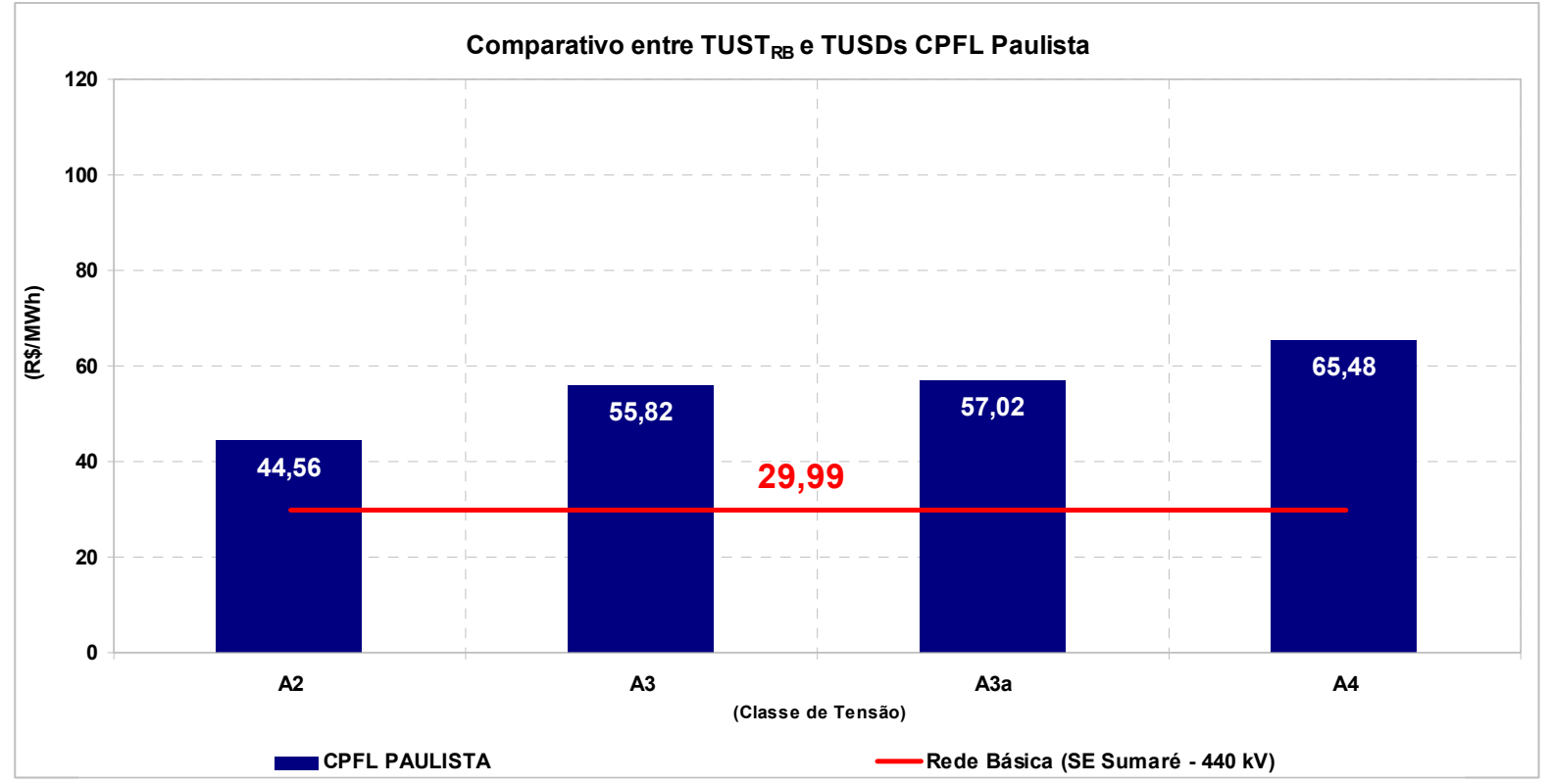

Figura 11 - Comparativo de TUSDs da distribuidora CPFL Paulista

Fonte: Resoluções ANEEL Nº 627/2008, 671/2008 e 567/2007 


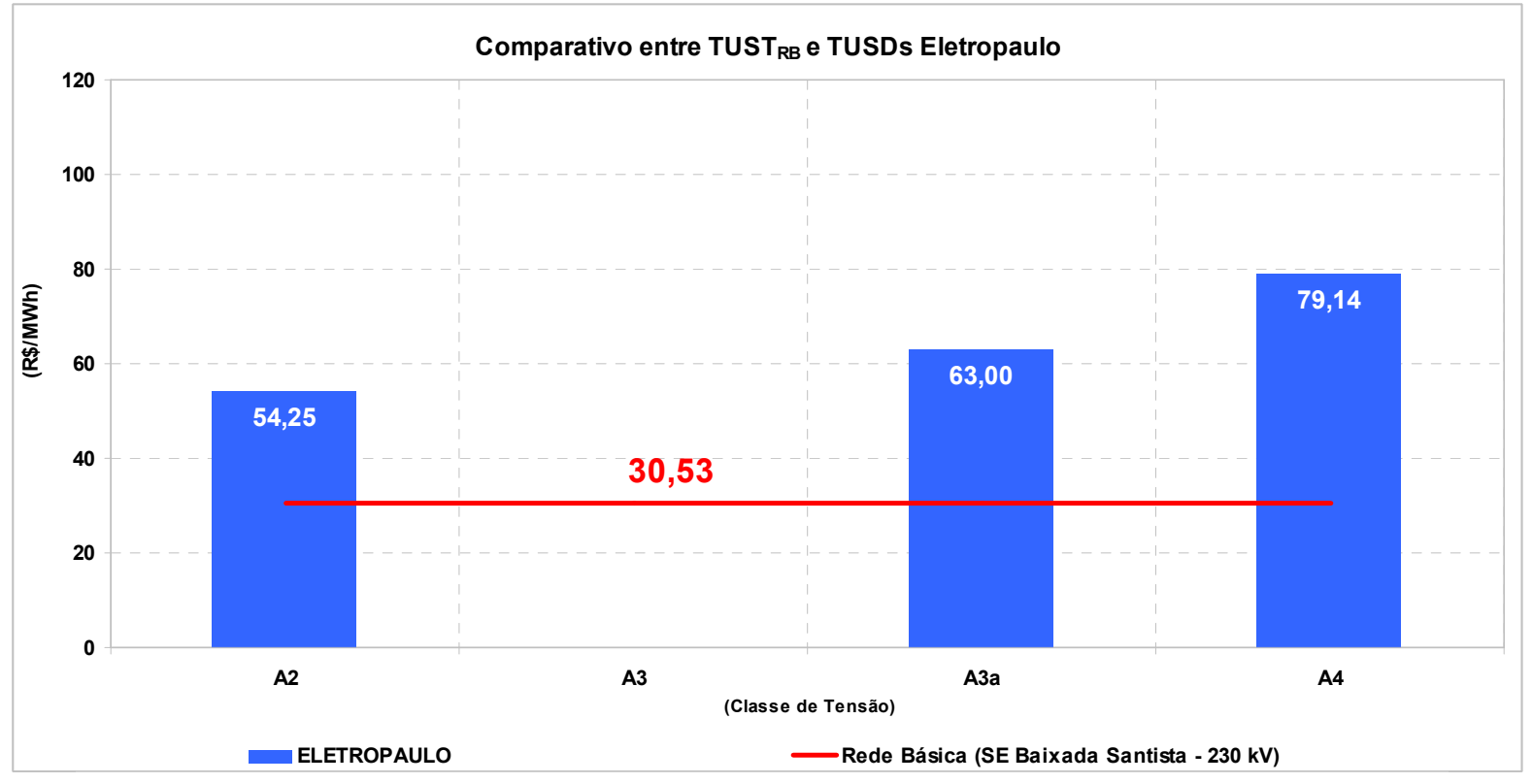

Figura 12 - Comparativo de TUSDs da distribuidora Eletropaulo

Fonte: Resoluções ANEEL № 675/2008, 626/2008, 671/2008 e 567/2007

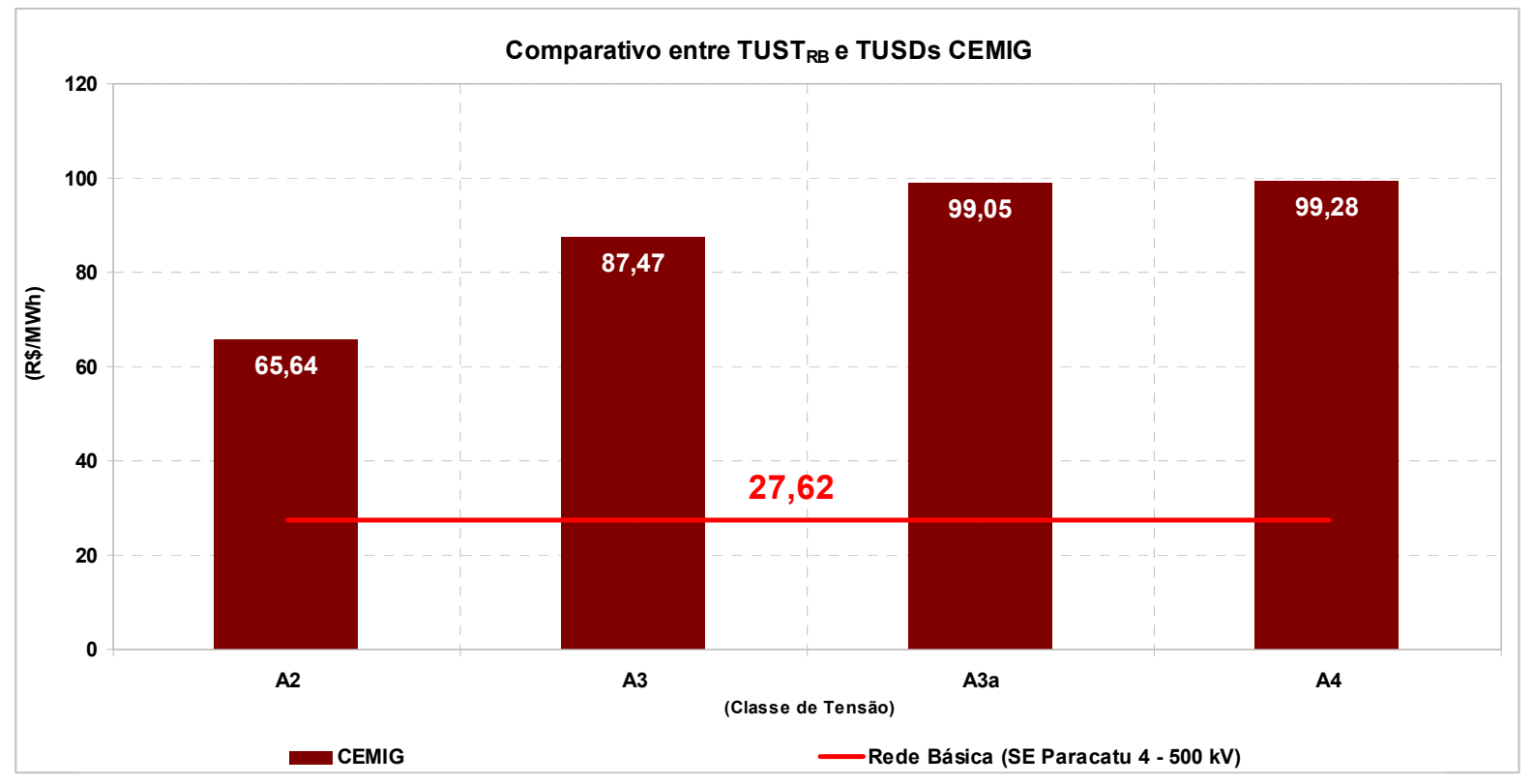

Figura 13 - Comparativo de TUSDs da distribuidora CEMIG

Fonte: Resoluções ANEEL N 626/2008, 671/2008 e 567/2007

A análise da Tarifa Fio comprova que o agrupamento de indústrias na forma de pólos industriais para compartilhar infra-estrutura elétrica e assim acessar tensões mais elevadas configura-se como uma importante estratégia para reduzir gastos com 
energia e, conseqüentemente, aumentar a competitividade ao setor industrial. Entretanto, a falta de regulamentação sobre o tema impede que esta estratégia seja aplicada de forma eficaz, em virtude dos riscos regulatórios atualmente existentes.

No Brasil já existem pólos em que este tipo de acesso conjunto é efetuado, como por exemplo, o Pólo Petroquímico de Triunfo, no Rio Grande do Sul, onde as indústrias se conectam à Rede Básica por meio de uma subestação transformadora 23034,5 kV compartilhada. Neste pólo todas as empresas são faturadas na tensão de $230 \mathrm{kV}$, sendo alguns consumidores cativos, que possuem demandas inferiores a $3 \mathrm{MW}$, e outros livres. Esta forma de faturamento gera uma vantagem competitiva substancial às empresas do pólo. Dado que este tipo de compartilhamento não é tratado de forma clara na legislação do setor elétrico, há incertezas se esta forma de faturamento permanecerá no futuro, o que pode inibir importantes expansões de unidade industriais existentes e instalação de novas indústrias no pólo.

\section{4 - Os Encargos Setoriais}

De forma simplificada, os encargos setoriais podem ser definidos como subsídios que são arrecadados dos geradores e consumidores, via concessionárias de transmissão e distribuição, para uma destinação específica relacionada ao mercado de energia, como por exemplo, incentivar a geração de fontes alternativas, sustentar as atividade de instituições, como ANEEL, ONS e CCEE, promover a universalização do serviço de energia elétrica, dentre outras.

Os aumentos dos encargos, em conjunto com outros fatores que pressionam para cima as tarifas de energia, elevam os custos de produção de importantes setores industriais, atingido, principalmente, os grandes consumidores de energia.

A falta de previsibilidade dos aumentos e a sua baixa aderência aos indicadores econômicos constituem um fator de risco permanente para os consumidores. A criação de novos encargos e a prorrogação daqueles previsto para serem extintos são fatores importantes e preocupantes na sistemática de aumento das tarifas do setor elétrico.

A Figura 14 apresenta a evolução de criação dos encargos setoriais ao longo do tempo. A descrição das siglas listadas nesta figura é apresentada na Tabela 10. 
Pode-se notar que, a partir de 1996, diversos encargos setoriais foram criados, o que contribuiu para aumentar as tarifas de energia.

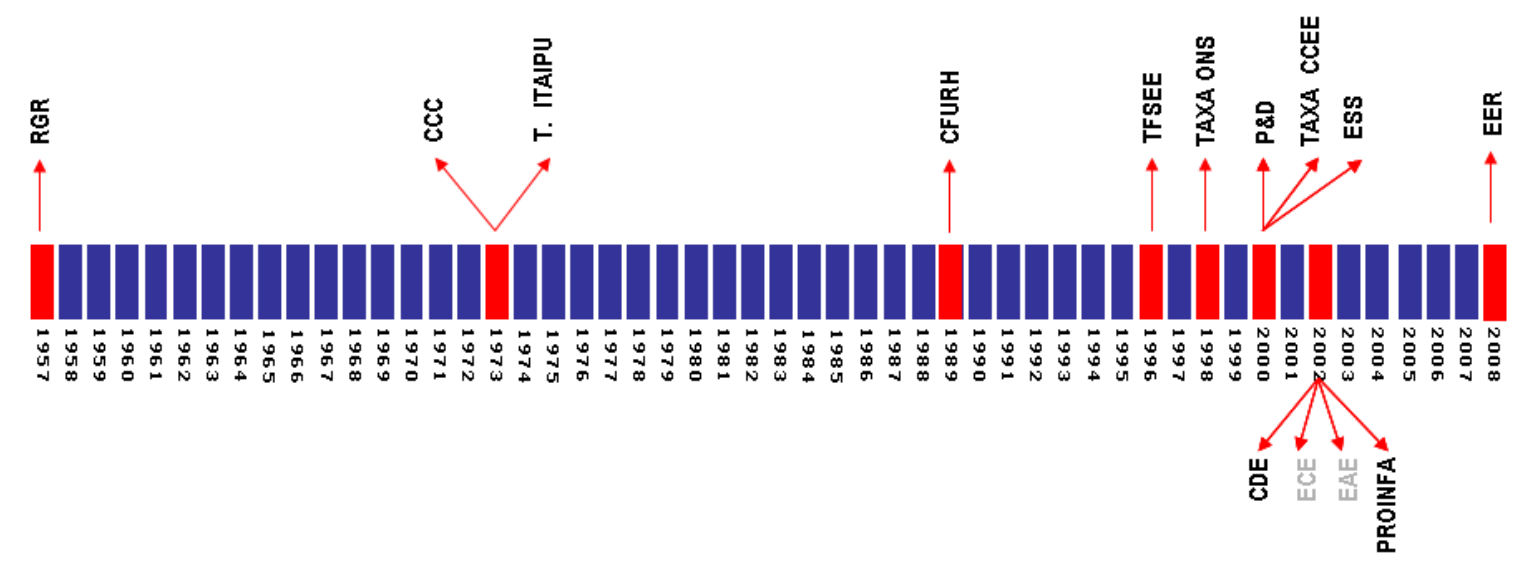

Linha do Tempo

Figura 14 - Evolução da criação de encargos setoriais

Fonte: Elaboração própria com base na legislação relacionada aos encargos setoriais

As siglas EAE e ECE indicados na Figura 14, correspondem ao Encargo de Capacidade Emergencial e ao Encargo de Aquisição de Energia Emergencial, que foram extintos em $2006 .^{6}$

A Tabela 10 apresenta em resumo a relação dos encargos setoriais que integram a tarifa de energia dos consumidores, descrevendo de forma resumida a finalidade de cada encargo.

6 O ECE e o EAE foram criados na época da crise de abastecimento de energia elétrica de 2001. O ECE era usado para remunerar os geradores termelétricos dos custos para que as usinas estivessem prontas para operar. O EAE era cobrado somente quando as usinas eram despachadas e tinham a finalidade de remunerar os custos com combustíveis usados durante o período em que as usinas estivessem gerando. 
Tabela 10 - Encargos setoriais incidentes nas tarifas de energia

\begin{tabular}{|c|c|c|}
\hline Encargo & Sigla & Finalidade \\
\hline Reserva Global de Reversão & RGR & $\begin{array}{l}\text { Indenizar ativos vinculados à concessão e fomentar a } \\
\text { expansão do setor elétrico }\end{array}$ \\
\hline Encargo de Serviço do Sistema & ESS & $\begin{array}{l}\text { Subsidiar a manutenção da confiabilidade e estabilidade } \\
\text { do Sistema Interligado Nacional e o despacho fora da } \\
\text { ordem de mérito por segurança energética. }\end{array}$ \\
\hline Pesquisa e Desenvolvimento & P\&D & $\begin{array}{l}\text { Promover pesquisa científica e tecnológicas relacionadas } \\
\text { à eletricidade e ao uso sustentável dos recursos naturais }\end{array}$ \\
\hline $\begin{array}{l}\text { Conta de Consumo de } \\
\text { Combustíveis }\end{array}$ & $\mathrm{CCC}$ & Subsidiar a geração térmica dos sistemas isolados. \\
\hline Royalties de Itaipu & - & $\begin{array}{l}\text { Pagar a energia gerada de acordo com o Tratado Brasil \& } \\
\text { Paraguai }\end{array}$ \\
\hline $\begin{array}{l}\text { Compensação Financeira pelo } \\
\text { Uso de Recursos Hídricos }\end{array}$ & CFURF & $\begin{array}{l}\text { Compensar financeiramente o uso da água e terras } \\
\text { produtivas para finas de geração de energia elétrica. }\end{array}$ \\
\hline $\begin{array}{l}\text { Taxa de Fiscalização dos } \\
\text { Serviços de Energia Elétrica }\end{array}$ & TFSEE & Prover recursos para o funcionamento da ANEEL. \\
\hline Taxa de Administração do ONS & Taxa ONS & Prover recursos para o funcionamento do ONS. \\
\hline $\begin{array}{l}\text { Taxa de Administração da } \\
\text { CCEE }\end{array}$ & Taxa CCEE & Prover recursos para o funcionamento da CCEE. \\
\hline $\begin{array}{c}\text { Conta de Desenvolvimento } \\
\text { Energético }\end{array}$ & CDE & $\begin{array}{l}\text { Propiciar o desenvolvimento a partir de fontes } \\
\text { alternativas, promover a universalização do serviço de } \\
\text { energia e subsidiar as tarifas residenciais dos } \\
\text { consumidores de Baixa Renda e a geração a carvão } \\
\text { vegetal no S/SE/CO. }\end{array}$ \\
\hline $\begin{array}{l}\text { Programa de Incentivo às } \\
\text { Fontes Alternativas de Energia }\end{array}$ & PROINFA & Subsidiar as fontes alternativas de energia. \\
\hline Encargo de Energia de Reserva & ERR & Subsidiar a geração de energia de reserva. \\
\hline
\end{tabular}

Fonte: Site ANEEL e legislação relacionada aos encargos setoriais

Apesar de não se configurarem como um encargo setorial, as perdas técnicas e comerciais de energia elétrica também são consideradas na formação de preços das tarifas de uso dos sistemas. As perdas técnicas correspondem às perdas inerentes 
ao processo de transmissão e distribuição, e são causadas pela dissipação de potência nos elementos que compõem os sistemas elétricos de potência, como os transformadores e linhas de transmissão e distribuição. As perdas comerciais são definidas como a diferença entre as perdas totais e as perdas técnicas, relacionando-se à energia efetivamente entregue ao consumidor, mas que não é faturada. Dentre suas causas destacam-se as ligações clandestinas, autoreligações, cadastro de iluminação pública desatualizado etc. As perdas comerciais estão diretamente associadas à gestão comercial da concessionária distribuidora.

No Brasil, a prática de criação de encargos setoriais tornou-se uma política muito comum para subsidiar programas, como por exemplo, incentivar o uso de fontes alternativas de energia, universalização do serviço de energia, a geração a biomassa, dentre outros.

Por outro lado, verifica-se historicamente que a extinção dos encargos é algo raro, como aconteceu com o ECE e EAE. Após criados, os encargos setoriais dificilmente são extintos, e passam a ser prorrogados, a exemplo do que ocorreu com a CCC dos sistemas isolados, que teve a sua extinção prorrogada para 2023.

Em 2007 a arrecadação de encargos sofreu uma redução de 17\% em relação ao ano de 2006, porém, em 2008 a arrecadação dos encargos setoriais voltou a aumentar e atingiu o mesmo patamar que a arrecadação de 2006.

Recentemente, outro encargo que até pouco tempo apresentava parcela pequena ganhou força com o despacho de termelétricas fora da ordem de mérito econômico ${ }^{7}$ pelo CNPE. Este encargo é o Encargos de Serviço do Sistema, que chegou a atingir a cifra de $\mathrm{R} \$ 8 / \mathrm{MWh}$ em 2008.

Como o ESS passou a desempenhar mais uma finalidade, a de segurança energética, a elevação deste encargo acabou compensando a extinção do ECE e EAE.

Em 2008 estima-se que o total arrecadado com encargos setoriais atingiu a cifra de R\$ 14 bilhões, sendo que apenas três encargos foram responsáveis por, aproximadamente, $60 \%$ do total recolhido. Estes encargos são CCC, CDE e

\footnotetext{
O despacho de termelétricas fora da ordem de mérito econômico foi autorizado pela Resolução Conselho Nacional de Política Energética - CNPE No 08, de 20.12.2007. Este despacho foi realizado a partir do início de 2008 para assegurar os níveis dos reservatórios das hidrelétricas do Brasil, que diminuíram significativamente em função do atraso no regime de chuvas do segundo semestre de 2007. A referida resolução do CNPE determinou que o Custo Variável Unitário - CVU das usinas despachadas fora da ordem de mérito econômico não seria utilizado para cálculo do Preço de Liquidação das Diferenças - PLD, ou preço no mercado spot de energia. Assim, o custo adicional do despacho passou a ser cobrado dos consumidores via Encargo de Serviços do Sistema - ESS.
} 
PROINFA. A Figura 15 apresenta a evolução da arrecadação de encargos setoriais de 2002 a 2008, comparando com a evolução do mercado de energia no mesmo período.

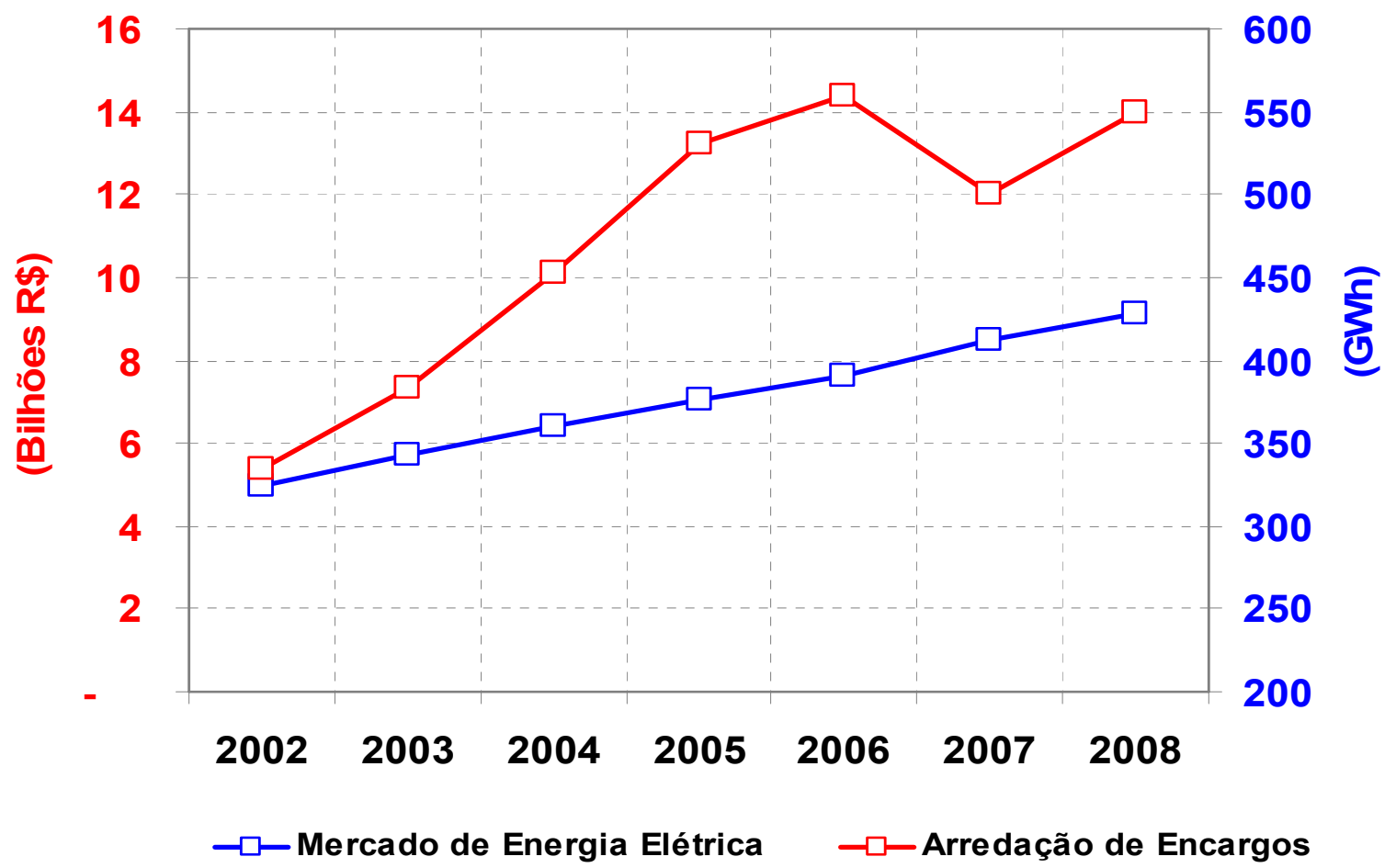

Figura 15 - Evolução da arrecadação dos encargos setoriais e do mercado de energia elétrica

Fonte: Associação Brasileira dos Grandes Consumidores de Energia e Consumidores Livre ABRACE / MME (Balanço Energético Nacional 2009 / Ano Base 2008).

$\mathrm{Na}$ Figura 16 são apresentados aumentos acumulados da arrecadação dos encargos setoriais e do mercado de energia elétrica. Nesta figura pode-se observar que a arrecadação dos encargos sofreu um aumento de $160 \%$ de 2002 a 2008, enquanto que no mesmo período, o mercado de energia elétrica aumentou $32 \%$. Isto mostra que a elevação da arrecadação dos encargos setoriais ocorreu mais em função do aumento do valor dos encargos setoriais do que devido ao crescimento do mercado de energia. 


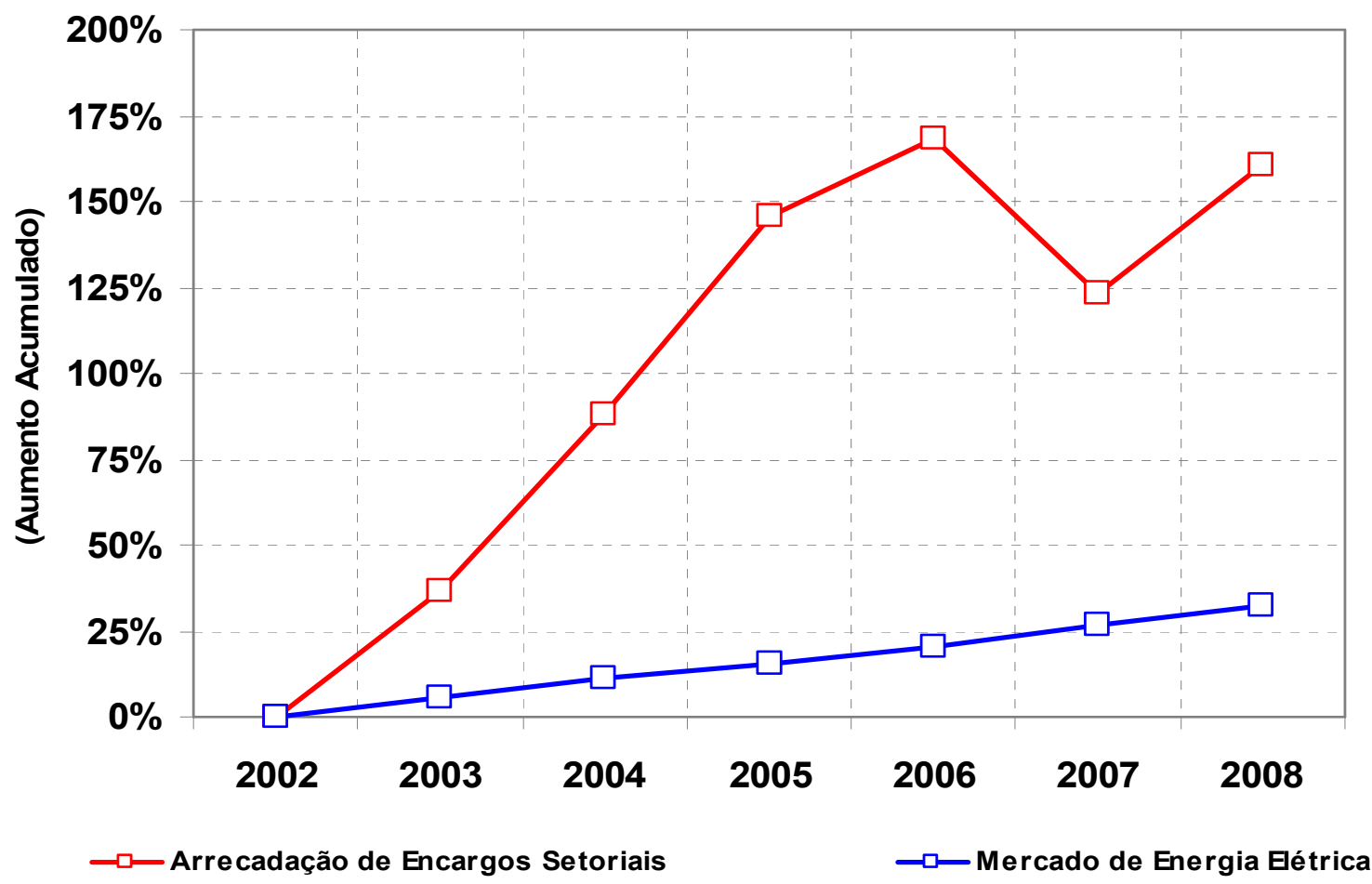

Figura 16 - Aumento acumulado da arrecadação dos encargos setoriais e do mercado de energia elétrica

Fonte: Associação Brasileira dos Grandes Consumidores de Energia e Consumidores Livre ABRACE / MME (Balanço Energético Nacional 2009 / Ano Base 2008)

Os encargos setoriais e os tributos são pagos por qualquer consumidor independente da tensão de conexão ao sistema elétrico e se o mesmo é cativo ou livre. Atualmente, a única forma de um consumidor reduzir o pagamento de encargos setoriais é por meio da auto-produção de energia elétrica, onde há isenção, sobre a parcela de energia gerada pelo próprio consumidor, dos encargos CCC, CDE, PROINFA e da parcela do ESS relacionada à segurança energética.

A instituição da uma legislação que isente o pagamento de encargos setoriais sobre a energia gerada e consumida internamente por indústrias integrantes de pólos industriais consiste numa medida muito interessante que pode incentivar a geração elétrica e, ao mesmo tempo, proporcionar energia mais competitiva às indústrias.

Atualmente, os encargos setoriais CCC, CDE e PROINFA juntos totalizam $\mathrm{R} \$ 23,65 / \mathrm{MWh}$ nos sub-mercados do Sudeste/Centro-Oeste e Sul, e R \$ 15,85/MWh nos sub-mercados Norte e Nordeste.

A isenção de encargos setoriais sobre a energia gerada e consumida internamente em pólos industriais poderia incentivar a implantação de novas plantas de cogeração 
de energia no país e contribuir para o uso racional de combustíveis e para o abastecimento elétrico do Brasil.

\section{5 - Os tributos}

O Brasil é um dos países com maior carga tributária incidente sobre a energia elétrica e o setor industrial vem cada vez mais perdendo competitividade devido à elevação das tarifas de energia elétrica, ocasionadas, em parte, pelo progressivo aumento da carga tributária.

A Tabela 11 a seguir apresenta os principais tributos incidentes sobre as tarifas de energia.

Tabela 11 - Tributos incidentes sobre energia elétrica

\begin{tabular}{ccc}
\hline Tributo & Sigla & Classificação \\
Programas de Integração Social & PIS & Federal \\
\hline Contribuição para o Financiamento da & COFINS & Federal \\
Seguridade Social & ICMS & Estadual \\
\hline Contribuição para Custeio do Serviço de lluminação \\
Pública
\end{tabular}

Fonte: Cartilha ANEEL - "Por Dentro da Conta de Luz" (2008)

A seguir é feita uma breve explicação sobre os tributos PIS/COFINS e ICMS, as quais foram obtidas da Cartilha ANEEL - "Por Dentro da Conta de Luz" (2008), disponibilizada no site desta agência. 


\section{PIS/COFINS}

Os tributos PIS/COFINS são cobrados pela União para manter programas voltados ao trabalhador e para atender a programas sociais do Governo Federal. A aplicação desses tributos foi recentemente alterada, com elevação no valor da conta de energia. Com a edição das Leis $n^{\circ} 10.637 / 2002$, $10.833 / 2003$ e $10.865 / 2004$, o PIS e a COFINS tiveram suas alíquotas alteradas para $1,65 \%$ e 7,6\%, respectivamente, passando a ser apurados de forma não cumulativa. Dessa forma, a alíquota média desses tributos passou a variar com 0 volume de créditos apurados mensalmente pelas concessionárias e com o PIS e a COFINS pagos sobre custos e despesas no mesmo período, tais como a energia adquirida para revenda ao consumidor.

\section{ICMS}

A cobrança do ICMS está prevista no Art. 155 da Constituição Federal de 1988. Este imposto incide sobre as operações relativas à circulação de mercadorias e serviços e é de competência dos governos estaduais e do Distrito Federal. O ICMS é regulamentado pelo código tributário de cada estado, ou seja, estabelecido em lei pelas casas legislativas. Por isso são variáveis. A distribuidora tem a obrigação de realizar a cobrança do ICMS direto na fatura e repassá-lo integralmente ao Governo Estadual.

A incidência do ICMS não é cumulativa, ou seja, há a possibilidade de se abater o ICMS pago (ou parte dele) com a parcela de ICMS recolhida com a venda final do produto industrializado. Por exemplo, o ICMS pago por uma indústria na aquisição de energia elétrica pode ser abatido do ICMS recolhido na venda de seus produtos finais. Em virtude desta possibilidade de obtenção de crédito do ICMS devido, o imposto acaba não sendo contestado com intensidade pelos contribuintes. Cabe ressaltar que sobre a parcela de produtos exportados, o crédito de ICMS acaba não sendo aproveitado.

A cobrança, não só do ICMS, mas de outros tributos sobre a energia elétrica ocasiona distorções substanciais, pois, ao incidir ao longo da cadeia de transformação de matéria e energia, os impostos acabam incidindo também sobre as perdas de todo o processo de transformação. Uma alternativa seria reduzir (ou até isentar) as alíquotas de tributos sobre a energia elétrica e aplicar os impostos sobre os produtos finais. 
Os tributos ICMS, PIS e COFINS são apurados na metodologia de cálculo por dentro, onde os próprios tributos integram a base de cálculo sobre a qual incidem suas respectivas alíquotas. Assim, o percentual real cobrado nas faturas de energia é maior que a alíquota fixada. Abaixo é apresentado o procedimento de cálculo da alíquota efetiva dos tributos sobre energia elétrica.

$$
\text { Alíquota Efetiva }=\frac{\text { Alíquota }}{(1-\text { Alíquota })}
$$

Uma alíquota de ICMS igual a 25\%, por exemplo, na metodologia de cálculo por dentro faz com que o peso real do tributo ao consumidor seja de $33 \%$, conforme procedimento de cálculo ilustrado a seguir.

$$
\text { Alíquota Efetiva }=\frac{25 \%}{(1-25 \%)}=33,33 \%
$$

$\mathrm{Na}$ conta de energia elétrica estão presentes tributos federais, estaduais e municipais e as distribuidoras são responsáveis apenas pelo recolhimento e repasse dos tributos às autoridades competentes pela sua cobrança. As resoluções publicadas pela ANEEL anualmente com as tarifas de cada distribuidora de energia elétrica não apresentam os tributos em seus valores.

A seguir é apresentado o procedimento de cálculo para se obter o valor final da tarifa de energia elétrica publicada pela ANEEL acrescendo os tributos PIS/COFINS e ICMS.

$$
\text { Tarifa Com Tributos }=\frac{\text { Tarifa publicada pela ANEEL }}{1-(P I S+C O F I N S+I C M S)}
$$


Ao longo dos anos a energia elétrica tornou-se um meio de arrecadação muito atraente, sendo o ICMS o imposto com maior peso nos custos de energia. Dada a facilidade na arrecadação de tributos sobre a energia elétrica, diversos estados brasileiros vem utilizando o ICMS como estratégia de arrecadação. A Figura 17 apresenta a evolução da arrecadação global do ICMS, bem como da parcela específica de arrecadação sobre energia elétrica. Verifica-se que a energia elétrica contribui com cerca de $12 \%$ sobre a arrecadação total do ICMS pelos estados.

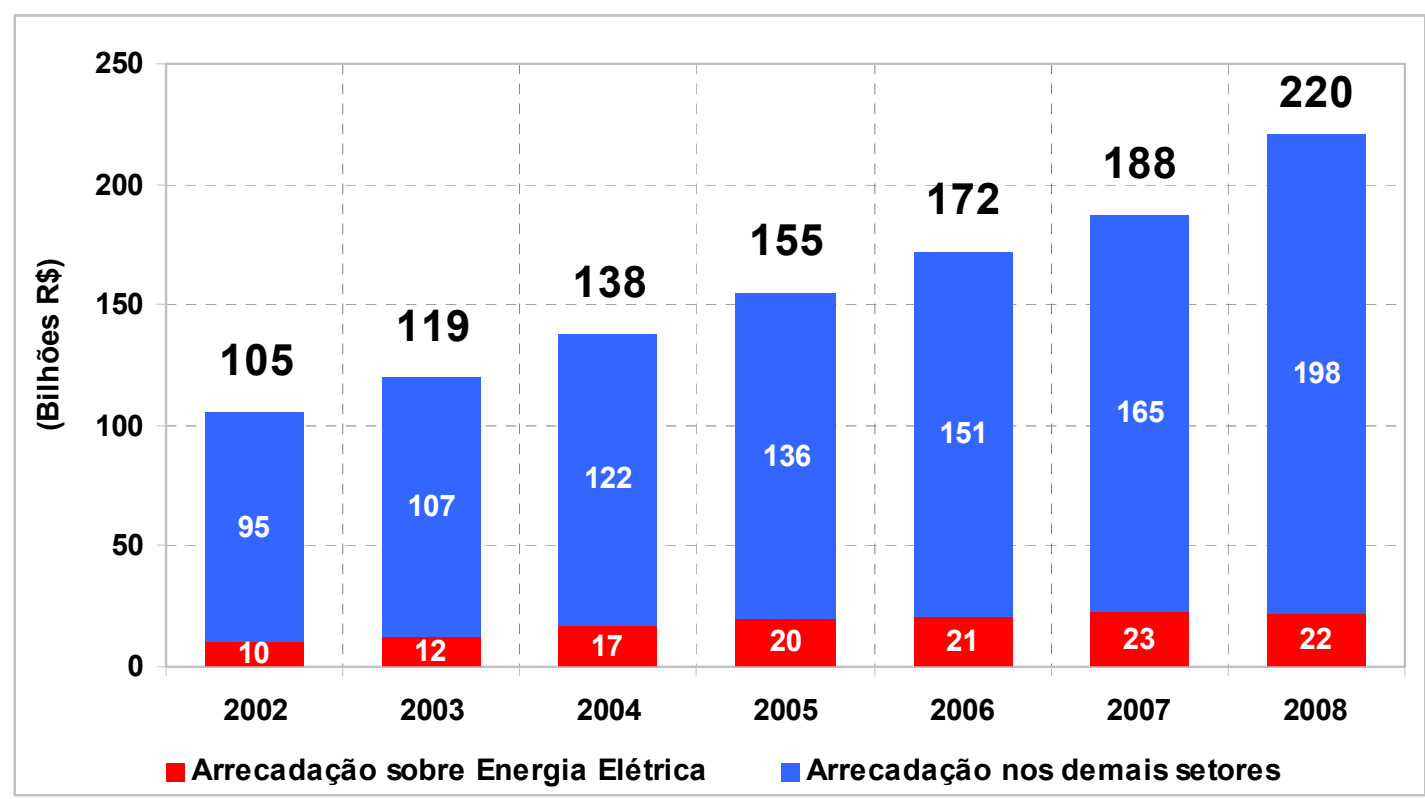

Figura 17 - Evolução da arrecadação de ICMS total e sobre energia elétrica

Fonte: Site do Conselho Nacional de Política Fazendária - Confaz, Comissão Técnica Permanente do ICMS - COTEPE (www.fazenda.gov/confaz/boletim/) - Acesso em 15.05.2009

Na Tabela 12 são apresentados dados do histórico de arrecadação do ICMS total e sobre a energia elétrica, comparando com a evolução do mercado de energia elétrica. Verifica-se que de 2002 a 2008 o mercado de energia elétrica teve um crescimento de $32 \%$, enquanto que a arrecadação de ICMS sobre a energia elétrica teve um aumento de $120 \%$ no mesmo período. Isto mostra que o aumento na arrecadação do ICMS sobre energia elétrica pode ter ocorrido devido a aumentos nas alíquotas fixadas pelos estados para este tributo. 
Tabela 12 - Análise da arrecadação de ICMS sobre energia elétrica e do mercado de energia

\begin{tabular}{lcccccccc}
\cline { 2 - 7 } & & $\mathbf{2 0 0 2}$ & $\mathbf{2 0 0 3}$ & $\mathbf{2 0 0 4}$ & $\mathbf{2 0 0 5}$ & $\mathbf{2 0 0 6}$ & $\mathbf{2 0 0 7}$ & $\mathbf{2 0 0 8}$ \\
\hline Mercado de Energia Elétrica & $(\mathrm{TWh})$ & 325 & 343 & 360 & 376 & 390 & 413 & 429 \\
\hline $\begin{array}{l}\text { Crescimento Acumulado do } \\
\text { Mercado de Energia Elétrica }\end{array}$ & $(\%)$ & - & $6 \%$ & $11 \%$ & $16 \%$ & $20 \%$ & $27 \%$ & $32 \%$ \\
\hline $\begin{array}{l}\text { Arrecadação do ICMS sobre } \\
\text { Energia Elétrica }\end{array}$ & $($ Bilhões R\$) & 10 & 12 & 17 & 20 & 21 & 23 & 22 \\
\hline $\begin{array}{l}\text { Crescimento Acumulado da } \\
\text { Arrecadação do ICMS sobre } \\
\text { Energia Elétrica }\end{array}$ & $(\%)$ & - & $21 \%$ & $66 \%$ & $95 \%$ & $107 \%$ & $124 \%$ & $120 \%$ \\
\hline
\end{tabular}

Fonte: Site do Conselho Nacional de Política Fazendária - Confaz, Comissão Técnica Permanente do ICMS - COTEPE (www.fazenda.gov/confaz/boletim/) - Acesso em 15.05.2009 e MME (Balanço Energético Nacional 2009 / Ano Base 2008)

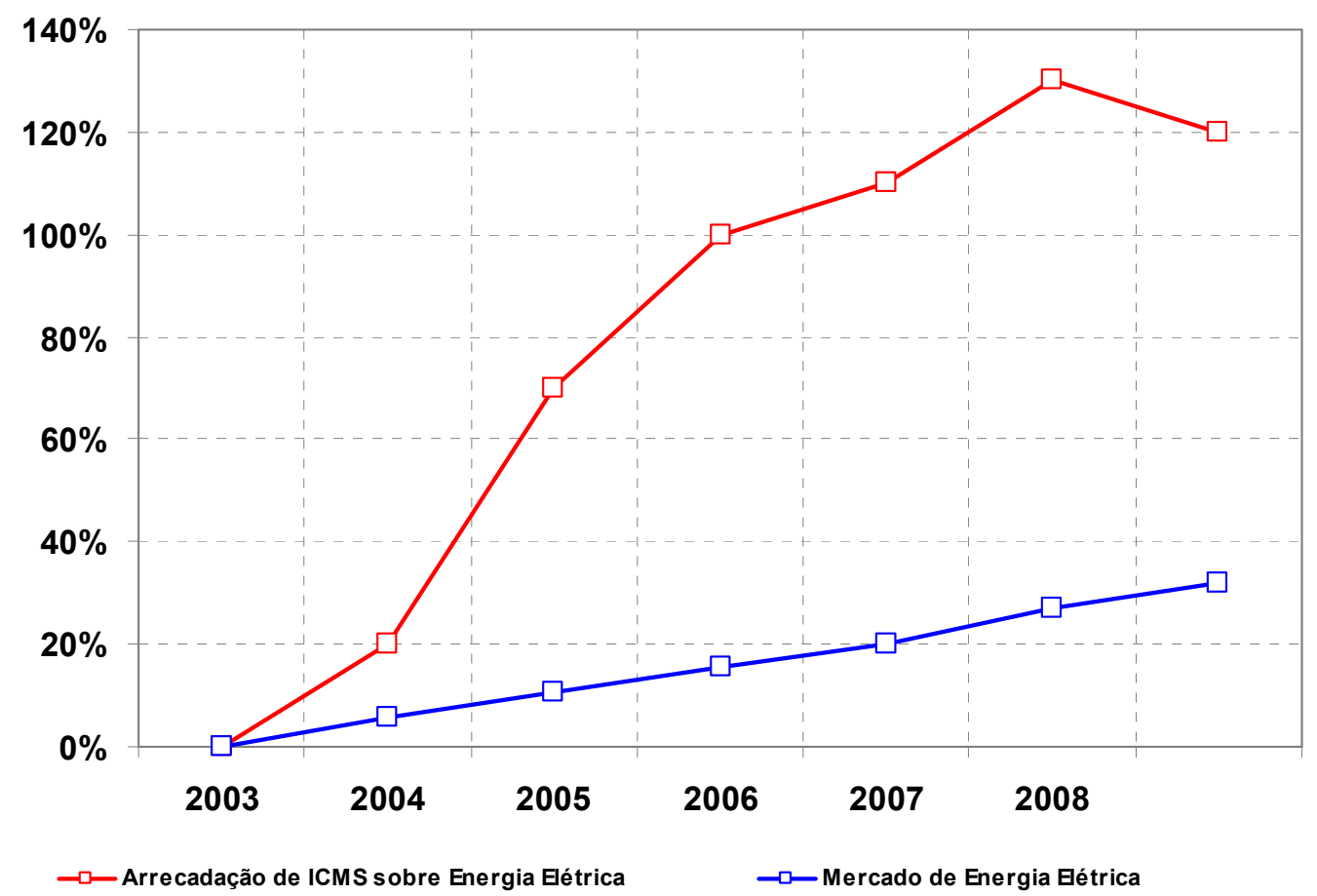

Figura 18 - Aumento acumulado da arrecadação de ICMS e do mercado de energia elétrica

Fonte: Site do Conselho Nacional de Política Fazendária - Confaz, Comissão Técnica Permanente do ICMS - COTEPE (www.fazenda.gov/confaz/boletim/) e MME (Balanço Energético Nacional 2009 / Ano Base 2008) 


\section{3 - ANÁLISE DAS TARIFAS INDUSTRIAIS DE ENERGIA ELÉTRICA EM OUTROS PAÍSES}

No capítulo anterior foi apresentada uma abordagem dos componentes da tarifa final de energia elétrica dos consumidores, indicando, em alguns casos, as medidas que podem ser adotadas para redução de cada componente.

Neste capítulo será feita uma análise comparativa das tarifas finais de energia elétrica do setor industrial no Brasil com as tarifas de alguns países industrializados, onde será evidenciado que nos últimos anos a tarifa industrial no Brasil sofreu aumentos expressivos, prejudicando a competitividade do setor.

Apesar de possuir uma matriz de geração de energia elétrica predominantemente hídrica, o Brasil possui uma das maiores tarifas de energia elétrica, quando considerados todos os componentes como uso do sistema elétrico, energia, encargos setoriais e impostos.

A Figura 19 apresenta a evolução, em valores médios e incluindo impostos, das tarifas finais de energia de alguns países. Verifica-se que a partir de 2004 as tarifas de energia elétrica no Brasil sofreram aumentos expressivos, chegando em 2008 a atingir o maior valor em relação aos países analisados. 


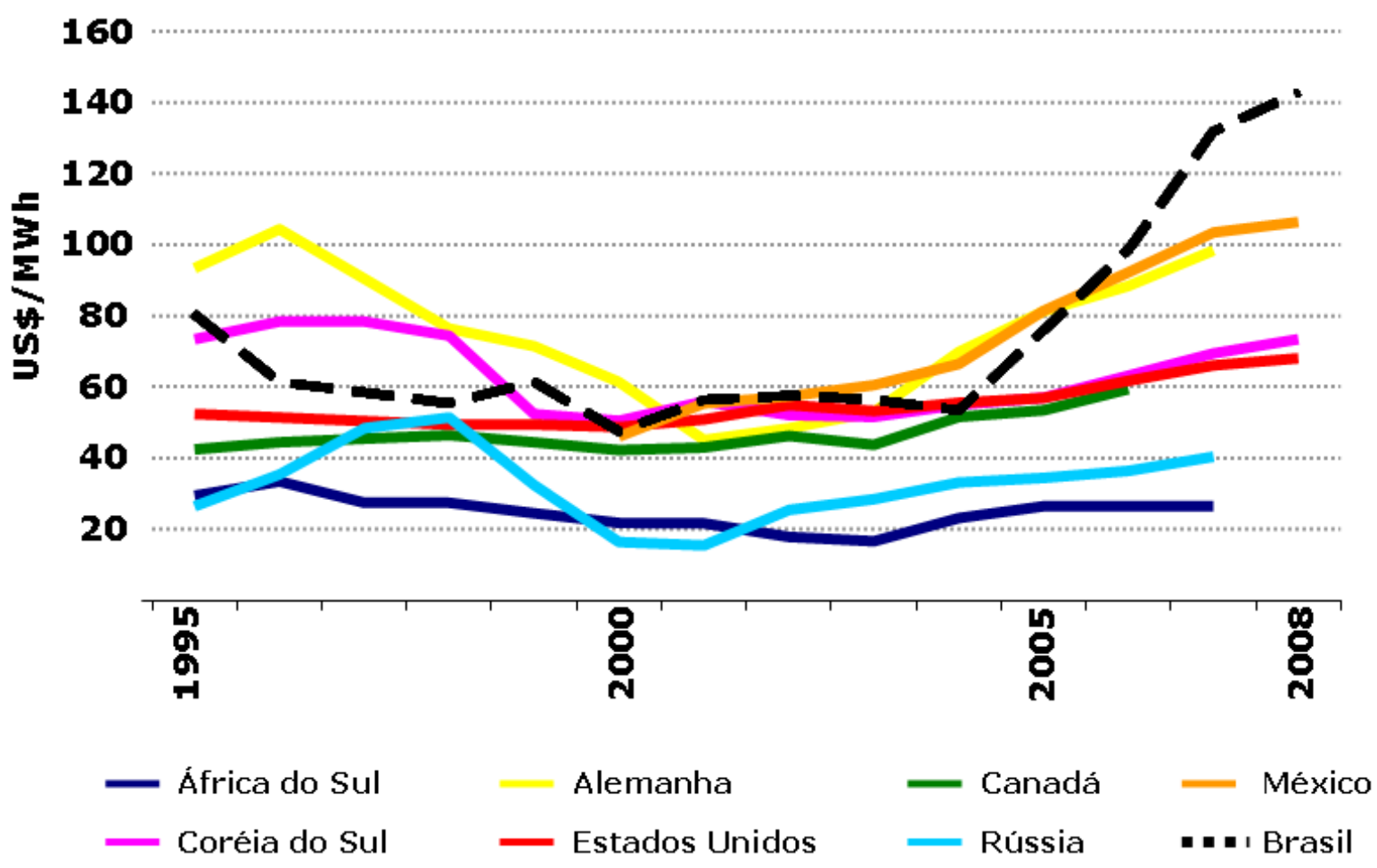

Figura 19 - Evolução das tarifas finais de energia em alguns países (Base: 2007) - Valores finais incluindo impostos. Taxa de câmbio de 2007 em 2,11 R\$/US\$

Fonte: Gráfico apresentado pela ABRACE no Evento "Agenda Regulatória 2009", promovido pelo Canal Energia em 11.05.2009.

Na Figura 20 é apresentada uma comparação entre as matrizes de geração de energia elétrica do Brasil, dos Estados Unidos da América - EUA e da França, sendo possível verificar claramente a predominância de geração hídrica no Brasil, térmica nos EUA e nuclear na França. 


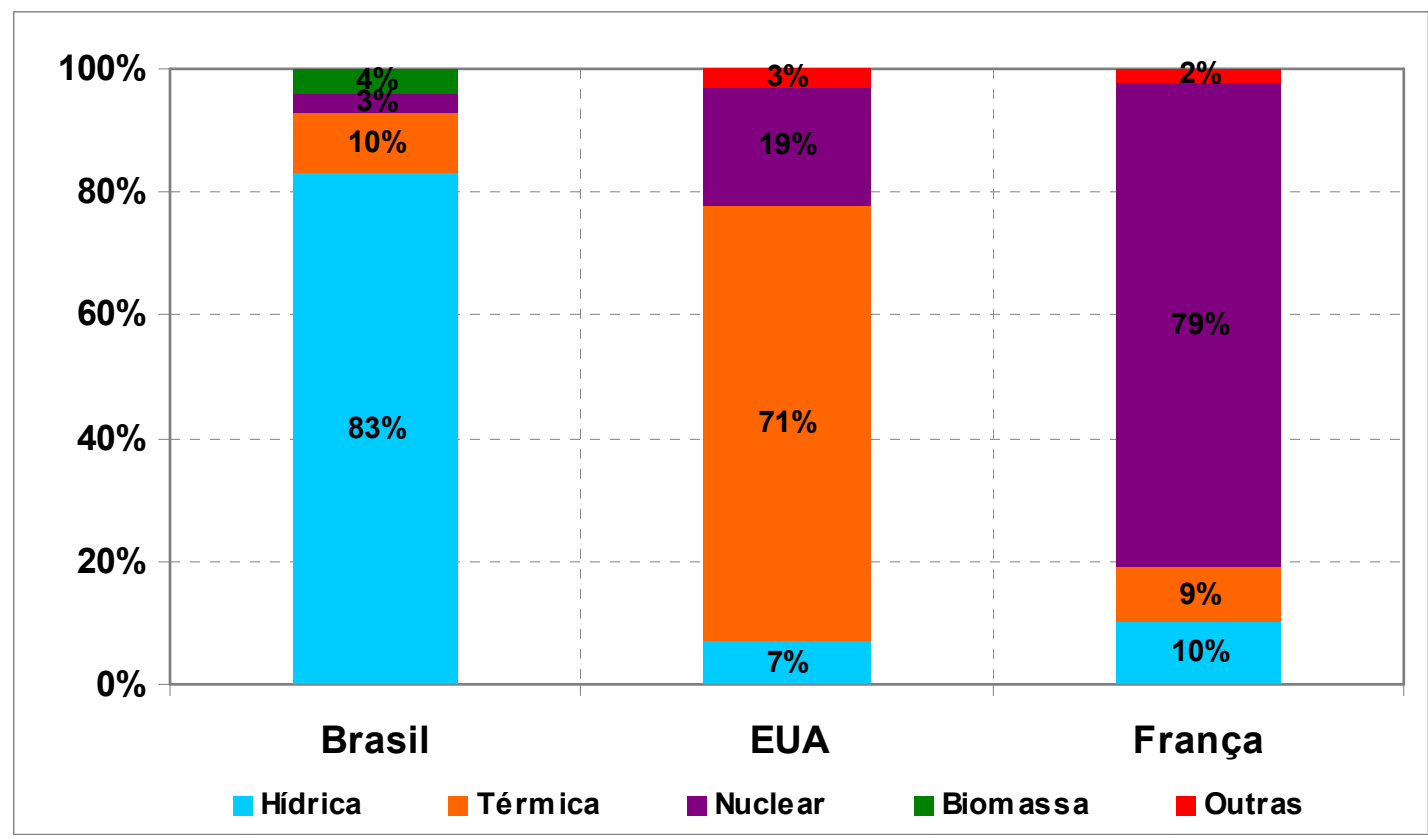

Figura 20 - Comparação da matriz de geração de energia elétrica do Brasil, EUA França Fonte: Energy Information Administration - EIA

Na Figura 21 são apresentados os custos médios de geração de energia elétrica por fonte. Os valores correspondem ao valor mínimo da tarifa que remunera o capital nos percentuais previamente definidos para o projeto, zerando o Valor Presente Líquido - VPL. Nota-se que a geração hidrelétrica possui os menores custos de geração.

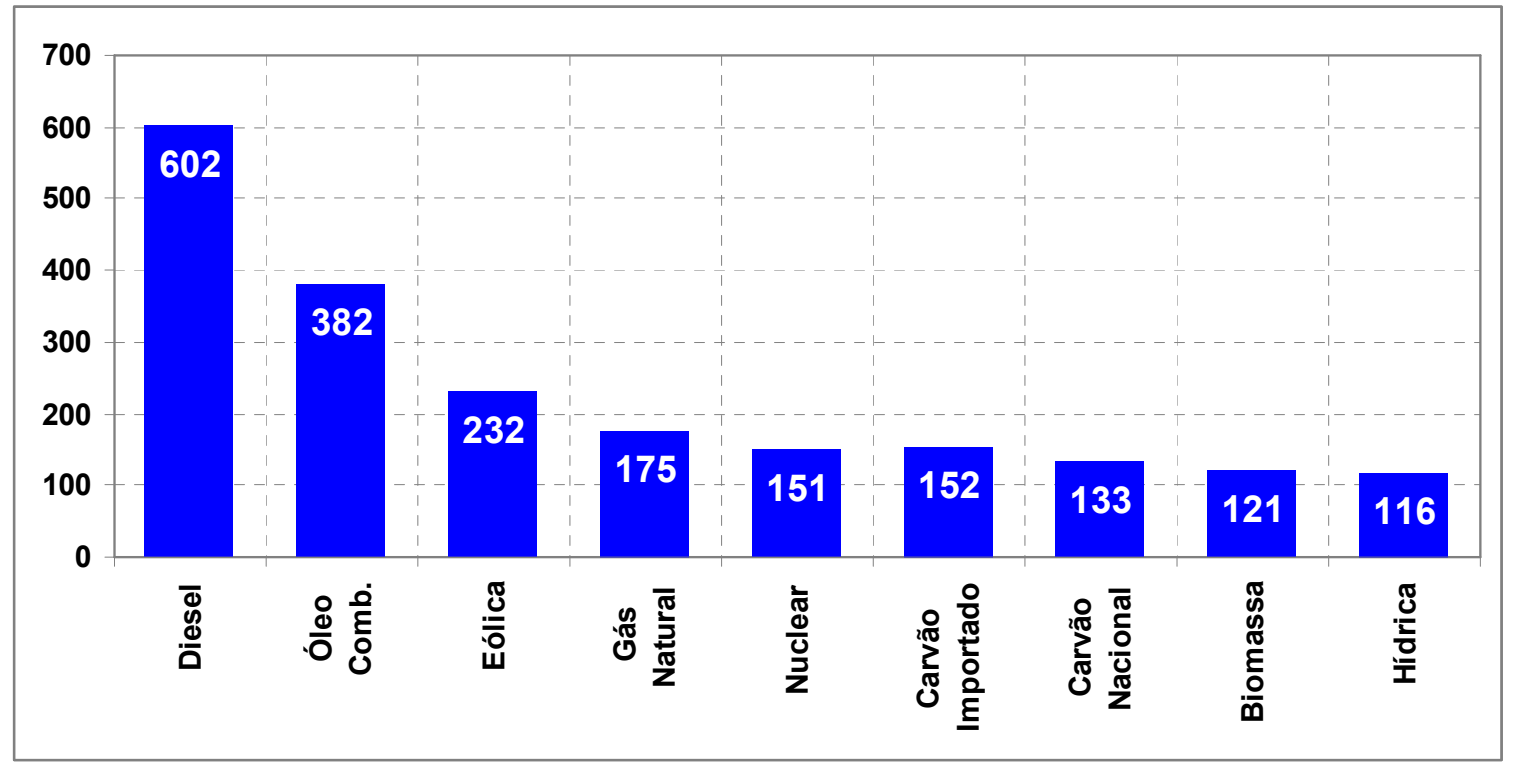

Figura 21 - Comparação dos custos médios de geração por fonte

Fonte: Energy Tax Fórum Brasil 2009 - Apresentação de Marcos Vinícius Gusmão no dia 19.05.2009 
Mesmo apresentando uma participação de $83 \%$ de fonte hídrica na matriz de geração de energia elétrica, o Brasil possui, em média, tarifas finais de energia elétrica superiores a dos Estados Unidos e França, que possuem matrizes energéticas baseada em geração térmica e nuclear, respectivamente. Este fato está relacionado, em parte, ao aumento dos impostos e encargos setoriais nas tarifas de energia elétrica, conforme abordado anteriormente nos Capítulo 2.5 e 2.4 .

A Figura 22 apresenta como evoluiu a participação dos encargos setoriais e tributos nas tarifas de energia no período de 2002 a 2007. Em 2007, a participação dos encargos setoriais e impostos nas tarifas de energia foi de $12 \%$ e $39 \%$, respectivamente, totalizando $51 \%$ da parcela da tarifa. Portanto, a maior parte da tarifa não está diretamente relacionada ao serviço de energia elétrica.

Ao mudar a base de cálculo colocando como referência a parcela relacionada de fato com o serviço energia elétrica, ou seja, $49 \%$, tem-se um pagamento adicional de 104\% sobre o que seria a remuneração pela prestação do serviço de energia elétrica e aquisição de energia. Em outras palavras, os encargos setoriais e tributos somam valor superior ao próprio valor da prestação do serviço de energia elétrica.

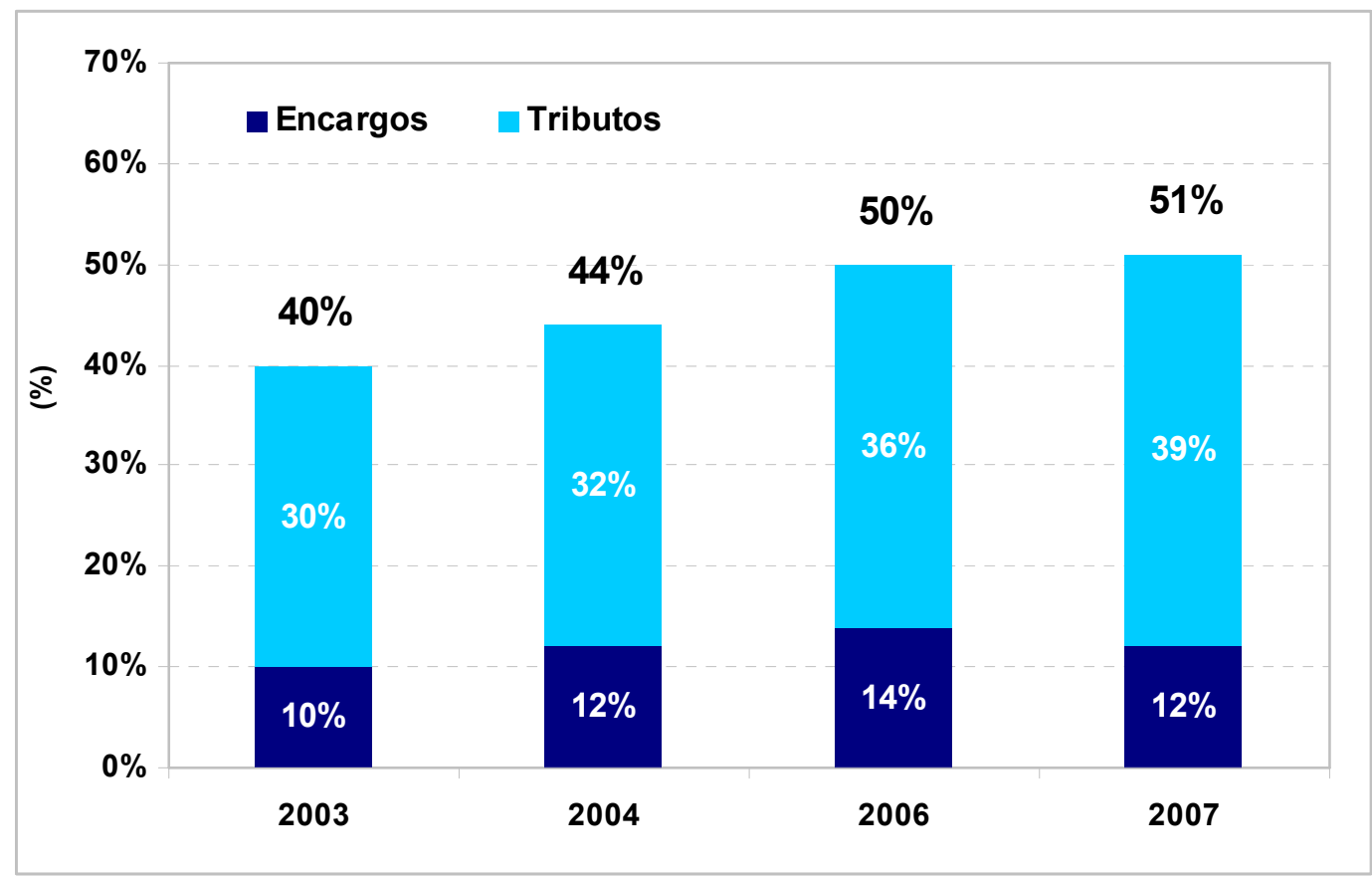

Figura 22 - Evolução da participação dos encargos e tributos como parte da tarifa de energia

Fonte: Estudo ABRACE com base em informações de Relatórios da Comissão de Valores Imobiliários - CVM, Eurostat; International Energy Agency - IEA. Gráfico apresentado pela ABRACE no Evento “Agenda Regulatória 2009”, promovido pelo Canal Energia em 11.05.2009. 
A carga tributária sobre a eletricidade no Brasil é bastante superior à de outros países, conforme pode ser observado na Tabela13. Este fato, em muitos casos, pode ocasionar a transferência de indústrias do Brasil para países onde os custos finais de energia são mais competitivos.

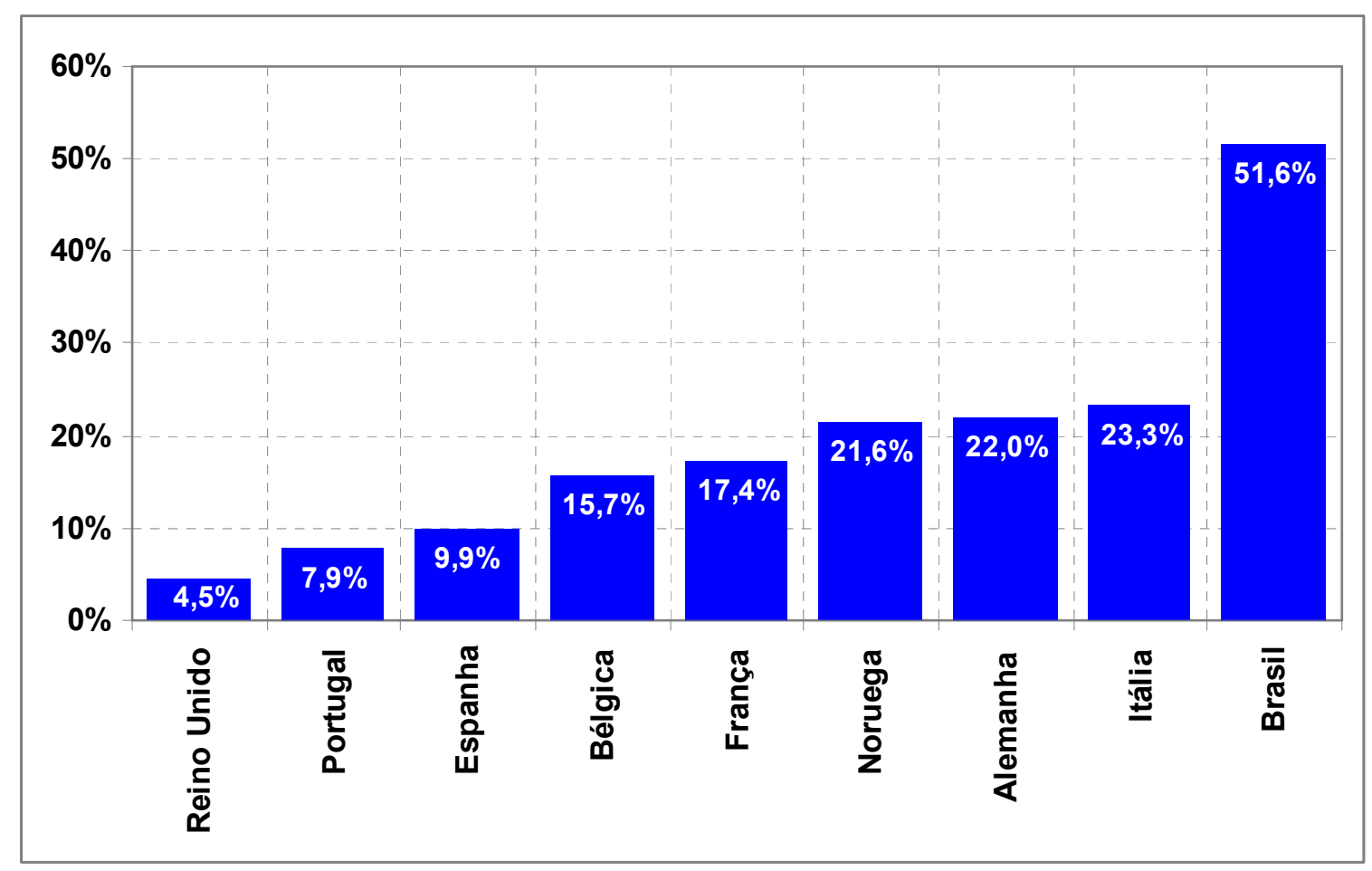

Tabela13 - Comparação da carga tributária tarifa final de energia elétrica de alguns países industrializados (Base 2007)

Fonte: Energy Tax Fórum Brasil 2009 - Apresentação de Marcos Vinícius Gusmão no dia 19.05.2009

Conforme pode ser observado na Figura 23 apresentada a seguir, a tarifa média final de energia elétrica do setor industrial do Brasil sofreu no período de 2002 a 2007 um aumento de 166\%, o que corresponde à uma taxa de crescimento anual composta de $21,6 \%$, percentual muito superior aos países analisados, como mostrado na Tabela 14. 


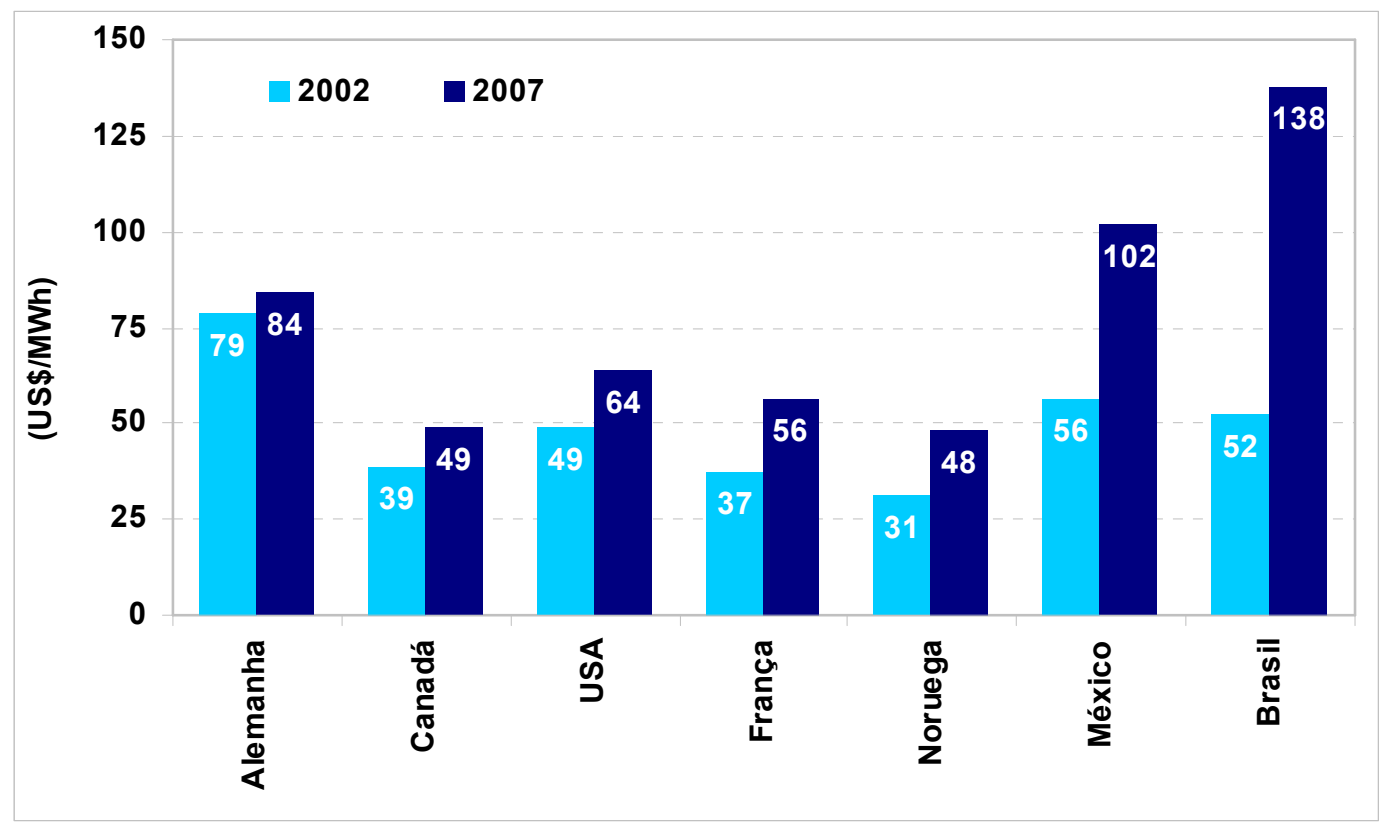

Figura 23 - Crescimento das tarifas finais de energia elétrica de 2002 a 2007 em alguns países Fonte: Estudo ABRACE com base em informações da EIA, IEA, ANEEL. Gráfico apresentado pela ABRACE no Evento “Agenda Regulatória 2009", promovido pelo Canal Energia em 11.05.2009.

Tabela 14 - Comparação da evolução das tarifas médias de energia elétrica do setor industrial de alguns países

\begin{tabular}{cccc}
\hline \multirow{2}{*}{ País } & \multicolumn{2}{c}{ Tarifa Média Industrial (US\$/MWh) } & Taxa de crescimento anual \\
\cline { 2 - 3 } composta
\end{tabular}

Fonte: Energy Tax Fórum Brasil 2009 - Informações apresentadas por Marcos Vinícius Gusmão no dia 19.05.2009 
O Brasil apresenta uma particularidade interessante que difere de alguns países desenvolvidos. De 2002 a 2007, a diferença relativa entre as tarifa médias do setor industrial e residencial vem diminuindo substancialmente.

$\mathrm{Na}$ Tabela 15 a seguir, são apresentados os valores das tarifas médias do setor industrial e residencial do Brasil e de alguns países industrializados em 2002 e 2007. Nota-se que de 2002 a 2007 a relação percentual entre a diferença de tarifa de energia elétrica industrial e residencial no Brasil passou de $27 \%$ para apenas $8 \%$, enquanto que em alguns países industrializadas a relação até aumentou. Entre os países industrializados estudados, o Canadá foi o que apresentou a maior redução na relação percentual das tarifas, passando de 35\% em 2002 para 27\% em 2007.

Tabela 15 - Comparação da evolução das tarifas médias industriais e residenciais de alguns países

\begin{tabular}{|c|c|c|c|c|c|c|}
\hline \multirow{2}{*}{ País } & \multicolumn{3}{|c|}{2002} & \multicolumn{3}{|c|}{2007} \\
\hline & Indust. & Resid. & $\begin{array}{c}\text { Relação } \\
\text { (Res-Ind)/Ind }\end{array}$ & Indust. & Resid. & $\begin{array}{c}\text { Relação } \\
\text { (Res-Ind)/Ind }\end{array}$ \\
\hline Alemanha & 79 & 167 & $52 \%$ & 84 & 212 & $60 \%$ \\
\hline Canadá & 39 & 60 & $35 \%$ & 49 & 68 & $27 \%$ \\
\hline USA & 49 & 84 & $42 \%$ & 64 & 106 & $40 \%$ \\
\hline França & 37 & 105 & $65 \%$ & 56 & 158 & $64 \%$ \\
\hline Noruega & 31 & 81 & $62 \%$ & 48 & 132 & $64 \%$ \\
\hline Brasil & 52 & 71 & $27 \%$ & 138 & 150 & $8 \%$ \\
\hline
\end{tabular}

Fonte: Energy Tax Fórum Brasil 2009 - Informações apresentadas por Marcos Vinícius Gusmão no dia 19.05.2009

Os números apresentados na Tabela 15 mostram que o Brasil está seguindo numa linha contrária a postura dos países desenvolvidos, nos quais as tarifas de energia elétrica do setor industrial são bem inferiores que as tarifas residenciais.

O fato de o Brasil ter em sua classe de consumidores residenciais com poder aquisitivo menor do que dos países desenvolvidos pode ser um dos fatores que explicam a redução gradativa na diferença entre as tarifas. 
Nos países desenvolvidos, os consumidores residenciais possuem um maior poder de compra e possuem condições de arcar com custos maiores de energia, inclusive para subsidiar a geração por meio de fontes alternativas, por exemplo. No Brasil, a tarifa de energia elétrica do setor industrial vem aumentando cada vez mais e se aproximando das tarifas residenciais.

A Figura 24 apresenta a composição do mercado de energia no Brasil, Estados Unidos e Alemanha. Nota-se que os Estados Unidos possui um mercado de consumidores residenciais de $35 \%$, enquanto que no Brasil este mercado representa $22 \%$. A Alemanha apresenta mercado industrial e residencial parecidos com os Brasil, porém, o poder aquisitivo da população alemã é muito superior ao Brasil.

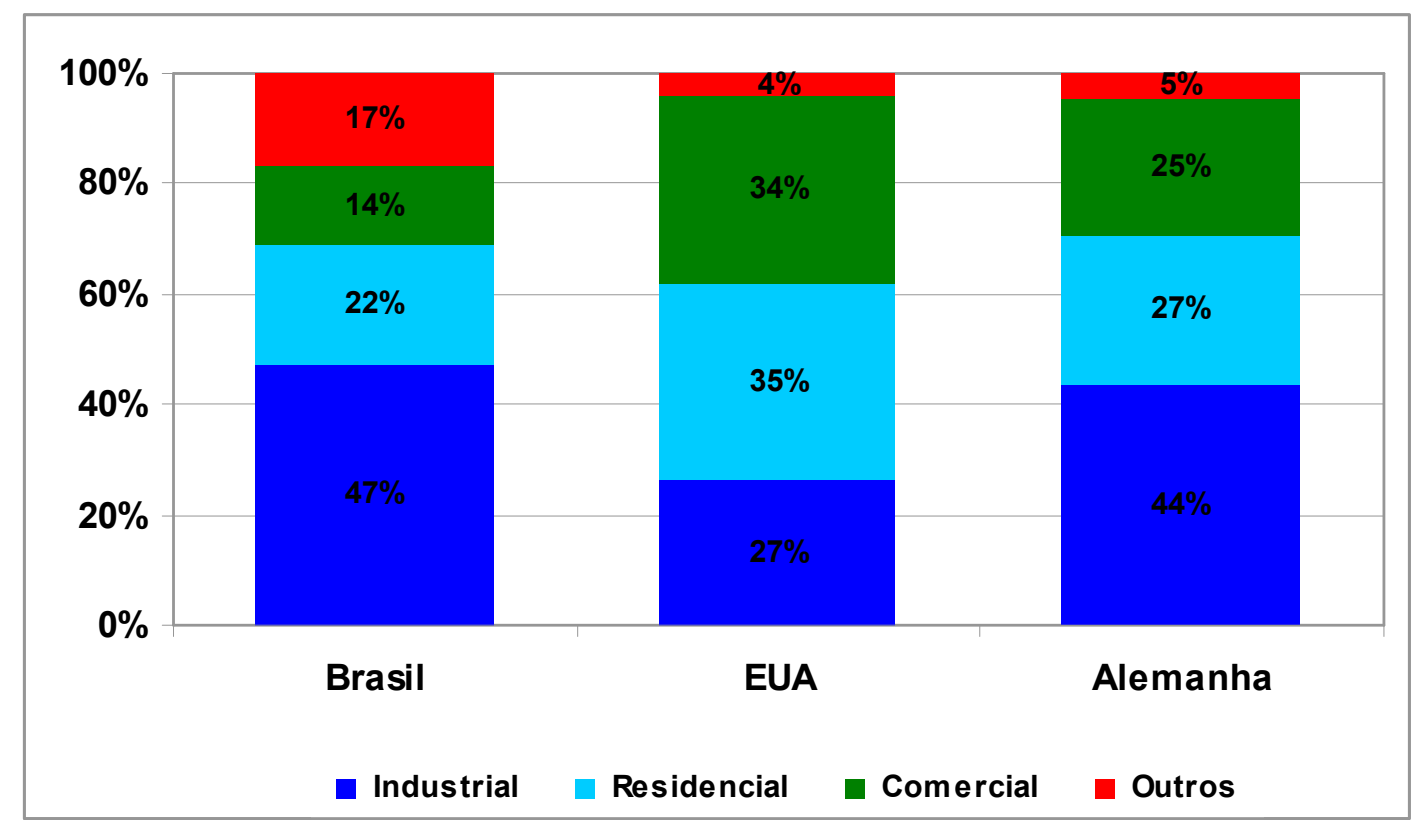

Figura 24 - Composição do mercado de energia elétrica do Brasil, Estados Unidos e Alemanha Fonte: EIA e EPE

A Tabela 16 seguinte apresenta uma análise do consumo de energia elétrica per capita do setor residencial e do PIB per capta do Brasil, Estados Unidos e Alemanha. Verifica-se que os Estados Unidos possui PIB per capta cerca de 5 vezes maior que o Brasil e consumo per capta de energia elétrico do setor residencial é 9,1 vezes maior.

A Alemanha, que possui participação parecida do setor industrial e residencial no mercado global de energia elétrica, o PIB per capta é 3,5 vezes maior que o Brasil e o consumo per capta de energia elétrica 3,4 vezes maior. Estas análises mostram 
que os consumidores residenciais dos países em desenvolvimento têm uma capacidade maior de absorver tarifas mais elevadas de energia elétrica.

Tabela 16 - Comparação dos aumentos das tarifas médias de energia elétrica do setor industrial de alguns países

\begin{tabular}{lcccc}
\cline { 3 - 5 } & & Brasil & EUA & Alemanha \\
\hline Mercado total & TWh & 390 & 3.814 & 526 \\
\hline População & $10^{6}$ hab. & 186 & 297 & 82 \\
\hline E.E. Residencial Per capta Mensal & kWh / hab/mês & 42 & 383 & 142 \\
\hline PIB Per capta (PPC / US\$ 2000) & US\$/hab/mês & 623 & 3.089 & 2.192 \\
\hline
\end{tabular}

Fonte: EIA / Key World Statstic (Ano Base 2006) / EPE (BEN 2008 / Ano Base 2007)

No Brasil a remuneração dos sistemas de distribuição é proporcional ao uso das redes elétricas e, portanto, a tarifa fio dos consumidores residenciais são maiores que de outros setores, uma vez que o serviço de distribuição residencial é feito em média e baixa tensão. Como a população do Brasil, em geral, possui baixo poder de compra, o setor industrial pode estar sendo onerado a fim de que as tarifas do setor residencial não atinjam valores muito elevados.

Transferir ao setor industrial parte dos custos da tarifa do setor residencial é uma forma prover à população energia elétrica mais barata, no entanto, esta política de subsídio deve ser analisada com bastante atenção, pois o encarecimento da tarifa da indústria pode prejudicar a competitividade deste setor e desestimular a atração de empresas ao país. Em alguns casos, acredita-se até ser possível o fechamento de plantas, principalmente as eletro-intensivas, em que os custos de energia elétrica contribuem com parcela significativa dos custos de produção, podendo atingir percentual da ordem de $60 \%$.

É importante pensar no fato de que a atração de indústrias ao país ocasiona aumento na geração de empregos, o que, conseqüentemente, gera um aumento no poder aquisitivo da população que passa então a ter condições de arcar com preços de energia elétrica maiores. 


\section{4 - PRINCIPAIS BENEFÍCIOS INERENTES À FORMAÇÃO DE PÓLOS INDUSTRIAIS}

Um dos primeiros autores a estudar os fatores que levam à concentração de empresas numa determinada região foi Marshall (1982), ao estudar os distritos industriais na Grã-Bretanha. Marshall observou que a concentração de empresas de negócios similares em localidades específicas fazem com que as mesmas se tornem mais eficientes e obtenham vantagens competitivas que individualmente não teriam. Os estudos de Marshall mostraram que a formação e a ampliação de redes de empresas industriais assumem uma dimensão estratégica no aumento da produtividade dos sistemas de produção locais e no fortalecimento da competitividade de cidades e regiões.

Após Marshall, outro importante autor sobre pólos foi Michael E. Porter (1990), que, aliás, é considerado um dos mais importantes estudiosos sobre o tema. Segundo Porter, a competição e cooperação entre empresas de um pólo são fatores essenciais ao desenvolvimento dos mesmos. Na visão de Porter, no mundo moderno a competição depende diretamente da produtividade, uma vez que o acesso à informação tornou-se muito facilitado a todos. Produtividade está relacionada na maneira que as empresas competem entre si e não nos campos em que elas competem.

Olímpio J. de Arroxelas Galvão (2000) ao estudar alguns casos de clusters em países industrializados conclui que "a idéia básica de Porter é que a vitalidade econômica de um setor é o resultado direto da competitividade de indústrias locais e que, num mundo globalizado, os indivíduos, as empresas, as regiões e o governo devem pensar globalmente, mas agir localmente". Segundo Galvão (2000) "essas idéias básicas trazem, como principal implicação, a de que o objetivo primordial a ser perseguido é o de criar, em cada local ou região, uma atmosfera favorável ao desenvolvimento de atividades econômicas, de modo a transformar essas regiões e locais em pólos dinâmicos de atração de novos investimentos e de inovação".

Porter estudou as características de pólos industriais de diversos países, dentre eles, Alemanha, Itália, Japão, Coréia, Cingapura, Suécia, Suíça, Reino Unido e Estados Unidos. Os estudos por Porter nos pólos da Dinamarca serviram de base empírica para formulação de sua teoria apresentada no livro "The Competitive Advantages of Nations", publicado em 1990. A Dinamarca é um país que possui uma 
política extremamente liberal em relação aos pólos industriais focando a questão energética, onde indústrias integrantes de pólos possuem liberdade para definir suas políticas sem interferências externas.

$\mathrm{Na}$ visão de Porter, os pólos promovem, ao mesmo tempo, a competição e cooperação entre seus integrantes, que são fatores fundamentais para que os pólos prosperem. Ao se desenvolverem, os pólos promovem não somente a competitividade entre suas empresas integrantes, mas também entre regiões e países, pois o pólo passa a ter vantagem competitiva em nível global.

As interações entre as empresas integrantes de um cluster, segundo Porter, podem ocorrer verticalmente, baseadas na relação comprador/fornecedor, como em cadeias produtivas completas, ou horizontalmente, entre concorrentes, clientes etc.

Goldstein e Toledo (2004) no trabalho "Vantagens Competitivas em Clusters Industriais", relatam as pesquisa de Piore e Sabel (1984, apud Bennet, 1994) que constataram o surgimento de aglomerações de empresas menores na Europa na década de 1970, especialmente na Itália, as quais foram denominadas distritos industriais. Esses distritos industriais concentrados em determinada cadeia produtiva despertaram a atenção de pesquisadores pela alta eficiência obtida por meio de especialização e pela forte relação entre seus integrantes.

A Europa tem diversas experiências bem sucedidas de políticas de incentivos a pólos utilizando-se várias iniciativas, tendo-se obtidos resultados animadores. A Europa hoje possui importante participação na economia mundial, indicando que o dinamismo da economia européia se deva, em grande parte, à existência de pólos industriais.

Goldstein e Toledo (2004) apresentam também conclusões de estudos de Schmitz e -Nadvi (1999, p.1508) sobre pólos industriais, que constataram que ao longo da história as empresas que aumentaram a cooperação apresentaram melhorias no seu desempenho.

A aglomeração de indústrias pode atrair serviços correlacionados à atividade principal do cluster. Goldstein e Toledo (2004) apresentam em seu trabalho "Competição e Cooperação em Clusters: Estágios e Políticas", a constatação de Dyer (1996, apud Hoffman e Molina, 2004) "de que o fato de os fornecedores estarem muito próximos às empresas, por se situarem geograficamente dentro ou perto do cluster, há um favorecimento do contato freqüente deles com as empresas. A partir do momento em que as empresas são agrupadas, naturalmente haverá uma 
mudança na relação comprador/fornecedor". Os fornecedores percebem que é vantajoso oferecer facilidades ao pólo e são estimulados a criarem filiais ou até mudarem suas instalações para a proximidade do pólo.

As empresas de um pólo têm maior facilidade de formar parcerias para terceirizar atividades e se concentrar no negócio principal, proporcionando uma administração mais enxuta. Essa prática leva a uma redução nos custos operacionais e uma vantagem competitiva nos custos finais dos produtos.

A cooperação entre as empresas de um pólo promovem a disseminação de informações, que consiste numa vantagem competitiva importante e que auxilia, por exemplo, na redução de custos e na descoberta de inovações tecnológicas. A cooperação entre empresas internas a um pólo com o propósito de aprendizagem e inovação é o que alguns autores chamaram de "eficiência coletiva ativa" (Goldstein e Toledo (2004).

Verifica-se claramente que cooperação e competição são fatores intrínsecos aos pólos industriais e que proporcionam vantagens substanciais às empresas.

A cooperação nos pólos pode ser verticalizada, onde há relação entre os processos produtivos das indústrias, ou seja, produtos de uma determinada indústria são usados como matérias primas ou insumos de outros processos industriais, como também horizontal, onde as empresas obtêm reduções de custos operacionais, devido ao uso compartilhamento de infra-estrutura e troca de conhecimentos.

A competição pode andar em conjunto com cooperação porque elas ocorrem em dimensões diferentes e entre diferentes agentes econômicos.

Os pólos podem afetar a competição por meio de três maneiras diferentes: (i) aumentando a produtividade das empresas; (ii) como vetor de inovação tecnológica; (iii) estimulando a formação de novos negócios, que fazem com que os pólos se fortaleçam ou novos pólos sejam criados.

O surgimento de um pólo ocasiona aumento na demanda por mão-de-obra qualificada e especializada, o que acaba gerando maior interesse dos governos em melhorar a educação da população local e também incentivar as empresas a investirem em cursos e treinamentos.

Além do crescimento econômico do país e maior geração de riquezas, os impactos da criação ou ampliação de pólos industriais geram efeitos regionais sobre a população. Estes efeitos compreendem a geração de empregos diretos e indiretos de alta qualidade, o incentivo a investimentos em educação e o aumento da 
arrecadação de impostos na região, que são posteriormente revertidos em benefícios à sociedade.

Os pólos industriais proporcionam também vantagens ambientais, uma vez que resíduos de um determinado processo industrial pode ser usado em processo de indústrias vizinhas. Há também maior interesse na reciclagem de materiais, dado que o volume produzido em conjunto pelas indústrias passa a ser significativo o suficiente para atrair empresas interessadas em instalar plantas de reciclagem de papel, plástico e outros.

A participação do governo é fator fundamental no desenvolvimento de pólos industriais. Goldstein e Toledo (2004) inclusive citam Bennet (1994, p.14/15) como um dos que defendia a participação do governo no incentivo aos pólos. Como exemplo Bennet usa os casos do Japão, América do Norte e Europa, onde os "governos regionais e locais deram ativo suporte aos seus distritos industriais, com uma variedade de serviços de infra-estrutura e de negócios".

Verifica-se que importantes estudiosos sobre o tema de pólos industriais, ou clusters, identificaram vantagens significativas inerentes a formação dos mesmos, não só para as empresas, como também para a sociedade.

Estas vantagens são ratificadas pela ABRACE eu seu documento "Pólos Industriais: uma ferramenta para o desenvolvimento" (2008), onde esta associação apresenta seus argumentos em defesa de incentivos para formação de pólos industriais no Brasil.

A Tabela 17 resume algumas das vantagens, reconhecidas pela ABRACE, que os pólos podem proporcionar tanto para a sociedade quanto para as empresas. 
Tabela 17 - Benefícios que os pólos industriais podem proporcionar à sociedade e às empresas

\section{Benefícios que os pólos industriais podem proporcionar à sociedade}

\begin{tabular}{|c|c|}
\hline Geração de empregos & $\begin{array}{l}\text { - Os pólos propiciam a geração de empregos diretos e de alta qualidade, } \\
\text { devido aos níveis de remuneração pagos e à qualificação dos funcionários. } \\
\text { - Aumento do número de empregos indiretos devido à atração de população } \\
\text { para a região e ao desenvolvimento da infra-estrutura necessária ao } \\
\text { funcionamento do pólo industrial. }\end{array}$ \\
\hline $\begin{array}{l}\text { Educação e qualificação } \\
\text { da mão-de-obra }\end{array}$ & $\begin{array}{l}\text { - Investimentos diretos em educação para qualificação da mão-de-obra } \\
\text { necessária às empresas dos pólos industriais. } \\
\text { - Parcerias com associações de classe para formação de pessoal } \\
\text { qualificado, com investimentos e benefícios duradouros. } \\
\text { - Projetos sociais ligados à educação básica das populações localizadas na } \\
\text { região, como é observado em pólos industriais já existentes. }\end{array}$ \\
\hline Arrecadação de impostos & $\begin{array}{l}\text { - Aumento da arrecadação em conseqüência direta do aumento da atividade } \\
\text { econômica. } \\
\text { - Posterior conversão dos impostos arrecadados em benefícios à sociedade. }\end{array}$ \\
\hline
\end{tabular}

Benefícios que os pólos industriais podem proporcionar às empresas

\section{Compartilhamento da infra-estrutura}

- Os pólos atraem empresas por meio da oferta de bens e serviços essenciais ao seu funcionamento, como terrenos, energia elétrica, água, tratamento de efluentes, acesso a transporte;

- Esta infra-estrutura em geral é fornecida pelas grandes empresas do pólo ou por parcerias com o setor público.

\section{Ganhos de escala por meio do compartilhamento de insumos e serviços}

- Geração interna ou aquisição conjunta de energia, vapor, gases e água;

- Custos de manutenção divididos;

- Atração e treinamento de mão-de-obra.

\section{Sinergias operacionais, geralmente \\ obtidas por meio da integração}

- Logística: redução de custos devido à proximidade entre produtores e consumidores;

- Co-geração: subprodutos de alguns processos são insumo para outros;

- Desenvolvimento tecnológico e compartilhamento de informações e conhecimento.
Incentivos fiscais
- Muitos estados e municípios oferecem incentivos fiscais para a instalação de pólos industriais, visando a atrair os benefícios decorrentes deles.

- Normalmente, os incentivos são temporários e perduram até que os ganhos de escala se efetivem e o pólo se torne vantajoso para novas empresas.

Fonte: ABRACE - Pólos Industriais: uma ferramenta para o desenvolvimento (2008) 
Estes benefícios descritos na tabela anterior podem ser verificados na prática quando analisado o desenvolvimento regional de locais como Triunfo e Gravataí, no Rio Grande do Sul, onde se encontra instalado um pólo petroquímico e automotivo (liderado pela General Motors - GM), respectivamente, e em Camaçari, na Bahia, onde também há a presença de um pólo petroquímico e automotivo (liderado pela Ford). Estes locais foram substancialmente beneficiados com a atração de indústrias, as quase contribuíram para aumentar a geração de empregos e arrecadação de impostos, dentre outros benefícios. Em todos estes pólos há compartilhamento de infra-estrutura elétrica pelos integrantes do pólo.

O pólo industrial desde sua criação gera um processo de desenvolvimento contínuo sustentável, o qual é ilustrado na Figura 25.

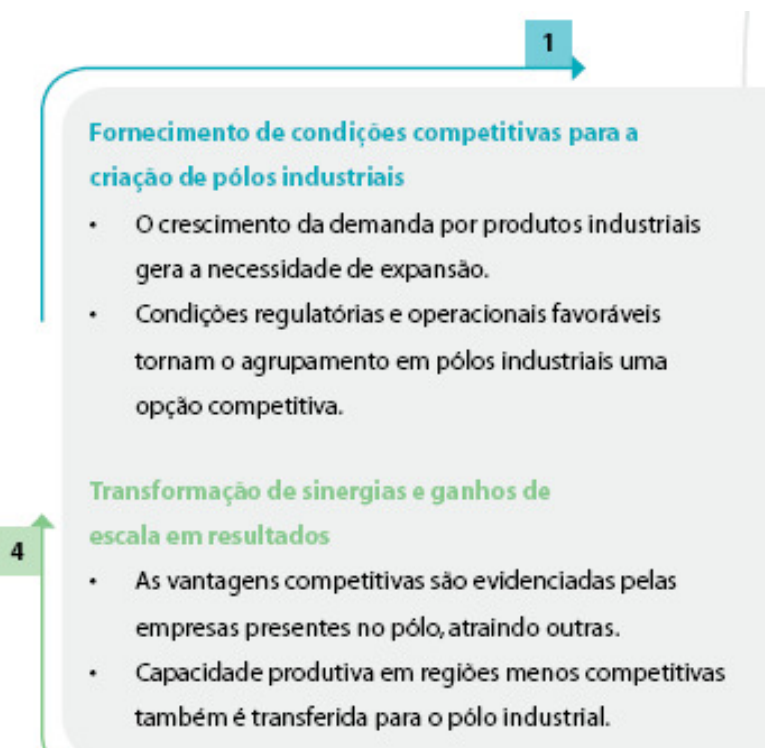

Criaçaào do pólo industrial com construçăo

de novas plantas

- Empresas săo atraídas para o pólo industrial pelo potencial de captura de vantagens competitivas.

- Parcerias entre o governo,empresas e outras entidades geram as condiçòes necessárias à criação do pólo.

Geraçāo de beneficios à sociedade

- A construçăo das indústrias e posteriormente a necessidade de måo-de-obra geram empregose desenvolvem a economia da regiào.

- Os impostos pagos pelas empresas do pólo sảo revertidos em beneficios à populaçào local.

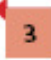

Figura 25 - Ciclo de desenvolvimento dos pólos industriais

Fonte: ABRACE - Pólos Industriais: uma ferramenta para o desenvolvimento (2008)

Para que os pólos industriais proporcionem vantagens competitivas é preciso que as políticas de desenvolvimento local sejam formuladas sob um enfoque sistêmico, levando em conta as características e demandas da região, procurando conhecer as potencialidades regionais, os problemas, interesses e necessidades das empresas locais e ao mesmo tempo, buscando conhecer outras experiências neste sentido para poder criar mecanismos de ajustes às características políticas, econômicas e sociais da região. 
Os pólos emergem em regiões que promovem vantagens específicas às empresas como forma de atraí-las e políticas de governo têm influência significativa no desenvolvimento dos mesmos.

Facilitar o processo de formação de pólos industriais, por meio de incentivos a sua formação, caracteriza-se como atribuição fundamental para os governos. Governos podem, e devem, direcionar o desenvolvimento de pólos industriais, particularmente promovendo ambiente apropriado, tais como, educação, financiamentos, competição e regulação.

Em geral, as políticas públicas de incentivos a formação de pólos industriais se baseiam em investimentos diretos e linhas de financiamento especiais às empresas. A participação do governo na expansão de infra-estruturas, como construção de rodovias e linhas de transmissão, para alcançar o raio de atuação dos pólos industriais é fundamental para auxiliar na competitividade das empresas.

Esta prática é muito comum em alguns países, sendo observados exemplos em que a infra-estrutura básica do pólo industrial é construída pelo governo e disponibilizada a empresas interessadas com valores inferiores aos investimentos realizados, visando fomentar a criação de novas empresas. Estas práticas são observadas principalmente em países mais desenvolvidos, nos quais o governo possui recursos disponíveis para estes tipos de investimentos.

No Brasil, onde a capacidade de investimento dos governos é menor que dos países desenvolvidos, soluções criativas de incentivos aos pólos industriais devem ser investigadas. A prática mais comum no Brasil foca a redução ou até isenção de tributos.

Uma forma inovadora seria a implantação de mecanismos de tratamento diferenciados visando ganhos de produtividade mediante reduções nos custos operacionais, o que pode ser efetuado por meio tratamento especial a determinados grupos de consumidores ou por meio da criação de tarifas e encargos diferenciados. Esta última alternativa, inclusive, é verificada em países como Dinamarca, EUA e Canadá, onde as indústrias possuem condições especiais para acesso à infraestrutura, conforme descrito no Capítulo 5. 


\section{5 - POLÍTICAS INTERNACIONAIS DE SUPRIMENTO ENERGÉTICO A PÓLOS INDUSTRIAIS}

No capítulo anterior, foram apresentadas as diversas vantagens inerentes à formação de pólos industriais, identificadas em função de estudos de importantes autores que pesquisaram casos de sucessos em diversos países.

No presente capítulo, são apresentados casos internacionais nos quais políticas de incentivos a pólos industriais envolvendo a questão energética foram adotadas, tendo-se obtido resultados importantes.

As informações aqui apresentadas tomaram como base os estudos desenvolvidos pela ABRACE, que teve como um de seus objetivos analisar os aspectos energéticos de pólos industriais. A utilização, nesta dissertação, dos estudos desenvolvidos pela ABRACE foi autorizada pelo seu Presidente Executivo, Dr. Ricardo Lima.

Vários países vêm utilizando políticas de incentivo à criação de pólos industriais não só como forma de incentivo à indústria, mas também com forma de fomentar o desenvolvimento em determinadas regiões. Diversas políticas de incentivo vêm sendo aplicadas há mais de vinte e cinco anos em muitos países e novas iniciativas de fomento estão sendo implementadas continuamente.

Nos EUA a regulamentação do sistema elétrico é determinada em grande parte pelos Estados. Em Novo México e Wisconsin, por exemplo, aos pólos industriais são oferecidas tarifas diferenciadas como forma de atrair empresas. No Texas, importantes incentivos são dados às empresas para viabilizar iniciativas conjuntas de co-geração e autoprodução. Dentre estes incentivos, destaca-se a isenção de encargos setoriais sobre a energia gerada e consumida internamente nos pólos.

A Figura 26 a seguir apresenta o mapa da distribuição de pólos industriais nos EUA. 


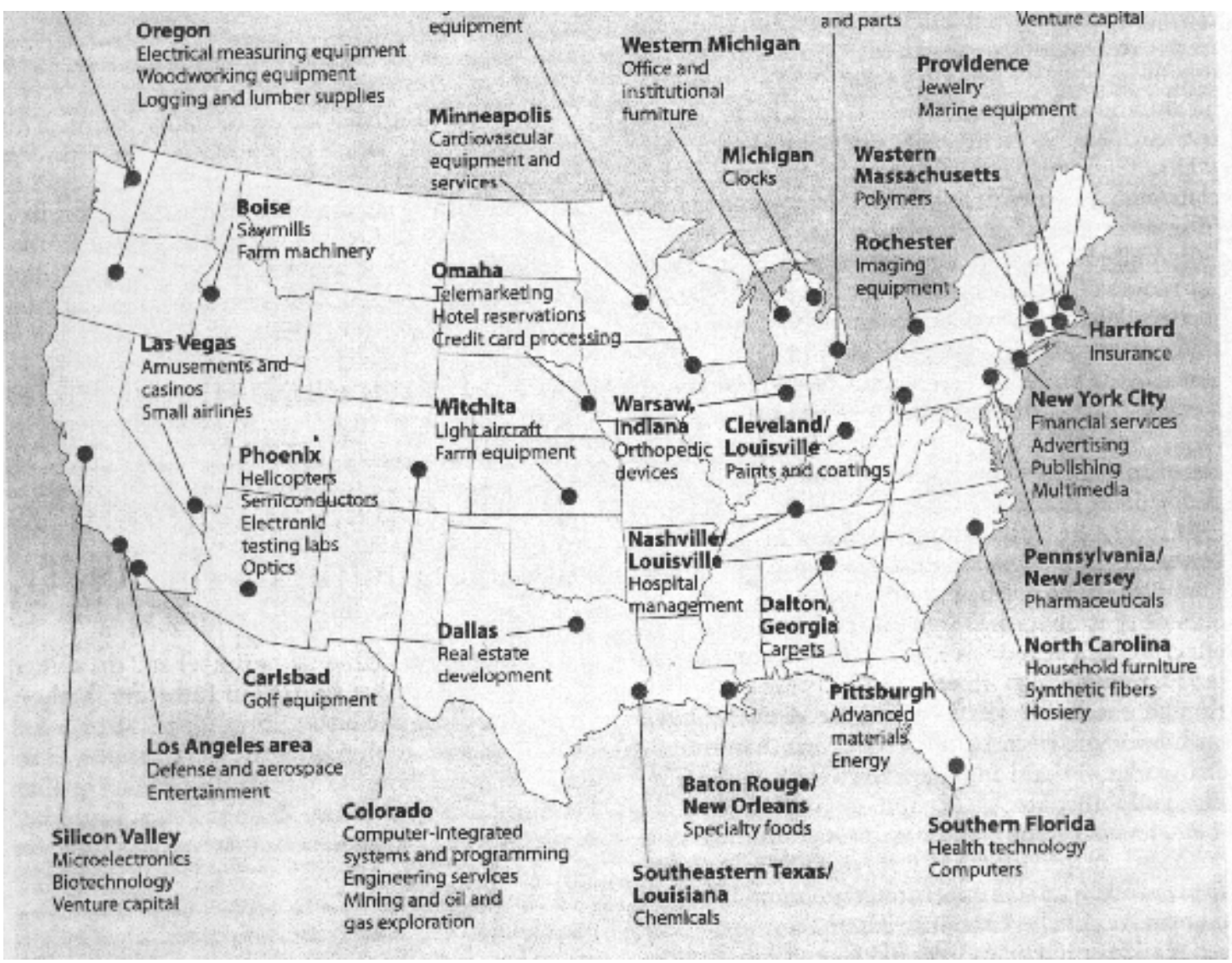

Figura 26 - Mapa de pólos industriais nos EUA

Fonte: Porter, Michael E.; "Clusters and the new economics of competition"; Harvard Business Review; Boston, 1998

Outro exemplo importante pode ser observado no Canadá, onde a regulamentação é flexível e permite a criação de "ecossistemas industriais", que são pólos industriais que compartilham uma serie de recursos e infra-estrutura, inclusive energia. Nestes sistemas, é permitida a aquisição conjunta de insumos e repasses internos entre duas ou mais empresas, havendo ou não co-geração envolvida.

Conforme já apresentado no capítulo anterior, na Europa o agrupamento de indústria sob a forma de pólos ocorre freqüentemente. Neste continente, os governos locais têm implantado uma série de políticas de fomento à criação de pólos industriais em países como Dinamarca, Reino Unido, Portugal, Alemanha e Noruega, muitas delas por meio de incentivos ao compartilhamento de infra-estrutura e a iniciativas de cogeração de energia.

$\mathrm{Na}$ Dinamarca, as indústrias desenvolveram redes de interação baseadas principalmente no compartilhamento de insumos e infra-estruturas, conhecidas no país como "simbiose industrial". A título de exemplo, no pólo industrial de 
Kalundundborg ocorre o agrupamento de uma refinaria, uma geradora de energia, uma fábrica de gesso e uma indústria farmacêutica (de diferentes proprietários), os quais compartilham poços artesianos, fornecimento externo de água, tratamento de rejeitos, vapor combustíveis, e principalmente subprodutos de seus processos internos. A energia elétrica gerada internamente pela planta de geração é utilizada pelas indústrias do pólo, não havendo interações com o sistema externo. Cabe destacar que a legislação da Dinamarca permite o compartilhamento e repasse interno de energia e outros insumos entre as empresas do pólo, bem como compartilhamento de custos de manutenção e ampliações. Estas transações são realizadas sem a interferência de agentes externos, sendo de total responsabilidade dos pólos industriais.

No Reino Unido, os incentivos a formação de pólos industriais iniciados em 1999 foram alinhados a iniciativas para aumento da capacidade de geração no país e do uso eficiente de energia. O governo tem incentivado o compartilhamento de energia através de duas modalidades principais:

- Fontes de geração distribuídas, onde grupos de empresas localizadas em pólos industriais têm incentivos ao compartilhamento de fontes de geração locais, sem necessidade de comercialização junto ao sistema centralizado. Quando estas redes locais utilizam apenas infra-estrutura privada, sem exportar energia para o sistema, as isenções de licenças e encargos são praticamente totais;

- Medidas de suporte a projetos de cogeração com benefícios como isenção de encargos, concessão de credito subsidiado para aquisição de subestações e outros equipamentos e redução de impostos.

Em Portugal, um programa de governo promove incentivo a pólos industriais para investimentos em cogeração de energia e a regulamentação fornece aos pólos industriais condições flexíveis para compartilhamento de energia, tais como tarifas diferenciadas e isenção ou redução de impostos e encargos sobre energia adquirida pelo pólo, bem como garantia de tarifas mínimas para a venda, ao sistema elétrico, de energia excedente gerada.

A Figura 27 a seguir apresenta o mapa da distribuição de pólos industriais em Portugal. 


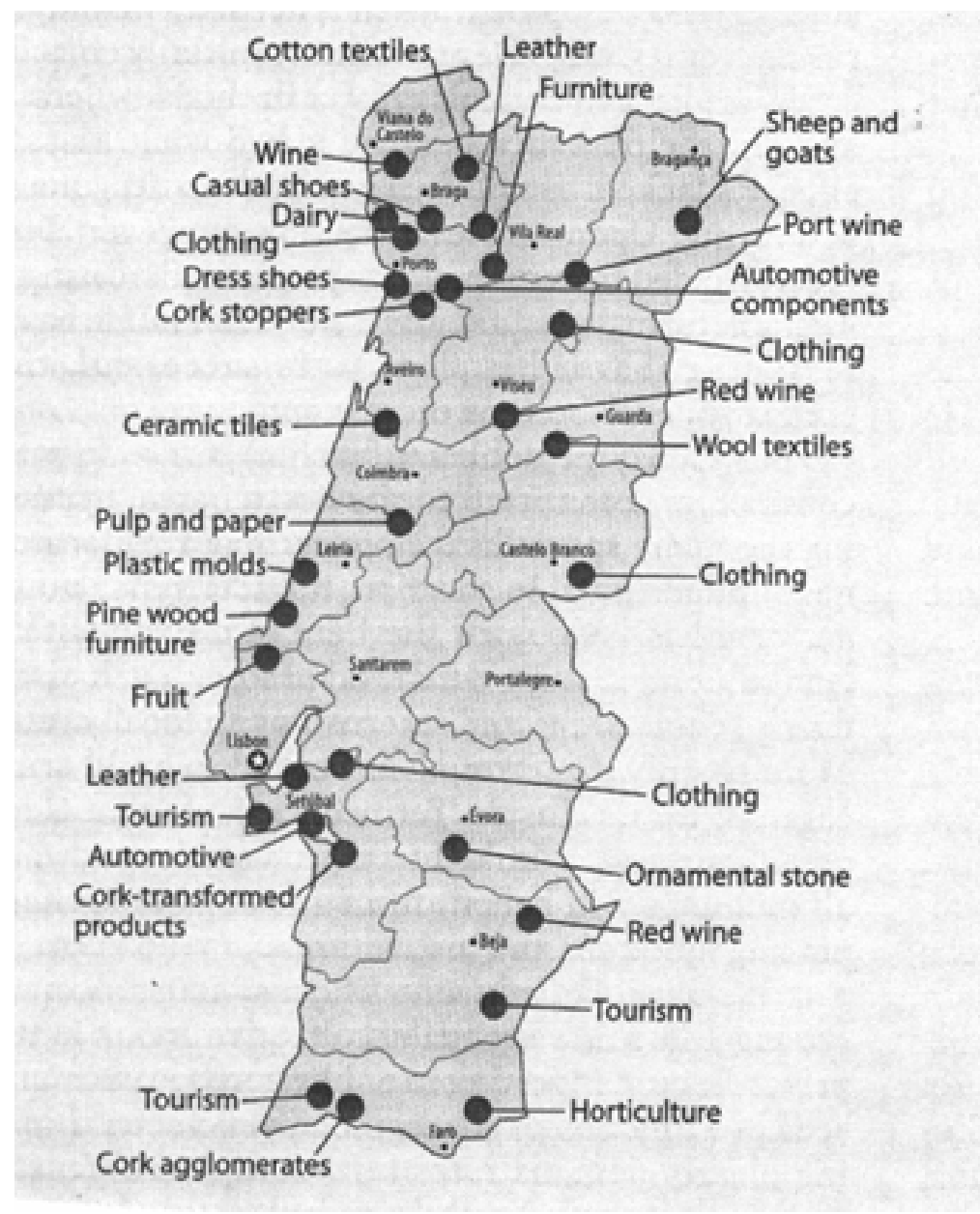

Figura 27- Mapa de pólos industriais em Portugal

Fonte: Porter, Michael E.; "Clusters and the new economics of competition"; Harvard Business Review; Boston, 1998

Na Ásia, os estudos da ABRACE observaram a adoção de modelo de "pólos ecoindustriais", que visam ao desenvolvimento industrial de forma sustentável, principalmente em países como Índia, Tailândia, Vietnam e Japão, onde este modelo tem se tornado uma tendência cada vez mais discutida, sendo que algumas definições incluem o compartilhamento eficiente de energia, matérias-primas e água como características essenciais à criação de novos pólos. 


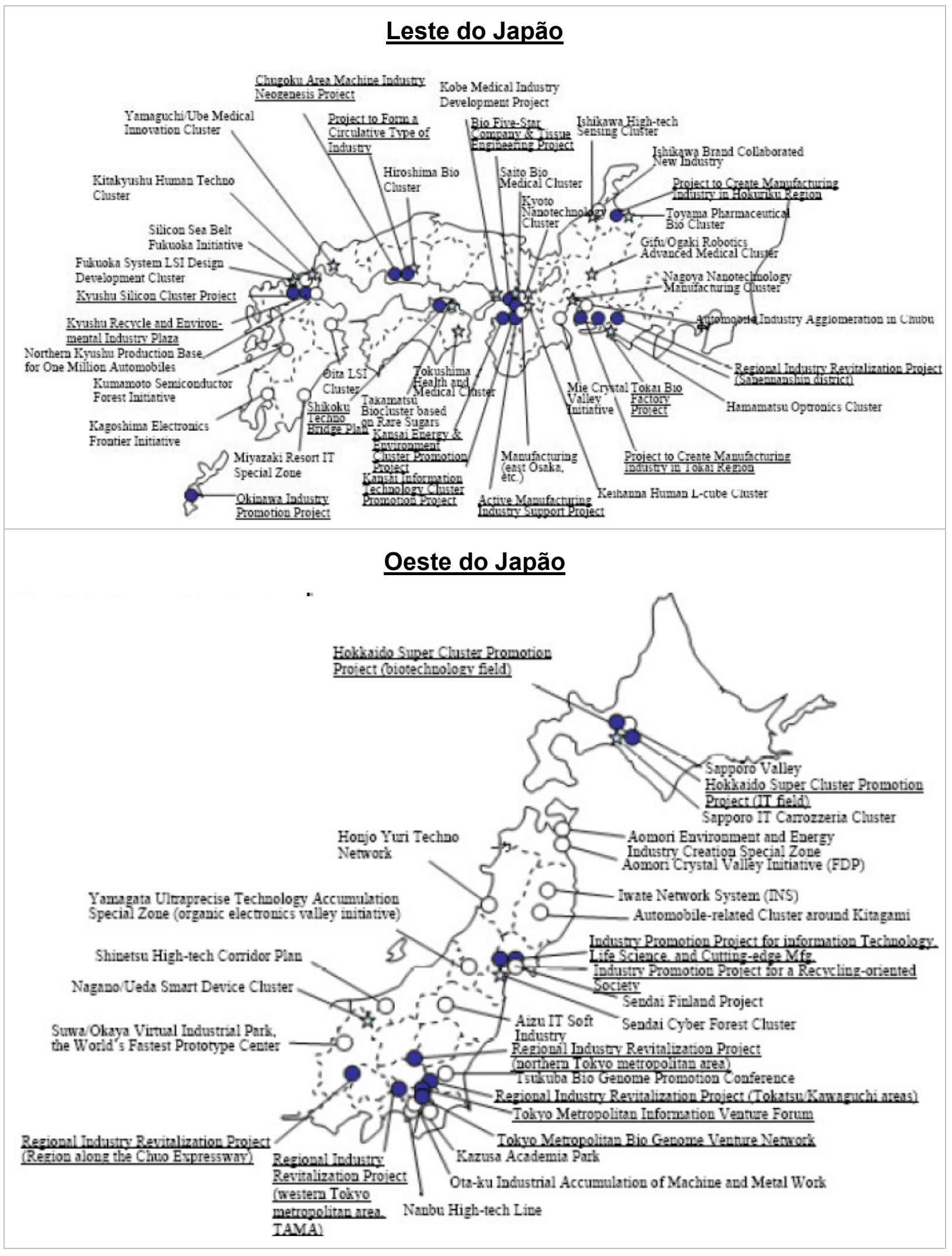

Figura 28 - Mapa de pólos industriais no Japão

Fonte: ABRACE, 2008 


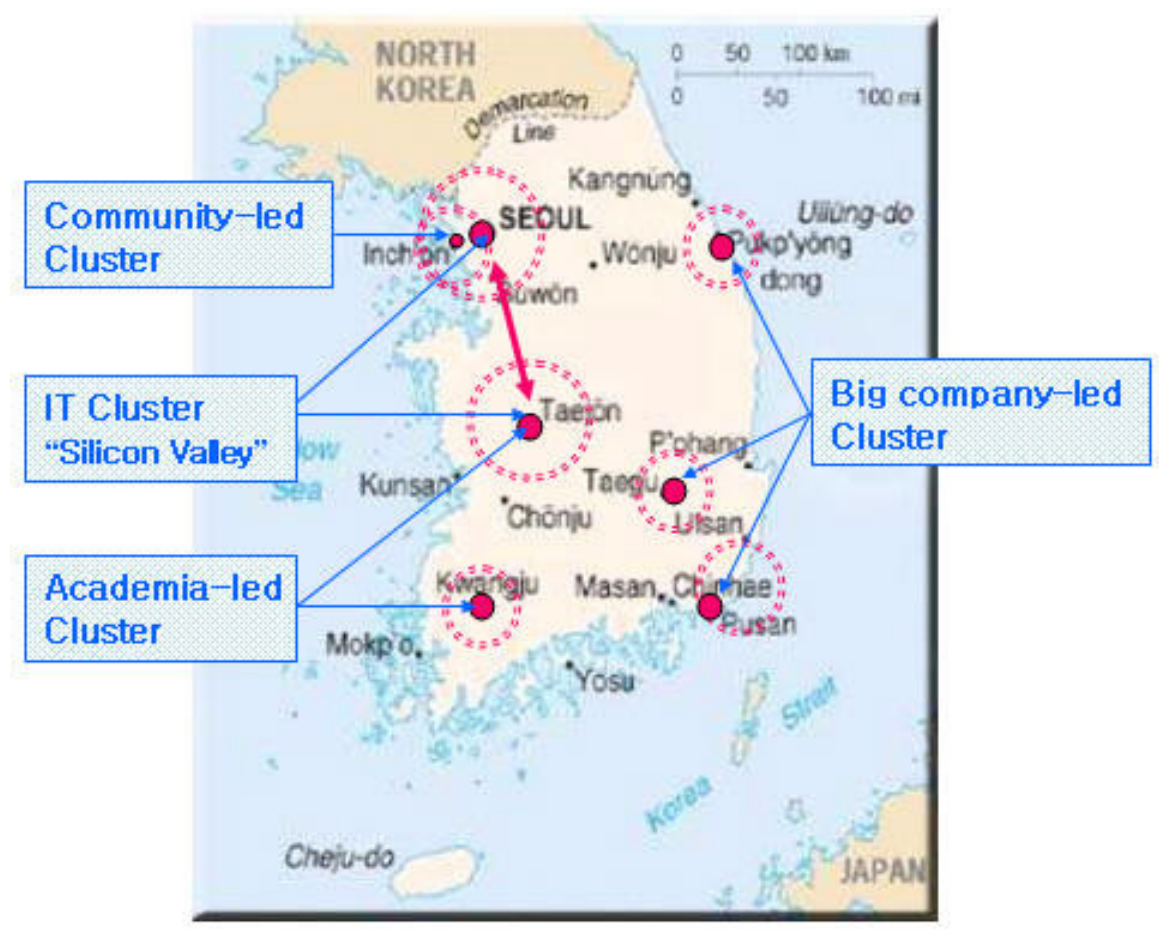

Figura 29 - Mapa de pólos industriais na Coréia do Sul

Fonte: Internet (http://www1.american.edu/initeb/hp2566a/IT\%20Geographic/new_page_3.htm)

$\mathrm{Na}$ China, por exemplo, diversas iniciativas de fomento à criação de pólos industriais com incentivos do governo central e de governos locais são verificadas. No pólo industrial de Guangzhou a construção da infra-estrutura básica foi realizada através de parcerias entre o governo e grandes montadoras de automóveis japonesas. Este pólo foi desenvolvido através da atração destas empresas-líderes, que receberam subsídios e isenções fiscais para se estabelecerem na região, atraindo outras indústrias menores. No caso citado, a infra-estrutura básica (incluindo estradas, estações de fornecimento de água e tratamento de efluentes, redes de energia, subestações e transformadores) é compartilhada pelas empresas do pólo e gerenciada pelo pólo industrial. O pólo também contém infra-estrutura compartilhada de hotéis e restaurantes, considerados integrantes do pólo e usufruindo dos mesmos benefícios e acesso à infra-estrutura básica. Adicionalmente, iniciativas de fomento à co-geração, similares às encontradas em alguns países europeus, também tem sido utilizadas pelo governo chinês como forma de incentivo ao aumento da geração de energia, promovendo a construção de infra-estrutura de geração e o compartilhamento da mesma entra as empresas de pólos industriais. 
Nas Filipinas, regras específicas para redistribuição de energia elétrica foram criadas, permitindo casos particulares de compartilhamento de infra-estrutura. Segundo esta regulamentação, um usuário final tem permissão para redistribuir serviços de energia elétrica e repassar aos demais consumidores do pólo os custos relacionados ao consumo de energia elétrica, tais como perdas elétricas internas, O\&M das redes e transformadores, dentre outros.

A análise de casos de pólos em outros países mostra que países que já atingiram patamares mais avançados de desenvolvimento continuam ativos em suas políticas de fomento à criação e ao crescimento de pólos industriais. Verifica-se também que a estratégia de obter desenvolvimento econômico por meio de agrupamentos industriais não é utilizada apenas por países desenvolvidos e exemplos com impactos significativos podem ser encontrados também em países em desenvolvimento. Independentemente do país, o foco recorrente na atração de empresas de setores considerados estratégicos para formação de pólos industriais foi, e ainda é, utilizado como parte fundamental de uma política de desenvolvimento, trazendo resultados positivos.

A Figura 30 apresenta um quadro resumo das principais políticas de incentivos envolvendo a questão energética aplicadas nos Estados Unidos, Canadá, Europa e Ásia. 


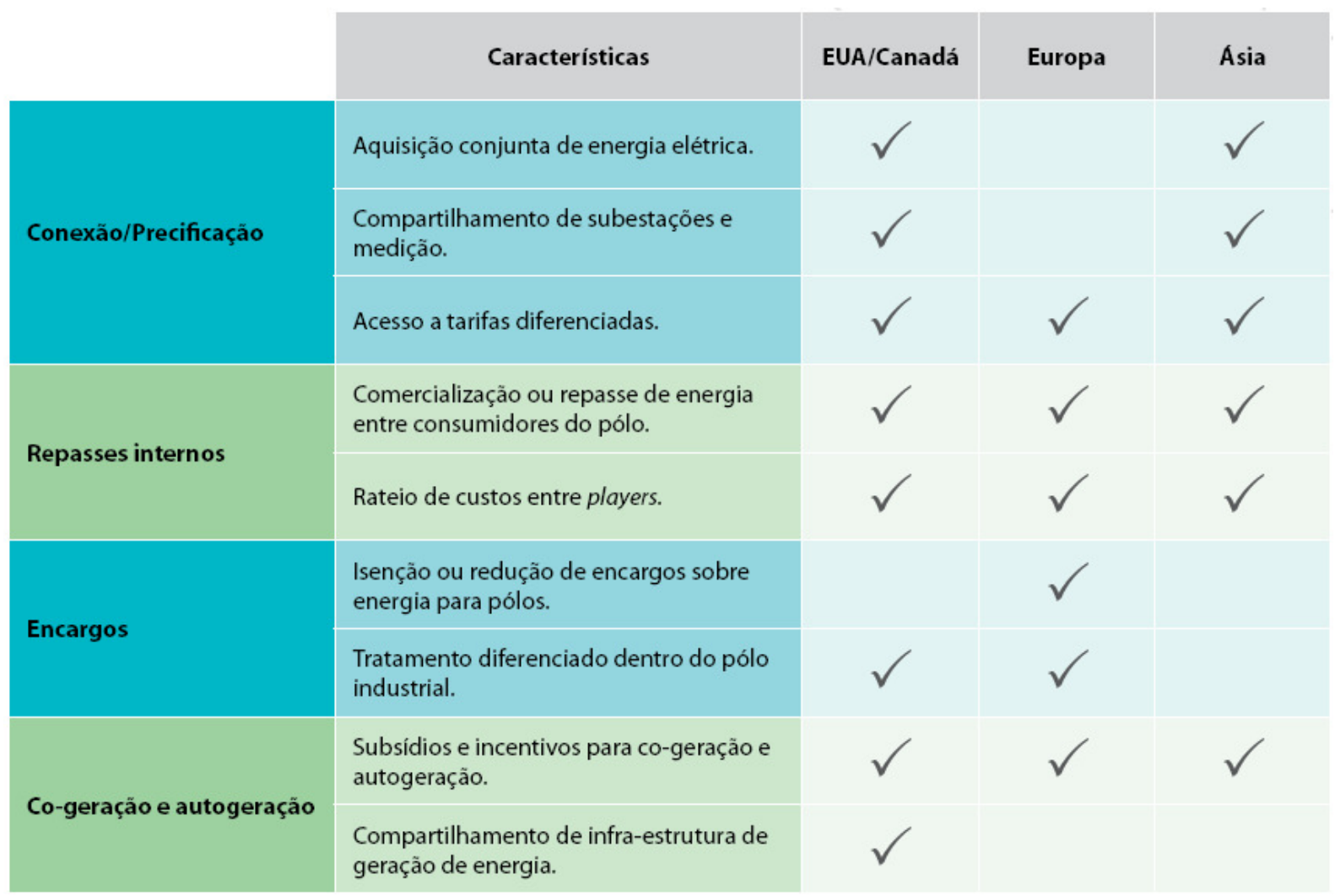

Figura 30 - Resumo de algumas políticas de incentivos à pólos industriais nos Estados Unidos, Canadá, Europa e Ásia

Fonte: ABRACE - Pólos Industriais: uma ferramenta para o desenvolvimento (2008)

As experiências internacionais de incentivos a pólos industriais envolvendo a questão energética mostram que existem diversas oportunidades que poderiam ser aproveitadas Brasil para fomentar o desenvolvimento dos pólos industriais atualmente em operação, bem como para promover a criação de novos pólos. 


\section{6 - SUPRIMENTO DE ENERGIA ELÉTRICA AOS PÓLOS INDUSTRIAIS BRASILEIROS}

No capítulo anterior foram apresentados casos de sucesso internacionais de aplicação de incentivos à formação de pólos industriais envolvendo a questão energética. Verificou-se que as políticas de incentivos variam conforme as necessidades de cada país, entretanto, nota-se que a função principal das políticas visa sempre ao encontro do desenvolvimento do país.

Para que uma regulamentação que aborde a questão energética de pólos industriais seja criada no Brasil, é extremamente importante conhecer as características dos pólos industriais em operação no Brasil, para que a competitividade dos mesmos seja preservada.

Atualmente, existem no país diversos sites em que duas ou mais indústrias compartilham infra-estrutura elétrica, entretanto, a legislação do setor elétrico não possui instrumentos que regulem estes casos, o que acaba gerando os aqui denominados "vácuos regulatórios".

Cabe ressaltar que o termo pólo industrial não é utilizado aqui exatamente da forma tradicional como estudados por importantes autores, como Porter (1990), que define um pólo industrial ou "cluster" como sendo a concentração de empresas relacionadas entre si, numa zona geográfica definida. O termo pólo industrial é abordado nesta dissertação referindo-se ao agrupamento de indústrias que de alguma forma compartilham infra-estrutura energética e, em especial, de energia elétrica. Assim, segundo esta definição, um site onde duas indústrias compartilhem uma subestação transformadora poderia ser considerado como um pólo industrial.

Outras denominações poderiam ser abordadas, como complexos industriais ou condomínios industriais. A denominação complexo industrial traz consigo uma idéia de inter-relação entre processos produtivos, enquanto condomínios industriais remete à um conceito de co-propriedade de terrenos, Assim, nesta dissertação optou-se pela denominação pólos industriais, que pode ser usada de forma mais abrangente, permitindo que duas ou mais indústrias compartilhem infra-estrutura elétrica mesmo não havendo qualquer relação entre seus processos produtivos. $O$ nome Pólos industriais também foi a terminologia adotada pela ABRACE em sua proposta de regulamentação sobre o assunto em pauta. 
Esta dissertação apresenta um enfoque sobre o suprimento de energia elétrica, não sendo abordados outros insumos energéticos como gás natural ou vapor. Isto porque o setor elétrico é o que apresenta uma legislação mais avançada, com maior complexidade e com diversas instituições já estabelecidas, como ANEEL, ONS, EPE, CCEE. Esta estrutura mais avançada e complexa do setor elétrico acaba gerando interpretações divergentes sobre um mesmo tema (neste caso sobre pólos industriais), o que não ocorre com outros insumos energéticos.

A maior parte dos pólos industriais existentes que compartilham infra-estrutura elétrica foi formada antes da estruturação do novo modelo do setor elétrico, que se iniciou em meados da década de 90.

Muitos pólos industriais hoje em operação no Brasil se formaram após reestruturações societárias, onde, por exemplo, partes de processo produtivo de uma indústria é vendida a outras empresas. Como exemplo deste tipo de formação de pólos industriais, a Figura 31 a seguir ilustra um esquemático de um site em operação no Brasil que no passado chegou a se configurar como um pólo industrial. O símbolo " $X$ " representa o término das operações da empresa, enquanto as setas indicam os processos de fusões/aquisições ou desmembramento de empresas. Atualmente, todas as unidades industriais em operação pertencem a uma única empresa e não há mais um pólo industrial como definido nesta dissertação. Entretanto, como pode ser observado na figura, este site no passado chegou a ter cinco diferentes indústrias, as quais compartilhavam infra-estrutura elétrica, enquanto que para o sistema elétrico apenas uma empresa era vista.

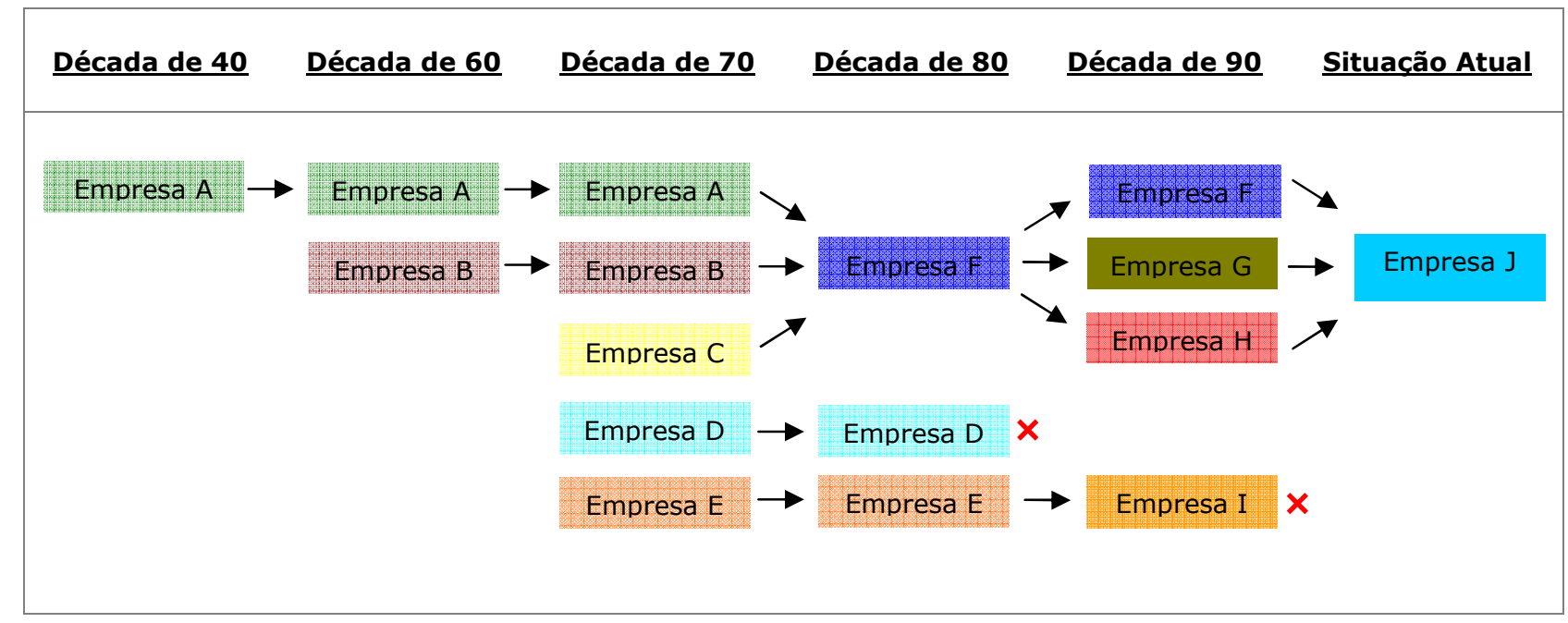

Figura 31 - Esquemático de reestruturações societárias de um caso específico 
Reestruturações societárias no Brasil são comuns e podem acontecer com uma rapidez impressionante. Mudar a estrutura física de um site para adequar a legislação a cada vez que ocorra uma incorporação ou desmembramento de empresa não é uma medida coerente. Mais plausível é a criação de uma regulamentação que aborde a questão de suprimento elétrico em pólos industriais, abrangendo a diversidade de casos existentes, bem como prevendo possíveis arranjos para os novos pólos industriais, garantindo assim segurança regulatória às empresas.

Dada a diversidade dos casos de pólos industriais e a falta de regulamentação no setor elétrico sobre o tema, os agentes do setor elétrico, nestes incluídos ANEEL, Distribuidoras e Agências Estaduais, adotam posturas diferenciadas para fiscalizar os pólos em operação.

É sabido que a ANEEL tem conhecimento que existem diferenças relevantes na questão elétrica de pólos industriais em operação no Brasil e já manifestou interesse em iniciar estudos para regulamentação em regular o tema. Em passado recente, a ANEEL enviou a diversas empresas um questionário solicitando informações relacionadas aos principais fatores de diferenciação dos pólos, o qual se encontra no ANEXO E. O questionário criado pela ANEEL foi adotado como base para um trabalho desenvolvido pela ABRACE que buscou identificar os pólos industriais que, devido suas particularidades em relação à questão de suprimento elétrico, enfrentam ou possam vir a enfrentar riscos regulatórios.

A ABRACE é uma sociedade sem fins lucrativos, formada por 64 grupos empresariais, que congrega grandes grupos industriais, de energointensivos a consumidores livres, que em 2008 respondeu por $20 \%$ de toda energia consumida no Brasil, sendo $45 \%$ do consumo de energia elétrica e $40 \%$ da energia térmica da indústria brasileira. No ANEXO F é apresentada a relação de empresas associadas da ABRACE, obtida no site desta associação em junho de 2009.

Dada a relevância da referida associação para o Brasil, a qual agrega as maiores e mais importantes indústrias do país, pode-se afirmar que as respostas representam parcela significativa dos casos de pólos industriais no Brasil onde há compartilhamento de infra-estrutura elétrica. Dentre os associadas da ABRACE, cerca de 14 afirmaram possuir unidades industriais instaladas pólos industriais conforme definido nesta dissertação. 
A ação da ABRACE no sentido de conhecer as características dos pólos industriais em operação no Brasil resultou na criação de um grupo especialmente criado para estruturar uma regulamentação sobre o tema. Este grupo teve a liderança da empresa petroquímica Braskem S.A., sob a coordenação do autor da presente dissertação. A Braskem S.A. é a empresa líder de dois importantes pólos petroquímicos no Brasil, um situado em Camaçari, no estado da Bahia, e outro em Triunfo, no estado do Rio Grande do Sul. Os trabalhos desenvolvidos por este grupo de trabalho tiveram como produto final uma minuta de decreto, apresentada no ANEXO A, que foi submetida ao Ministério de Minas e Energia - MME, Ministério do Desenvolvimento da Indústria e Comércio - MDIC e Ministério da Integração Nacional - MIN para apreciação.

Os pólos foram analisados e comparados com os seguintes critérios:

- Existências de vias públicas, tais como rios, rodovias, ferrovias etc., que atravessem redes elétricas internas ao pólo;

- Existências de consumidores não industriais que utilizem a infra-estrutura elétrica do pólo;

- Propriedade dos terrenos onde as indústrias estão instaladas;

- Como foram custeados os investimentos na construção da infra-estrutura elétrica do pólo;

- Classificação dos consumidores no interior do pólo, verificando se os mesmos são cativos ou livres;

- Formas de aquisição de energia (individual por cada empresa ou de forma coletiva);

- Como é feita a medição de faturamento (individual ou de forma coletiva);

- Formas de contratação do uso do sistema de transmissão e de distribuição (individual empresa ou de forma coletiva);

- Verificação da existência de geração de energia internamente ao pólo por uma ou mais empresas;

- Exportação de energia ao SIN;

- Comercialização entre os integrantes do pólo da energia gerada, por meio de infra-estrutura própria. 
Os pólos industriais foram nomeados de forma genérica para manter sigilo em relação às empresas que os integram. Todos os casos relacionados são reais e consistem em importantes pólos industriais em operação no Brasil.

Apenas os pólos petroquímicos de Camaçari e Triunfo, ambos liderados pela empresa Braskem S.A., tiveram seus nomes divulgados, pois tal divulgação foi autorizada pelo Diretor de Energia desta empresa.

A Tabela 18, a seguir, apresenta as principais características do pólo petroquímico de Triunfo, considerando os fatores de diferenciação de pólos industriais listados anteriormente. 
Tabela 18 - Características de suprimento elétrico do Pólo Petroquímico de Triunfo

\section{PÓLO PETROQUÍMICO DE TRIUNFO}

Pólo petroquímico composto por diversas empresas independentes que compartilham subestação transformadora de Rede Básica com tensão primária de $230 \mathrm{kV}$.

A Braskem S.A. é a empresa líder do pólo e possui uma unidade de insumos básicos, a qual é responsável pelo fornecimento de produtos petroquímicos e utilidades (vapor, água desmineralizada, ar de processo etc.) às demais indústrias do pólo.

A empresa líder possui também outras unidades industriais, produtoras de polipropileno e polietileno, que recebem utilidades de sua unidade de insumos básicos.

\begin{tabular}{ll}
\hline & O pólo não possui vias públicas em seu interior, mas é delimitado por uma rodovia \\
& estadual. \\
Vias públicas & No entorno do pólo, há rodovias, ferrovia e rios. Assim, caso uma nova unidade \\
& industrial se instale fora da área hoje delimitada, o pólo passará a ter redes \\
& elétricas atravessando vias públicas.
\end{tabular}

Presença de consumidores não industriais

Não há consumidores não industriais no interior do pólo.

Propriedade dos terrenos

Cada indústria é proprietária do terreno onde se encontra instalada.

Investimentos em infra-estrutura

Todos os investimentos em infra-estrutura interna ao pólo foram custeados pelas indústrias que lá se instalaram. Parte dos equipamentos de entrada do pátio de $230 \mathrm{kV}$ de Rede Básica compartilhada foi custeada pela transmissora, a qual continua como proprietária destes equipamentos.

Classificação dos consumidores

A maioria dos consumidores instalados no pólo é livre, entretanto, há alguns consumidores cativos atendidos pela distribuidora local.

Aquisição de energia

Medição de faturamento
A aquisição de energia é feita individualmente pelas empresas, seja no mercado livre ou cativo.

Cada indústria possui seu sistema de medição de faturamento individual. Há também medição na entrada da subestação em $230 \mathrm{kV}$, para contabilização e rateio das perdas elétricas internas. Todos consumidores são faturados em $230 \mathrm{~V}$. Os consumidores livres são consumidores de Rede Básica, enquanto que os cativos são consumidores $\mathrm{A} 1$ da distribuidora local.

Contratos de uso e conexão

Geração de energia
Os consumidores livres possuem contrato de conexão e uso com a transmissora, enquanto que os consumidores cativos possuem contratos de fornecimento com a distribuidora local.

A empresa líder possui em sua unidade de insumos básicos uma planta de cogeração de energia que é usada para consumo próprio. As demais empresas não possuem geração de energia elétrica.

Exportação de energia ao SIN

A energia gerada pela empresa líder é utilizada integralmente para consumo próprio. Apesar de ser possível, não há exportação de energia ao SIN. 
A Figura 32 a seguir apresenta uma imagem de satélite do pólo petroquímico de Triunfo, sendo indicada a área onde está localizada a unidade de insumos básicos da Braskem S.A., empresa líder do pólo, bem como da subestação compartilhada. É possível verificar também a delimitação do pólo pelas ruas e rodovias.

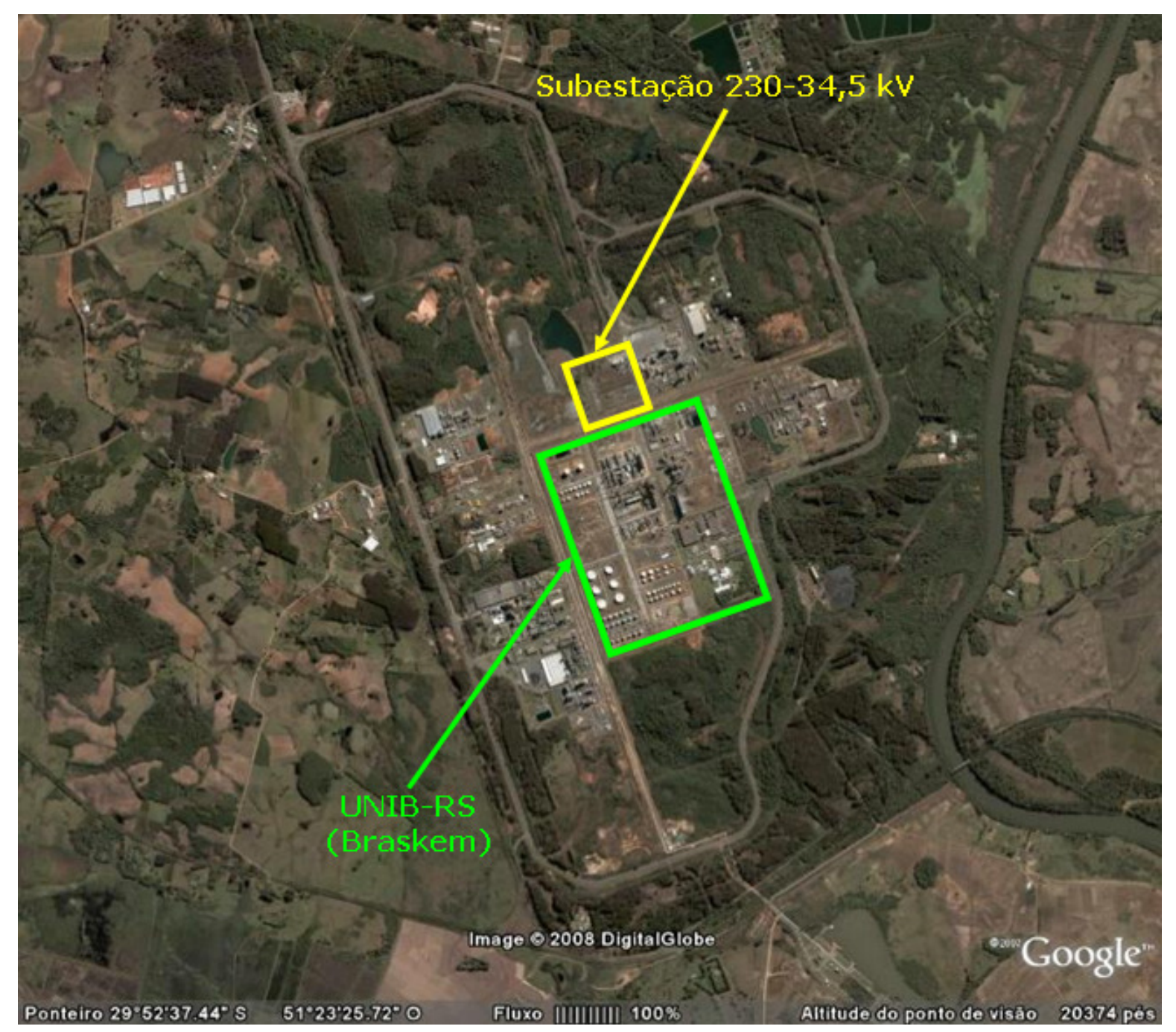

Figura 32 - Vista aérea do Pólo Petroquímico de Triunfo - RS

Fonte: Google Earth

As tabelas que se seguem, de 19 a 24, resumem a análise dos demais pólos, conforme os mesmos critérios utilizados para análise do pólo petroquímico de Triunfo. 
Tabela 19 - Características de suprimento elétrico do Pólo Petroquímico de Camaçari

\section{PÓLO PETROQUÍMICO DE CAMAÇARI}

\begin{tabular}{|c|c|}
\hline Descrição geral & $\begin{array}{l}\text { Pólo petroquímico composto por diversas empresas independentes. } \\
\text { A Braskem S.A. é a empresa líder do pólo e possui uma unidade de insumos } \\
\text { básicos, a qual é responsável pelo fornecimento de produtos petroquímicos, } \\
\text { energia elétrica e utilidades (vapor, água desmineralizada, ar de processo etc.) às } \\
\text { demais indústrias do pólo. } \\
\text { Há importação de energia do SIN mas a mesma é utilizada apenas para consumo } \\
\text { da empresa líder. As demais indústrias do pólo são atendida pela cogeração da } \\
\text { Braskem por meio de redes elétricas privativas e expressas que interligam a } \\
\text { cogeração ao consumidor. } \\
\text { A empresa líder possui também outras unidades industriais, produtoras de } \\
\text { polietileno, que recebem utilidades da unidade de insumos básicos. }\end{array}$ \\
\hline Vias públicas & $\begin{array}{l}\text { O pólo possui diversas redes elétricas, pertencentes à empresa líder, que } \\
\text { atravessam vias públicas. }\end{array}$ \\
\hline $\begin{array}{l}\text { Presença de consumidores não } \\
\text { industriais }\end{array}$ & O pólo possui consumidores não industriais, tais como prestadores de serviços. \\
\hline Propriedade dos terrenos & Cada indústria é proprietária do terreno onde a mesma encontra-se instalada. \\
\hline Investimentos em infra-estrutura & Informação não disponível. \\
\hline Classificação dos consumidores & $\begin{array}{l}\text { Para o sistema elétrico apenas a empresa líder caracteriza-se como unidade } \\
\text { consumidora, a qual está conectada à Rede Básica. } \\
\text { As demais indústrias, como são atendidas pela cogeração da empresa líder por } \\
\text { meio de redes privativas, não "aparecem" para o sistema elétrico. }\end{array}$ \\
\hline Aquisição de energia & $\begin{array}{l}\text { A energia adquirida do SIN é usada apenas para consumo das unidades } \\
\text { industriais da empresa líder, não havendo transferência de energia. }\end{array}$ \\
\hline Medição de faturamento & $\begin{array}{l}\text { A medição de energia adquirida do SIN é feita na fronteira com a Rede Básica. } \\
\text { Cada indústria possui sistema de medição de faturamento, entretanto estes } \\
\text { sistemas são usados apenas para faturamento da energia gerada e vendida pela } \\
\text { empresa líder. }\end{array}$ \\
\hline Contratos de uso e conexão & $\begin{array}{l}\text { Apenas a empresa líder possui contrato de conexão e uso com a transmissora. As } \\
\text { demais indústrias não "aparecem" para o sistema elétrico. }\end{array}$ \\
\hline Geração de energia & $\begin{array}{l}\text { A empresa líder possui em sua unidade de insumos básicos uma planta de } \\
\text { cogeração de energia, a qual é responsável pelo suprimento, por meio de redes } \\
\text { privativas, de energia elétrica às demais indústrias do pólo, }\end{array}$ \\
\hline Exportação de energia ao SIN & Não há exportação de energia ao SIN. \\
\hline Comercialização da energia gerada & $\begin{array}{l}\text { A energia elétrica gerada pela empresa líder é vendida às demais indústrias do } \\
\text { pólo por meio de redes privativas. }\end{array}$ \\
\hline
\end{tabular}


A Figura 33, a seguir, apresenta uma ilustração do pólo petroquímico de Camaçari, onde se pode observar as estradas e ferrovias atravessando o pólo industrial.

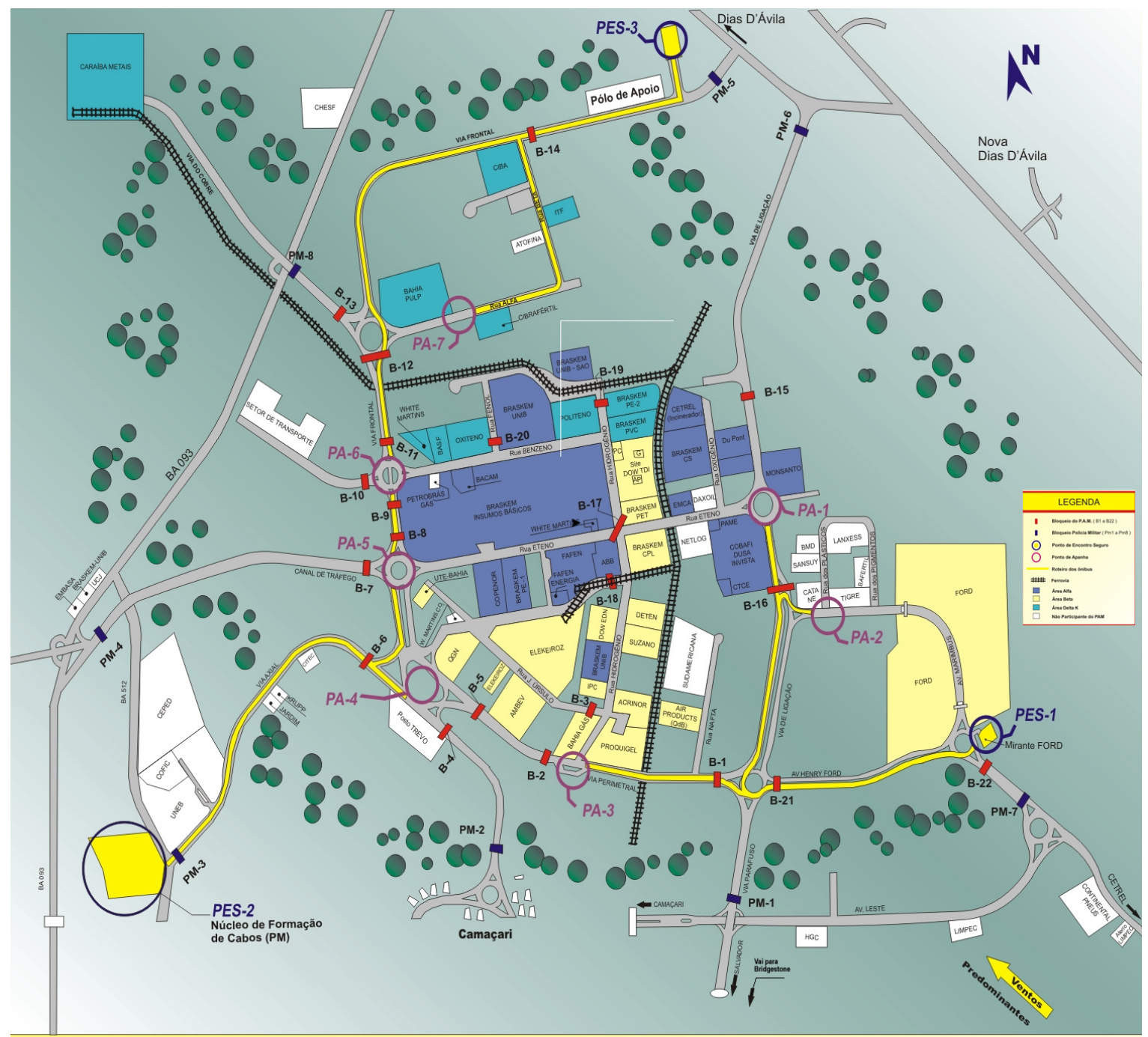

Figura 33 - Esquemático do Pólo Petroquímico de Camaçari - BA

Fonte: Site COFIC (www.cofic.org.br) 
Tabela 20 - Características de suprimento elétrico do Pólo A

\section{PÓLO A}

\begin{tabular}{|c|c|}
\hline Descrição geral & $\begin{array}{l}\text { Presença de duas empresas sendo que uma delas (Indústria } X) \text { é fornecedora de } \\
\text { utilidades, tais como, energia elétrica, vapor, água quente, etc., à outra empresa } \\
\text { (Indústria Y). }\end{array}$ \\
\hline Vias públicas & Neste pólo não existem vias publicas em seu interior. \\
\hline $\begin{array}{l}\text { Presença de consumidores não } \\
\text { industriais }\end{array}$ & Não há consumidores não industriais no interior do pólo. \\
\hline Propriedade dos terrenos & $\begin{array}{l}\text { Terreno onde as indústrias estão instaladas pertence à Indústria } Y \text {, que é a } \\
\text { compradora de utilidades produzidas na Indústria } X \text {. }\end{array}$ \\
\hline Investimentos em infra-estrutura & Todos os investimentos foram feitos pelas indústrias do pólo. \\
\hline Classificação dos consumidores & $\begin{array}{l}\text { Apenas a Indústria } \mathrm{X} \text { é vista pelo sistema elétrico e caracteriza-se como } \\
\text { consumidor livre. }\end{array}$ \\
\hline
\end{tabular}

Aquisição de energia

A energia é adquirida do SIN apenas em casos de parada na planta de cogeração da Indústria X. Quando adquirida do SIN, a energia é negociada no mercado livre.

\begin{tabular}{cl}
\hline Medição de faturamento & $\begin{array}{l}\text { A medição para faturamento da energia proveniente do SIN é feita de forma } \\
\text { centralizada na subestação principal compartilhada. }\end{array}$ \\
\hline Contratos de uso e conexão & $\begin{array}{l}\text { Há apenas contrato de Reserva de Capacidade para utilização em casos de } \\
\text { parada na planta de cogeração, o qual foi firmado entre Indústria } X \text { e a } \\
\text { distribuidora local. Para o sistema elétrico a Indústria } Y \text { não se configura como } \\
\text { uma unidade consumidora. }\end{array}$ \\
\hline Geração de energia & $\begin{array}{l}\text { A Indústria X possui uma planta de cogeração de energia para consumo próprio e } \\
\text { suprimento à Empresa Y. }\end{array}$ \\
\hline Exportação de energia ao SIN & Não há exportação de energia ao SIN, embora exista esta possibilidade. \\
\hline Comercialização da energia gerada & $\begin{array}{l}\text { A energia elétrica gerada pela Indústria X é vendida à Indústria Y em conjunto com } \\
\text { outras utilidades, como vapor e água quente etc. }\end{array}$ \\
\hline
\end{tabular}


Tabela 21 - Características de suprimento elétrico do Pólo B

\section{PÓLO B}

\begin{tabular}{|c|c|}
\hline Descrição geral & $\begin{array}{l}\text { Pólo composto por diversas empresas independentes que compartilham } \\
\text { subestação transformadora com tensão primária de } 138 \mathrm{kV} \text {. Pólo possui uma } \\
\text { empresa líder que é responsável pela interface com o SIN. }\end{array}$ \\
\hline Vias públicas & Este pólo possui rios atravessando suas instalações. \\
\hline $\begin{array}{l}\text { Presença de consumidores não } \\
\text { industriais }\end{array}$ & O pólo possui em seu interior alguns prestadores de serviços. \\
\hline Propriedade dos terrenos & Cada indústria é proprietária do terreno onde a mesma encontra-se instalada. \\
\hline Investimentos em infra-estrutura & Todas as obras de infra-estrutura foram custeadas pelas empresas do pólo. \\
\hline Classificação dos consumidores & O pólo possui consumidores livres e cativos em seu interior. \\
\hline
\end{tabular}

Aquisição de energia

A aquisição de energia é feita de forma centralizada pela empresa líder, com rateio dos custos entre seus integrantes proporcionais aos seus consumos.

\begin{tabular}{ll}
\hline Medição de faturamento & o faturamento dos consumidores livre é feito com base nas medições individuais \\
existentes em suas unidades industriais. & Já o faturamento dos consumidores cativos é feito considerando a diferença entre \\
o medidor geral da subestação principal e o somatório das medições dos \\
consumidores livres.
\end{tabular}

Contratos de uso e conexão

A contratação do uso e conexão com a distribuidora é feita de forma centralizada pela indústria líder. Demais indústrias não constituem unidades consumidoras para o sistema elétrico.

Geração de energia

A indústria líder possui planta de cogeração de energia, que é utilizada apenas para consumo próprio.

Exportação de energia ao SIN

Não há exportação de energia ao SIN.

Comercialização da energia gerada

A energia elétrica gerada é usada para consumo próprio da indústria líder do pólo, não havendo venda ou transferências internas de energia. 
Tabela 22 - Características de suprimento elétrico do Pólo C

\section{PÓLO C}

\begin{tabular}{cl}
\hline Descrição geral & $\begin{array}{l}\text { Pólo composto por diversas empresas independentes que compartilham } \\
\text { subestação transformadora com tensão primária de 138 kV. Pólo possui uma } \\
\text { indústria líder que é responsável pela interface com o SIN. }\end{array}$ \\
\hline Vias públicas & $\begin{array}{l}\text { O pólo é atravessado por avenidas, linhas de distribuição de energia elétrica e } \\
\text { terrenos de terceiros. }\end{array}$ \\
\hline $\begin{array}{c}\text { Presença de consumidores não } \\
\text { industriais }\end{array}$ & $\begin{array}{l}\text { Há prestadores de serviços que são atendidos eletricamente pela redes elétricas } \\
\text { do pólo. }\end{array}$ \\
\hline $\begin{array}{l}\text { Propriedade dos terrenos } \\
\text { Investimentos em infra-estrutura }\end{array}$ & Área do pólo pertence apenas à indústria líder. \\
\hline Tlassificação dos consumidores obras de infra-estrutura foram custeadas pelas indústrias do pólo. \\
\hline
\end{tabular}

Aquisição de energia

A aquisição de energia é feita de forma centralizada pela indústria líder, com rateio dos custos entre seus integrantes proporcionais aos seus consumos.

\begin{tabular}{cc}
\hline Medição de faturamento & $\begin{array}{l}\text { Medição de faturamento é feita de forma centralizada na subestação principal do } \\
\text { pólo. }\end{array}$ \\
\hline Contratos de uso e conexão & $\begin{array}{l}\text { A contratação do uso e conexão com a distribuidora é feita de forma centralizada } \\
\text { pela indústria líder. Demais indústrias não constituem unidades consumidoras para } \\
\text { o sistema elétrico. }\end{array}$ \\
\hline Geração de energia & $\begin{array}{l}\text { A indústria líder possui planta de cogeração de energia, que é utilizada apenas } \\
\text { para consumo próprio. }\end{array}$ \\
\hline Exportação de energia ao SIN & Não há exportação de energia ao SIN. \\
\hline Comercialização da energia gerada & $\begin{array}{l}\text { A energia elétrica gerada é usada para consumo próprio da indústria líder do pólo, } \\
\text { não havendo venda ou transferências internas de energia. }\end{array}$ \\
\hline
\end{tabular}


Tabela 23 - Características de suprimento elétrico do Pólo D

\section{PóLO D}

\begin{tabular}{|c|c|}
\hline Descrição geral & $\begin{array}{l}\text { Pólo constituído apenas por duas indústrias independentes, conectados à Rede } \\
\text { Básica em } 230 \mathrm{kV} \text {. }\end{array}$ \\
\hline Vias públicas & Este pólo não possui vias públicas em seu interior. \\
\hline $\begin{array}{l}\text { Presença de consumidores não } \\
\text { industriais }\end{array}$ & Não há consumidores não industriais no interior do pólo. \\
\hline Propriedade dos terrenos & $\begin{array}{l}\text { Área do pólo pertence apenas a uma indústria, que cede em comodato parte de } \\
\text { seu terreno para utilização da outra empresa. }\end{array}$ \\
\hline Investimentos em infra-estrutura & $\begin{array}{l}\text { Todos os investimentos em infra-estrutura interna do pólo foram feitos pelas } \\
\text { indústrias do pólo. }\end{array}$ \\
\hline Classificação dos consumidores & Ambas as indústrias são consumidores livres de energia. \\
\hline Aquisição de energia & $\begin{array}{l}\text { A aquisição de energia é feita individualmente pelas empresas, seja no mercado } \\
\text { livre ou cativo. }\end{array}$ \\
\hline Medição de faturamento & Cada indústria possui seu sistema de medição de faturamento individualizado. \\
\hline Contratos de uso e conexão & $\begin{array}{l}\text { Cada indústria possui contrato de uso e conexão individualizado com a } \\
\text { transmissora. }\end{array}$ \\
\hline Geração de energia & $\begin{array}{l}\text { A indústria proprietária do terreno possui uma planta de cogeração de energia } \\
\text { para consumo próprio com venda de excedente à segunda indústria, que também } \\
\text { adquire uma parcela de energia do SIN para atender sua demanda global. }\end{array}$ \\
\hline Exportação de energia ao SIN & $\begin{array}{l}\text { Não há exportação de energia ao SIN. A transferência de energia de uma indústria } \\
\text { à outra é feita utilizando apenas o pátio de alta tensão da subestação } \\
\text { compartilhada, não havendo circulação no SIN da energia gerada. }\end{array}$ \\
\hline
\end{tabular}


A Figura 34 - apresenta o esquemático do fluxo de energia elétrica no pólo denominado "D", em condições usuais de operação. Nesta figura, observa-se que a energia gerada por uma indústria e transferida à outra não circula no SIN, mas apenas em instalações particulares. Todavia, há cobrança de encargos setoriais sobre a energia gerada e vendida internamente no pólo.

O Pólo "D" configura-se como um caso típico em que uma política de isenção de encargos sobre a energia gerada e consumida internamente no pólo poderia aumentar a competitividade das indústrias nele instaladas. Conforme abordado no Capítulo 5, este tipo de política já foi aplicada no estado do Texas, nos EUA, e em alguns países da Europa, como Dinamarca e Reino Unidos, tendo sido obtidos resultados importantes.

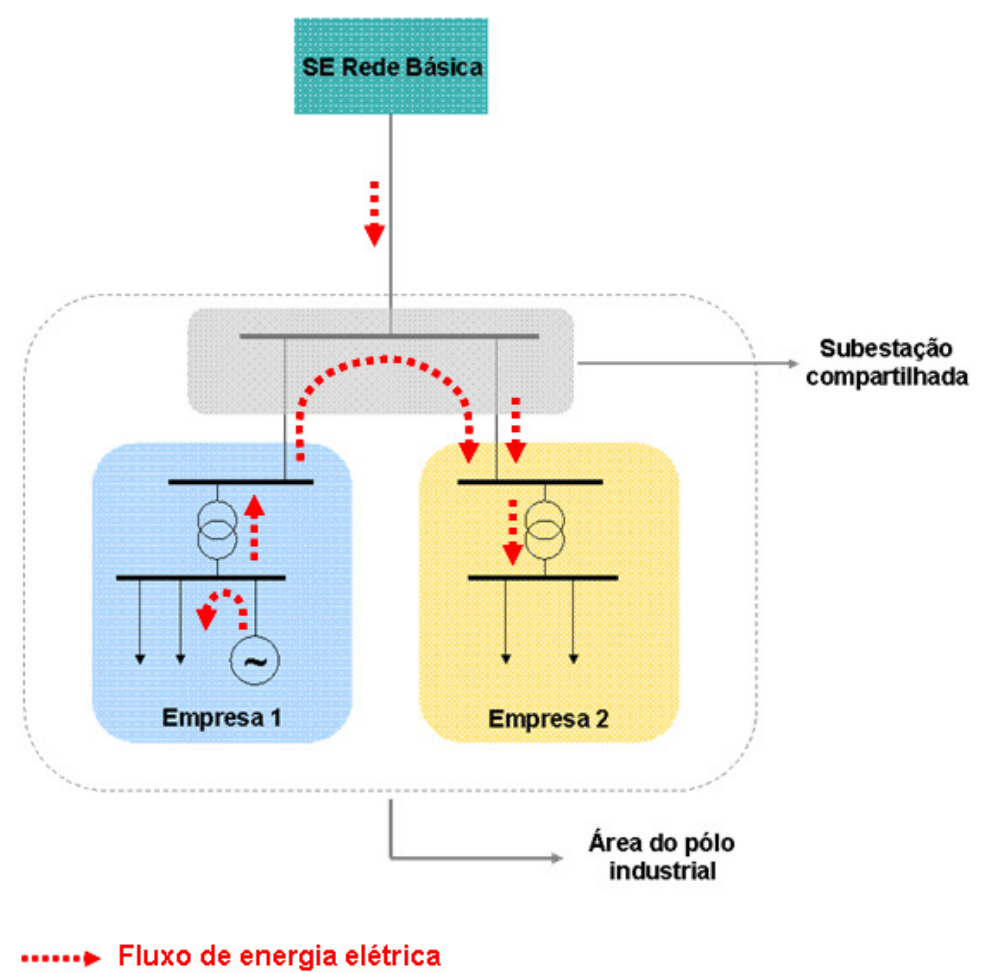

Figura 34 - Esquemático simplificado do fluxo de energia elétrica no Pólo D

Fonte: ABRACE 
Tabela 24 - Características de suprimento elétrico do Pólo E

\section{PÓLO E}

Pólo constituído por diversas indústrias, que se formou devido ao desmembramento de grupos empresariais. Pólo possui uma indústria líder que é responsável pelo fornecimento de utilidades às demais indústrias instaladas.

Vias públicas

Este pólo não possui vias públicas em seu interior.

Presença de consumidores não industriais

Não há consumidores não industriais no interior do pólo.

Propriedade dos terrenos Área do pólo pertence apenas à indústria líder.

Investimentos em infra-estrutura Todas as obras de infra-estrutura foram custeadas pelas indústrias do pólo.

Classificação dos consumidores

Consumidores do pólo são tratados como uma unidade consumidora, que atualmente é livre.

Aquisição de energia

A aquisição de energia é feita de forma centralizada pela indústria líder, com rateio dos custos entre seus integrantes proporcionais aos seus consumos.

Medição de faturamento

Medição de faturamento é feita de forma centralizada na subestação principal do pólo.

A contratação do uso e conexão com a distribuidora é feita de forma centralizada

Contratos de uso e conexão pela indústria líder. Demais indústrias não constituem unidades consumidoras para o sistema elétrico.

Geração de energia

Este pólo não possui geração de energia, sendo constituído apenas de unidades consumidoras.

Exportação de energia ao SIN

Não há geração de energia elétrica no pólo.

\section{A tabela a seguir apresenta uma comparação das principais características dos pólos industriais estudados.}


Tabela 25 - Resumo das principais características dos pólos industriais estudados

\begin{tabular}{|c|c|c|c|c|c|c|c|}
\hline Característica & Triunfo & Camaçari & A & B & C & D & $\mathbf{E}$ \\
\hline Há vias públicas no interior do pólo & Não & Sim & Não & $\operatorname{Sim}$ & $\operatorname{Sim}$ & Não & Não \\
\hline Há consumidores não industriais dentro do pólo & Não & Sim & Não & $\operatorname{Sim}$ & Sim & Não & Não \\
\hline Terreno pertence apenas à uma indústria & Não & Não & Não & Não & Sim & Sim & Sim \\
\hline Indústrias custearam a infra-estrutura elétrica & Sim & - & $\operatorname{Sim}$ & Sim & $\operatorname{Sim}$ & Sim & $\operatorname{Sim}$ \\
\hline Há convivência de consumidores livres e cativos & Sim & Não & Não & $\operatorname{Sim}$ & Não & Não & Não \\
\hline Aquisição de energia é feita de forma centralizada & Não & Não & $\operatorname{Sim}$ & $\operatorname{Sim}$ & $\operatorname{Sim}$ & Não & $\operatorname{Sim}$ \\
\hline Medição de faturamento é feita de forma centralizada & Não & Não & $\operatorname{Sim}$ & Sim & $\operatorname{Sim}$ & Não & $\operatorname{Sim}$ \\
\hline Contrato de uso/conexão é centralizado & Não & Não & $\operatorname{Sim}$ & $\operatorname{Sim}$ & Sim & Não & Sim \\
\hline Há geração de energia & Sim & Sim & $\operatorname{Sim}$ & $\operatorname{Sim}$ & $\operatorname{Sim}$ & Sim & Não \\
\hline Há exportação de energia ao SIN & Não & Não & Não & Não & Não & Não & Não \\
\hline Energia gerada é comercializada entre os integrantes do pólo & Não & Sim & $\operatorname{Sim}$ & Não & Não & Sim & Não \\
\hline
\end{tabular}


As características dos pólos descritas acima mostram que a grande maioria possui via públicas em seu interior, tais como ruas, rodovias, ferrovias e rios. Em alguns casos, as ruas e rodovias foram construídas e custeadas pelas próprias indústrias dos pólos com posterior doação aos órgãos municipais ou estaduais.

Na maioria dos pólos estudados, os investimentos na infra-estrutura, em especial de energia elétrica, foram custeados pelas próprias indústrias, não havendo participação financeira das concessionárias de distribuição. Apenas em um caso, no pólo petroquímico de Triunfo, é que parte dos equipamentos do setor de alta tensão (230 kV) da subestação principal foi custeada pela transmissora local, porém, estes equipamentos integram a Rede Básica e pertencem à transmissora.

Com relação aos contratos de uso do sistema (CUST/CUSD/Acordo Operativo) verifica-se grande variedade de situações. Em alguns casos verifica-se a celebração de um único contrato de uso/conexão por uma indústria líder, enquanto em outros casos a contratação é feita individualmente.

Em alguns pólos há convivência de consumidores livres e cativos, porém sendo faturados na tensão da entrega da subestação compartilhada. Com relação à aquisição de energia verificam-se casos em que a compra é feita de forma centralizada por uma empresa líder, com rateio entre seus integrantes sem obtenção de lucro, e casos onde cada indústria adquire sua energia. No primeiro caso, se houver uma posição da ANEEL contrária em relação à forma de aquisição de energia no mercado livre, algumas indústrias não poderiam ser consumidores livres, pois não se enquadrariam nos requisitos necessários de carga maior ou igual $3 \mathrm{MW}$. Em muitos pólos é comum a existência de consumidores não industriais, como restaurantes, bancos e demais prestadores de serviços. Assim, uma proposição de regulamentação sobre pólos industriais deve considerar a possibilidade dos prestadores de serviços instalados em pólos industriais serem atendidos pelas instalações elétricas do pólo.

Nem todos os pólos possuem geração de energia, mas verifica-se que nos pólos em que a geração está presente as características de destinação da energia são bem diferentes. Em alguns pólos as indústrias geram energia apenas para consumo próprio, enquanto que em outros ocorre a venda de energia às demais indústrias integrantes do pólo. 


\section{7 - PRINCIPAIS OBSTÁCULOS AO DESENVOLVIMENTO DE PÓLOS INDUSTRIAIS ENVOLVENDO A QUESTÃO ENERGÉTICA}

No Capítulo 6 foram apresentados os principais fatores de diferenciação de alguns pólos industriais em operação no Brasil, onde se verificou casos muito diversos em relação aos parâmetros de suprimento elétrico.

Ao longo deste capítulo serão apresentados os principais obstáculos ligados ao suprimento de energia elétrica que impedem o desenvolvimento dos pólos industriais no Brasil. Cabe ressaltar novamente que ao longo desta dissertação o termo pólo industrial não é utilizado da forma tradicional como estudados por importantes autores, como Michael Porter, que define um pólo industrial ou "cluster" como sendo a concentração de empresas relacionadas entre si, numa zona geográfica relativamente definida. O termo pólo industrial é utilizado referindo-se ao agrupamento de indústrias que de alguma forma compartilham infra-estrutura energética e, em especial, de energia elétrica.

Conforme citado anteriormente, o acesso conjunto de duas ou mais indústrias ao SIN por meio de compartilhamento de infra-estrutura elétrica consiste numa excelente alternativa, em especial para as que possuam menores demandas elétricas, para viabilizar conexão em níveis de tensão mais elevados e, conseqüentemente, reduzir custos com energia elétrica por meio da diminuição da tarifa de uso do sistema. Entretanto, a legislação vigente do setor elétrico brasileiro não aborda de forma clara e objetiva a questão do compartilhamento de infraestrutura elétrica.

Conforme apresentado no Capítulo 6, os pólos industriais em operação no Brasil apresentam características diferenciadas no que se refere ao suprimento elétrico e ao compartilhamento de infra-estrutura, bem como com relação à aquisição de energia elétrica, seja no mercado cativo ou livre.

Em alguns casos, o compartilhamento de subestações transformadoras e redes elétricas em média tensão, como por exemplo $34,5 \mathrm{kV}$, ocorre devido a estruturações societárias, oriundas de fusões e aquisições empresariais, que fizeram com que duas ou mais indústrias fossem atendidas por uma infra-estrutura elétrica comum. Em outros casos, como nos pólos petroquímicos e automobilísticos, o 
agrupamento de indústrias ocorre de forma natural, devido à forte inter-relação entre os processos produtivos das indústrias integrantes do pólo.

Dado que a legislação do setor elétrico brasileiro não aborda de forma clara a questão de compartilhamento de infra-estrutura elétrica e aquisição conjunta de energia nos pólos industriais, as indústrias enfrentam riscos regulatórios que geram um cenário de incerteza com relação aos custos futuros de energia.

Basicamente, os riscos regulatórios dos pólos industriais consistem em:

- Risco de reclassificação na tarifa de uso dos sistemas elétricos;

- Risco de incorporação (com ressarcimento aos proprietários) pela concessionária de distribuição local, dos ativos de redes elétricas internas ao pólo industrial;

- Risco da aplicação de penalidades devido à aquisição conjunta de energia pelas empresas dos pólos, com rateio entre seus integrantes.

Os riscos enfrentados em cada pólo industrial estão relacionados às suas características individuais, como as apresentadas na Tabela 25.

A principal referência na legislação do setor elétrico brasileiro com relação ao compartilhamento de infra-estrutura elétrica é feita no Art. 12 da Resolução ANEEL $N^{\circ} 456 / 2000$, o qual estabelece que o compartilhamento de subestações é permitido somente em instalações contíguas. Todavia, é justamente na terminologia contígua que reside a maior parte dos complicadores regulatórios.

A regulamentação do setor elétrico abre espaço para uma interpretação divergente, onde a existência de vias públicas, como uma rodovia, por exemplo, entre duas unidades industriais possa ser utilizado como argumento para descaracterizar a contigüidade entre as instalações, embora, em alguns casos, esteja claro que as unidades fabris são vizinhas e cheguem mesmo a otimizar processos industriais compartilhando operações.

Sob a lógica da interpretação citada, as indústrias de um pólo industrial teriam então que ser atendidas pela distribuidora local e faturadas na tensão de suprimento de suas plantas industriais, ou seja, na tensão secundária dos transformadores da subestação compartilhada pelas indústrias do pólo (que em geral são 13,8 kV, 23 kV e $34,5 \mathrm{kV})$, com tarifas nas classes de tensão A3a (30 kV a 44 kV) e A4 (2,3 kV a $25 \mathrm{kV})$. 
A mudança no faturamento da classe de tensão, como 138 kV (classe A2) ou 230 kV (classe A1 ou Rede Básica), para as classes A3a e A4 ocasionaria aumento significativo nos custos finais de energia elétrica das indústrias dos pólos, prejudicando de forma expressiva a competitividade das mesmas. Em muitos casos, os aumentos nos custos finais de energia elétrica poderiam até ocasionar o encerramento das atividades da indústria no Brasil e transferência a outros países, em busca de menores custos de energia e maior segurança regulatória.

A Figura 35 apresenta o resultado de uma pesquisa feita pela consultoria AT Kerney sobre os fatores que motivam empresas a se instalarem em países. Esta figura foi apresentada pela Prof. Virgínia Parente, do Instituto de Energia elétrica - IEE da Universidade de São Paulo - USP, no evento Energy Tax Fórum Brasil 2009, promovido pelo International Quality \& Productivity Center - IQPC em maio de 2009. Verifica-se que 0 ambiente regulatório foi considerado 0 terceiro fator mais importante para atração empresas num determinado país.

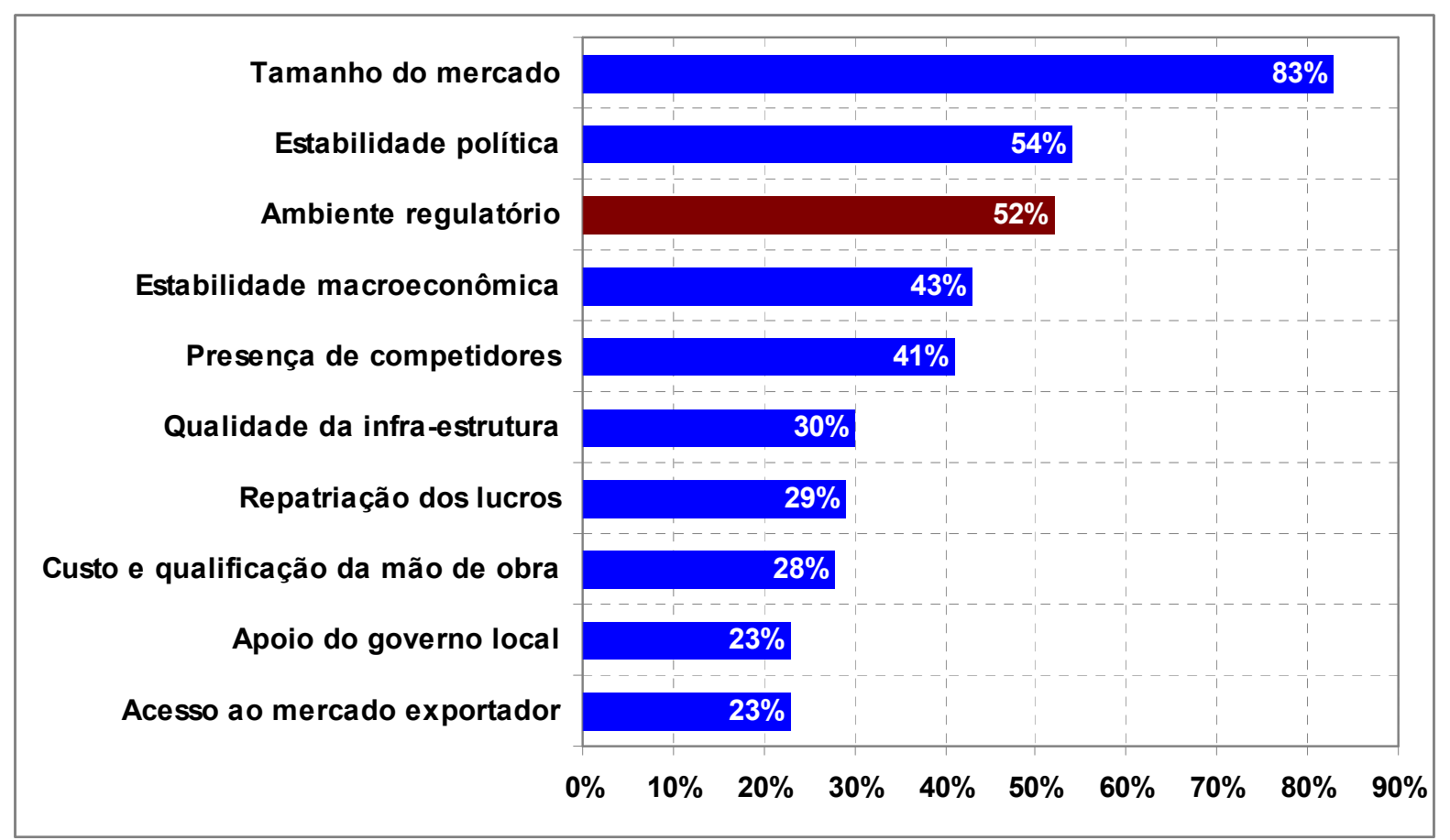

Figura 35 - Fatores de atração de empresas

Fonte: Energy Tax Fórum Brasil 2009 - Apresentação da Prof. Virgínia Parente no dia 19.05.2009

Em decorrência da falta de definição regulatória, pode se estabelecer um conflito de interesses que colocam em lados opostos consumidores e distribuidoras, abrindo espaço para que as distribuidoras busquem, por meio de instâncias administrativas, 
como a ANEEL, a reclassificação tarifária das indústrias instaladas em pólos industriais.

Mesmo nos pólos que já estão conectados diretamente à Rede Básica, onde as empresas possuem CUST e CCT celebrados diretamente com as concessionárias de transmissão, há o risco de que estas mesmas empresas passem a ser atendidas via distribuidoras, sendo faturadas na tensão secundária da subestação compartilhada. Apesar das distribuidoras não possuírem ativo algum que justificasse o faturamento dos consumidores na tensão secundária de transformação, o risco de reclassificação existe devido à existência de redes elétricas compartilhadas atravessando vias públicas ou terrenos de terceiros.

Este conjunto de indefinições, que se pode denominar "vácuo regulatório", cria uma situação de incerteza com relação aos custos finais de energia às empresas instaladas em pólos industriais, o que pode inibir importantes investimentos no país, seja no desenvolvimento dos pólos existentes ou por meio da criação de novo pólos industriais.

Em matéria publicada no site Canal Energia em 02 de abril de 2009, intitulada "Pólos industriais: segurança regulatória e energia competitiva" e assinada pelo Deputado Federal Arnaldo Jardim, integrante da Comissão Especial da Lei do Gás e da Comissão de Minas e Energia da Câmara dos Deputados, é ressaltado que a eliminação da insegurança jurídica aos pólos proporcionaria um aumento de $11 \%$ nos investimentos previstos em expansão industrial nos próximos cinco anos e de $47 \%$ nos próximos 10 anos. Em termos absolutos, estes percentuais representariam $\mathrm{R} \$ 40,3$ milhões e $\mathrm{R} \$ 75$ bilhões, respectivamente.

Conforme mostrado no Capítulo 6, há pólos industriais em operação no Brasil que possuem redes elétricas compartilhadas atravessando vias públicas e terrenos de terceiros. Portanto, caso a ANEEL adote uma postura em favor das distribuidoras de energia elétrica e exija na prática a mudança no faturamento das indústrias que compartilhem redes elétricas em pólos, o impacto que seria causado ao setor industrial seria significativo. Este impacto, pode-se imaginar, seria refletido na economia nacional e poderia prejudicar o desempenho do setor industrial brasileiro. Por outro lado, haveria um fortalecimento de algumas distribuidoras de energia, devido ao aumento de suas receitas. Todavia, é importante refletir com cuidado sobre este tema. A mudança na classe de faturamento das indústrias poderia prejudicar a competitividade das mesmas e desestimular investimentos em 
expansões ou instalação de novas unidades fabris. Dependendo do impacto causado pela reclassificação na tarifa fio, algumas indústrias poderiam até encerrar suas atividade no Brasil e transferi-las a outros países.

Políticas de incentivos ao desenvolvimento de pólos industriais podem também proporcionar aumento na receita das concessionárias de distribuição, uma vez que o crescimento do setor industrial traz consigo aumento na geração de empregos, o que, conseqüentemente, pode ocasionar uma elevação no consumo de eletricidade no setor residencial. Trata-se de uma estratégia que deve ser analisada com atenção, levando-se em consideração os interesses da indústria, das concessionárias de distribuição e da população.

Nos pólos industriais em que há geração interna de energia elétrica, em plantas de cogeração com venda interna às indústrias do pólo por meio de redes elétricas privativas, o risco regulatório é ainda maior. O Art. 12 da Lei $N^{\circ}$ 9074/1995 e o Art. 23 do Decreto $N^{\circ}$ 2003/1999 estabelecem que a venda de energia elétrica por produtor independente pode ser feita para consumidores de energia elétrica integrantes de complexo industrial ou comercial, aos quais o produtor independente também forneça vapor oriundo de processo de co-geração. Todavia, pelo fato de não haver citação clara a respeito da cobrança da parcela "Fio", algumas distribuidoras de energia se sentem encorajadas a buscar o faturamento desta parcela. Há casos no qual as distribuidoras desejam até mesmo a incorporação dos ativos de rede elétricas dos pólos industriais, mediante indenização ao proprietário, como por exemplo ocorreu no Pólo Petroquímico de Camaçari, na Bahia, que será abordado com maiores detalhes no Capítulo 8.

O Art. 12 da Lei N 9074/1995 e Art. 23 do Decreto $N^{\circ}$ 2003/1999 explicitam permissão de que energia gerada por um produtor independente seja vendida ao consumidor final em conjunto com a venda de vapor. Assim, caso não haja venda de vapor, a venda de energia do gerador diretamente ao consumidor por meio de redes particulares não seria permitida, devendo o transporte ser pago ao concessionário local.

O Art. 12 da Lei N 9074/1995 e o Art. 23 do Decreto $N^{\circ}$ 2003/1999 são muito parecidos, diferindo-se apenas em alguns pontos. A seguir são transcritos os referidos artigos. 


\section{Artigo 12 da Lei $N^{\circ}$ 9074/1995}

Art. 12. A venda de energia elétrica por produtor independente poderá ser feita para:

I - concessionário de serviço público de energia elétrica;

II - consumidor de energia elétrica, nas condições estabelecidas nos arts. 15 e 16 ;

III - consumidores de energia elétrica integrantes de complexo industrial ou comercial, aos quais o produtor independente também forneça vapor oriundo de processo de co-geração;

IV - conjunto de consumidores de energia elétrica, independentemente de tensão e carga, nas condições previamente ajustadas com o concessionário local de distribuição;

$\mathrm{V}$ - qualquer consumidor que demonstre ao poder concedente não ter o concessionário local the assegurado o fornecimento no prazo de até cento e oitenta dias contado da respectiva solicitação.

Parágrafo único. A comercialização na forma prevista nos incisos I, IV e $V$ do caput deste artigo deverá ser exercida de acordo com critérios gerais fixados pelo Poder Concedente. (Redação dada pela Lei n 10.848 , de 2004)

\section{Artigo 23 do Decreto 2003/1999}

Art. 23. O produtor independente poderá comercializar a potência e/ou energia com:

I - concessionário ou permissionário de serviço público de energia elétrica;

II - consumidores de energia elétrica nas condições estabelecidas nos artigos 15 e 16 da Lei n 9.074, de 1995;

III - consumidores de energia elétrica integrantes de complexo industrial ou comercial, aos quais forneça vapor ou outro insumo oriundo de processo de cogeração;

IV - conjunto de consumidores de energia elétrica, independentemente de tensão e carga, nas condições previamente ajustadas com o concessionário local de distribuição;

$\mathrm{V}$ - qualquer consumidor que demonstre ao poder concedente não ter o concessionário local the assegurado o fornecimento no prazo de até 180 dias, contado da respectiva solicitação.

Parágrafo único. A comercialização de energia elétrica nas hipóteses dos incisos I, IV e $\mathrm{V}$ deste artigo deverá ser feita a preços sujeitos aos critérios gerais fixados pelo poder concedente 
Conforme se pode verificar, no caput do Art. 23 do Decreto № 2003/1999 é citado que o produtor independente pode comercializar potência e/ou energia, enquanto que no Art. 12 da Lei N 9074/1995 há referência apenas sobre a venda de energia. Apesar de comumente conhecido no setor elétrico que potência (em kW ou MW) está relacionada à demanda ou carga e energia se refere ao insumo, a divergência nos textos da legislação abre espaço para diferentes interpretações sobre a comercialização de energia entre PIE e consumidores de complexos industriais.

No Art. 12 da Lei $N^{\circ}$ 9074/1995 não está claro se a venda de energia está relacionada apenas ao insumo ou se engloba também a parcela Fio, enquanto que no Art. 23 do Decreto $N^{\circ}$ 2003/1999 há a citação de possibilidade de venda de potência, o que dá um entendimento de que o PIE pode comercializar energia elétrica por meio de redes particulares.

Trata-se de um tema muito importante uma vez que em alguns pólos industriais, como o Pólo Petroquímico de Camaçari, na Bahia, há venda de energia elétrica, em conjunto com vapor de processo, por cogeradores por meio de redes privativas.

Em complexos petroquímicos, por exemplo, é comum a existência de plantas de cogeração de energia que utilizam combustível residual do processamento da nafta para geração de energia elétrica e vapor. A produção de energia elétrica e vapor estão fortemente relacionados e eventuais desequilíbrios entre o consumo de vapor e de eletricidade podem gerar condições desfavoráveis de operação, ocasionando elevados custos de geração. Um aumento elevado no consumo de eletricidade, sem contrapartida no consumo de vapor, colocaria a central de utilidades ${ }^{8}$ numa condição de operação inviável do ponto de vista econômico, tornando necessária a aquisição de energia externa para suprir as necessidades do pólo, uma vez que a venda interna estaria limitada pelo nível de consumo de vapor. Como a aquisição de energia externa para repasse a terceiros não apresenta tratamento regulatório adequado, a carga elétrica adicional teria, em princípio que ser suprida por uma das alternativas:

(i) Atendida via concessionária de distribuição de energia elétrica, a qual teria que construir suas redes próprias para suprir o consumidor;

\footnotetext{
8 Em pólos industriais é comum a existência de uma Central de Utilidades que, em geral, é responsável pelo fornecimento, aos demais integrantes do pólo, de vapor, energia elétrica, água, água desmineralizada, água clarificada, ar de processo, ar comprimido, dentre outros.
} 
(ii) Atendida por meio de compra direta de energia para cada consumidor no mercado livre, utilizando a infra-estrutura elétrica interna do pólo. Neste último caso, a indústria que comprasse energia elétrica no mercado livre teria então que utilizar uma rede privativa pertencente à outra indústria do pólo, que por usa vez teria que cobrar um aluguel pelo uso de sua rede para remunerar seus custos de O\&M. Entretanto, este tipo de aquisição de energia externa com cobrança de uso de redes particulares por um gerador ou consumidor não é abordado na legislação do setor elétrico, o que pode impedir a sua prática.

A segurança operacional em alguns complexos industriais petroquímicos consiste num fator de extrema importância, uma vez que as indústrias manuseiam, em muitos casos, produtos voláteis com elevado riscos de explosão. Alguns processos industriais exigem índices de confiabilidade de suprimento elétrico elevadíssimos, que dificilmente seriam possíveis de serem obtidos via sistema elétrico das concessionárias de distribuição, até mesmo em função da regulação sobre qualidade de atendimento estabelecer parâmetros menos rigorosos que os necessários às indústrias. Nestes casos, cabe às indústrias a responsabilidade pelos investimentos em melhorias no sistema elétrico para que a qualidade requerida de suprimento seja atingida.

Incentivos à comercialização interna da energia gerada nos pólos industriais poderiam ser criados como forma de proporcionar o desenvolvimento dos pólos industriais e também para contribuir com a ampliação do parque gerador elétrico brasileiro. A instituição de uma regulamentação que elimine interpretações divergentes e que permita, livremente entre as empresas de pólos industriais, as operações de compra, venda e fornecimento de energia elétrica gerada, sem restringi-la a uma venda conjunta de vapor, configura-se como uma importante estratégia para contribuir com o desenvolvimento do setor industrial e também com a expansão da capacidade de geração de energia elétrica no Brasil.

As diversas formas de aquisição de energia elétrica pelas indústrias de pólos é outro ponto que merece atenção especial e também acarreta riscos regulatórios substanciais. Em muitos pólos, nos quais indústrias compartilham infra-estrutura elétrica, é comum a aquisição conjunta de energia, que é feita por uma empresa líder, com rateio entre seus integrantes, sem obtenção de lucro. Do ponto de vista do 
sistema elétrico, o pólo consiste de apenas uma empresa, que celebra contratos de uso (CUSD ou CUST) e conexão (CCT ou CCD) com o concessionário local e adquire energia no mercado para todas as empresas integrantes do pólo.

Nos pólos industriais em que isto ocorre, diversas empresas são prestadores de serviço da empresa líder, como produtores de ar comprimido e de oxigênio, que possuem unidades industriais menores com pequenas demandas elétricas. Caso estas empresas menores passem a ser faturadas em média tensão pela distribuidora local, seus custos produtivos seriam aumentados e a competitividade das empresas do pólo seria prejudicada de forma geral.

A criação de uma regulamentação que permita a aquisição conjunta de energia para empresas instaladas em pólos industriais, por meio de uma empresa líder, por exemplo, consiste numa inovação regulatória que contribuiria de forma substancial para preservar a operação dos pólos existentes e para criar condições de competitividade para formação de novos pólos.

No Artigo 14 da Resolução ANEEL N 456/2000 é citada a possibilidade de aquisição de energia de forma conjunta, porém, especificamente para prédios com predominância de estabelecimentos comerciais de serviços, varejistas e/ou atacadistas. A seguir é transcrito o referido artigo.

Art. 14. Prédio com predominância de estabelecimentos comerciais de serviços, varejistas e/ou atacadistas, poderá ser considerado uma só unidade consumidora, se atendidas, cumulativamente, as seguintes condições:

I - que a propriedade de todos os compartimentos do imóvel, prédio ou o conjunto de edificações, seja de uma só pessoa física ou jurídica e que o mesmo esteja sob a responsabilidade administrativa de organização incumbida da prestação de serviços comuns a seus integrantes;

II - que a organização referida no inciso anterior assuma as obrigações de que trata o inciso III, art. $2^{\circ}$, na condição de consumidor;

III - que a demanda contratada, para prédio ou conjunto de estabelecimentos comerciais varejistas e/ou atacadistas, seja igual ou superior a $500 \mathrm{~kW}$, e, para conjunto de estabelecimentos comerciais de serviços, seja igual ou superior a $5000 \mathrm{~kW}$;

IV - que o valor da fatura relativa ao fornecimento seja rateado entre seus integrantes, sem qualquer acréscimo; e

V - que as instalações internas de utilização de energia elétrica permitam a colocação, a qualquer tempo, de equipamentos de medição individualizados para cada compartimento do prédio ou do conjunto de edificações. 
$\S 1^{\circ}$ À organização mencionada no inciso I deste artigo caberá manifestar, por escrito, a opção pelo fornecimento nas condições previstas neste artigo. $\S 2^{\circ} \mathrm{A}$ organização de que trata $\mathrm{o}$ inciso I deste artigo não poderá interromper, suspender ou interferir na utilização de energia elétrica por parte dos integrantes do prédio ou do conjunto de edificações.

$\S 3^{\circ}$ Qualquer compartimento do prédio, com carga instalada superior ao limite mínimo estabelecido para atendimento em tensão primária de distribuição, poderá ser atendido diretamente pela concessionária, desde que haja pedido neste sentido e que sejam satisfeitas as condições regulamentares e técnicas pertinentes.

Pode-se concluir que os conceitos estabelecidos no Artigo 14 da Resolução ANEEL $N^{\circ} 456 / 2000$ foram criados para shoppings, aeroportos e instalações similares, uma vez que a referida resolução permite aquisição conjunta de energia apenas para estabelecimentos comerciais de serviços, varejistas e/ou atacadistas. Não há para os pólos industriais uma regulamentação parecida. 


\section{8 - PRINCIPAIS PONTOS DE DIVERGÊNCIAS ENTRE SETOR INDUSTRIAL E CONCESSIONÁRIAS DE DISTRIBUIÇÃO DE ENERGIA ELÉTRICA}

No Capítulo 7 foram apresentados os principais riscos regulatórios enfrentados pelos pólos industriais em operação no Brasil, resultantes do fato da legislação do setor elétrico brasileiro não ser clara o suficiente em relação ao tema em pauta, permitindo a existência de pontos de divergências.

No presente capítulo são descritos alguns pontos de divergências criadas na legislação do setor elétrico, que colocam em campos opostos os interesses das indústrias e das concessionárias de distribuição de serviços de eletricidade.

A distribuição de energia consiste num serviço público de concessão, que é prestado por empresas privadas ou estatais, as quais devem obedecer rigorosamente os conceitos estabelecidos na legislação do setor elétrico.

Como citado anteriormente, em alguns casos, as concessionárias de distribuição de energia elétrica buscam a cobrança do "Fio" em indústrias integrantes de pólos industriais que compartilham infra-estrutura elétrica, seja por meio de incorporação das redes privativas, ou simplesmente pela reclassificação da "Tarifa Fio", instituindo-se assim a cobrança de uma taxa.

A seguir serão apresentados os principais pontos da regulamentação do setor elétrico que permitem interpretações divergentes sobre um mesmo tema.

\section{1 - A Questão da Contigüidade}

A principal referência na legislação do setor elétrico com relação ao compartilhamento de infra-estrutura elétrica é feita no Art. 12 da Resolução ANEEL $N^{\circ} 456 / 2000$, a qual estabelece as condições gerais de fornecimento de energia elétrica. No referido artigo, que foi alterado pela Resolução ANEEL N 226/2002, são estabelecidos os critérios a serem respeitados para que dois ou mais consumidores compartilhem uma subestação.

A seguir é feita a transcrição do Artigo 12 da Resolução ANEEL N 456/2000 já com as alterações inseridas pela Resolução ANEEL N²26/2002: 
Art. 12. A cada consumidor corresponderá uma ou mais unidades consumidoras, no mesmo local ou em locais diversos.

$\S 1^{\circ} \mathrm{O}$ atendimento a mais de uma unidade consumidora, de um mesmo consumidor, no mesmo local, condicionar-se-á à observância de requisitos técnicos e de segurança previstos nas normas e/ou padrões da concessionária.

$\S 2^{\circ}$ Poderá ser efetuado fornecimento a mais de uma unidade consumidora do Grupo "A", por meio de subestação transformadora compartilhada, desde que pactuados e atendidos os requisitos técnicos da concessionária e dos consumidores, e observadas as seguintes condições: (Redação dada pela Resolução ANEEL nº 226, de 24.04.2002)

a) Somente poderão compartilhar subestação transformadora, nos termos do parágrafo anterior, unidades consumidoras do Grupo A, localizadas em uma mesma propriedade e/ou cujas propriedades sejam contíguas, sendo vedada utilização de propriedade de terceiros, não envolvidos no referido compartilhamento, para ligação de unidade consumidora que participe do mesmo. (Alínea acrescentada pela Resolução ANEEL nº 226, de 24.04.2002)

b) Não será permitida a adesão de outras unidades consumidoras, além daquelas inicialmente pactuadas, salvo mediante acordo entre os consumidores participantes do compartilhamento e a concessionária. (Alínea acrescentada pela Resolução ANEEL $n^{\circ} 226$, de 24.04.2002)

$3^{\circ} \mathrm{O}$ compartilhamento a que se refere o parágrafo anterior, poderá ser realizado entre concessionária e consumidores, mediante acordo entre as partes. (Redação dada pela Resolução ANEEL n 226, de 24.04.2002)

$4^{\circ}$ As medições individualizadas deverão ser integralizadas para fins de faturamento quando, por necessidade técnica da concessionária, existirem vários pontos de entrega no mesmo local e desde que o fornecimento esteja sendo efetuado na mesma tensão. (Parágrafo acrescentado pela Resolução ANEEL n²26, de 24.04.2002)

A Alínea a, $\S 2^{\circ}$ do Artigo 12 da Resolução ANEEL $N^{\circ} 456 / 2000$ deixa claro que o compartilhamento de subestação transformadora somente é possível caso as unidades consumidoras estejam localizadas numa mesma propriedade ou em propriedades contíguas. Acontece que em nenhum documento da legislação do setor elétrico é apresentada a definição de propriedades contíguas. Uma definição que aparentemente seria muito simples de ser entendida acaba gerando interpretações divergentes sobre seu entendimento. 
A existência de vias públicas, tais como rios, rodovias e ferrovias, gera uma situação em que a contigüidade de terrenos possa ser contestada. Interpretando-se o Art. 12 da Resolução ANEEL $N^{\circ}$ 456/2000, pode-se entender que não havendo contigüidade o compartilhamento de subestações por duas ou mais indústrias não é permitido.

Dado que no Brasil existem muitos pólos industriais com vias públicas em seu interior e com redes elétricas privativas atravessando-as, as indústrias destes pólos ficam vulneráveis ao risco de reclassificação tarifária na parcela correspondente ao uso do sistema elétrico.

Recentemente, a ANEEL, no processo de Audiência Pública $N^{\circ}$ 008/2009, que teve como objetivo obter subsídios e informações adicionais para aprimoramento das condições gerais de fornecimento de energia elétrica, propôs, como alteração do Art. 12 da Resolução ANEEL N 456/2000, a eliminação da possibilidade de compartilhamento de subestação em caso de existência de vias públicas entre terrenos.

No texto apresentado a seguir, o qual foi extraído da minuta de resolução proposta pela ANEEL na AP 008/2009, pode-se verificar o posicionamento da ANEEL com relação ao tema citado:

Art. 9o. Poderá ser efetuado o fornecimento de energia elétrica a mais de uma unidade consumidora do Grupo A, por meio de subestação compartilhada, desde que atendidos os requisitos técnicos da distribuidora e observadas as seguintes condições:

I - as unidades consumidoras estejam localizadas em uma mesma propriedade e/ou em propriedades contíguas, sendo vedada a utilização de vias públicas e propriedades de terceiros não envolvidos no referido compartilhamento; e

II - é vedada a adesão de outras unidades consumidoras além daquelas inicialmente pactuadas, salvo mediante acordo entre os consumidores participantes do compartilhamento.

Parágrafo único. O compartilhamento de subestação pertencente a consumidor do Grupo A, mediante acordo entre as partes, poderá ser realizado com a distribuidora para atendimento a unidades consumidoras de sua responsabilidade, desde que haja conveniência técnica e econômica para seu sistema elétrico. 
Da forma como proposto pela ANEEL na minuta de resolução, a grande maioria dos pólos industriais existentes no Brasil seria prejudicada.

No Módulo 3 dos Procedimentos de Distribuição de Energia Elétrica no Sistema Elétrico Nacional - PRODIST ${ }^{9}$, que aborda o acesso ao sistema de distribuição, não há um tratamento sobre o tema de compartilhamento de subestação.

No Item 2.3.1 do Módulo 3 do PRODIST é citado que a conexão de mais de uma unidade consumidora por meio de subestação transformadora compartilhada deve seguir o disposto em regulamentação específica. Acontece que a regulamentação específica vigente sobre compartilhamento de subestações, que é a Resolução ANEEL N 456/2000, não é clara e ocasiona complicadores de ordem regulatória.

Nesta resolução, se define o ponto de entrega como sendo o ponto de conexão do sistema elétrico da concessionária com as instalações elétricas da unidade consumidora, caracterizando-se como o limite de responsabilidade do fornecimento. Ou seja, até o ponto de entrega a concessionária é responsável pelas instalações elétricas. Após o ponto de entrega, cabe ao consumidor a responsabilidade pelas instalações elétricas.

A Figura 36 - apresenta um exemplo genérico de um pólo industrial composto por oito empresas que compartilham uma subestação transformadora 138-13,8 kV, onde vias públicas atravessam as redes elétricas internas do pólo. Neste exemplo, caso o compartilhamento de subestação transformadora não seja possível devido à existência de vias públicas entre as unidades industriais, estas passariam então a ser faturadas na tensão secundária do transformador compartilhado e não mais na tensão primária da subestação, pois haveria alteração no ponto de entrega.

9 Os PRODIST são normas que disciplinam o relacionamento entre as distribuidoras de energia elétrica e demais agentes (unidades consumidoras e centrais geradores) conectados aos sistemas de distribuição, que incluem redes e linhas em tensão inferior a $230 \mathrm{kV}$. Tratam, também, do relacionamento entre as distribuidoras e a Agência, no que diz respeito ao intercâmbio de informações. Os PRODIST foi aprovado pela Resolução Normativa n 345, de 16 de dezembro de 2008, publicada no Diário Oficial da União - DOU em 31 de dezembro de 2008. 


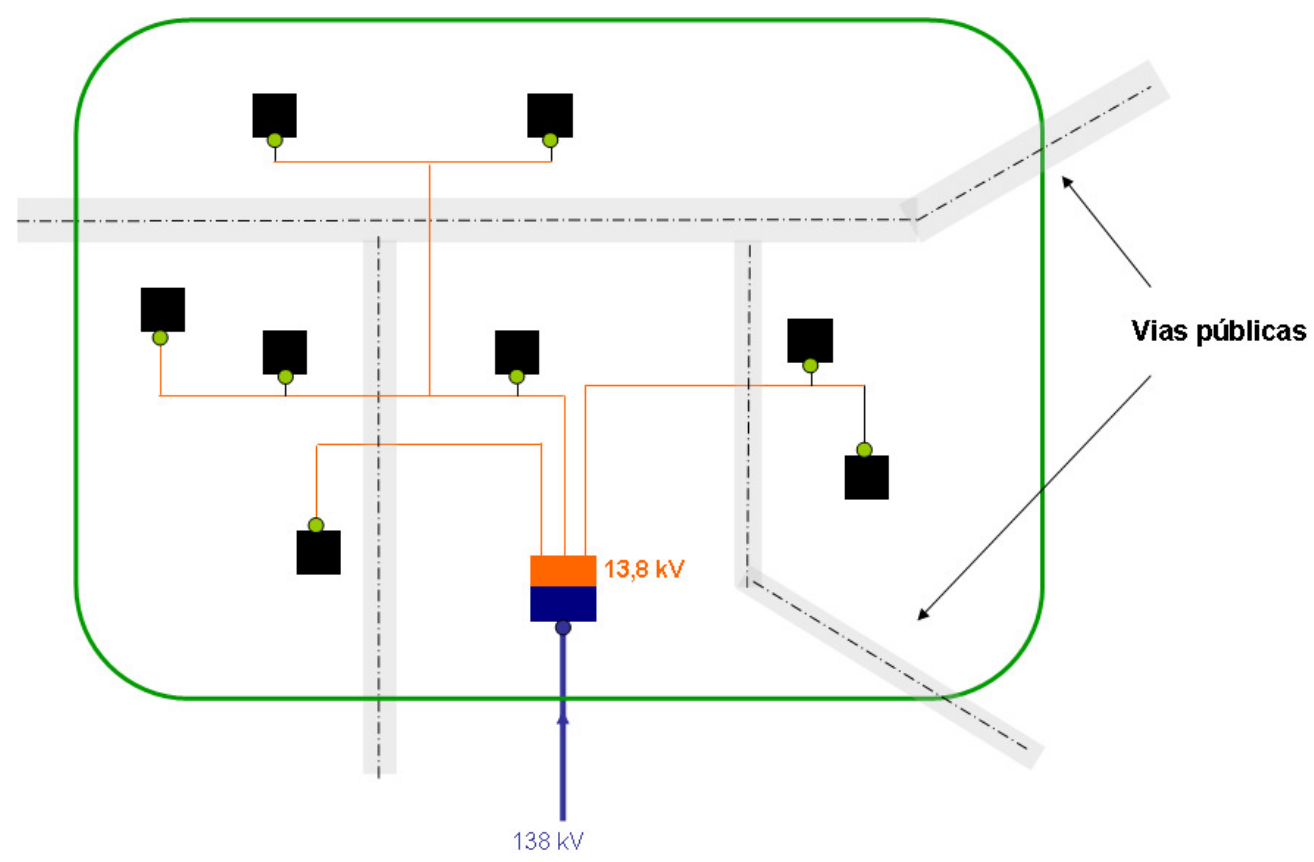

Figura 36 - Exemplo genérico de um pólo industrial onde há compartilhamento de subestação transformadora

Caso as indústrias permaneçam como proprietários das redes elétricas, a distribuidora não teria o direito faturar o consumidor na tensão secundária, pois estaria cobrando um serviço que não estaria sendo realizado. Este tipo de cobrança vai contra a lógica da concessão de serviço público, onde a concessionária deve ser remunerada pelos serviços prestados e por ativos existentes a partir de investimentos por ela realizados.

Assim, para efetuar a alteração no faturamento das indústrias do pólo, a concessionária de distribuição local teria que incorporar as redes elétricas internas aos pólos, para ficar como responsável pelas instalações até o ponto de entrega de cada indústria e ser então remunerada por um serviço prestado.

Para extinguir o risco regulatório da reclassificação e garantir o faturamento na tensão de entrada da subestação compartilhada, cada indústria do pólo teria que implantar sistemas de transformação de tensão independentes, a fim de eliminar o compartilhamento existente. Esta hipótese levaria as indústrias a efetuar elevados investimentos em equipamentos elétricos, como transformadores, disjuntores, seccionadores, pára-raios dentre outros, para evitar a reclassificação.

Caso as oito indústrias do pólo do exemplo acima tomassem a decisão de implantar suas próprias transformações para atendimento de suas cargas para evitar a 
reclassificação tarifária, a subestação do pólo seria gigantesca e com capacidade de transformação ociosa.

A proposta da ANEEL para alteração do Art. 12 da Resolução ANEEL N 456/2000 pode vir a prejudicar o setor industrial e favorecer os interesses das concessionárias de distribuição de energia elétrica. A exigência de contigüidade para compartilhamento de subestações sem uma definição clara gera um "vácuo regulatório" no setor elétrico que permite interpretações divergentes e afeta muitos pólos industriais existentes.

\section{2 - A Questão do Monopólio dos Serviços de Distribuição de Energia Elétrica}

A questão do monopólio dos serviços de distribuição configura-se como um tema extremamente polêmico, que foi fortemente usado pela Associação Brasileira de Distribuidores de Energia Elétrica - ABRADEE como argumento para impedir que consumidores livres acessassem diretamente Rede Básica do SIN, prescindindo do sistema de distribuição.

Como abordado anteriormente, a diferença entre TUST e TUSD em muitos casos é muito elevada e acaba por motivar a saída de consumidores dos sistemas das distribuidoras para conectar-se diretamente à Rede Básica. Este acesso à Rede Básica por consumidores é atualmente regulamentado pelo Decreto $N^{\circ} 5.597 / 2005$. De acordo com o referido decreto, para que um consumidor possa ser conectar diretamente à Rede Básica, pelo menos um dos requisitos citados a seguir devem ser obedecidos:

- Ligação de nova unidade consumidora não conectada anteriormente, desde que seja tecnicamente compatível com o nível de tensão igual ou superior a $230 \mathrm{kV}$, nos termos do que dispuser a portaria do Ministério de Minas e Energia prevista no inciso I do art. $2^{\circ}$; ou

- Alteração da forma de conexão de unidade consumidora já atendida em tensão inferior a $230 \mathrm{kV}$, em decorrência de:

- Aumento de carga; ou

- Necessidade de melhoria de qualidade, devidamente demonstrada pelo consumidor interessado e reconhecida pela ANEEL. 
O Decreto $N^{\circ} 5.597$, que se encontram transcrito no ANEXO B, exige que a conexão à Rede Básica obedeça ao critério do mínimo custo global para o sistema elétrico. Neste estudo analisam-se as alternativas de suprimento elétrico considerando os investimentos nas instalações de conexão e perdas elétricas, sempre sob a óptica do sistema elétrico.

Antes da publicação do Decreto N 5597/2005, havia um entendimento por parte da ABRADEE e da ANEEL, de que o acesso de consumidores à Rede Básica somente seria possível se as instalações do consumidor fossem contíguas às instalações de Rede Básica. Com a publicação do Decreto $N^{\circ} 5597 / 2005$ a questão de contigüidade para acesso à Rede Básica foi eliminada, permitindo ao consumidor construir suas linhas de transmissão particulares, desde que com tensão igual ou superior a 230 kV, e acessar diretamente o sistema de transmissão.

Entretanto, após a publicação do Decreto $N^{\circ}$ 5597/2005 pelo governo federal, a ABRADEE entrou com Ação de Descumprimento de Preceito Fundamental ADPF $^{10} \mathrm{~N}^{\circ} 93$ no Supremo Tribunal Federal - STF solicitando anulação do citado decreto, alegando diversos motivos, dentre eles, que o acesso à Rede Básica de consumidores violaria o monopólio de sua área de concessão.

O pleito da ABRADEE foi de anulação do Decreto $N^{\circ} 5.597 / 2005$, sob a alegação de o mesmo "viola preceitos fundamentais da Constituição de 1998". No ANEXO C, são apresentados os principais pontos de contestação pela ABRADEE na ADPF $N^{\circ} 93$.

Dentre diversos argumentos, a ABRADEE manifesta na ADPF $N^{\circ} 93$ que o Decreto $N^{\circ} 5597 / 2005$ :

- Desvaloriza o serviço público de distribuição de energia elétrica;

- Provoca incremento tarifário aos consumidores cativos;

- Contraria a lógica econômica de funcionamento das atividades de rede;

- Afronta o objeto claro e definido dos contratos de concessão de distribuição;

- Gera incerteza jurídica, dados seus efeitos colaterais.

Ao longo da ADPF N93 a ABRADEE argumenta diversas vezes que ao consumidor de energia elétrica não é permitido ser detentor de redes elétricas fora de sua

10 Argüição de Descumprimento de Preceito Fundamental (ADPF) é a denominação dada no Direito brasileiro à ferramenta utilizada para evitar ou reparar lesão a preceito fundamental resultante de ato do Poder Público. 
propriedade e que o acesso à Rede Básica fere a exclusividade de atendimento do serviço de distribuição de energia elétrica.

A ABRADEE afirma ainda que a conexão à Rede Básica dos consumidores industriais é uma "distribuição de riqueza às avessas levada a efeito por meio da desconstrução do conceito constitucional de serviço público".

É constante a posição da ABRADEE de que a migração de consumidores à Rede Básica prejudica o serviço de concessão e principalmente os consumidores cativos, e alega que estes consumidores acabam sendo onerados devido ao aumento em sua tarifa.

Na visão da ABRADEE, a área de concessão do serviço de distribuição de energia elétrica caracteriza-se como um condomínio, que deve ter a participação de todos os consumidores integrantes de sua área de concessão.

Há que se destacar que esta visão de condomínio chegou a ser também defendida pela ANEEL, conforme pode ser verificado no texto transcrito abaixo, extraído da Nota Técnica 034/2005, que integrou o processo da Audiência Pública 010/2205. Esta AP tinha como objetivo obter subsídios e informações adicionais para 0 aprimoramento das Resoluções Ns 281/1999, 715/2001, 513/2002, 67/2004 e $68 / 2004$.

"Portanto, o negócio de uma concessionária ou permissionária de distribuição de
energia elétrica é administrar um condomínio que deve ter participação de
todos os consumidores inseridos em sua área de concessão ou permissão,
sob pena que as exclusões deste universo onerem os remanescentes deste
condomínio. Não é, portanto, o negócio de uma concessão ou permissão de
distribuição a venda de energia elétrica."

“Não pode haver diferenciação de tratamento entre consumidores iguais apenas pela sua posição geográfica, nem pela sua opção pela compra de energia, quando se trata da divisão dos encargos de um condomínio, que neste caso está ligado a uma área de concessão."

"Dar tratamento diferenciado a estes consumidores com livre opção de compra de energia é transferir aos demais remanescentes o ônus da divisão, com um denominador cada vez menor, dos encargos de uma área de concessão, contrariando portanto tanto ao principio da isonomia de tratamento quanto ao principio legal de que esta opção não pode onerar o resto da concessão."

Nos argumentos apresentados pela ABRADEE na ADPF $\mathrm{N}^{\circ}$ 093, bem como nos pontos abordados na Nota Técnica ANEEL 034/2005, a conexão direta de um 
consumidor à Rede Básica estaria ferindo a concessão dos serviços de distribuição de energia elétrica.

Em sua ADPF, a ABRADEE chega até a fazer uma comparação da migração de consumidores livres à Rede Básica com os condôminos do andar térreo de um edifício, que entendem não ser justo pagar os custos do elevador e da faxina das escadas, posto que não os utilizam.

Em resposta às alegações apresentadas pela ABRADEE na ADPF $N^{\circ} 93$ contra o Decreto 5597/2005, a Advocacia Geral da União - AGU contestou a analogia usada pela associação das distribuidoras citando outra analogia, esta relacionada ao transporte coletivo. A AGU cita os casos em que grandes empresas e grandes indústrias efetuam o transporte de seus empregados de casa para o trabalho e viceversa. Segundo a AGU, se a visão da ABRADEE fosse aplicada neste caso, tal transporte de passageiros pelas empresas violaria o serviço público de passageiros, cuja obrigação da concessionária é atender a todos indistintamente. A AGU ressalta ainda que na interpretação da ABRADEE, seria uma afronta à solidariedade social dar carona ao colega de trabalho que mora no mesmo prédio, pois haveria uma diminuição da receita da concessionária com o não pagamento da tarifa (preço de transporte).

Contra a alegação da ABRADEE, de que um consumidor não poderia ser atendido diretamente por uma concessionária de transmissão, a AGU faz referência ao Art. $4^{\circ}$ do Decreto $N^{\circ} 41.019 / 1957$ para embasar sua defesa, o qual estabelece que:

\footnotetext{
Art. $4^{\circ} \mathrm{O}$ serviço de transmissão de energia elétrica consiste no transporte desta energia do sistema produtor às subestações distribuidoras, ou na interligação de dois ou mais sistemas geradores.

$\S 1^{\circ} \mathrm{A}$ transmissão de energia compreende também o transporte pelas linhas de subtransmissão ou de transmissão secundária que existiram entre subestações de distribuição.

$\S 2^{\circ} \mathrm{O}$ serviço de transmissão pode ainda compreender o fornecimento de energia a consumidores em alta tensão, mediante suprimentos diretos das linhas de transmissão e subtranmissão.
}

O Art. $4^{\circ}$ do Decreto $N^{\circ} 41.019 / 1957$ prevê expressamente a possibilidade do agente de transmissão conectar o consumidor final na chamada "alta tensão". 
Com relação ao direito de exclusividade defendido pela ABRADEE, ou seja, o monopólio dos serviços de distribuição, a AGU utiliza-se do Art. 16 da Lei N 8.987/1995, conhecida como Lei Geral das Concessões, para fazer sua defesa. Abaixo é transcrito o citado artigo.

Art. 16. A outorga de concessões ou permissão não terá caráter de exclusividade, salvo no caso de inviabilidade técnica ou econômica justificada no ato a que se refere $o$ art. $5^{\circ}$ desta Lei.

No artigo transcrito acima fica evidente que o serviço de concessão não tem caráter de exclusividade como defendido pelas distribuidoras de energia elétrica.

Outro ponto defendido pela ABRADEE, formulado com base nos Arts. 15 e 16 da Lei $N^{\circ}$ 9074/1995, é de que a liberdade do consumidor está apenas na compra de energia e não no Fio.

A seguir são descritos os artigos supracitados da Lei N 9074/1995.

\footnotetext{
"Art. 15. Respeitados os contratos de fornecimento vigentes, a prorrogação das atuais e as novas concessões serão feitas sem exclusividade de fornecimento de energia elétrica a consumidores com carga igual ou maior que $10.000 \mathrm{~kW}$, atendidos em tensão igual ou superior a $69 \mathrm{kV}$, que podem optar por contratar seu fornecimento, no todo ou em parte, com produtor independente de energia elétrica.

(...)"

"Art. 16. É de livre escolha dos novos consumidores, cuja carga seja igual ou maior que $3.000 \mathrm{~kW}$, atendidos em qualquer tensão, o fornecedor com quem contratará sua compra de energia elétrica."
}

Este mesmo entendimento chegou a ser defendido pela ANEEL no passado, conforme texto apresentado na NT 034/2005, onde é citado que não existe liberdade do consumidor em acessar as redes de transmissão, mas apenas a opção pela compra de energia. A seguir é transcrito o texto extraído da citada nota técnica.

\footnotetext{
"Também, a tarifa de uso do sistema de distribuição, quando o acesso do consumidor de uma determinada área de concessão ou permissão de distribuição se dá diretamente no sistema da transmissora, ou através de ativos em tensão de transmissão, mas de propriedade da distribuidora, obedece ao sinal locacional, sendo calculada pelo método nodal exatamente da mesma forma da tarifa de uso do sistema de transmissão, acrescida dos encargos que são pagos pelos demais consumidores, independente de sua opção de compra de energia ou de sua posição geográfica dentro da área de concessão ou
} 
permissão. Não existe liberdade para escolha do provedor de serviço de rede (transporte da energia), existe sim, o livre comercio para a energia elétrica para aqueles consumidores que se enquadram no disposto no art. 15, da Lei $n^{\circ} 9.074$, de 1995, com redação dada pela Lei $n^{\circ} 9.648$, de 1998."

Na visão da AGU, a ABRADEE utilizou-se de interpretação de pontos isolados da legislação do setor elétrico para embasar sua tese de que a migração à Rede Básica fere a concessão do serviço público de distribuição e prejudica os consumidores cativos.

Os argumentos apresentados no parecer da AGU apresentam um posicionamento de que não existe o tal monopólio dos serviços de distribuição de energia elétrica como defendido pelas distribuidoras e que um consumidor tem o direito de buscar condições mais viáveis de suprimento elétrico. Os argumentos apresentados pela AGU, o que existe na verdade é uma obrigação por parte das distribuidoras de energia elétrica de atender ao consumidor, todavia, não há obrigação por parte do consumidor em ser atendido pela distribuidora.

O entendimento da AGU foi validado pelo relator do processo, o Ministro Ricardo Lewandowski, do STF, que acolheu o parecer do Ministério Público Federal e não reconheceu a argüição de descumprimento de preceito fundamental da ABRADEE. No ANEXO D, é apresentada o despacho do Ministro Ricardo Lewandowski.

Em julgamento realizado em 20 de maio de 2009, o Plenário do STF por maioria de votos decidiu manter a decisão do ministro Ricardo Lewandowski e, em conseqüência, arquivou ADPF $N^{\circ} 93$ movida pela ABRADEE contra o Decreto $\mathrm{N}^{0} 5.597 / 05$.

O resultado da ADPF $N^{\circ} 93$ permite concluir que o papel de uma concessão pública de distribuição de energia elétrica não se configura como um monopólio exclusivo e que a atividade de distribuição de energia elétrica significa um "dever de atender" e não "um direito irrestrito de prestar o serviço".

Um exemplo interessante citado pela AGU em seu parecer é do setor de telecomunicações, em que é citado que os agentes autorizados de telefonia fixa podem oferecer seus serviços em determinadas localidades, sem exclusividade nem obrigação de atendimento a todas as localidades. Já as concessionárias de serviço público de telefonia fixa têm a obrigação de atendimento a todos os consumidores, independentemente da área geográfica em que se localizem. 
O mesmo raciocínio utilizado pela ABRADEE em sua ADPF contra o Decreto $N^{\circ} 5.597 / 2005$ é utilizado pela distribuidora COELBA contra a petroquímica Braskem S.A, que fornece energia elétrica em conjunto com vapor às industriais do pólo petroquímico de Camaçari. No Capítulo 9, este caso será abordado com a maior profundidade, suficiente para evidenciar um caso real de risco regulatório enfrentado por um pólo industrial.

Fazendo uma analogia aos pólos industriais com os argumentos da AGU contra a ADPF da ABRADEE, pode-se concluir que o compartilhado de indústrias na forma de pólos industriais e a venda de energia por meio de redes particulares não fere o direito de concessão das distribuidoras de energia elétrica, dado que não há exclusividade no atendimento elétrico. Todavia, pelo fato de não haver citação clara a respeito destes tópicos, a insegurança regulatória nos pólos industriais ainda existe e pode dar ensejo ao surgimento de ações administrativas e judiciais.

\section{3 - Propriedade de Redes Elétricas Particulares}

Outro argumento polêmico que gera risco aos pólos industriais é a possibilidade de um consumidor ser detentor de redes elétricas fora de suas propriedades ou que atravesse vias públicas, tais como rios, ferrovias e rodovias.

Antes da publicação do Decreto $N^{\circ}$ 5597/2005, a Superintendência de Regulação dos Serviços de Transmissão - SCT da ANEEL tinha o entendimento de que um consumidor não poderia ser proprietário de redes elétricas fora de sua propriedade. Esta posição da ANEEL é claramente percebida na Nota Técnica 012/2005, no processo de Audiência Pública 010/2205.

Na referida nota técnica, é citado como uma das conclusões da ANEEL, com relação aos princípios de concessão de distribuição, que:

\footnotetext{
"O consumidor, como particular que é, não é considerado agente setorial regulado, pois não é titular de autorização, permissão ou concessão para explorar serviços e instalações de energia elétrica. $\underline{A}$ ele é vedado, portanto, deter a propriedade de instalações de energia elétrica em áreas públicas, pois não existe a possibilidade legal de instituição de servidão administrativa ou desapropriacão de terras em seu favor. Se isso ocorresse, o interesse particular estaria sendo beneficiado em detrimento do interesse público."
} 
Na mesma Nota Técnica, com relação ao acesso de consumidores diretamente à Rede Básica por meio de instalações elétricas próprias, a ANEEL volta a mencionar:

“...pois é vedado ao consumidor instituir linha de transmissão (redes particulares) em áreas que não sejam de sua propriedade."

"O segundo, e bem menos óbvio, decorre da impossibilidade legal do consumidor deter instalações de energia elétrica fora de sua propriedade (áreas públicas), conjugado com a responsabilidade da distribuidora pelo atendimento aos consumidores em sua área de atuação. Para estes casos, mesmo os acessos à Rede Básica deverão ser feitos por intermédio da distribuidora."

Este entendimento da ANEEL prejudicou o acesso de muitos consumidores à Rede Básica, que passou a ser permitido apenas nos casos em que a instalação do consumidor fosse vizinha à uma instalação de Rede Básica. Caso contrário, o acesso do consumidor deveria ser feito via distribuidora local.

Os pontos abordados na Nota Técnica 012/2005, permitem concluir que, no passado, criou-se internamente na ANEEL um conceito de contigüidade para acesso à Rede Básica que não é abordado em regulamentação alguma do setor elétrico.

A questão de contigüidade, como já descrita no Capítulo 7 , é abordada apenas no Art. 12 da Resolução ANEEL N 456/2000 e com foco no compartilhamento de subestações transformadoras.

Na Figura 37 e Figura 38 são apresentados esquemáticos, extraídos da Nota Técnica 012/2005, que ilustram o entendimento da SCT da ANEEL em relação ao acesso à Rede Básica, antes da publicação do Decreto № 5597/2005.

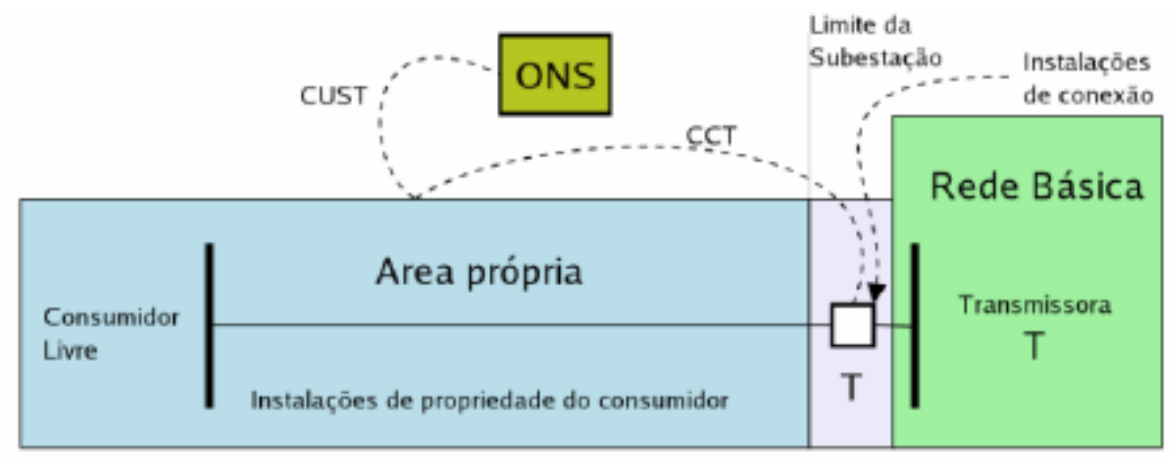

Figura 37 - Esquemático do entendimento da ANEEL para acesso de consumidor diretamente à Rede Básica (Anterior ao Decreto $N^{\circ} 5597 / 2005$ )

Fonte: Nota Técnica ANEEL Nº12/2005 


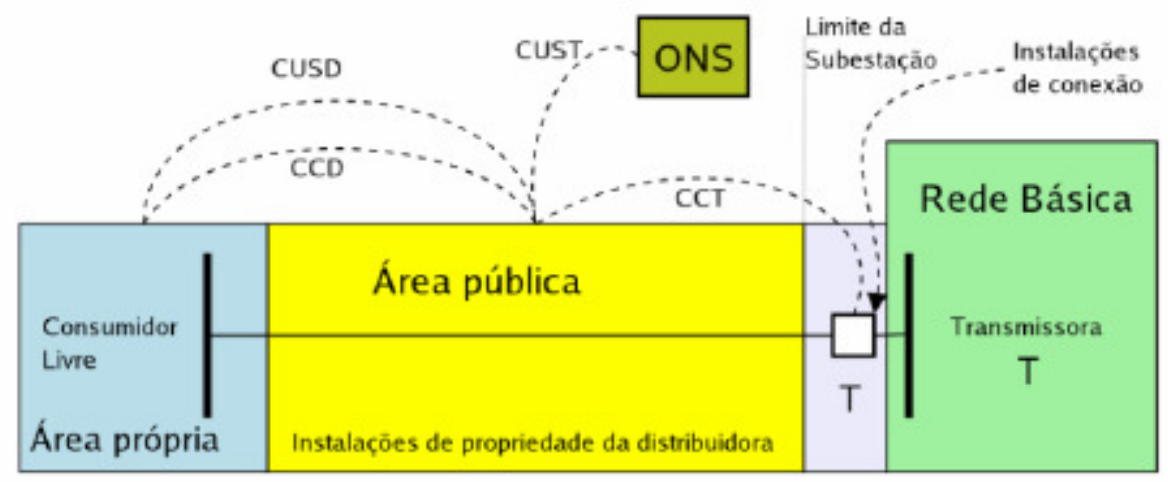

Figura 38 - Esquemático do entendimento da ANEEL para acesso de consumidor à Rede Básica via distribuidora (Anterior ao Decreto $N^{\circ} 5597 / 2005$ )

Fonte: Nota Técnica ANEEL N 012/2005

As figuras acima ilustradas evidenciam claramente o posicionamento da ANEEL contra a possibilidade de um consumidor ser detentor de redes privativas para acesso à Rede Básica. Nota-se que na visão da ANEEL, caso haja terrenos de terceiros ou vias públicas entre a propriedade do consumidor e a Rede Básica acessada, o consumidor teria então que ser atendido via concessionária de distribuição.

Na NT 034/2005, que também integrou o processo da Audiência Pública 010/2205 e foi divulgada pela Superintendência de Regulação dos Serviços de Distribuição SRD a posição da ANEEL é ainda mais contundente, conforme pode ser observado no texto transcrito a seguir.

A relação contratual de uso de sistemas elétricos, seja de distribuição ou de transmissão, pelos consumidores, livres ou não, é sempre com a concessionária ou permissionária de distribuição responsável pela área onde estes consumidores estão inseridos, independentemente de sua situação particular de contigüidade com ativos da rede básica, de demais instalações de transmissão ou de instalações de outras concessionárias ou permissionárias de distribuição que por ventura se encontrem na área de atendimento.

O conceito de contigüidade defendido pela ANEEL para acesso à Rede Básica foi derrubado pelo Decreto $N^{\circ} 5.597 / 2005$, que estabeleceu os critérios de conexão de consumidores livres à Rede Básica, permitindo o acesso è Rede Básica por meio de redes privativas desde que em tensão igual ou superior a $230 \mathrm{kV}$. 
O argumento de que um consumidor não possui o direito de ser detentor de redes elétrica fora de sua propriedade, ou que atravessa vias públicas, também foi usado pela ABRADEE na ADPF $N^{\circ}$ 93. Em sua defesa a ABRADEE citou o Art. 17 da Lei $N^{\circ} 9074 / 1995$, que relaciona algumas das instalações que o poder concedente deve definir como integrantes dos sistemas de transmissão. Pelo fato do referido artigo não fazer citação a respeito de redes elétricas de consumidores, o entendimento da ABRADEE foi que consumidores somente poderia ser detentor de redes elétricas que estejam integralmente em sua propriedade.

Por outro lado, a AGU, em seu parecer apresentado contra a ADPF da ABRADEE, manifesta o entendimento em favor dos consumidores afirmando que nada impede consumidor de ser detentor de redes elétricas fora de sua propriedade, desde que as mesmas sejam devidamente autorizadas pela ANEEL.

Para os pólos industriais ainda não há uma regulamentação clara como o Decreto $N^{\circ} 5597 / 2005$ que aborde a questão de compartilhamento de infra-estrutura elétrica por duas ou mais indústrias. Assim, o risco de uma eventual reclassificação tarifária das indústrias integrantes de pólos industriais ainda existe, principalmente quando analisados os posicionamentos da ANEEL em relação a temas similares.

Nos pólos industriais há o compartilhamento de subestações e transformadores, sendo as indústrias proprietárias de redes particulares que, em muitos casos, atravessam via públicas e/ou terrenos de terceiros. Estas redes elétricas interligam as indústrias ao barramento de baixa tensão dos transformadores compartilhados, mas as mesmas são faturadas na tensão de entrada da subestação.

Caso a ANEEL adote uma posição que proíba ao consumidor ser detentor de redes particulares fora de sua propriedade, o mesmo teria então que ser faturado na tensão secundária dos transformadores compartilhados. Por exemplo, num pólo em que a subestação compartilhada faça o abaixamento de 230 para $34,5 \mathrm{kV}$, os consumidores deixariam de ser faturados em $230 \mathrm{kV}$, como consumidores de Rede Básica, e passariam a ser faturados como consumidor A3a. Esta reclassificação acarretaria prejuízos expressivos às indústrias dos pólos, podendo, em alguns casos, ocasionar o encerramento das operações da indústria.

A Lei $N^{\circ} 10848 / 2004$ estabeleceu em seu Art. 15 que as concessionárias de distribuição devem incorporar a seus patrimônios as redes particulares que não possuam autorização do Poder Concedente, ou aqueles que possuam, mas que haja interesse das partes para transferência das redes. 
O Art. 15 da Lei $N^{\circ} 10848 / 2004$ foi regulamentado pela Resolução ANEEL $N^{\circ} 229$, de 08.03.2006, a qual estabeleceu as condições gerais para a incorporação de redes particulares, conectadas aos sistemas elétricos de distribuição. No Art. $4^{\circ}$ desta resolução é estabelecido que as "redes particulares, em qualquer tensão, localizadas integralmente em imóveis de seus proprietários não serão objeto de incorporação, ficando dispensadas, inclusive, da obtenção de ato autorizativo do Poder Concedente".

Apesar de estar subentendido na Resolução ANEEL N²29/2006 que a finalidade desta é de regularizar a situação de redes elétricas particulares que não possuem autorização, esta resolução poderia ser usada como argumento para incorporação de redes privativas internas aos pólos industriais, pelo fato das mesmas não estarem integralmente em terrenos de seus proprietários.

\section{4 - A Aquisição Conjunta de Energia}

Conforme verificado no Capítulo 6, em alguns pólos industriais do Brasil é comum ocorrer aquisição conjunta de energia por uma empresa líder com rateio entre os demais integrantes do pólo.

No entanto, pelo fato de não haver tratamento legal desta forma de aquisição de energia, as indústrias, em especial a indústria líder do pólo, enfrentam riscos constantes de sofrer uma penalidade e ter o suprimento elétrico interrompido.

Em geral, as indústrias que são supridas eletricamente por meio das indústrias líderes são menores e consistem em prestadores de serviços, como por exemplo, fornecedores de ar comprimido, água desmineralizada, vapor e oxigênio. Dados que estas indústrias fornecedoras de serviços possuem baixas demandas elétricas, inferiores a $3 \mathrm{MW}$, por exemplo, caso fossem atendidas pela concessionária local de distribuição de energia elétrica as mesmas teriam que ser atendidas em tensões reduzidas, como $13,8 \mathrm{kV}$. Isto elevaria os custos globais de energia dos fornecedores de utilidades e insumos, que seriam então repassados às indústrias consumidoras, prejudicando a competitividade do pólo industrial de forma geral.

A Resolução ANEEL $N^{\circ}$ 247, 21.12.2006, criou para aquisição de energia no mercado livre a figura do "Consumidor Especial", que se configura como "responsável por unidade consumidora ou conjunto de unidades consumidoras do 
Grupo A reunidas por comunhão de interesses de fato ou de direito, cuja carga seja maior ou igual a 500 kW".

Assim, é possível que empresas com carga elétricas individuais inferiores a $500 \mathrm{~kW}$ se agrupem e adquiram energia no mercado livre por meio de fontes incentivadas, desde que a carga do conjunto de consumidores seja superior a $500 \mathrm{~kW}$.

Como condição para esta aquisição conjunta, as empresas devem possuir reunião por comunhão de interesses de fato ou de direito e estarem localizadas em áreas contíguas. Caso as unidades não sejam contíguas, as mesmas devem possuir o mesmo CNPJ.

No caso de unidades não contíguas, fica evidente que a compra de energia em conjunto se aplica apenas para uma mesma empresa, que pode adquirir energia para suas filiais. Não sendo o mesmo CNPJ, além da necessidade de reunião por comunhão de interesse ou de fato, há a restrição de que as empresas devem ser contíguas, o que remete novamente a questão abordada no Capítulo 8.1.

Novamente, há a referência na legislação para a questão de contigüidade, que, como já citado, não possui uma abordagem clara e objetiva.

No Art. 90 da Resolução ANEEL N456/2000 são estabelecidas as situações em que a concessionária pode suspender, de imediato, o fornecimento de energia elétrica. A seguir é transcrito o referido artigo.

Art. 90. A concessionária poderá suspender o fornecimento, de imediato, quando verificar a ocorrência de qualquer das seguintes situações: I - utilização de procedimentos irregulares referidos no art. 72;

II - revenda ou fornecimento de energia elétrica a terceiros sem a devida autorização federal;

III - ligação clandestina ou religação à revelia; e

IV - deficiência técnica e/ou de segurança das instalações da unidade consumidora, que ofereça risco iminente de danos a pessoas ou bens, inclusive ao funcionamento do sistema elétrico da concessionária.

É claro no texto do Art. 90 da Resolução ANEEL N 456/2000 que em caso de revenda ou fornecimento de energia elétrica a terceiros a concessionária pode suspender de imediato fornecimento de energia elétrica ao consumidor. Como não há um tratamento regulatório sobre a aquisição conjunta de energia com rateio interno entre as indústrias integrantes dos pólos, gera-se um risco regulatório nos pólos onde este tipo de aquisição de energia é praticado. 
Há de se destacar também que em muitas indústrias é comum a existência, por exemplo, de bancos, lanchonetes, restaurantes, bancas de jornais, dentre outros, que são administrados por terceiros e consumem água e energia elétrica da indústria onde estão instalados. Estes estabelecimentos pagam à indústria em que estão instaladas, na forma de contrato de utilidades, uma determinada quantia para remunerar o consumo de água e energia elétrica.

Se o Art. 90 da Resolução ANEEL N 456/2000 for aplicado nestes casos, a concessionária poderia suspender de imediato o fornecimento de energia elétrica à indústria. Os estabelecimentos de serviço teriam então que ser supridos via distribuidora, que teria que construir suas redes elétricas para atendê-los, uma vez que a incorporação de redes privativa nestes casos seria completamente inviável.

A aquisição conjunta de energia elétrica é um dos principais temas que gera forte insegurança regulatória aos pólos industriais, por não ser suficientemente esclarecido na legislação.

Trata-se de um tema de grande importância para os pólos automotivos, onde uma indústria líder atrai para sua proximidade fornecedores de peças e serviços necessários à fabricação de automóveis, como por exemplo, fabricantes de pneus, vidros, rodas, carpetes, dentre outros. Nestes pólos, o compartilhamento de infraestrutura e aquisição conjunta de energia elétrica caracteriza-se como fator de extrema importância na manutenção da competitividade. 


\section{9 - EXEMPLO DE CASO DE CONFLITO ENTRE INDÚSTRIA E CONCESSIONÁRIA DE DISTRIBUIÇÃO}

Este capítulo apresenta os riscos enfrentados pelas indústrias integrantes do pólo petroquímico de Camaçari, em especial a Braskem S.A., empresa líder do pólo e que efetua venda, por meio de redes elétricas particulares, de energia elétrica gerada em sua planta de cogeração. As informações aqui apresentadas foram baseadas em documentos públicos de diversos processos em andamento na ANEEL, os quais estão relacionados nas referências bibliográficas.

A partir da definição do governo federal, que escolheu a região de Camaçari como a adequada para implantação de um pólo de indústrias petroquímicas no nordeste brasileiro, o Conselho de Desenvolvimento Industrial - CDI, do Ministério da Indústria e Comércio, por meio da Resolução $N^{\circ} 002$, de 20.07.1970, delegou à Secretaria Geral a responsabilidade pelas ações necessárias para implantação do Pólo Petroquímico do Nordeste. A liderança do empreendimento foi atribuída à Petrobrás por intermédio de sua subsidiária Petroquisa - Petrobrás Química S.A., a qual constituiu a COPENE - Petroquímica do Nordeste S.A., com a finalidade de coordenar a implantação desse complexo básico.

Ao estado da Bahia coube a responsabilidade pela execução das obras de infraestrutura e apoio. Uma área de $233 \mathrm{~km}^{2}$ foi declarada de utilidade pública para desapropriação e implantação do pólo petroquímico, a qual foi transferida à entidade responsável pela implantação do empreendimento, a COPEC - complexo Petroquímico de Camaçari. Em 1974 o estado da Bahia transferiu à COPENE a área desapropriada.

O Complexo Petroquímico de Camaçari teve como principal objetivo conciliar a necessidade de ampliação da indústria petroquímica nacional com características regionais específicas. O complexo foi estruturado de forma a proporcionar uma sinergia de logística entre as empresas e para isto, foi instalada uma Unidade de Insumos Petroquímicos Básicos com uma Central de Utilidades associada, compondo a antiga COPENE, que atualmente constitui a Unidade de Insumos Básicos da Braskem na Bahia, a UNIB-BA.

A maioria das empresas do Pólo está interligada por dutovias à unidade de insumos básicos da Braskem S.A., a qual recebe derivados de petróleo, principalmente a nafta, em sua UNIB-BA e os transforma em petroquímicos básicos (eteno, propeno, 
benzeno, tolueno, butadieno, xilenos, solventes e outros). Estes produtos e também utilidades, como energia elétrica, vapor, água e ar de instrumento, são fornecidos às outras unidades produtivas da própria Braskem S.A. e às indústrias vizinhas, de segunda geração da cadeia petroquímica, que, por sua vez, fabricam os petroquímicos intermediários, como polietileno e polipropileno, e alguns produtos finais.

A Braskem S.A. possui uma central de cogeração na UNIB-BA com capacidade instalada de aproximadamente $230 \mathrm{MW}$, como PIE. Para tal atendimento, a Braskem utiliza suas instalações de uso restrito, compreendendo a unidade de geração e o sistema elétrico associado destinado ao transporte da energia elétrica produzida, nos termos da Portaria MME N³21/1996.

O fornecimento da energia e vapor gerados pela planta de cogeração até as cargas das unidades industriais localizadas no pólo petroquímico ocorre por meio de interligações expressas e diretas de exclusiva propriedade da Braskem S.A. Todos os usuários são servidos por dois alimentadores expressos, redundantes e exclusivos, o que garante, adicionalmente, altos índices de confiabilidade e flexibilidade para manutenções.

A título de comparação, as figuras seguintes apresentam uma análise, de 2000 a 2006, dos valores de Duração Equivalente de Interrupção por Conjunto de Consumidores - DEC e Freqüência Equivalente de Interrupções por Conjunto de Consumidores - FEC do sistema COELBA com os valores de DEC e FEC adotados pela ANEEL como benchmarking, para o grupo de distribuidoras do qual a COELBA faz parte. Os dados de DEC e FEC são apresentados para sistema COELBA como um todo e também para o grupo de consumidores da região de Camaçari.

O DEC possui relação com o tempo que as unidades consumidoras ficaram sem energia elétrica, enquanto que o FEC relaciona-se ao número de interrupções ocorridas. Assim quanto maiores são o DEC e o FEC, piores são as condições de suprimento elétrico.

Verifica-se que a COELBA apresenta índices superiores aos valores adotados pela ANEEL como benchmarking. 


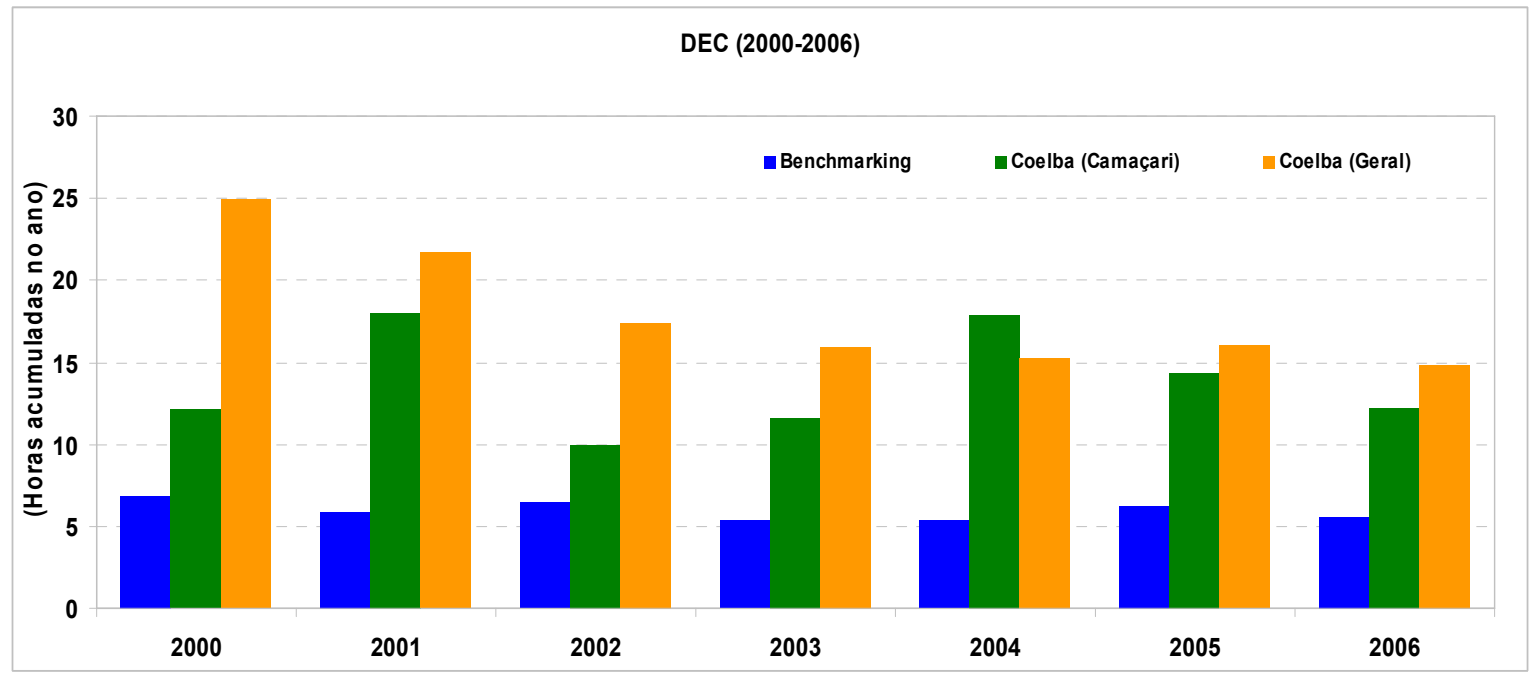

Figura 39 - Análise comparativa do DEC

Fonte: Site ABRADEE (www.abradee.org.br) / Site ANEEL (www.aneel.gov.br)

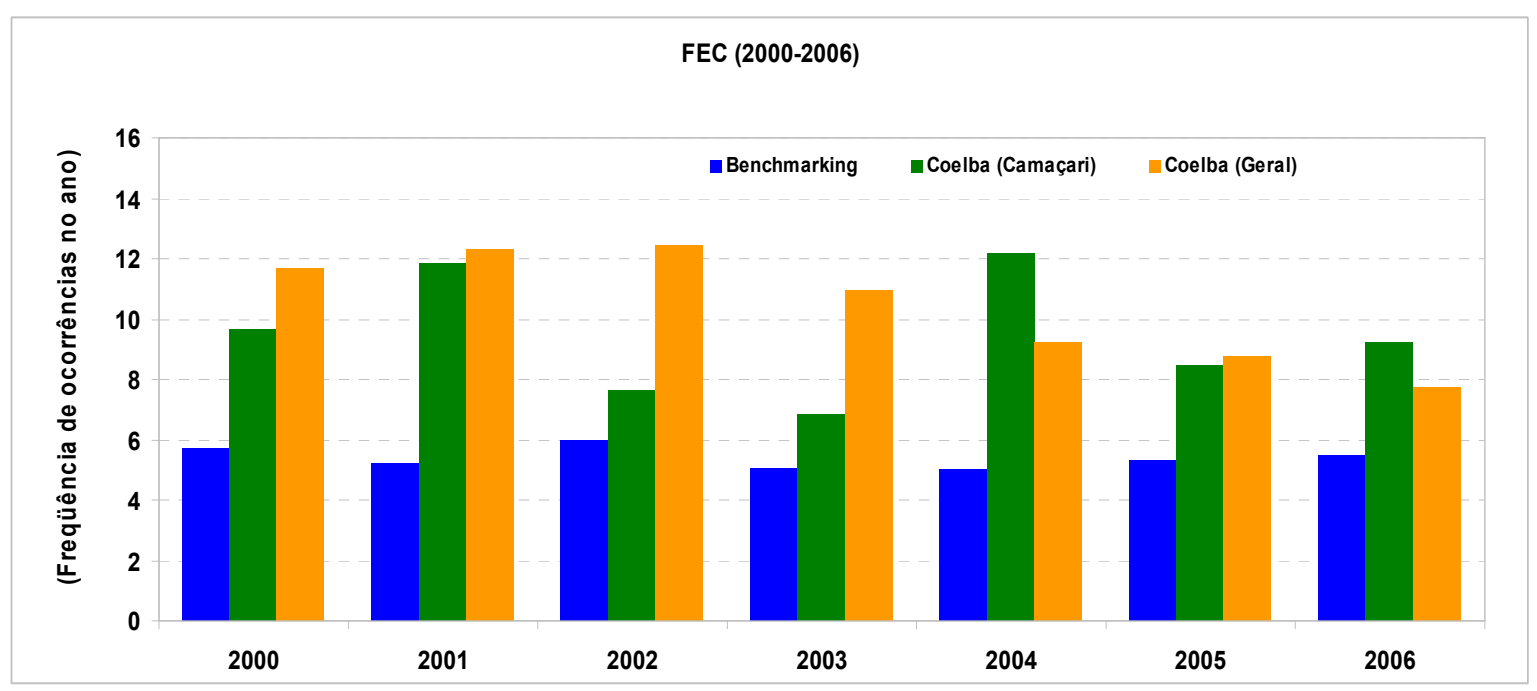

Figura 40 - Análise comparativa do FEC

Fonte: Site ABRADEE (www.abradee.org.br) / Site ANEEL (www.aneel.gov.br)

Índices de DEC e FEC estão muito relacionados às particularidades do sistema elétrico de cada distribuidora e diferem conforme o nível de tensão. Sabe-se que a COELBA cumpre os limites de DEC e FEC estabelecidos pela ANEEL. O fato é que em muitos casos os limites estabelecidos pela ANEEL não são satisfatórios para o setor industrial, que necessita de extrema confiabilidade de suprimento elétrico. Interrupções de fornecimento elétrico com baixa duração podem acarretar horas para retomada de alguns processos industriais, ocasionando perdas significativas. 
Ressalta-se também que desligamentos de produção não ocorrem somente devido a interrupções de fornecimento elétrico, sendo comum ocorrer parada em processos produtivos devido a oscilações de tensão. Para processos produtivos sensíveis, como o petroquímico, por exemplo, a qualidade e confiabilidade de atendimento elétrico são fatores fundamentais e qualquer oscilação no suprimento pode ocasionar perdas substanciais.

A estrutura de suprimento elétrico no pólo Petroquímico de Camaçari foi concebida no início da década de 80 , ou seja, antes da estruturação do novo modelo do setor elétrico brasileiro, que ocorreu em meados da década de 90. Em 1983 a antiga COPENE e a COELBA firmaram um acordo em que foram estabelecidas poligonais delimitando as áreas em que o atendimento elétrico das indústrias do pólo deveria ser feito pela COPENE ou pela distribuidora local. Neste acordo, duas poligonais foram estabelecidas para definição das áreas de fornecimento de energia elétrica.. $O$ Acordo Operacional previa que a COPENE efetuasse $O$ atendimento de energia elétrica as indústrias que estivessem dentro da Poligonal $\mathrm{A}$. Na outra área, entre a Poligonal A e B, o suprimento elétrico pela COPENE é facultativo. A tabela e figura apresentadas a seguir resumem a questão de suprimento nas poligonais.

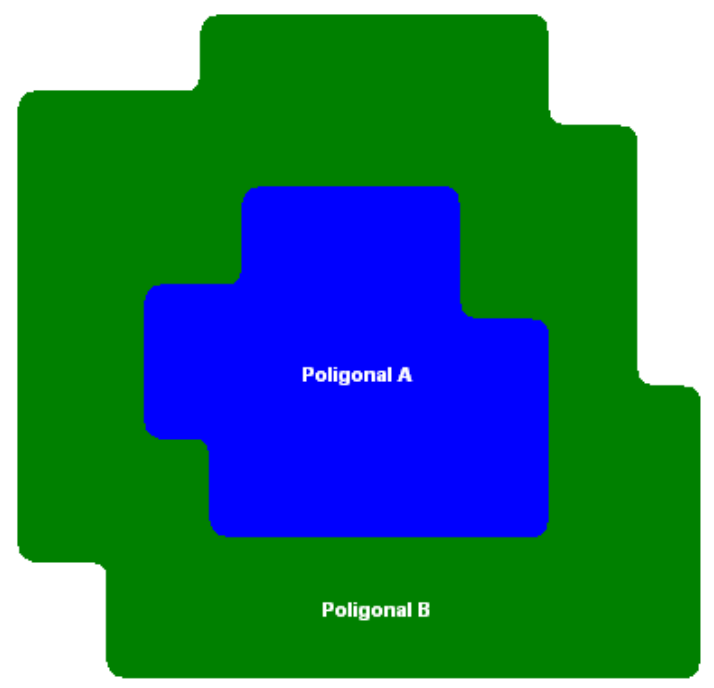

Figura 41 - Esquemático das Poligonais definidas no Acordo Operacional celebrado entre COPENE e COELBA no Pólo Petroquímico de Camaçari

Fonte: Processo ANEEL 48100.000383/1996-58 
Tabela 26 - Detalhamento do atendimento elétrico definido no Acordo Operacional celebrado entre COPENE e COELBA no Pólo Petroquímico de Camaçari

Área

Descrição do suprimento elétrico

A Braskem S.A. (COPENE) efetua o atendimento elétrico a todas as

Poligonal A empresas instaladas, e que venham a se instalar, no interior da poligonal A.

As empresas instaladas entre as poligonais $A$ e $B$, tem o direito de

Poligonal B
razões técnicas e econômicas, a maioria das empresas atualmente
situadas entre as poligonais A e B são atendidas pela Braskem S.A.

$\begin{array}{ll}\text { Poligonal B } & \begin{array}{l}\text { optar pelo atendimento via Braskem S.A. (COPENE) ou COELBA. Por } \\ \text { razões técnicas e econômicas, a maioria das empresas atualmente } \\ \text { situadas entre as poligonais A e B são atendidas pela Braskem S.A. }\end{array}\end{array}$

Poligonal B $\begin{aligned} & \text { optar pelo atendimento via Braskem S.A. (COPENE) ou COELBA. Por } \\ & \text { razões técnicas e econômicas, a maioria das empresas atualmente } \\ & \text { situadas entre as poligonais A e B são atendidas pela Braskem S.A. }\end{aligned}$

Área Externa

$\mathrm{Na}$ área externa à poligonal $\mathrm{B}$ as empresas devem ser atendidas pela distribuidora local.

Fonte: Processo ANEEL N 48100.000383/1996-58

Analisando a definição de atendimento elétrico das indústrias do pólo petroquímico de Camaçari conforme poligonais $\mathrm{A}$ e $\mathrm{B}$, pode-se concluir que os limites foram definidos em função da viabilidade econômica do transporte de vapor e utilidades.

No interior da Poligonal A, onde o transporte de vapor é técnica e economicamente viável, a COPENE passou a ter preferência pelo atendimento elétrico. Entre as Poligonais $\mathrm{A}$ e $\mathrm{B}$, onde a viabilidade técnica e econômica do transporte de vapor e utilidades é reduzida, a COELBA passou a ter preferência pelo atendimento elétrico. Entretanto, a indústria que se instalasse entre as Poligonais A e B, poderia optar por ser atendida pela COPENE em função de outros fatores.

$\mathrm{Na}$ área externa à Poligonal $\mathrm{B}$, onde a viabilidade de transporte de vapor e utilidades é mais reduzida e viável apenas em casos específicos, o atendimento elétrico foi atribuído à COELBA.

Após a estruturação do novo modelo do setor elétrico, em que se criaram as figuras do produtor independente de energia, auto-produtor, comercializador etc., a então COPENE solicitou sua regularização perante a ANEEL.

Em 15.10.1996 o MME por meio da Portaria MME N 321 autorizou a COPENE a se estabelecer como produtor independente de energia. Esta portaria foi embasada pelo Parecer CONJUR /MME N²08/1996, que ao longo do texto chega a citar que 
"o modelo de suprimento elétrico adotado pela COPENE é piloto e serve como modelo ao país, pois proporcionou ao país um modelo exemplar de geração e utilização de energia elétrica associada ao fornecimento de outro insumo, como o vapor".

Após a incorporação da COPENE pela Braskem S.A., esta solicitou alteração da razão social da primeira, o que ocorreu em por meio do Despacho ANEEL $N^{\circ} 2706 / 2006$.

Com a publicação da Resolução ANEEL N²29/2006, que estabeleceu as condições gerais para a incorporação de redes particulares, conectadas aos sistemas elétricos de distribuição, a Braskem S.A. efetuou consulta à ANEEL sobre a regularidade de suas redes elétricas particulares. O Parecer 220/2005 PGE/ANEEL afirmou que as instalações operadas pela Braskem S.A. estavam devidamente regularizadas e não deveriam ser incorporadas pela distribuidora local.

Em 2000, a Monsanto, indústria do setor de alimentos, decidiu implantar uma nova unidade industrial no pólo de Camaçari, na Bahia, e solicitou o atendimento de vapor e energia elétrica à Braskem S.A., na época ainda COPENE. A área prevista para instalação da unidade industrial da Monsanto estava fora da Poligonal B, ou seja, onde o atendimento elétrico deveria ser feito pela COELBA, conforme acordo operativo já citado. Mesmo assim, a Monsanto manifestou interesse em ser atendida pela então COPENE.

Com base nos limites de atendimento definidos no acordo operativo e também devido ao fato da Monsanto ser o primeiro consumidor a se instalar no pólo de Camaçari depois da estruturação do novo modelo de setor elétrico, a então COPENE comunicou à ANEEL que desenvolveria projeto para atendimento da Monsanto. A COPENE também solicitou as autorizações de passagem ao Departamento de Infra-Estrutura e Transportes do Estado da Bahia - DERBA e à Ferrovia Centro Atlântico, dado que a rede elétrica para atendimento da Monsanto cruzava rodovia e ferrovia.

O atendimento da Monsanto pela COPENE foi aprovado pela Superintendência de Regulação dos Serviços de Transmissão - SRT e pela Procuradoria Geral - PGE da ANEEL e em 10.05.2001 esta agência publicou a Resolução $N^{\circ} 175$ autorizando a COPENE a implantar a linha de transmissão de $69 \mathrm{kV}$, em circuito duplo, com extensão de 3,8 km, para atendimento da nova planta da Monsanto. 
Em 2005, a Columbian Chemicals, produtora de negro de fumo (que é utilizado na fabricação de pneus, artefatos de borracha, plásticos e tintas) encaminhou à Braskem termo de intenção solicitando o fornecimento de energia elétrica, vapor e matérias primas. A planta industrial da Columbian Chemicals foi construída em área localizada entre as Poligonais A e B, ou seja, onde o atendimento elétrico poderia ser feito tanto pela COELBA quanto pela Braskem. A instalação da planta da Columbian Chemicals em Camaçari mobilizou investimentos ordem de $\mathrm{R} \$ 165$ milhões e foi concluída em 2006.

Segundo informações dos processos em andamento na ANEEL ${ }^{11}$, a Columbian Chemicals após discussões com a COELBA, concluiu que devido aos rigorosos padrões de confiabilidade e segurança, sua nova unidade industrial somente seria factível em razão da possibilidade da Braskem S.A. fornecer a matéria prima essencial e todas as utilidades necessárias ao seu processo produtivo (energia elétrica, água clarificada, água potável e vapor), com destaque para o alto índice de confiabilidade de suprimento elétrico. O contrato entre Braskem S.A. e Columbian Chemicals foi firmado em agosto de 2005.

Os diversos processo em andamento na ANEEL mostram que o atendimento elétrico da Monsanto e Columbian Chemicals pela Braskem S.A. passou a ser fortemente contestado pela COELBA. Em 2006, esta distribuidora protocolou na ANEEL pedidos de embargo e interdição das obras para atendimento da Columbian Chemicals e de invalidação contra a Resolução ANEEL № 175/2000.

Nos processos, a COELBA argumenta que a Braskem S.A. "não é titular de outorga do Poder Concedente que a legitime a prestar serviço público de distribuição de energia elétrica e que ela não obteve, e nem poderia obter, as necessárias autorizações da ANEEL para construção de rede de distribuição de energia elétrica para conectar sua UTE à Columbian".

Em documentos apresentados pela COELBA à ANEEL nos processos relacionados ao suprimento elétrico no pólo de Camaçari, a distribuidora afirma que o fornecimento de energia pela Braskem à Columbian Chemicals "representa quebra do contrato de concessão e gera um perigoso precedente que poderia se estender a outras áreas do país".

11 Processos 48100.000383/1996-58, 48500.001256/2006-80.

48500.002882/2000-15,

48500.001550/2005-56 
No processo a COELBA pede a cassação por parte da Braskem do fornecimento de energia elétrica à Columbian Chemicals, bem como todo e qualquer outro comprador de energia do PIE sem o uso da suas redes de distribuição.

A distribuidora afirma que autorização dada pela Portaria MME N 321/1996 à então COPENE para operar como PIE refere-se somente à energia e não ao transporte e que, desta forma, ela teria o direito de efetuar o serviço de transporte de energia pelo fato de ser uma concessionária de serviço público. Segundo a COELBA, caso um PIE queira vender energia elétrica que produz, ele terá obrigação de acessar e utilizar os sistemas de transmissão e distribuição de energia elétrica para viabilizar o seu transporte até seu comprador.

A COELBA cita que tanto ela quanto os consumidores cativos são prejudicados, pois a receita proveniente do uso do sistema de distribuição integra a rubrica Receita Requerida das concessionárias para fins de cálculo do reposicionamento tarifário por ocasiões das revisões periódicas. Afirma ainda que quanto menor for o mercado da concessionária, maior será o índice de reposicionamento tarifário a ser aplicado aos seus consumidores.

Com relação ao atendimento da Monsanto a COELBA em seu pleito solicita que este consumidor celebre CUSD e CDD com ela. No entanto, não se verifica no processo solicitação da distribuidora para a incorporação das redes elétricas.

Em sua defesa, a Braskem S.A. argumenta que o fornecimento de energia elétrica de sua planta de cogeração às indústrias do pólo petroquímico de Camaçari ocorre por meio de redes elétricas expressas, ponto a ponto, em sua maioria por dutos subterrâneos, não havendo redes de atendimento múltiplo e muito menos de distribuição. Desta forma, afirma a Braskem S.A., o fornecimento de energia elétrica efetuado por ela no pólo de Camaçari não se caracteriza como uma atividade de distribuição de energia elétrica, que envolve malhas de redes e outras instalações conectadas ao sistema de transmissão, regidas por normas de fornecimento e tarifas fixadas pelo poder concedente.

A Braskem defende que a comercialização de energia em complexos industriais, nos casos de cogeração, decorre de uma situação técnica específica, cujas peculiaridades impõem relacionamento direto com o cogerador, que produz vapor e energia elétrica e fornece às demais indústrias do pólo. Esta empresa ressalta que as especificidades técnicas do processo de cogeração existentes no pólo 
petroquímico de Camaçari comprovam que a atividade de produção e fornecimento de insumos (vapor, energia elétrica, água e outros) são indissociáveis e inerentes ao processo produtivo das indústrias dele integrantes e afirma ainda que estas especificidades foram considerada no Inciso II, do Art. 12 da Lei № 9074/1995, que permite ao PIE cogerador comercializar energia em conjunto com vapor de processo.

A Braskem S.A. afirma que suas atividades no pólo de Camaçari sempre foram autorizadas por órgãos competentes do setor de energia, como MME, DNAEE e ANEEL, por meio de resoluções, portarias e demais documentos, e que a Lei $N^{\circ}$ 9074/1995 prove respaldo legal as atividades que são contestadas pela COELBA.

A Columbian Chemicals também apresentou seus argumentos ao longo do processo, os quais foram sempre em defesa do atendimento de sua planta industrial pela Braskem S.A. por meio de redes elétricas particulares.

Sobre os casos Monsanto e Columbian Chemicals a ANEEL elaborou uma nota técnica em conjunto com três superintendências, a SFG, a SCT e a SCG, a qual teve posicionamento contrário aos pleitos da COELBA. Nesta NT, é citado "que o fornecimento de energia elétrica pela Braskem às empresas do pólo é parte indissociável do processo dessas indústrias, sem o qual não se sustenta o processo produtivo."

O processo foi analisado também pela Procuradoria Federal - PF da ANEEL, que elaborou uma nota técnica sobre o caso, porém, com posicionamento contrário ao adotado pelas superintendências acima citadas. A Procuradoria Federal chega a argumentar que "o serviço de distribuição de energia elétrica é prerrogativa da concessionária de distribuição e que PIEs tem função exclusiva de gerar energia elétrica, jamais de praticar atividades típicas de distribuição". Na mesma NT, a Procuradoria Federal cita ainda o exemplo do suprimento elétrico das empresas Aracruz e Nexen, em que há cogeração de energia pela Aracruz com venda de energia elétrica e vapor à Nexen, sem pagamento de parcela fio à distribuidora. A Procuradoria Federal afirma que neste caso o fornecimento de energia elétrica ocorre dentro de "muros" de propriedade da Aracruz, sendo que o fluxo de energia se dá exclusivamente dentro de uma área privada à unidade do mesmo processo industrial. 
A PF afirma que no caso do pólo de Camaçari a situação é diferente, pois dentro das poligonais há fornecimento de energia elétrica pela COELBA a algumas empresas e ressalta ainda que existem vias públicas atravessando o complexo petroquímico.

Em 05.06.2007, a ANEEL por meio do Despacho ANEEL N 1767/2007 determinou algumas medidas em relação ao atendimento elétrico da Braskem S.A. à Monsanto e à Columbian Chemicals, seguindo, basicamente, os pontos estabelecidos na Nota Técnica elaborada pela Procuradoria Federal.

Com relação ao suprimento da Monsanto, o Despacho ANEEL N 1767/2007 estabeleceu que a Resolução ANEEL N 175/2000 não fosse invalidada. Assim, o suprimento elétrico da Braskem à Monsanto foi ratificado pela ANEEL. Esta decisão foi tomada mais em função de aspectos jurídicos do que técnicos, pois o prazo decorrido para contestação da COELBA havia ultrapassado cinco anos, período que uma vez ultrapassado, impede que atos administrativos sejam anulados, conforme estabelecidos pelo Art. 54 da Lei 9784/1999.

Com relação ao suprimento elétrico da Columbian Chemicals pela Braskem as determinações do Despacho ANEEL N 1767/2007 foram diferentes. Este despacho determinou que "os bens e instalações de distribuição implantadas pela Braskem para o fornecimento de energia elétrica à empresa Columbian Chemicals fossem incorporados ao imobilizado em serviço da COELBA, mediante o correspondente ressarcimento à Braskem".

No mesmo despacho é determinado que a Braskem poderia fazer uso das instalações a serem transferidas para comercialização da energia gerada em sua planta de cogeração, porém, mediante ressarcimento do custo pelo transporte à COELBA.

Ainda de acordo com o Despacho ANEEL N 1767/2007, a ANEEL estabeleceu que a implantação de novas redes elétricas pela Braskem a indústrias localizadas no Complexo Petroquímico de Camaçari fosse condicionada à autorização específica prévia da ANEEL, devendo ser comprovado, dentre outras coisas, mas como condição imprescindível, a integração na cadeia produtiva do Complexo da nova indústria a ser atendida pela Braskem.

Após liminar judicial impetrada por uma das partes envolvidas no processo, a ANEEL por meio do Despacho $N^{\circ}$ 417/2008 voltou a atrás em sua decisão e anulou o Despacho ANEEL N¹767/2007, o que eliminou, temporariamente, a necessidade 
de transferência à COELBA dos ativos implantados pela Braskem para atendimento da Columbian Chemicals, entretanto, o caso ainda encontra-se em andamento na ANEEL aguardando um posicionamento final desta agência.

Os dois casos apresentados ao longo deste capítulo evidenciam os conflitos atualmente existentes entre indústria e concessionárias de distribuição de energia elétrica em pólos industriais.

Uma política de incentivo à formação de pólos industriais deverá ser respaldada, necessariamente, por uma regulação adequada que evite estes tipos de divergências e proporcione um ambiente regulatório claro que favoreça a atração de empresas ao país. 


\title{
10 - PROPOSIÇÃO DE REGULAMENTAÇÃO SOBRE PÓLOS INDUSTRIAIS ABORDANDO A QUESTÃO ENERGÉTICA
}

Em diversos países, observa-se que algumas definições criadas para pólos industriais são mais genéricas, permitindo maior flexibilidade quanto aos tipos de empresas que podem se agrupar e usufruir dos benefícios gerados. Existem definições que permitem de forma explícita a inclusão de prestadores de serviço ou de outras empresas não industriais relacionadas ao dia-a-dia do pólo. Outra ocorrência comum é a exigência de uma área delimitada, aceitando vias públicas ou acidentes geográficos internos a esta área.

As definições de pólos industriais variam dependendo do contexto e das necessidades, mantendo-se constantes somente alguns parâmetros básicos da definição, como, por exemplo, a limitação do contexto a empresas industriais ou relacionadas a elas e algum tipo de restrição geográfica, obrigando que estas empresas se agrupem fisicamente para obter ganhos de escala e sinergias.

A seguir são apresentados alguns exemplos de definições para pólos industriais.

\footnotetext{
"Conjunto de indústrias que capturem benefícios através de ganhos de escala ou escopo, associadas por meio de relações de fornecedor-cliente, ou por tecnologias, clientes ou canais de distribuição em comum, ou pelo compartilhamento do mesmo pólo de mão-de-obra."
}

Michael E. Porter, 1990 - EUA

\begin{abstract}
"Toda área próxima a uma planta de produção industrial cuja atividade esteja relacionada à operação, incluindo mas não se limitando a estacionamentos, áreas fabris, edifícios, áreas verdes, tubulações, terminais ferroviários ou portuários e toda a área relacionada à produção industrial, sendo limitada, quando possível, por fronteiras legais ou naturais."
\end{abstract}

South California Legislature - EUA

"Concentrações de firmas envolvidas em processos interdependentes de produção freqüentemente na mesma indústria ou setores de mercado, cujas empresas estão relacionadas à mesma comunidade local e delimitadas pela distância diária de deslocamento dos funcionários."

Piore e Sabel, 1984; Goodman e Bamford, 1990 et al, Brusco, 1992 - Itália 
"Grupo de plantas industriais cujos membros se encontram em proximidade geográfica, ou seja, aglomerados de empresas do mesmo setor ou de setores similares."

Michael J. Enright, 1992, 1993 - Hong Kong

"qualquer conjunto de edifícios utilizado para a produção de bens, incluindo construções que ofereçam moradia ou serviços aos empregados, localizadas nas redondezas e separadas fisicamente das propriedades externas ao pólo. A área deve ser propriedade de uma única entidade."

Regras para Redistribuição de energia Elétrica (Energy Regulatory

Commision) - Filipinas

"Agrupamentos industriais com um mínio de 50 unidades, fabricando produtos relacionados e localizados dentro de um raio de $10 \mathrm{~km}$ de um local determinado. O número de unidades e distância podem ser flexibilizados pelo Estado para casos específicos."

Departamento de Minas e Indústria - Índia

Utilizando como referência as experiências internacionais, pode-se concluir que existe uma serie de oportunidades para fomentar o desenvolvimento por meio de incentivos à criação de novos pólos industriais ou ao crescimento de pólos já existentes no Brasil.

A regulamentação a ser estabelecida deve garantir o funcionamento do mercado sob regras claras, com tratamento padronizado, e manter o equilíbrio econômico entre os agentes do setor, permitindo o acesso aos benefícios a um número limitado de empresas com potencial para trazer desenvolvimento industrial a determinadas regiões do Brasil.

Dentre as condições relevantes que devem constar na regulamentação, destaca-se a definição do pólo industrial, as condições de gestão, inclusive para compartilhamento de infra-estrutura e a aquisição de insumos, o tratamento que deve ser dado à compra de energia elétrica e à contratação do uso e da conexão aos sistemas elétricos e a caracterização do ponto de entrega para fins destas contratações, incidência de encargos e aferição da medição.

Considerando a variedade de situações identificadas, a criação de uma regulamentação que aborde a questão energética de pólos industriais deve conter, 
mas sem se limitar a eles, os seguintes pontos para garantir da competitividade das indústrias:

- Possibilidade de existência de vias públicas internas ao pólo;

- Presença de consumidores não industriais, como prestadores de serviços, bancos, restaurantes etc;

- Possibilidade de convivência de consumidores livres e cativos;

- Possibilidade de aquisição de energia de forma centralizada por uma empresa líder ou de forma independente;

- Possibilidade de celebração de contratos de conexão (CUST/CUSD e CCT/CCD) de forma centralizada ou independente;

- Compartilhamento de infra-estrutura energética, como subestações, redes elétricas etc.;

- Faturamento dos consumidores com base na tensão de entrada da subestação compartilhada;

- Existência de contratos de reserva de capacidade (conexão de backup) ${ }^{12}$

- Possibilidade de comercialização de energia para fora do pólo.

O pólo industrial passaria a ter liberdade para definir a melhor forma de contratação de uso dos sistemas, medição de faturamento e aquisição de energia, cabendo aos integrantes do pólo definir se estes fatores são adquiridos em conjunto ou individualmente.

O faturamento dos consumidores seria efetuado com base na tensão de entrada da subestação do pólo, podendo as indústrias ser consumidores cativos ou livres.

Os encargos setoriais incidiriam somente sobre a energia proveniente do SIN, sendo isenta de encargos a energia gerada e vendida internamente no pólo. Esta medida poderia proporcionar incentivos à ampliação de plantas de cogeração existentes e à instalação novas cogerações.

A regulamentação deve garantir um ambiente propício para atração de novas empresas, visando o desenvolvimento dos pólos existentes e a criação de novos

12 A Reserva de Capacidade é regulamentada pela Resolução ANEEL No 371, de 29.12.1999 com alterações feita pela Resolução No 304, de 04.03.2008. A Reserva de Capacidade se refere ao "montante, em MW, requerido dos sistemas de transmissão e distribuição quando da ocorrência de interrupções ou reduções temporárias na geração de energia elétrica das usinas de autoprodutor ou produtor independente. A contratação deve ser efetuada entre o autoprodutor (ou produtor independente) e a concessionária de transmissão ou distribuição de energia elétrica que atue na área onde se localizada a unidade consumidora. 
pólos. Deve evitar ambigüidade de interpretação, eliminando assim os vácuos regulatórios hoje existentes.

Tomando como base os casos de sucesso em outros países em que políticas de incentivos a pólos industriais envolvendo a questão energética foram adotadas, e também as diversas características dos pólos industriais do Brasil, a ABRACE, em conjunto com empresas de consultoria técnica e jurídica, estabeleceu a seguinte definição para pólo industrial:

\footnotetext{
Pólo industrial é a reunião de empresas industriais, em área geográfica delimitada por um raio de até $10 \mathrm{~km}$, que tenham interesse comum no compartilhamento de infra-estrutura e na aquisição de insumos, compreendendo energia, água, vapor, gás, transporte, dentre outros".
}

A definição proposta pela ABRACE para pólos industriais é bastante abrangente e acredita-se que englobe todos os pólos existentes no Brasil e poderá comportar muitos outros futuros pólos.

O trabalho desenvolvido pela ABRACE teve como resultado a estruturação de uma minuta de decreto ministerial que aborda todos os pontos polêmicos envolvendo à questão energética de pólo industriais. No ANEXO A é apresentada a minuta de decreto proposto pela ABRACE.

A regulamentação do tema de pólos industriais envolvendo a questão de suprimento elétrico é polêmica e com certeza enfrentará obstáculos para sua concretização.

A proposta de decreto da ABRACE visa aos interesses dos pólos industriais existentes no Brasil e proporciona condições favoráveis para a criação de novos pólos, contribuindo para a manutenção da competitividade do setor industrial. Essa posição está coerente com a missão de uma associação de consumidores.

Entretanto, os pontos defendidos na minuta de decreto elaborado pela ABRACE divergem dos interesses das concessionárias de distribuição de energia elétrica e eventuais impactos que possam ser causados às mesmas devem ser analisados com atenção.

A solução do conflito deve ser uma decisão política. Os incentivos ao desenvolvimento de pólos industriais são ações no sentido de promove a geração de empregos mediante o crescimento do setor industrial, mas é necessário também financiar o setor elétrico e garantir a modicidade tarifária. 
O desenvolvimento do setor industrial pode levar também ao crescimento do setor elétrico, uma vez que o crescimento da indústria leva a uma maior geração de empregos. Isto proporciona um fortalecimento da economia com conseqüente aumento do poder aquisitivo da população, gerando crescimento do mercado residencial de energia elétrica. 


\section{1 - CONCLUSÃO}

Ao longo desta dissertação foram apresentados alguns dos obstáculos enfrentados por indústrias instaladas em pólos industriais no que se refere ao suprimento de energia elétrica.

As análises apresentadas no Capítulo 3 mostraram que as tarifas de energia elétrica do setor industrial no Brasil sofreram aumentos expressivos o que prejudicou a competitividade do setor. Verificou-se que apesar de o Brasil possuir uma matriz de geração de energia elétrica com base em hidrelétricas, o país apresenta uma das tarifas finais de energia mais elevadas, sendo superior às tarifas de países como Estados Unidos e França, que possuem base em geração térmica e nuclear, respectivamente.

O Capítulo 4 apresentou algumas das vantagens inerentes à formação de pólos industriais, tanto para as empresas quanto para a região onde os pólos se instalam. Para a região destaca-se a geração de empregos, qualificação de mão de obra, arrecadação de impostos etc. Para as empresas, tem-se, por exemplo, ganhos de escala na aquisição de produtos ou insumos, sinergias operacionais e redução de custos de O\&M.

O Capítulo 5 mostrou que diversos países, tais como Estados Unidos, Canadá, Dinamarca, dentre outros, tem adotado políticas de incentivos a pólo industriais envolvendo a questão energética e que estas políticas proporcionaram resultados substanciais, contribuindo assim para o desenvolvimento industrial do país.

Acontece que, com relação ao suprimento elétrico de pólos industriais, a legislação brasileira não é clara e apresenta vácuos regulatórios que acabam permitindo que interpretações divergentes sejam feitas sobre um determinado tema.

As análises das características diversas dos pólos industriais brasileiros apresentadas no Capítulo 6 em conjunto com os riscos regulatórios abordados no Capítulo 7 mostraram que a criação de uma regulamentação sobre pólo industriais envolvendo a questão energética é fundamental para garantir o funcionamento dos pólos existentes e permitir a criação de novos pólos. A regulamentação proposta pela ABRACE consiste numa iniciativa interessante que pode vir ao encontro destes interesses.

O suprimento elétrico aos pólos industriais consiste num tema polêmico que, acredita-se, enfrentará obstáculos para que seja regulamentado. Entretanto, é 
preciso refletir sobre o papel de uma concessão pública de distribuição de energia elétrica, que não é de um monopólio exclusivo, conforme pode-se observar ao longo da dissertação. Deve-se refletir sobre as diferentes missões: "dever de atender" ou "um direito irrestrito de prestar o serviço".

Políticas de incentivos a pólos industriais são fundamentais para fortalecer o setor industrial de um país e, conforme apresentado, muitos países já adotaram esta estratégia para alavancar o crescimento dos mesmos.

Os casos de sucesso internacionais indicam que no Brasil há ainda diversas ações de incentivos a pólos industriais envolvendo a questão energética que poderiam ser aplicadas, de forma a incentivar o desenvolvimento do setor industrial e, conseqüentemente do país. 


\section{REFERÊNCIAS BIBLIOGRÁFICAS}

A. Lagendijk, A., Charles, D.; "Clustering as a New Growth Strategy for Regional Economies? A discussion of New Forms of Regional Industrial Policy in United Kingdom"; OECD Proceedings: Boosting Innovation - The Cluster Approach (1999);

Carrão, A. M. R.; "Cooperação entre empresas de pequeno porte em pólos industriais: um estudo comparativo"; Universidade Metodista de Piracicaba UNIMEP (2003);

Ceglie, G., Clara, M., Dini, M.; "Cluster and Network Development Projects in Developing Countries: Lessons Learned through the UNIDO Experience"; Private Sector Development Branch, UNIDO, Vienna; OECD Proceedings: Boosting Innovation - The Cluster Approach - (1999);

"The European Cluster Memorandum: Promoting European Innovation through Clusters"; Centre for Strategy and Competitiveness, CSC; Europe Cluster Observatory - (2007);

Cerejeira, J. C.; "Distritos Industriais em Portugal: Identificação e Avaliação das Externalidades Dinâmicas Associadas"; Universidade do Minho - Escola de Economia e Gestão - (1999);

Cezarino, L. O., Campomar, M. C.; "Vantagem competitiva para micro, pequenas e médias empresas: clusters e APLs" - (2006);

Coutinho, L; Ferraz, J.C. "Estudo da Competitividade da Indústria Brasileira". Campinas: Papirus e Ed.Unicamp - (1994);

Dias, Ana Valéria C.; "Consórcio modular e condomínio industrial: elementos para análise de novas configurações produtivas na indústria automobilística"; Dissertação de Mestrado - Departamento de Engenharia de Produção, Escola Politécnica, Universidade de São Paulo - (1998);

Dias, A. V. C., Salerno, M. S.; "Condomínios Industriais: Novas Fábricas, Novos Arranjos Produtivos e Novas Discussões na Indústria Automobilística Brasileira"; Departamento de Engenharia de Produção - Escola Politécnica - Universidade de São Paulo; 
Drejer, I., Kristensen, F. S., Laursen, K.; "Studies of Clusters as a Basis for Industrial and Technology Policy in the Danish Economy" - Danish Reserch Unit for Industrial Dynamics - (1997)

Decreto $N^{\circ} 41.019$, de 26 de fevereiro de 1957;

Decreto $N^{\circ} 2.003$, de 10 de setembro de 1999;

Decreto $N^{\circ} 5.597$, de 28 de novembro de 2005;

Decreto $N^{\circ} 5.163$, de 30 de julho de 2007;

Despacho ANEEL № 2.706, de 17 de novembro de 2006;

Despacho ANEEL No 1.767, de 5 de junho de 2007;

Despacho ANEEL N².329, de 25 de julho de 2007;

Despacho ANEEL № 417, de 12 de fevereiro de 2008 ;

E.M. Bergman (Vienna University of Economics and Business), E.J. Feser (University of North Carolina); "Industry Clusters: A Methodology and Framework for Regional Development Policy in the United States"; OECD Proceedings: Boosting Innovation The Cluster Approach - (1999);

Galvão, O. J. de A.; "Clusters e Distritos Industriais: Estudos de Casos em Países Selecionados e Implicações de Política"; Departamento de Economia da Universidade Federal de Pernambuco - UFPE - (2000);

Hoffmann, V.M.; Molina, F.X. "Cooperação e Transferência de Conhecimento entre Empresas Integradas a Redes de Base Territorial", Anais do congresso SLADE Sociedade Latino-Americana de Estratégia - (2004);

Ketels, C.; "European Clusters"; Harvard Business School, Boston MA, USA; Hagbarth Publications - (2004)

Lei $N^{\circ}$ 9.074, de 7 de julho de 1995;

Lei $N^{\circ}$ 8.631, de 4 de março de 1993;

Lei $N^{\circ} 8.987$, de 13 de fevereiro de 1995;

Lei $N^{\circ} 10.847$, de 15 de março de 2004;

Lei $N^{\circ} 10.848$, de 15 de março de 2004; 
Lei $N^{\circ}$ 9.648, de 27 de maio de 1998;

Lei $\mathrm{N}^{\circ}$ 9.427, de 26 de dezembro de 1996;

MARSHALL, A. "Princípios de Economia”, São Paulo: Abril Cultural - (1982.);

Medeiros, A. M. M., Pinhão, C. M. A.; "Pólos Automotivos Brasileiros"; BNDES Setorial, Rio de Janeiro - (1999);

Nota Técnica Nº12/2005-SRT/ANEEL

Nota Técnica Nº 034/2005-SRT/ANEEL

Nota Técnica Nº 046/2006-SFG-SCT-SCG/ANEEL;

Nota Técnica N²21/2007-PF/ANEEL;

Parecer CONJUR /MME N²08/1996;

Portaria DNAEE N 1.347, de 03 de novembro de 1975;

Portaria DNAEE N 881 , de 04 de julho de 1977;

Portaria MME N 1.555, de 03 de novembro de 1981;

Portaria DNAEE N 85 , de 16 de abril de 1984;

Portaria MME N 666, de 16 de maio de 1984;

Portaria DNAEE N 11, de 05 de março de 1990;

Portaria MME Nº 321 de 15/10/1996;

Procedimentos de Distribuição de Energia Elétrica no Sistema Elétrico Nacional PRODIST, Módulo 3 - Acesso ao Sistema de Distribuição, 2008

Processo da Audiência Pública ANEEL № 010 de 2005

Processo da Audiência Pública ANEEL № 008 de 2009

Processo ANEEL Nº 48100.000383/1996-58;

Processo ANEEL Nº 48500.004959/1999-03;

Processo ANEEL N ${ }^{\circ}$ 48500.004078/2001-25;

Processo ANEEL № 48500.002882/2000-15;

Processo ANEEL № 48500.001550/2005-56; 
Processo ANEEL N 48500.001256/2006-80;

Porter, Michael E.; How Competitive Forces Shape Strategy, Harvard Business Review; Boston - (1979);

Porter, Michael E.; "The Competitive Advantage of Nations"; Harvard Business Review Boston - (1990);

Porter, Michael E.; "Creating and Sustaining Superior Performance"; Harvard Business Review Boston;

Porter, Michael E.; "Clusters and the new economics of competition"; Harvard Business Review; Boston (1998);

Prochnik, V.; "Cadeias Produtivas e Complexos Industriais"; Seção do capítulo FIRMA, INDÚSTRIA E MERCADOS, do livro HASENCLEVER, L. \& KUPFER, D. ORGANIZAÇÃO INDUSTRIAL, Ed. Campus, 2002)

Queiroz, L. S., Mendonça, F. A. S.; "Regulação da Concorrência e Monopólios Naturais"; Anais do $3^{\circ}$ Congresso Brasileiro de P\&D em Petróleo e Gás promovido pelo Instituto Brasileiro de Petróleo e Gás - IBP - (2004);

Resolução ANEEL N² 281, de 01 de outubro de 1999;

Resolução ANEEL № 360, de 22 de dezembro de 1999;

Resolução ANEEL N 456, de 29 de novembro de 2000;

Resolução ANEEL N 175, de 10 de maio de 2001;

Resolução ANEEL N 715, de 28 de dezembro de 2001;

Resolução ANEEL N² 226, de 24 de abril de 2002;

Resolução ANEEL N 513, de 17 de setembro de 2001;

Resolução ANEEL N 67, de 08 de junho de 2004;

Resolução ANEEL N 68, de 08 de junho de 2004;

Resolução ANEEL Nº 77 de 18 de agosto de 2004

Resolução ANEEL N 166, de 10 de outubro de 2005; 
Resolução ANEEL N 229, de 8 de agosto de 2006;

Resolução ANEEL $N^{\circ}$ 247, de 21 de dezembro de 2006;

Resolução ANEEL $N^{\circ}$ 567, de 27 de novembro de 2007;

Resolução ANEEL № 626, de 07 de abril de 2008;

Resolução ANEEL № 627, de 07 de abril de 2008;

Resolução ANEEL № 635, de 17 de abril de 2008;

Resolução ANEEL № 636, de 17 de abril de 2008;

Resolução ANEEL № 638, de 17 de abril de 2008;

Resolução ANEELN 671, de 24 de junho de 2008;

Resolução ANEEL № 675, de 01 de julho de 2008;

Resolução ANEEL $N^{\circ}$ 345, de 16 de dezembro de 2008;

Site Associação Brasileira de Grandes Consumidores de Energia e Consumidores Livre - ABRACE (www.abrace.org.br);

Site Canal Energia (www.canalenergia.com.br);

Site Comitê de Fomento Industrial de Camaçari (www.cofic.org.br);

Site da Câmara de Comercialização de Energia Elétrica (www.ccee.org.br);

Site da Agência Nacional de Energia Elétrica - ANEEL (www.aneel.gov.br);

Site da Energy Information Administration - ElA (www.eia.doe.gov);

Sonzogno, V. E.; "Clusters Industriais: Um Estudo Sobre o Cluster de Calçados de Franca e seu Real Grau de Internacionalização"; FEA-USP - (2003);

Szafir-Goldstein, C.; Toledo, G.L. Comparação entre Clusters Industriais - breve caracterização do setor cerâmico de revestimento no Brasil e no mundo; VII SEMEAD - (2007);

Szafir-Goldstein, C.; Toledo, G.L.; Competição e Cooperação em Clusters Industriais: Estágios e Políticas; VII SEMEAD - (2007); 
Szafir-Goldstein, C.; Toledo, G.L. "Estratégia Competitiva, Cooperação e Relacionamento em Clusters Industriais", XVII Congresso Latino-Americano de Estratégia, Slade, Santa Catarina, Brasil - (2004);

Udo Staber, U., Morrison, C.; "The Empirical Foundations of Industrial District Theory"; Faculty of Administration University of New Brunswick - (200?);

Yamawaki, H.; "The Evolution and Structure of Industrial Clusters in Japan"; The International Bank for Reconstruction and Development/The World Bank; Washington, D.C. (2001) 


\section{ANEXOS}

ANEXO A Minuta de decreto proposta pela ABRACE para regulamentação da questão energética de pólos industriais

ANEXO B Decreto 5.597/2005

ANEXO C Pontos questionados pela ABRADEE em sua Ação de Descumprimento de Preceito Fundamental $\mathrm{N}^{\circ} 93$

ANEXO D Despacho do Ministro Ricardo Lewandowski, relator do procedo da ADPF 93

ANEXO E Questionário encaminhado aos associados ABRACE para coletar informações sobre os pólos industriais

ANEXO F Relação de empresas associadas à ABRACE 


\section{ANEXO A \\ Minuta de decreto proposta pela ABRACE para regulamentação da questão energética de pólos industriais}

Decreto $\mathrm{n}^{\circ}$ de de de 2008

Dispõe sobre normas gerais aplicáveis a empresas integrantes de pólos industriais, e dá outras providências.

O PRESIDENTE DA REPÚBLICA, no uso da atribuição que the confere o art. 84, inciso IV, da Constituição, e tendo em vista o disposto no Decreto n ${ }^{\circ}$ 41.019, de 26 de fevereiro de 1957, nas Leis nos.9.074, de 7 de julho de 1995 e 9.427, de 26 de dezembro de 1996,

DECRETA:

Art. $1^{\circ}$. Este Decreto estabelece normas e diretrizes regulamentadoras para o funcionamento dos pólos industriais, compreendendo a gestão e o compartilhamento de infra-estrutura e a aquisição de insumos pelas empresas integrantes dos pólos industriais.

Art. $2^{\circ}$. Para fins da aplicação do presente Decreto, entende-se como pólos industriais a reunião de empresas industriais, em área geográfica delimitada por um raio de até $10 \mathrm{~km}$, que tenham interesse comum no compartilhamento de infra-estrutura e na aquisição de insumos, compreendendo energia, água, vapor, gás, transporte, dentre outros.

$\S 1^{\circ}$. O conceito referido no caput abrange as empresas prestadoras de serviços, instaladas nos pólos industriais, que atendem as indústrias neles localizadas.

$\S 2^{\circ}$. A existência de vias de terceiros, sejam públicas ou privadas, e/ou acidentes geográficos na área do pólo industrial, não descaracteriza o conceito definido no caput, devendo ser obtidas as autorizações de passagem correspondentes.

Art. $3^{\circ}$. As empresas integrantes do pólo industrial estabelecerão livremente, mediante instrumento particular, as condições que regerão suas relações e deverão nomear uma empresa, que, dentre outras atribuições, será responsável pela gestão do compartilhamento de infra-estrutura, aquisição de insumos e rateio dos custos correspondentes.

Parágrafo único. A empresa gestora do pólo industrial poderá ser uma entidade criada para este fim ou uma empresa industrial integrante do pólo nomeada pelas demais, proprietária ou não da área geográfica ou das instalações do pólo. 
Art. $4^{\circ}$. As empresas integrantes do pólo industrial poderão adquirir energia elétrica individualmente ou através da empresa gestora nomeada na forma prevista no artigo anterior.

$\S 1^{\circ} \mathrm{A}$ empresa que optar por adquirir energia elétrica individualmente, como consumidor regulado ou livre na forma da legislação aplicável, deverá ter as medições e contratações de acesso e de energia aferidos e celebrados separadamente.

$\S 2^{\circ}$ A compra de energia elétrica, quando realizada através da empresa gestora do pólo industrial, ressalvado o disposto no artigo $6^{\circ}$ deste Decreto, observará as seguintes condições:

A carga total do pólo deverá ser igual ou superior a $3.000 \mathrm{~kW}$ e a tensão de atendimento do pólo deverá ser igual ou superior a 69kV;

A contratação será formalizada mediante a assinatura de contrato de compra e venda de energia elétrica, entre a empresa gestora e o vendedor;

Os custos com a aquisição de energia elétrica serão rateados entre as empresas integrantes do pólo proporcionalmente ao consumo individualizado de cada uma.

Art. $5^{\circ}$. Na hipótese prevista no $\S 2^{\circ}$ do artigo $4^{\circ}$, a contratação do uso e da conexão aos sistemas de transmissão ou de distribuição será formalizada pela empresa gestora com o concessionário ou permissionário local e os custos correspondentes serão rateados entre as empresas integrantes do pólo industrial, proporcionalmente à demanda de cada uma.

Art. $6^{\circ}$. Para fins do disposto nos artigos $4^{\circ}$ e $5^{\circ}$ acima, inclusive para medição, perdas, encargos, acesso aos sistemas elétricos e/ou aquisição de energia elétrica, deverá ser considerado como ponto de entrega a instalação elétrica que conectará o pólo industrial aos sistemas elétricos de distribuição ou de transmissão.

Art. $7^{\circ}$. A partir do ponto de entrega, definido conforme artigo $6^{\circ}$, as condições operacionais e contratuais pertinentes à infra-estrutura interna do pólo industrial, inclusive o rateio das perdas e dos custos de operação e manutenção desta, serão estabelecidas no instrumento particular a que se refere o artigo $3^{\circ}$.

Parágrafo único. As instalações referidas no caput são de uso exclusivo das empresas integrantes do pólo industrial e não constituem instalações destinas ao serviço público de distribuição e/ou transmissão.

Art. $8^{\circ}$. A energia elétrica e/ou outros insumos oriundos de processo de cogeração de empresa integrante do pólo industrial, autorizada sob regime de autoprodução ou produção independente, vendidos às demais empresas integrantes do pólo industrial, serão entregues diretamente através de instalações pertencentes à empresa produtora ou através das instalações de infra-estrutura do pólo industrial.

Art. 9 ${ }^{\circ}$. As disposições deste Decreto aplicam-se aos pólos industriais novos e existentes, que deverão observar o disposto neste Decreto a partir de sua publicação.

Art. 10. Este Decreto entra em vigor na data de sua publicação. 
Brasília, ...... de ..... de $2008 ; 187^{\circ}$ da Independência e $120^{\circ}$ da República.

LUIZ INÁCIO LULA DA SILVA

Edson Lobão 


\section{ANEXO B \\ Decreto 5.597/2005}

\section{DECRETO N 5.597, DE 28 DE NOVEMBRO DE 2005.}

Regulamenta o acesso de consumidores livres às redes de transmissão de energia elétrica e dá outras providências.

O PRESIDENTE DA REPÚBLICA, no uso da atribuição que the confere o art. 84, inciso IV, da Constituição, e tendo em vista o disposto nos arts. 59 do Decreto-Lei no 227, de 28 de fevereiro de 1967, 15 e 16 da Lei no 9.074, de 7 de julho de 1995, 2 o e 3o-A da Lei no 9.427, de 26 de dezembro de 1996 , e 15 da Lei no 10.848 , de 15 de março de 2004,

\section{DECRETA:}

Art. $10 \mathrm{O}$ acesso de consumidores atendidos em tensão igual ou superior a $230 \mathrm{kV}$ à rede básica de transmissão de energia elétrica deverá ser efetuado pelas formas a seguir descritas:

I - atendimento por intermédio do concessionário local de distribuição de energia elétrica;

II - atendimento por intermédio do concessionário de transmissão de energia elétrica, nos termos do $\S 20$ do art. 40 do Decreto no 41.019, de 26 de fevereiro de 1957; ou

III - mediante construção das instalações necessárias para o acesso diretamente pelo próprio consumidor.

$\S 10 \mathrm{O}$ acesso de consumidores nas formas referidas nos incisos II e III deste artigo será objeto de autorização a ser expedida pela Agência Nacional de Energia Elétrica - ANEEL.

$\S 20$ As autorizações de que trata o $\S 10$ serão concedidas apenas nos casos de atendimento exclusivo ao respectivo consumidor.

Art. $20 \mathrm{O}$ acesso a que se refere o art. 10, para atendimento exclusivo de um único consumidor, deverá ser precedido de:

I - portaria do Ministério de Minas e Energia fundamentada em parecer técnico, o qual deverá considerar o critério de mínimo custo global de interligação e reforço nas redes, além de estar compatibilizado com o planejamento da expansão do setor elétrico para um horizonte mínimo de cinco anos; e

II - parecer de acesso emitido pelo Operador Nacional do Sistema Elétrico - ONS.

Parágrafo único. Quando da elaboração do parecer de acesso, pelo ONS, deverão ser observados os Procedimentos de Rede aprovados pela ANEEL e os padrões técnicos da instalação de transmissão acessada.

Art. 3o O acesso de que tratam os incisos II e III do art. 10 será autorizado apenas nos seguintes casos:

I- ligação de nova unidade consumidora não conectada anteriormente, desde que seja tecnicamente compatível com o nível de tensão igual ou superior a $230 \mathrm{kV}$, nos termos do que dispuser a portaria do Ministério de Minas e Energia prevista no inciso I do art. 20; ou 
II - alteração da forma de conexão de unidade consumidora já atendida em tensão inferior a 230 $\mathrm{kV}$, em decorrência de:

a) aumento de carga; ou

b) necessidade de melhoria de qualidade, devidamente demonstrada pelo consumidor interessado e reconhecida pela ANEEL.

Parágrafo único. O consumidor autorizado na forma deste artigo somente poderá efetivar o acesso após a celebração de contratos de conexão e de uso dos sistemas de transmissão.

Art. 40 A autorização de que trata o art. 3o poderá incluir as seguintes instalações, sujeitas à fiscalização da ANEEL:

I - a construção de entradas de linhas de transmissão igual ou superior a $230 \mathrm{kV}$ na subestação da rede básica;

II - o seccionamento de linhas do sistema de transmissão;

III - o barramento de alta tensão da subestação da unidade consumidora; e

IV - as linhas de transmissão em tensão igual ou superior a $230 \mathrm{kV}$, para conexão da unidade de consumo com o sistema de transmissão.

$\S 10$ No caso de o acesso, previsto na forma do inciso II deste artigo, ser promovido pelo próprio consumidor, os bens e instalações necessários ao seccionamento e acesso serão cedidos sem qualquer ônus ao concessionário de transmissão acessado, na forma de doação, e incorporados à rede básica.

§ 20 Caso o acesso do consumidor, previsto no referido inciso II, seja feito por meio do concessionário de transmissão, os bens e instalações e adequações necessários ao seccionamento e acesso deverão ser remunerados pelo respectivo consumidor, nos termos previstos no contrato de conexão de transmissão celebrado entre o consumidor e a concessionária de transmissão acessada.

§3o Os bens e instalações necessários exclusivamente ao seccionamento nas hipóteses previstas nos $\S \S 10$ e 20 deste artigo deverão ser incorporados à rede básica.

Art. 5o As instalações de transmissão para uso exclusivo de um consumidor ou de um agente poderão ser acessadas por outro agente ou consumidor interessado que atenda às condições legais e à regulação expedida pela ANEEL.

$\S 10$ A regulação do acesso de que trata o caput deverá dispor sobre:

I - as condições gerais de acesso, de acordo com estudos técnicos aprovados pelo ONS;

II - o ressarcimento a quem promoveu, às suas custas, a construção da obra de uso exclusivo;

III - a incorporação à rede básica da rede de transmissão de uso comum; e

IV - a remuneração do agente de transmissão que incorporar a rede de transmissão de uso comum.

§ 20 No acesso de que trata este artigo, o acessante interessado deverá atender às mesmas exigências técnicas e legais previstas para o acesso de consumidor ou agente ao sistema de transmissão.

§ 30 A parte de uso comum das instalações de transmissão acessada, na tensão de $230 \mathrm{kV}$ ou superior, será doada à concessionária de transmissão que celebrou o contrato de conexão com o consumidor ou agente e será incorporada à rede básica. 
Art. 6o A autorização de que trata o art. 3o deste Decreto, no caso de consumidores já conectados à rede de distribuição e que pretendam se conectar à rede básica, somente será outorgada após a homologação pela ANEEL do instrumento contratual cabível, a ser celebrado entre o consumidor e seu respectivo agente de distribuição.

$\S 10$ Como condição para pleitear a autorização, os consumidores interessados deverão observar os seguintes aspectos relacionados ao pagamento de encargos:

I - ressarcimento ao agente de distribuição dos investimentos específicos feitos na rede de distribuição para atendimento ao consumidor, descontada a depreciação contábil;

II - quitação, pelo consumidor, do valor referente aos Encargos de Serviços de Sistema - ESS e do saldo da Conta de Compensação de Variação de Valores de Itens da Parcela A - CVA, das parcelas relativas ao respectivo consumidor no período em que utilizou a rede de distribuição; e

III - quando cabível, pagamento, ao agente de distribuição, dos encargos relativos à Recomposição Tarifária Extraordinária - RTE, de que trata o art. 4o da Lei no 10.438, de 26 de abril de 2002, conforme regulação da ANEEL.

$\S 20$ Caberá à ANEEL estabelecer os critérios, montantes e prazos para as obrigações previstas neste artigo.

Art. 7o A ANEEL estabelecerá os procedimentos para que o consumidor possa ser atendido pela concessionária de distribuição, mediante participação financeira, no todo ou em parte.

Art. 8o Aplicam-se as disposições deste Decreto no livre acesso de autoprodutor de energia elétrica, para conexão de suas unidades de produção e de consumo aos sistemas de transmissão e distribuição, mesmo que estas se localizem em áreas geográficas distintas, de forma a permitir a utilização e comercialização da energia produzida, nos termos do Decreto no 2.003 , de 10 de novembro de 1996.

Art. 90 o § 80 do art. 71 do Decreto no 5.163 , de 30 de julho de 2004, passa a vigorar com a seguinte redação:

"§ 80 As redes particulares instaladas exclusivamente em imóveis de seus proprietários não serão objeto de ato autorizativo ou de incorporação, salvo, neste último caso, se houver expresso acordo entre as partes." (NR)

Art. 10. Este Decreto entra em vigor na data de sua publicação.

Brasília, 28 de novembro de 2005; 184o da Independência e 117o da República.

LUIZ INÁCIO LULA DA SILVA

Silas Rondeau Cavalcante Silva

Este texto não substitui o publicado no DOU de 29.11.2005 


\section{ANEXO C \\ Pontos questionados pela ABRADEE em sua Ação de Descumprimento de Preceito Fundamental $N^{\circ} 93$}

Em sua ação de ADPF a ABRADEE argumenta que o Decreto $N^{\circ} 5.597 / 2005$ fere os seguintes princípios:

a) o princípio da solidariedade social que inspira o conceito de serviço público e que faz indissoluvelmente ligado à satisfação de necessidades individuais básicas, vinculadas à conservação e/ou promoção da dignidade da pessoa humana (arts. $1^{\circ}, \mathrm{III}, 3^{\circ}$, I e 175 da Constituição de 1988);

b) princípio da isonomia, tanto no sentido da igualdade do art. $5^{\circ}$, caput, quanto no sentido de impessoalidade no art. 37, caput, da Constituição de 1988, por instituir discriminação fundada em critério material constitucionalmente não permitindo, uma vez que favorece os fortes às custas dos hipossuficientes no universo dos usuários do serviço público de energia elétrica;

c) O princípio da proteção do consumidor, inscrito nos arts. $5^{\circ} \mathrm{XXXII}$ e art. 170, V. da Constituição de 1988, não só por instituir discrimen não permitido (alínea "b", supra) como, especialmente, porque tal discrimen tem por efeito prático prejudicar economicamente a grande massa dos consumidores do serviço de energia elétrica;

d) O princípio da legalidade da ação administrativa, tanto em sua vertente "reserva" quanto "supremacia" da Lei (arts. $5^{\circ}$ II e 37, caput, da Constituição de 1988) porque o Decreto não só regula matéria afeita à lei como também viola, positivamente, inúmeros dispositivos de lei; 
e) $O$ princípio da separação dos Poderes do art. $2^{\circ}$, com desdobramentos pelo art. 48, e art. 84, IV, da constituição de 1988, em decorrência da violação citada na alínea anterior;

f) O princípio da moralidade, do art. 37, caput, e o princípio da confiança, enquanto princípio componente do Estado de Direito , do art. $1^{\circ}$, caput, da Constituição de 1988, porque o Decreto repropõe, parcialmente, matéria que já foi objeto de impugnação judicial da ABRADEE - e disso resultou a retirada do ato normativo anterior que tratava da mesma matéria agora regulada no indigitado Decreto (uma Resolução da ANEEL). 


\title{
ANEXO D \\ Despacho do Ministro Ricardo Lewandowski, relator do procedo da ADPF 93
}

\author{
ADPF 93 / DF - DISTRITO FEDERAL \\ ARGÜIÇÃO DE DESCUMPRIMENTO DE PRECEITO FUNDAMENTAL \\ Relator(a): Min. RICARDO LEWANDOWSKI \\ Julgamento: 24/08/2006
}

Publicação

DJ $31 / 08 / 2006$ PP-00026

Partes

ARGTE.(S): ASSOCIAÇÃO BRASILEIRA DE DISTRIBUIDORES DE ENERGIA

ELÉTRICA - ABRADEE

ADV. (A/S): JOÃO GERALDO PIQUET CARNEIRO E OUTRO (A/S)

ARGDO. (A/S): PRESIDENTE DA REPÚBLICA

ADV. (A/S) : ADVOGADO-GERAL DA UNIÃO

\section{Despacho}

Trata-se de argüição de descumprimento de preceito fundamental, com pedido de medida liminar, promovida pela Associação Brasileira de Distribuidores de Energia Elétrica - ABRADEE com o objetivo de ver desconstituído o Decreto no 5.597, de 28 de novembro de 2005, editado pelo Senhor Presidente da República. O ato normativo impugnado "dispõe sobre condições de livre acesso de consumidores atendidos em tensão igual ou superior a 230 kilovolts (i.e. os grandes consumidores industriais), à Rede Básica de energia elétrica" (fl. 03). A ABRADEE, que se qualifica como "pessoa jurídica sem fins lucrativos que representa em âmbito nacional os interesses das empresas concessionárias do serviço público de distribuição de energia elétrica" (fl. 02), após sustentar a sua legitimidade ativa ad causam, alega ofensa a preceitos fundamentais, nos seguintes termos: "(...) Ao perseguir seu objetivo, o Decreto no 5.597/05 viola as seguintes normas constitucionais, cuja natureza de 'preceito fundamental' será oportunamente considerada: a) o princípio da solidariedade social que inspira o conceito de serviço público e que o faz indissoluvelmente ligado à satisfação de necessidades individuais básicas, vinculadas à conservação e/ou promoção da dignidade da pessoa humana (arts. 10, III; 30, I e 175 da Constituição de 1988); b) o princípio da isonomia, tanto no sentido da igualdade do art. 50, caput, quanto no sentido de impessoalidade no art. 37, caput, da Constituição de 1988, por instituir discriminação fundada em critério material constitucionalmente não permitido, uma vez que favorece os fortes às custas dos hipossuficientes no universo dos usuários do serviço público de energia elétrica; c) o princípio da proteção do consumidor, inscrito nos arts. 50, XXXII e art. 170, V, da Constituição de 1988, não só por instituir discrímen não permitido (alínea 'b', supra) como, especialmente, porque tal discrímen tem por efeito prático prejudicar economicamente a grande massa dos consumidores do serviço de energia elétrica; d) o princípio da legalidade da ação administrativa, tanto em sua vertente 'reserva' quanto 'supremacia' da Lei (arts. 50, II e 37, caput, da Constituição de 1988) porque o Decreto não só regula matéria afeita à lei como também viola, positivamente, inúmeros dispositivos de lei; e) o princípio da separação dos Poderes do art $2^{\circ}$, com desdobramentos pelo art. 48, e art. 84, IV, da Constituição de 1988, em decorrência da violação citada na alínea anterior; f) o princípio da moralidade, do art. 37, caput, e o principio da confiança, enquanto princípio componente do Estado de Direito, do art. 10, caput, da Constituição de 1988, porque o Decreto repropõe, parcialmente, matéria que já foi objeto de impugnação judicial da ABRADEE - e disso resultou a retirada do ato normativo anterior que tratava da mesma matéria agora regulada no indigitado Decreto. (...)." (Fls. 04-05) Requisitadas prévias informações (fl. 403), foram estas prestadas às fls. 408-627. Determinei, ainda, a audiência da douta Procuradoria Geral da República que ofereceu parecer no sentido do não-cabimento da presente ADPF, por se tratar de impugnação a ato regulamentar apto a produzir mera ofensa reflexa à Constituição da República (fls. 629-632), o que não viabiliza o controle concentrado de constitucionalidade. Passo a decidir. Tendo em conta que o objeto desta ação é, precisamente, a invalidação jurídico-constitucional de dispositivos do Decreto no 5.597/2005, ato normativo secundário editado pelo Senhor Presidente da República que "regulamenta o acesso de consumidores livres às redes de transmissão de energia elétrica" (fl. 134), tenho que se revela absolutamente preciso o entendimento esposado pela douta Procuradoria Geral da República. Por essa razão de ordem formal não vejo, pois, como franquear o acesso à via do controle normativo abstrato em sede de argüição de descumprimento de preceito fundamental, nos termos de remansosa jurisprudência desta Corte. No entanto, ainda que se pudesse ultrapassar esse óbice de natureza formal, entendo que também não se viabilizaria o conhecimento da presente ação por outras razões. Em primeiro lugar, devo afirmar, desde logo, que, diante da jurisprudência da Corte, não há como reconhecer-se legitimidade ativa ad causam à associação argüente. Com efeito, o Estatuto Social da ABRADEE prevê a possibilidade da participação, em seus quadros, de pessoas físicas ou jurídicas (art. $4^{\circ}$ ), sendo que as primeiras, além de possuírem direitos explicitamente elencados (art. $6^{\circ}$ ), também devem pagar contribuições (art. $8^{\circ}$, b). Configurada está, em conseqüência, a composição híbrida da ABRADEE, tendo em vista a existência, entre os associados, de pessoas físicas e jurídicas, ainda que aquelas na qualidade de associados 
assinantes, eventualmente sem poder decisório. Insista-se, nesse caso, no fato de que os assinantes pagam contribuição e detêm direitos definidos no próprio estatuto social. Forçoso é concluir, portanto, que essa heterogeneidade na participação social macula a legitimidade da argüente para agir em sede de controle abstrato de constitucionalidade. No mesmo sentido: ADI 23/SP, Rel. p/ acórdão o Min. Moreira Alves; ADI 967/SP, Rel. Min. Celso de Mello; ADI 1.631-AgR/União Federal, Rel. Min. Maurício Corrêa; ADI 2.041-MC/RJ, Rel. Min. Sepúlveda Pertence; ADI 2.360/MS, Rel. Min. Moreira Alves. Entendo, ainda, que a Associação Brasileira de Distribuidores de Energia Elétrica constitui apenas uma fração do setor elétrico, composto, também, por outras associações, representantes de outros segmentos, quais sejam os de geração e de transmissão de energia elétrica. É certo, ainda, que o Supremo Tribunal Federal, em situação análoga à destes autos, entendeu que "não é parte legítima para a proposição de ação direta a entidade que congrega mero segmento do ramo das entidades das empresas prestadoras de serviços de telecomunicações ou dedicadas à indústria e ao comércio nessa área" (ADI 2.183-AgR/AM, Rel. Min. Octavio Gallotti). No mesmo sentido, menciono as ADI 353-QO/DF, Rel. Min. Celso de Mello; 976/RJ, Rel. Min. Carlos Velloso; 1.771/DF, Rel. Min. Moreira Alves; 1.409/ES, Rel. Min. Moreira Alves; 1.427/PE, Rel. Min. Néri da Silveira; 1.574-QO/RS, Rel. Min. Octavio Gallotti; 1.580-QO/União Federal, Rel. Min. Maurício Corrêa; 1.806-QO/DF, Rel. Min. Maurício Corrêa. Por outro lado, mesmo que se pudesse, em tese, superar o óbice da ilegitimidade ativa ad causam da argüente, também não caberia reconhecer-se, no caso, a existência de controvérsia constitucional relevante (como pretende a ABRADEE), cuja mera potencialidade, segundo sustenta, seria bastante para permitir a via do controle concentrado. É que a jurisprudência do STF assentou a necessidade de vislumbrar-se claramente a possibilidade de séria ameaça ao princípio da segurança jurídica (ADPF 33-MC/PA, Rel. Min. Gilmar Mendes), o que não verifico ocorrente neste caso. De todo modo, quanto a esse aspecto, entendo, apenas para o fim de mero registro, que a Associação argüente não conseguiu demonstrar inequívoca potencialidade lesiva a decorrer de graves e amplas repercussões jurídicas capazes de afetar, seriamente, a segurança jurídica como um todo. Ao contrário, o raciocínio no tema constrói-se por uma superposição de pressuposições, seja quanto ao eventual prejuízo das operações das empresas distribuidoras de energia elétrica, em seu todo, em razão das prescrições inscritas no decreto presidencial ora impugnado; seja quanto ao incerto repasse de custos, sempre dependente de uma fórmula econômico-financeira complexa em face da realidade de mercado; seja, por essas mesmas razões, pela alegação de que essa cadeia de eventos levaria, supostamente, a uma situação de gravíssima ameaça ao princípio da segurança jurídica. Assim, bem examinadas as alegações da parte argüente quanto à possível existência de potencial controvérsia constitucional relevante ainda que delas, como se vê, não derive nenhum efeito processual, pois há, quanto a esta ação de controle objetivo, óbice intransponível relativo a questões preliminares em torno do cabimento desta ação, não tenho como conclusivo que se configurasse possível antever qualquer situação de extrema ameaça ao princípio da segurança jurídica. Não fossem bastantes as considerações que venho de tecer apenas para simples registro, ressalto, ainda, a conclusiva passagem do parecer de lavra do eminente Procurador-Geral da República, Dr. Antonio Fernando Barros e Silva de Souza, no que se refere à aplicabilidade dos precedentes invocados pela Associação argüente: "(...) Note-se que na ADPF 33, Rel. Min. Gilmar Mendes, e na ADPF 47, Rel. Min. Nelson Jobim, cujos julgados (na última só em sede de liminar) foram invocados pela argüente com o fim de embasar a sua tese de que é cabível ADPF contra ato regulamentar, as normas eram anteriores à atual Constituição Nacional, o que autoriza o cabimento da referida ação, ante o comando do art. 10, parágrafo único, inciso I, da Lei 9.882/1999. (...)." (Fl. 631) Isso posto, tendo em consideração a remansosa jurisprudência desta Suprema Corte, que não reconhece a possibilidade de controle concentrado de atos que consubstanciam mera ofensa reflexa à Constituição, tais como o ato regulamentar consubstanciado no Decreto presidencial ora impugnado, e em razão, ainda, da ilegitimidade ativa ad causam da ABRADEE e da inocorrência de controvérsia constitucional relevante, acolho o parecer do Ministério Público Federal para não conhecer desta argüição de descumprimento de preceito fundamental, ficando prejudicado, em conseqüência, o exame do pedido de medida liminar. Arquivem-se estes autos. Publique-se. Brasília, 24 de agosto de 2006. Ministro RICARDO LEWANDOWSKI - Relator -

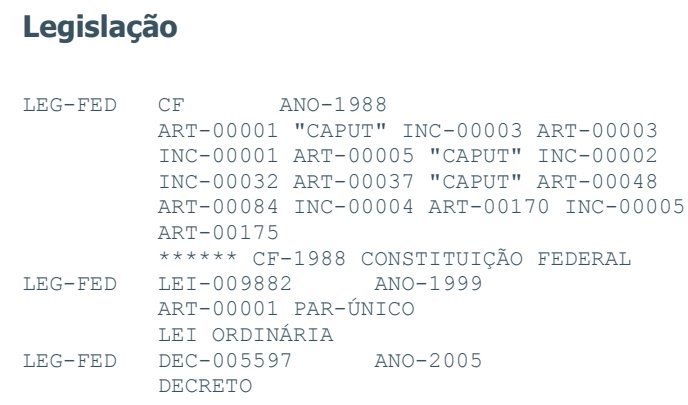

\section{Observação}

Legislação feita por: (WAS) .

\section{fim do documento}




\section{ANEXO E \\ Questionário encaminhado aos associados ABRACE para coletar informações sobre os pólos industriais}

a) Qual o nome e a data de criação do pólo industrial ao qual essa empresa pertence?

b) Há quaisquer atos legais, normativos ou contratuais disciplinando ou tratando do pólo industrial (informar se o funcionamento do pólo ocorre como condomínio)? Quais são e o que dizem?

c) Informar as relações societárias entre os integrantes do pólo, indicando as subsidiárias, coligadas, as empresas totalmente independentes, as eventuais SPE's na produção/gestão de energia e utilidades, etc.

d) O pólo tem área própria ou região delimitada geograficamente?

e) O pólo possui vias públicas (redes de distribuição e transmissão de serviço público, ruas, rodovias, ferrovias, etc.) e/ou rios cruzando a área que o delimita?

f) Há outros consumidores que não pertencem ao pólo e que poderiam ser agregados pela sua condição de proximidade e atendimento energético?

g) Existem consumidores não industriais dentro pólo com atendimento diferenciado do da distribuição?

h) Como se dá o fornecimento (compra) de energia elétrica no interior do pólo? De quem é a responsabilidade (distribuidor, gerador ou outro consumidor)?

i) Informar o arranjo físico simplificado do sistema elétrico que atende ao pólo.

j) Caso a responsabilidade citada não seja da concessionária local de distribuição, quem é o responsável? Há algum tipo de outorga para esse serviço (autorização ou permissão)?

k) Caso o fornecimento não seja feito pela concessionária de distribuição, como é custeada esta distribuição interna?

I) Existe geração de energia elétrica dentro do pólo? Qual o regime (produção independente ou autoprodução)? Há exportação de excedente de energia para o sistema elétrico?

m) Como é contratado o uso dos sistemas de transmissão e/ou de distribuição, individualmente ou de forma coletiva através de um consumidor com rateio interno?

n) Por quem foram custeadas as obras de infra-estrutura energética para suprimento do pólo (subestações e linhas de transmissão/distribuição bem como a rede de distribuição interna)? Distribuidora? Transmissora? Consumidor(es)? Governos?

o) Há pagamento de encargos setoriais na transferência de energia entre as unidades do pólo? Os encargos incidem apenas sobre o aporte líquido de energia do Sistema Elétrico Interligado?

p) Como se dá a medição para faturamento da energia consumida? Apenas na fronteira da rede básica ou da rede de distribuição e/ou em cada unidade consumidora ou geradora? 
q) Todos os consumidores do pólo são livres ou também há consumidores cativos e potencialmente livres? No caso de haver consumidores cativos, como é a atuação da distribuidora na garantia da qualidade, no rateio dos custos e na leitura do consumo?

r) Existe comercialização de energia entre consumidores/geradores dentro do pólo? Em caso afirmativo, essa comercialização é realizada por meio de contratos bilaterais de compra e venda de energia, registrados na Câmara de Comercialização de Energia Elétrica - CCEE?

s) O sistema de medição de faturamento - SMF já está adequado em relação aos padrões da CCEE?

t) Existe comercialização ou troca de insumos energéticos e/ou não energéticos entre empresas do pólo industrial? Como se dá essa troca? A energia elétrica participa da troca?

u) No caso de existir um gerador de energia que atenda parte ou todo o pólo, como se dá a relação contratual com os consumidores? Cada consumidor detém cota deste gerador, ou a energia é comercializada?

v) Houve por parte da distribuidora local ou da ANEEL manifestação sobre a situação do pólo? Caso afirmativo, indicar. 


\section{ANEXO F}

Relação de empresas associadas à ABRACE

(Fonte: Site ABRACE: julho de 2009)

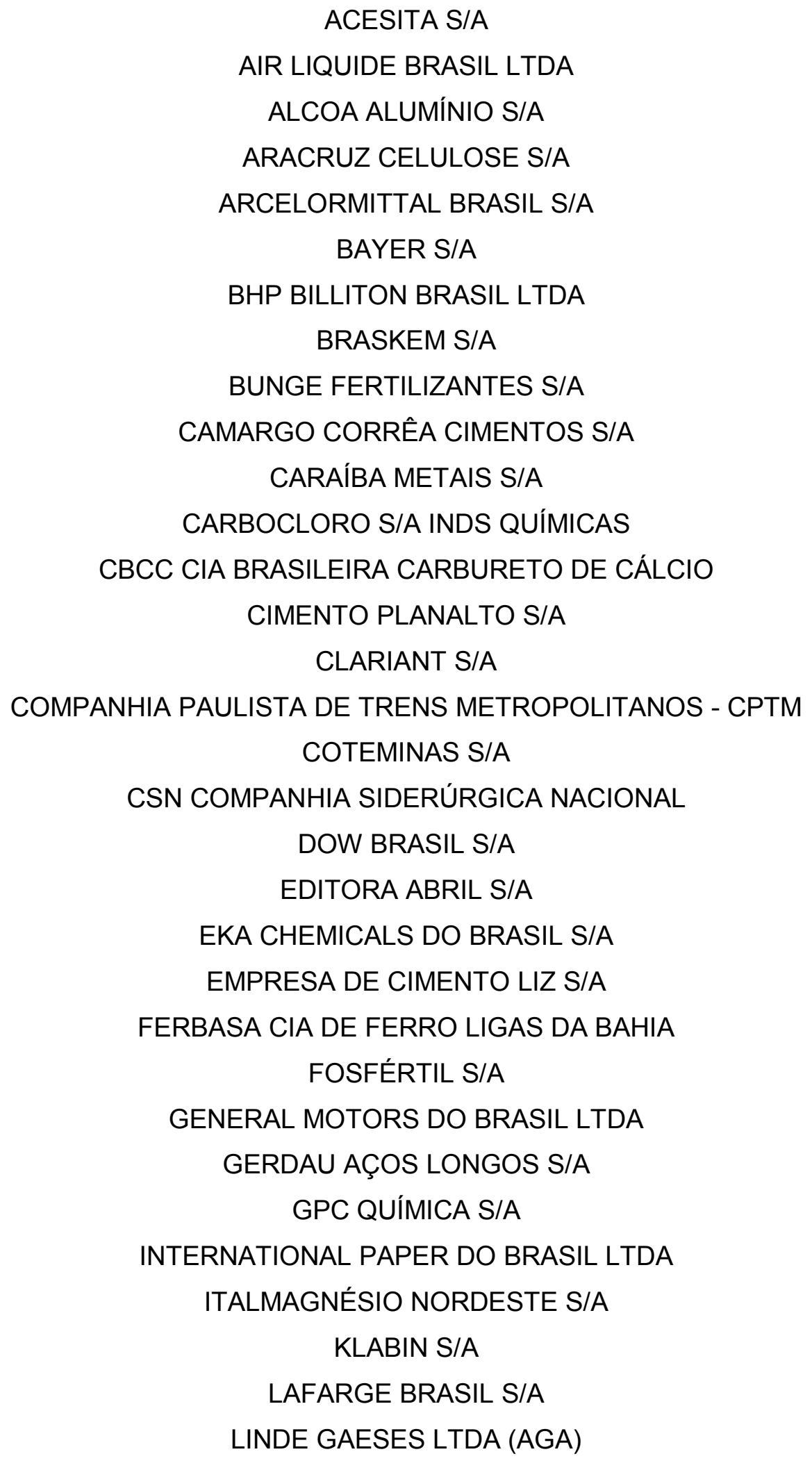


NADIR FIGUEIREDO IND E COM S/A

NESTLÉ BRASIL LTDA

NOVELIS DO BRASIL LTDA

RHODIA BRASIL LTDA

RIGESA, CELULOSE, PAPEL E EMBALAGENS LTDA

RIO TINTO ALCAN BRASIL LTDA.

SAINT-GOBAIN DO BRASIL PRODUTOS INDUSTRIAIS E PARA CONSTRUCAO LTDA

SAMARCO MINERAÇÃO S/A

SANTANA TEXTIL S/A

SOLVAY DO BRASIL

STORA ENSO ARAPOTI INDUSTRIA DE PAPEL S.A.

SUZANO PAPEL E CELULOSE S/A

TBM TÊXTIL BEZERRA DE MENEZES S/A

USIMINAS - USINAS SIDERÚRGICAS DE MINAS GERAIS S/A

VALE

VALLOUREC \& MANNESMANN TUBES

VOTORANTIM CELULOSE E PAPEL S/A

VOTORANTIM CIMENTOS LTDA

WHEATON BRASIL VIDROS LTDA

WHITE MARTINS GASES INDS S/A

YAMANA DESENVOLVIMENTO MINERAL S/A 